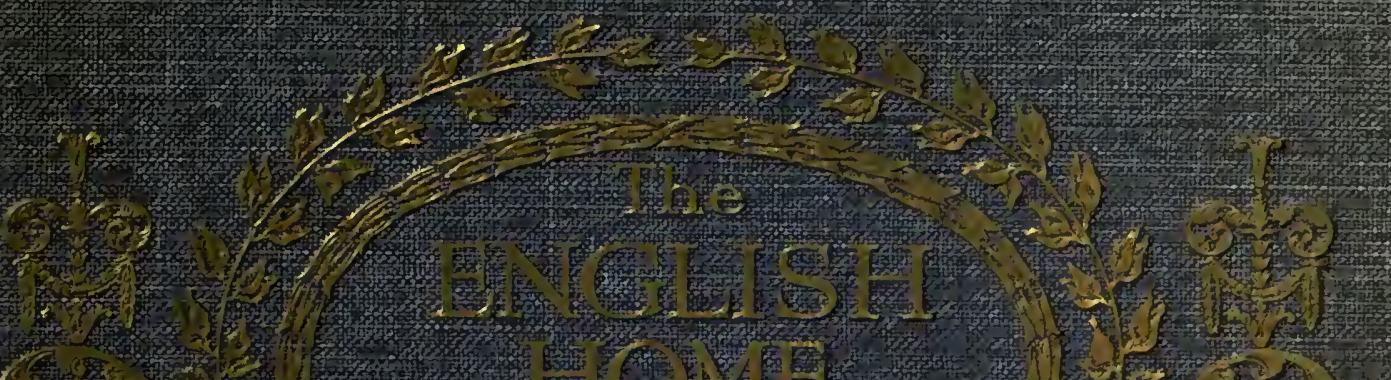

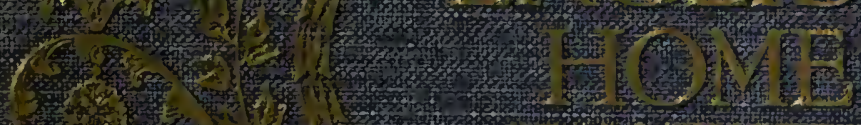

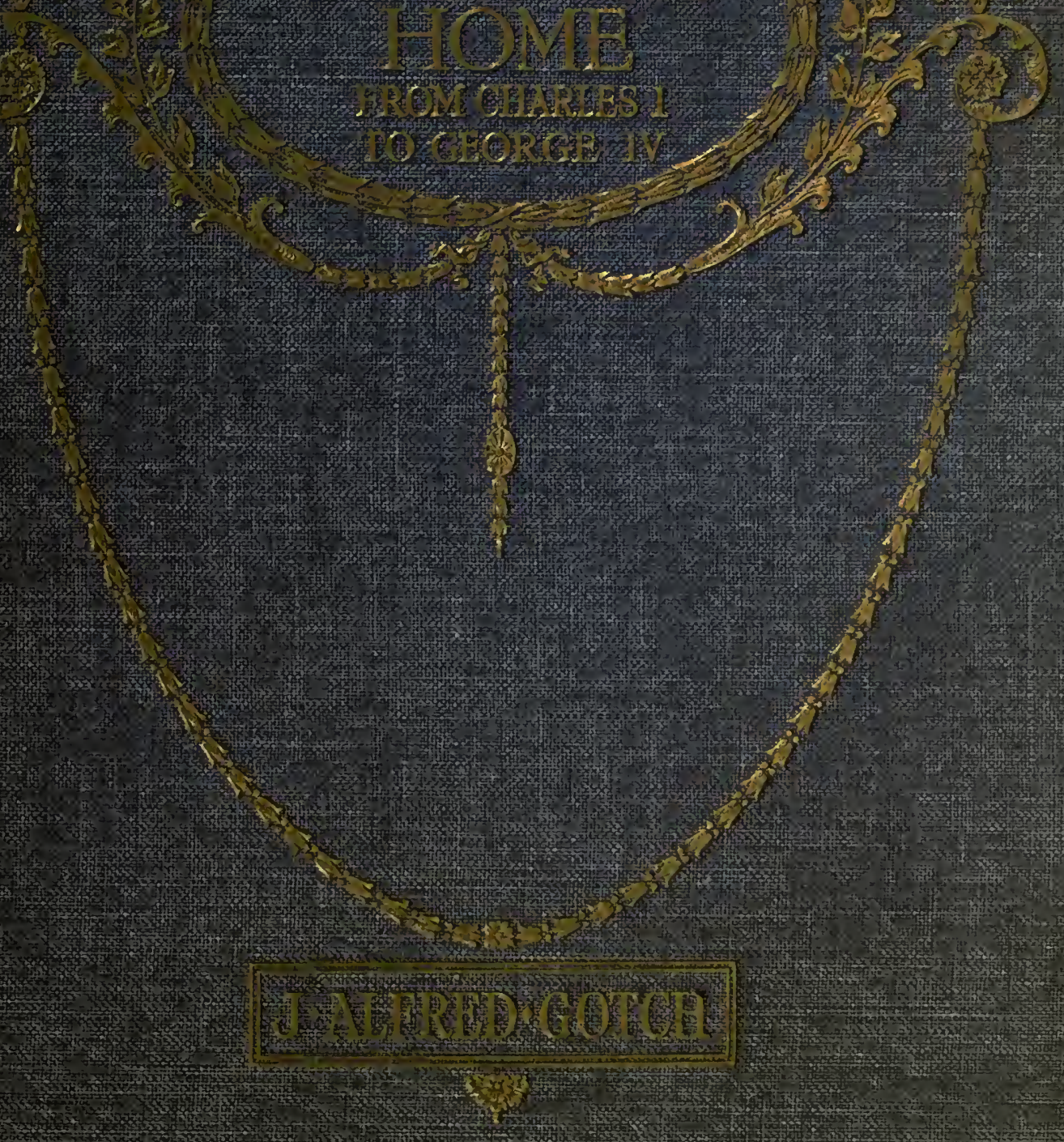



$R E A S T O N$

mel 
Digitized by the Internet Archive in 2007 with funding from Microsoft Corporation 


\section{THE ENGLISH HOME}

FROM CHARLES I. TO GEORGE IV. 


Frontispiece:

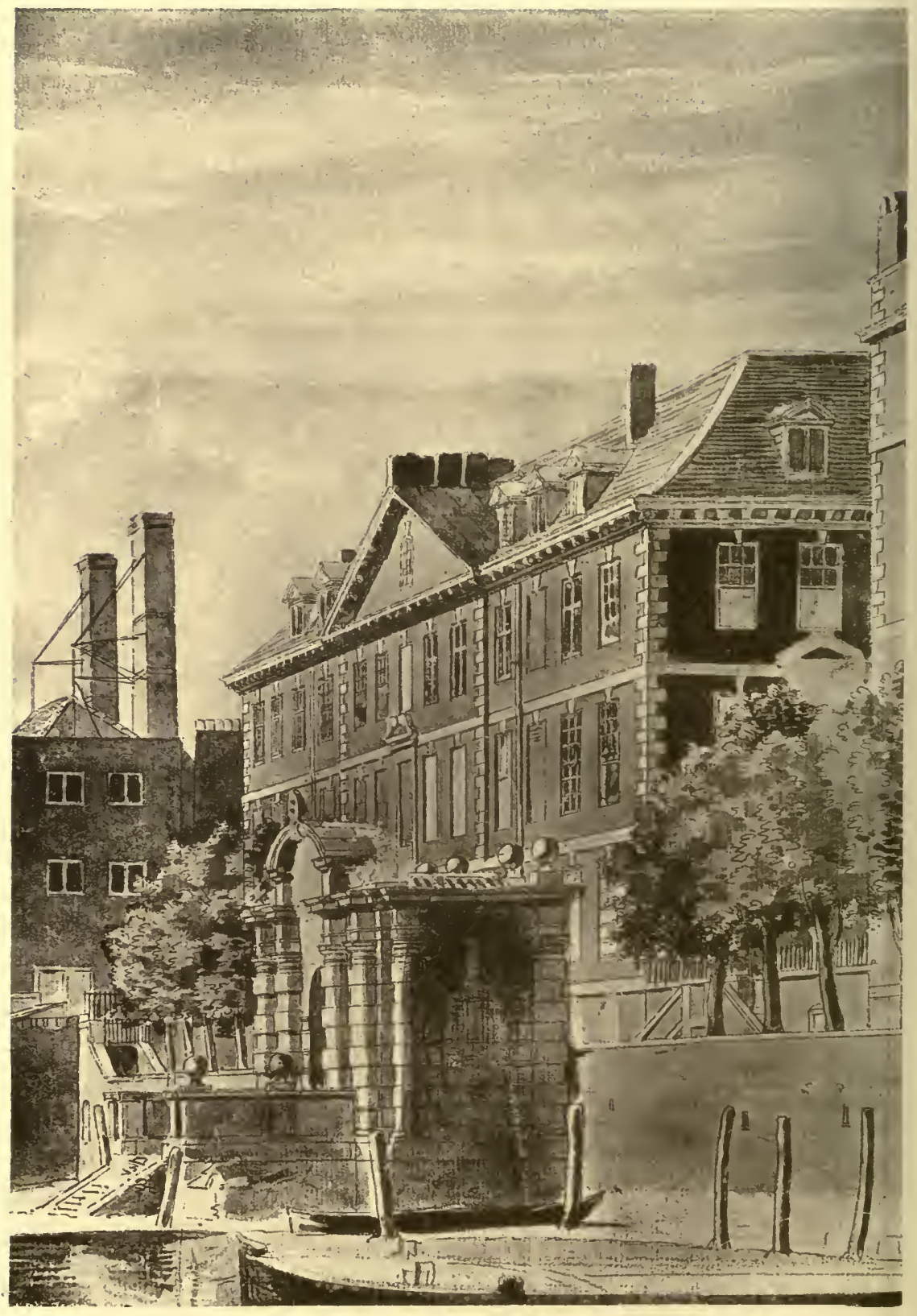

YORK BUILDINGS, ADELPH STAIRS AND WATERWORKS.

(from a water-colour drawing by Thomas Sandby, R.A.) 


\title{
THE
}

\section{ENGLISH HOME}

FROM CHARLES I. TO GEORGE IV.

\author{
ITS ARCHITECTURE, \\ DECORATION \\ AND GARDEN DESIGN
}

BY

J. ALFRED GOTCH, F.S.A., F.R.I.B.A. AUTHOR OF "ARCHITECTURE OF THE RENAISSANCE IN ENGLAND," "EARLY RENAISSANCE ARCHITECTURE IN ENGLAND," "THE GROWTH OF THE ENGLISH HOUSE," ETC.

WITH UPWARDS OF 300 ILLUSTRATIONS FROM PHOTOGRAPHS, DRAWINGS, AND ENGRAVINGS

SECOND IMPRESSION

With Corrections

LONDON

B. T. BATSFORD Ltd., 94 HIGH HOLBORN 
First Impression, August 1918

Second Impression, April 1919

PRINTED IN GREAT BRITAIN AT THE DARIEN PRESS, EDINHURGH 


\section{LIST OF SUBSCRIBERS.}

\section{HER MOST GRACIOUS}

The Most Hon. The Marquis of Ailsa The Rt. Hon. The Countess of

Ancaster

The Rt. Hon. The Countess of Antrim Capt. The Rt. Hon. Viscount Althorp The Architectural Association, London, per F. R. Yerbury, Esq., Secretary

The Society of Architects, London, per C. McArthur Butler, Esq., Secretary

J. R. de M. Abbott, Esq., Acton, W. Peter Adam, Esq., J.P., Cairndhu, Kidderminster

Philip L. Agnew, Esq., J.P., Farthingstone, Northants Messrs. Ahrend \& Zoon, Booksellers, Amsterdam

Akademiska Bokhandeln, Helsingfors Bryce Allan, Esq., Wemyss Bay, Renfrewshire

Messrs. E. G. Allen \& Son, Ltd., Booksellers, London, W.C.

J. A. O. Allan, Esq., F.R.I.B.A., Aberdeen

Arthur Acland Allen, Esq., M.P., L.C.C., London, S.W.

Walter C. Alston, Esq., Newmarket Chas. Ambler, Esq., Bradford, Yorks John Ambler, Esq., Baildon, Yorks

S. Ambler, Esq., Harrogate, Yorks

Victor Ames, Esq., Thornham, King's Lynn

J. A. Amschell, Esq., London, S.W. Cecil Bruyn Andrews, Esq., Hove, Sussex

Messrs. Angus \& Robertson, Ltd. Booksellers, Sydney, N.S.W.

F. H. Anstruther-Gough-Calthorpe, Esq., J.P., Winchfield, Hants

Lieut.Col. W. Anstruther-Gray, M.P., Kilmany, Fife

\section{MAJESTY THE QUEEN}

Harold D. Arbuthnot, Esq., Worplesden

Messrs. James Archibald \& Co., Ltd., Booksellers, Hull

Mrs. H. R. Armitage, Walton Lea, Warrington

Chas. Armstrong, Esq., Cambridge

T. M. E. Armstrong, Esq., Limpsfield, Surrey

Army \& Navy Co-operative Society, Ltd., Book Dept., London, S.W.

Chas. A. Ashe, Esq.

The Rev. Dr. Dukinfield Astley,M.A. East Rudham, King's Lynn

His Grace The Duke of Buccleuch

The Most Hon. The Marchioness of Bute

The Rt. Hon. Earl Bathurst

The Rt. Hon. Earl Beauchamp,K.G. Major The Rt. Hon. Lord Blythswood The Rt. Hon. Sir John Brunner, Bt. D.L., LL.D.

Belfast Public Library

Birmingham University Library, pet

W. H. Cope, Esq., Librarian

Bootle Public Library, per C. H. Hunt, Esq., Librarian

Bradford Public Library, per Butler Wood, Esq., Librarian

Brighton Public Library, per Henry D. Roberts, M.B.E., Director

Mrs. J. T. Babington, Great Durnford, Salisbury

W. St. Clair Baddeley, Esq., J.P., Painswick, Glos.

Mr. James Bain, Bookseller, London, W.C.

Mr. Edward Baker, Bookseller, Birmingham

Messrs. J. Baker \& Son, Booksellers, Clifton, Bristol 


\section{LIST OF SUBSCRIBERS}

Mrs. A. H. Shorland Ball, Burton, Westmorland

C. H. Barber, Esq., Chelford, Cheshire

S. Barker, Esq.

Messrs. Barnicott \& Pearce, Booksellers, Taunton

Captain F. Jardine Barnish, Appleton Cross, nr. Warrington

Stanley G. R. Barratt, Esq.,

Totteridge, Herts

F. C. W. Barrett, Esq., London, S.W.

Thomas Barrett-Lennard, Esq., D.L. J.P., Horsfold Manor, Norwich

Ernest R. Barrow, Esq., F.R.I.B.A., London, W.C.

J. M. Barwick, Esq., Yeadon, nr. Leeds

C. F. Bates, Esq., Newport, Mon.

Messrs. Battiscombe \& Harris, Ltd., London, W.

Señor M. Bayès, Bookseller, Barcelona A. Chester Beatty, Esq., London, W. W. Gedney Beatty, Esq., New York J. W. Beaumont, Esq., F.R.I.B.A., Manchester

A. Stuart Beazley, Esq., Reigate

George Lord Beeforth, Esq., F.S.A., D.L., J.P., Scarborough

Walter P. Belk, Esq., Sheffield

The Rev. Randolph Berens, M.A., London, S.W.

Mrs. Berkeley, Cotheridge Court, Worcester

Mrs. Berkeley, Spetchley Park, Worcester

H. F. M. Berthon, Esq., R.N., H.M.S. Warspite

The Rev. E. Best-Dalison, M.A., Boxley, Maidstone

R. A. P. Bevan, Esq., J.P., Cuckfield, Sussex

Messrs. Bickers \& Son, Ltd., Booksellers, London
Mr. J. G. Bisset, Bookseller, Aberdeen

George Blackall-Simonds, Esq., Goring Heath, Oxon

Norman A. Blackburn, Esq., Dewsbury, Yorks.

Mr. B. H. Blackwell, Bookseller, Oxford

Thomas R. Blampied, Esq., Samares, Jersey

Frank Ed. B. Blanc, Esq., Edinburgh Edw. T. Boardman, Esq., F.R.I.B.A. Norwich

Percy Bois, Esq., Godalming, Surrey The Rev. Canon Bonney, Sc.D., LL.D., F.R.S., F.S.A., Cambridge The Bon Marché, Book Dept., Liverpool

J. A. N. Booker, Esq., D.L., J.P., Woodfield, nr. Ross, Herefordshire John Borie, Esq., London, W.

F. K. Borrow, Esq., Haslemere, Surrey Señor Agustin Bosch, Bookseller, Barcelona

Hubert S. M. Bourke, Esq., Harlow, Essex

Messrs. Bowes \& Bowes, Booksellers, Cambridge

Frederick Bradbury, Esq., Sheffield

R. F. Brain, Esq., Chatham

Mr. T. A. Braithwaite, Bookseller, Wakefield

W. R. Branagan, Esq., Fairfield, Liverpool

Major Leonard Brassey, M.P., Peterborough

John C. E. Bridge, Esq., J.P., Aylesbury

Harry Bridson, Esq., M.A., Bolton T. R. Bridson, Esq., London, S.W. Walter H. Brierley, Esq., F.S.A., F.R.I.B.A., York

Messs. Bright's Stores, Ltd., Booksellers, Bournemouth 


\section{LIST OF SUBSCRIBERS}

Miss Mary Brindle, Polperro, Cornwall Messrs. Brintons, Ltd., Kidderminster Mrs. G. O. Broms, Dormans Park, Surrey

The Rev. C. C. Brookes, M.A., Lillington Vicarage, Leamington

Mrs. Brooks, Clifton, Bristol

C. W.Wilsone' Broun, Esq., Rugeley, Stafls

W. Langdon Brown, Esq., M.D., London, $W$.

W. Talbot Brown, Esq., F.R.I.B.A., Wellingborough

Mr. William - Brown, Bookseller, Edinburgh

Messrs. Browne \& Browne, Ltd., Booksellers, Newcastle-on-Tyne

Mr. Charles E. Brumwell, Bookseller, Hereford

John M. Bryce, Esq., Glasgow

Miss Bulley

Messrs. J. \& E. Bumpus, Ltd., Booksellers, London, W.

Alfred W. N. Burder,Esq., J.P.,F.S.A. Belcombe, Bradford-on-Avon

Rowland Burdon-Muller, Esq., London, W.

Messrs. Burleigh's Library, Booksellers London, S.W.

J. W. Stanley Burmester, Esq., F.R.I.B.A., Westminster, S.W.

Messrs. Burnside, Ltd., Booksellers, Blackheath, S.E.

Jas. E. Bush, Esq., Melksham, Wilts. G. C. Bushy, Esq.

Mrs. A. J.Agard Butler, Church Langton Rectory, Market Harborough

The Most Hon. The Marquis of Crewe, K.G.

The Rt. Hon. Earl Curzon of Kedleston, G.C.S.I., G.C.I.E.
Lady George Campbell

The Rt. Hon. Sir Fairfax Cartwright, G.C.M.G., G.C.V.O.

The Fitzwilliam Museum, Cambridge

Cardiff Public Libraries, per Harry Farr, Esq., Librarian

Charterhouse School Library, Godalming, per J. L. Stokes, Esq., Librarian

Chelsea Public Libraries, per J. Henry Quinn, Esq., Librarian

J. T. Cackett, Esq., F.R.I.B.A., Newcastle-on-Tyne

Frank R. Calburn, Esq., Effingham Manor, Surrey

Arthur Card, Esq., St. Albans

Miss M. Smith-Carington, Ashby Folville Manor, Melton Mowbray W. D. Caröe, Esq., M.A., F.S.A., F.R.I.B.A., Westminster, S.W.

B. Carpenter, Esq., London, W.

Walter J. Carter, Esq., Oxford

Walter Cave, Esq., F.R.I.B.A., London, W.

A. Cay, Esq., Leigh Woods, Bristol

H. E. Chafy, Esq., Rous Lench Court, Evesham

E. Beresford Chancellor, Esq., M.A., Wargrave, Berks.

Wm. J.Checkley, Esq., London, N.W. Frederick Clark, Esq., F.R.I.B.A., Darlington

Messrs. Clarke \& Satchell, Booksellers, Leicester

Mrs. C. E. Clayton, Henfield, Sussex

H. M. Cleminson, Esq., Writtle, Chelmsford

Messrs. Coates \& Bairstow, Booksellers, Huddersfield

S. Pepys Cockerell, Esq., Kensington

J. W. Cockrill, Esq., A.R.I.B.A., M.I.C.E., Gt. Yarmouth

Mons. E. Coenen, Sous-Intendant Militaire Belge, Bourbourg, France 


\section{LIST OF SUBSCRIBERS}

Marcus E. Collins, Esq., F.R.I.B.A., London, E.C.

Messrs. Combridge, Ltd., Booksellers, Dublin

Mr. J. G. Commin, Bookseller, Exeter

R. C. de la Condamine, Esq., Chelsea The Rev. A. H. Coombes, M.A., Hurstpierpoint College, Sussex

Edwin Cooper, Esq., F.R.I.B.A., London, W.C.

Mr. Ernest Cooper, Bookseller, Bournemouth

L. A. Cooper, Esq., Ealing, W.

G. Wilfred Copeland, Esq., Basford, Stoke-on-Trent

Ronald Copeland, Esq., Tittensor Chase, Stoke-on-Trent

Messrs. Cornish Bros., Ltd., Booksellers, Birmingham

Messrs. James Cornish \& Sons, Booksellers, Liverpool

Messrs. J. E. Cornish, Ltd., Booksellers, Manchester

Reginald Cory, Esq., Duffryn, nr. Cardiff

Country Life, Ltd., London, W.C.

Alfred W. Cox, Esq., Glencarse, Perthshire

Frank Crawley, Esq., M.D., Dublin G. A. Crawley, Esq., London, S.W. Miss Natalie de M. Croft, Ware, Herts W. J. Croome, Esq., Feltrim, Weston-super-Mare

Fred. H. Crossley, Esq., Chester

John K. Currie, Esq., Billingham, Stockton-on-Tees

Laurence Currie, Esq., M.A., J.P., Farnborough, Hants

Mrs. Cuthbert, Beaufront Castle, Hexham

His Highness Prince Frederick Duleep Singh, M.V.O.
The Most Hon. Flora, Marchioness of Dufferin and Ava

The Rt. Hon. Earl of Donoughmore Lady Eva Dugdale

The Rt. Hon. Lady D'Abernon

The Rt. Hon. Lord Desborough, K.C.V.O.

Sir Thomas L. Devitt, Bt.

Deptford Public Libraries, per F. J. Peplow, Esq., Librarian

National Library of Ireland, Dublin

Dundee Public Library, per A. H. Millar, Esq., LL.D., Librarian

Hylton B. Dale, Esq., London, W.C.

T. W. Dannatt, Esq., Blackheath

T. J. Daniel, Esq., Moseley, Birmingham

William J.Dargan,Esq., M.D., Dublin

Francis Hastings Dauney, Esq., Ryde, I. of W.

Edward O. Davey, Esq., Dunmow, Essex

E. Guy Dawber, Esq., F.R.I.B.A., London, W.

The Rev. William Dawson, M.A., Loughton, Essex

Messrs. Wm. Dawson \& Sons, Ltd., Booksellers, London, E.C.

W. M. Dean, Esq., Sunningdale, Berks

Messrs. Deighton, Bell \& Co., Ltd., Booksellers, Cambridge

Messrs. A. \& F. Denny, Booksellers, London, W.C.

H. Llewellyn Dent, Esq., Kew

Devonshire Library, Ltd., Booksellers, Buxton

T. F. G. Dexter, Esq., B.A., B.Sc., Perranporth, Cornwall

Edward Percival Dickin, Esq., Brightlingsea

Messrs. B. Diver \& Son, Booksellers, Cambridge

Mrs. Dodsley, Mansfield, Notts 


\section{LIST OF SUBSCRIBERS}

Mrs. Donaldson-Hudson, Market Drayton

Messrs. Aitken Dott \& Son, Booksellers, Edinburgh

Messrs. Douglas \& Foulis, Booksellers, Edinburgh

Mrs. Edward Douty, Clifford Manor, nr. Stratford-on-Avon

Ernest Dunkels, Esq., Maidenhead

James B. Dunn, Esq., A.R.S.A., F.R.I.B.A., Edinburgh

Ralph S. Dutton, Esq., Alresford, Hants

Mr. W. Dymock, Bookseller, Sydney, N.S.W.

Royal Scottish Museum, Edinburgh

Major Cyril Earle, T.D., Hull

The Rev. H. V. S. Eck, M.A., Ardeley Vicarage, Hertfordshire

Colonel Robt. W. Edis, C.B., Great Ormesby, Norfolk

The Educational Depository, Booksellers, Dublin

Mr. Francis Edwards, Bookseller, London, W.

Major J. Edward Elin, London, W.

The Rev. Prof. Henry Ellershaw, M.A., Durham

Mr. Andrew Elliott, Bookseller, Edinburgh

Colonel W. Elliott, Sutton Valence, Maidstone

Geoffrey Ellis, Esq., St. Leonards-onSea

H. C. Ellis, Esq., Hemel Hempstead

Captain H. C. Ellis, Jarvis Brook, Sussex

John Every, Esq., Lewes, Sussex

Miss M. Fairholme, Mitchelstown Castle, Co. Cork
A. Douglas Farmer, Esq., Windham Club, St. James', S.W.

Miss Margaret Farnley-Smith, Sherborne, Dorset

Lionel Faudel-Phillips, Esq., Braintree, Essex

J. E. Fawcett, Esq., J.P., Farnham, Knaresborough, Yorks

Major Guy Feilden, Witney, Oxon

Miss V. M. Feilden, Bebington, Cheshire

P. H. Feilding, Esq., Chiddingly, Sussex

F. Fenwick, Esq., Wolsingham, Durham

Ivor A. B. Ferguson, Esq., London

Lieut. F. E. Fetherstonhaugh, R.N.V.R., North Berwick, Scotland

E. Willoughby Firth, Esq., J.P., Hope, nr. Sheffield

Major Benton Fletcher, Cobham, Surrey

Miss M. Fletcher, Newnham College, Cambridge

Messrs. Flooks \& Manning, Booksellers, Melksham

Mrs. Follett, Thetford, Norfolk

Chas. W. Forbes, Esq., D.L., J.P., of Callendar, Falkirk, Scotland

Mrs. James Forman, Nottingham

Mr. Robert Forrester, Bookseller, Glasgow

George Fottrell, Esq., Dublin

Mr. E. S. Fowler, Bookseller, Eastbourne

T. Musgrave Francis, Esq., D.L.,J.P. Quy Hall, Cambridge

Herbert Freyberg, Esq., F.S.I., M.S.A., London, S.W.

Mr. C. E. Fritze, Bookseller, Stockholm

T. W. Fry, Esq., J.P., F.S.A., Darlington 


\section{LIST OF SUBSCRIBERS}

Major Robert F. Fuller, J.P., Great Chalfield, Wilts

Lady Henry Grosvenor

Sir Ernest Goodhart, Bt.

Sir William Garforth, LL.D.

Galignani Library, Booksellers, Paris

Messrs. Galloway \& Porter, Booksellers, Cambridge

Arthur Galton, Esq., M.A., Bourne, Lincs.

Ewan Cameron Galton, Esq., J.P., Eynsham, Oxon

Miss Clare Galwey, Monkstown, co. Dublin

Mr. Alex. Gardner, Bookseller, Paisley

Mrs. Garnett, Leckhampton, Glos.

Major S. H. Garrard, Daventry, Northants

Francis N. A. Garry, Esq., London MM. Georg \& Co., Librairie, Geneva

Messrs. William George's Sons, Booksellers, Bristol

Edward M. Gibbs, Esq., F.R.I.B.A., Sheffield

Lt.-Colonel George A. Gibbs, M.P., Bristol

H. Martin Gibbs, Esq., J.P., FlaxBourton, Somerset

John Gibson, Esq., London, E.C.

Messrs. H. M. Gilbert \& Son, Booksellers, Southampton

Messrs. Godfrey Giles \& Co., London, $W$.

Francis V. Gill, Esq., Bradford, Yorks Henry Neville Gladstone, Esq., J.P., Burton Manor, Chester

Maurice Glyn, Esq., J.P., Much Hadham, Herts.

Walter H. Godfrey, Esq., F.S.A., London, S.W.
Messrs. W. E. \& J. Goss, Booksellers, Kettering

Mr. H. J. Goulden, Bookseller, Canterbury

Prof. Chas. Gourlay, Esq., B.Sc., A.R.I.B.A., F.S.A.Scot., Glasgow

W. V. S. Gradwell-Goodwin, Esq., J.P., Silverdale, Staffordshire

Mrs. Robert Grant, Lingfield, Surrey Trevor Grant, Esq., London, W.

H. St. George Gray, Esq., Taunton Castle, Somerset

T. Grazebrook, Esq., The Dene, nr. Stourbridge

Frank Green, Esq.,F.S.A., Treasurer's House, York

Benson Greenall, Esq., Lt. Cheshire Regt., London, E.C.

O. W. Greene, Esq., Beckenham, Kent

Messrs. Greene's Library, Dublin Hubert J. Greenwood, Esq., J.P., L.C.C., F.S.A., London, S.W.

Mr. George Gregory, Bookseller, Bath

John R. Gregory, Esq., London, W. Major L. Gregson, London, S.W.

E. Hyla Greves, Esq., M.D., Bournemouth

Geo. J. Gribble, Esq., J.P., London J. Henry Griffith, Esq., Llanbedr, Merioneth.

Percival D. Griffiths, Esq., Sandridge, Herts.

W. H. Grinstead, Esq., Eastbourne

Mrs. Gerald Guinness, Chippenham, Wilts.

Lieut. R. S. Guiness, R.N.V.R., H.M.S. "Monarch"

Mr. N. J. Gumperts, Bookseller, Gothenburg

Dr. Gunther, Hampton Wick, Kingston-on-Thames

Mrs. Reginald Gurney, Norwich 


\section{LIST OF SUBSCRIBERS}

The Rt. Hon. Viscount Halifax, M.A., F.S.A.

The Rt. Hon. Lord Hastings

The Rt. Hon.F.Leverton Harris, M.P. Sir William St. John Hope, Litt.D., D.C.L., M.A.

The Rev. Andrew Halden, Inverkeilor, Forfarshire

Charles A. H. Hall, Esq., J.P., Basingstoke

Ernest B. Hall, Esq., Market Drayton, Staffs.

John Hall, Esq., F.R.I.B.A., Sunderland

Mr. Fred. Hanna, Bookseller, Dublin George Hampton, Esq., Lingham, Wimborne, Dorset

Mrs. Hargreaves, Bury St. Edmunds

R. L. Harmsworth, Esq., M.P., London, W.

W. H. Harrison, Esq., F.R.I.B.A., Westminster, S.W.

Mr. W. Harrison, Bookseller, Ipswich

Messrs. Harrison \& Sons, Booksellers, London, W.

Ernest Hartland, Esq., M.A., F.S.A., J.P., Chepstow, Mon.

Messrs. Hatchards, Booksellers, London, W.

Lt.-Colonel Hawkshaw, Liphook, Hants.

E. S. Haynes, Esq., London, W.

A. R. Hayward, Esq., Misterton, Somerset

Messrs. Aldam Heaton \& Co., Ltd., London, $W$.

Messrs. W. Heffer \& Sons, Ltd., Booksellers, Cambridge

Andrew G. Henderson, Esq., A.R.I.B.A., Glasgow

Mrs. A. Heneage, Prestbury, Glos.

Claud W. Heneage, Esq., London

Messrs. John Heywood, Ltd., Booksellers, Manchester
Mrs. Hicks-Beach, Witcombe Park, nr. Gloucester

G. Higgs, Esq., London, W.C.

E. D. Hildyard, Esq., Kirby Moorside, Yorkshire

Chas. H. Hill, Esq., J.P., Woodborough Hall, Notts

Mr. F. R. Hockliffe, Bookseller, Bedford

Victor T. Hodgson, Esq., F.S.A., Harpenden, Herts

Mrs. George Holdsworth, London, W.

Mrs. Jaqueline Hope-Nicholson, Chelsea, S.W.

Donald Hopewell, B.A., LL.B., Old Basford, Nottingham

Mr. Hugh Hopkins, Bookseller, Glasgow

Chas. H. Hopwood, Esq., F.S.A., Stamford Hill, N.

Mrs. Horan, Lamberhurst, Kent

P. Morley Horder, Esq., F.R.I.B.A., London, S.W.

Percy P. Hore, Esq., M.Inst.C.E., Streatham, S.W.

C. H. St. John Hornby, Esq., London

A. B. Horne, Esq., Balcombe

E. J. Horniman, Esq., J.P., London

J. P. Hornung, Esq., J.P., Horsham, Sussex

T. C. Horsfall, Esq., Swanscoe Park, nr. Macclesfield

Mr. Bertram Hosier, Bookseller, Sheffield

H. W. Paget Hoskyns, Esq., J.P., Crewkerne, Somerset

F. T. S. Houghton, Esq., Birmingham

Messrs. Edward Howell, Ltd., Booksellers, Liverpool

George Hubbard, Esq., F.S.A., F.R.I.B.A., London, E.C.

H. A. Hubbersty, Esq., J.P., Buxton, Derbyshire 


\section{LIST OF SUBSCRIBERS}

Mr. E. F. Hudson, Bookseller, Birmingham

C. Lang Huggins, Esq., J.P., Hadlow Grange, nr. Uckfield

Maurice Hulbert, Esq., J.P., A.R.I.B.A., Ealing, W.

Sydney Humphries, Esq., Lamport Hall, Northamptonshire

Mrs. F. J. C. Hunter, Bystock, Exmouth

Jas. Kennedy Hunter, Esq., F.R.I.B.A., Ayr

John Hunter, Esq., Belper

Messrs. Hunter \& Longhurst, Booksellers, London, E.C.

W. Hutchinson, Esq., Liverpool

Mrs. Florence H. S. Iliffe, Foxcombe Hill, Oxford

Mrs. Alfred Illingworth, Daisy Bank, Bradford

Major Douglas Illingworth, Eastcote, Middlesex

Mrs. Harry Illingworth, Wydale, Brompton, Yorks.

W. L. Ingle, Esq., Morley Grange, Churwell

Ernest Innes, Esq., London

Captain A. Linton Iredale, Newhaven

Lady Jenner

Col. Sir Herbert Jekyll, K.C.M.G.

Mr. Richard Jackson, Bookseller, Leeds

W. Geoffrey Jackson, Esq., Witley, Surrey

Messrs. Jackson \& Fox, Halifax

W. A. James, Esq., Maidenhead George Jameson, Esq., Raheny, Co. Dublin

Messrs. Jarrold \& Sons, Ltd., Booksellers, Norwich

Mrs. Jarvis, Doddington Hall, Lincoln
Mrs. Leo Jenner, Avebury, Wilts.

Walter Johnston, Esq.

Lieut. C. A. Johnsțone, K.S.L.I., Oswestry, Shropshire

C. Sydney Jones, Esq., Princes Park, Liverpool

E. Peter Jones, Esq., J.P., Greenbank, Chester

Frederick Jones, Esq., East Hoathly, Sussex

H. E. Jones, Esq., Mayfield, Sussex Ronald P. Jones, Esq., M.A., London, W.C.

W. Campbell Jones, Esq., F.R.I.B.A., London, E.C.

Messrs. Jones \& Evans' Bookshop Ltd., London, E.C.

W. Joynson-Hicks, Esq., M.P., London, S.W.

The Rt. Hon., Lord Kenyon

The Rt. Hon. Lady Kinloch

Sir Charles Knightley, Bt., D.L.,J.P.

Kensington Public Libraries, per Herbert Jones, Esq.

Walter K. Kaye, Esq., M.I.Mech.E. Harrogate

James Kent, Esq., Edenbridge, Kent John Keppie, Esq., F.R.I.B.A.,

\section{Glasgow}

Kettering Book Club, per The Rev. A. K. Pavey, M.A.

Harold C. King, Esq., Westminster Captain Sydney D. Kitson, F.S.A., F.R.I.B.A., Kirklington, Notts.

Frederick A. Konig, Tyringham, Bucks.

Messrs. H. A. Kramers \& Son, Ltd., Booksellers, Rotterdam

M. Kundig, Libraire, Geneva

Major The Rt. Hon. Viscount Lascelles, D.S.O.

The Rt. Hon. Lady Leconfield 


\section{LIST OF SUBSCRIBERS}

The Rt. Hon. Lord Leith of Fyvie

The Rt. Hon. Lord Leverhulme

The Hon. Claud Lambton

The Hon. Mrs. Archibald Langman

The Hon. Irwin B. Laughlin

Sir Edwin L. Lutyens, A.R.A.,

F.R.I.B.A.

The Leeds Library, Leeds

Leeds Public Libraries, per Thomas

W. Hand, Esq., City Librarian

Leeds \& West Yorkshire Architectural Society, per G. J. Coombs, Esq., A.R.C.A.

Leicestershire Society of Architects, per F. B. Cooper, Esq., A.R.I.B.A.

Leicestershire Book Society, per Major W. J. Freer, V.D., D.L., F.S.A.

Liverpool Public Libraries, per

G. T. Shaw Esq., Librarian

The London Library, per C. T. Hagberg Wright, Esq., LL.D.

Charles E. Lamb, Esq., Kettering

R. E. Lambert, Esq., Battle, Sussex

Messrs. Lamley \& Co., Booksellers, Kensington, S.W.

Mrs. Laycock, Wiseton, Bawtry, Yorks.

Stanley H. le Fleming, Esq., D.I.,, J.P., Ambleside

Frank H. Lehany, Esq., London,N.E. Mrs. Gerard Leigh, London, W.

Walter L. Levett, Esq., Monmouth Walter Lewis, Esq., Redditch

Messrs. Liberty \& Co., Ltd., London Captain C. O. Liddell, Chepstow

Mrs. Linley-Howlden, Freshford, Somerset

F. H. Livens, M.Inst.C.E., Lincoln

Nathaniel Lloyd, Esq., O.B.E.,

Great Dixter, Northiam

James Lochhead, Esq., F.R.I.B.A., Hamilton

Mr. Morton Loder, Bookseller, Woodridge
London Literary Lounge, London, W. per James Truslove, Esq.

The Rev. A. M. Luckock, M.A., Titchmarsh, Thrapston

G. D. Lumb, Esq., F.S.A., Leeds

The Rt. Hon. The Countess of Mount-Edgcumbe

The Rt. Hon. Lady Monk Bretton

The Hon. Lady Miller

The Rt. Hon. H. D. McLaren, M.P. Sir Kenneth Matheson, Bt., D.L., J.P. A. C. Macdonald, Esq., J.P., Ipley Manor, Marchwood, Hants

J. W. Macfie, Esq.

James McLachlan, Esq., Edinburgh Messrs. James Maclehose \& Sons, Booksellers, Glasgow

S. A. Macleish, Esq., Liverpool

George A. Macmillan, Esq., D.Litt., J.P., London, S.W.

Messrs. Macniven \& Wallace, Booksellers, Edinburgh

Donald D. Macpherson, Esq., Radbrook Hall, Salop

Major F. Maitland, R.G.A., Nodes Point Battery, St. Helen's, I. ofW.

Lieut. S. Mallinson, Leeds

Colonel E. W. Margesson, Worthing A. E. Marlow, Esq., Preston Deanery Hall, Northampton

Mrs. Henry W. Marsh, Warwick Castle

R. T. Marsh, Esq., J.P., Kenyon, Lancs.

Messrs. Marsh, Jones \& Cribb, Leeds

Messrs. H. H. Martyn \& Co., Ltd., Cheltenham

T. P. Marwick, Esq., A.R.I.B.A., Edinburgh

H. R. Maunsell, Esq., Dublin

Messrs. Mawson, Swan, \& Morgan, Booksellers, Newcastle-on-Tyne 


\section{LIST OF SUBSCRIBERS}

Medens Bokhandels, A.B., Gothenburg

Melville \& Mullen Propty, Ltd., Booksellers, Melbourne

Claude Miller, Esq., London, W.

James Miller, Esq., A.R.S.A., F.R.I.B.A., Glasgow

Lt.-Col. David Milne-Home of Wedderburn, D.L., J.P., Berwickon-Tweed

Messrs. Minchin \& Gibbs, Booksellers, Gloucester

Messrs. Minshull \& Meeson, Booksellers, Chester

Major Charles Mitchell, J.P., Cornhill-on-T.weed

F. C. Montague, Esq., Oxford

F. Frankfort Moore, Esq., Lewes, Sussex

William Mordey, Esq., King's Acre, Newport, Mon.

Reginald Morphew, Esq., Polperro, Cornwall

J. H. Morrison, Esq.

William J. Moscrop, Esq., F.R.I.B.A. Darlington

Thomas Muddiman, Esq., London

Messrs. Wm. Mullan \& Son, Booksellers, Belfast

D. L. Murdoch, Esq., Mauchline, Ayrshire

Mrs. Evelyn Murray, London, W. John Murray, Esq., F.R.I.B.A., London, S.W.

H. E. C. Murton, Esq., Jesmond, Newcastle-on-Tyne

The Rev. The Most Hon. The Marquis of Normanby, D.L.,J.P. Lady Henry Nevill

The Rt. Hon. Lady Newborough

The Hon. Harold Nicholson

Newcastle-upon-Tyne Public Library per Basil Anderton, Esq., M.A.
Northampton Public Library, per Reginald W. Brown, Esq.

Nottingham School of Art, per - Joseph Harrison, Esq., A.R.C.A.

Miss C. Clare Nauheim, London, N.W.

Mrs. Nelson, Sandford St. Martin, Oxon

The Rev. Hugh Nelson-Ward, M.A. Wicken, Stony-Stratford

Captain T. N. C. Nevill, Bramall Hall nr. Stockport

Arthur C. Newsum, Esq., Lincoln

Messrs. Nicholls \& Jones, High Wycombe

Monsieur Edouard Isidore Niffle, U.P.A. Lg., London, E.C.

Mr. Martinus Nijhoff, Bookseller, The Hague

Nordiska Kompaniet, Booksellers, Stockholm

E. Norkett, Esq., Art Metal Works, Maidenhead

Simeon H. Norman, Esq.,

Burgess Hill, Sussex

Lady Beatrice Ormsby-Gore

Lady Christian Ogilvy

Sir John R. O'Connell, M.A., LL.D. The Ven. Archdeacon of Oakham, Uppingham

George H. Oatley, Esq., F.R.I.B.A., Bristol

Maurice A. Ockenden, Esq., M.I.Mech.E., F.G.S., London John A. O'Connell, Esq., Cork John H. Oglander, Esq., D.L., J.P.

F.S.A., Brading, I. of W.

Basil Oliver, Esq., A.R.I.B.A.,

Dunfermline

Mr. S. Opdenberg, Bookseller, The Hague

H. Ormerod, Esq., Brighouse, Yorks Mr. John Orr, Bookseller, Edinburgh 


\section{LIST OF SUBSCRIBERS}

Joseph Oswald, Esq., F.R.I.B.A., Newcastle-on-Tyne

Mrs. E. Grace Outhwaite, Roxford, Marton, Yorks.

Mr. George E. Over, Bookseller, Rugby

Segar Owen, Esq., F.R.I.B.A., Warrington

Captain Tudor Owen, London, W.

Her Grace The Duchess of Portland The Rt. Hon. The Earl of Powis

Paisley Public Library, per John Renfrew, Esq., Librarian

F. E. Pagniez, Esq., Leigh-on-Sea

Messrs. Parker \& Son, Booksellers, Oxford

Edmund Parsons, Esq., Tyhurst, Andover

Messrs. E. Parsons \& Sons, Booksellers, London, S.W.

Mrs. Paynter, Amlwch, N. Wales

James Bernard Paynter, Esq., Yeovil

Messrs. Percival Pearse, Ltd., Booksellers, Warrington

Herbert Pearson, Esq., Wokingham, Berks.

Mrs. Albert J. Pell, Bury St. Edmunds Herbert S. Pepper, Esq., Birmingham F. Thorpe Perry, Esq., Carcolston, Notts.

Mrs. J. M. Perry, Nottingham

J. T. Perry, Esq., Nottingham

Messrs. Perry \& Co., London, W.

Charles H. Petter, Esq., Ilfracombe

Mrs. Petty, Crosshills, nr. Keighley

Messrs. Philipson \& Golder, Booksellers, Chester

S. Perkins Pick, Esq., F.S.A., F.R.I.B.A., Leicester

Robert Young Pickering, Esq., Conheath, Dumfries

H, H. Pillans, Esq., Edinburgh
Ernest Pitman, Esq., London, W.C.

Francis W. Pixley, Esq., J.P.,F.S.A.

Wooburn House, Wooburn,

Buckinghamshire

Walter Plomer-Young, Esq.,

London, S.W.

John Poland, Esq., F.R.C.S., Seal, Kent

Lt.-Col. D'Arcy Power, R.A.M.C. (T.), F.S.A., London, W.

Mr. Fred. Power, Bookseller, Bradford

Mr. G. A. Poynder, Bookseller, Reading

E. R. Pratt, Esq., J.P., D.L., C.C., Downham, Norfolk

Messrs. Christopher Pratt \& Sons, Ltd., Bradford

A. N. Prentice, Esq., F.R.I.B.A., London, W.C.

Mrs. Price, Coggeshall, Essex

L. L. Price, Esq., M.A., Fellow of Oriel College, Oxford

B. C. Prichard, Esq., Cambridge

J. Sutcliffe Pyman, Esq., London,W.

Messrs. Bernard Quaritch, Ltd., Booksellers, London, W.

C. H. B. Quennell, Esq., F.R.I.B.A. Westminster, S.W.

The Rt. Hon. The Earl of Rocksavage

Sir Herbert Raphael, Bt., M.P., J.P. Royal Institute of British Architects, per Rudolf Dircks, Esq., Librarian Mrs. Ratcliffe, Prestbury, Glos.

Willingham Franklin Rawnsley, M.A., J.P., Shamley Green

Thomas Rayson, Esq., A.R.I.B.A., Witney, Oxon

R. Charles Reed, Esq., Bourne End, Bucks. 


\section{LIST OF SUBSCRIBERS}

Messrs. Hugh Rees, Ltd., Booksellers, London, W.

Herbert K. Reeves, Esq., Leatherhead The Rev. Oswald J. Reichel, M.A., F.S.A., Lympston, Devon

Captain F. H. Reynard, Bedale, Yorks. Mrs. Reynolds, Bloxham, nr. Banbury E. F. Reynolds, Esq., Lic.R.I.B.A., Birmingham

Mrs. H. Davis-Richter, London, S.W.

Messrs. J. Rimell \& Son, Booksellers, London, W.

Mr. Jacs. G. Robbers, Bookseller, Amsterdam

Vernon Roberts, Esq., Kincardine Castle, Auchterarder

Messrs. G. Robertson \& Co. Propy, Ltd., Booksellers, London, E.C.

Robert Burns Robertson, Esq., F.S.A. (Scot.), Windsor Castle

Miss D. C. Robinson, Dalston, Cumberland

W. H. Romaine-Walker, Esq., A.R.I.B.A., London, W.

Miss Rooke, Mealsgate, Cumberland W. Roscoe, Esq.

Messrs. Wilson Ross \& Co., Ltd., Booksellers, Edinburgh

Miss Roughsedge, Hoylake, Cheshire

Mr. Walter Ruck, Bookseller, Maidstone

C. D. Ruding-Bryan, Esq., Clifton, Bristol

Captain C. E. A. L. Rumbold, Godminster Manor, Bruton

Barrie Russell, Esq., Gloucester Hotel, Weymouth

S. B. Russell, Esq., Broadway, Worcestershire

Charles T. Ruthen, Esq., O.B.E., Lic.R.I.B.A., Swansea

The Most Hon. The Marquis of Salisbury, G.C.V.O.
The Most Hon. The Marchiones: of Sligo

The Rt. Hon. The Earl of Stafford

Lady Octavia Shaw Stewart

The Rt. Hon. The Viscountess St. Davids

The Rt. Hon. Lady Sackville

The Rt. Hon. Lord Sheffield

The Rt. Hon. Lord Sherborne

Sir Henry Samuelson, Bt.

Sir Edward Stern

Sir Frank Swettenham, G.C.M.G.

Sheffield Public Libraries, per Samue Smith, Esq., Librarian

Sheffield University Library, per W. S. Purchon, Esq., M.A.

Somersetshire Archæological Societ! per H. St. George Gray, Esq. Atkinson Free Library, Southporı per F. H. Mills, Esq., Librarian Juán E. Sackman, Esq., London, S.E S. G. Stopford Sackville, Esq., M.A D.L., J.P., Thrapston

Julian Sampson, Esq., London, W.C Mrs. Mahlon Sänds, Campden, Glo: Messrs. Sands \& McDougall Propy Ltd., London, E.C.

V. G. Santo, Esq., A.R.I.B.A., Coddington Hall, Newark

A. Sassoon, Esq., for Clifton Colleg Library

Octavius Satchell, Esq., London, W H. N. Savill, Esq., London, W.C.

Mr. Henry B. Saxton, Bookselle Nottingham

John Scott, Esq., Ilkley, Yorks

Allen W. Seaby, Esq., Universit College, Reading

H. Gordon Selfridge, Esq., London, $\mathrm{W}$ Mrs. Arthur Shephard, Kensington

Messrs. Sherratt \& Hughes, Bool sellers, Manchester

R. D. Shirley, Esq., Burlesdon Rectory, Southampton 


\section{LIST OF SUBSCRIBERS}

Coningsby C. Sibthorpe, Esq., D.L., J.P., Canwick, Lincoln

Mr. S. W. Simms, Bookseller, Bath Messrs. Simpkin, Marshall, Hamilton, Kent \& Co., Ltd., London, E.C.

Jonathan Simpson, Esq., F.R.I.B.A., Bolton

J. J. Simpson, Esq., Cotham Park, Bristol

Messrs. Sinclair \& Woolston, Ltd., Booksellers, Nottingham

Messrs. Walter Skull \& Son, Ltd., High Wycombe

Major E. H. Sleigh, The Curragh, Kildare

H. Sutcliffe Smith, Esq., Baildon, Yorks.

J. P. Smith, Esq., Barrow-in-Furness

Messrs. John Smith \& Son, Ltd., Booksellers, Glasgow

R. Freeman Smith, Esq., Hampstead Messrs. W. H. Smith \& Son, Booksellers, London, W.C.

Messrs. W. H. Smith \& Son, Ltd., Booksellers, Harrogate

Messrs. W. H. Smith \& Son, Ltd., Booksellers, York

Mrs. Aldwin Soames, Moor Park, Farnham

Messrs. H. Sotheran \& Co., Booksellers, London, W.

Messrs. Spottiswoode, Ballantyne \& Co., Ltd., Eton

Wm. Barclay Squire, Esq., Kensington, W.

H.M. Stationery Office, London, S.W.

Messrs. G. E. Stechert \& Co., Booksellers, London, W.C.

H. Steel, Esq., Skellow Grange, nr. Doncaster

Albert J. Stephens, Esq., Gloucester Prof. J. E. A. Steggall, M.A., J.P., University College, Dundee
Capt.William J. Stephens, R.A.M.C. Newquay

R. H. Stephenson, Esq., Leicester Messrs. B. F. Stevens \& Brown, Booksellers, London, W.C.

Henry Stewart, Esq., Lieut., R.G.A., Kelvinside, Glasgow

J. Hutton Stott, Esq., Southport

Philip Sidney Stott, Esq., Broadway,

Worcestershire

Mrs. John C. Straker, Hexham

Arthur Stratton, Esq., F.S.A.,

F.R.I.B.A., London, W.C.

W. G. Strickland, Esq., Dublin

Charles W. Stringer, Esq., Kettering

Mr. F. Sturt, Bookseller, Farnham, Surrey

Canon A. F. Sutton, F.S.A., Newarkon-Trent, Surrey

Col. M. A. W. Swinfen-Broun, Swinfen Hall, Lichfield

Commander Harold Swithinbank, Denham, Bucks.

The Rt. Hon. Lord Triowen

The Hon. Mrs. Townshend

Sir A. Brumwell Thomas, F.R.I.B.A. Travellers' Club, London, S.W., per

Sir Almeric Fitzroy, K.C.V.O.

The Rev. Prebendary Talbot, M.A.,

Newport, Salop

Mrs. J. M. Tankard, Baildon, Yorks Henry Tanner, Esq., F.R.I.B.A., London, W.

W. G. Tarrant, Esq., Byfleet, Surrey Sydney Tatchell, Esq., F.R.I.B.A., Westminster, S.W.

Captain Hurford Tatlow, M.C., London, W.

Mrs. Tempest, Skipton-in-Craven, Yorks.

A. H. Ryan Tenison, Esq., F.R.I.B.A., London, W. 


\section{LIST OF SUBSCRIBERS}

William C. Terry, Esq., Clapton

Mr. James Thin, Bookseller, Edinburgh

Mr. Charles E. Thomas, Bookseller, Worthing

P. A. Thomas, Esq., M.A., Malvern

Miss Amy H. Thompson, Bromley, Kent

C. W. W. Thompson, Esq., 2nd

Lieut. R.E., A.R.I.B.A.,Rochester

Edward P. Thompson, Esq., J.P., Whitchurch, Salop

H. D. Thompson, Esq., Lincoln

W. Stuart Thompson, Esq.,

Peterborough

T. Thornton-Berry, Esq., Bishop's Hull, Taunton

E. Thornton-Smith, Esq., London

Messrs. Thornton-Smith, Ltd., London, W.

Messrs. Thurnam \& Sons, Booksellers, Carlisle

Messrs. Frederick Tibbenham, Ltd., Ipswich

Times Book Club, London, W.

Cecil Torr, Esq., Yonder Wreyland

W. Charles Tozer, Esq., London, W.

Messrs. Truslove \& Hanson, Ltd., Booksellers, Clifford Street, W.

Messrs. Truslove \& Hanson, Ltd., Booksellers, Oxford Street, W.

Messrs. Truslove \& Hanson, Ltd., Booksellers, Sloane Street, S.W.

Mrs. F. Cecilia Tubbs, St. Leonardson-Sea

Grahame B. Tubbs, Esq., London

Mrs. Tuke, Chiswick, W.

W. Gladwin Turbutt, Esq., J.P., Ogston Hall, Alfreton

Mrs. Warner Turner, Mansfield

John Tweedy, Esq., Howth, Dublin

Mr. G. H. Tyndall, Bookseller, Ely
University College, London, Dept. of Architecture

The Hon. Mrs. Douglas Vickers

Sir Richard V. Vassar-Smith, Bt., D.L., J.P.

Sir Harry Vernon, Bt., D.L., J.P.

Sir Arthur Vicars, K.C.V.O., F.S.A. J. J. Van Alen, Esq., New York Messrs. H. A. Van Winsum \& J. Ver Wymeren, London, W. Lt.-Colonel T. T. Vernon, Chester

The Royal Library, Windsor Castle, per'The Hon. John Fortescue, F.S.A. Her Grace'The Duchess of Wellington The Rt. Hon. The Countess of Winchilsea \& Nottingham The Rt. Hon. Lady Wenlock The Hon. Mrs. Edward Wyndham Sir Aston Webb, R.A., F.S.A., F.R.I.B.A.

Wallasey Library, per The Rev. A. E. Parry, Librarian

Warrington Municipal Museum

Westminster Public Libraries, per Frank Pacy, Esq., Librarian

Weston-super-Mare Public Library, per Miss Alston

Chas. Wade, Esq., Forest Gate, Essex Philip K. Wake, Esq., J.P., Handsworth Grange, Sheffield

Mr. Henry Walker, Bookseller, Leeds J. Reid Walker, Esq., J.P., Shifnal, Salop

Captain J. W. Walker, F.S.A., Chapelthorpe, Wakefield

Colonel W. Hall Walker, M.P., D.L. Gresford, Denbigh

Pickford Waller, Esq., Boscombe, Hants.

Colonel Horace Walpole, Winchfield 


\section{LIST OF SUBSCRIBERS}

Miss E. M. Walters, Long Stanton, nr. Cambridge

Mrs. Warde-Aldam, Hooton Pagnell Hall, Doncaster

S. J. Waring, Esq., London, W.

Messrs. Waring \& Gillow, Ltd., Lancaster

Messrs. Waring \& Gillow, Ltd., London

Messrs. Waring \& Gillow, Ltd., Manchester

Bertrand J. Waterhouse, Esq., Sydney, N.S.W.

Vernon Watney, Esq., M.A., J.P., F.S.A., Cornbury Park, Oxon

Humphry Watts, Esq., Clent, Stourbridge

Hugh Weguelin, Esq., London, S.W.

R. W. S. Weir, Esq., London, W.C.

R. Douglas Wells, Esq., F.R.I.B.A., Kensington, W.

Adolph H. C. Wenger, Esq., Trentham Priory, nr. Stoke-on-Trent

Arthur Whereat, Esq., Clifton, Bristol

Messrs. J. Whitehead \& Sons, Ltd., London, S.E.

Lt.-Col. Henry Wickham, C.M.G., J.P., Cotterstock Hall, Oundle

Chas. Wicksteed, Esq., J.P., C.A., Kettering

Mrs. Wigan, Windsor

Mr. J. M. Wigley, Bookseller, Lancaster

The Rev. H. J. Wilkins, D.D., Redland Vicarage, Bristol

Chas. Williams, Esq., Cheltenham
Messrs. Clement Williams \& Sons, Halifax

H. Williams, Esq., London, E.C. Sidney Herbert Williams, Esq., St. Leonards-on-Sea

Henry Williamson, Esq., Maryport

J. Bertram Wills, Esq., A.R.I.B.A., Bristol

Mr. D. Wilson, Bookseller, Bradford

W. B. Winckworth, Esq., Taunton

E. Ernest Winterbotham, Esq., Hampstead, N.W.

F. Arthur Wodsworth, Esq., Nottingham

P. W. Wood, Esq., Emmanuel College, Cambridge

G. Grey Wornum, Esq., Nottingham George Wragge, Esq., Kensington Wm. Wright, Esq., One Ash, nr. Loughborough

The Rev. W. Wykes-Finch, M.A., J.P., Chaddesley Corbett

York Public Library, per A. H. Furnish, Esq., City Librarian

Edward Yates, Esq., London, E.C.

Thomas Charles Yates, Esq., Kensington, W.

H. S. Young, Esq., Crosby, Liverpool

Messrs. Henry Young \& Sons, Ltd., Booksellers, Liverpool

J. M. Zarifi, Esq., London, W.

Agents for the United States of America CHARLES SCRIBNER'S SONS FIFTH AVENUE, NEW YORK 



\section{PREF A CE}

THE following pages take up the story of the English House at the point to which it was carried in my former work on Early Renaissance Architecture in England, and carry it to the beginning of the nineteenth century. Between them the two books present the history of domestic architecture from the time when houses were becoming homes instead of fortresses, until a period well within the recollection of our grandfathers.

During the three centuries thus covered, houses were built and decorated in successive styles, which were universally accepted at the time. The prevailing character of these styles was derived from classic sources, as distinguished from our native Gothic traditions, and it owed its origin to the Renaissance style of Italy. The earlier efforts towards the change are visible in the work of the sixteenth century and of the first quarter of the seventeenth.

With the advent of Inigo Jones, however, a further impulse was given to the desire for a classic treatment of architecture; and it is this impulse and its consequences which form the basis of the present inquiry.

There are two views as to English architecture of the seventeenth and eighteenth centuries. On the one hand, it is held that in the days of Elizabeth architectural design shows a freshness, vivacity, and originality which express the genius of the time, and result in a truly national style, albeit one which never quite fulfilled its promise; and that in later periods designers became more and more imitative, and thereby lost from their 
work, however correct and refined, those qualities which make for supreme achievement. On the other hand, it is held that the designers of Elizabeth's time were hampered in their efforts at architectural expression by a lack of knowledge; that they discarded many of the old ideas without appreciating the full significance of the new ideas which they were anxious to adopt; and that as they gained wider knowledge, so did their architecture improve.

Much can be said for either of these views, which indeed are not wholly inconsistent with each other; but it is my desire in the following pages to avoid controversy, and to present the domestic side of the subject throughout the period under review in a sympathetic spirit.

During the nineteenth century an increase of acquaintance with the past led to the adoption of so many different phases of style as almost to eliminate the interest derived from historical continuity. But the study of the past need not necessarily have this effect; if rightly directed, the inventive genius of the present will find in the past a great help for the future.

I have to express my thanks to many persons who have assisted by supplying material for the illustrations, and especially to the owners of the various houses who have kindly permitted them to be photographed. Of the numerous drawings which have been reproduced, some, connected with Inigo Jones, are from the collection at Chatsworth House, by the kindness of the Duke of Devonshire; and others by Jones and John Webb are from the Burlington-Devonshire Collection, in the possession of the Royal Institute of British Architects, by permission of the Council. For leave to include other contemporary drawings I have to thank the Provost of Worcester College, Oxford; the Warden of All Souls College, Oxford; and the authorities of the Bodleian 
Library; while the illustrations selected from the Smithson Collection are reproduced by the kind permission of the owner. The drawings by Thomas Sandby and Edward Dayes are from the British Museum and the Victoria and Albert Museum, South Kensington, respectively.

The proprietors of Country Life have kindly furnished Figs. 162-63, and the Publishers have supplied illustrations from various works issued by them, including reproductions of two of $\mathrm{Mr}$ Triggs' drawings from "Formal Gardens in England and Scotland," and some of $\mathrm{Mr}$ Tanner's drawings from "Inigo Jones" and "Interior Woodwork."

I am indebted to the following photographers for permission to include photographs taken by them :-Messrs Bedford, Lemere \& Co., Figs. I41, I43-44, 3 I 8 ; Messrs F. Frith \& Co., Figs. 4, 5, 56, and 255; Messrs Hills and Saunders, Fig. I 55 ; and Mr H. Evans, Fig. 52 . A number of photographs have been contributed by $\mathrm{Mr}$ Montague Cooper, Mr F. H. Crossley, Mr Horace Dan, and Dr G. Granville Buckley. Other subjects have been furnished by $\mathrm{Mr}$ A. E. Walsham, Messrs Thos. Lewis Ltd., of Birmingham, and the late Mr W. Galsworthy Davie, while those not otherwise mentioned are from negatives taken by myself.

I must also acknowledge with thanks the kindness of Mr E. R. M. Pratt, of Ryston Hall, Norfolk, in placing at my disposal the contents of his ancestor's note-books mentioned in the Appendix.

$$
\text { J. A. GOTCH. }
$$

KETTERING, April I918. 



\section{CONTENTS}

CHAP.

I. INTRODUC'TION

PAGE

Evolution of the Modern House-Elizabethan Domestic Arrangements-First Signs of Transition-Gradual Disappearance of Jacobean Features-Predominance of the Classic Style-The Gothic Revival

\section{THE CHANGE IN STYLE}

The Native versus the Italian Method-Change in the Status of the Architect-The Influence of Architectural Books-The Smithson Drawings

\section{INIGO JONES}

Jacobean Design still Prevalent-Significance of the Banqueting House, Whitehall-The Early Life of Inigo Jones-His Drawings and his Authentic Exe. cuted Work-His Pupil and Assistant-Work Attributed to Jones--Characteristics of his Genius

\section{THE DRAWINGS OF INIGO .JONES AND JOHN WEBB}

The Whitehall Designs and their Authorship - John Webb: his Relation to Jones and Subsequent Career-Contemporary Evidence on the Drawings - Webb's Executed Work

\section{THE TRANSITION IN MINOR BUILDINGS AND INTERIORS}

Lingering Jacobean Detail-Some Country Houses of the Transitional Period-Curious Blending of the Old and New Styles-Charm of some of the Successful Examples--Remodelling of Domestic Fittings - 
CllAP.

PAGE

VI. SIR CHRISTOPHER WREN

His Life and Early Work-First Design for St Paul's Cathedral-The Work of Building-Other Work, including Greenwich and Hampton Court-Contemporary Esteem-His Influence on the Subsequent Course of Architecture-Domestic Work Attributed to him

VII. SOME FURTHER WORK OF THE 'TIME OF CHARLES II.

Sir Balthazar Gerbier's "Counsel to Builders"-_"Captain Wynne" and his Work-Hamstead Marshall and Old Buckingham House-L - London after the Great FireCity Halls and Churches-Some Smaller Houses Outside London

I $6 I$

\section{GREAT HOUSES AND GARDENS OF THE EIGHTEENTH CENTURY}

Houses of the Nobility-Grandeur of the Designs and Lay Outs - Boughton House, Dyrham Park, and Chatsworth--Nicholas Hawksmoor and his Work at Easton Neston - Lord Burlington and Sir John Vanbrugh-Castle Howard and Blenheim-Formal and Landscape Gardens

I95

\section{GEORGIAN HOUSES}

The Character of Eighteenth-Century Houses-Campbell, Gibbs, and other Designers-Interior Design and Decoration-Typical Georgian Mansions: Houghton and IVentworth Woodhouse-The Woods of Bath and Contemporary Town-Planning - William Kent and Holkham-The Brothers Adam -

\section{SMALLER HOUSES, TOWN HOUSES, AND EX'TERIOR FEA'TURES}

Charm of the Smaller Georgian House - Streets and Market Places of Country Towns-Inns and ShopsLondon Houses of the Period-Their Interior Planning-Growth of the Suburbs in the Nineteenth Century - Exterior Features of Smaller Georgian Houses: Chimneys, Gates, Doors, and Porches-. Cupolas, Lantern Lights, Date-Stones, and Sundials - Garden Ornaments-Ornamental Iron and Lead Work - 
CHAP.

PAGF

XI. DECORATION AND INTERIOR FEATURES OF EIGHTEENTH-CENTURY HOUSES

Evolution of the Staircase-Its Treatment in Wood and Stone-The Classic Over-Door-Decoration of Walls : Wood Panelling and Carving, Moulded Plaster, Wall. Paper, and Tapestry-The Chimney-Piece, the FireGrate and its Accessories-Modelled and Painted Ceilings-Gradual Decline of the Personal Note in Craftsmanship-Conclusion -

APPENDIX I.-SIR ROGER PRATT - - 395

APPENDIX II.-THE ARCHITEC'TS OF COLES-

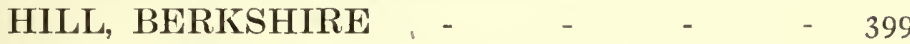

INDEX TO ILLUSTRA'TIONS AND 'TEX'T - 40I 



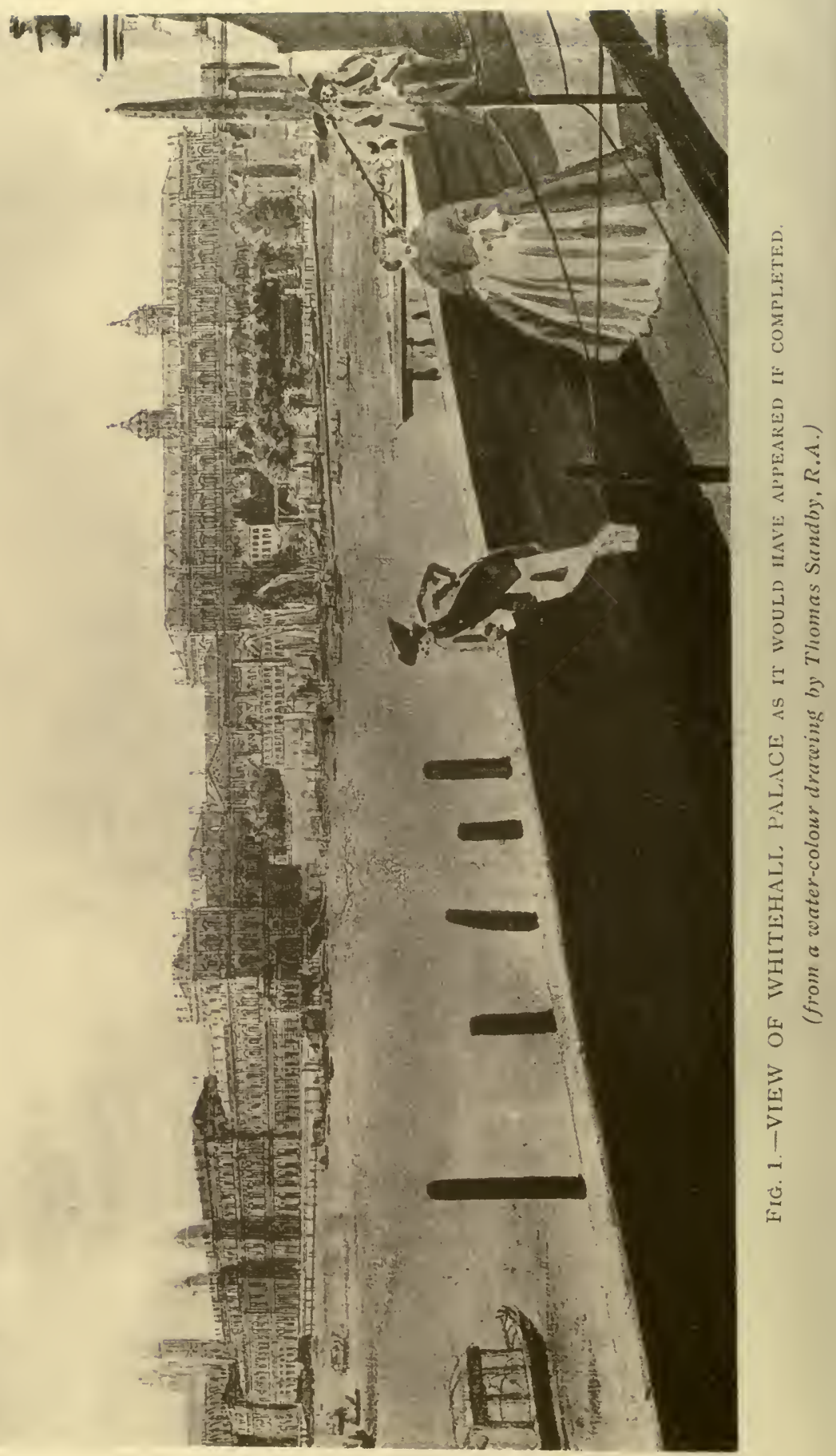




\section{THE ENGLISH HOME FROM CHARLES I. TO GEORGE IV.}

\section{I \\ INTRODUCTION}

Is England, more than in any other country, the affections of people in all ranks of life have clung round their homes; and to learn something of how those homes have changed in disposition and appearance with the changing times is an occupation not only fascinating in itself, but one which leads into regions of that personal interest which lends life and colour to the pictures of the historian.

So far as our present conception of a home is concerned, the time of Elizabeth may be held to have seen its birth; for, although the English house has an ancestry which goes back to the Conquest, yet it was in Elizabeth's days that houses were first built almost exclusively, for pleasure and delight. Hers was a great age of house building. Peace, wealth, and security from serious turmoil led men in all parts of the country to reconstruct their old homes or to build new ones; and records remain, either in actual buildings or in old plans, of houses of every size, from the great palaces of Burghley or Hatton wherein they entertained their sovereign, down to the little house, not forty feet square, which was devised for Sir Walter Raleigh in St James's. Much pains and great skill were expended in contriving these houses so that they should be convenient and welllooking. The planning of them was in the nature of a new experiment, for there was no precedent, either of extent or disposition, which was exactly to the point. The treatment of the exterior-in other words, their style of architecture-was also something fresh; for it became the fashion, gradually increasing in extent, to seek inspiration in this direction from Italy, a country which for more than a century had produced most marvellous buildings, both as to conception and as to the lovely detail with which they were embellished. 
This new demand in regard to style was partly met by inviting foreign workmen to this country, and partly by sending English designers to study in Italy; but the knowledge thus acquired was utilised by our native craftsmen in their own way. It influenced them, but did not enslave them. At first it puzzled them, with the result that much hybrid work was done which would have astonished both their Gothic forefathers and their Italian contemporaries, but which nevertheless has an attractive piquancy of its own.

This tentative stage lasted well into the seventeenth century, until the knowledge and genius of Inigo Jones, most ably seconded by John Webb, gradually wrought a revolution, and English architecture freed itself from the pleasant inaccuracies of its earlier exponents.

It is at the time when the old order was beginning to give way to the new that the story of the English House is taken up in the following pages. It will be pursued through the next two centuries. We shall see how the crude ideas of Elizabethan and Jacobean architects were mellowed under the influence of Inigo Jones; how John Webb carried on his master's teaching through the disturbed years of the Civil War; how wealthy men, following the lead of the Earl of Arundel, indulged their growing taste for collecting antiques, pictures, and other works of art. Houses will be described and pictured in which Evelyn and Pepys must have watched many of the events which they record in their pages.

In due course will come the great homes of the great nobles of William and Mary, of Anne and the Georges; homes which express in a vivid way the social distinctions of the times, and indicate the vast interval which lay between the duke and the merchant-more particularly in the opinion of the duke. It was at this period that domestic architecture reached the zenith of its splendour, aided, as it was, not only by the patronage of noblemen like Lord Burlington, but by their participation in the work of design. That they were able so to participate was largely owing to the publication of books on architecture, both ancient and modern. The point of view from which architecture was then regarded, largely determined by this literature, is of great historical interest, although the march of events has been adverse to its continued acceptance.

Contemporary with these great efforts in design were in- 
numerable smaller houses, essentially English in expression, and charmingly simple. In them lived men and women who helped to make the eighteenth century famous-Addison and Cowper, Reynolds and Garrick, Mrs Thrale and Frances Burney. But all through the eighteenth century the artificiality which marks much of its sentiment becomes every now and then apparent in its houses and their lay outs, wherein are sometimes to be found manufactured ruins and strange attempts at Gothic temples. Yet always is perceptible an earnest attempt at design. If in architecture itself the sense of design became somewhat dulled, it was still acute in the smaller matters of decoration, of furniture, and of articles for household use; the ornament which prevailed towards the close of the long period under review is quite admirable of its kind.

Such, very briefly indicated, is the ground to be traversed in the following inquiry. Some of it must be trodden with a light and hasty step; but it is hoped that the journey may not be without interest, and may perhaps induce the reader to explore at his leisure parts of the country of which here he will possibly catch but a glimpse. In the meantime let us return to our starting-point, where the old order began to give way to the new.

The history of English houses, from the time of James I. onwards, is a record of development on lines that were laid down in the time of Elizabeth. It was in her days that the great change from medirevalism took place, and houses were built for comfort and pleasure without any serious thought of defence. Such houses are still habitable; there are plenty of people living to-day in Elizabethan houses, but the enthusiasts are comparatively few who live from choice in the ill-lighted, vaulted rooms of the Middle Ages. Spaciousness, cheerfulness, dignity, and often magnificence, were the qualities aimed at in houses of the end of the sixteenth century; and these qualities are appropriate in the present day. Convenience is another matter; it is a relative term, and its significance varies with the varying wants of mankind, changes with their changing habits and customs.

An Elizabethan house provided admirable rooms for the common use of the family and guests-reception rooms as they would be called now. It also provided an adequate number of bedrooms. Further, so long as the great hall was the customary place for eating, the kitchen was conveniently situated, and the 


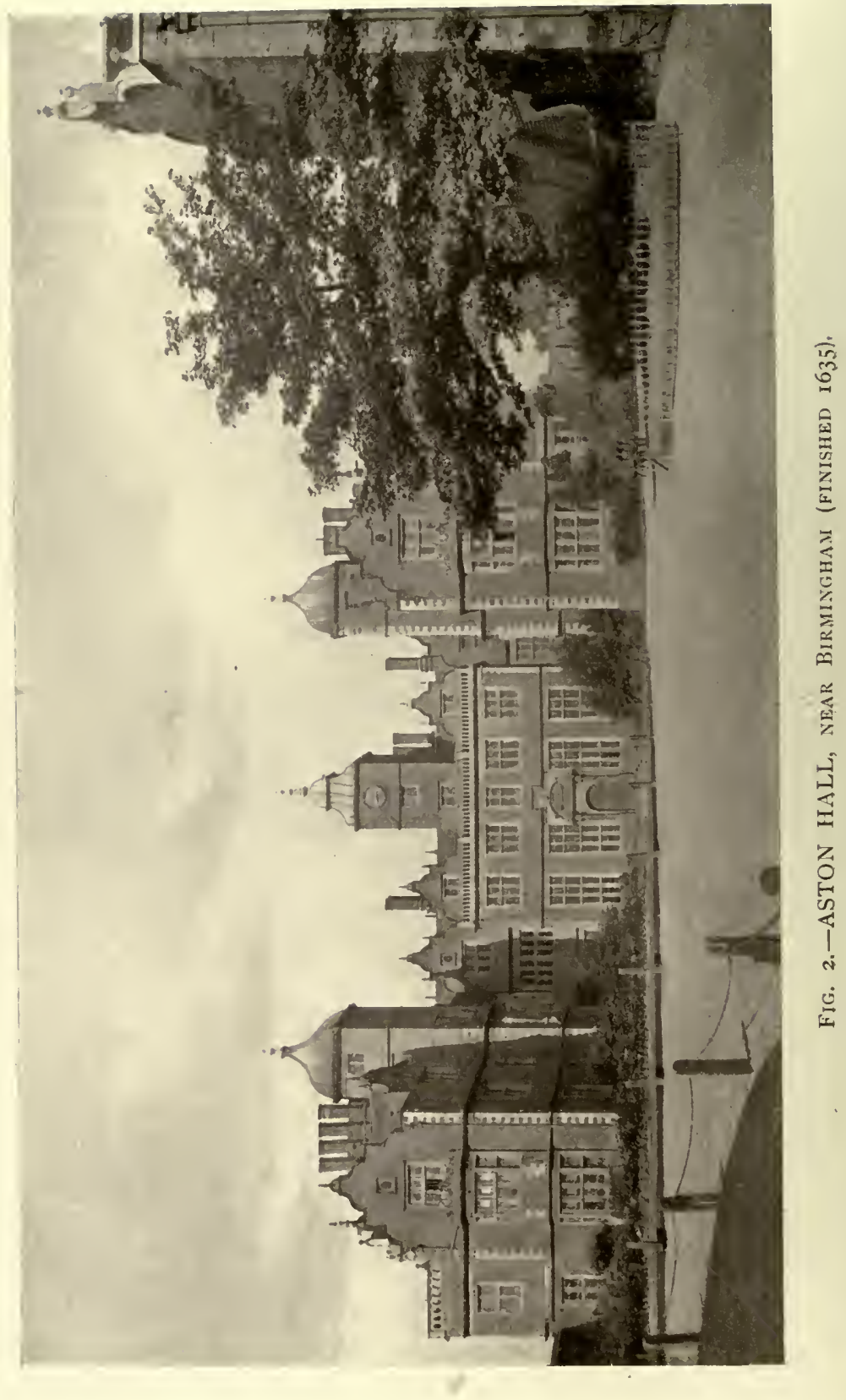


food was cooked within a reasonable distance of where it was consumed. In these respects, therefore, a house of that period fulfilled some of the chief requirements of the present day. The direction in which it failed when measured by modern standards was in its sanitary arrangements, which, indeed, judged by our own ideas, did not exist at all. But we must be careful not to argue backwards, and conclude that because things were lacking which we consider essential, therefore houses were found uncomfortable at the time. The better way is to accept what existed as satisfying the wants of the period, and to argue from that, if we please, how vastly we have improved in our own habits upon those of our ancestors.

In tracing the changes which took place in the arrangement and disposition of rooms during the seventeenth and eighteenth centuries, therefore, it will be found that not much was done which made houses essentially more comfortable, according to modern notions, than they had been in the late sixteenth century. Indeed, during much of the time comfort was very little studied, and it is one of the reproaches levelled at the architects of the early eighteenth century, more especially those who were concerned with houses of vast size, that their first thought was for display and their last for comfort. Pope's exclamation about Blenheim palace, "'Tis very fine, but when d'ye sleep and where d'ye dine?" crystallises much of the criticism that might be bestowed upon the large houses of that period, which, however, only reflected the spirit of the age. In these houses the most striking change that occurred was the abolition of homeliness. When the great Elizabethan house was planned, the household was in the nature of a large family. It is true that the members of the actual family grouped themselves in one wing and the servants in another, but the great hall was their common meeting ground, and the relations between the heads of the household and their servants were more affectionate than they became in later years. All the rooms, moreover, were intended for daily use, however finely they were decorated. The whole effect was one of stately homeliness. When the Queen Anne mansion was planned, much of it was devoted to state functions as a first consideration, and was intended for occasional use only; apartments suitable for this purpose having been provided, the rest of the space was allotted to the ordinary use of the family, and the servants were relegated to the basement (which they some- 


\section{INIGO JONES AND THE ITALIAN INFLUENCE}

times shared with their employers) or to a detached wing. Stateliness, not homeliness, was now the keynote. The nobleman stood on a pedestal of grandeur, round which his dependants grouped themselves as best they could, and among them struggled the parson, the poet, and the man of letters. The glorification of the individual found expression in his house and his gardens which were all designed with theatric magnificence.

The changes here indicated will be dcalt with at length in subsequent chapters; the first step towards them was taken when the hall ceased to be a living-room and became a vestibule, as the result of an alteration in domestic habits, an alteration which rendered easy the adoption of a house-plan more closely related than was formerly possible to those Italian models to which architects had been approximating their designs for half a century. So far, the models had been copied but halfheartedly, partly because of the conservatism of English habits, partly from incomplete knowledge of Italian methods of design. But as knowledge increased, both from the study of books and from the first-hand investigations of travelling students, so was the Italianising of English buildings accelerated; and a great obstacle to this progress was removed when the ancient use and position of the hall-which had a tradition of three centuries behind them-were no longer preserved. The movement indicated was by no means regular; it was quicker in some places than in others, and in some hands than in others: much depended upon the architects employed. Those who were learned, those who had travelled, and again those who were influenced by the cultured few, departed more completely from old-fashioned ways than did those who had not enjoyed the same advantages. The main stream of architectural development is fairly well marked and continuous; but there are innumerable backwaters in which the impetus of the current is hardly perceptible. As a consequence there are to be found as. late as the end of the seventeenth century buildings which look almost contemporary with those of the beginning:

The man who did more than anyone else to bring learning. to bear on design, and to introduce into England a true and correct knowledge of Italian detail, was that great artist, Inigo Jones. His first architectural work of importance was the Banqueting House at Whitehall, which was finished in I622, 
It has no trace of traditional English design about it (see Fig. 22). To us it appears a beautiful building, but by no means abnormal, because we can see many others of the same type. But to those who saw it when it was just built, it was something entirely novel, something in which they sought in vain for any of the customary devices for producing architectural effect. Doubtless it was a stimulant, but it did not revolutionise English architecture. Indeed, it was only Inigo Jones, and after him his pupil John Webb, who could pretend to work on such learned lines. The ordinary surveyors-of whom there must have been a large number, although their names have not survived-still worked in the hybrid style in which they had been trained, with the result that such a house as Aston Hall, near Birmingham, which was completed in 1635 , is thoroughly Jacobean in character (Fig. 2), although of sufficient importance to have warranted the adoption of the latest ideas in design, had they been at all widespread.

There is one point, however, in which Aston Hall shows the impending change in house-planning, and that is the disposition of the great hall. It is entered in the middle of one side, instead of through screens at the end, thus making a large vestibule of it instead of a living-room. The same treatment is to be found in some of the plans of John Smithson, an eminent architect of the time; and an examination of his drawings will presently be undertaken, in order to illustrate the steps which led from the Jacobean style to the more fully developed classic.

Nothing illustrates this change more aptly than a comparison between Smithson's drawings and those of Inigo Jones and John Webb. The first are Jacobean, the second are classic. In the Jacobean are seen efforts to sever the ties which ancient traditions still imposed; a striving after I talian detail, which was never thoroughly achieved; a mixture of a little oldfashioned romance, with a little new-fashioned learning. In the classic are seen an ignoring of tradition; a mastery of Italian methods; a mixture of sound knowledge with a feeling for good proportion. As an illustration of the first large building in England conceived in the fully developed classic style, nothing could be better than the drawing made by Thomas Sandby about the middle of the eighteenth century, showing how the great palace designed for Charles I. would have appeared (see Fig. I). It is also interesting in connection with 


\section{\& THE JACOBEAN TRADITION-ASTON HALL}

the inquiry into the Jones and Webb drawings, which will be fully dealt with in Chapter IV.

Incidentally a study of the drawings by Jones and Webb forces the inquirer to reconsider the relations of those two men as hitherto accepted, and compels him to readjust his ideas as to some of the work he had been taught to attribute to Jones.

IVith the seventeenth century we get into much closer touch with the designers of buildings than was possible in earlier times: in many cases we can get behind the buildings to their architects. But the chief purpose of the following pages is to trace the changes that took place in the houses themselves and their accessories, and although it would be neither possible nor desirable to omit all mention of the architects, the latter will be subsidiary to the main theme, and will be dealt with not so much biographically as by way of showing how their training, their opportunities and their idiosyncrasies affected the buildings with which they were concerned.

The present and immediate purpose is to give a brief and broad outlook over the period dealt with in detail in subsequent chapters; and to that end a series of houses has been selected, separated from each other in point of date by intervals of some twenty or thirty years.

The first of the series is Aston Hall (Fig. 2), which may be considered an example of how the old order lingered on. It has all the characteristics of Jacobean design, with its two pronounced wings, its curved gables, its fine chimney-stacks, and its mullioned windows : not to mention an open arcade and a forecourt with garden houses at the two outlying corners. These characteristics were gradually to disappear from houses. The plan became more compact, and wings were discarded, except that version of them which became fashionable later on, and which consisted of a separate block on either side of the main building, connected to it by a colonnade. Gables disappeared, the only approach to such features being the flat pediments which were often employed as central ornaments to the façades. Chimney-stacks became plainer, and the flues were massed into solid blocks, instead of rising in separate shafts from a common base. Mullioned windows lingered on for some years, but the mullions were of wood, and were insignificant compared with their stone predecessors. They were merely part of the wood window frame, and they dis- 
appeared almost entirely after the advent of the sash-window in the last quarter of the seventeenth century.

In the meantime, greater attention was paid to the cornices which made the circuit of the buildings; more especially was the topmost cornice emphasised-that from which the roof sprang. The general proportions of the building were more closely studied, and in particular the proportion of the window openings to the plain wall space.

Broadfield Hall, in Hertfordshire (Fig. 3), illustrates the advance along these lines. There are no wings and no gables.

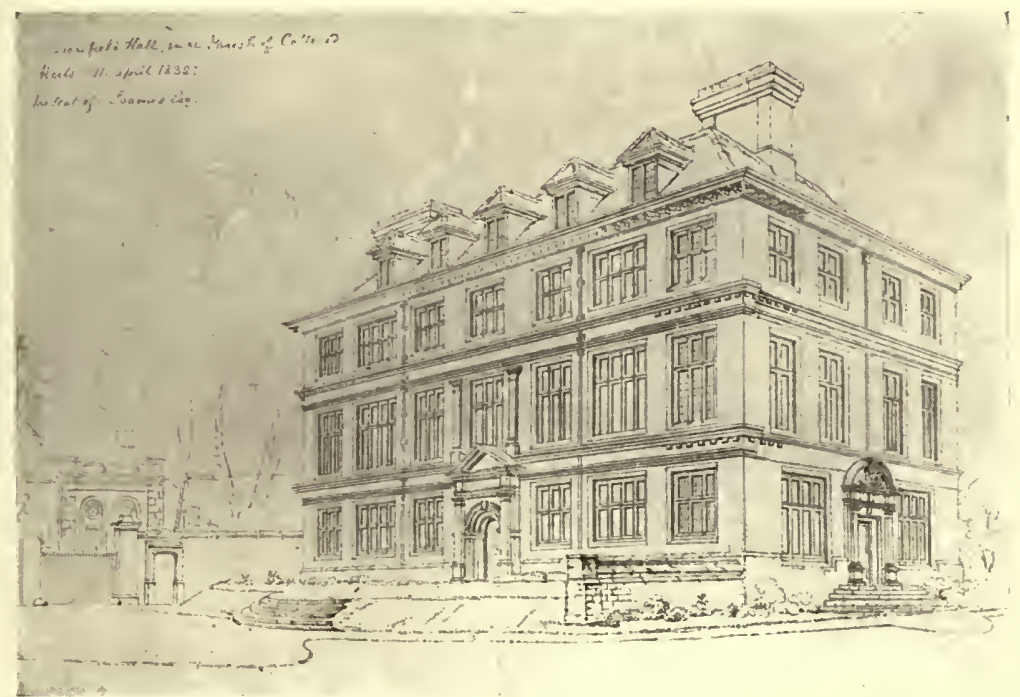

FIG. 3. - Broadfield Hall, Hertfordshire.

From a Drawing by Buckler, $18_{32}$.

Stone mullions are still retained; a bold cornice marks each story, the boldest being that on which the hipped roof rests. The flues are massed in two large stacks, and their existence is duly acknowledged, no attempt being made, as was sometimes the case in later times, to conceal them among irrelevant ornament. The dormer windows rise from the roof, and are no longer placed in portions of the main wall carried up for their reception. The unbroken cornice at the eaves necessitated this change. The old love of light still shows itself in the size of the windows, which are not yet subordinated to the claims of proportion. 


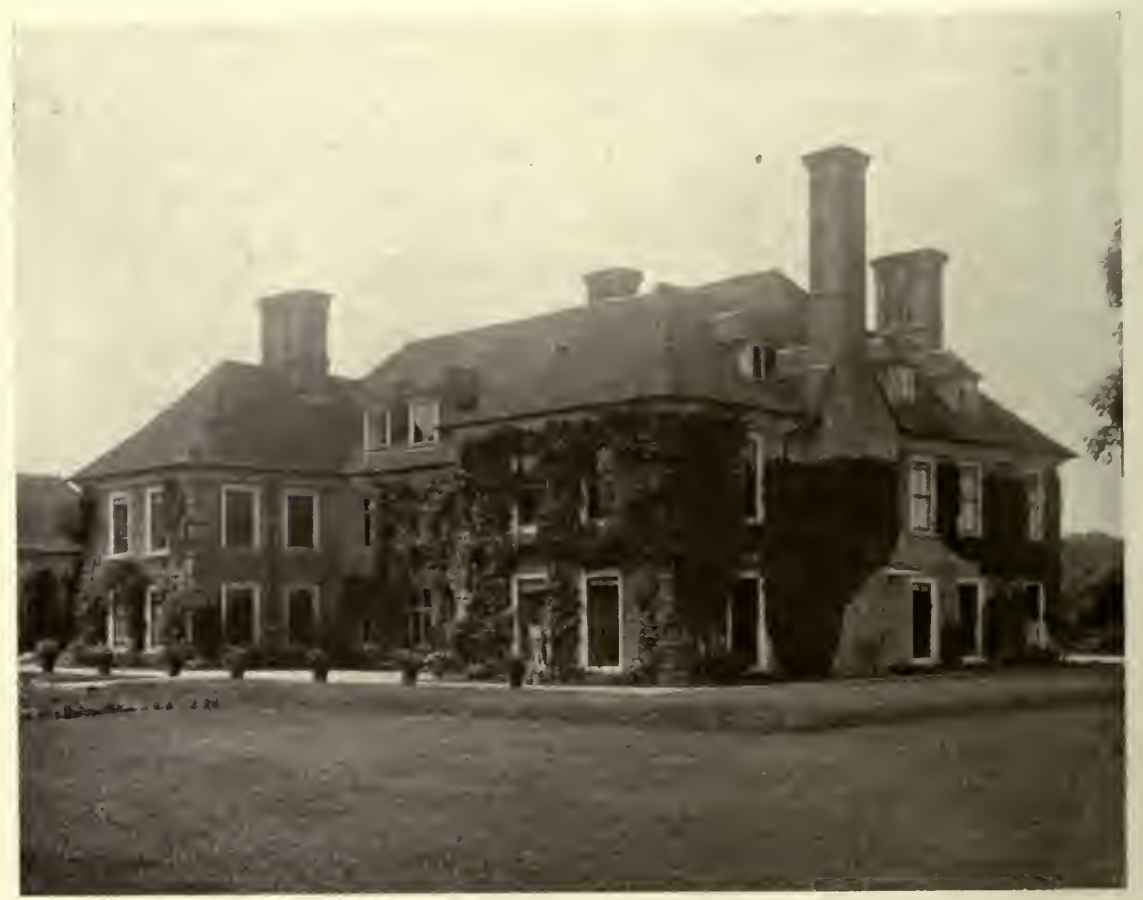

F1G. 4.-Moyles Court, Hampshire.

The exact date of this house has not been ascertained, but the style is characteristic of the middle of the seventeenth century, a period when no great amount of building was undertaken, owing to the disturbed state of the country consequent upon the Civil War. The time of Shakespeare is marked by a distinct style represented in hundreds of houses, but no such wealth of illustration enriches the time of Milton.

With the return of Charles II. a more settled state of affairs came about, and once more the stream of architecture flowed steadily onwards. Such houses as Moyles Court, in Hampshire (Fig. 4), were built in considerable numbers. There is nothing pretentious about them; they depend for their effect upon the regular spacing of the windows, and upon the strong shadow cast by the eaves cornice. The intermediate cornices of Broadfield have given way to a plain string. The windows are, many of them, sashes; but it would be rash to assert definitely that originally they were all so, because sashes had only recently been introduced. The chimney-stacks are large, and 


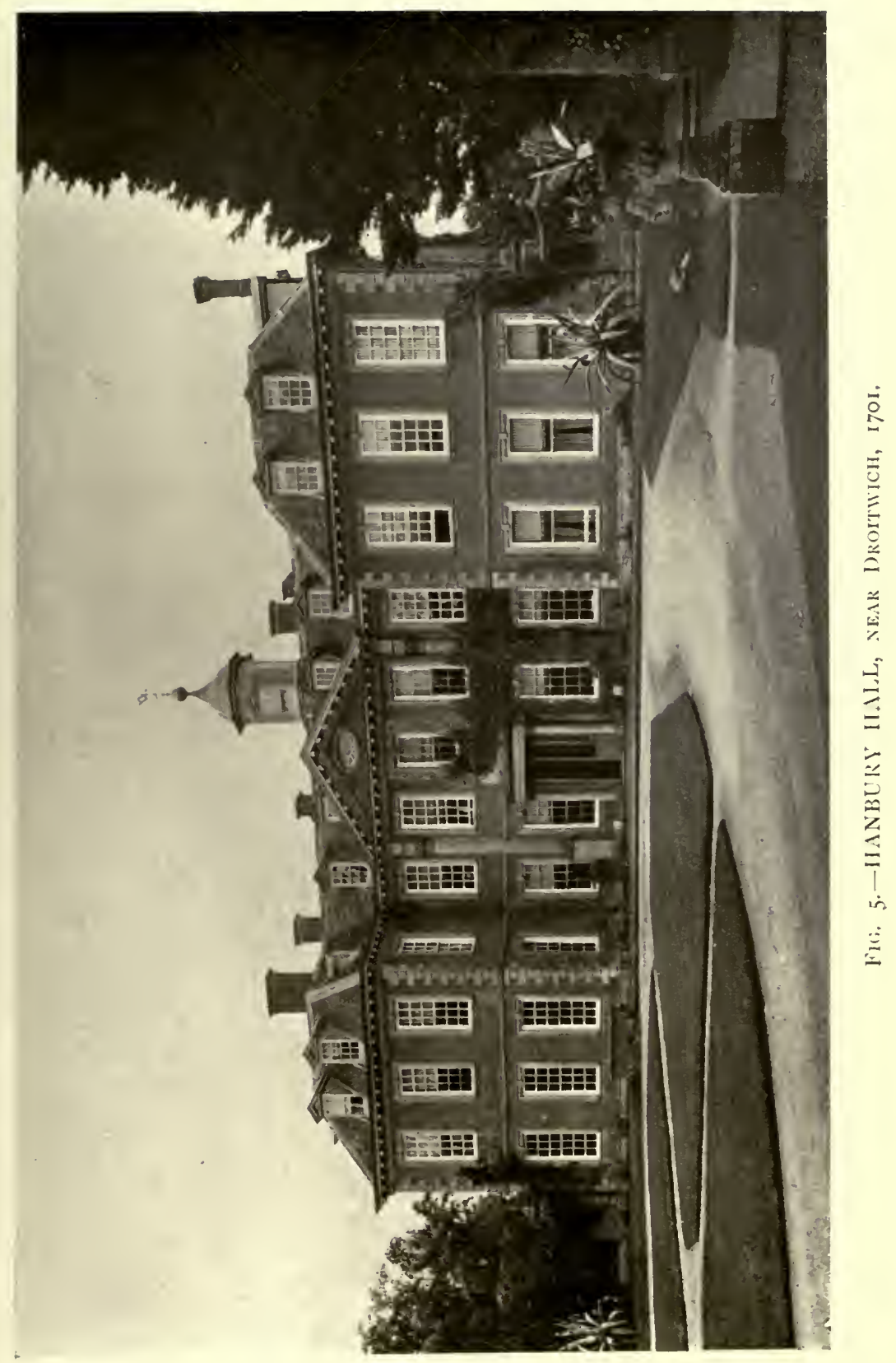




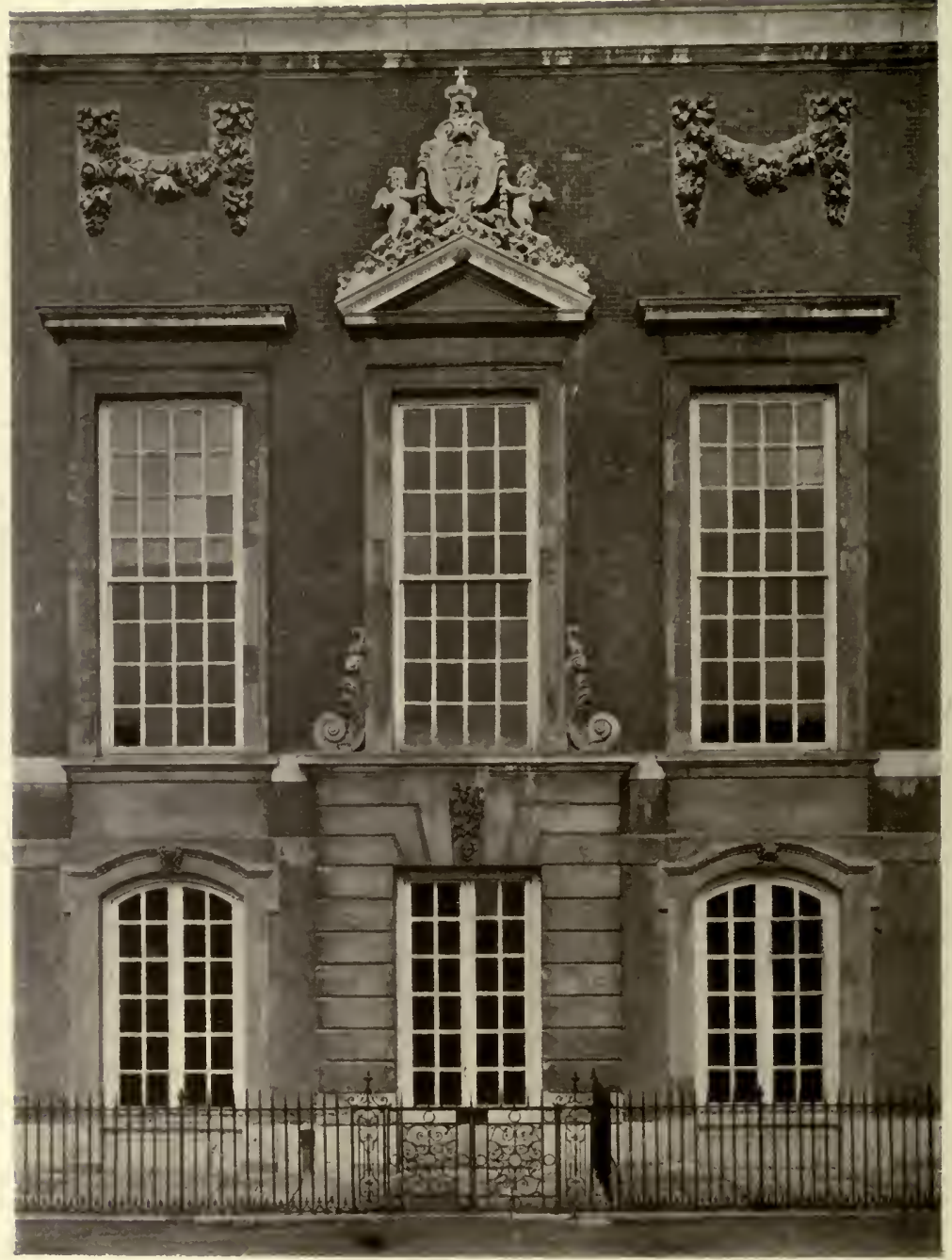

FIG. 6.-HAMPTON COURT.

PART OF THE RIVER FroNt, I689. 
have a certain amount of character about them. This particular example has two projecting wings, which may indicate that the house followed the lines of an earlier one, or they may merely be a survival of old ways; in either case they are not of the essence of the period. The date of the house is not recorded, but it was probably built between 1670 and 1680 , by that Dame Alice Lisle who suffered death in 1685 at the hands of Judge Jeffreys for sheltering a Nonconformist minister and a fugitive from Sedgemoor.

Of much the same character, but loftier and more dignified, is Hanbury Hall, near Droitwich, built in 1701 for a certain Thomas Vernon (Fig. 5). The façade is here emphasised by a pediment, which professes to be partly carried on two columns. Ornament goes but a little way towards producing the pleasing effect, which, in fact, is obtained by the windows (including the dormers), the quoins, and the bold eaves cornice. The cupola adds a note of interest; it is a feature which had been used by Inigo Jones, and before him, although designed on other lines, by Jacobean architects.

But a greater figure than the men who designed Moyles Court or Hanbury Hall occupied the stage at this time. This was Sir Christopher Wren, the greatest architect that England has produced. His work, however, lay for the most part outside the scope of the present inquiry which is chiefly concerned with domestic architecture. It was largely the city churches, and especially the noble cathedral of St Paul, that occupied and developed Wren's uncommon powers. Of ordinary domestic work, but little can be put to his credit with certainty. However, at the palace of Hampton Court (Fig. 6), he showed the same strong hand, the same virility of design which appear in his churches. Wren had mastered the medium in which he worked, and he used it with freedom, unfettered by slavish obedience to the rules which kept his less gifted successors in leading strings, and induced them to tread the paths of safety rather than those of adventure.

There was, perhaps, one exception to this slavery in the person of Sir John Vanbrugh, who had a singular gift for grandiose design. Kings Weston, near Bristol (Fig. 7), is one of his simpler and more restrained efforts, but even here the scale is large and the detail rerging on coarseness. But it is neither the personal note nor the minutiae of design which 


\section{FL'THER ADVANCES FROM EARLIER TYPE}

concerns us at present. Kings Weston is advanced as illustrating, not so much Vanbrugh's style, as the complete departure from the old ways which architectural design had by this time taken. The date of Kings Weston is about I7 I5. It is not only in the external appearance that this departure is noticeable, but also in the plan, and in the internal embellishments. These points will be dealt with fully in due course, but even on looking at the outside of Kings Weston, it is obvious that it is disposed on lines widely different from those of a Jacobean house.

These differences are still more apparent in the next illustration of the series, Wolterton Hall, in Norfolk (Fig. 8). This house is attributed to Ripley, and its date is put at 1736 . It is staid and eminently respectable, but there is none of the picturesqueness of the Jacobean methods about it, none of those unexpected human touches which help us to condone the ignorance of classic detail exhibited by Jacobean designers; no " accident," as Sir Joshua Reynolds puts it, which might lead to variety or intricacy. In making the circuit of its walls, the visitor knows exactly what he is likely to find. The appeal is to narrower sympathies than of old, to sympathies which spring from an acquired feeling for proportion, and are not merely. roused by quaint personal incidents attractive to all alike, whether trained in architecture or not. The dignified effect is produced by the stone base, the proportion of the windows in relation to the wall space, and the bold cornice at the eaves. The chimneys are symmetrically placed, but they have had no design worthy of the name bestowed upon them.

At Fonthill House, in IViltshire, built about I 760 (Fig. 9), there is a reversion to a type of plan which had almost died out, a central block, namely, with detached wings connected to it by curved colonnades. This type had been frequently adopted in the earlier part of the eighteenth century, and was still advocated in some of the text-books on house design. But its obvious inconveniences in dissipating the forces of domestic service instead of concentrating them, so far outweighed the advantages of stateliness and grandeur which it bestowed, that it fell into disuse. Fonthill House was built by Alderman Beckford in succession to a house which was burnt in 1755 , and it is doing the alderman no injustice to suppose that he strove to make his new house a very splendid affair, and accordingly adopted a 


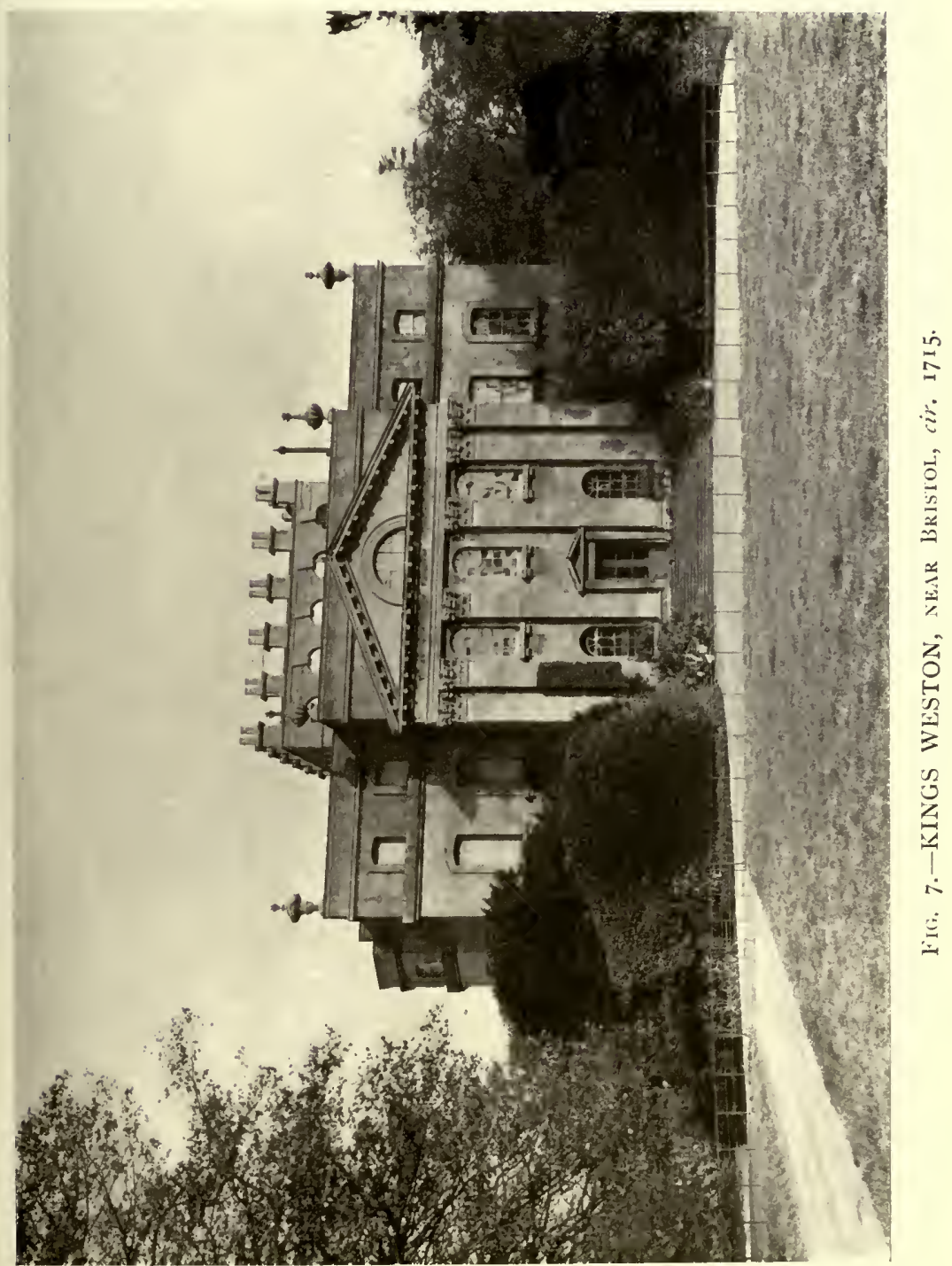


A DIGNIFIED GEORGIAN TYPE

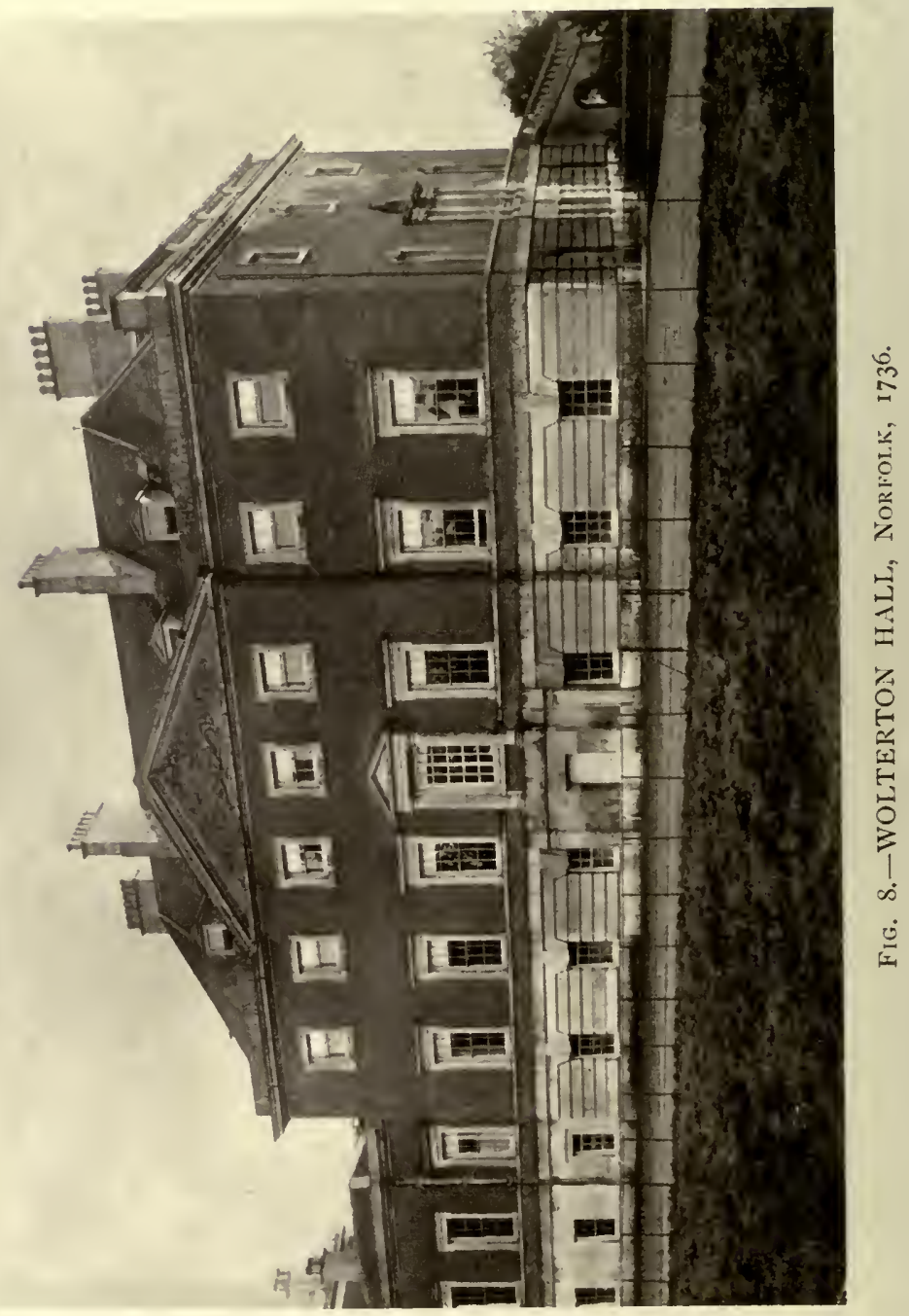


striking, if inconvenient, plan. He succeeded to such an extent that the result of his labours has been referred to as "Fonthill splendens." His son, the author of "Vathek," is said to have been born at Fonthill in 1759 , possibly in the new house, but there is no record of the actual date of its erection. The son eventually sold it for $£ 9,000$, a mere bagatelle in comparison with its cost, which was nearly a quarter of a million. He was then, about I 795, building on a vast scale, with the help of Wyatt, one of those freaks in which the late eighteenth century delighted, a mansion in the guise of a sham abbey, costing another quarter of a million. This wonderful edifice had but a short life, for in 1825 , two years after he had sold the estate, the great tower fell and started the decay of the whole structure. So famous were Fonthill Abbey and its contents that half England had flocked to the sale, filling every inn for miles around, and eating the countryside bare. Beckford the younger, like many of his contemporaries, was a man of great wealth and of considerable culture; a great collector of art treasures, and one who spent large sums in building in an ancient style of which neither he nor anyone living knew the rudiments. Reynolds, however, may be held to have countenanced the practice, for he says that the imagination being affected by the association of ideas, and we having naturally a veneration for antiquity, whatever building brings to our remembrance ancient customs and manners, such as the castles of the barons of ancient chivalry, is sure to give delight.

It is often very difficult to determine the date of old country houses; no records of the building of them survive, or if they do they are stowed away in unexplored muniment rooms. Tradition is vague or unreliable. Additions may have been made from time to time of which no precise account remains. The lapse of years may have toned everything down to the same antique appearance, rendering the disentanglement of the various periods a laborious task, and the results uncertain. The work of a later period may, perhaps, predominate to such an extent as to overwhelm what remains from an earlier, and cause the whole house to be dated half a century later than it ought to be. This is the case at Normanton Park, in Rutland, where such considerable alterations were made about i 780 that the house is held to be of the Adam period, whereas its main disposition was almost certainly settled fifty years before that 
18 A ONCE-FAMOUS XVIII.-CENTURY MANSION

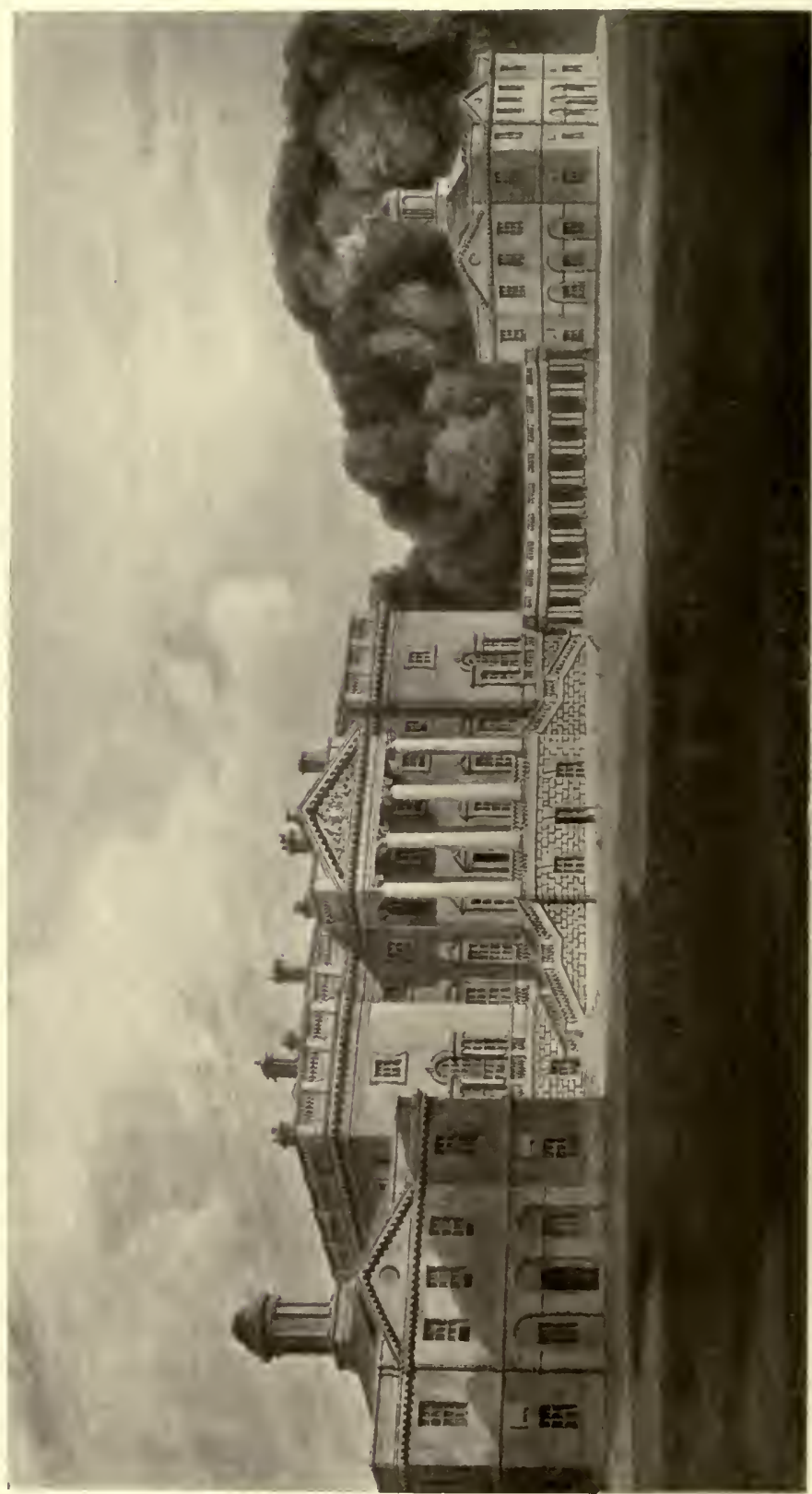

焉 


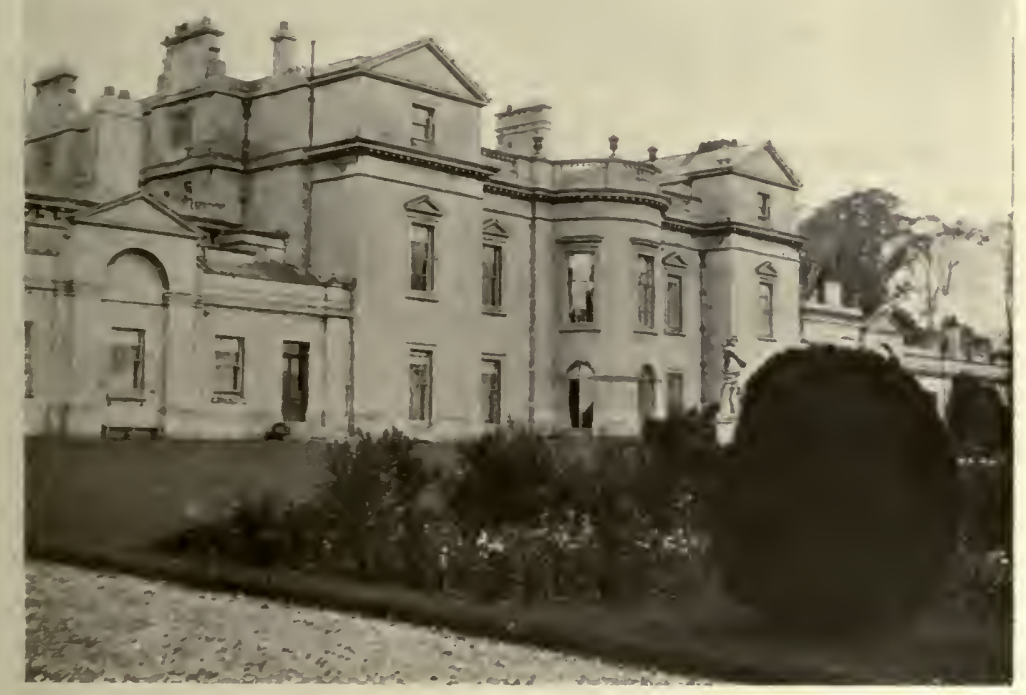

FIG. IO.-Normanton Park, Rutland, cir. 1780.

time. Enough of the earlier work remains in various parts to support this idea, and to show that the plan adopted-that of a central block with detached wings connected by colonnadeswas the production of the beginning of the century rather than of the end. At the later period, however, many of the external walls must have been recased if not rebuilt, and the garden front (Fig. IO) is a good example of the time. The circular bay is a characteristic feature, and so are the attic stories of the wings, although the placing of a plainly treated attic over a more majestic substructure was by no means a novelty. The real touch of the Adam period is to be found in the detail, which has all the delicacy and reinement connected with the name of the accomplished brothers Adam. That it is useless to argue about matters of taste is a dictum as old as the time when thoughts were usually expressed in the Latin tongue. Whether the delicacy of Adam or the vigour of Vanbrugh is to be preferred is a matter of individual liking. Some people admire Ganymede, others regard Hercules as a finer type; yet others admire both. With such predilections we need not be concerned; 


\section{PERSISTENCE OF THE CLASSIC TRADITION}

all that is necessary at present is to point out the change that had taken place in architectural treatment during the course of the eighteenth century.

As the century grew older the severance from the traditions of medireval times grew wider. Those traditions, indced, were lost, and although a few attempts were made-by Horace Walpole and others-to revive the late Gothic style, they only served to show how superficial was the current knowledge of Gothic architecture, and how futile it is to apply imitations of a departed.style, merely by way of ornament, to buildings which have no affinity to those from which inspiration is sought. These attempts at revival were not numerous, they lay outside the normal course of design, which steadily followed the classic lead which had been first given whole-heartedly by Inigo Jones. But the virility of Jones, Wren, and Vanbrugh had gradually declined, and domestic architecture had become correspondingly tame. It was highly respectable, much of it was refined, all of it was safe and rather uninteresting. To us it is so correct and well-meaning that it escapes the fate of much that succeeded itthe exciting of violent dislike. Indeed, after the lapse of more than a century, interest in it is reviving, and it bids fair to acquire enthusiastic admirers. It was otherwise when it was in full possession of the field, for in spite of its excellent qualities it roused the fury of Pugin and his followers, and was overwhelmed by the Gothic revival.

There was no essential change in the general treatment of houses all through the last half of the eighteenth century, as may be seen by comparing Gwydyr House, Whitehall (Fig. I I), which was built in I796, with Wolterton Hall (Fig. 8), built in 1736 ; that is, the general effect is obtained by the same means. The windows are carefully proportioned, and the eaves cornice is the only important shadow-producing feature. At Gwydyr House the attic story is a later addition. The windows in both cases are plain, unornamented oblong openings. In the house No. 32 St James's Square (Fig. I2), which was built in I 815 , and is the last of this particular series of illustrations, while the main effect is the result of the window proportion and the eaves cornice, some additional interest is given by the form of the first floor windows, by the arches in which they are placed, and by the balconies.

Although there was no great originality in the manner in 
which the bulk of the houses was handled at this time, there was much ingenuity bestowed upon the detail and ornament. The brothers Adam, who were busy during the last quarter of the eighteenth century, have given their name to a particular style of decoration, marked by much delicacy and refinement, but they did nothing of first-rate importance in architecture

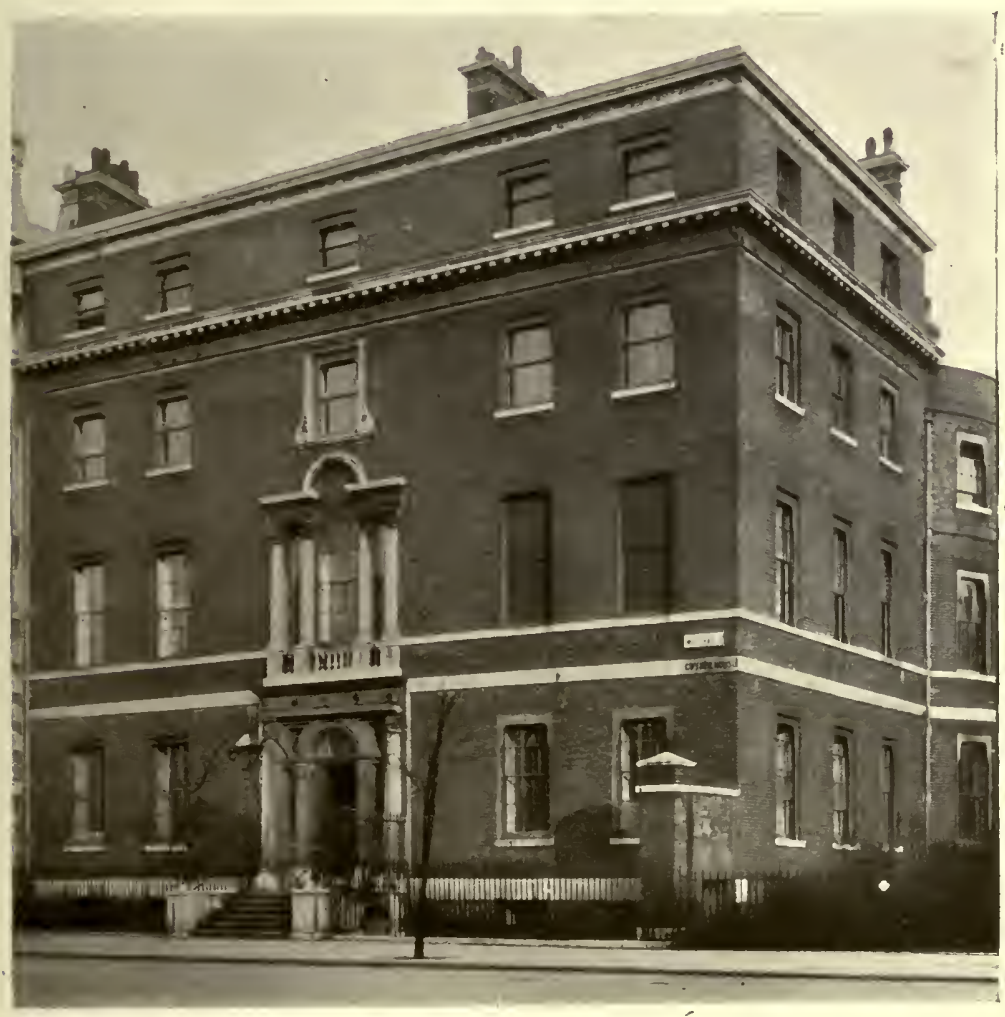

FIG. I1.-Gwydyr House, Whitehall, London, I796.

itself, nothing that set men building in a fresh way. After them came the Greek influence, which affected a number of designers. The ambitions of Napoleon absorbed the attention of nearly the whole of Europe, but Greece was at that time exciting a considerable amount of interest, which was fostered to a certain extent by the poetry of Byron. But although he hymned the Isles of Greece and burning Sappho, but little of her fire found 


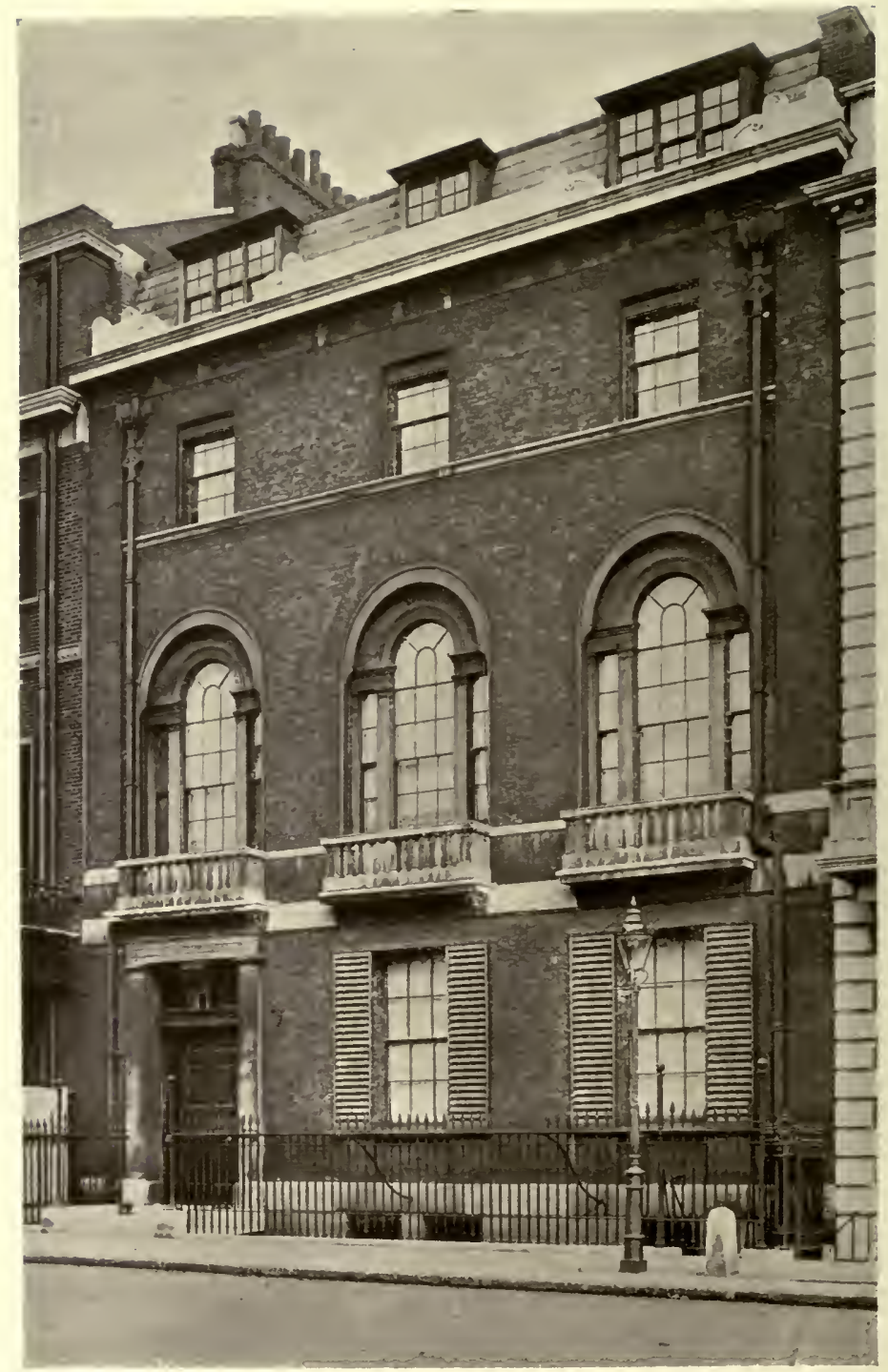

FIg. 12.-NO. 32 ST JAMES'S SQUARE, LONDON, ISI5. 
its way into the forms which her country lent to England. Then there followed the Age of Romance, inaugurated by the great Wizard of the North; all the world fell in love with ancient castles and old houses. Scott's magic wand lifted the veil from the past, and disclosed scenes of bygone manners, affecting, amusing, and exciting, thus making easy the advent of the Gothic Revival.

This revival broke the thread of classic tradition in house building, a thread already attenuated. It brought about the chaos of style which marks the nineteenth century. But it set men thinking; it gave them a fresh start; it led them to attack problems in a logical way, to adapt their designs to circumstances instead of insisting that circumstances must conform to established laws of design. In a word it produced the wide outlook and the reasonable attitude of adapting means to the end, which are the hope of architecture to-day.

Having thus given a bird's-eye view of the course followed by house builders during the whole period under consideration, we will now proceed to an examination in detail of the various stages of its development. 


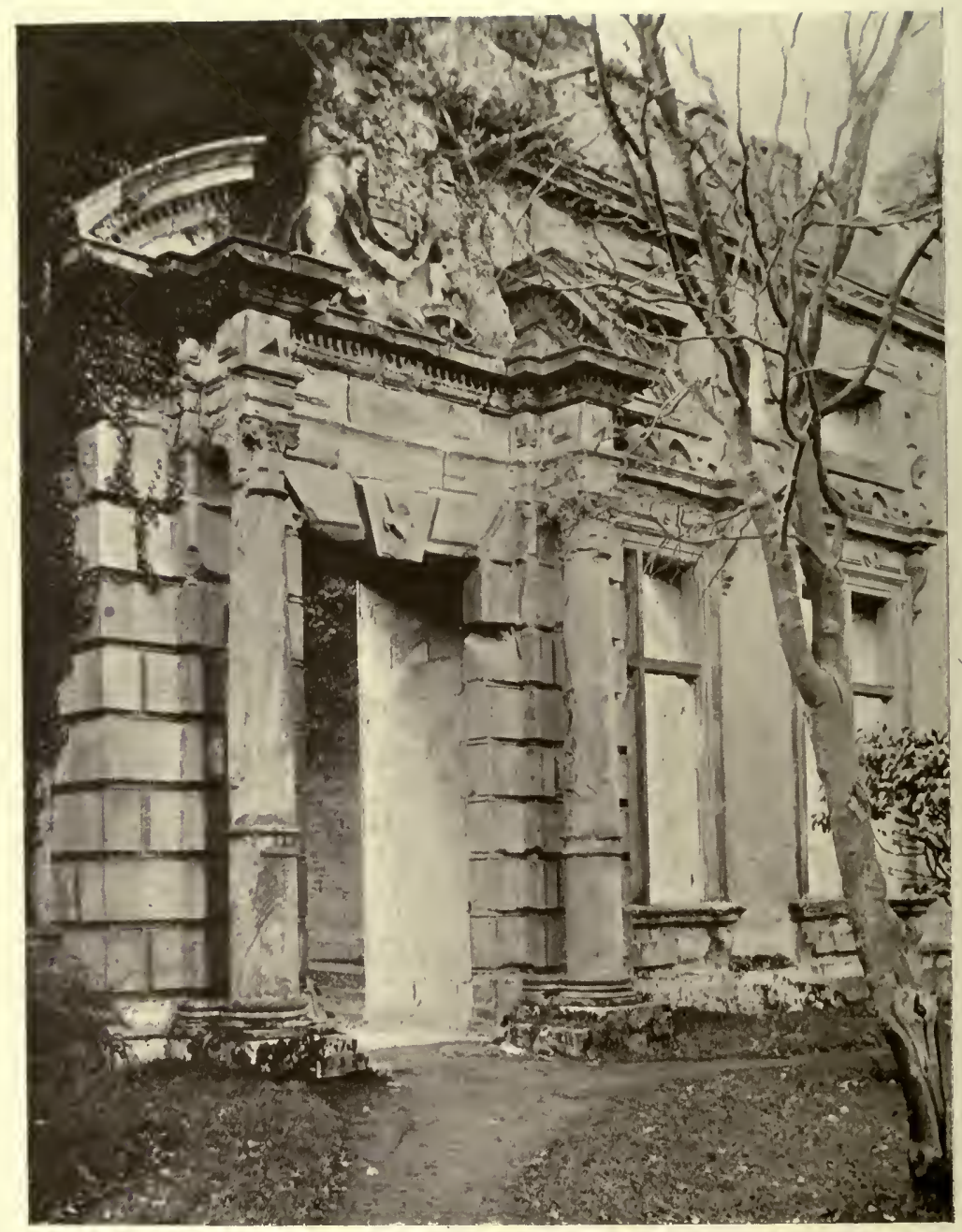

Fig. 13.-BOLSOVER CASTle, Derbyshire.

Entrance Doorway to the Galleky. 


\section{II}

\section{THE CHANGE IN STYLE}

DURING the seventeenth century a very significant change took place in architectural design. All through the mediæval period design seems, so far as our knowledge enables us to form an opinion, to have been impersonal, the result of a number of men working together, each concerned with the portion affecting his particular trade. It is probably true that some one individual controlled the general scheme, and gave an oversight to the work of the others; but not in such a sense as to have been entitled to be called the "architect," as we understand the term. To us the architect is the individual who not only provides the plan, not only puts into practicable form the ideas of the employer, but also designs most of the details. He not only informs the various artificers that particular work is required in particular places, but he also provides them with drawings showing what the work is to be, and how it is to be fashioned. His influence to-day is much wider and much more intimate than it was in the Middle Ages, the ages which produced our cathedrals, our ancient churches, castles, and manor-houses.

The term "architect" occurs very seldom either in literature or in documents previous to the seventeenth century. Shakespeare uses the word once; in contracts of Elizabeth's time it appears seldom, if ever; although the documents refer to the provision of design as well as workmanship. In the numerous books published for the guidance of designers in building matters during the reigns of Elizabeth and James, it appears now and then: but the appeals which these books made on their title-pages and in their prefaces to those for whom they were written, were addressed primarily to artificers and only incidentally to architects, who seem to have been included in order to catch a possible purchaser. The reason for the absence of the 


\section{ARCHITECTURAL PUBLICATIONS OF THE TIME}

term is obvious: there were hardly any people who called themselves architects.

The publication of these books is itself a sign of the change which was coming over the methods of design. Hitherto design had been a matter of tradition, preserved by guilds, handed down from father to son or from master to man. The horizon of a medieval workman was limited: he neither knew nor cared much for what was being done in distant lands. His style was influenced by local considerations, and although he conformed to the general changes which affected the whole of Gothic architecture, there was usually a local flavour about his work. The difference in character between the work in Norfolk, Northamptonshire, and Somerset is obvious at first sight: but a closer scrutiny will often reveal local variations in those districts themselves.

Why were these books published, and what kind of architectural style did they illustrate? Did they bring before the eye of the designer masterpieces of Gothic architecture, or details of Gothic work? Not at all: no book illustrating Gothic architecture was published till the end of the eighteenth century. $^{1}$ There was, in truth, no need for such a book: the mediæval workmen had their own traditional knowledge, and it concerned them not at all to learn how the workmen in Germany or southern France or Spain differed in method from themselves. They gave no thought to such matters, nor did they think of themselves as being concerned with architecture ; they merely built in the manner of their fathers.

But although the successors of the medireval craftsmen in the mid-sixteenth century shared their predecessors' apathy in respect of what was being done abroad, it was otherwise with those for whom they worked-the great men who were building fine houses all over the land. To these had come new ideas in relation to their buildings. They had heard of the splendid work that for years had been executed in Italy: some of them had

${ }^{1}$ The publication of "Gothic Architecture, Improved by Rules and Proportions," by B. and T. Langley, in 1742 , does not invalidate this statement, for the illustrations are intended to show how a kind of Gothic detail might be applied to a kind of classic "order." The "Historical Dissertation on Gothic Architecture," attached by way of introduction, is absolutely negligible in the light of modern knowledge, and conld have helped nobody to a comprehension of the subject. 
seen it; monarchs and wealthy nobles had even brought foreign craftsmen over to exercise their skill in the northern parts of Europe. The Italian manner was a novelty in this land of Gothic traditions, it was unlike anything to which England was accustomed. But the new fashion became popular. Employers demanded the novel detail in their houses; the foreign artists were not numerous, and so the English workmen had to supply the best imitation they could contrive on a scanty training. Here came the opportunity for the bookmakers. They showed the way in which Italian buildings were designed; they illustrated the "Orders" which gave those buildings their distinctive character so far as appearance went; they showed how classic detail might be applied or perverted to meet the exigencies of buildings which had a Gothic parentage. The books, therefore, were published in order to help designers who aimed at working in the new classic style.

The effect, of course, was to foster that style at the expense of the native Gothic. It is true that books were not widely distributed ; there was not in those days the rapid dissemination of ideas that there is in our own. But if anyone wanted a book about building, he could only find such as dealt with classic architecture. Hence in a short time the operations which had hitherto been thought of as building, began to be thought of as Architecture, and the only architecture that was formulated was classic architecture. The idea of that art became inseparably connected in the minds of men with classic expressions of it. Thus it came about that in the course of half a century people of culture regarded all Gothic buildings-even the noblest -as barbarous, and not worthy the name of Architecture. ${ }^{1}$ The "Gothic order," as it was called, was merely a "fantastic and licentious manner of building."

It was only a small proportion of the actual workmen who were able to study books; the rest picked up the new manner from such foreigners as they met, from work which they saw as they moved about, and occasionally, perhaps, from verbal description. Some worked all their lives on the old lines. One result of the difficulty of imbuing the workmen with the requisite knowledge was that some of the men whose duty it was to overlook buildings - the surveyors-made a point of studying

1 Evelyn's "Account of Architects and Architecture." 


\section{EFFECT OF ARCHITECTURAL TREATISES}

the new style either through books or by foreign travel or both. They rendered themselves familiar with classic detail, and were thus enabled to give the desired character to the buildings under their charge. They gradually became more and more responsible for design in the various branches of the building trades, and thus grew to be architects as well as surveyors. The inevitable tendency was for architectural design to become more personal, and for its results to become less like a spontaneous growth of the land.

The number of architectural books published was not in reality very great; they were mostly of foreign production, and probably few copies found their way into England. The earliest were printed in Italy during the closing years of the fifteenth century. By the middle of the sixteenth century there were, perhaps, half a score in existence, some in Italian, some in French. These were obviously of no use to unlettered workmen, but they were appreciated by men of learning, and were studied by some of the surveyors of the time. One or two Englishmen had produced treatises on architecture by the end of the century, but their direct effect on English design can hardly be traced. It is, indeed, unwise to look to any of the books of the time for direct and immediate influence; their effect seems to have been gradual. As may be supposed, it would be the illustrations which would have the greatest weight, for they would be intelligible to men unacquainted with the language of the text. The more important treatises confined themselves largely to drawings of the orders, but a few smaller books, published by Germans and Dutchmen, gave many illustrations of particular features such as doorways, windows, and so forth, and these appear to have appealed more powerfully to English workmen and to have influenced in some degree the appearance which they imparted to their details.

In another and different direction some of the French books would seem to have had an interesting effect. Philibert de l'Orme and Androuet clu Cerceau had published remarkably fine illustrations of the more important buildings then recently erected in France. It is certain that John Thorpe, who was the most accomplished and ingenious of the English surveyors of his time, had studied du Cerceau's books, and it is quite conceivable that, fired by such an example, he may himself have contemplated a similar production for England, and that 

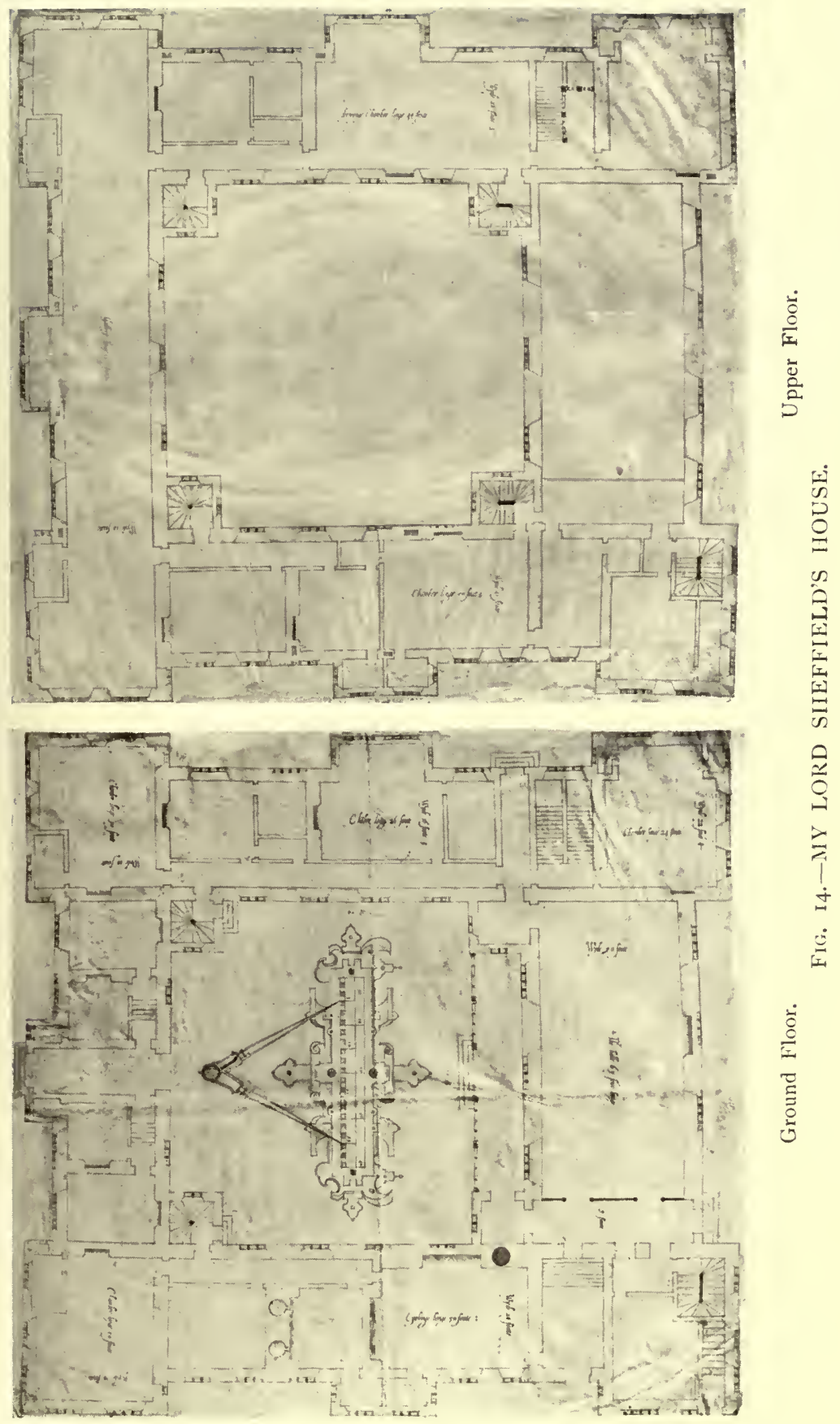

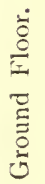




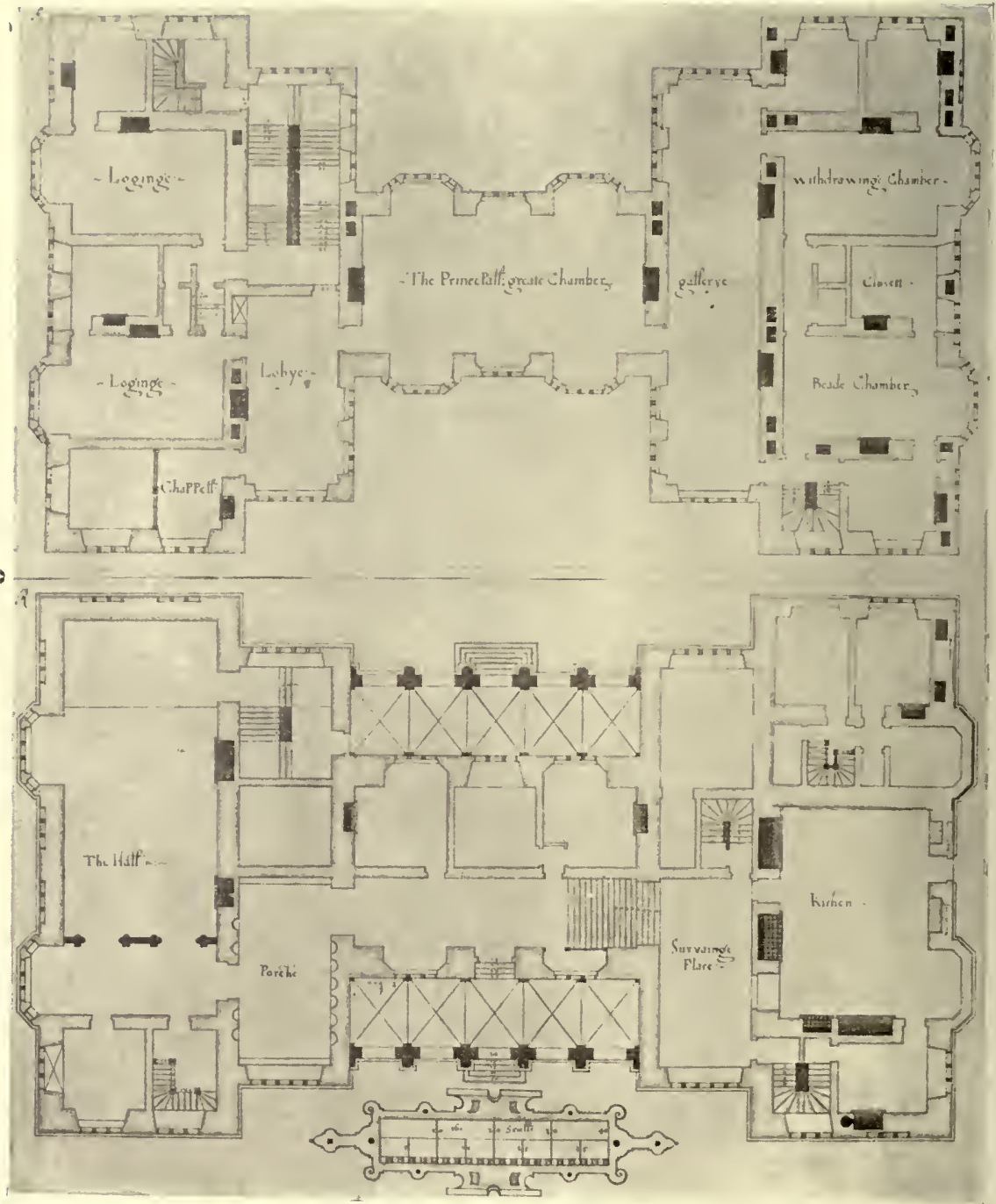

FIG. 15-GROUND AND UPPER PLANS OF A HOUSE, NOT NAMED.

From the Smithson Collection. 
to this idea is owing the very interesting collection of drawings now preserved at the Soane Museum. But however this may be, it is clear that some of the men who were concerned with the design of large houses thought it worth while to preserve their drawings, for, in addition to the Thorpe collection, there is that other collection by Thorpe's contemporary and successor, Smithson; while in later years are those connected with the work of Inigo Jones, John Webb, and Wren; and in still later times Campbell, Gibbs, and other architects made a point of publishing illustrations of the buildings which they and their contemporaries had designed.

But although we may perhaps see in the books of the sixteenth century the genesis of our own English architectural publications, their immediate interest lies in the fact that whatever was published about the beginning of the seventeenth century dealt with classic architecture, and that anyone who sought in books for information about building, found nothing about the old Gothic detail, but only instructions how to design in the classic style.

The Thorpe collection of drawings is well known, and belongs to the order of things which was passing away. But the Smithson collection is but little known, and as it forms a link between what was passing and what was approaching, it will be of interest to say a few words about it, and to give a few illustrations from it.

Of Smithson, as of his predecessors in his calling, very little is actually known. He seems to have belonged to a family of architectural designers, the members of which have been rather confused by IValpole and other writers who have referred to them. The facts seem to be that of his parentage there are no records, although chronology would admit of Robert Smithson, of Wollaton, being his father; his own name was John, he had a son named Huntingdon, a grandson named John and a great-grandson named Huntingdon. He himself died in 1634 , and his son Huntingdon in 1648 . They were both buried at Bolsover, in Derbyshire, and an inscription over the grave of the son speaks of his "skill in architecture." The two have been confused with each other, but their separate identity has recently been made clear. ${ }^{1}$ According to Walpole.

1 See a communication from Mr Walter L. Spiers to the Journal of the Royal Institute of British Architects, Ioth Dec. I908, where a short pedigree is given. 
in his "Anecdotes of Painting," "John Smithson was an architect in the service of the Earls of Newcastle. He built part of Welbeck in 1604 , the riding-house there in $1623,{ }^{1}$ and the stables in 1625 ; and when William Cavendish, Earl and afterwards Duke of Newcastle, proposed to repair and make great additions to Bolsover Castle, Smithson, it is said, was sent to Italy to collect designs. From them I suppose it was that the noble apartment erected by that duke, and lately pulled down, was completed, Smithson dying in $1648 .^{2}$ Many of Smithson's drawings were purchased by the late Lord Byron from his descendants who lived in Bolsover." On Lord Byron's death the drawings were purchased by the Rev. D'Ewes Coke, and they are now in the possession of his descendants at Brookhill Hall.

Many of the drawings have no title or other means of identifying them; but such as have go to show that Smithson, who, it would seem, was not only buried but also lived at Bolsover on the north-east border of Derbyshire, had a considerable local practice, as well as a certain amount of work in London. The riding-house and stables at Welbeck, mentioned by Walpole, are both in the collection, and there are also several drawings relating to Bolsover Castle.

The buildings which go to make the "castle" may be divided into three groups: First, there is the castellated portion, built on the site of the old keep and begun in 1613 : this part is still in good repair. Then there is a long range on the terrace-the "noble apartment" mentioned by Walpole. This was built by" Sir William Cavendish, afterwards Duke of Newcastle, who presumably found the older building too small. Its principal apartment was a magnificent gallery, but, so far as its ruinous state permits the other rooms to be made out (and among them was a kitchen), it would appear to have been a completely equipped residence. On the view of the castle which adorns the Duke of Newcastle's book on Horsemanship, this building is called " $\mathrm{La}$ Gallerie." The third group comprises the riding-house and its adjuncts, which adjoin the gallery at its western end.

The few drawings in the Smithson collection which refer to Bolsover are all, except one, connected with the castellated

1 "As appears by his name over the gate."

2 It was, however, John Smithson's son, Huntingdon, who died in 1648 . John Smithson died in 1634 . 
portion, and they go to prove that John Smithson must have been concerned with that particular building. But there is one drawing of a large doorway (No. 40) which closely resembles the central doorway on the terrace front of the gallery, and the general detail of this building, which is large in scale, heavy and rather spoilt by laboured freaks, is akin to much else that is to be found among the Sinithson drawings. This gallery block is evidently of two dates. The eastern portion has a certain amount of detail in the simpler style of the Jacobean period, while that of the western half is more laboured and contorted. At the eastern end are five small projecting stones bearing initials and dates; one of them has on it H. S. I629, and may conceivably commemorate Huntingdon Smithson. But as it has four neighbours with other initials and the dates I629, I630, it would appear that in any case he was only one out of five persons entitled to recognition. However, the evidence of tradition, the datestone and the drawings clearly point to the Smithsons being responsible for the design of the buildings generally, and it may well be that the influence of the father is visible in the earlier and simpler work, and that of the son in the grandiose gallery, with which he may have been busy at some time between his father's death in 1634 and the outbreak of hostilities in 1642. The riding-house is much quieter in treatment than the gallery, and its detail is more refined. In spite of the tradition that the designs were collected in Italy, the work shows more affinity to Dutch models than to Italian, as may be gathered from the illustrations (Figs. I 3, I6).

The riding-house at Welbeck (Fig. 20) follows the established lines in its treatment ; it has steep gables with finials, mullioned windows, and an open hammer-beam roof: the very heavy pediments over the doors are in keeping with those at Bolsover, and with many other details in the collection, and they show how crude Smithson was in his treatment of classic features. It is important to bear this in mind, because he may be considered (although he had an uncommonly heavy hand) as typical of the majority of English designers before the influence of Inigo Jones began to be felt.

Smithson's house-plans are of great interest, inasmuch as they belong to the order of things which was shortly to pass away. Some of them follow the traditional lines which made 


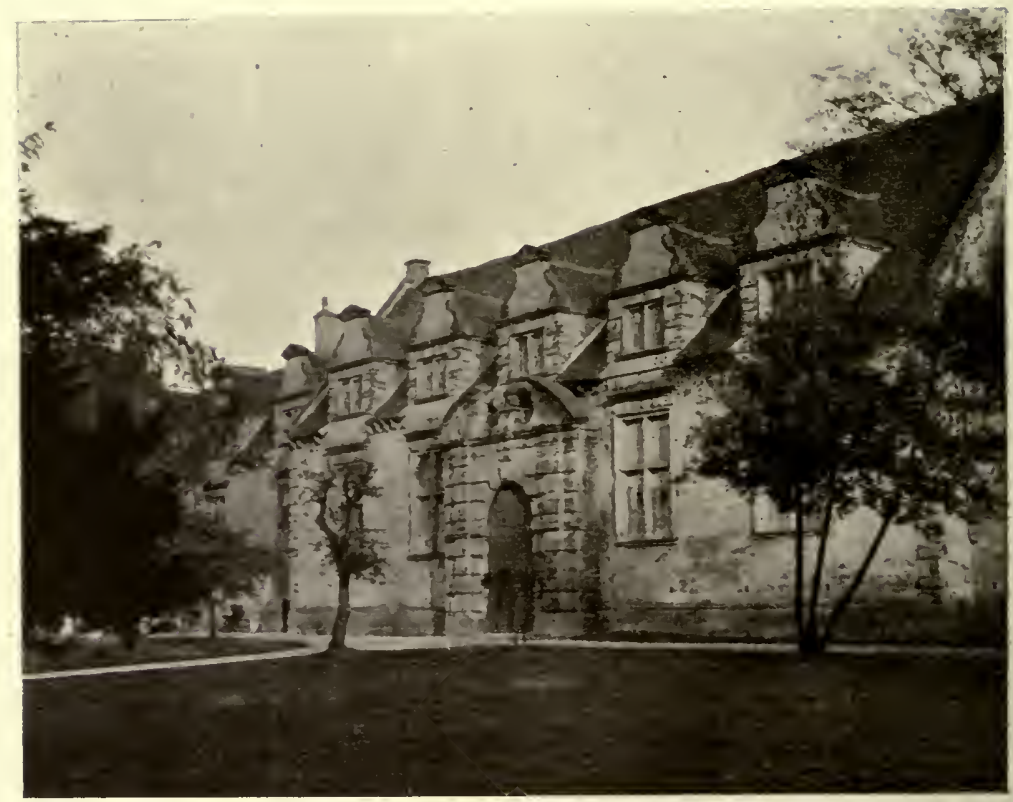

FIG. 16.-Bolsover Castle, Derbyshire. The Riding.House.

the hall the principal apartment of the house, placing it between the family rooms and the servants' quarters. The plan "for My Lord Sheffield's house" is an example of this arrangement (Fig. 14). It shows the rooms grouped in the old way round a courtyard, which had to be traversed in approaching the hall from the front door. The hall itself was entered through the screens at its lower end, and was flanked at its upper end by the parlour and other family rooms, and by the grand staircase. On the opposite side of the court were the kitchen, pantry, and other rooms for the service of the house. In the four corners of the court were square turrets containing subsidiary staircases. On the upper floor (Fig. 14) the chief rooms were the diningchamber, placed as far from the kitchen as the limits of the house would allow, and the long gallery. The fact of a special room being set apart for dining itself indicates a fairly late datein respect of this ancient type of plan. As my Lord Sheffield was created Earl of Mulgrave in 1626 , the plan must be prior to. that year, but the house was probably not more than ten years old when the change of title took place. 
The other specimen of Smithson's planning is one of the $\mathrm{H}$ type, with the hall in one of the wings (Fig. I 5). This is a departure from the old arrangement, which would have placed the hall in the central block, and thus have brought the buttery (which opens from the screens) into close touch with the kitchens. The hall becomes here more of a passage-room and less of a living-room than under the ancient disposition. There are no sitting-rooms for the family on the ground floor, but the principal staircase leads to the great chamber on the upper floor, thence to the long gallery and a distant

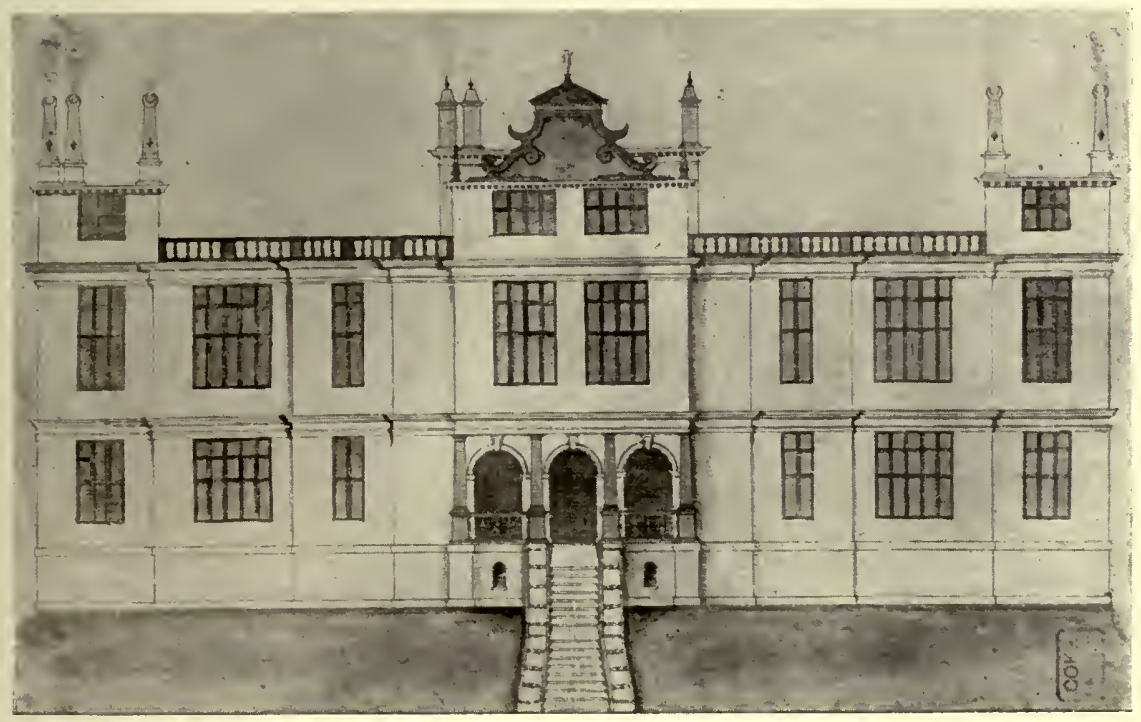

FIG. 17.-Elevation of a House, not named.

From the Smithson Collection.

"withdrawing-chamber," as well as to the chapel and several bedrooms.

Both these houses are rigidly symmetrical in their external treatment, and it is interesting to note how, in addition to preserving such old-established rooms as the great chamber and long gallery, they depend for their external effect upon old features, such as mullioned windows, arcaded entrances, turrets, and the breaking up of the various fronts with substantial projections and large bay-windows. These devices were customary among the designers of the time of Elizabeth and James I., but they were gradually to be superseded by other methods. 


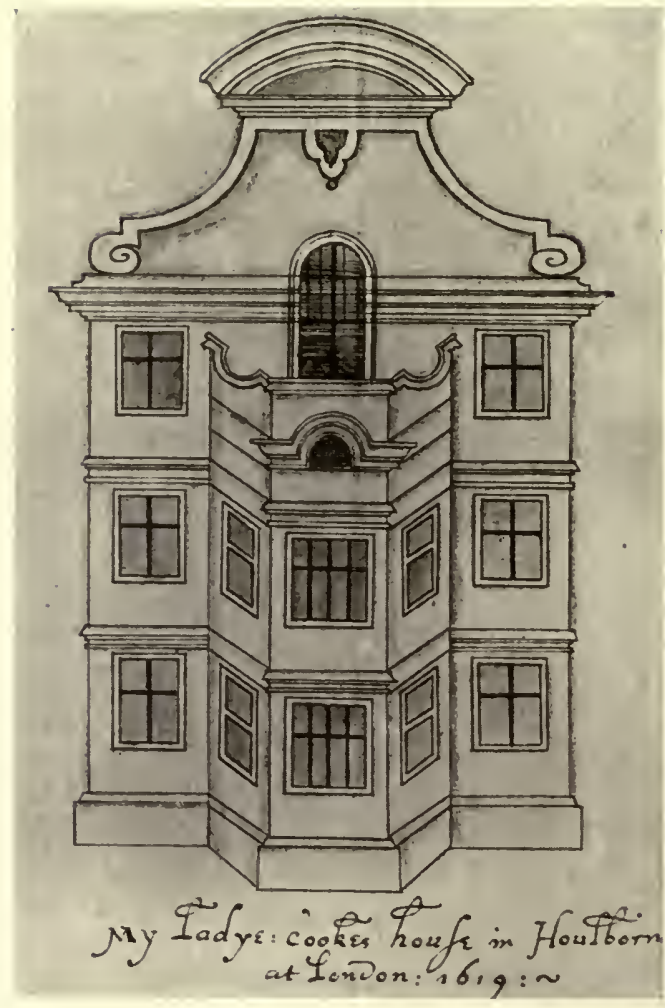

F1G. 18.-Lady Cook's House in Holborn, 1619.

From the Smithson Collection.

There are no elevations preserved which fit these plans, but Smithson has left a number of specimens of his way of dealing with the exterior of his buildings. The most important in size is illustrated in Fig. 17. It follows the usual lines of the period with its mullioned windows, large horizontal cornices, arcaded entrance, balustraded parapets, and curly central gable; but it is rather clumsy compared with most of John Thorpe's elevations. So, also, is the elevation of "My Ladye Cookes house in Houlborn" (Fig. I8) to which additional interest is lent by the fact that it is dated I6I9. This front, with its large dominating pediment and circular headed window has a later touch about it, and has lost most of the light-hearted piquancy which characterises the work of the preceding fifty years.

The hankering after Italian detail which had affected English designers in an increasing degree for many years finds expression in the Smithson drawings, among which are several "Italyan" windows and doors, an "Italyan" gate (Fig. 2I), and one or two "pergulars."

The Thorpe and Smithson drawings are closely allied both in architectural style and in methods of draughtsmanship, although the latter collection is obviously later in feeling. There 

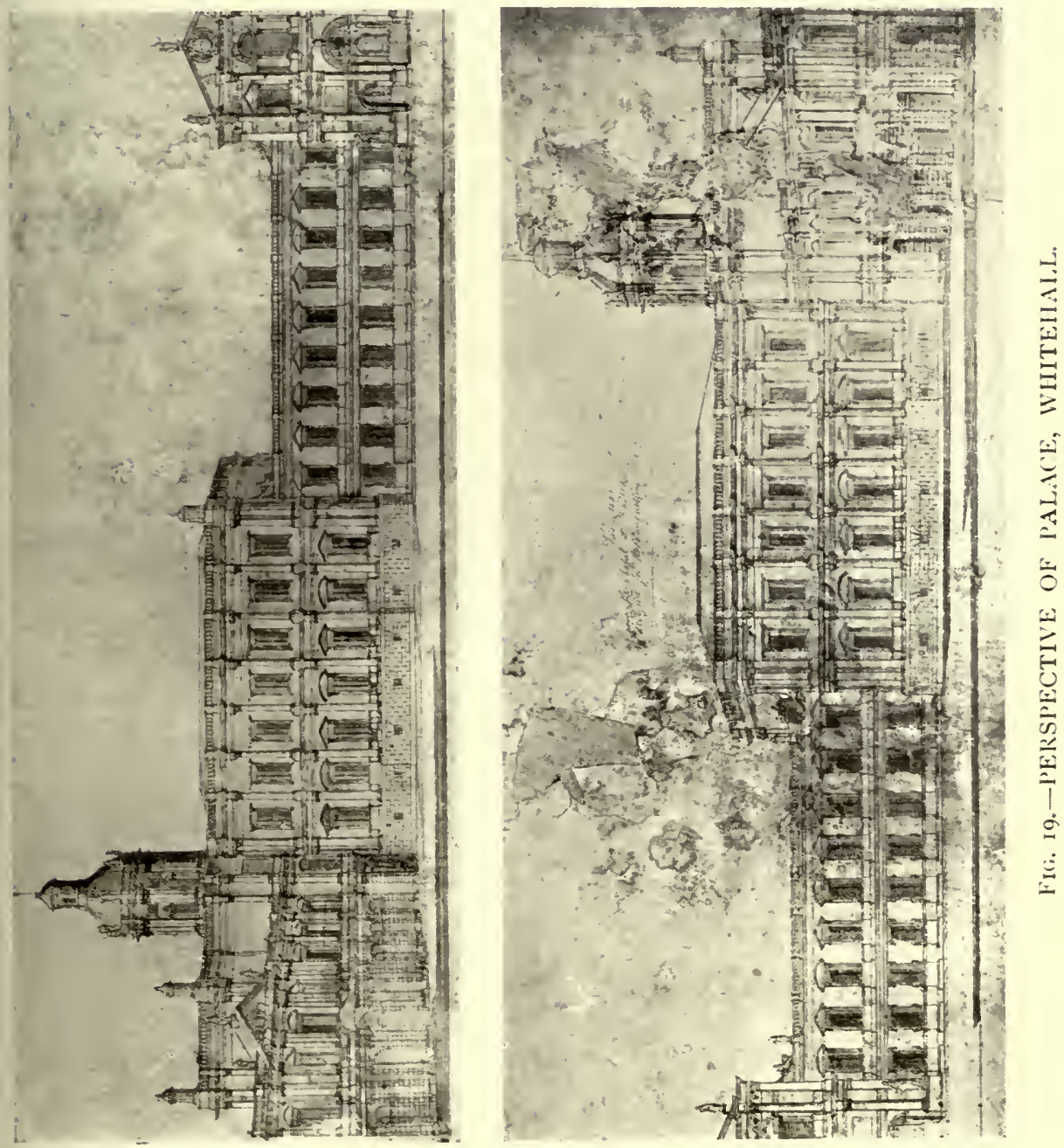


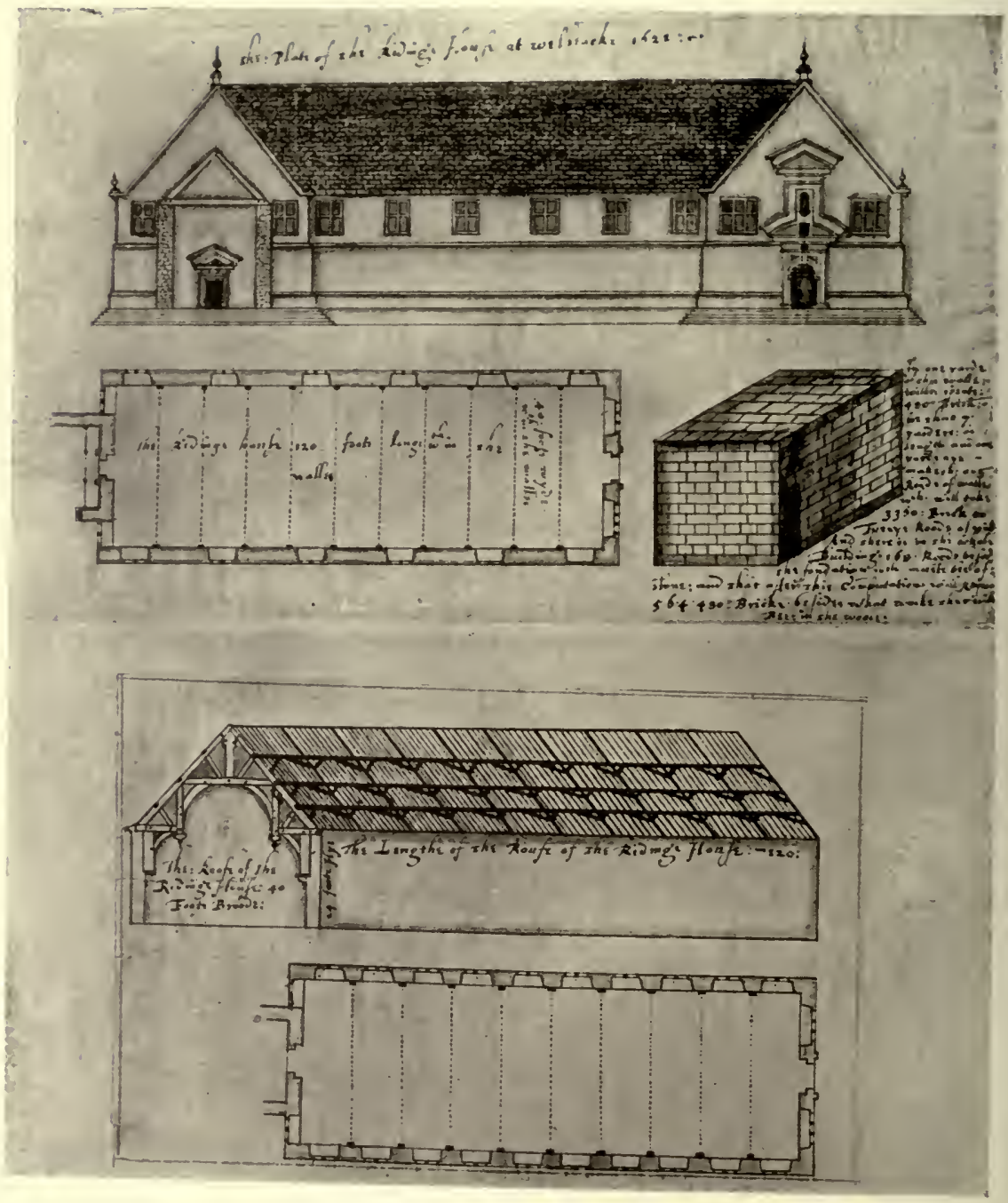

FIG. 20.-THE RIDING-HOUSE AT WELBECK, 1622.

From the Smithson Collection. 
is a vast difference in both respects between them and the drawings prepared by Inigo Jones and John Webb, which will presently be described. There are comparatively few details in the Thorpe and Smithson collections, especially in the former. The designers concerned themselves primarily with the mass of the building rather than with its particular features. The plans in all the collections, both
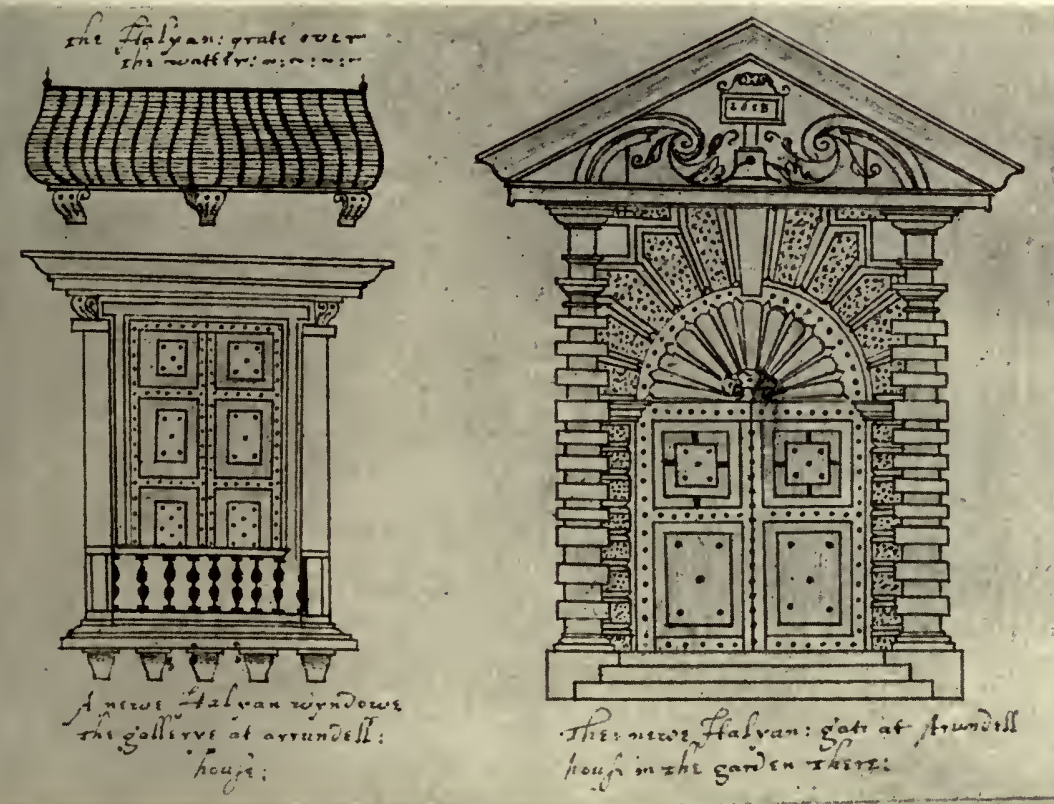

F1G. 21.-The Italyan grate over the Watter. A newe Italyan wyndowe, the gallerye at Arrundell house. 'The newe Italyan gate at Arrundell house in the garden there, I6I8.

From the Smithson Collection.

early and late, are drawn with much care and many of them with singular neatness. But the elevations and perspective views are not of equal excellence. The latter are generally drawn by Thorpe as bird's-eye views. They are in the nature of diagrams. There are, it is true, hardly any perspectives among the architectural drawings of Jones and Webb, but in the one notable instance-the view of a front for Whitehall Palace, at the British Museum-the spectator is supposed to be standing on the ground and not floating in the air (Fig. I9). In Jones's designs for the scenery of masques there are many interesting 
architectural compositions, and these are perforce drawn to satisfy the eye of a spectator on the floor of the theatre. They show great skill in perspective drawing. The difference between the two methods is best indicated by describing the earlier as archaic and the later as modern. Indeed with the advent of Inigo Jones we enter upon a new phase in architectural design; we are leaving the ancient ways and turning into the modern. 


\section{INIGO JONES}

THE accession of Charles $I$. to the throne in 1625 marks a convenient date in the development of architectural design to consider briefly its condition and tendencies. The king and his court still exercised an enormous influence over the life and habits of the people in directions other than political. In medireval times the king was the centre of public affairs, the pivot upon which the State turned. His own will, even his whims and fancies, counted for much. But for the last threequarters of a century this influence had been gradually lessening, and the king's personal power had been curtailed. It was in opposing this tendency, in endeavouring to reassert his personal ascendancy, in re-establishing his prerogatives, that Charles came into conflict with his subjects and ultimately succumbed. But bearing this state of things in mind, it will be more readily understood that the influence of the king in relation to architecture, for instance, would be very considerable; vastly more so than the influence of any individual in the present day. Charles was a man of culture, and without crediting him with an intimate knowledge of architectural design, we may well believe that he would foster the growth of a refined and scholarly version of the style at which English designers had been aiming for many years. That is to say, since the tendency was to adopt Italian ideas he would like to see them adopted thoroughly and with full knowledge. The man to do this for him was there in the person of Inigo Jones, who had already been employed by his father, and who was the only man in England possessing really competent knowledge of Italian detail. Here then was another powerful influence at work tending to divert English design from the old traditional channels.

No doubt had Charles been blessed with leisure to gratify his refined tastes, and to devote himself to the encouragement of the arts, had he been in possession of funds commensurate 
with his artistic ambitions, the Italianising of English architecture would have been more rapid than it actually was. But his time was occupied with sterner matters, and the huge palace at Whitehall which he is said to have contemplated (and his father before him, according to many writers), but of which the true history will be presently outlined, never went further than to be committed to paper. What he did do, however, was to foster the seed which had been sown by his father, and which bore fruit later in the century.

The love of Charles for the fine arts was shared by many of his court. Thomas Howard, Earl of Arundel, caused not only the marbles which still bear his name, but many other fine relics of antiquity, to be brought to England. Inigo Jones was frequently employed by the nobility to purchase pictures and other treasures, and to see them suitably displayed in the houses they were to adorn. John Webb made it one of his claims to consideration that he had been commissioned by the "great nobility and eminent gentry " to acquire for them medals, statues, and other works of art.

Meanwhile, in the country generally, and outside the circle influenced by Inigo Jones, the old habits still prevailed, and many houses were built, including such important buildings as Aston Hall, in Warwickshire, already mentioned, in which the old arrangements of plan were retained, and all the old devices for obtaining architectural effect were used-mullioned windows, steep or curved gables, large and lofty chimneystacks, turrets and bay-windows, with a strong infusion of Italian detail in the form of cornices and pilasters; just such devices indeed as had been employed by John Smithson and his contemporaries.

When this is borne in mind, when it is remembered what Smithson stands for, and that he lived until I634; that Aston Hall, where Jacobean methods were still paramount, was not completed until $\mathrm{I} 635$; it will be easier to grasp the significance of Inigo Jones's Banqueting House at Whitehall (Fig. 22), designed in 1619 and finished in 1622 , in which there is no trace of traditional English design, which in fact approaches nearer to Italian models than any building of the seventeenth century. No wonder, considering the goal at which all designers were more or less aiming, that it was quoted as a masterpiece, as the finest flower of modern architecture in England. This 


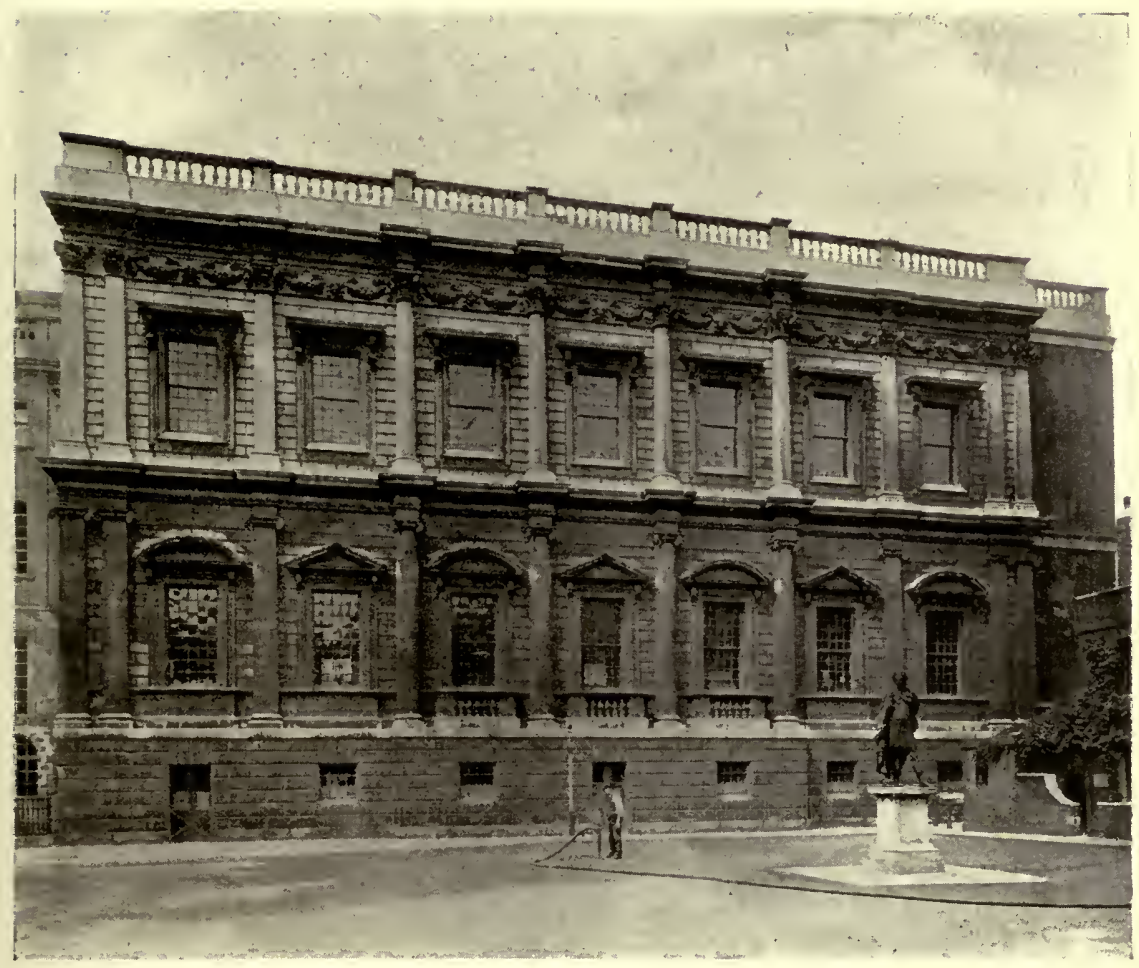

FIG. 22.-The Banqueting House, Whitehall, 1619-22.

position it held all through the century, and indeed still holds in the opinion of many competent judges. At the time it was built it was unique, and for thirty years afterwards travellers might have searched England in vain for anything so thoroughly Italian in treatment, unless they happened to see the Queen's House at Greenwich, or one or two other buildings by the same architect, such as Sherborne, in Gloucestershire, between Northleach and Burford, which was described in 1634 as a "stately, rich, compacted Building all of Free-stone, flat, and couer'd with Lead, with Strong Battlements about, not much unlike to that goodly, and magnificent Building the Banquetting House at Whitehall." 1

1 "A Relation of a Short Survey of 26 Counties observed in a seven weekes Journey begun on August II, 1634, by a Captain, a Licutenant, and an Ancient." 
The Banqueting House must not be regarded as a step in the normal development of English design; it was something outside, the work of a specially trained and exceptionally gifted man, who achieved in 1619 what less learned and less skilful men were striving after, consciously or unconsciously, for nearly half a century afterwards.

The ultimate influence of Inigo Jones on English architecture was so important that it is desirable to know something of his training and of his history. He was born in 1573 , in the parish of St Bartholomew, Smithfield. ${ }^{1}$ The church register records his baptism: "Enego Jones the sonne of Enego Jones was christened the xixth day of July 1573." His father was a cloth-worker in good circumstances at that time, but when the lad was sixteen years old, the father was obliged to compound with his creditors. There were other children, but it would seem that only Inigo and three sisters survived their father, who died in the early months of I 597 ; as he left his property to be divided among his four children, he must, to a certain extent, have recovered from his financial embarrassments. In any event it would appear that Inigo the younger was left to make his own career. It is not known where he received his education, nor how thorough, or otherwise, it was: but it was apparently up to the average bestowed upon youths of his condition, and probably of much the same character, mutatis mutandis, as would be acquired by boys of the upper middle class to-day." That he was a man of culture is indicated by a copy of rhymes in Latin written by Thomas Cariat (Coryat) of Brasenose College, Oxford, in I6I $\mathrm{I}$, and preserved among the State Papers. ${ }^{3}$ They describe a philosophical feast, among the guests at which was Inigo Jones. There is a tradition, but without evidence to support it, that he was apprenticed to a joiner in St Paul's Churchyard. If this were so, it would at least give him an amount of practical knowledge which would be of material assistance in his later career. But his early training is really a matter for conjecture. He says in the preface to "Stone-Heng Restored": "Being naturally inclined in my younger years to study the arts of design, I passed into foreign parts to

1 "Lives of the British Architects," by E. Beresford Chancellor.

${ }^{2}$ It is true that his spelling, especially that of the notes in his sketchbook, is eccentric, even for those days.

${ }^{3}$ "Cal. State Papers, Domestic," Sept. 2, 16r I. 
converse with the great masters thereof in Italy; where I applied myself to search out the Ruins of those ancient Buildings, which, in despite of Time itself, and violence of Barbarians, are yet remaining. Having satisfied myself in these, and returning to my native country, I applied my mind more particularly to the study of Architecture."

At whose expense he passed into foreign parts, or in what year he first did so, there is no record. But it is agreed that he paid two visits to Italy, the first somewhere about the year 1600 ; the second in $1613-14$. Of the first visit little or nothing is known $;^{1}$ but of the second there are definite records in the shape of his sketch-book preserved at Chatsworth, and of his marginal notes on a copy of Palladio which he carried with him from place to place, and which is now in Worcester College, Oxford.

During his first visit he seems to have achieved such a reputation that Christian IV., King of Denmark and brother of the queen of James I., invited him to enter his service. Here, again, there is no reliable information as to his achievements; the only evidence indeed is of a negative character and consists of the remark of a Danish gentleman to the effect that "your great architect left nothing to my country but the fame of his presence."

On his return to England he seems to have been occupied chiefly in the devising of masques and plays, among the earliest of which were some given at Christ Church, Oxford, to entertain James I. Oddly enough the comment of the chronicler in this case is that he "undertook to further them much and furnish them with rare devices, but performed very little of that which was expected." 2 That this failure must have been an exceptional case is sufficiently proved by the numerous drawings of scenery by him preserved at Chatsworth.

Soon after his return to England he was appointed surveyor to the queen (Anne of Denmark), and in the year 16Io surveyor of the works to Henry, Prince of IVales, but there is no record

"John Webb, in his "Vindication of Stone-Heng Restored" (1725), p. II refers to his first visit. He was back in England before Twelfth Night, 1605 , as he designed the "Mlasque of Blackness," which was produced on that day. (See Peter Cunningham's "Life of Inigo Jones.")

2 Peter Cunningham's "Life of Inigo Jones," p. 6. 
of these appointments having resulted in any architectural wort. Prince Henry died in 1612 , and in 1613 Jones secured the reversion, after Simon Basil, of the office of surveyor of works to the king. ${ }^{1}$ In the same year he went to Italy for the second time, where he studied the work of celebrated painters and architects, as well as the splendid remains of ancient architecture which were even more abundant in those days than in these. His intercourse with living architects and painters shaped his own methods of study and design, and there can be no doubt that he returned not only fully equipped to undertake any work that might fall to his lot, but deeply imbued with the spirit of Italian art and the prevalent Italian methods of design.

He walked on a high plane, his outlook was wider than that of any of his contemporaries at home. He had acquired conceptions of architecture nobler than those engendered by its application to the ordinary needs of daily life. He has left us very little record of his own opinions on any subject; it is all the more interesting, therefore, to find in his sketch-book, under the date, "Friday $y^{\mathrm{e}} 20$ January I6I4" (I6I 5 new style), a page of reflections of which the following is the gist. "In all designing of ornament one must first design the ground plain as it is for use, and then adorn and compose it with decorum according to its use. To say true, all this composed ornament resulting from abundance of design, such as was brought in by Michael Angelo and his followers, does not in my opinion suit solid architecture but is more appropriate to gardens, the ornaments of chimneys, friezes and the inside of houses, where such things must of necessity be used. For as outwardly every wise man carries himself gravely in public places, yet inwardly has imagination and fire which sometimes flies out unrestrained, just as Nature sometimes flies out to delight or amuse us, to move us to laughter, contemplation, or even horror; so in architecture the outward ornament is to be solid, proportionable according to rule, masculine and unaffected."

No epithets more suitable than the two last-masculine and unaffected-could be applied to Jones's own work.

The amount of Jones's own work in architecture is scarcely so large as has hitherto been supposed. In regard to the various buildings with which he has been credited, some of

1 "Cal. State Papers, Domestic," April 27, 16r3. 


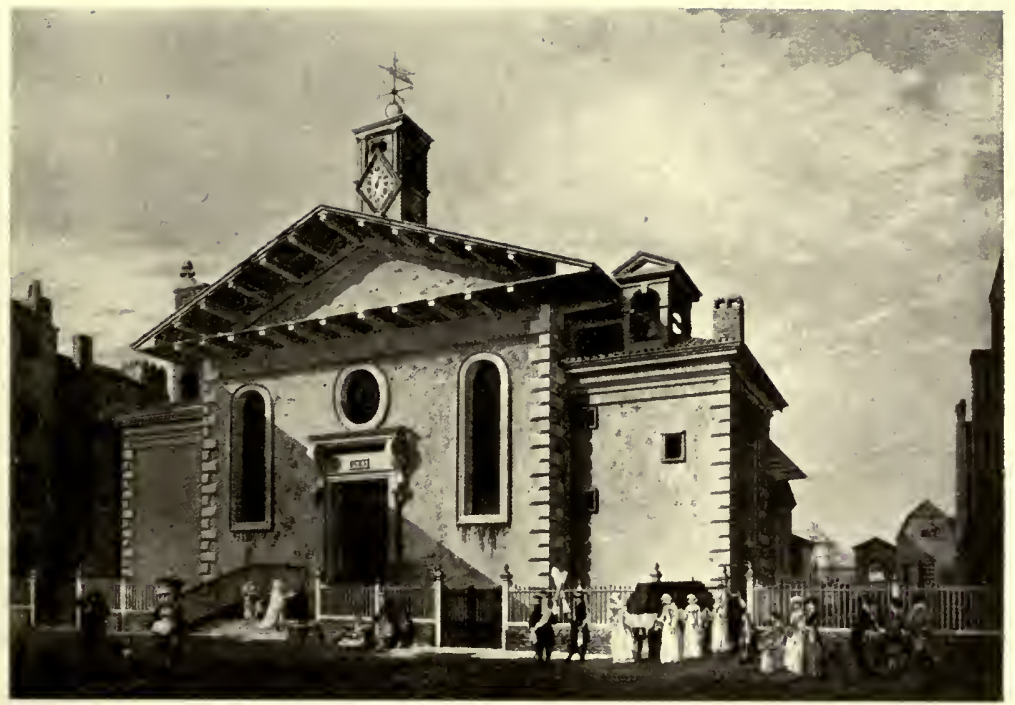

FIG. 23.-St Paul's Church, Covent Garden. West Front.

From an Engraving by Thomas Sandby.

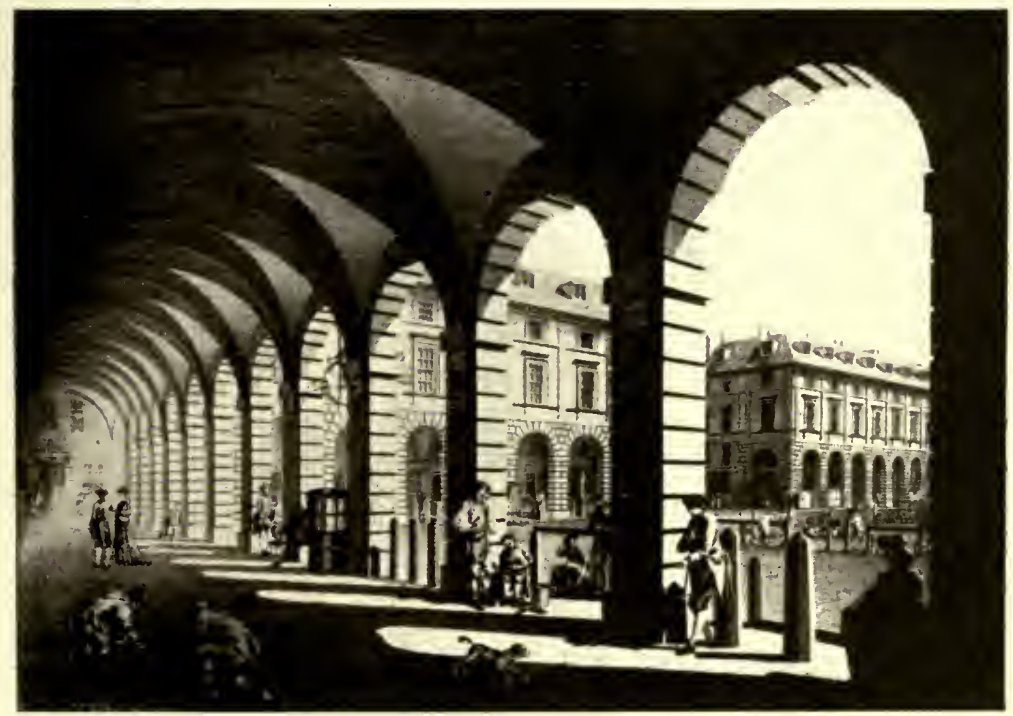

Fig. 24.-The Piazza, Covent Garden.

From an Engraving by Thomas Sandby. 


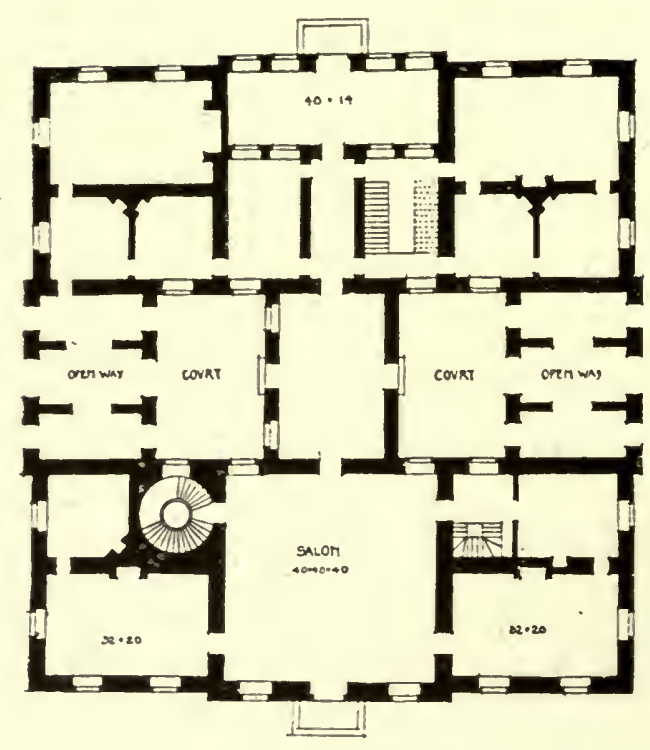

FiG. 25.-Ground Plan, Queen's House, Greenwich, 1635 .

the attributions are supported by contemporary evidence in the shape of drawings or of references in letters and documents; others by the direct enumeration of his staunch admirer, John Webb, who was his pupil and assistant, who married a kinswoman of his, and was the executor of his will. Others rest upon tradition or upon the opinions of critics. Tradition is not altogether reliable, owing partly to a natural tendency to attribute any outstanding piece of work to the most celebrated artist of the time, and partly to the natural desire of owners to attach a well-known name to their possessions. The value of a critic's opinion obviously depends upon that uncertain factor-the ability and equipment of the critic for his task, and although the opinion of a competent critic will always count for much, it cannot count for so much as direct evidence. The evidence in this casc consists of allusions in contemporary letters, not very numerous or helpful; of architectural drawings by Jones, which are helpful but not numerous; and of the testimony of Webb, who was in the best position to know what his master actually designed. Webb has occasion in his "Vindication of Stone-Heng Restored," to mention Jones's principal works, which he thus enumerates: The west portico of St Paul's Cathedral, and the reducing. of the body of it "from the steeple to the west end, into that order and uniformity we now behold "; ${ }^{1}$ St Paul's, Covent

1 "A Vindication of Stone-Heng Restored," p. 27. All this work was destroyed in the great fire. The loss of the portico was considered a national misfortune. 


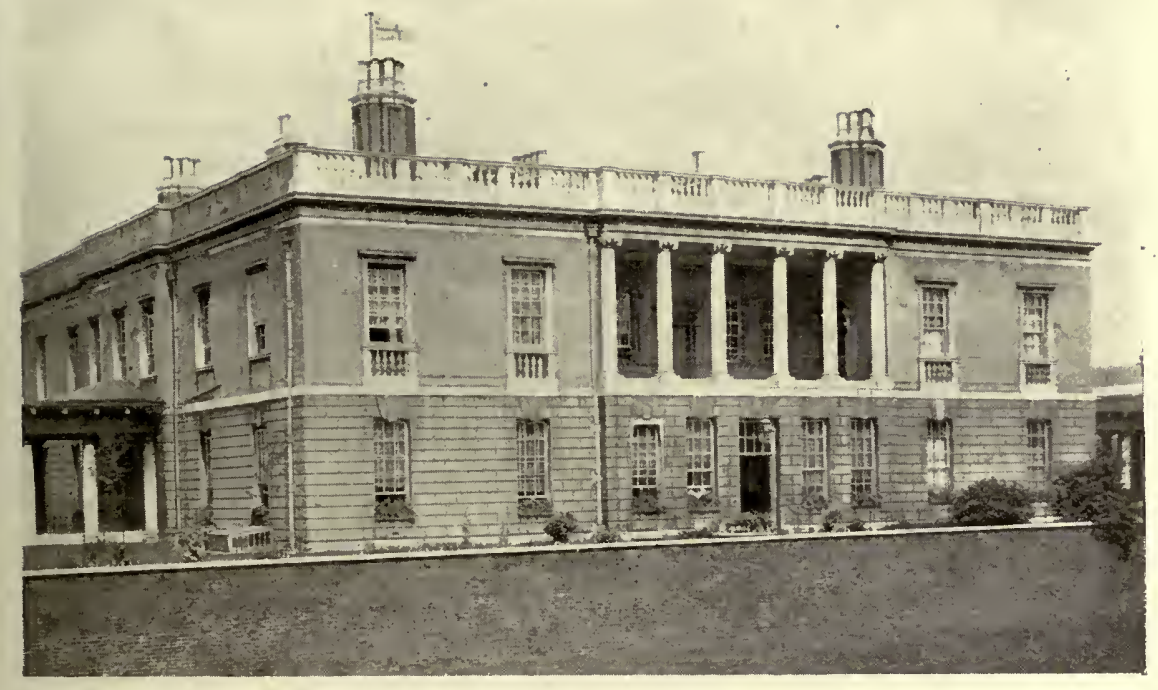

FIG. 26.-The Queen's House, Greenwich, I6I9-35.

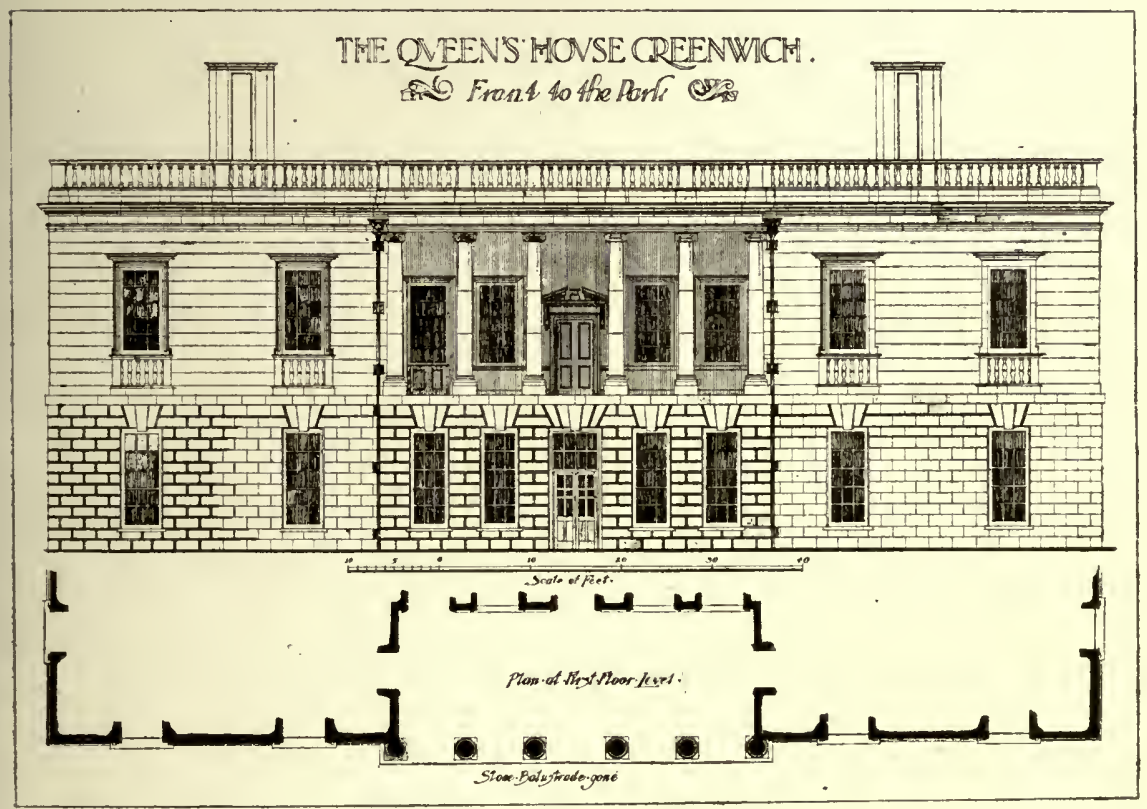

FIG. 27.-Elevation. 

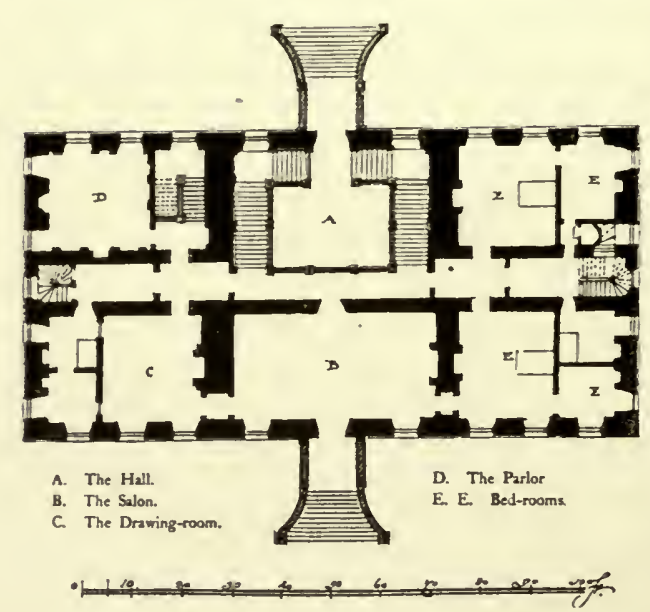

FIG. 28.-Coleshill, Berkshire, I650. Ground Plan.

Garden (Fig. 23), "built likewise with the porticoes about the Piazza there by Mr Jones" (Fig. 24) ${ }^{1}$; the royal chapels at Denmark House and St James's ; ${ }^{2}$ the Banqueting House at Whitehall; the royal house at Newmarket; ${ }^{2}$ and the queen mother's new building at Greenwich. ${ }^{3}$ The inscription on Jones's monument which was put up by $\mathrm{IVebb}$, designated him as "architectus celeberrimus," and recorded merely that he built the Royal White Hall (Aul. Alb. Reg.) and restored the Cathedral of St Paul. ${ }^{4}$

This list need not necessarily be considered as complete, but Webb evidently regarded the buildings he mentions as the most noteworthy of Jones's productions, inasmuch as he advances them as proofs of his skill in architecture, upon which his fame would rest much more securely than upon his literary and antiquarian effort in "Stone-Heng Restored." 5

The authority for the attribution to Jones of other buildings, such as the enlargement of Somerset House, the chirurgeon's

1 "A Vindication," p. 36. This work has been much altered.

2 Destroyed. 3 "A Vindication," p. I 19.

" Kennet, in Wood's "Ath. Ox.," by Bliss, iii. 806; quoted in Peter Cunningham's "Inigo Jones."

${ }^{5}$ In the year 1620 , King James I., being at Wilton on one of his progresses, sent for Inigo Jones, and instructed him to produce out of his own practice in architecture and experience in antiquities abroad, what he could discover about Stonehenge. The "few undigested notes" which Jones made were amplified by John Webb and published by him as "Stone - Heng Restored" in 1655. They went to show that Stonehenge was a Roman temple. A Dr Charleton attacked this conclusion in a pamphlet called "Chorea Gigantum," whereupon Webb retaliated in his "Vindication of Stone-Heng Restored." From the antiquarian point of view the controversy is of no value, but it is interesting because of the references to Inigo Jones. 


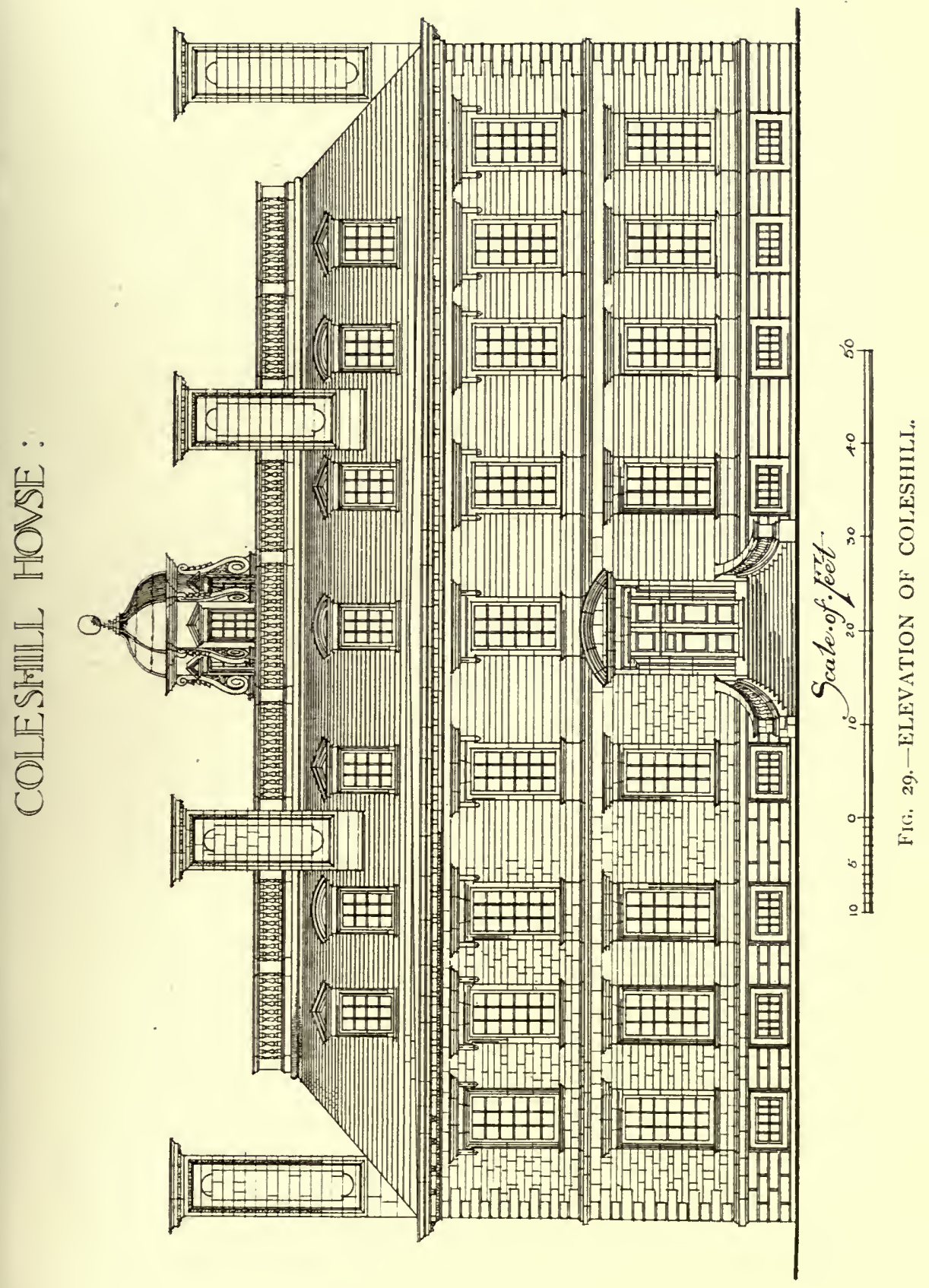




\section{REMAINING EXAMPLES OF JONES'S WORK}

theatre, and King Charles's block at Greenwich, rests upon the Worcester College and Burlington-Devonshire drawings, but these buildings should more properly be credited to Webb, by whose hand they were drawn.

The largest design by far which has hitherto been ascribed to Jones is that for the great palace at Whitehall, but it will be presently shown that the ascription is wrong, and that here also the chief credit ought to be given to John Webb.

But although in the interests of historical accuracy it is necessary to throw doubt upon much of the work with which Inigo Jones has been credited, what remains is sufficient to establish his fame, and it is beyond controversy that he was regarded as the "Vitruvius of his age." What he undoubtedly did was to introduce into England a refined and scholarly rendering of that Italian manner at which all designers had been aiming for half a century. As Webb says in addressing Dr Charleton, "I must tell you that what was truly meant by the Art of Design was scarcely known in this kingdom, until he, under the protection of his late Sacred Majesty, and that famous Mœcenas of Arts, the Right Honourable Thomas Earl of Arundel and Surrey, brought it in use and esteem among us here." IVe can also agree with him when he says that "Mr Jones was generally learned, eminent for Architecture, a great geometrician, and in designing with his pen (as Sir Anthony Vandike used to say) not to be equalled by whatever great masters in his time, for boldness, softness, sweetness, and sureness of his touches." 1 Of the buildings ascribed by Webb to Inigo Jones there remain but three-the Banqueting House, St Paul's, Covent Garden, which has been much altered, and. the Queen's House at Greenwich, which was begun in 1619 and finished in 1635 . It is quite as far removed as the Banqueting House from the traditional type of English design. It is essentially Italian both in plan and elevation (Figs. 25-27), and it indicates how completely Inigo Jones had departed from the old ways. The original drawings for the house itself have not been preserved, but there exist several sketches by Jones's hand of chimney-pieces and other details connected with it. ${ }^{2}$

1 Webb's "Vindication," p. II. It would seem that Vandyke is here quoted as using the phrase "designing with his pen," and not (as biographers have freely supposed) as having given Jones a certificate of ability.

${ }^{2}$ In the collection at the Royal Institute of British Architects. 


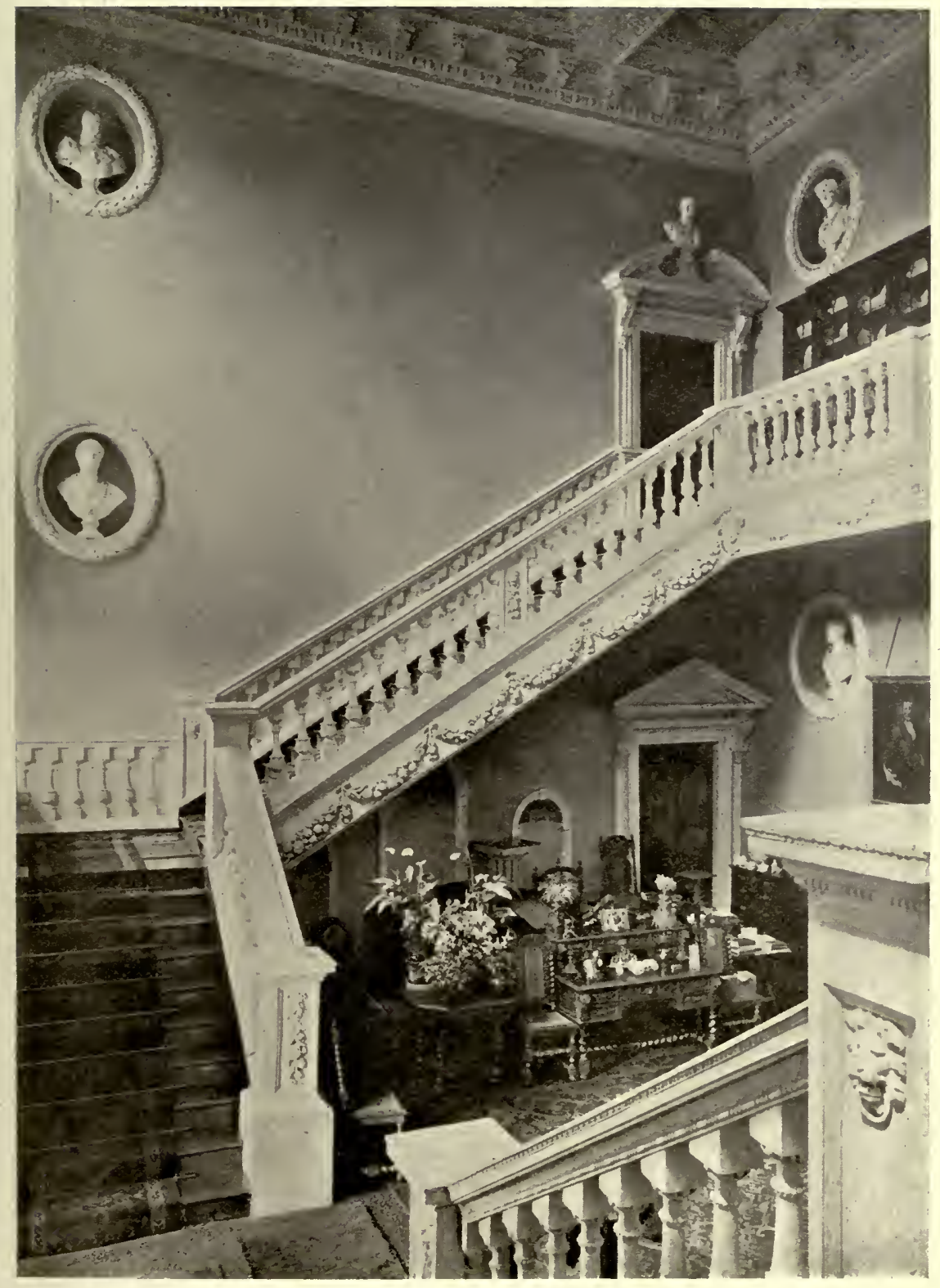

Fig. 30.-COLEShill. The Staircase. 
Another house attributed to Jones on fairly good evidence is Coleshill, in Berkshire, which stands on a steep hillside facing westwards across the valley to Highworth. It is a striking embodiment of that cultivated manner in architecture which was begun by Jones, continued by Webb, and was destined gradually to supersede the traditional methods of the countryside. Although thoroughly English in feeling it could never have been devised without an intimate knowledge of Italian detail. It is simple, dignified, and regular, depending for its effect upon nice proportion and skilful detail, not at all upon picturesque variety or broken grouping. It is a plain oblong in plan, without wings or projections (Fig. 28); it is lofty in elevation, without gables or even a pediment (Fig. 29); the corners are emphasised with bold quoins, the roof springs from a widely projecting cornice, and is crowned with a stout balustrade surrounding a spacious lead-covered flat, out of which rises a large central cupola. The slopes of the roof are diversified with dormers; the massive chimney-stacks are accurately and symmetrically placed, each answering to each. There is nothing about it haphazard or unexpected, nothing quaint or piquant; everything is correct, regular, and stately. It cannot, however, be deemed, like Tennyson's Maud,

"Eaultily faultless, icily regular, splendidly null,"

for its effect is both striking and attractive; it is noble without being oppressively grand.

The simplicity of the exterior arises from the simplicity of the plan. The ground floor, which is mainly occupied by the reception rooms and the great staircase, is raised high above the ground, thus leaving space for the windows of the basement, which is devoted to the kitchens and servants' quarters. The upper floor contains the grand saloon and bedrooms; in the roof are commodious attics; a staircase in the cupola leads on to the flat roof, whence fine views are obtained of the distant Marlborough Downs.

Although the house is of considerable size, the accommodation is not ample in proportion; the bedrooms are large and lofty, but few in number. Homeliness is somewhat sacrificed to stateliness. It is inevitable that these fine, regular houses should have the defects of their qualities.

The plan is as different from the traditional plan of English 


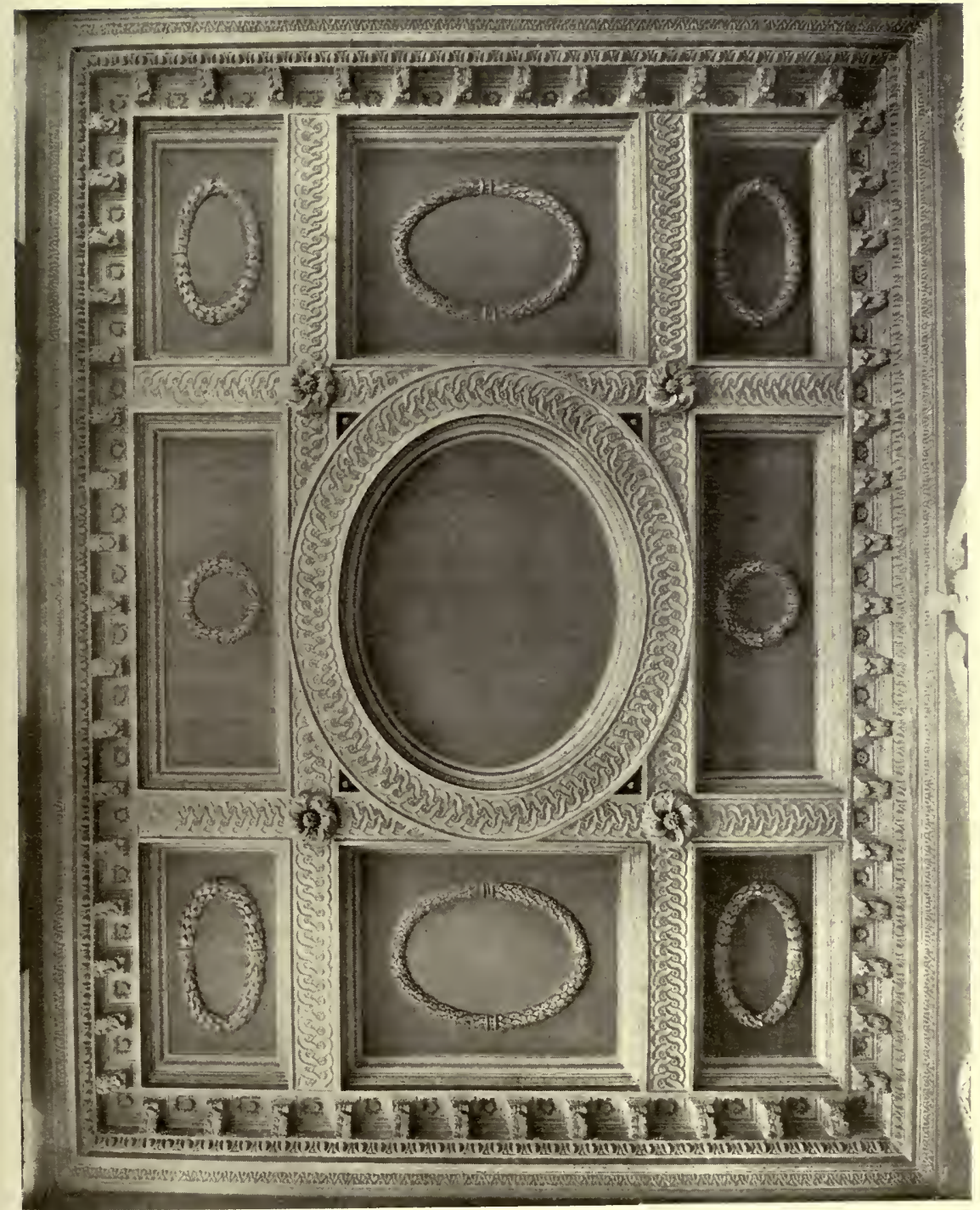

Fig. 3i.-COLESHill. Ceiling of the Hall. 
houses as are those in - Kent's "Designs of Inigo Jones," a collection which will be dealt with more particularly later on. There is no great hall connecting the parlours with the kitchens, and serving itself as one of the chief living-rooms. The servants are relegated to the basement, the whole of the ground floor is given up to the family, the hall is more of a vestibule than a living-room. In former times the staircase, although often handsomely treated, consisted of a single series of flights occupying a compact space. At Coleshill a vast hall is devoted to the staircase, or rather to two staircases, each equally eligible, starting from the same place and terminating at either end of the same landing (Fig. 30).

Although the servants were sent half underground, some of

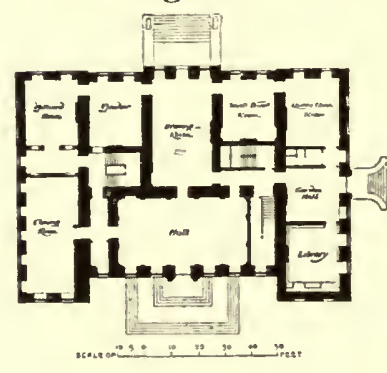

F1G. 32.--Raynham Park, Norfolk. Ground Plan.

the stateliness followed them, and the approach to the back door is flanked by two massive pillars, each of which contains a coved niche.

The building is attributed to Inigo Jones on the testimony of a tablet in the house, and its date, according to the same authority, is 1650 . In the absence of any other evidence this assertion, although not contemporaneous with the building, may be accepted ${ }^{1}$ but it should be remembered that Jones died in 1652 , and that the last years of his life, or almost the last, were spent in the turmoil of the Civil War. So much did the unrest disturb his life that he appointed John Webb to be his deputy in the office of surveyor of the works. ${ }^{2}$ In any case it must have been either Jones or WVebb who designed Coleshill, for there was nobody else who had at that time received the training necessary to produce it.

There are several fine ceilings (Fig. 3I) wrought in Jones's bold fashion, which was as different from that which produced the busy and slender patterns of Elizabethan work, as was the general treatment of plan and elevation from that of an Elizabethan mansion. It is interesting to find one of the smaller rooms panelled in an earlier style, Jacobean in character, with panelling designed for its position, not imported from elsewhere; and as it is difficult to suppose that Jones would have departed 


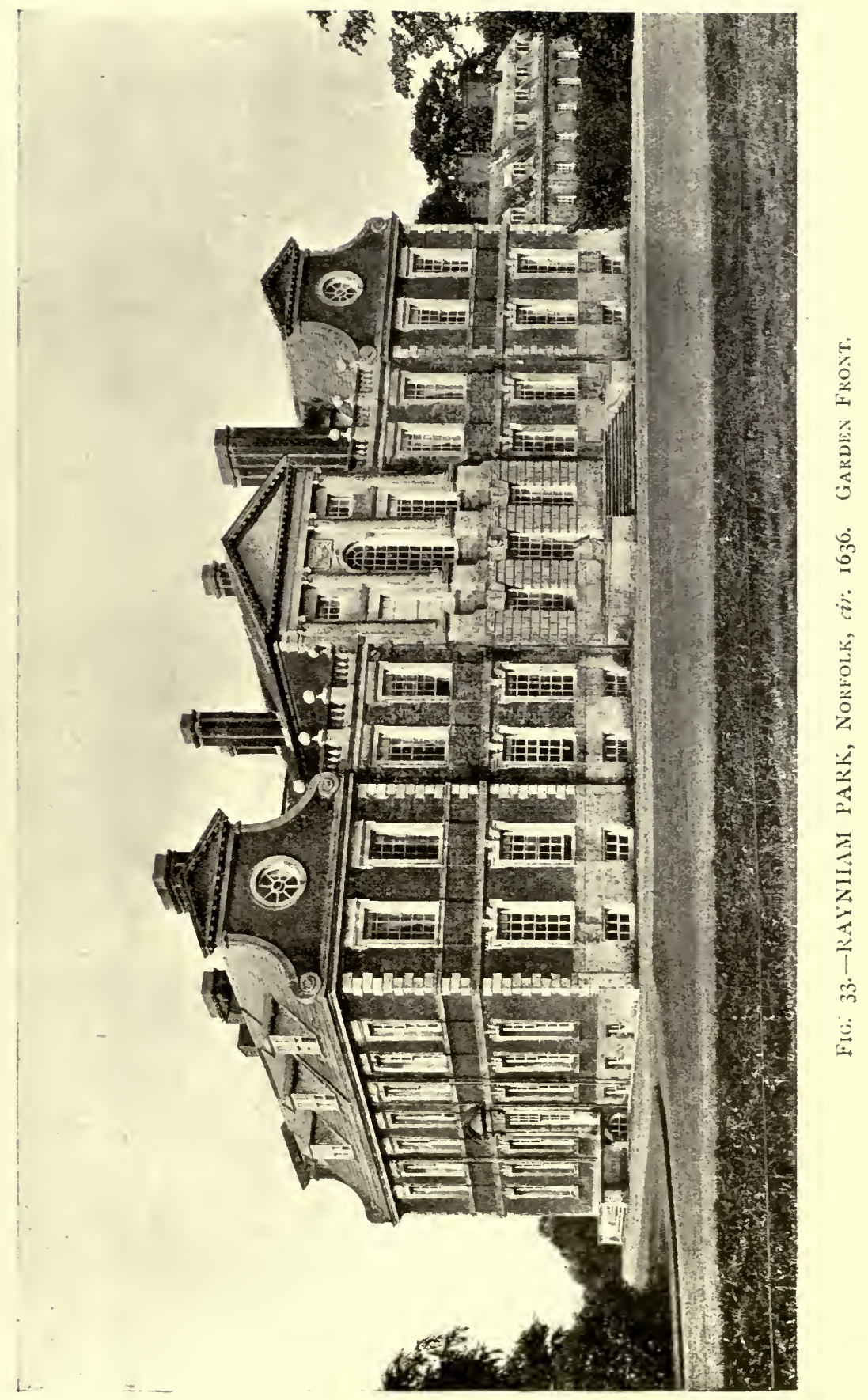


from his usual manner in this particular case, it is probable that the room was left to the unaided skill of some local craftsman, who relied on his own traditions.

Of Jones's connection with Raynham Park, in Norfolk (Figs. 32,33 ), there is no evidence beyond tradition and the style of the work itself; but much of this has touches about it which are quite in his manner. There are indications that the house was built at two periods, and these make it difficult to attribute the whole work to one designer. But the treatment of the front, with its two wings of decided though slight projection, and its rather heavily-curved gables, serves to make it a connecting link between the old and the new styles. The date of this house is generally stated to be 1636 , but further investigation is required in order to arrive at its true history, and to account for the two periods of building.

At Wilton, in Wiltshire, is some of the finest of Jones's internal work, and his connection with this house is established by a series of designs for the ceilings preserved among the IVorcester College drawings. The south front, of which there is a sketch in the R.I.B.A. collection, would hardly have served to make his reputation, but the splendid suite of state rooms is unrivalled in any English house. One of these is a double cube, being $60 \mathrm{ft}$. by $30 \mathrm{ft}$. by $30 \mathrm{ft}$. high, and another is a single cube of $30 \mathrm{ft}$. The double cube, with its stately panelling filled with Vandyke's portraits of the family, deserves its reputation as the finest room in the country (Fig. 34). A plain, double cube of these dimensions would be unpleasantly lofty (as may be realised by , visiting one at St James's Palace), but here at Wilton the great height is lessened to the eye by the introduction of a large cove which springs from a bold cornice some $9 \mathrm{ft}$. below the ceiling, thus reducing the height of the walls to $2 \mathrm{I} \mathrm{ft}$.

The double cube and such precise proportions were quite new in English architecture; so also were the careful proportions of the windows and their relation to the wall space, the pervading refinement of the mouldings, and the simplicity (almost amounting to baldness in some cases) of the general treatment. These factors inevitably influenced the plan of the house, which became much less elastic than of old, and less adaptable to the wants of English life. They tended towards the glorification of the house at the expense of its inhabitants and to subordinate household comfort to architecture. 


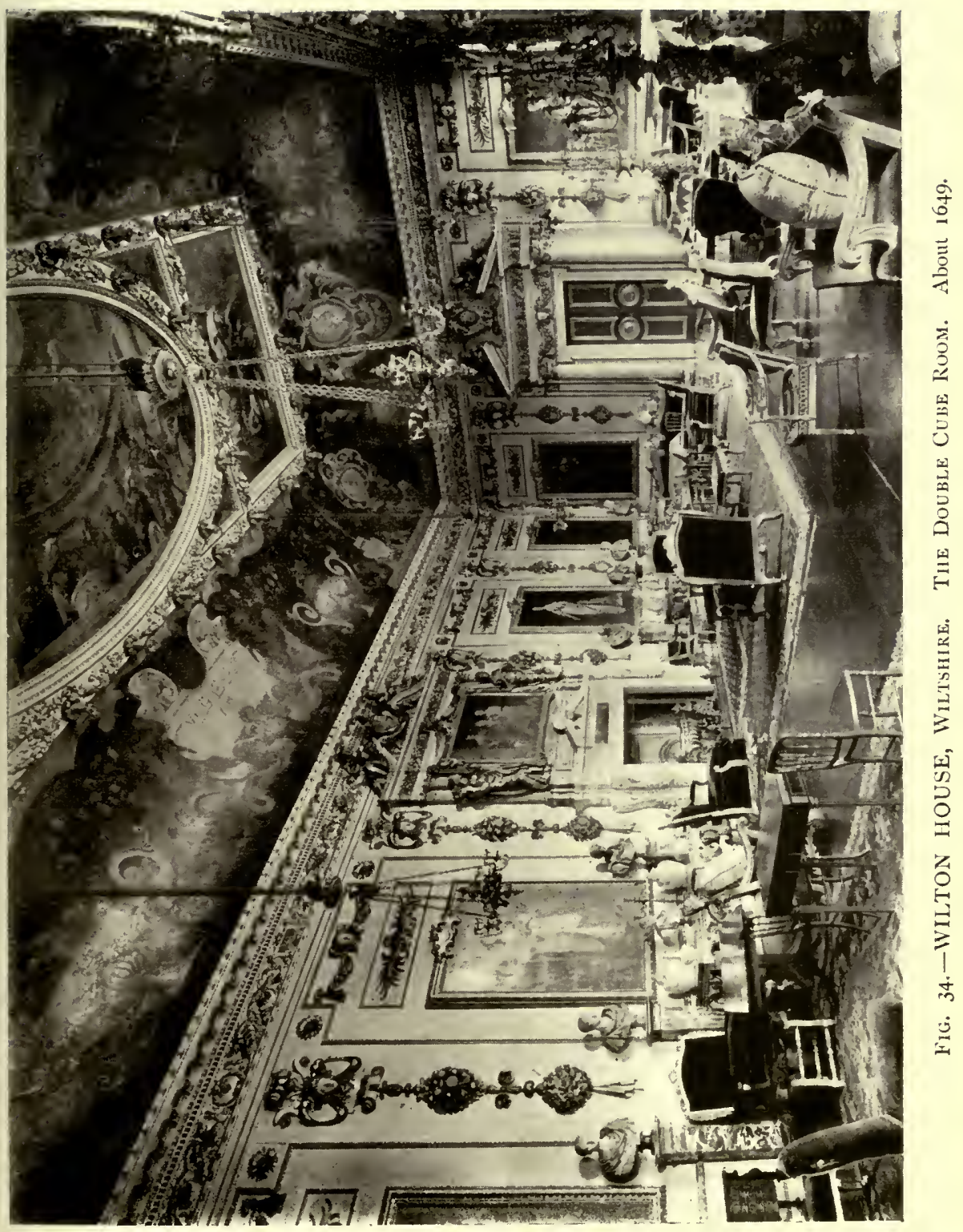




\section{WILTON HOUSE-THE DOUBLE CUBE ROOM}

A small but admirable piece of work which may safely be assigned to Jones is the water-gate of York House (Fig. 35). Its present rather forlorn situation at the bottom of Buckingham Street, Strand, gives no indication that it was an adjunct of the town house of the princely Villiers, Duke of Buckingham, the "Steenie" of Charles I. York House, for so the place was called, had belonged to the Archbishops of York, but when it came into the hands of Buckingham, he pulled it down and built a large and temporary structure, apparently for the purpose of using it for state occasions. Within its walls he housed a magnificent collection of pictures and other works of art, purchased from Rubens. ${ }^{1}$ Gerbier (who will be mentioned again later) was employed by the duke to design some of the new work at York House, and hence the water-gate has been attributed to him. But the fact that a drawing of it by Webb is included among the "Inigo Jones" drawings precludes this idea, for it is hard to imagine either Jones or Webb condescending to delineate any work of Gerbier's. Apart from this it is improbable that Gerbier could have designed anything so good. That excellent mason and sculptor, Nicholas Stone, was employed upon its execution, and he put in a claim to the design, but IVebb's drawing is a sufficient answer to this pretension also.

York House was sold in 1672 by the second duke, the "chymist, fiddler, statesman, and buffoon" of Dryden, to a syndicate who pulled down the house, and covered the site with new buildings, leaving the water-gate as practically the sole relic of the old palace. Its appearance, backed by its newer neighbours, is well indicated in a drawing by Thomas Sandby, made about i 760 (reproduced as the frontispiece).

Inigo Jones died in June $1652 .{ }^{2} \quad$ His will is dated the $22 \mathrm{nd}$ July I650, when he was "aged seaventy-seaven yeares." He left in specified sums the amount of $£ 4$, I 50 , and he bequeathed the debt owing to him from the late king and queen, of which the amount is not stated, in equal shares to his executor, John Webb, and one Richard Gammon, a carpenter, after deducting $£_{50}$ for the paymaster of the works payable within a month after the discharge of the debt. He disposes of one half of his wearing apparel, but does not mention the other half, nor does

1 "London Past and Present," by Wheatley and Cunningham.

${ }^{2}$ Peter Cunningham's "Life," where it is stated that the register of St Bennet's records his burial on the 26 th June. 


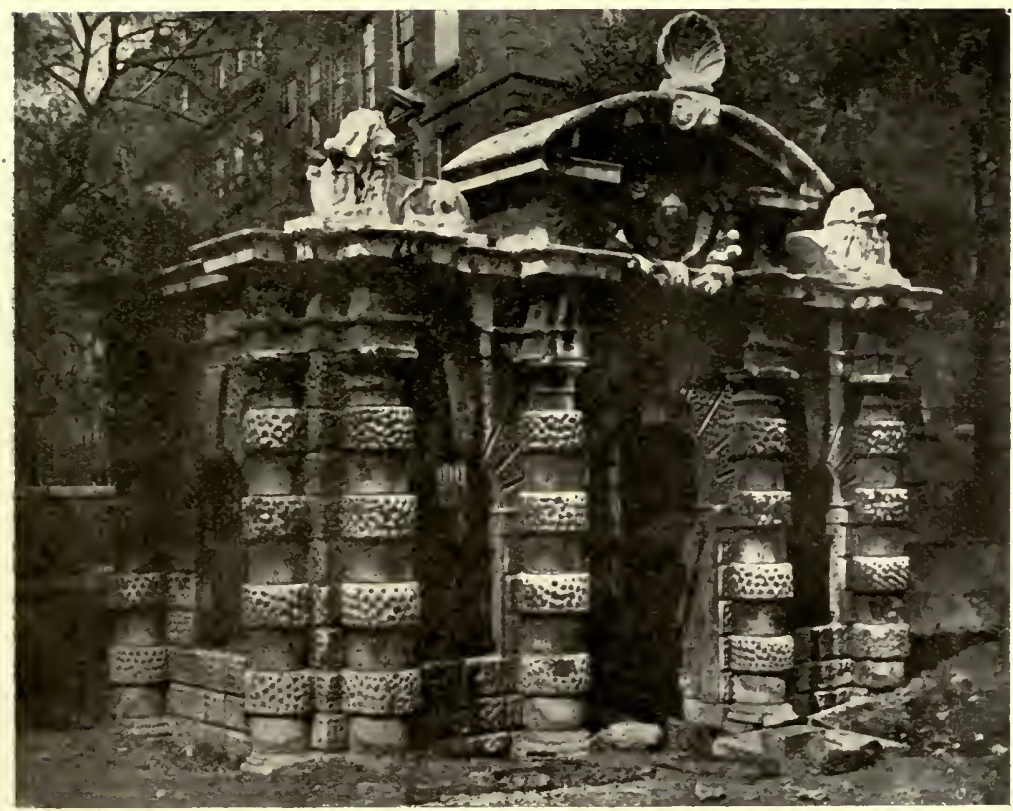

F1G. 35.-The Water-Gate of York House, London.

he dispose of the residue of his estate. He mentions no collection of drawings (as did John Webb) nor any books. On the face of it he can hardly be considered a wealthy man at his death. A really exhaustive account of his life has yet to be written; one which shall be free from the undemonstrable attribution of work to him; free from baseless eulogy on the one hand and detraction on the other; one which shall fairly balance tradition and evidence; which shall take account of him as an artist and scene painter, as a surveyor dealing from day to day with prosaic details, and as an architectural designer. It has been no part of the present purpose to enter minutely into these particulars; it was outside the scope of this work to marshal all the evidence for or against his authorship of every building with which he has been credited. The aim has been to indicate the general influence he had upon English architecture, particularly in respect of house design.

He was the most notable figure that had hitherto appeared upon the stage of English architecture, the most refined and scholarly, with an exquisite sense of proportion. He was at heart an artist, just as IVren was at heart a man of science. 


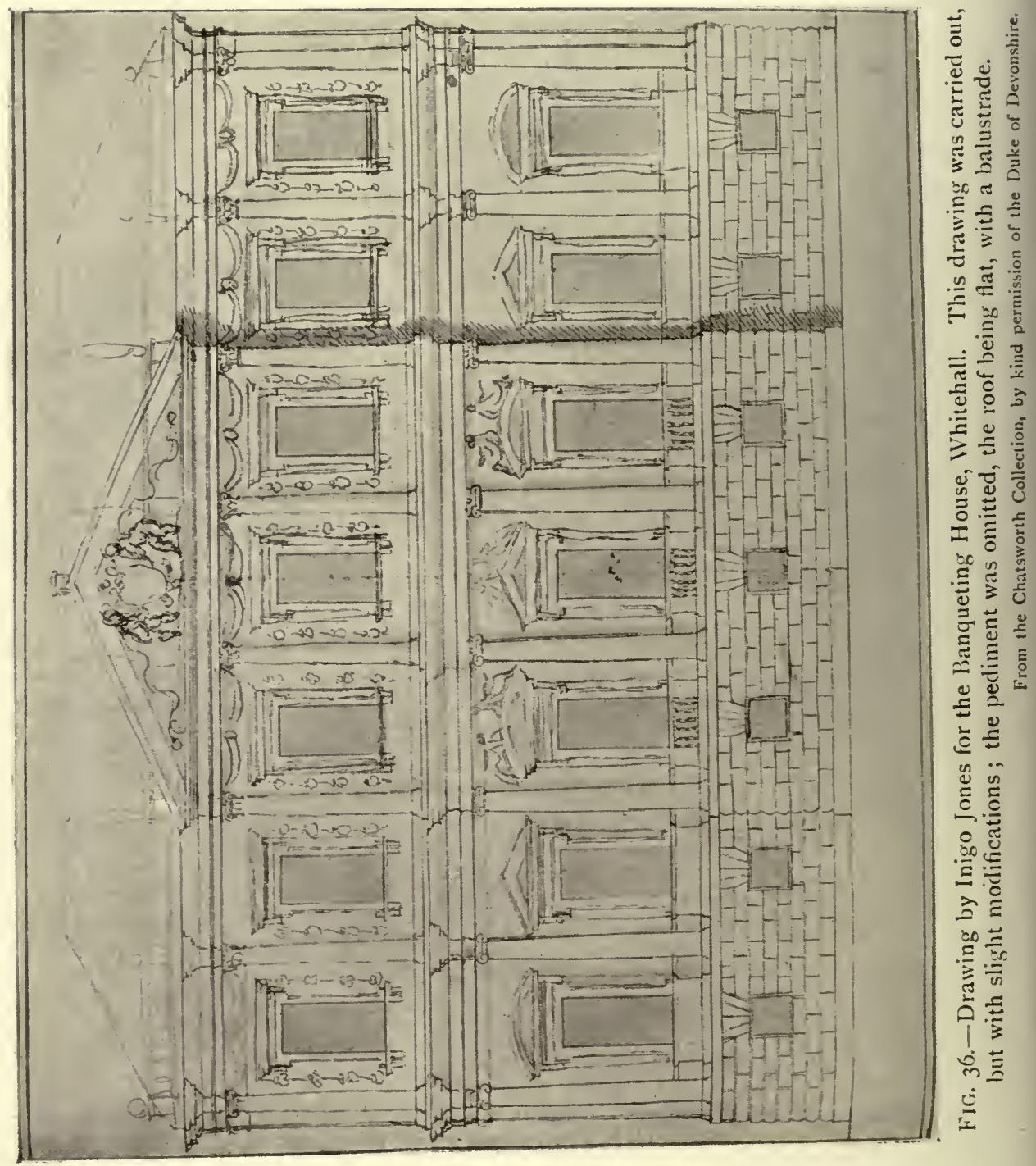




\section{THE DRAWINGS OF INIGO JONES AND JOHN WEBB}

\section{WEBB'S OWN WORK}

REFERENCE has been made more than once to the design for an immense palace at Whitehall. The drawings for this, which are, most of them, preserved at Worcester College, Oxford, were first introduced to the public by William Kent, the architect, in the year 1727, under the title of "Designs of Inigo Jones." There are two volumes of this book, the first occupied chiefly with the great palace; the second with miscellaneous designs, principally houses. The drawings used by Kent were in the possession of Lord Burlington, the well-known dilettante; at any rate, some of them were, while others seem to have belonged to Dr Clarke of All Souls College, Oxford, who subsequently left them to. Worcester College.

The history of the drawings is not altogether free from obscurity, but it appears to be as follows. John Webb had in his possession a large number of drawings, mostly done by himself, but including some by his old master, Inigo Jones. At his death in 1672 Webb left all his "library and books, and all his prints and cuts and drawings of architecture" to his son IVilliam, with strict injunctions that they were to be kept together. ${ }^{1}$ This injunction was not respected, and it is said that the widow of William Webb disposed of the collection. John Aubrey, writing between I 669 and I 696 , says that "Mr Oliver, the City Surveyor, hath all his [Jones's] papers and designs, not only of St Paul's Cathedral, etc., and the Banqueting House, but his designs of all Whitehall suitable to the Banqueting House; a rare thing, which see." 2 It is almost certain that the drawings

1 Peter Cunningham's "Inigo Jones," p. 39.

2 John Aubrey's "Brief Lives," ed. by Andrew Clark. Oxford, 1898, vol. ii. Io. 
mentioned by Aubrey were those left to William Webb by his father, for it is extremely unlikely that there would have been two collections of the kind. There is no record of how $\mathrm{Mr}$ Oliver obtained them, nor of how he disposed of them; the next thing that is known is that Lord Burlington had acquired the larger half and Dr Clarke the smaller, but in some respects the more important. Lord Burlington's portion descended to the Dukes of Devonshire, and the seventh duke made a gift of a great part to the Royal Institute of British Architects, in whose library they are preserved. Some, however, he retained at Chatsworth, including a series entitled "Designs for Whitehall," which are, as a matter of fact, mostly preliminary sketches by Webb for the various versions of the great palace; and a large number of designs by Jones for the scenery; setting, and costumes of masques, as well as some by Webb. Dr Clarke bequeathed his portion to Worcester College, Oxford, on his death in 1736 . It is practically certain that the Burlington collection and that at Worcester College were originally one collection, inasmuch as each contains drawings which supplement some of those in the other. At Worcester College are the "designs for all Whitehall suitable to the Banqueting House," together with a large number of miscellaneous drawings. At Chatsworth are designs of the Banqueting House itself, together with many preliminary drawings for the palace at Whitehall. At the Royal Institute of British Architects is a drawing of the west front of St Paul's, together with many others, notably those of the King Charles block at Greenwich, and almost the whole series which Kent used for his second volume of "Designs of Inigo Jones."

Besides these drawings there are yet others attributed to Jones at the British Museum. Some of these are the originals of the design for Whitehall Palace published by Campbell in his "Vitruvius Britannicus," which is quite different from that published by Kent. Others are sketches of figures and drapery undoubtedly drawn by Jones. The drawings used by Campbell were in I 7 I 7 in the possession of William Emmett, of Bromley, an architect, but it is not known how he became possessed of them, nor whether they once formed part of WVebb's collection, but their style links them up with the rest of the drawings of the palace. ${ }^{1}$

The whole of these drawings have until quite recently been

${ }^{1}$ One of this series is illustrated in Fig. 39. 
regarded as the work of Jones himself. Aubrey mentions them as his; Kent published many of them as his; Campbell attributed to him those which he used, presumably on the authority of Emmett. All subsequent writers have taken the authorship for granted, although some have agreed that Jones's hand is not visible in the finished designs of the palace, preserved at Worcester College. This acquiescence in established opinion is not surprising. The drawings had not been thoroughly examined and catalogued, and in particular those at one library had not been collated with those at the others. But when recently the various collections came to be catalogued and definitely arranged, when, by the aid of photographs, they were brought together and compared one with another, very interesting results were obtained. It soon became easy to differentiate between Jones's draughtsmanship and Webb's. The result was that it bccame apparent that nearly the whole of the drawings should be assigned to Webb and very few to Jones. Nor would logic allow a halt to be called there, and suffer us to say that Webb may have been the draughtsman, but Jones was still the designer. For many of the drawings are sketches with notes in Webb's writing, which go to show how he developed his ideas as he went along. It would be impossible in the space at command to indicate fully which drawings are by Jones, which are by Webb inspired by Jones, and which are of Webb's own design. But in the latter category the evidence constrains us to place the designs for the palace at Whitehall, the designs in the second volume of Kent, and those for King Charles's block at Greenwich. ${ }^{1}$

Although the pursuit of truth compels us to credit Webb rather than Jones with the bulk of the designs in both of Kent's volumes, admirers of the great master will probably not only survive the shock, but will eventually be grateful to find that the indifferent pieces of design which mar many of those excellent conceptions need not be attributed to him.

It would be impossible to pursue the subject fully here, but the branch of it which refers to the palace of Whitehall is sufficiently curious to justify a brief account.

${ }^{1}$ Those who desire to pursue the subject more fully are referred to two papers by the author-_"The Burlington-Devonshire Drawings," in the Journal of the Royal Institute of British Architects, Third Series, vol. xriii., No. Io, and "The Original Drawings for the Palace at Whitehall, attributed to Inigo Jones," Architectural Reviea', June igrz. 
The generally received opinion was that two designs were prepared for the palace, one of which was published by Campbell in 1722 , and the other by Kent in 1727 . Authorities have differed as to which was the earlier to be derised, but both are attributed to Jones. Both designs include the well-known Banqueting House, and it has been taken for granted that they must have been designed before that building was erected. The date of its erection is on record. It was begun on Ist June I6I9, and completed in March I622. The assumption, therefore, was that James I. contemplated either the vast palace illustrated by Kent, or the smaller version of Campbell, but that the only portion actually built was the Banqueting House.

As a matter of fact, James can have had nothing to do with either of these designs. Campbell states that the design which he published was submitted to Charles I. by Inigo Jones in I639. The accuracy of this statement has been questioned, but it was evidently made on the authority of a formal inscription written by Emmett on one of the drawings. If true, it disposes of the idea that this design was made prior to the building of the Banqueting House. But that idea is in any case not tenable, for the Banqueting House was built to replace an older building which was burnt down in January I6I9; it was built immediately after that catastrophe, and built on the same site. As onlysome three months elapsed between the destruction of the old building and the completion of the design for the new one, any idea of the conception of so vast a scheme as the new palace in that space of time must be abandoned. Moreover, there are preserved at Chatsworth Jones's own drawings for the new Banqueting House, which is there shown as an isolated structure (Figs. 36, 37). Further, although the accounts for the new Banqueting House are preserved, together with a detailed description of it, and a record of a payment to Inigo Jones for the "model" of it, there is no mention of any other buildings in connection with it, contemplated or otherwise. Nor is there any contemporary reference to the projected palace of any kind until the one presently to be mentioned.

In the Smithson collection there is an interesting drawing which shows a plan of the old Banqueting House previous to its destruction, and an elevation of the ground story of the new Banqueting House (Fig. 38). They are obviously not drawn to the same scale, inasmuch as the new building was $100 \mathrm{ft}$. long as against I $20 \mathrm{ft}$. for the old. The fact that Smithson thought it 


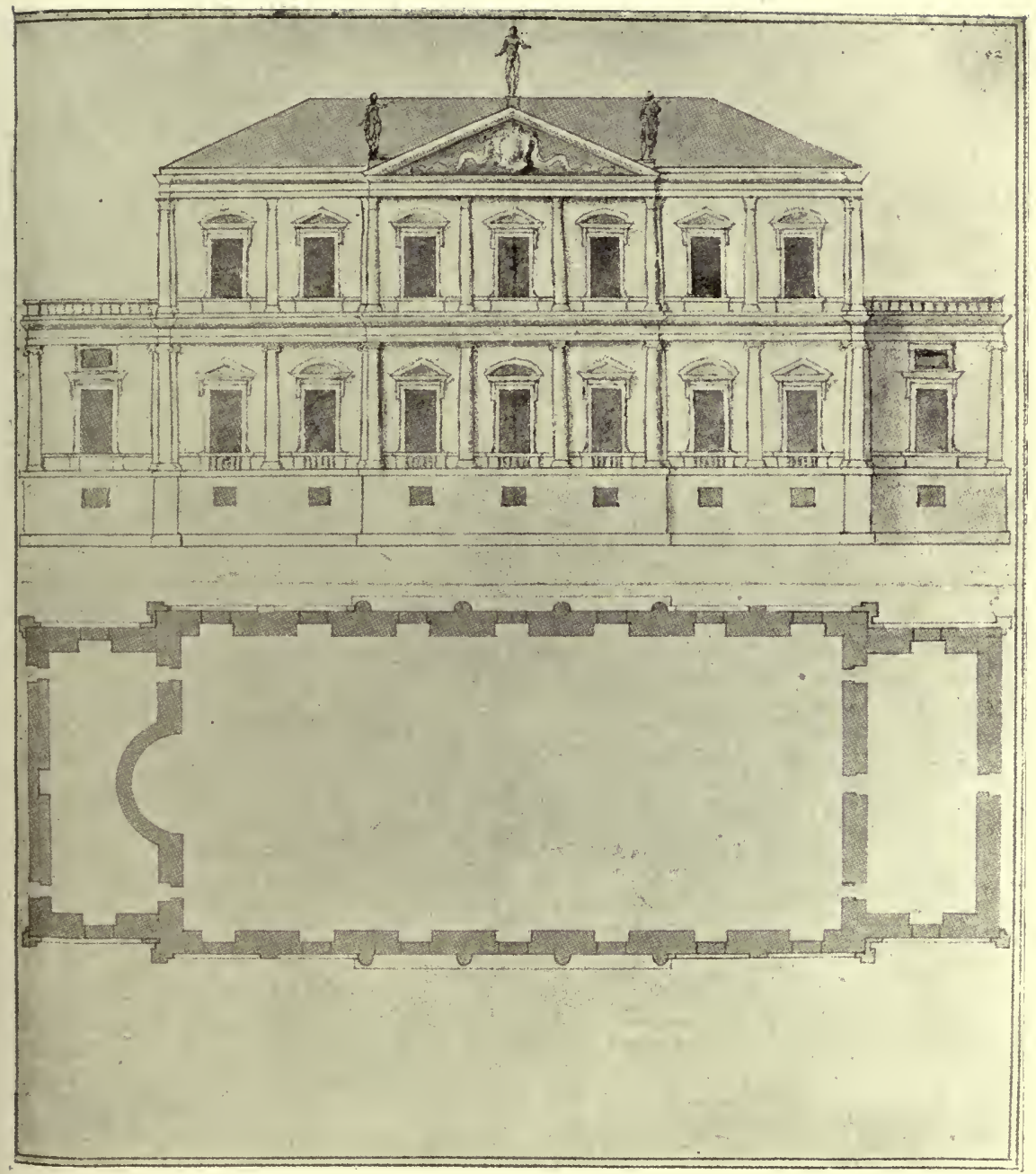

FiG. 37.-Drawing by Inigo Jones for the Banqueting House,"Whitehall. A preliminary sketch, subsequently modified. The annexes were omitted.

From the Chatsworth Collection.

worth while to draw the ground story, so far as then built, suggests that he was struck by its novel treatment. The rusticated stonework, the flat arched openings, and the unmoulded plinth and stringcourse were unfamiliar features.

There is so far nothing to connect Jones with the designs for the palace, as distinguished from the Banqueting House, except the assumption of Kent and Campbell. An examination of the various 


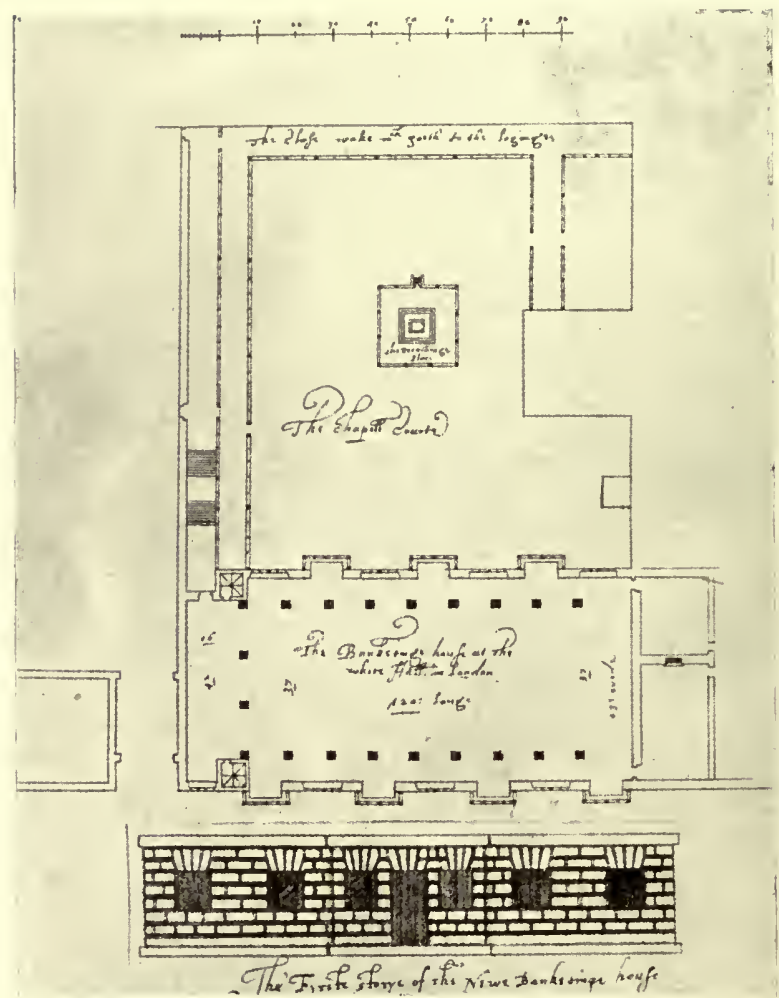

Fig. 38. - Plan of the Old Banqueting House which was burnt down. Below is an Elevation of "The First Storye of the Newe Banketinge house."

From the Smithson Collection.

drawings serves further to dissociate him from them. At Worcester College are the finished drawings for the scheme published by Kent: but in addition to those which he used are others which have not hitherto been elucidated; some of them are, in fact, the elevations and sections of a different scheme, while one is the isolated plan of a third. The key to this part of the puzzle lies at Chatsworth in the shape of the collection of drawings and sketches, bound together and entitled "Designs for Whitehall." These turn out to be almost entirely the work of Webb, among them being, however, the drawings of the Banqueting House by Jones himself. The drawings by Webb are the preliminary sketches for the finished set at Worcester College, as well as some for yet other schemes, and 
among them are the elevations, as well as a plan, corresponding to the isolated plan at Worcester College. The writing and the drawing, the thumb-nail sketches, the alterations, variations, and corrections all go to show that here we have the inception of several schemes, all by $\mathrm{W}$ ebb, the ultimate outcome of which was the well-known design published some eighty years afterwards by Kent.

There are, in fact, not two, but at least seven different schemes for the palace, more or less worked out. Of these two are by Webb, and are preliminary to the third, which was published by Kent; a fourth is a variant of the third; the fifth and sixth are undoubtedly by Webb; the seventh is the British Museum design published by Campbell.

The conclusion forced upon the inquirer by a prolonged examination of the drawings - that IVebb was the real author of the designs for the palace-is curiously confirmed by a document preserved in the "State Papers," an important passage in which has hitherto escaped the attention it deserves. This is a petition, signed by $\mathrm{Webb}$, presented soon after the restoration of Charles II., wherein he seeks the office of surveyor of the king's works, which was about to be bestowed upon $\mathrm{Mr}$ Denham, afterwards Sir John. ${ }^{1}$ The whole document is interesting, but is too long to quote in its entirety. In the petition itself, Webb says that he was by the especial command of "your Majesty's Royal Father of ever blessed memory brought up by Inigo Jones, Esq., your Majesty's late surveyor of the works, in the study of architecture, for enabling him to do your Royal Father and your Majesty service in the said office. In order whereunto he was by $\mathrm{Mr}$ Jones, upon leaving his house at the beginning of the late unhappy war, appointed his Deputy to execute the said place in his absence, which your petitioner did, until by a Committee of Parliament in the year I643 he was thrust out." He then goes on to say that in preparing the royal houses for His Majesty's reception he has engaged his own credit to the amount of $£ 8,140$. 5s. 4 d., of which he has only received $£_{500}$, and prays the king to "settle upon him the surveyor's office of your majesty's work, whereunto your Royal Father assigned him, and to that end only ordered his education." In the "Brief of Mr Webb's Case," attached to the petition, occurs the remarkable piece of testimony alluded to: "That he was Mr Jones's Deputy and in actual possession of

1 "State Papers, Domestic: Charles II.," vol. v., Nos. 74, 74, I. 
the office upon his leaving London, and attended his Majesty in that capacity at Hampton Court and at the Isle of IVight, where he received his majesty's command to design a palace for Whitehall, which he did until his majesty's unfortunate calamity caused him to desist."

This striking statement supplies an explanation of the whole intricate series of drawings, including those at the British Museum. It is the culminating proof that they were the work of $\mathrm{Webb}$ and not of Jones. It accounts for the absence of any reference in earlier documents to a project which would have been vast enough to attract much attention in court circles had it been in contemplation; and indeed it goes to show that the project never had any real vitality, but was merely an exercise on paper. Incidentally, it illustrates the inability of Charles I. to perceive the real trend of events, for he gave instructions for this huge palace when already the shadow of death had almost enveloped him.

Webb's petition did not serve to divert the gift of the coveted office from Denham to himself, but it may have suggested to Charles II. the idea of resuscitating the project of a palace at Whitehall; for there is a block plan by Webb of a scheme differing from all the others, dated 17 th October 1661 , and there are notes in Webb's hand on some of the drawings which show that he submitted to the second Charles some of the designs which he had prepared for the first, and that they were "taken," or accepted. It is certain that Charles II. did entertain for a time the idea of rebuilding the palace, for Evelyn relates, under the date 27 th October 1664 , that being at Whitehall, the king took him asicle into a window recess, and having borrowed from him a pencil and paper, proceeded to draw, using the window-sill as a table, a plan for the projected palace, with the rooms of state and other particulars. But in Webb's case, as in so many others, the bright hopes inspired by the Restoration were overclouded; the projected palace went no further than to be a design on paper; the surveyorship was given to Denham, and on his death, in spite of a promise of its reversion, Webb suffered the mortification of seeing the young and wholly inexperienced Wren, who was at that time not even an architect, passed over his head.

With regard to the design of the palace much has been written in praise, something in dispraise. Nearly all that has been said has been founded upon Kent's version. The vastness 


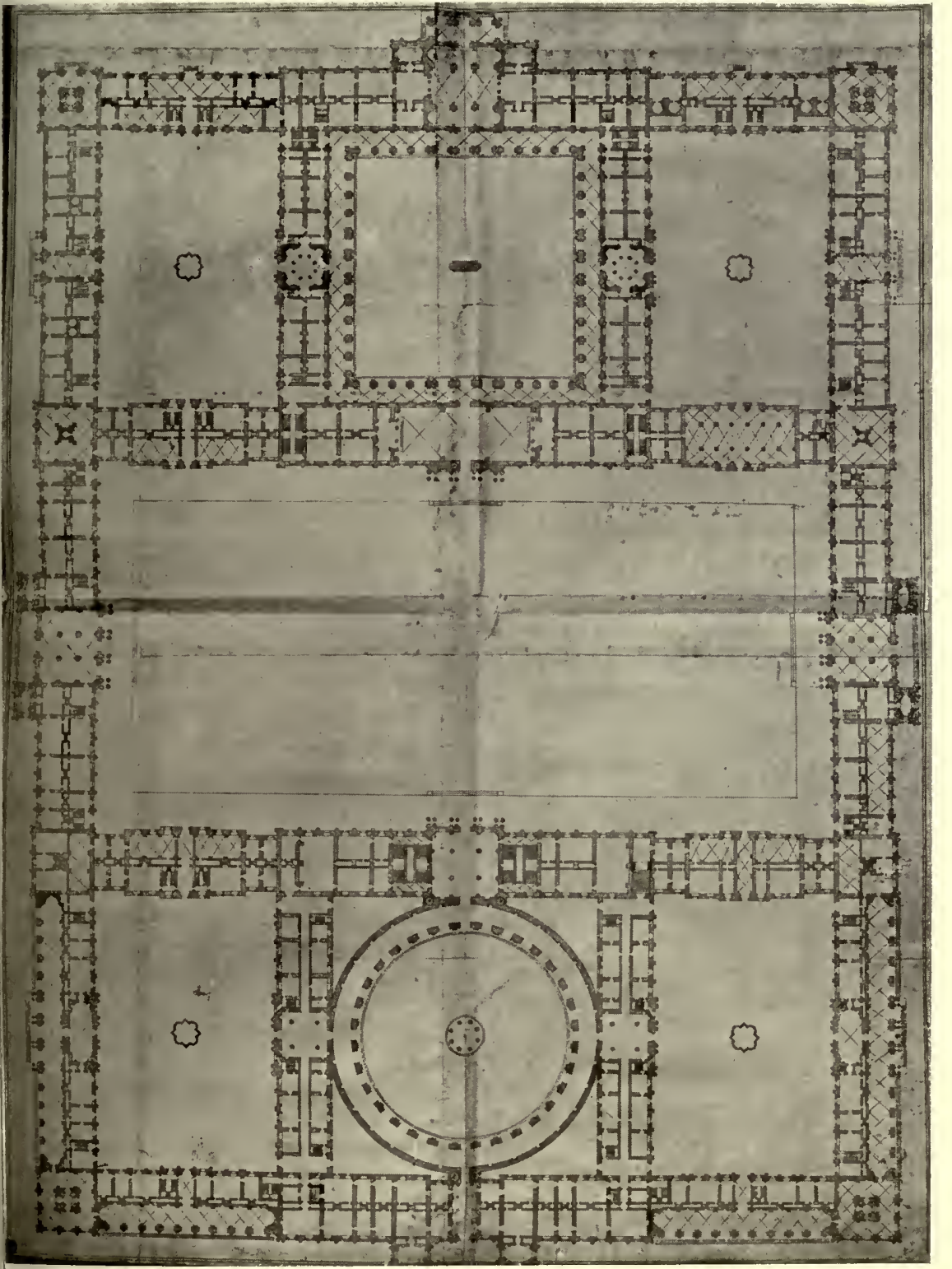

苛 竞

$\stackrel{\leftrightarrow}{\stackrel{5}{*}}$

ن

过

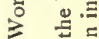

․ํㅇํㅇ

;

되 त

出 $\triangleq$

되 현

曰1

$\geqslant$ U

$=$ ko

世 氙

(5)

단

$\Rightarrow \quad . \quad$ to

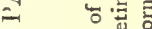

가.

F .

a

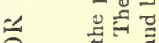

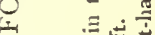

乙 手岂

3

=

( गु

○ं ड

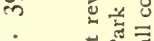

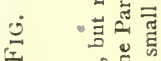

ث气

过藏

단

उЕ

등

$\Xi$ 品

든해

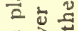

芷齐

in

吾告 


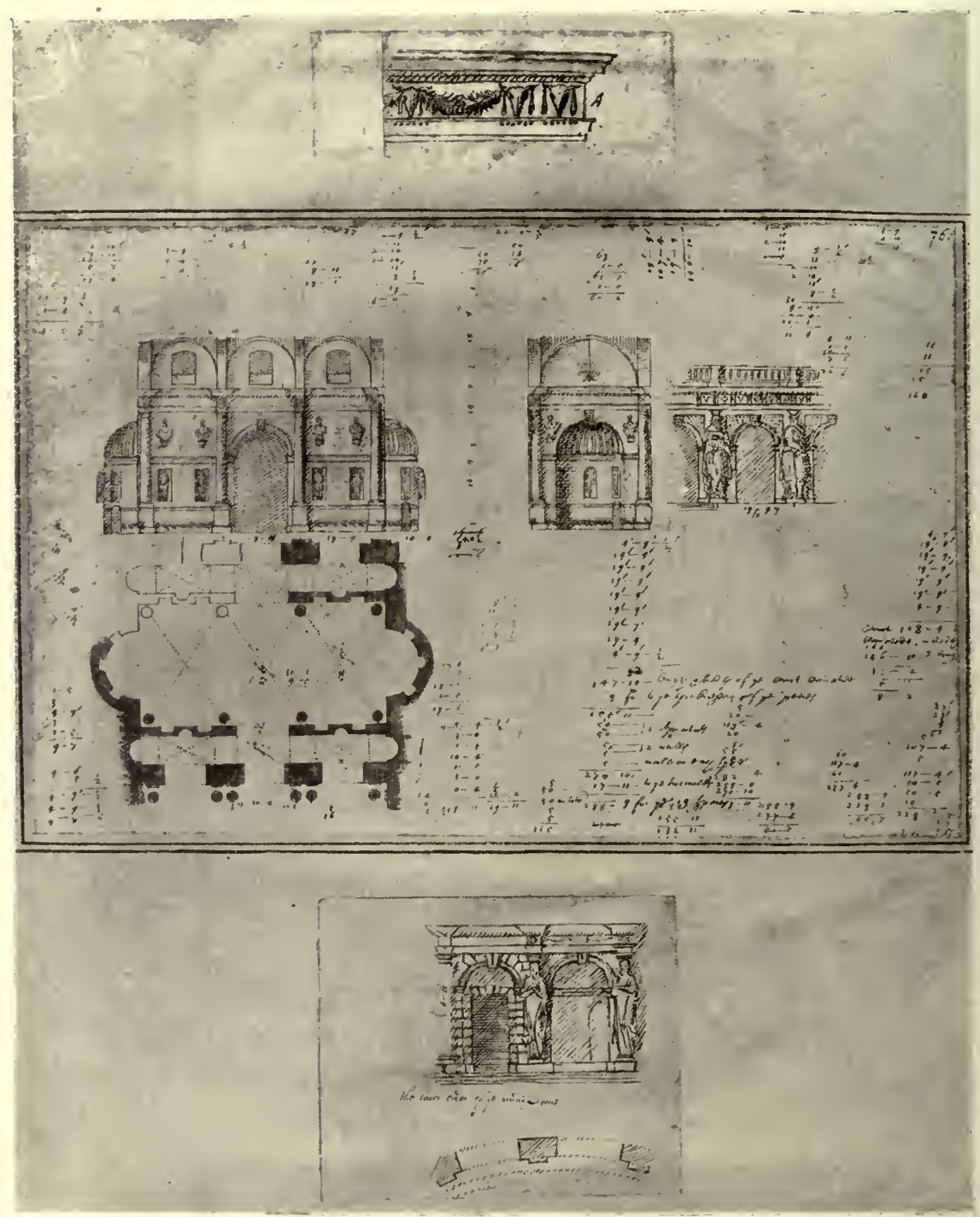

Fig. 40.-SKETCHES FOR PARTS OF THE PALACE AT WHITEHALL, INCI.UDING TWO FOR THE "PERSIAXs." The sketches and writing are by Webb's hand.

From the Chatsworth Collection, by kind permission of the Duke of Devonshire. 


\section{SCHEME OF THE WHITEHALL BUILDINGS 73}

of the scheme and the belief that Jones devised it have acted and reacted upon each other in stimulating admiration. Had the project been of ordinary dimensions, or had not Jones been credited with it, it is conceivable that less eulogistic language might have been employed.

The scheme, however, is truly remarkable. ${ }^{1} \quad$ It is of vast size ; the buildings and courts would have covered an area of some 23 acres (Fig. 39). They would have extended from the Charity Commission's offices, south of the Banqueting House, to within a hundred feet of Craig's Court on the north ; and from Whitehall Court on the east, right across the Horse Guards parade and up to the enclosure of the park on the west. They are skilfully disposed, with great architectural magnificence. The noble Banqueting House was to be incorporated, but it was to be one of the minor features. There were to be seven courts; the largest, in the middle of the building, was $732 \mathrm{ft}$. long by 370 $\mathrm{ft}$. wide; the four corner courts, each $280 \mathrm{ft}$. by $\mathrm{i} 8 \mathrm{O} \mathrm{ft}$. ; one of the courts was to be circular, $220 \mathrm{ft}$. in diameter, and its columns were to be fashioned in the likeness of renerable men in flowing draperies, called Persians, as distinguished from the female figures which, fulfilling a similar purpose, were called Caryatides.

All these particulars can be gathered from Kent's published version. He gives plans, elevations, and sections, but he gives no internal features save the insignificant matters inherent in the sections. Webb's drawings, on the other hand, include not only sketches for the general plan and for detailed portions of it, not only sketches for external features, and among them several alternatives for the Persians, but also the working out of lobbies, staircases, chapels and the like (Figs. 40, 4I). It is true that these details are part of one of the preliminary schemes, but they show how seriously he took his work, and how thoroughly he had mastered the details of classic design. These sketches are unmistakably Webb's; there are none by Jones relating to the designing of the palace. It is interesting to compare Webb's large plan for Whitehall with Philibert de l'Orme's plan for the Tuileries, which has two oval courts set within larger ones. Webb may have got his idea of the circular Persian court from this source, and indeed the whole plan may have been a help to him, possibly; but his scheme is far larger and

${ }^{1}$ It is the version published by Kent which is here dealt with, as being the best known. 


\section{SCHEME OF THE WHITEHALL BUILDINGS}

more elaborate than De l'Orme's and is treated in a different style.

The appearance which the building would have presented from the river is well shown in Thomas Sandby's drawing (Fig. I), hitherto unknown. The view is supposed to have been taken from the gardens of old Somerset House previous, of course, to the erection of Waterloo Bridge. It is the most poetic rendering of the great scheme which has been attempted. It is founded on the version published by Kent, so far as the river front is concerned, and on one of the other seven designs in respect of the front facing to the right of the spectator. On the original drawings this front is considerably longer than Sandby makes it, the lower portion being more than half as long again; a good idea may thus be obtained of the magnitude of the conception.

Admitting to the full the great skill and knowledge which the designs display and which prove that Webb was not unworthy of the august influence which placed him under the tuition of Inigo Jones, it is nevertheless no great matter for regret that the palace was never built. It can hardly be held that the complete design maintains the high standard of the Banqueting House. Much of it indeed verges on the commonplace. So vast a building would have been a burden on any monarch; it would inevitably have fallen from its high estate, and would probably have drifted to being put to such ignoble uses as was the much smaller palace of the Louvre in Paris. If fate had been less relentless it might eventually have been devoted to some public use for which it was ill-contrived-public offices or a museum. Architecture, although apparently the most permanent of all the arts, suffers most from change. Buildings may remain, but the uses for which they were designed either cease or are so modified that the buildings become unsuitable. Then follows degradation, decay, or even destruction: at the luckiest, a diversion from the original purpose. The Banqueting House itself is a case in point; for who among those who inspect the interesting collection it now contains have any notion of why it was built, or can picture, even faintly, the scenes enacted within its walls?

In addition to the direct evidence which goes to show that Jones was not the designer of the palace at - Whitehall, there is the evidence of such architectural drawings as are either actually signed by him, or such as can almost certainly be 


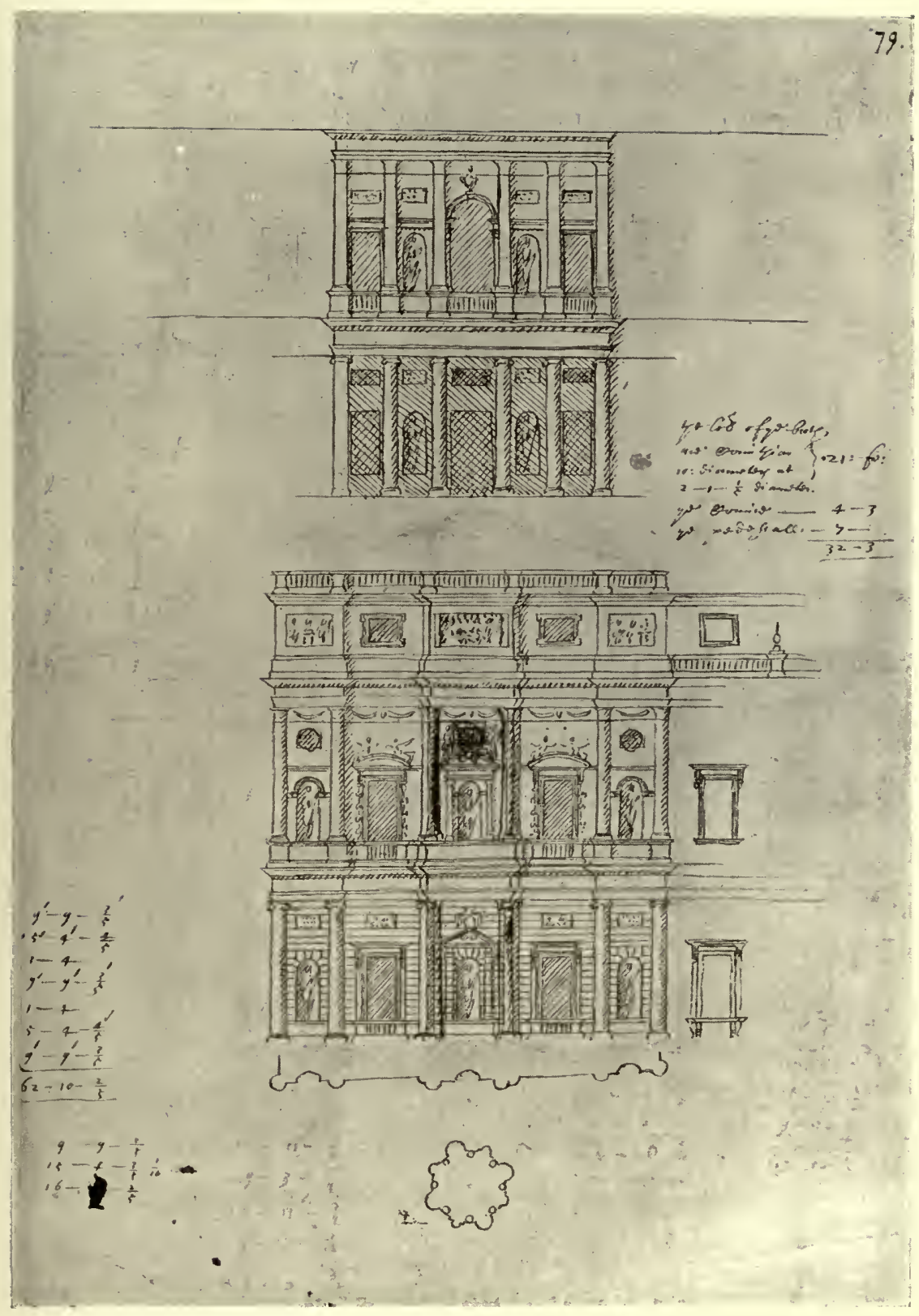

FIG. 41.-SKETCHES FOR PARTS OF THE PALACE AT WHITEHALL, BY WEBB.

From the Chatsworth Collection. 


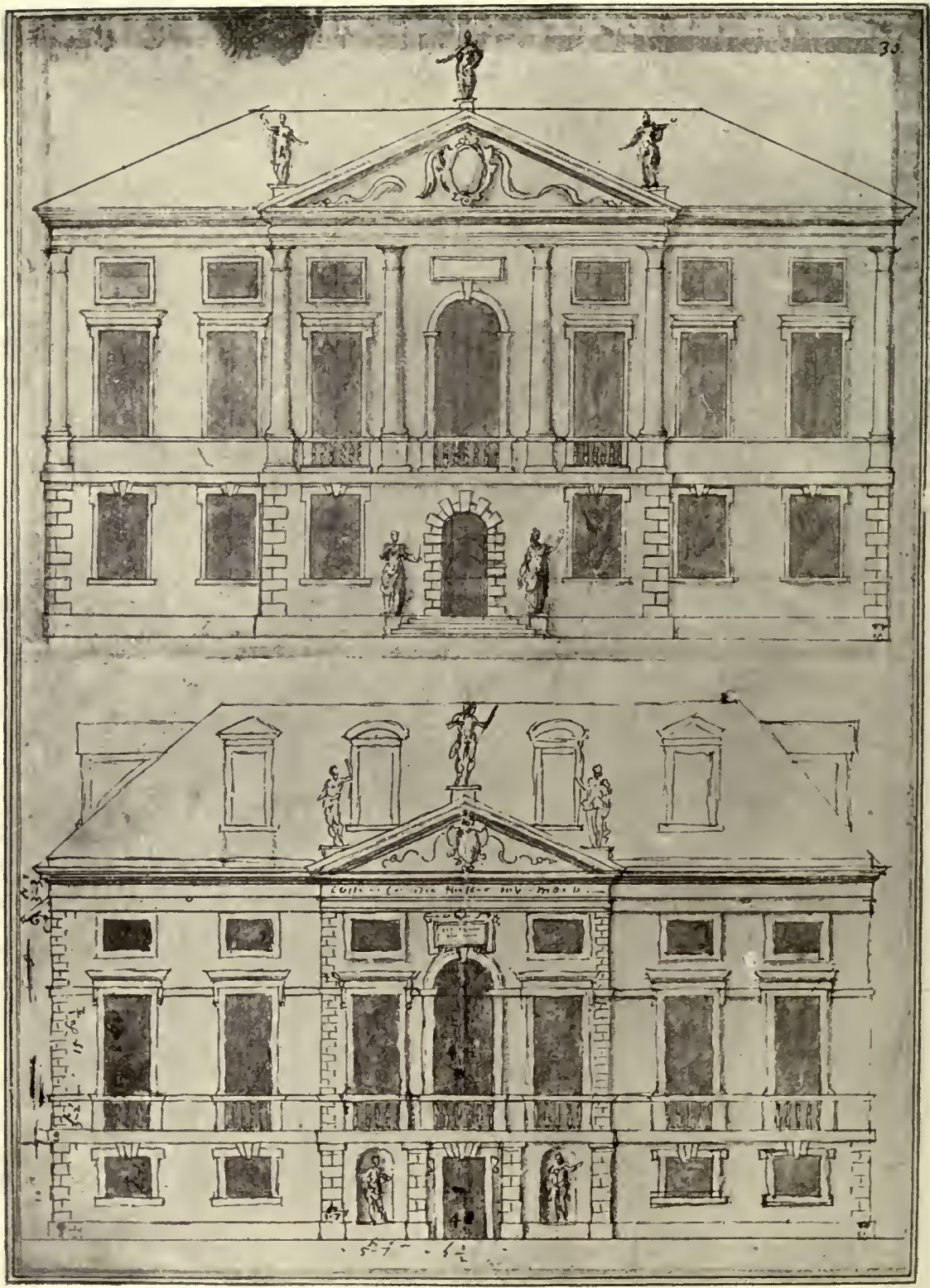

Fig. 42.-ELEVATIONS OF A HOUSE, By Ixigo Joxes.

From the Burlington-Devonshire Collection at the Royal Institute of British Architects. 
attributed to him. All told, these amount to comparatively few, and they exhibit curious inconsistencies. Some are almost puerile, although drawn when he was mature in years. Others (and these are more numerous) are strong, simple, and noble, full of restraint, and depending chiefly upon proportion for their effect (Fig. 42). They are large in scale, and are mainly drawn with a free hand. Indeed it is characteristic of Jones to draw to a large scale and with little aid from instruments. He appears to have been impatient of petty details, and it is extremely doubtful whether he could have brought his wide-sweeping hand down to the working out of a complicated plan on the small scale actually employed in the Whitehall drawings. ${ }^{1}$

In the collections of earlier date, John Thorpe's and Smithson's, the bulk of the drawings may safely be attributed to Thorpe and Smithson respectively; which makes the absence of drawings by Jones all the more remarkable. And it must be remembered that although there are few architectural drawings by him there are many of other kinds, notably of the scenery for masques and of the human figure. ${ }^{2}$ Indeed, to judge only by his drawings one would regard him as a painter rather than an architect. His surviving architectural drawings may be reckoned by dozens; those for masques, figure studies, and drapery by hundreds. His figure studies and drapery are executed with great vigour and a masterly touch. His sketches for the numerous masques, of which he designed the setting, are spontaneous and bold (Fig. 43). Many of them have an architectural character, and, needless to say, the architecture is alway's classic in style. There is onc, however, which represents a scene near London; the wings are composed of old houses, the backcloth is a distant view of London itself with old St Paul's as the principal feature. ${ }^{3}$ It is interesting to see that the houses in the foreground are Jacobean in treatment, yet Jacobean with a larger infusion of classic detail than houses

${ }^{1}$ In an article by Mr W. Grant Keith, published in the Burlington Magazine of January 1913, are given some reproductions of half a dozen drawings by Inigo Jones, which are among the most carefully finished specimens of his handiwork that survive. They include a ceiling for Wilton, I649, and some decorative work at Oatlands Palace in Surrey.

2 Mostly preserved at Chatsworth; there are also a few at the British Museum.

${ }^{3}$ It has not been found possible to illustrate this scene, as was intended, owing to the war having rendered the drawings at Chatsworth inaccessible for the time being. 


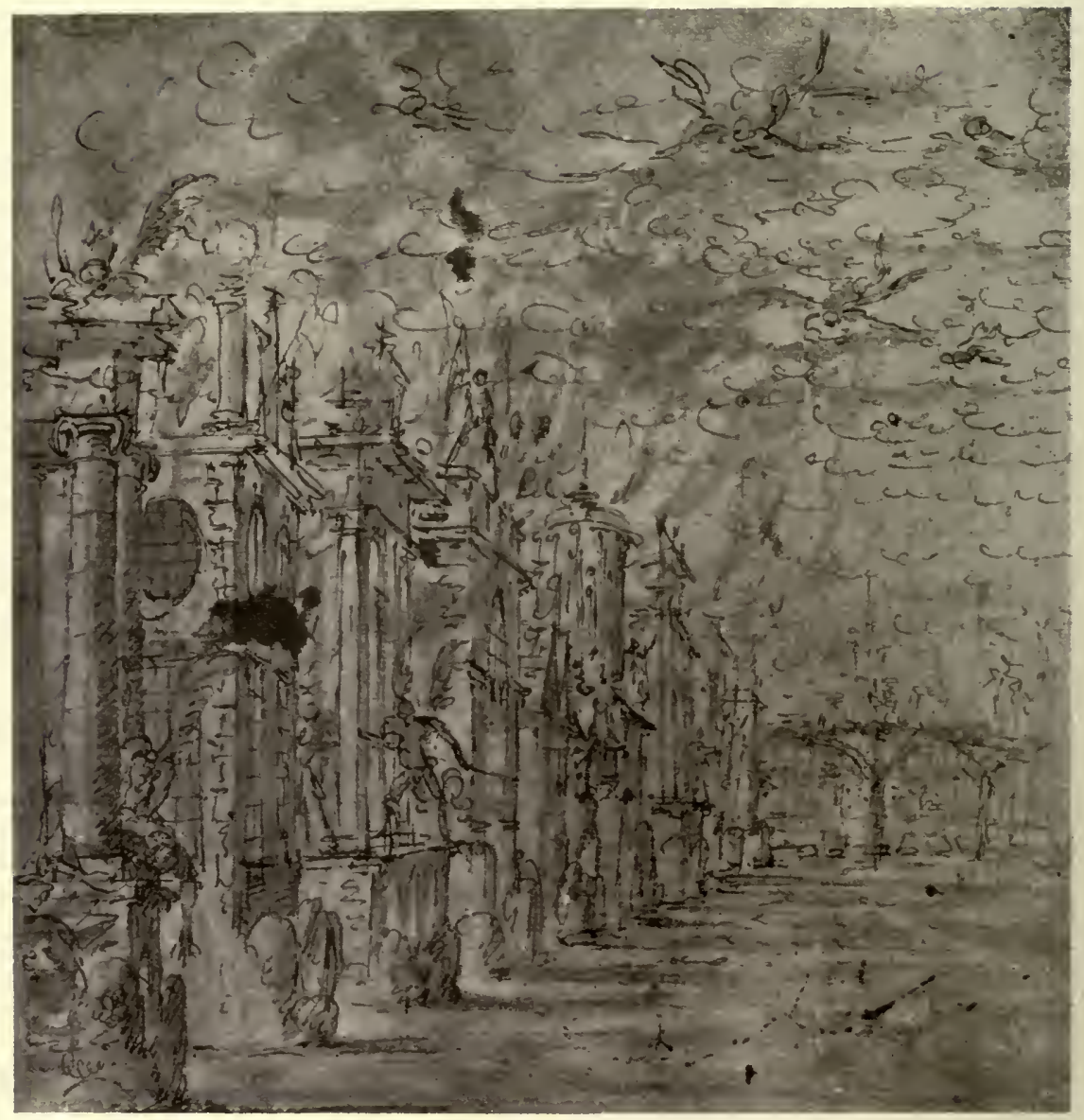

FIG. 43.-Masque by Inigo Jones.

From the Burlington-Devonshire Collection at the R.I.B.A.

of the period actually exhibited. The artist's hand instinctively sought a classic expression.

Jones, indeed, designed most of the masques presented at court during the reigns of James I. and his son, and collaborated with several of the different poets who wrote the words of these fanciful plays; with Ben Jonson, Samuel Daniell, Thomas Campion, George Chapman, and Aurelian Townshend. One of his efforts was less successful than could have been wished, although it was for an occasion when expectation was particularly high - the masque on 'Twelfth Night 1618, when the prince was to take a part for the first time. Gossiping 
letters dubbed it poor, said that Inigo Jones had lost reputation, and that it was indeed so dull that the poet, Ben Jonson, ought to return to his old trade of brick making. ${ }^{1}$

But in spite of the gossips Jones was a skilful scene-painter, and owed much of his facility in the art to the months he had spent in Italy conversing, as he says, with the great masters in design. To him we owe the first introduction of movable scenery into English theatres. He was also a practical surveyor of some ability; already in. I6I 3 he had been appointed surveyor of his majesty's works, and although in those days it was not necessarily a practical man who was appointed to such a post, yet a clever man, eren if ill-equipped at first, would soon acquire experience. The State Papers show that he was kept busy with the duties of his office, duties which included many matters of dull routine. It is perhaps worthy of note that in matters requiring detailed reports and estimates he was generally commissioned along with one or two others who may (or may not) have had more practical knowledge than himself. It is also interesting to find that in several cases where repairs or alterations were under consideration, special stress was laid in the reports upon the probable result on the beauty of the buildings they affected. This particular and uncommon touch may certainly be credited to Jones.

In order fully to understand the subject of the so-called Inigo Jones drawings and their influence on English architecture, it will be advisable to set out again what and where they are.

Firstly, there are those for the palace at Whitehall. Of these the finished designs, utilised by Kent, are at Worcester College, Oxford, and the preliminary drawings are at Chatsworth. These, as already shown, must be credited to WVebb. There is also at the British Museum another and much scantier set, utilised by Campbell.

Secondly, there are at Worcester College a number of miscellaneous drawings, mostly by Webb, but including a few by Jones.

Thirdly, there are in the library of the Royal Institute of British Architects a large number of miscellaneous drawings, also mostly by Webb, but also including a few by Jones. The most important of these are the series of designs utilised by Kent in his "Designs of Inligo Jones," and the drawings for the Charles II. block at Greenwich Hospital. Practically all these are by Webb.

1 "Cal. State Papers, Domestic," xcv. I2. 
These drawings were unknown to the public until Kent published the "Designs" in 1727. His two volumes comprise, as already mentioned, the designs of Whitehall Palace, and a series of houses, large and small. It was not until they were published that the public generally knew anything about them, and it was accordingly not till then that they affected architectural design. Walpole makes this quite clear: "It was in this reign," he saysthat of George II.- "that architecture resumed all her rights. Noble publications of Palladio, Jones, and the antique recalled her to true principles and correct taste; she found men of genius to execute her rules, and patrons to countenance their labours." 1

But apart from their effect upon the public, the insight which these drawings give into the inner working of the designers' minds is of great interest. Besides the finished drawings there are innumerable sketches for plans, elevations, and details, as well as many scraps copied from Italian books on architecture, notably from Serlio. Comparing these and Jones's own sketches with similar memoranda and sketches by Italian architects of the period, it is curious to find how thoroughly he adopted their particular methods of work, and after him Webb likewise. Everything is classic in style, all the proportions are carefully worked out. The lengths and heights of buildings are not the result of caprice, or chance, or even primarily of convenience, but of systems of proportion. So also in the plans: these are largely adaptations of Italian models, not only in their formality. and symmetry, but also in the disposition of the rooms. There is nothing haphazard, fortuitous, or rambling about them: they are the result of carefully considered proportion. Every house was complete in itself, and to be altered or enlarged afterwards was to be spoilt.

This sort of precision had a natural tendency to become mechanical, and in later years, notably in the early part of the eighteenth century, the tendency asserted itself strongly. But it is interesting to find that the foibles of Campbell, Gibbs, and their contemporaries had their justification in the work of Jones and Webb.

It was more particularly Webb who founded himself so carefully on definite proportions. Jones had a natural instinct for good proportion. His studies of the human figure and of drapery, his construction of scenery for masques, gave him freedom of touch and sureness in achieving the result at which

\footnotetext{
${ }^{1}$ Horace Walpole's "Anecdotes of Painting:"
} 


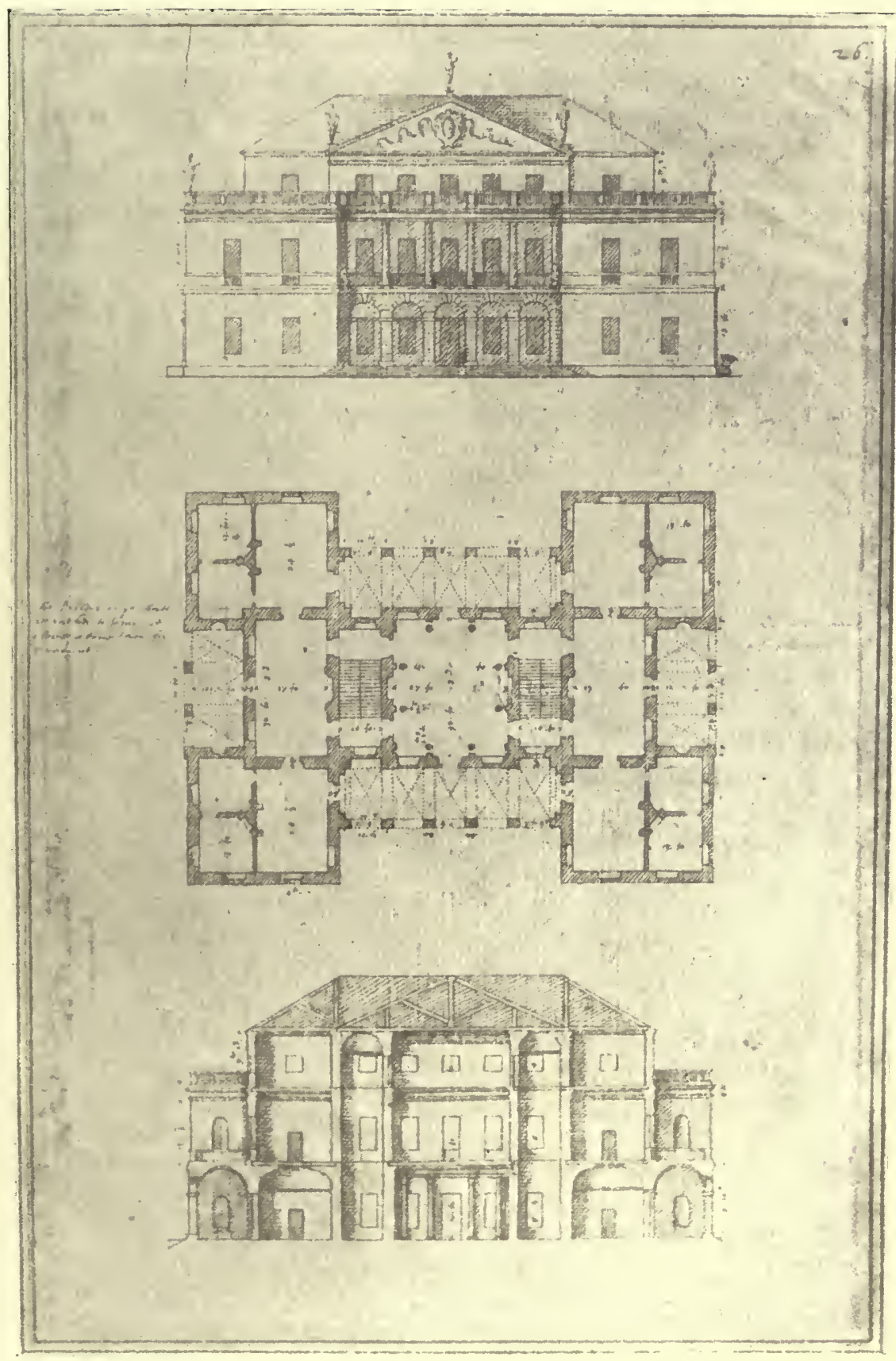

Fig. 44--DESIGN FOR A HOUSE, nу Johx WebB.

From the Burlington-Devon-hire Collection at the R.I.B.1. 
he aimed not to be found in Webb. Jones's youth had been passed in that atmosphere of freedom and joyous fancy in housedesign which was characteristic of Elizabethan days. The intelligent ignorance with which Italian detail was treated he set himself to correct; but he did not altogether crush out its light-heartedness. His own work, although purer and more severe than that of his predecessors, retained something of their freedom.

The same, but in a less degree, may be said of Webb. Immersed though he seems to have been in his endeavours to saturate himself with the true rules of proportion, when he came to put his ideas into execution, he showed a pretty play of natural fancy, and much of his detail has a freshness and individuality sadly lacking in the work of fifty years later.

Apart entirely from the question as to the authorship of the Inigo Jones drawings, the ideas embodied in them are of the first importance. For the purpose of grasping these, the second volume of Kent's "Designs of Inigo Jones" will answer almost as well as the originals. Comparing them with Elizabethan or Jacobean houses, a complete change will be seen to have taken place, both in the plans and the elevations (Fig. 44). There is no resemblance to the older manner. The time-honoured arrangement which placed the great hall centrally between the family wing and the servants' wing has been superseded by one which places the kitchens in a basement, devotes the ground floor to the principal living-rooms, abolishes the great hall as a living-room, and substitutes for it a central saloon of great height, which not infrequently reaches from the ground floor to the roof. The orderly straggling of the ancient plan has given way to a trim compactness in the new. The plan, of course, controls the elevation, which is more precise and far less picturesque than of old. There are few, if any, gables; the chimneys are solid and staid; the windows consist each of one large opening, instead of being a group of small lights formed by mullions and transoms. It does not need an examination of the elaborate proportions tabulated by Webb on many of the original drawings to realise that here the old instinctive and even haphazard, methods have been superseded by a system of carefully calculated design. The change is apparent at a glance, and one feels at once that the source of inspiration is not English 
but Italian. Very few of these designs appear to have been actually carried out, but they had a considerable influence on domestic architecture after their publication. They include practically none of the houses attributed to Jones or IVebb which still exist.

John Webb has hardly received his due as an architect, either from his contemporaries or from posterity. Evelyn spoke of him as "Inigo Jones's man." Most modern writers have regarded him as merely a pale shadow of his master. But from what has just been said about his share in the "Inigo Jones" drawings, this estimate of his position ought to be revised, for there can be no doubt that he was the actual draughtsman of the designs for the palace at Whitehall; of nearly all those in the second volume of Kent inscribed "Inigo Jones, architectus"; and of King Charles's block at Greenwich (Fig. 45). It may be said, indeed it has been said, that even if that be so, he was only carrying out ideas which had been already devised in the rough by the older man. To which the reply is that there is no evidence of this among the drawings themselves, and that the evidence of contemporary documents, preserved among the State Papers, confirms the presumption that IVebb was the designer of the Whitehall Palace and of the Greenwich block. With regard to the series of house designs in Kent's second volume, no extraneous evidence is likely to be found, for they can only be regarded as exercises in design; to transfer these works from Jones's account to Webb's is to do no injustice to the former's reputation, it is rather to enhance it. It relieves a first-rate artist from the weight of work which is not quite firstrate: and the same may be said, as already pointed out, of the Whitehall drawings. With regard to the Greenwich design, it has, with justice, been highly extolled; but this is the less surprising when it is remembered that it is a clever adaptation of an excellent Italian design to be found in the pages of Palladio. ${ }^{1}$

Webb's drawings of the Greenwich designs are fairly numerous, and they include a plan for a complete scheme, as well as plans, elevations and many details of King Charles's block. They are dated I663, I665, I666, and one I669-70. It is interesting, therefore, to find in the Audit Office Enrol-

${ }^{1}$ See the article on the Burlington-Devonshire Drawings in the Journal of the Roy'al Institute of British Architects, Third Series, vol. xviii., No. Io. 
ments ${ }^{1}$ a warrant dated "the 2Ist day of November I666," and directed "To Our Trusty and IVellbeloved John Webb, of Butleigh, in Our County of Somerset, Esq ${ }^{\text {re," which begins }}$ thus: "Charles R. Trusty and wellbeloved, wee greet you well. Whereas wee have thought fit to employ you for the erecting and building of Our palace at Greenwich, Wee doe hereby require and authorizc you to execute, act, and proceed there, according to your best skill and judgment in Architecture, as our Surveyor Assistant unto $S^{r}$. John Denham, $K^{\text {nt. }}$ of the Bath, Surveyor General of Our IVorks, with the same power of executing, acting, proceeding therein, and graunting of Warrants for stones to be had from Portland, to all intents and purposes, as the said Sir John Denham have or might have..." The salary is to be $£ 200$ per annum with travelling charges. This appointment, together with Webb's drawings and the absence of any preliminary drawings or sketches by Jones, seems to establish Webb as the actual designer.

It is not at all probable that Webb destroyed any sketches that might have been in existence, with a view to his own reputation. For he preserved several slight sketches by Jones, and whereas he nowhere publicly pushes himself, he was extremely jealous of Jones's fame, as appears on page after page of his "Vindication of Stone-Heng Restored." Indeed, he subordinates himself completely to his old master, and posterity appears to have taken him at his own valuation.

He must have been, nevertheless, a very clever man, an apt pupil, and a most painstaking student, judging by the voluminous notes as to proportions, and so forth, which he wrote on his drawings. He went to Jones in 1628 at the age of seventeen; and according to the brief attached to his petition, already mentioned, "he was brought up by his Unckle Mr Inigo Jones upon his late Maiestyes command in the study of Architecture, as well that $\mathrm{w}^{\mathrm{ch}}$ relates to building as for masques Tryumphs and the like." It will be remembered that Mr John Denham, as he then was in the year 1660 , had been granted the post of surveyor of the king's works, although he had received no suitable training; the brief concludes with the following apt remarks: "That Mr Denham may possibly, as most gentry in England at this day have some knowledge in the Theory of Architecture; but nothing

1 Vol. vi. p. 129, printed in full in Peter Cunningham's "Life of Inigo Jones," p. 48. 


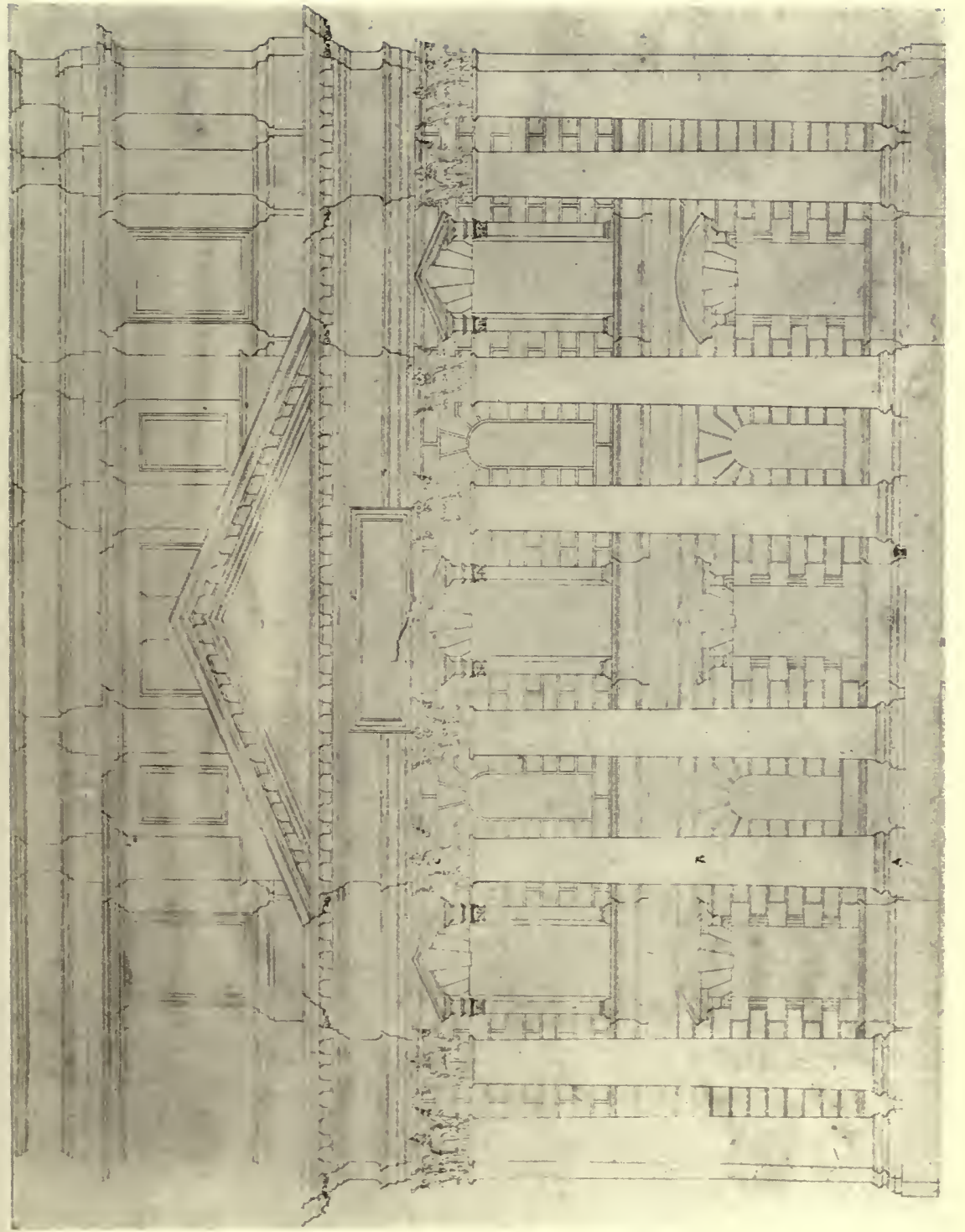

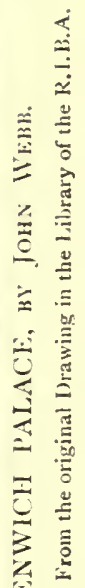

空

4

资

工

$\stackrel{1}{2}$

约

ว

高

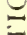

$\because$

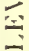

栗

in

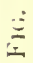




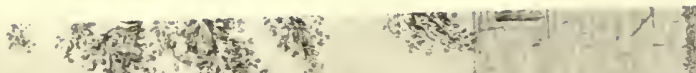
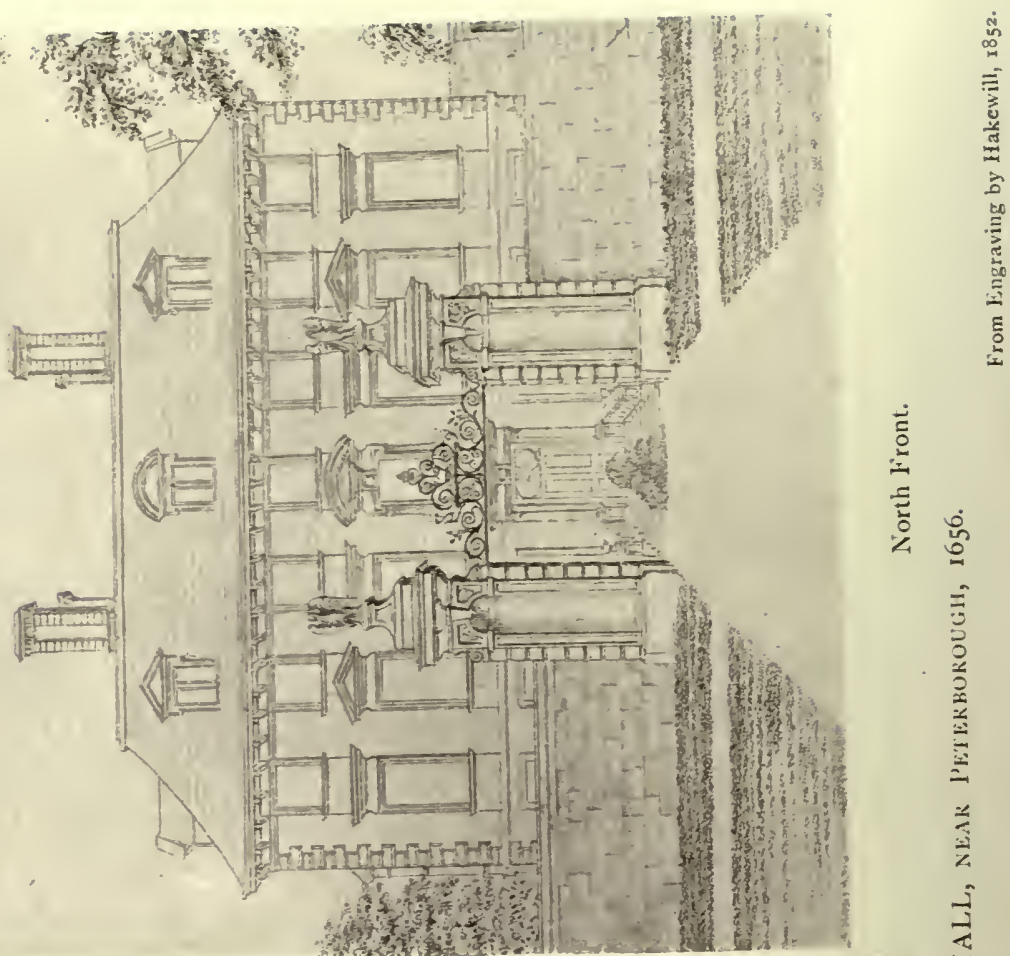

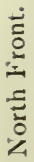

$\stackrel{\leftrightarrow}{\leftrightarrow}$

$\bar{\vdots}$

3

$\frac{1}{5}$

竞

$=$

坚

$\frac{5}{3}$

E.

?
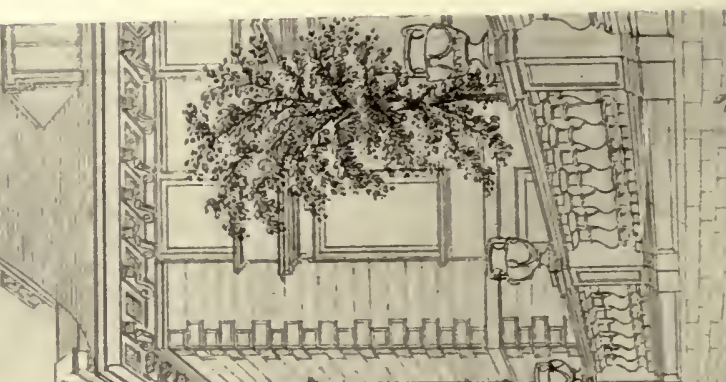

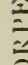

ב

$F$

$\stackrel{+}{\dot{q}}$

$\stackrel{3}{-}$

ב⿱艹

है

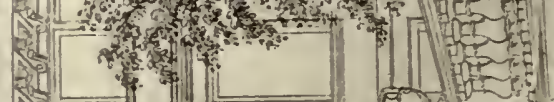

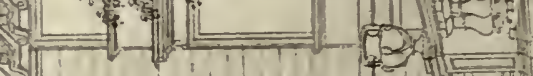

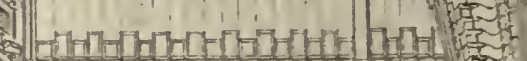
(I)
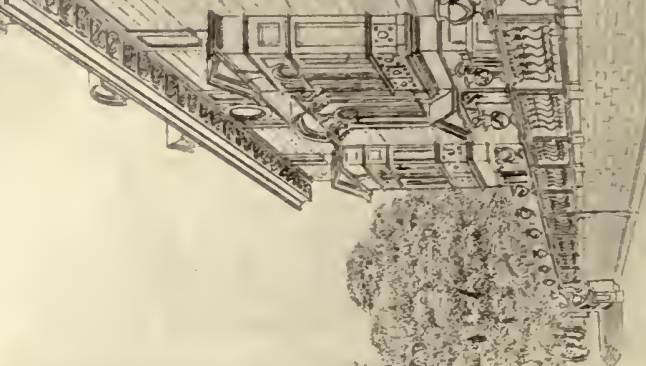
of ye practique soe that he must of necessity have another at his Mai ${ }^{\text {ites }}$ charge to doe his business; whereas Mr IVebb himself designes, orders, and directs, whatever given in command $w^{\text {th }}$ out any other man's assistance. His Maitie may please to grant some other place more proper for Mr Denham's abilityes and confirme unto $\mathrm{Mr} \mathrm{W}^{\prime}$ ebb the Surveyors place wherein he hath consumed 30 years study, there being scarce any of the greate Nobility or eminent gentry of England but he hath done service for in matter of building, ordering of meddalls, statues and the like."

The common sense of this contention, although not flattering to $\mathrm{Mr}$ Denham, was vindicated by the appointment of $\mathrm{Vebb}$ as assistant surveyor at Greenwich. But the petition and brief are interesting in other ways. They assert that Charles I. expressly caused Webb to be trained in architecture and the preparation of masques, in order to succeed Inigo Jones and carry on his work. They confirm roughly the date of his apprenticeship: and the brief states that he had worked for most of the great nobility and eminent gentry, thereby showing that he was a man of large independent practice, and not merely' "Inigo Jones's man"- conclusion to which his drawings had already led.

The fact that Webb was actually trained in the preparation of masques as well as in architecture has hitherto escaped notice, but recent researches show that he made drawings for the scenery of some of those devised by Inigo Jones, particularly in the case of the pastoral of "Florimene" in I635, and D'Avenant's "Salmacida Spolia" in 1640. A year or two after the death of Jones, namely in 1656 , D'Avenant again sought Webb's help, and got him to design the scenery for his "Siege of Rhodes," the first opera produced in England. Webb's drawings for this work are preserved at Chatsworth. ${ }^{1}$

The illustrations in the second volume of Kent's " Designs of Inigo Jones," give a good idea not only of Webb's powers as a designer, but also of the kind of house which was becoming fashionable. But it is worth while to supplement them by others which were actually carried out.

1 "The Designs for the First Movable Scenery on the English Public Stage," by William Grant Keith, in The Burlington Magazine, Nos. cxxxiii. and cxxxiv., April and May I9I 4 , where reproductions of Webb's drawings are given. 
The best known of the houses attributed to Webb is Thorpe Hall, near Peterborough (Fig. 46). It was built for Oliver St John, Lord Chief Justice of Common Pleas, and a kinsman of Oliver Cromwell, 1 about the year 1656 , which date is on the

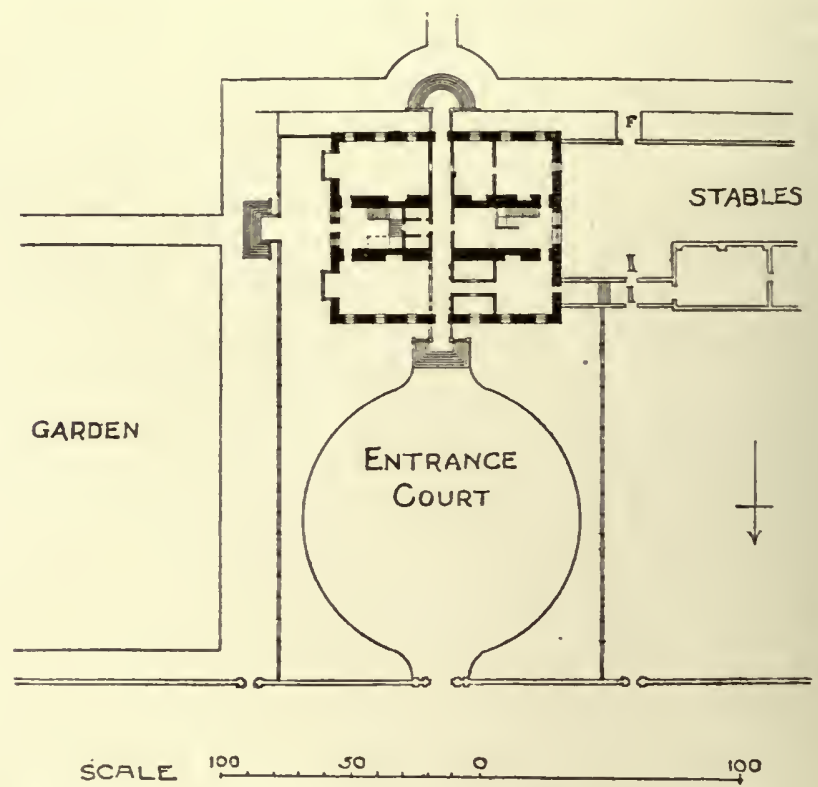

Fig. 47.-Thorpe Hall, near Peterborough. Ground Plan.

stables. It is a fine massive house of oblong shape, and, like Coleshill, it is without wings, gables, or dominating pediments; the detail is large and simple, the principal effect being gained by a widely projecting cornice at the eaves. The roof is hipped at the four corners, and its slopes are broken by dormers. The windows are carefully spaced, the angles of the building are emphasised with bold quoins, there is an open columned porch in the middle of each of the two principal fronts, and on one of the short fronts there are two square bay-windows. These are the means adopted to give interest to the design, and slight as they are, they achieve their purpose. A plinth, and a bold string over the ground floor windows help the general proportions, and 


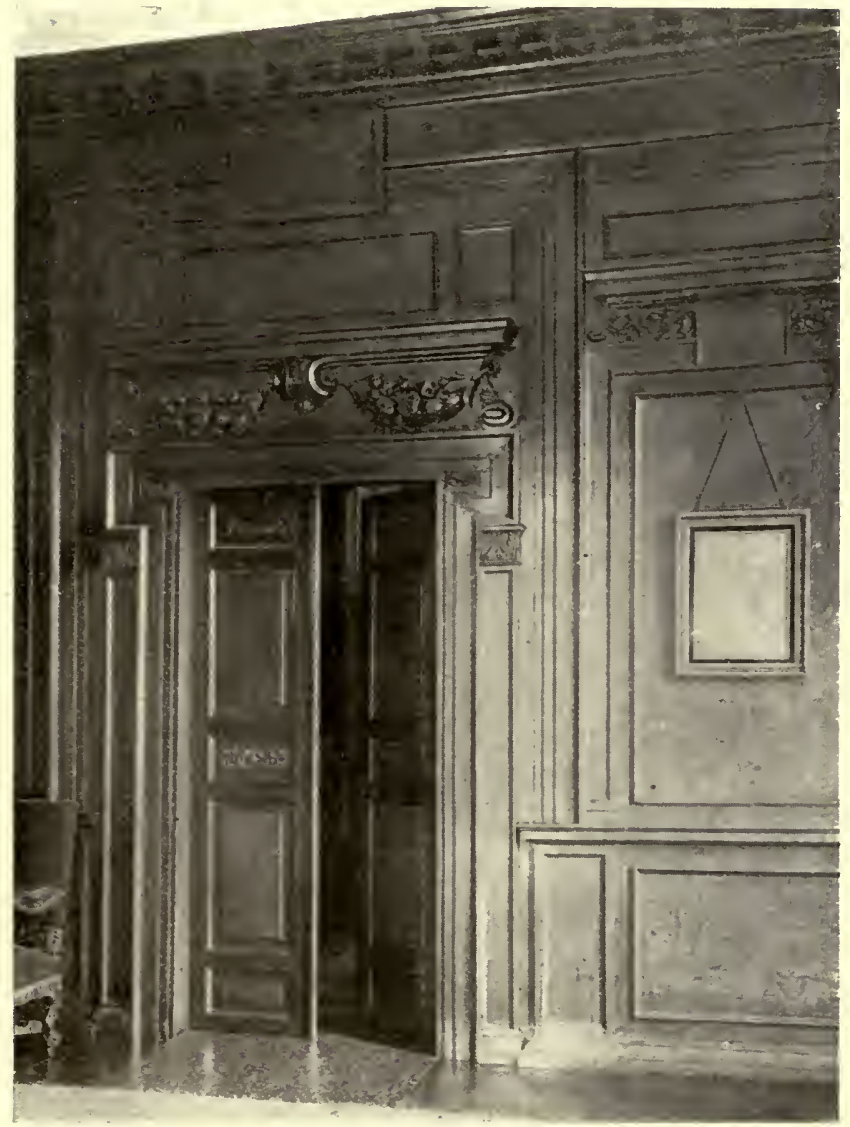

FIG. 48.-Thorpe Hall. Panelling in Dining-Room.

a little liveliness is imparted by the introduction of pediments over some of the windows. The whole effect is refined and severe, widely different from the picturesque variety of Elizabethan work. The open porches are probably the first examples of their kind to be found in England. The bay-windows, it must be confessed, are poor and meagre; they would not be out of place in a suburban villa; they are a disappointing substitute for the noble bays of earlier times. They appear to be original, but they may derive some of their character from the restoration which the house underwent in the middle of last century. The chimneys are well designed, massive features, of the somewhat 


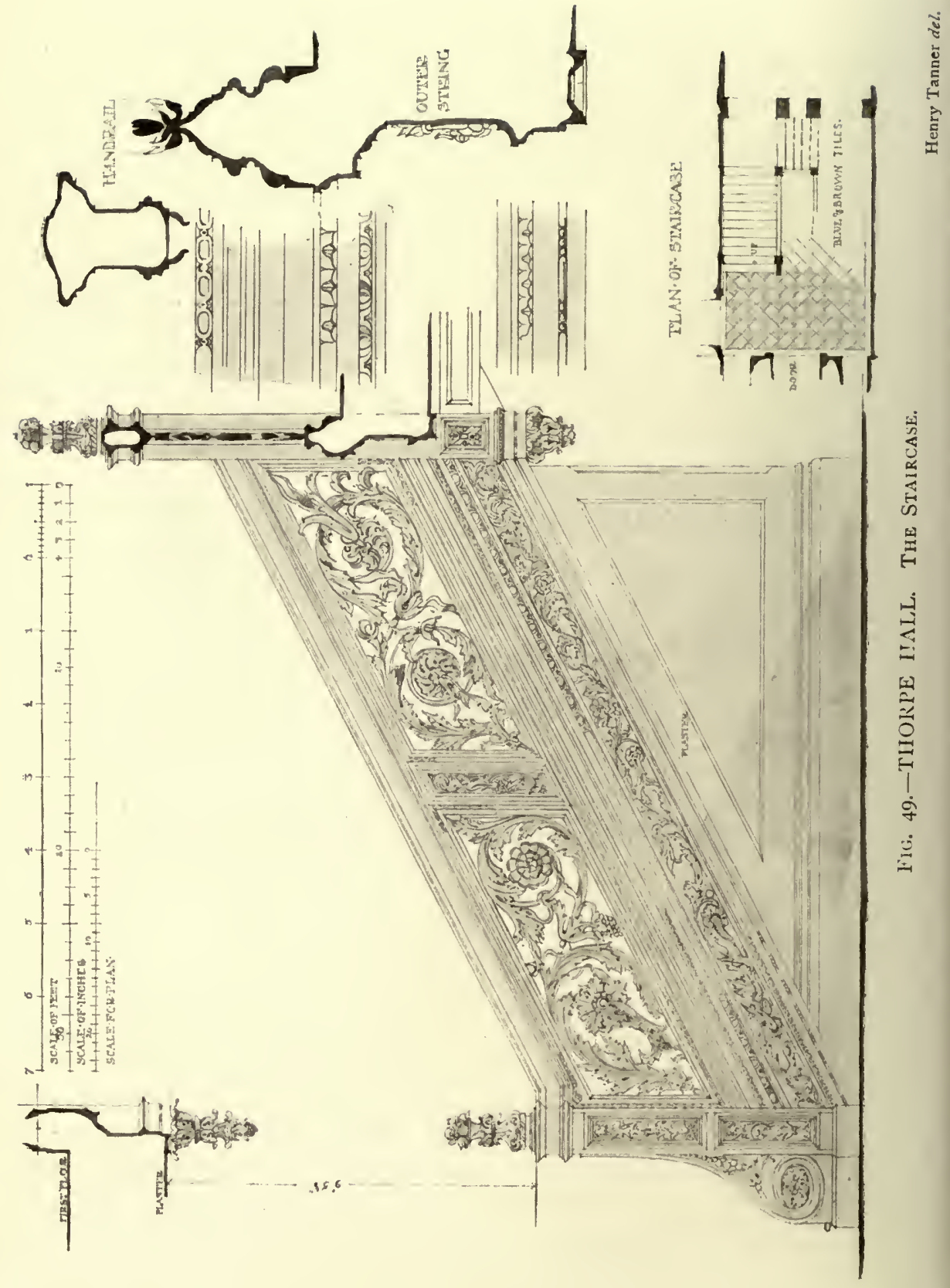


plain type which was supplanting the more varied and ingenious designs of fifty years before.

The plan of the house, as given by Hakewill (Fig. 47), is of the modern order, although faintly reminiscent of the ancient arrangement in respect of the hall, which is approached from the entrance passage through a screen. The ground floor, containing the hall, library, and dining-room, is raised well above the ground, and the servants' quarters are in the basement. Subsequent to the making of Hakewill's plan, certain alterations were made which did away with the necessity of passing through one room to get to the next, but they did not affect the main dispositions.

Much of the detail inside is quite charming, especially the ceilings, the panelling of the dining-room and the staircase. The sober yet fanciful treatment of the dining-room is delightful (Fig. 48) and strongly resembles that of some of Webb's designs at Worcester College. Indeed the detail throughout abounds in touches such as are to be found in his drawings, and it has a freedom from pedantry which is quite refreshing, and may be regarded as a legacy from his less learned predecessors. The staircase has a carved and pierced floral balustrade of a type which had a considerable vogue in England during the second half of the seventeenth century (Fig. 49). The carving is particularly vigorous, especially in the newels and the great scroll at the foot of the stairs. The carved work is in lime, while the framework is in oak, but time has coloured the whole to one tone. The newels are crowned with fanciful vases full of flowers, another feature characteristic of the period. Some of the doors have panels over them, filled with painted landscapes, one of the earliest instances of a method of treatment that became very general in later years. The fireplaces, with one or two exceptions, are not fine examples of their kind.

The lay out is quite formal. The house stands in the midst of a large oblong enclosure, some $700 \mathrm{ft}$. long by $350 \mathrm{ft}$. wide, containing between five and six acres. The stables and garden houses occupy part of this space, the remainder being devoted to a forecourt and gardens. The enclosing wall is pierced with gateways of which the piers arc of varied and interesting design (Fig. 50). The stables themselves are less formal and more picturesque than the house, but the same strong and masterful treatment prevails throughout (Fig. 5I). As within the house so without, the detail has more individuality than was possible in 

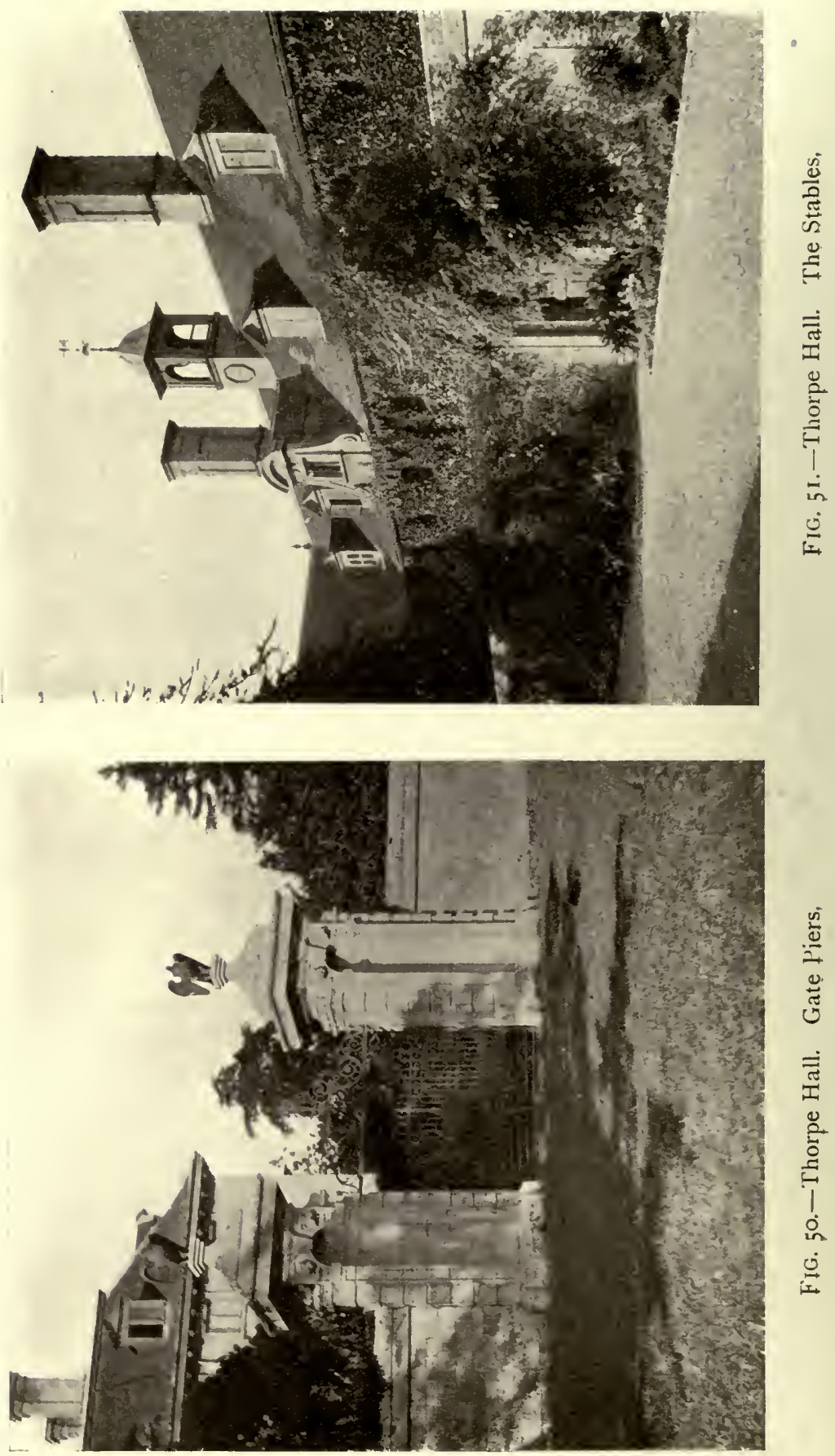


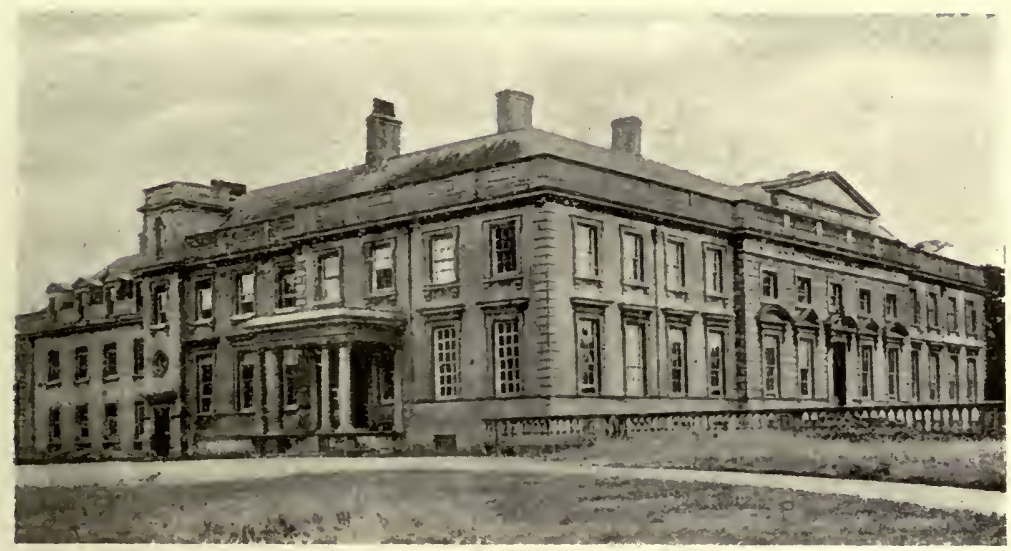

FIG. 52.-Lamport Hall.

later times when the continued study of Italian models appears to have made designers too fearful of committing solecisms to allow them to give free play to their fancy.

The attribution of Thorpe Hall to Webb rests on tradition and the character of the work. His connection with another Northamptonshire house, Lamport Hall, is vouched for by Bridges, the county historian, who says (writing in the early years of the eighteenth century): "Sir Justinian Isham . . . hath here a very elegant seat ; part of which is old, and part new built in his father's time, by John Webb, son-in-law to Inigo Jones. He hath several drawings of mouldings, architraves, and freezes, made in the years 1654 and 1655 , with some letters from $\mathrm{Mr}$ Webb dated in 1657 , relating to the gate, and pilasters, and the execution of an intended depository." Owing to alterations which have been made from time to time, there is little of the original work left except the front (Fig. 52), which exhibits the simple, dignified yet interesting treatment characteristic of Webb's manner. Here the whole of the architectural detail is in stone, there are two principal stories which stand on a windowed basement; there are no strings nor cornices between the basement and the main cornice which crowns the walls; above this is a parapet which seems to have been aitered from its original design. The wall space is occupied by windows carefully proportioned, and in the centre of the façade is a slight projection according to Webb's custom. The angles of the building are emphasised with quoins. The whole design is 


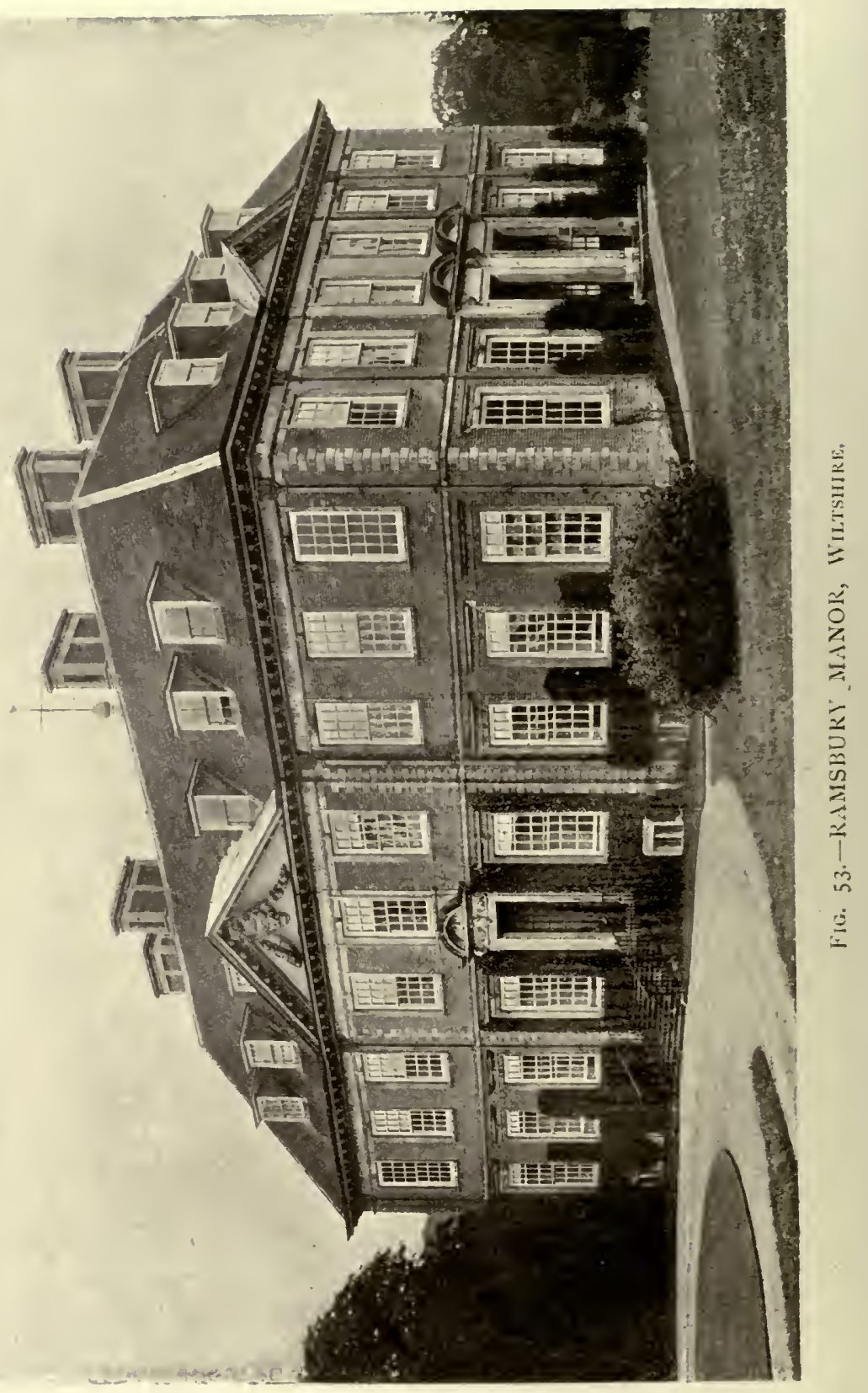


simple in the extreme, but its excellent proportions give it dignity and charm.

It must surely have been the old house to which the epithet "vile" was applied by the charming Dorothy Osborne in one of her letters to her future husband, Sir IVilliam Temple. The elder Sir Justinian, forty-two years old and a widower, was a persistent but unwelcome suitor of Dorothy's, just about the time when he altered his house. He was esteemed, according to a biographer, one of the most accomplished persons of the time, and, doubtless, it was in that capacity that he employed the hardly less accomplished Webb. But Dorothy put a different reading on his character, and considered him a selfconceited, learned coxcomb. Her letter, wherein she speaks of "a vile house he has in Northamptonshire," is assigned to January 1653 , so it is just possible that during the course of his wooing she may have indicated her opinion of his home, and thus have been an unintentional agent in its improvement.

Ramsbury, in IViltshire, is another house attributed to IVebb, ${ }^{1}$ but no date is given in connection with it. Its admirable proportion and simplicity of detail ally it with other work of his (Fig. 53). Like Thorpe Hall it is a simple oblong in plan, but the front and side are broken by slight projections which give the opportunity of breaking the roof with pediments as well as with the customary dormers. The effect depends primarily upon the spacing of the windows, the extent of roof in relation to the walls, and the bold cornice at the eares. The detail is refined. and a welcome change from uniformity of treatment is afforded by the introduction of twin doorways in the middle of the shorter front. The ground floor is kept up above the ground, as was customary with Webb, and the servants are placed in the basement. The drawbacks of this disposition are less than would appear from the front view, as the ground at the other end is so much lower that the basement floor is on the same level with it, and there is easy access from the kitchen department to the outbuildings which are grouped some distance awayon the lower level.

The detail inside is not of striking interest: much of it looks rather later than Webb's time, especially the ceiling (Fig. 54); but the way in which the cupola, which is almost buried between

1 Neal, in his "Seats," says it was designed by Webb; and although he quotes no authority he must have had some reason for the statement. 


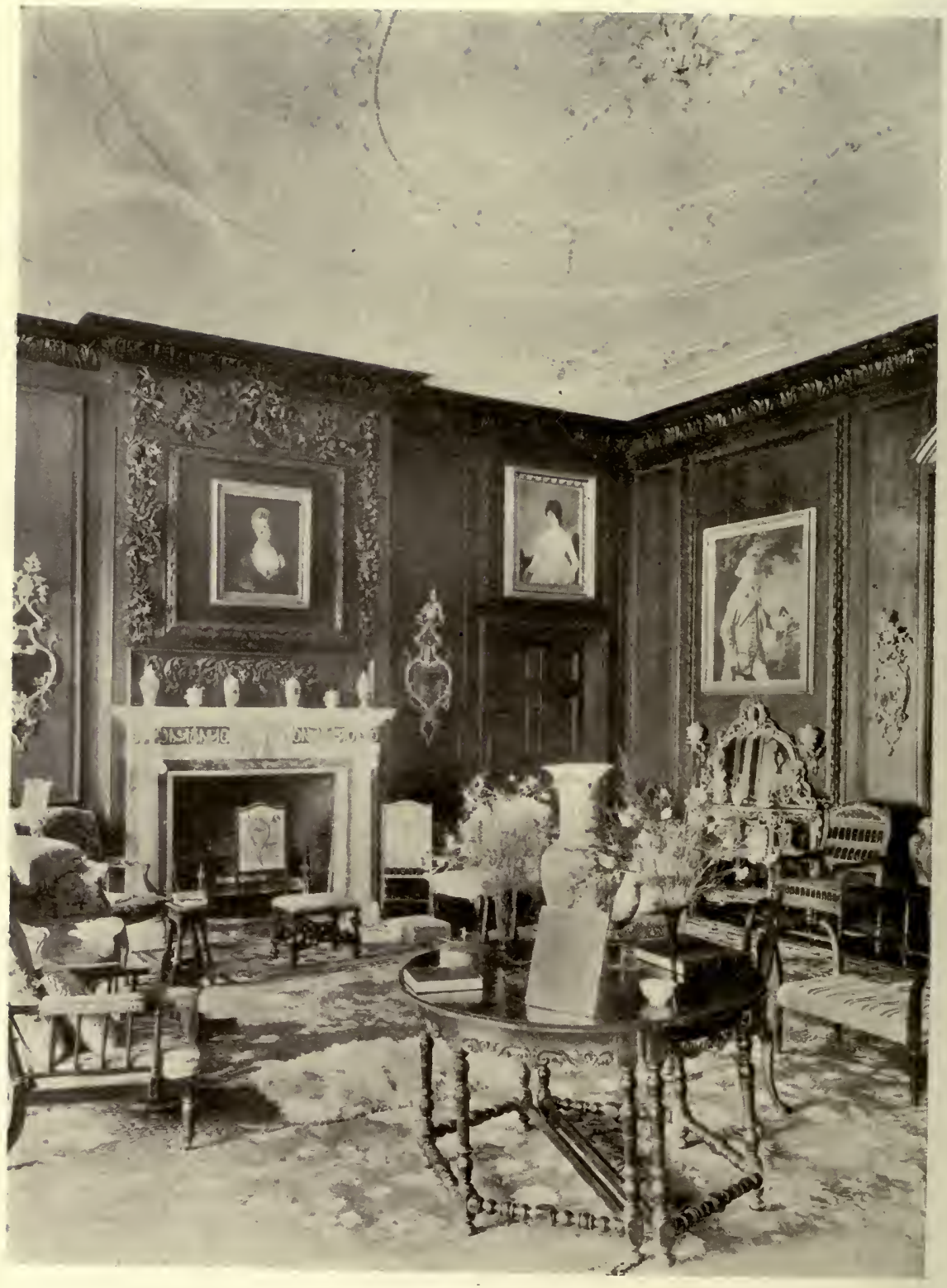

FIC. 54.-RAMSBURY MANOR. THE SALOON. 


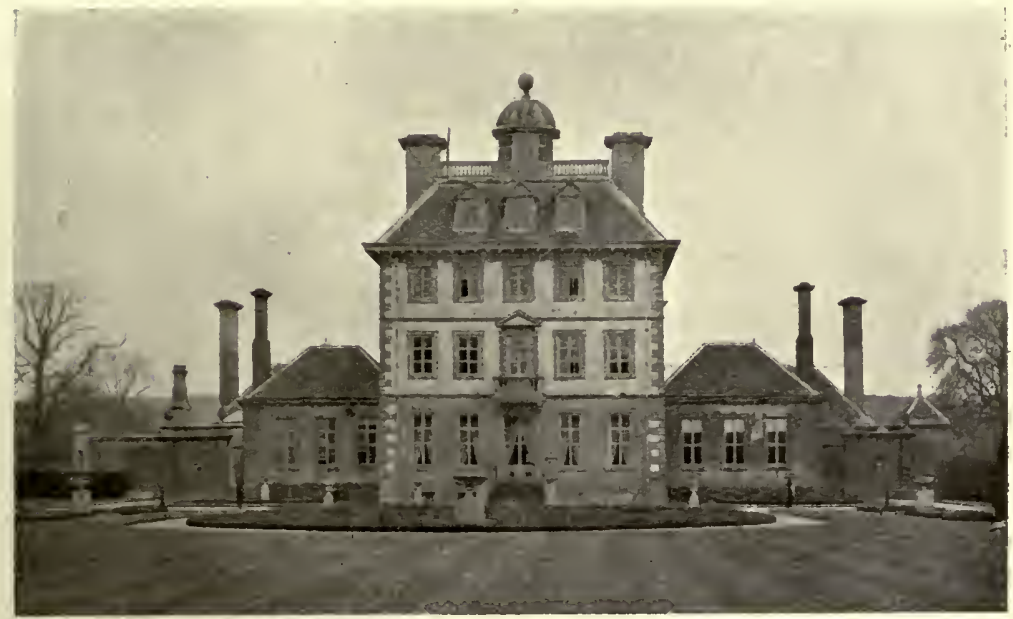

F1G. 55.-Ashdown House, Berkshire.

the roofs, is made to light the attic landing, and, by means of a ceiling light, the landing also of the floor below, is quite ingenious, and incidentally produces a charming feature in the ceiling of the principal landing.

These are some among the houses that are attributed to. IVebb. Ashdown House (Fig. 55) is another, a rather gaunt place, built high on the downs in the extreme west of Berhshire, far away from everywhere, so that the builder, it is said, might run no risk of infection from the plague. Taken in conjunction with his dated drawings-such as ceilings at Wilton in 1649; designs for Durham House, London, in the same year; the Physicians' College in 1651 ; a chimney-piece for Drayton in Northamptonshire in 1653 ; and another for Northumberland. House in I660-they show that Webb was tolerably busy all through the time of the Commonwealth. But it is probably the fact, confirmed by the absence of dated drawings between $16_{3} \mathrm{~S}$ and I649, that he was not doing much work, beyond the Whitehall designs, during the course of the actual hostilities. This is only what might be expected, and indeed it is likely that beyond what Webb did, there was very little important work carried out during the period of twenty years from 1640 to 1660 .

The consideration of Inigo Jones's work and that of Webb. has taken the story down to about 1670 ; it is necessary now to go back a little in order to look at work by less distinguished designers. 


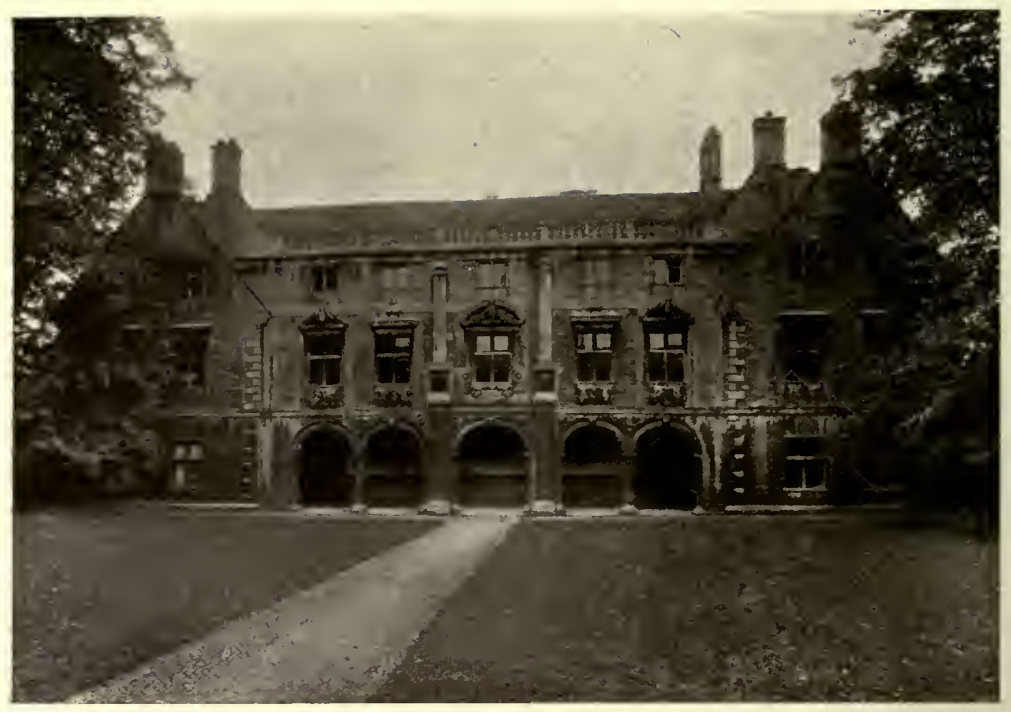

FIG. 56.-Pepysian Library, Magdalene College, Cambridge.

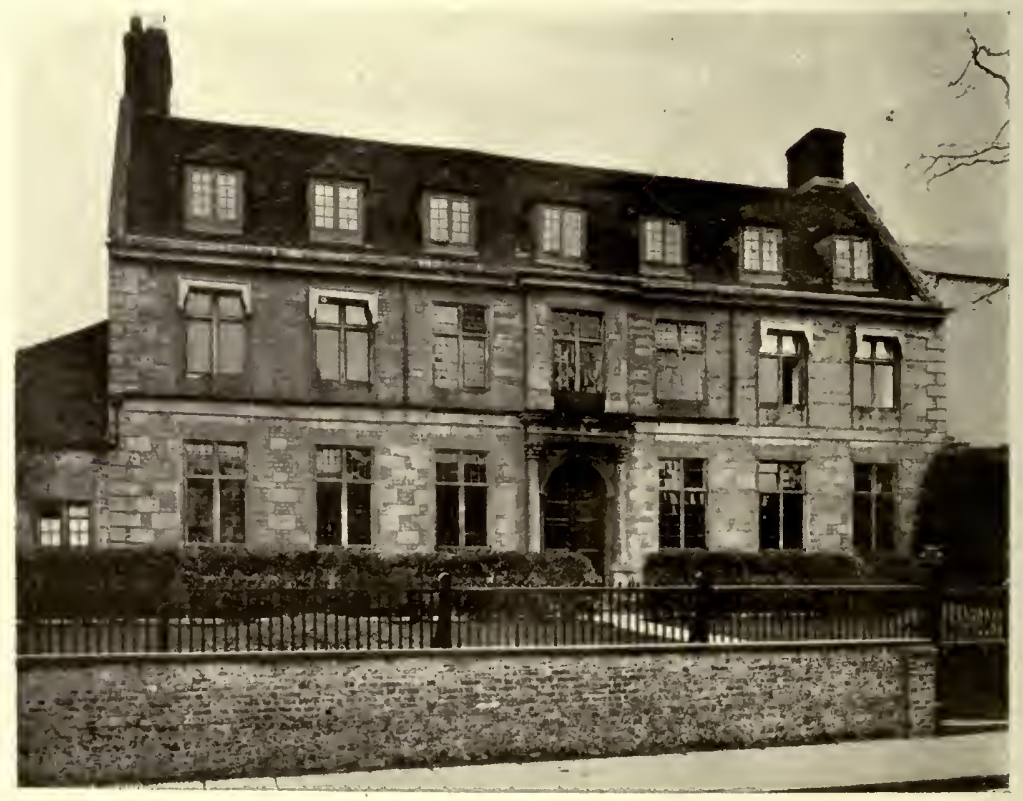

FIG. 57.-The Latin School, Warminster, Wiltshire, 1707. 


\section{THE TRANSITION IN MINOR BUILDINGS AND INTERIORS}

THERE are numberless buildings in all parts of the country which show in their external treatment how gradual was the supersession of the old style by the new and more correct treatment, and how limited in range was the influence of even so eminent an architect as Inigo Jones. Indeed, throughout the seventeenth century it would appear that architectural design followed two paths; one was that trodden by trained architects who aimed at correctitude; the other was that taken by less learned designers, whether architects or (as of old) masons and artificers, who had not mastered the niceties of classic design, and therefore mixed ancient methods with such of the new as they could compass. The mullioned window was one of the old features to which they long held fast. The new idea of large window openings such as prevailed in the Banqueting House they seem to have disliked. Their reluctance had, no doubt, a constructional basis, for the narrow lights of a mullioned window are easily bridged, whereas a wide opening requires either a deeper head to carry the weight above it, or else an arch. The introduction of an arch or a deep head involved a more serious departure from ancient ways, and a more complete committal to new design than the ordinary man could face. He did not mind pilasters, and he did not mind a heavy cornice, and consequently there are plenty of instances in which the old mullioned windows are accompanied by the more stiff and straight arrangement which a heavy cornice involves. Such an instance is to be seen in the free school at Warminster, founded as late as I 707 (Fig. 57).

Another feature to which designers clung was the gable. This, of course, had been from time immemorial a dominant feature of English houses; it was the simplest and most natural 


\section{DISAPPEARANCE OF GABLES AND MULLIONS}

way of closing the end of a roof, and as roofs were nearly always of a steep pitch, so, too, were the gables. But there was no place in classic architecture for steep gables, nor indeed for gables of any kind; the nearest approach to them was the pediment. It was only by a determined effort that the English architect could get rid of gables, and this effort was too much for any but the most resolute to make. Gables survived eren longer than mullioned windows, and as our climate, with its rain and snow, is better encountered by steep roofs than by flat, the roofs continued to be steep.

An interesting example of the mixture of mullioned windows, gables, and classic details is to be found in the Pepysian Library at Magdalene College, Cambridge (Fig. j6). The precise date of this building is not known. In many of the colleges accounts have survived from which may be gathered the date, the cost, and even the names of the designers of the various buildings which make both Cambridge and Oxford so extremely interesting to architects. But unluckily in this instance there are no accounts left, and it is only inferentially and vaguely that a date can be suggested. Subscriptions for a new building were being asked for in $1640,{ }^{1}$ and again in 1679 , and the building was apparently finished, or nearly so, in 1703 when Pepys made his will, by which he left his library (after his nephew's death) either to Trinity College or Magdalene, but preferably to the latter, in which case it was to be in the "New Building," where, in fact, it was eventually placed.

It would appear from the plan, and also from the external treatment, that the design was made when the project first started in 1640; but if Professor Willis's suggestion be accepted that the Civil War interrupted the scheme and that, in view of the change in taste, a fresh design was adopted on the resumption of effort in Charles II.'s time, the survival of the old methods'becomes still more striking. But a close examination of the work strengthens the supposition that the front was designed as a whole when the project was started in 1640; and that the pediments and cornices over the windows, together with the carving, were inserted at the close of the century. The later mouldings are larger and bolder in scale than the earlier.

1 Willis and Clarke's "Architectural History of the University of Cambridge," ii. 366 . 
When it is remembered that in I640 John Webb was drawing none but classic buildings, and that by 1679 St Paul's Cathedral was already rising above the ground, and that it was designed on fully developed classic lines, the significance of the mixed taste in this building at Magdalene College will be the more readily appreciated. But it must be borne in mind that Webb and Sir Christopher Wren were members of a learned confraternity, while the unknown designer at Magdalene had evidently not had

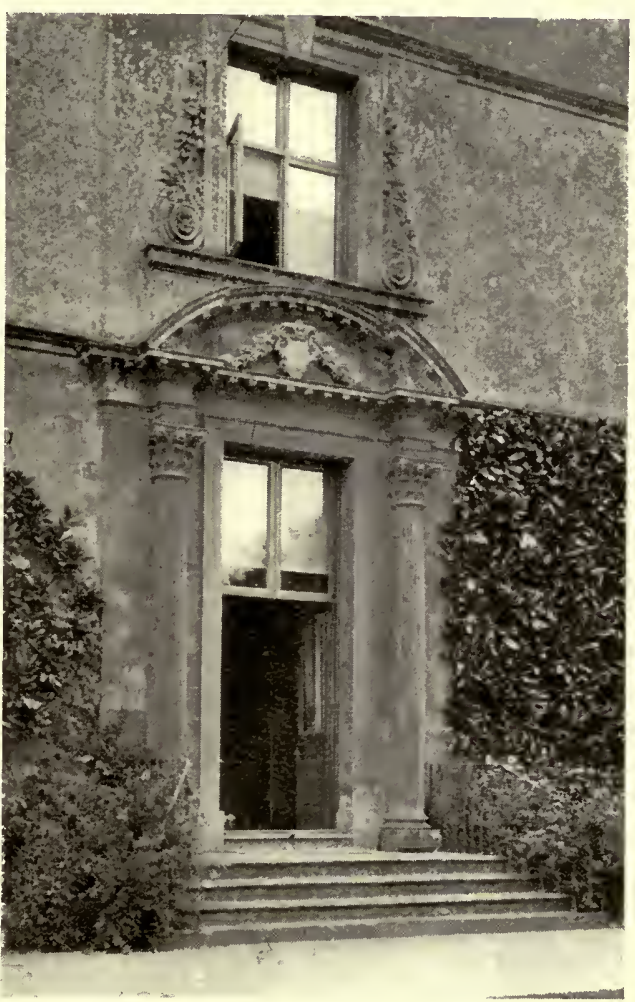

FIG. 58.-Doorway at Stanway, Gloucestershire.

the same opportunities as they enjoyed for acquiring familiarity with classic detail.

Stanway House, in Gloucestershire, belongs in its general treatment to the Jacobean period, but there are numerous late touches about it ; among them are the front door and the window above it (Fig. 58). The latter appears to be a later insertion, but the doorvay is probably original, as it agrees in its general character with the arch of the fine gate-house, which is contemporary with the mullioned windows by which it is encompassed. It was quite a usual custom to adhere to the old ways in the general design of a house, but to treat some special feature, such as a doorway, in the more modern and correct fashion. This is easily intelligible when it is remembered that the books 


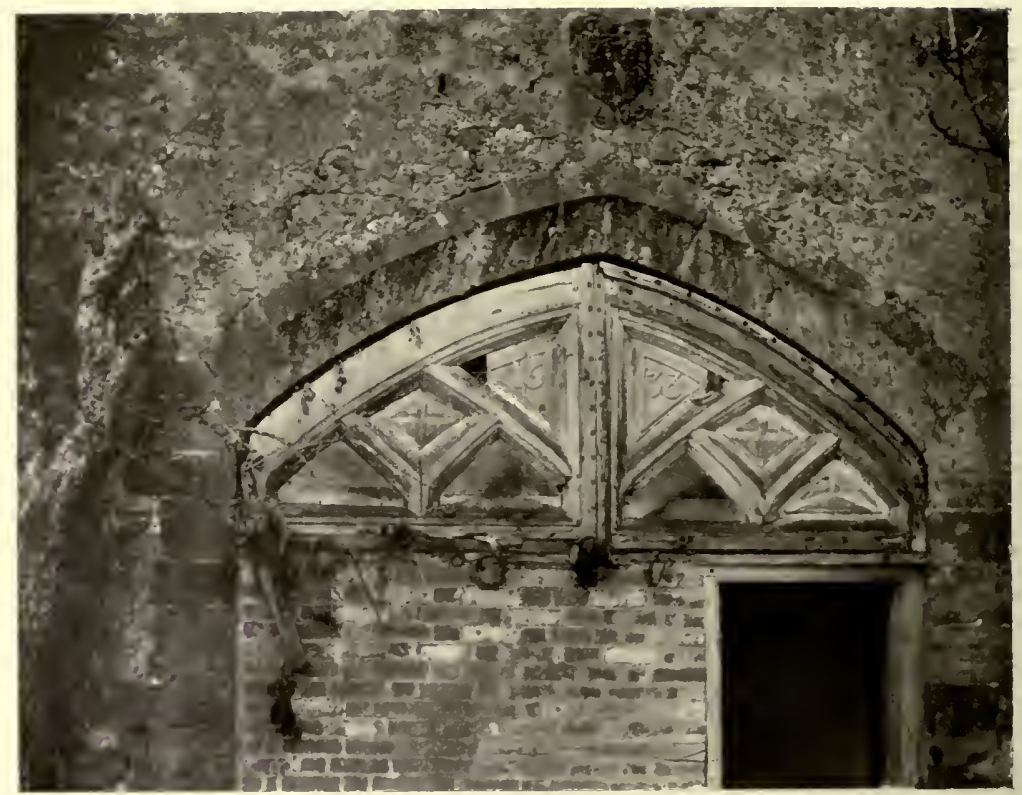

FIG. 59.-Gateway at Astwell, Northamptonshire, 1638 .

on classic architecture confined themselves largely to details, and dealt but sparingly with the designs of entire buildings. At this time, that is about 1637 , there was probably no one who gave himself up entirely to the pursuit of consistent purity of detail, except Jones and his pupil Webb.

At Astwell, in Northamptonshire, there are the remains of some gates dated ${ }_{16} 638$ which were fitted into an old Gothic opening (Fig. 59). They have traceried heads of a sort, in imitation of mediaval work, but the mouldings are allied more nearly to the ordinary work of the time, and the whole is an interesting example of the mixture of old and new ideas.

Swakeleys, near Uxbridge, which carries its date, 1638 , on some of its rain-water heads, is a good example of late Jacobean work, in which the old treatment is more apparent than the new (Fig. 60). It has mullioned windows and many gables, but the flat pediments which crown the latter are evidence of its having been built towards the close of the Jacobean period. The actual 


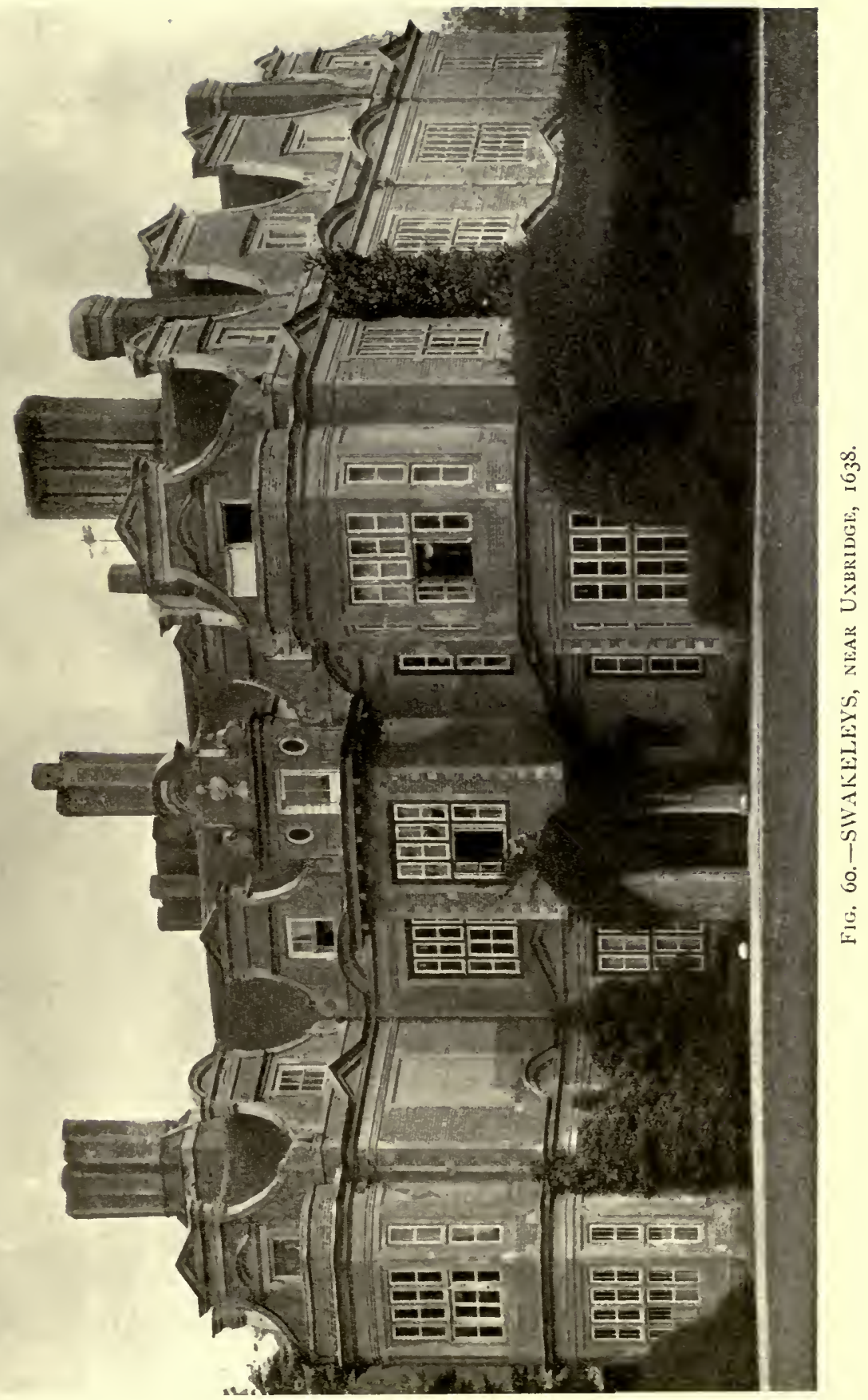




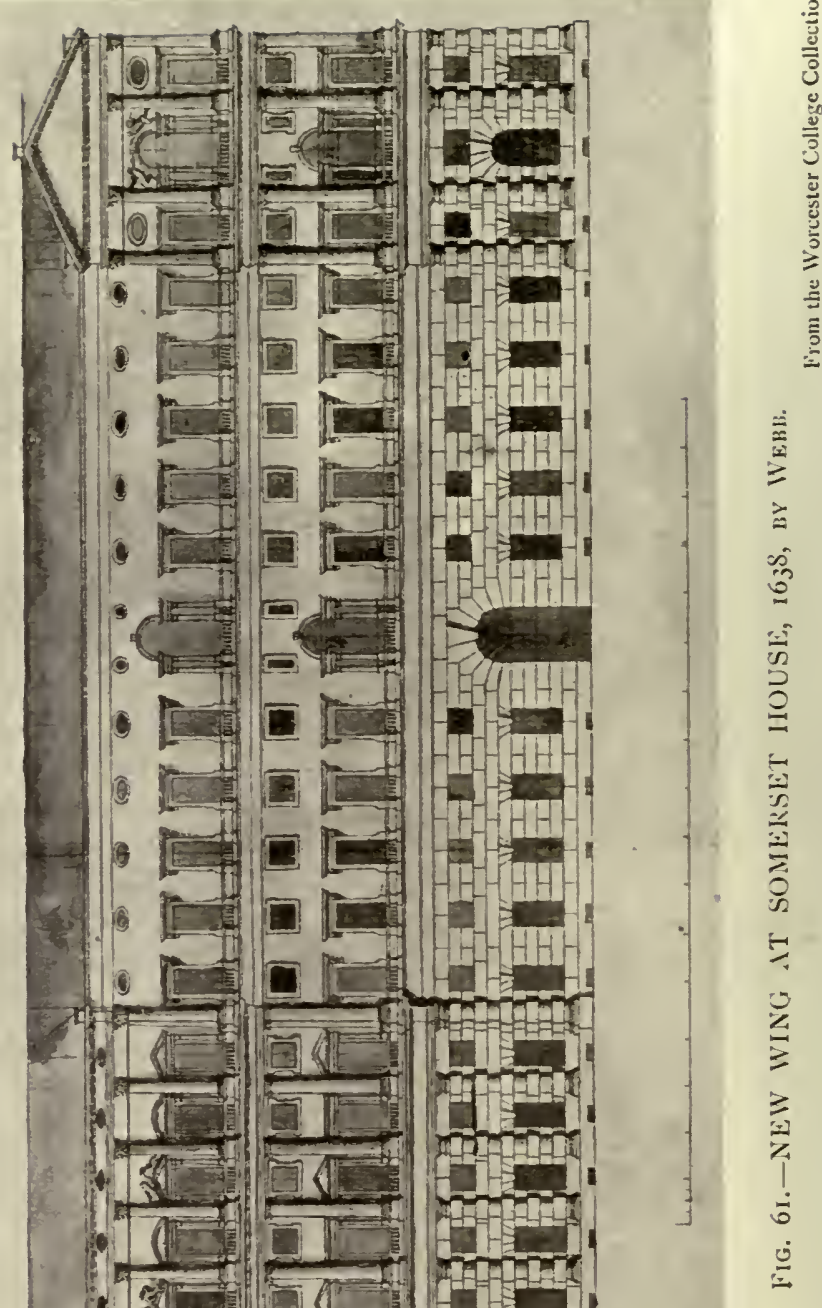

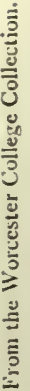

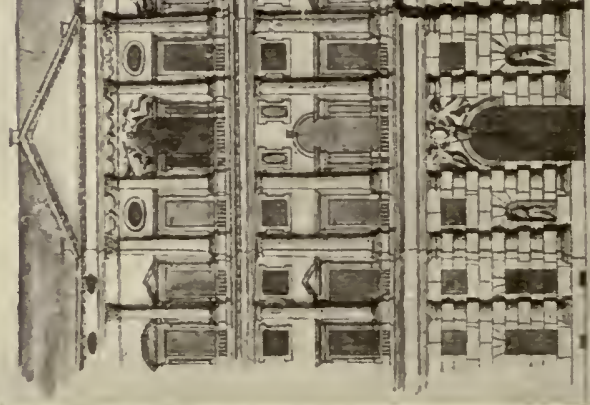


THE BLENDING OF JACOBEAN AND CLASSIC 105

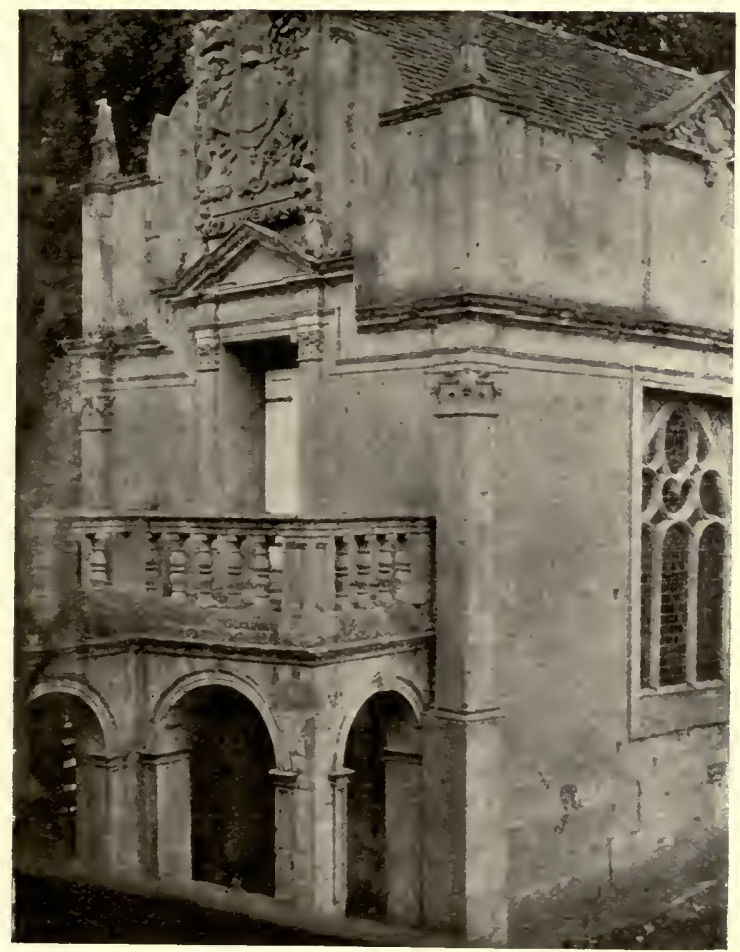

FIG. 62.-.The Chapel, Burford Priory, Oxfordshire.

roofs behind the gables are quite steep and are so complicated that some difficulty was found in getting rid of the rain water. Part of it is taken in a trough in the thickness of the attic floor; and in order to lessen the number of down-pipes, much of it is collected into lead troughs which are carried along the inside of the attic walls to the few pipes which are provided. The result of these arrangements is that every heavy storm or fall of snow entails an inspection by the plumber in order to prevent the accumulation of debris and the risk of spoiled ceilings and walls. The whole of the cornices and pediments are worked in cement, and not, as might be supposed, in stone.

If this house is compared with VVebb's drawing of a proposed new wing at Somerset House (Fig. 6I), made in the same year, ${ }_{163} 8$, the difference becomes strikingly apparent between the 


\section{THE BLENDING OF JACOBEAN AND CLASSIC}

style of the ordinary designer and that of the learned student; and yet Swakeley's was less than twenty miles from London, where the new methods were being sedulously cultivated.

Perhaps the most remarkable attempt to weld Jacobean and classic design into one consistent whole is to be found in the charming chapel attached to Burford Priory, in Oxfordshire (Fig. 62). There is much more here than a mixture of separate features, some in one style, and some in the other. The general treatment is reminiscent of Jacobean. There is a lofty story crowned with a cornice and an attic above it. There are shafts at the angles round which the cornice breaks, and they are terminated at the top with obelisks as pinnacles; there are also curved gables. But the shafts are fashioned into classic pilasters; the cornice not only breaks round them, but jumps up to make way for a door. The traceried windows have a novel disposition of curves, and the rose window is not a mere travesty of ancient methods, but has a vigorous individuality of its own, and is set in a classic framework. The whole work is consistent throughout, and the detail is refined and carefully handled. It is the successful attempt of a clever designer to solve old problems in new ways, and it is a pity that neither his name nor any other work from his hand is known. The chapel, as well as the house to which it is attached, was built by Speaker Lenthall, subsequent to his acquiring the property in 1634 .

The chapel and library of Brasenose College, Oxford, have escaped the full amount of attention which they deserve, probably because they lie outside the range of books dealing with the accepted division of architecture into Gothic and classic. But for that very reason they are of interest to the present inquiry. The detail on the whole is more classic than Gothic, but it is dealt with in a manner reminiscent of Gothic; the cornices break forward over the pilasters, and round the slight projections caused by the advancing of alternate windows; the windows have Gothic tracery ; pilasters are used in the place of buttresses (Fig. 63). Indeed the general design is Gothic in its arrangement, but classic detail has been applied to it, which in its turn has modified the Gothic handling. The whole effect is interesting. The designer has not merely made a Gothic design carrying it out with classic detail, nor has he made a classic design, giving his windows Gothic tracery. But each style has influenced the other. The Gothic treatment has modified the classic detail, the 


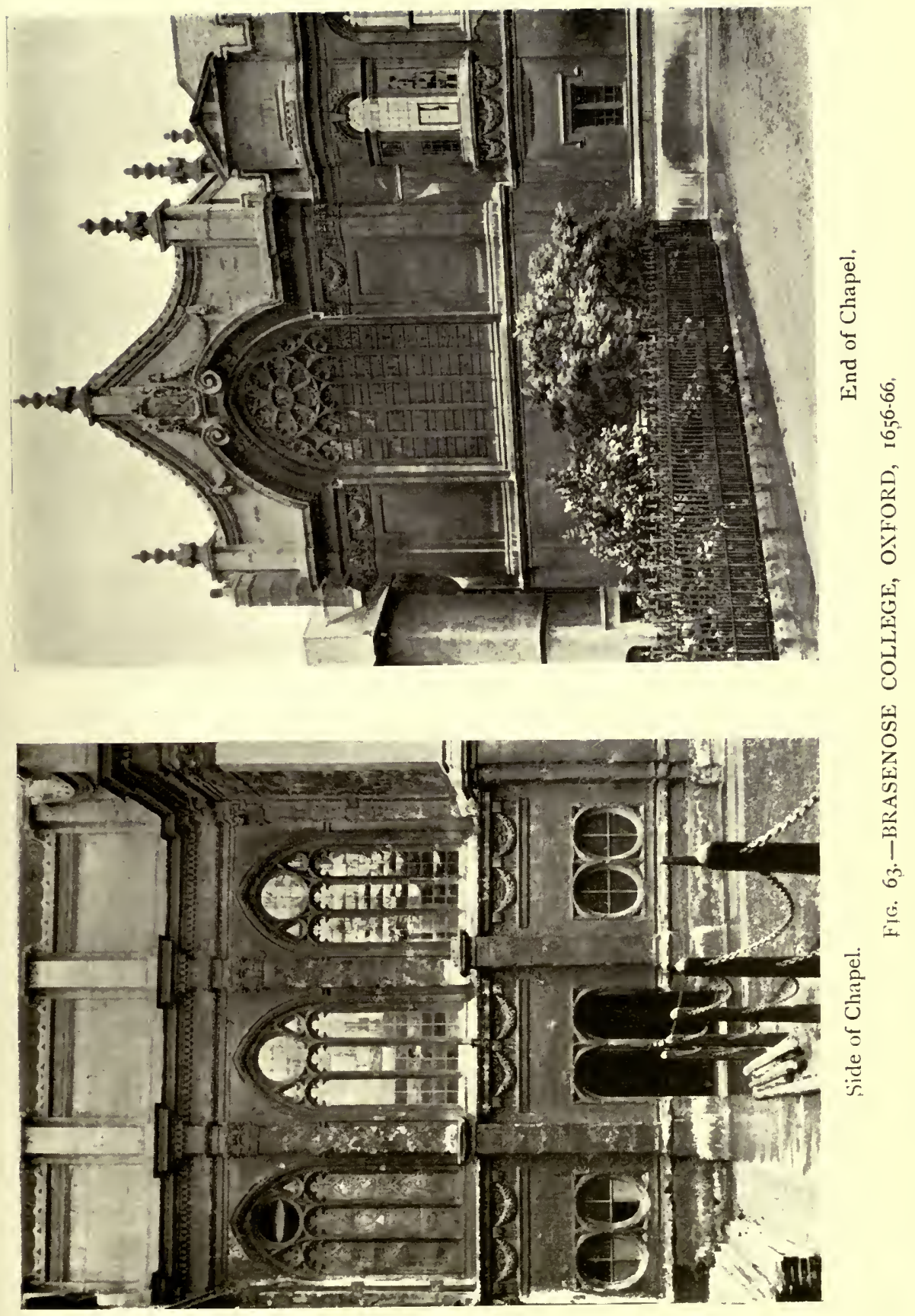




\section{THF BLENDING OF JACOBEAN AND CLASSIC}

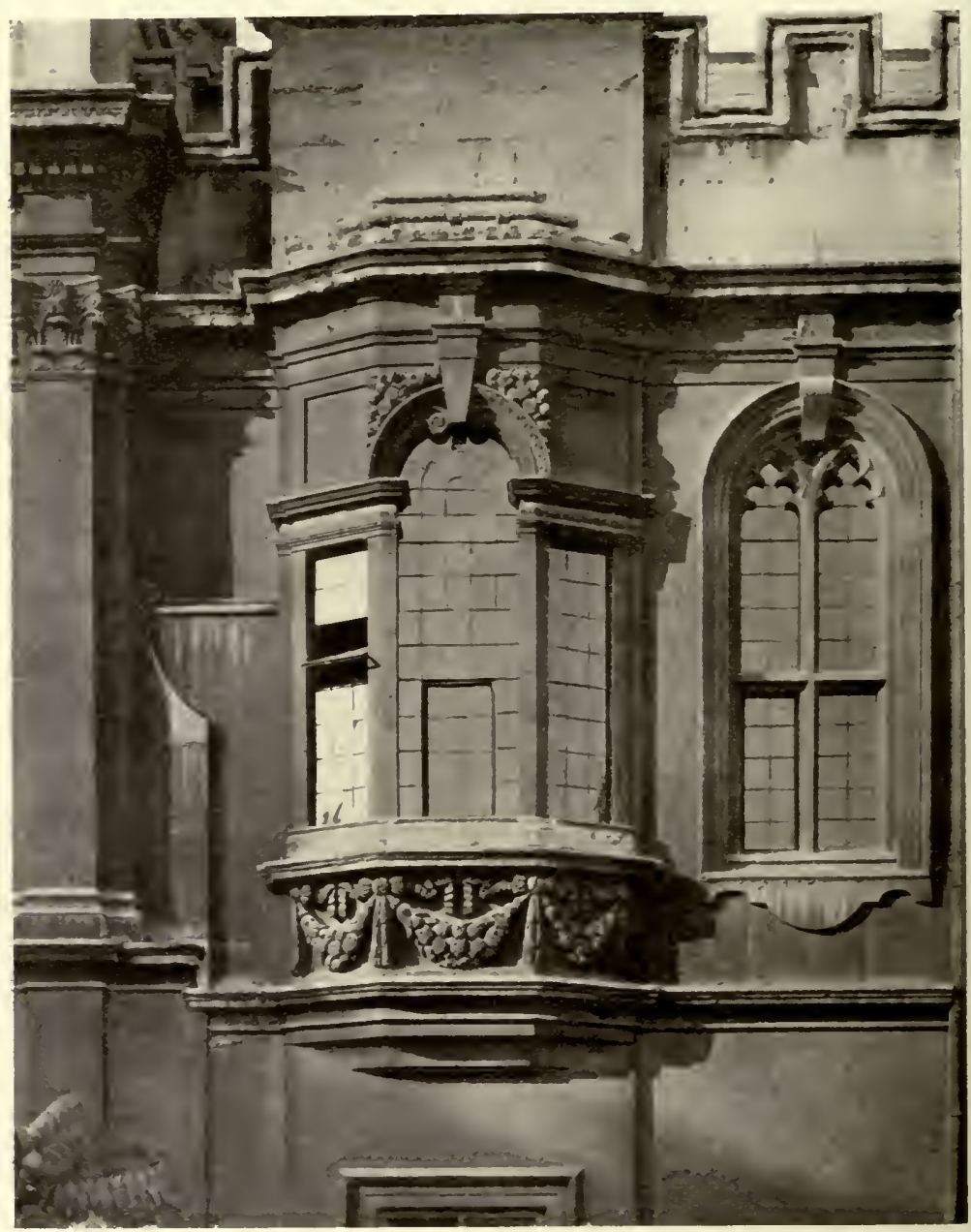

Fig. 64--Oriel at Brasenose College, Oxford.

classic detail has modified the Gothic treatment. The detail itself is quite refined, it is not the work of an ignorant man; the ornament is judiciously introduced, and applied with knowledge and skill. The oriel window on the external front (Fig. 64) adjoining the east end of the chapel is a charming piece of design, and the work generally is so well done that it has been attributed to Sir Christopher Wren; but although the attribution is erroneous it shows that popular opinion held the 
building worthy of being coupled with a great name. It would appear that a $\mathrm{Mr}$ John Jackson superintended the building operations, and as he made a model for the chapel roof, ${ }^{1}$ he may fairly be credited with the whole design. The first stone of the chapel was laid on the I 8 th June I 656 , and the work was practically finished by 1666 , in which year, on the I 7 th November, the dedication took

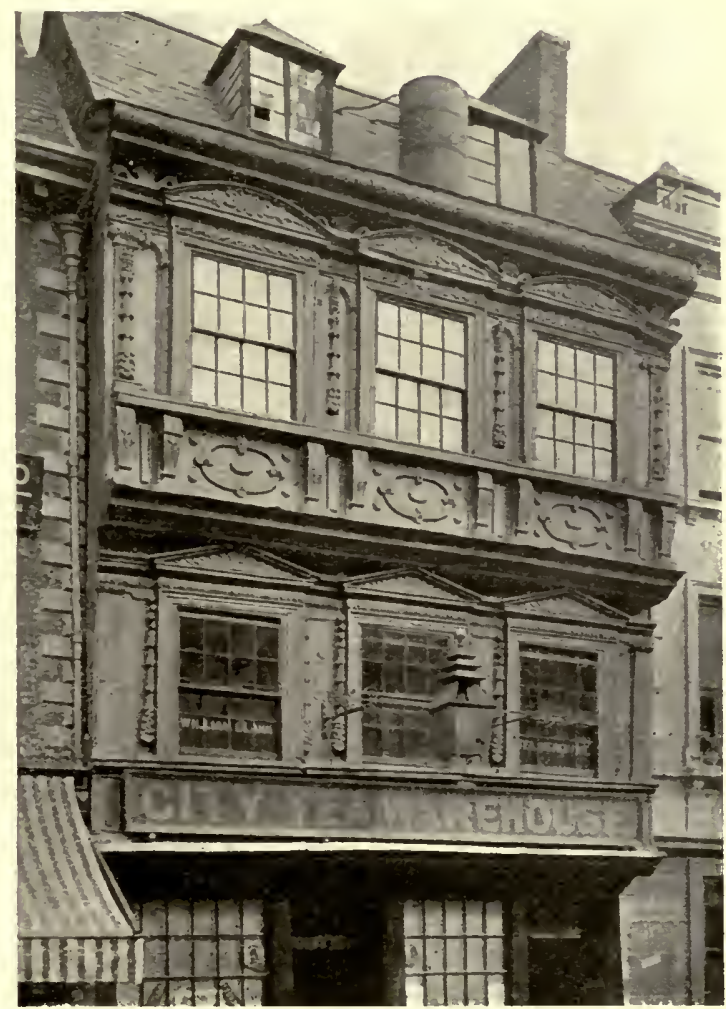

FIG. 65.-House in Southgate, Gloucester, I6 place.

The old house in Southgate, Gloucester (Fig. 65), until recently the City Tea Warehouse, is a curious mixture of the old and new styles. According to the date on a chimney-piece it was built in 1650 . The projecting stories, the panels and brackets below the windows of the top floor, and, indeed, the general treatment of the whole front, belong to the order of things that was passing away. The wide windows with their pediments, some straight and some curved, and the stiff floral pendents are indicative of the new style then coming into vogue. If the sash-windows were adopted from the outset, they would be a still more decidedly modern note. But if, as in all probability was the case, they merely replace the original mullions the native aspect of the front would have been less classic.

1 "The Old Colleges of Oxford," by Aymer Vallance, p. 62. 


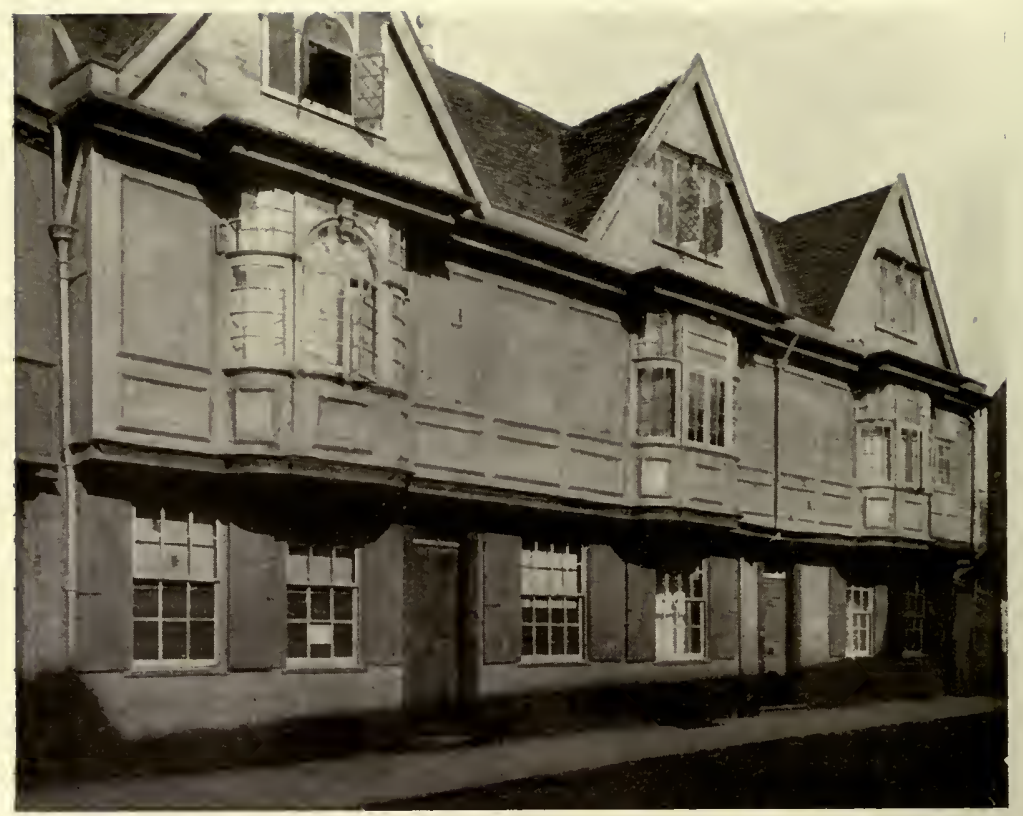

FIG. 66.-Houses at Ipswich.

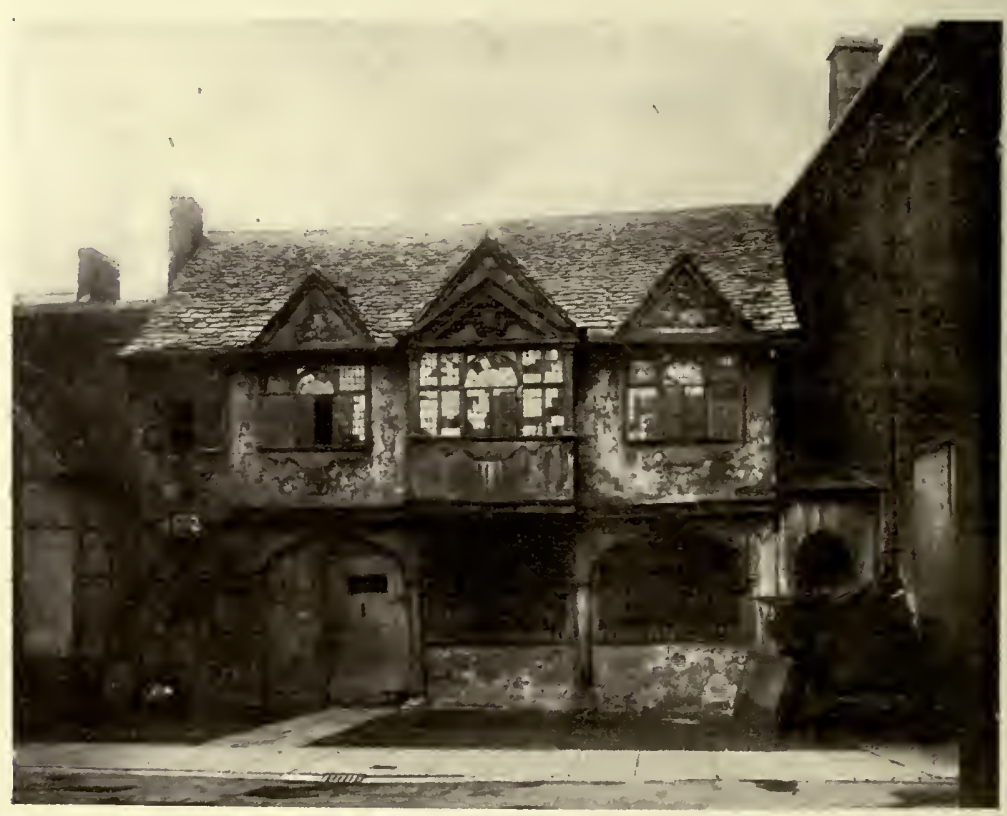

FIG. 67.-Nixon's Grammar School, Oxford, 1658 (now destroyed). 
Another type of the quaint mixture of the old and the new is to be seen at Ipswich in the well-known Sparrow's house, and in the less ornate example shown in Fig. 66. Here the ancient practice of overhanging the upper stories is utilised to obtain the strong horizontal lines which are characteristic of the classic style; but instead of the walls being full of windows, their blank spaces are larger in extent than the windows, and they are panelled in a simple fashion. Above the bold cornice spring three sharply pointed gables, which give an old-fashioned appearance to the house. The original windows are mullioned, but some of them (and probably all at first were alike) have an arched central light of double the width of the others. No doubt this treatment was introduced in order to vary the monotony of a series of windows composed entirely of small rectangular openings. It was very generally adopted, but the curved side lights are a variation not often found; the more frequent form is that employed in the picturesque Grammar School at Oxford (Fig. 67) which was built in the year 1658 for the education of freemen's sons, on the foundation of Alderman John Nixon. The steep gables appear to be later additions, the original arrangement was the flatter and more carefully devised gable over the middle window. The arcade on the ground floor is quite Jacobean in feeling.

At Saffron Walden, in Essex, there is a row of houses of ancient aspect, with projecting corbelled gables. One of them is dated 1676 , which probably gives the period when the modelled plasterwork was applied to an existing front, for some of the woodwork is Gothic in character. They are interesting examples of the ornamental plasterwork which at one time abounded in the eastern counties (Figs. 68 and 69).

The red brick inn at Scole, in Norfolk (Fig. 72), is another example of the mixture of classic cornices and quasi-pilasters with curved gables, and it gives a good idea of how local designers strove to modernise their buildings and were yet unable to shake off the old fetters which bound them to the traditions of their youth. There used to be, stretching across the road, a very substantial and picturesque sign attached to this inn, a wonderful piece of allegorical design. ${ }^{1}$ It was dated 1655 , which may be taken as the date of the building itself.

1 Illustrated in "Early Renaissance Architecture in England," by the present author (Batsford). 


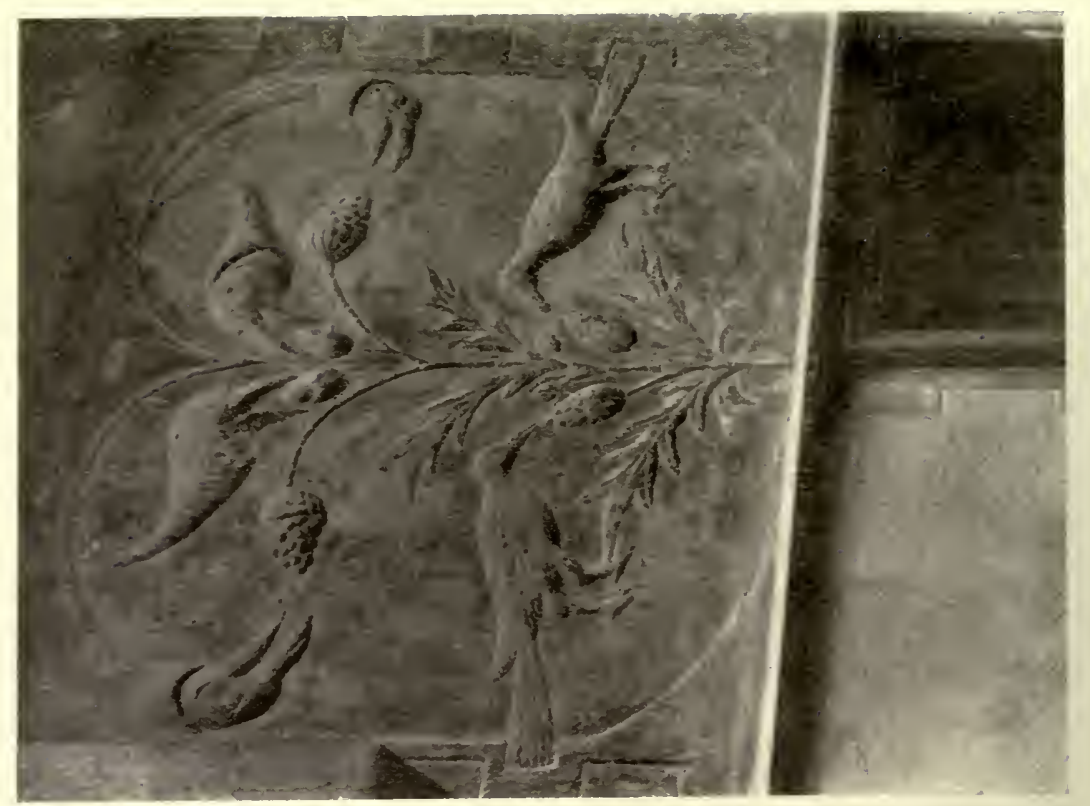

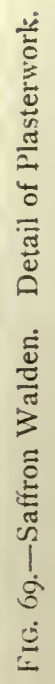

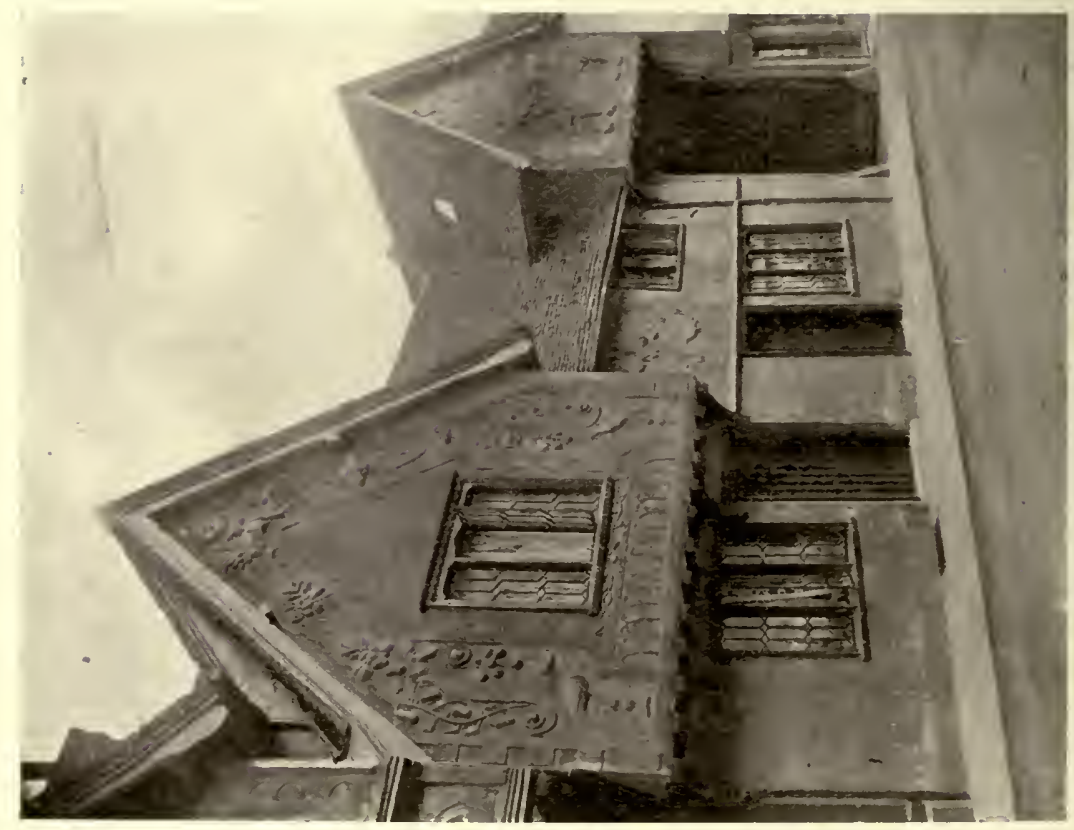

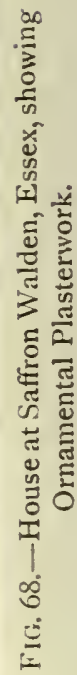




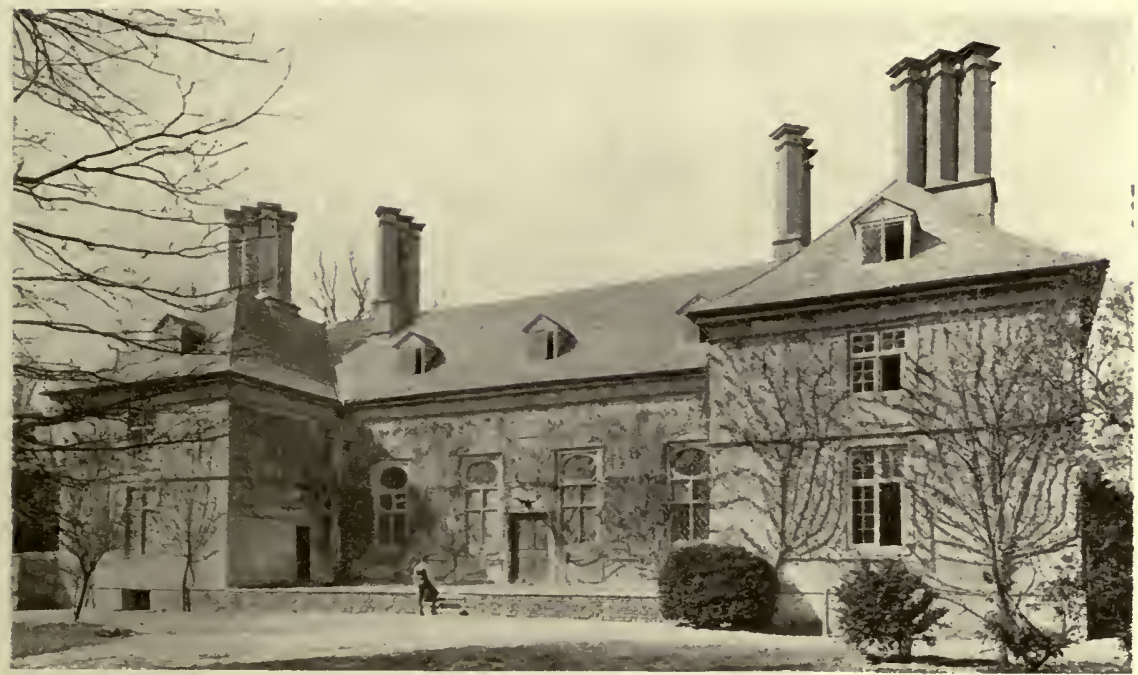

FIG. 70.-School at Witney, Oxfordshire, I660.

Another good example of the transitional stage between Jacobean work and classic is the school at Witney, in Oxfordshire (Fig. 70). The wings are still part of the main structure; the windows are mullioned, but the larger ones have an oval light in the uppermost compartment; the chimneys have square detached shafts set angleways on their base. All these are features of the earlier type. On the other hand, the absence of gables, the widely projecting coved eares, and small detached dormers are characteristic of the new methods of design. The date of the building, as stated on the panel over the principal door, is I660.

Of such houses as the farmhouse at Stanton Harcourt, in Oxfordshire (Fig. 7I), there are plenty of examples to be found. Here the mullioned windows are still retained; but the absence of gables, the straight front, the marked cornice at the eaves, the hood over the door, and the plain, severe outline are all in keeping with the more pronounced classic treatment which was being gradually adopted, even in remote places, by the end of the seventeenth century.

Such are some of the smaller houses built during the years in which Inigo Jones and Webb were working; links between the Jacobean style and that purer version of Italian to which those eminent men devoted themselves. 


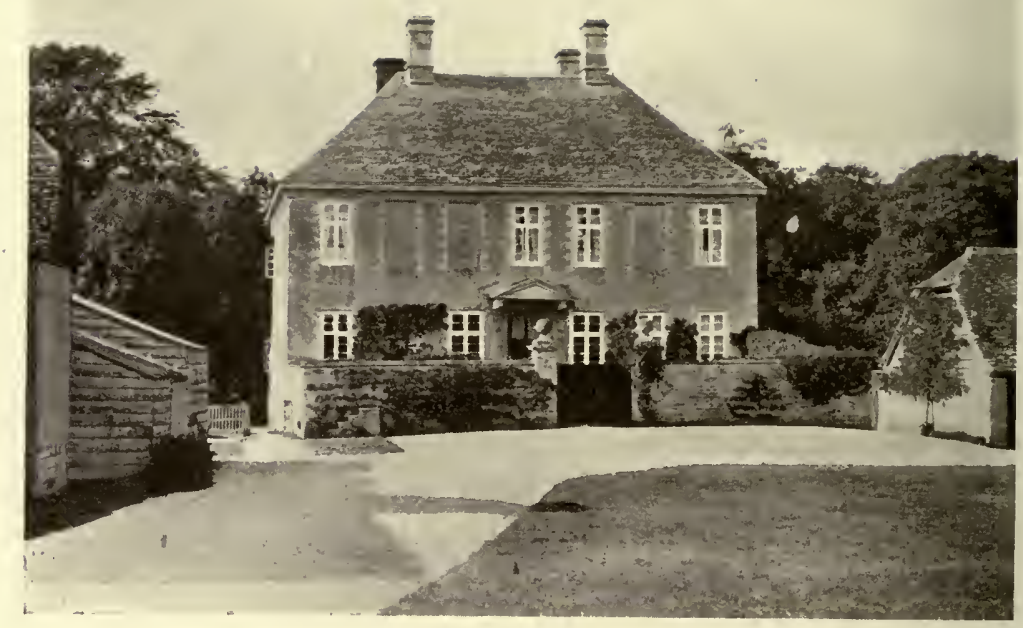

FIG. 7I.-House at Stanton Harcourt, Oxfordshire.

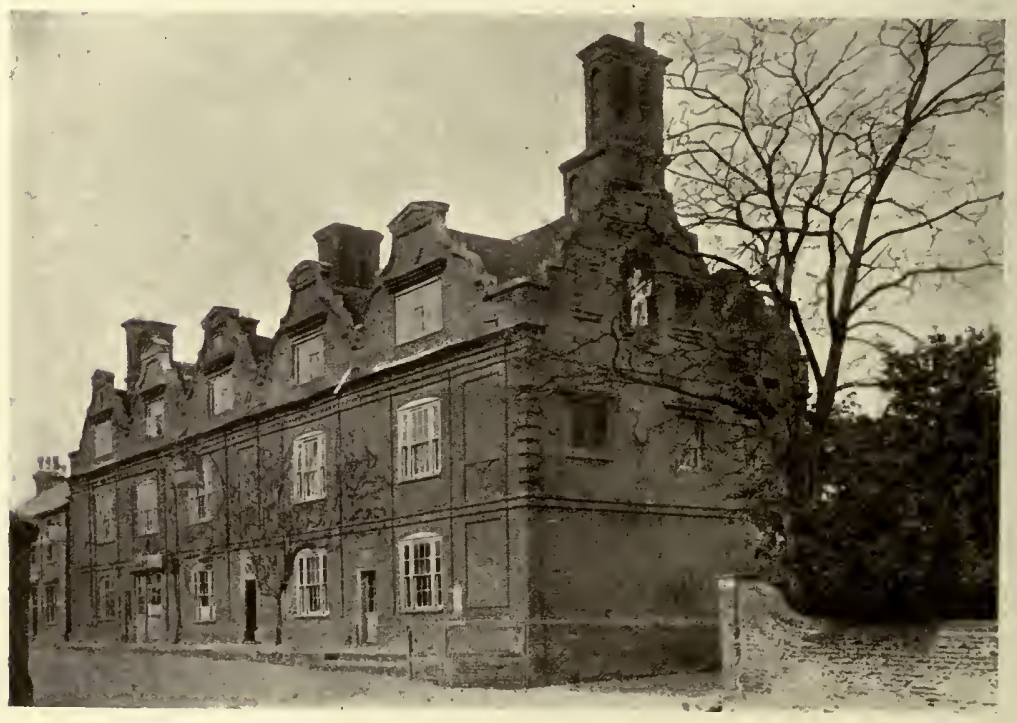

FIG. 72.-Inn at Scole, Norfolk, 1655. 
It has been shown how the general character of houses had changed during the period between the accession of Charles I. and the Restoration in regard to their arrangement and appearance; it will be well now to show briefly how their decoration had also altered. But before doing so, it will be useful shortly to recapitulate the principal changes that had taken place.

The old idea of the house-plan, derived from mediæval times, was to provide a great hall for the daily use of the whole household, and to supplement it by a group of rooms at each end, onc for the use of the family, the other for the servants. The relations between the family and their retainers were then closer than they became in later times. Gradually the custom of dining all together died out; the family secluded themselves in their own apartments, the servants in theirs. The great hall was deserted as a living-room and degenerated into a vestibule leading to the rooms where the daily life was led. The distinction between the family and the servants was emphasised somewhat to the disadvantage of the latter; for when sacrifices of comfort had to be made for the sake of architectural effect, it was the servants upon whom discomfort was laid with the least scruple. They were frequently relegated to a basement during the day, and to attics during the night. The ground floor and the floor above it were reserved for the use of the family and for state occasions. The increase in the subdivisions of household work may be realised from Swift's satirical "Advice to Servants," addressed to persons whose duties (many of them) had not been specialised, even if they had come into vogue, in the old days.

It is interesting to compare the names of the rooms on the plans in the Thorpe collection, which dates from 1570 to 1620 , with those on Webb's plans for Durham House, dated I649. Many of them are identical, such as the hall, the dining-room, the great chamber, the withdrawing-room, the gallery, and the servants' rooms-kitchen, pastry, larder, buttery, and so forth. But Webb has a few new designations, such as the secretary's room, the apothecary's lodging, the housekeeper's room, and the under-housekeeper's, the baker's and cook's rooms, the page's room, the master of the horse, the receiver-general, and the surveyor's chamber. Then there are rooms of state, a presence chamber, a private dining-room to serve both his lordship's and lady's apartments, his lordship's cabinet and his wardrobe, a 


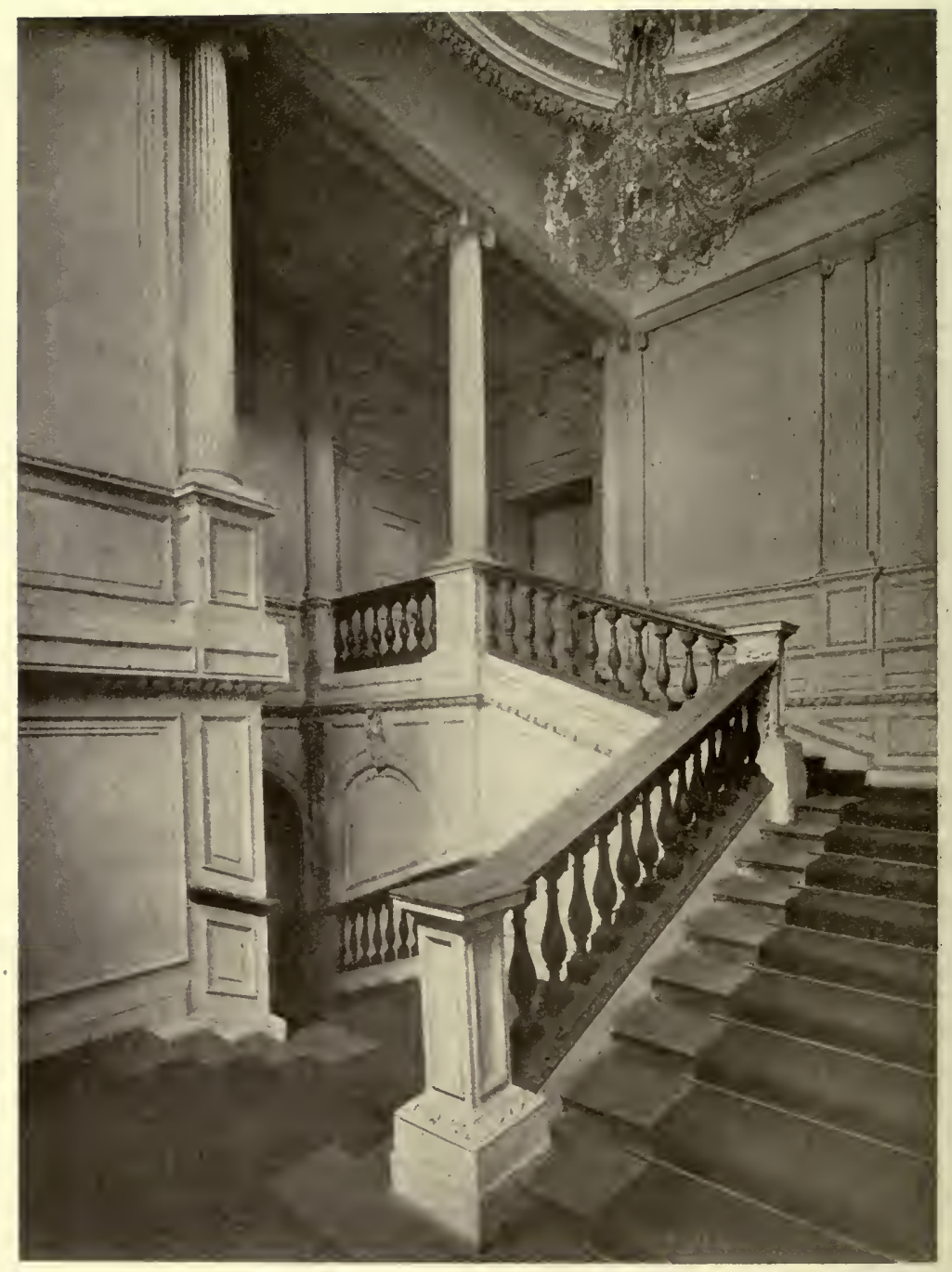

FIG. 73. -STAIRCASE-AT ASHBURNHAII HOUSE, IVESTMINSTER. 
dressing-room, and various back stairs serving both his lordship's rooms and those of his lady.

From this it will be seen that the tendency was to increase the subdivision of duties and the general convenience of arrangement (by means of back stairs, among other things), and to allot more rooms to the principal servants. At the same time special provision was made for state occasions in the state rooms and presence chamber. It must be remembered that these plans of Durham House were made in 1649 , although they were never carried out. They indicate a desire to increase at once the convenience and the stateliness of the house, and although it was designed on strictly classic lines, everything was not yet subordinated, as in later years, to the supposed necessities of architectural grandeur. In some of his other plans, many of which were studies in design rather than practical work, Webb was almost as great a sinner as his successors of the early eighteenth century.

The external appearance of houses had changed even more than their plans. Gables had almost disappeared; dormer windows no longer rose from the walls, wrought in stone or brick, but from the roofs and made of wood; the roofs themselves assumed a flatter pitch and generally started from widely projecting eaves. Windows were no longer mullioned and transomed into many small lights, but consisted of one large opening enclosing a wooden frame, which at first was divided by wood mullions, but later was filled with sliding sashes. The general appearance of the house was more compact than of old but less picturesque; it was more regular, and depended largely upon the nice spacing of the windows, upon its proportions, and its more scholarly detail.

This scholarly detail gradually ousted the naive design of the Jacobean craftsmen. To be scholarly you had to be correctly Italian, and therefore the quaint mixtures and the quaint native growths that sprang from an imperfect acquaintance with the true gospel of Italian design were discountenanced. Fancy was to be smothered by knowledge. Nevertheless it is odd to find how long the strapwork motif survived, which we are apt to think of as Dutch ; it is found in work of Charles II.'s time and even later; Webb made use of it, and even Jones himself did not disdain it, as may be seen from some of his designs for chimney-pieces (Figs. 9I-94). 


\section{8

Staircases had also changed in the character of their detail; they were still arranged in straight flights, but we have already seen at Coleshill that they sometimes formed a more imposing feature than in Jacobean days; in that instance the staircase is doubled, each portion being of equal importance, and they occupy a considerable part of the entrance hall. This double arrangement was by no means of universal adoption, it depended upon the space at command, and at Ashburnham House, Westminster, for instance, where space was restricted, a single staircase was. ingeniously planned, but was treated in a monumental manner. The design is attributed by some to Inigo Jones, and it is almost certain that it must be either by him or by Webb. The house was originally fashioned out of some of the old monastic buildings, and had been used as a dwelling for many years before the time of Elizabeth. It was known as the Dean's House, and wasoccupied by a succession of tenants. In 1621 a lady became the tenant; she was succeeded in 1628 by Sir Edward Powell, who obtained a lease in 1629. The question of the tenancy is important as it sets limits to the number of those who would be likely to embark on considerable alterations. In I640 the house was transferred to trustees for the benefit of Sir Edward's wife. Then came the Civil War, and the next tenant who appears is William Ashburnham, who, already in occupation, obtained a forty years' lease in 1662. As he was an ardent royalist, it is supposed that he could not have taken the house previous tothe Restoration. ${ }^{1}$

The choice of the individual who caused the new work to be done appears to lie between Sir Edward Powell and IVilliam Ashburnham, for Lady Powell's trustees of 1640 would not belikely to undertake anything of such magnitude, and it is. improbable, although not impossible, that it was done during the Civil WVar or the Commonwealth. The reasonable dates lie, therefore, between 1629-1640, and $1662-1672$, in which latter year Webb died. On the whole, the character of the work points to the later period; it looks as though it were the outcome of longer experience than the earlier period could have supplied. It should be borne in mind that the treatment of the ceiling, with the open cupola above it, resembles that of one or two drawings made by Jones and Webb for Wilton and elsewhere.

1 "Ashburnham House and the Precincts of Westminster Abbey," by Harry Sirr, Journal of the R.I.R.A., 8th January 1910. 


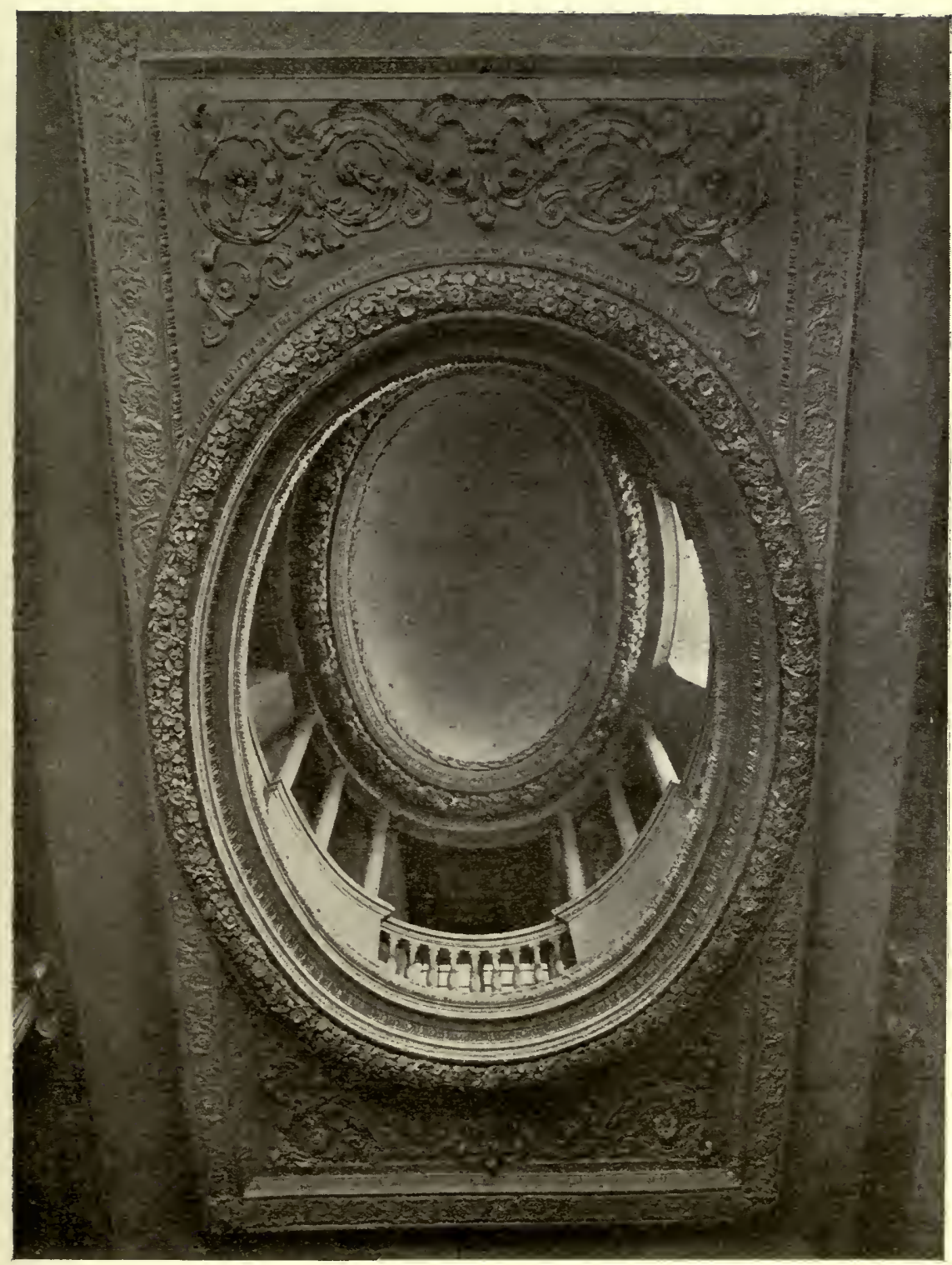

Fig. 74.-ASHBURNhAM HOUSE. Ceiling orer Staircase. 

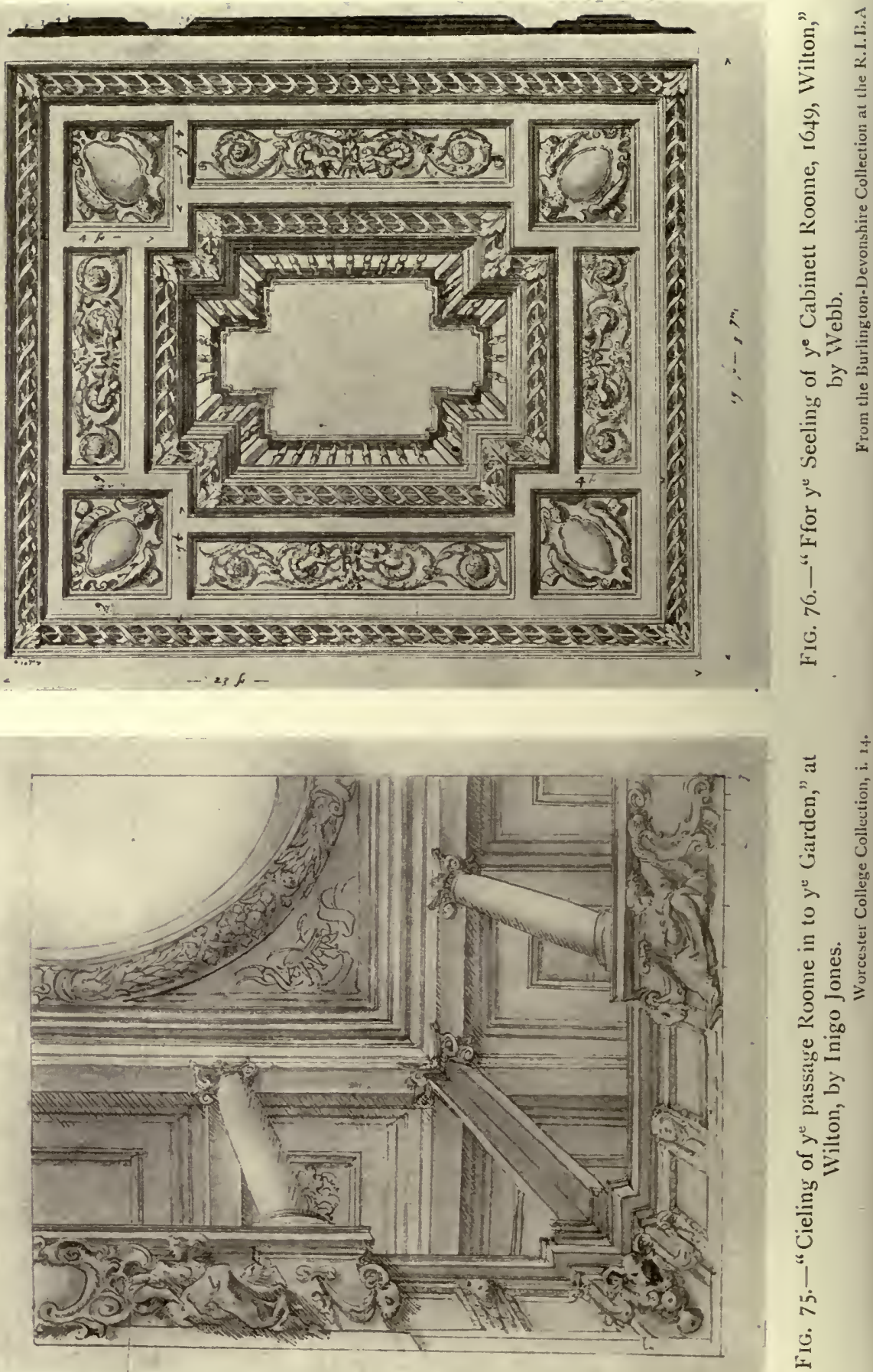


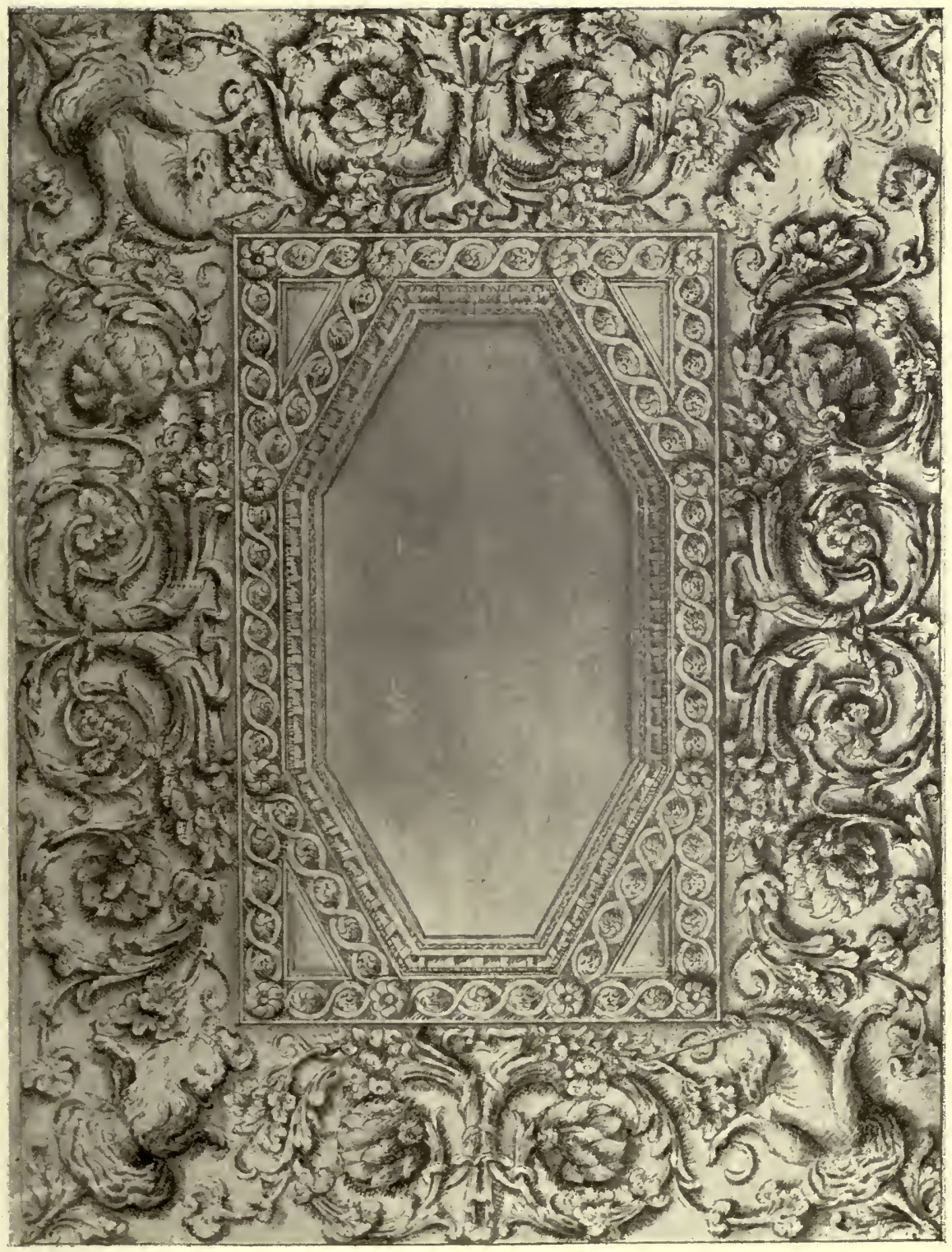

Fig. 77.-CEILING AT GREENIIICH PALACE, by Webb.

From a Drawing in the Burlington-Devonshire Collection at the R.I.B.A. 
In any case, and whoever designed it, the detail of the work is of interest as showing the departure from Jacobean ideals. The staircase, it is true, retains the solid newels, the massive handrail, and the stout balusters hitherto in vogue (Fig. 73); but the ornament has changed, and the balusters are almost as stout as if intended to be of stone. The panels on the wall are larger in size and in scale than those of Jacobean design, and they are marshalled with more pomp. The ceiling has no. affinity with the busy and intricate ceilings of the departing style. The framework is large, and its members are adorned with foliage in high relief; the open cupola, with its balustrade and detached columns, is a new idea in English work (Fig. 74). If it was executed between 1629 and 1640 , it would be the first example of its kind; if between 1662 and 1672 , it would have had predecessors among the drawings of Jones and Webb. It is perhaps worthy of note that in Jones's designs of ceilings the ornament is usually confined to the ribs, the intermediate spaces (that is, the ground of the ceiling itself) being plain. Here the ground is covered with foliage as well as the ribs, and curiously enough, those of Jones's designs which include cupolas are similarly treated. His drawing for the "cieling of $y^{\text {e }}$ passage Roome in to $y^{\mathrm{e}}$ Garden" (at Wilton) is illustrated in Fig. 75, and Webb's drawing " ffor $y^{\mathrm{e}}$ Seeling of $y^{\mathrm{e}}$ Cabinett Roome, 1649 , Wilton," in Fig. 76. Although the perspective treatment of the cupolas is a somewhat special feature, the general design of these and of that at Ashburnham House gives a good idea of the manner in which ceilings of the period were managed.

Another and more ambitious design for a ceiling by Webb is that for "his Majesty's Presence at Greenwich, I666" (Fig. 77), preserved at the Royal Institute of British Architects. The outer border represents a bold cove filled with modelled plasterwork in high relief; the four angles are occupied by lions and unicorns, emblematic of England and Scotland. If this design was ever carried out, it has disappeared, and there is no example to be found of modelling treated on so large a scale; the cove would have been some eight feet on the curve, and the effect of its plaster ornament would have been rather overwhelming.

Returning to the consideration of staircases, there is one at Can Court, in Wiltshire (Fig. 78), which is earlier in feeling, if not in date, than the Ashburnham House staircase. It retains many of the characteristics of Jacobean work, particularly in the stout- 


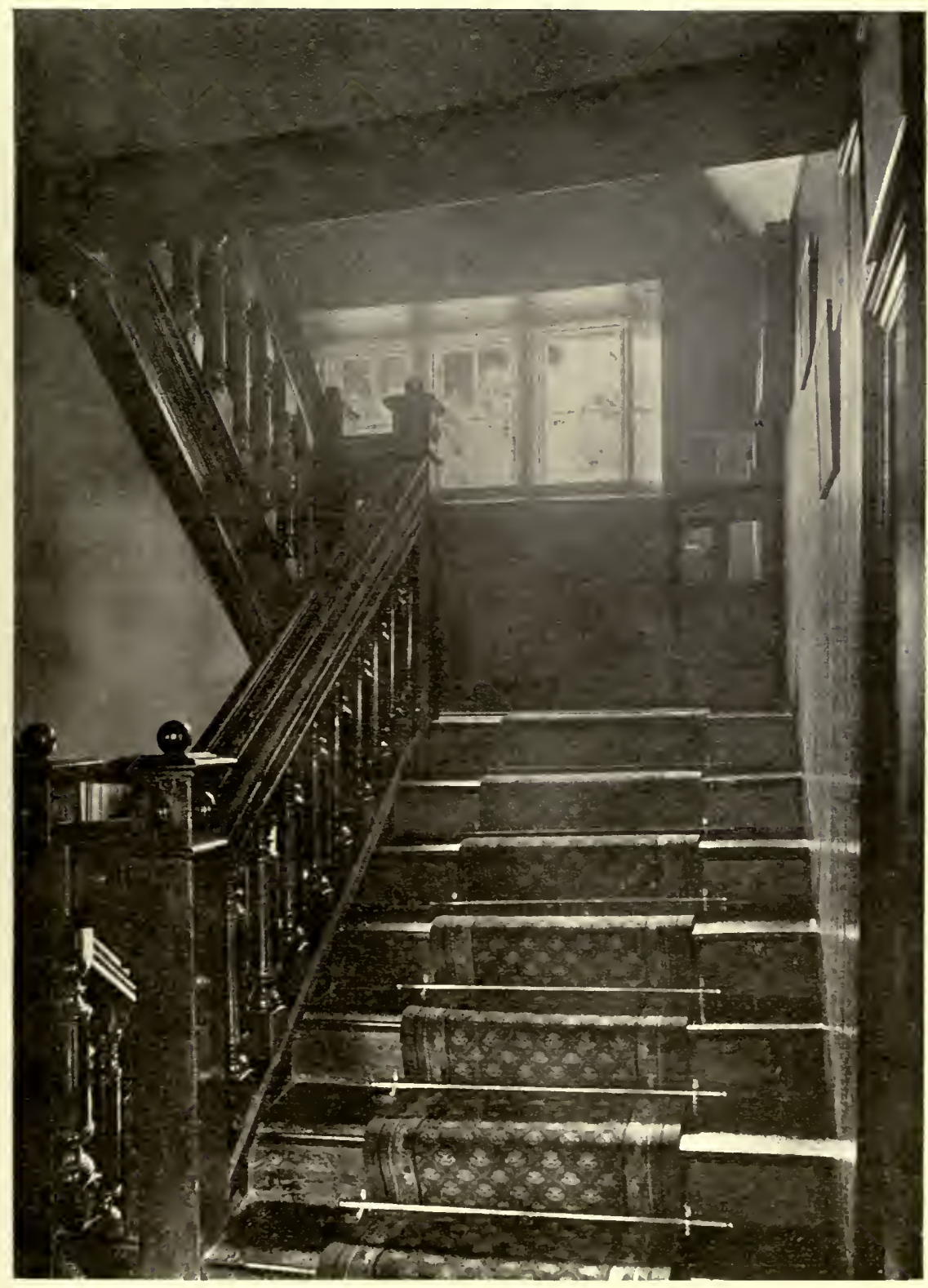

Frg. 7S.-CAN COURT, Wiltihre. The Starkasf. 


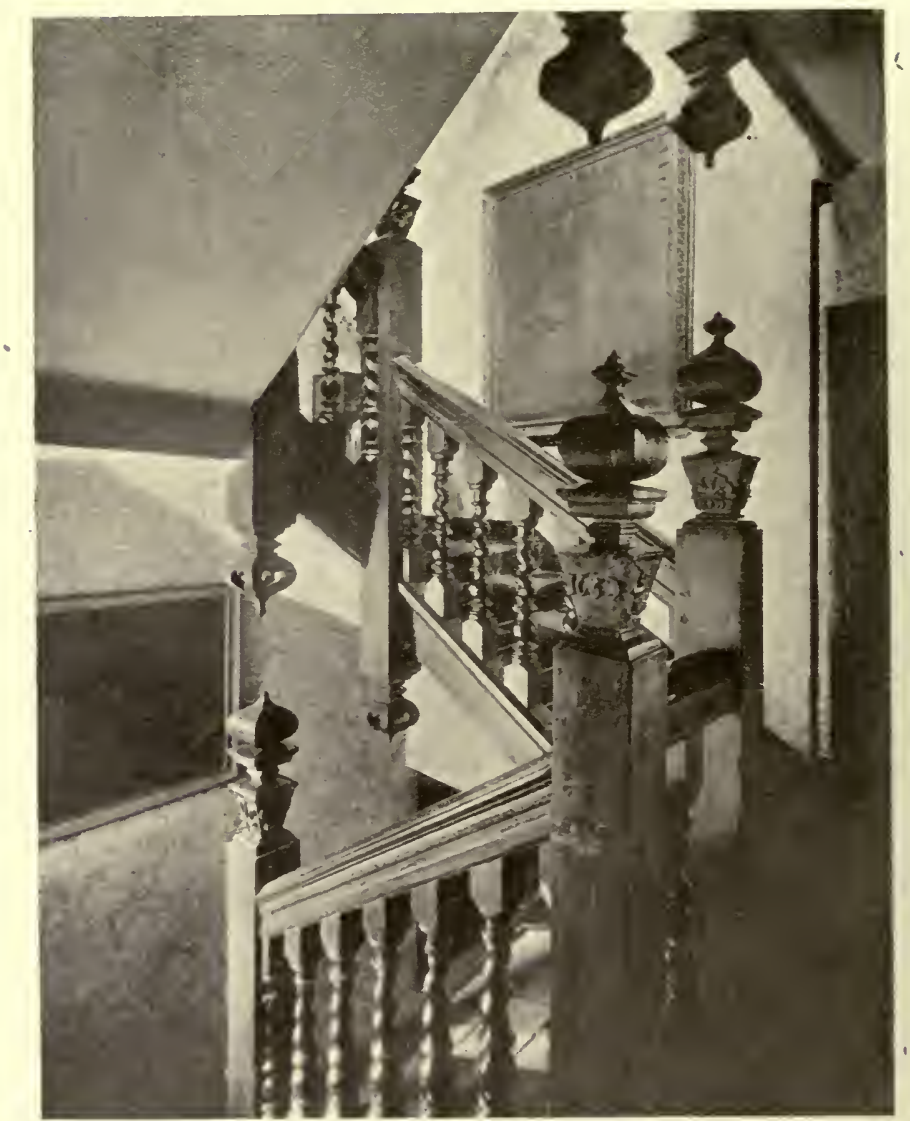

FlG. 79.-Staircase at Dawtrey Mansion, Petworth, 16;2.

ness of the newels, the handrail and the string. In the balusters, however, a later touch is apparent, as well as in the upper part of the newels. It is obvious, nevertheless, that the two staircases belong to the same type.

An interesting staircase both as to date and detail is one at Dawtrey Mansion, Petworth (Fig. 79). It is dated 1652, and while it retains the Jacobean form of finial, not gracefully designed, it has twisted balusters of the kind usually associated with work of fifty years later. It is one of the numerous links which connect the old and the new forms.

Of the same type as these in essence, although differently 
CONTINUOUS SCROLL FOLIAGE IN S'TAIRCASES 12:

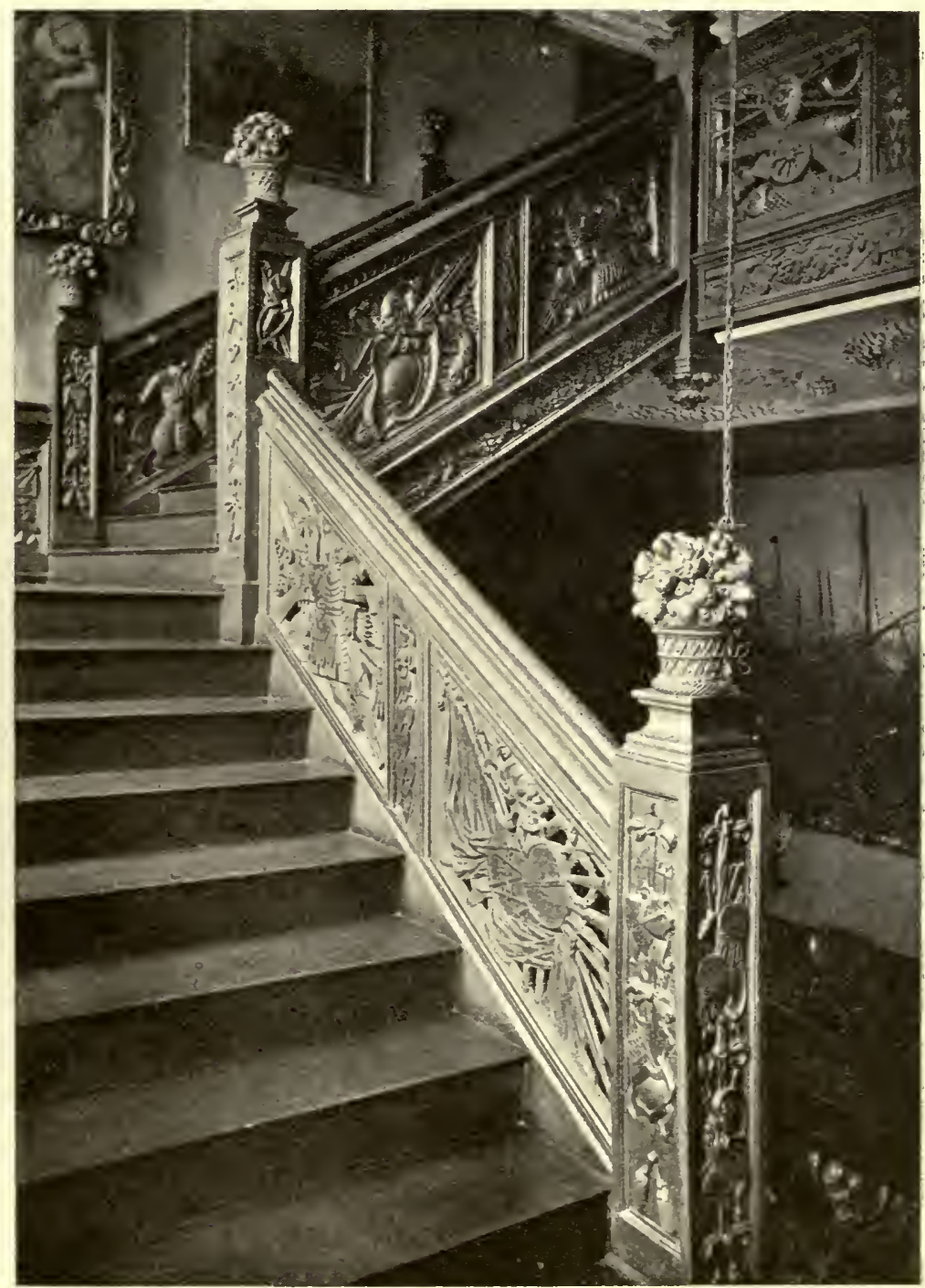

F1G. So.-Ham House, Surrey. The Staircase.

treated, is that kind of balustrade already mentioned in connection with Thorpe Hall (Fig. 49), where the balusters are replaced by scrolls of foliage. There was a rery interesting example of this fashion at the Castle Inn, Kingston, now destroyed (Fig. 


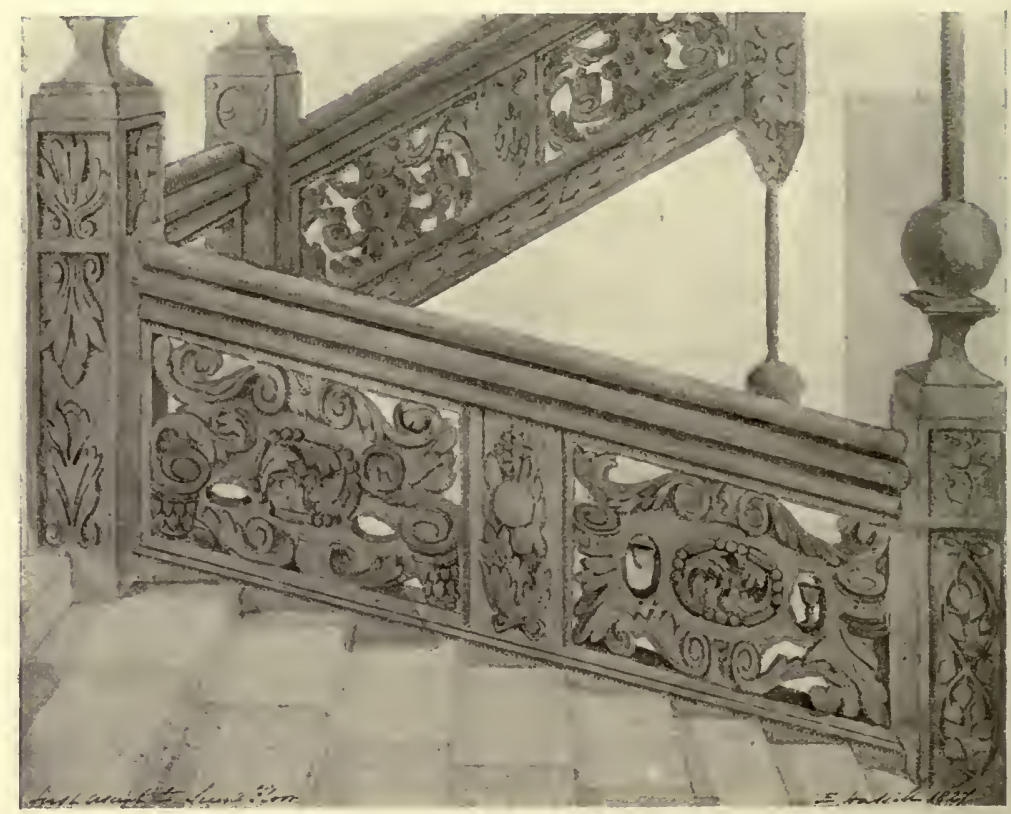

FIG. 8r.-.-The Staircase, Castle Inn, Kingston-on-Thames.

$8 \mathrm{I}$, and there is another at Ham House (Fig. So), where, however, the panels display flags, armour, guns, and other martial emblems, which may perhaps have some reference to Thomas Talmash, a brother of Lord Dysart (the owner) and a general in the time of William III.

There was an ancient house at Greenwich called the "Old Palace," but distinct from the building which was at one time the royal residence, sometimes known as Crowley House. It has been destroyed, but some sketches by C. J. Richardson of the in.. teresting work it contained have survived, and among them is one of a staircase with foliated balustrade (Fig. 32). The character of the detail suggests a date in the middle of the seventeenth century, and the general treatment recalls the work which was being done by $\mathrm{Webb}$ at that period. There is a slight survival of the earlier style, but the design is handled in a more refined spirit than was usually the case with sumptuous examples of Jacobean work. This is particularly observed in the door (Fig. 83).

In the hands of Inigo Jones and Webb both doorways and windows assumed a correct Italian appearance, but in less 


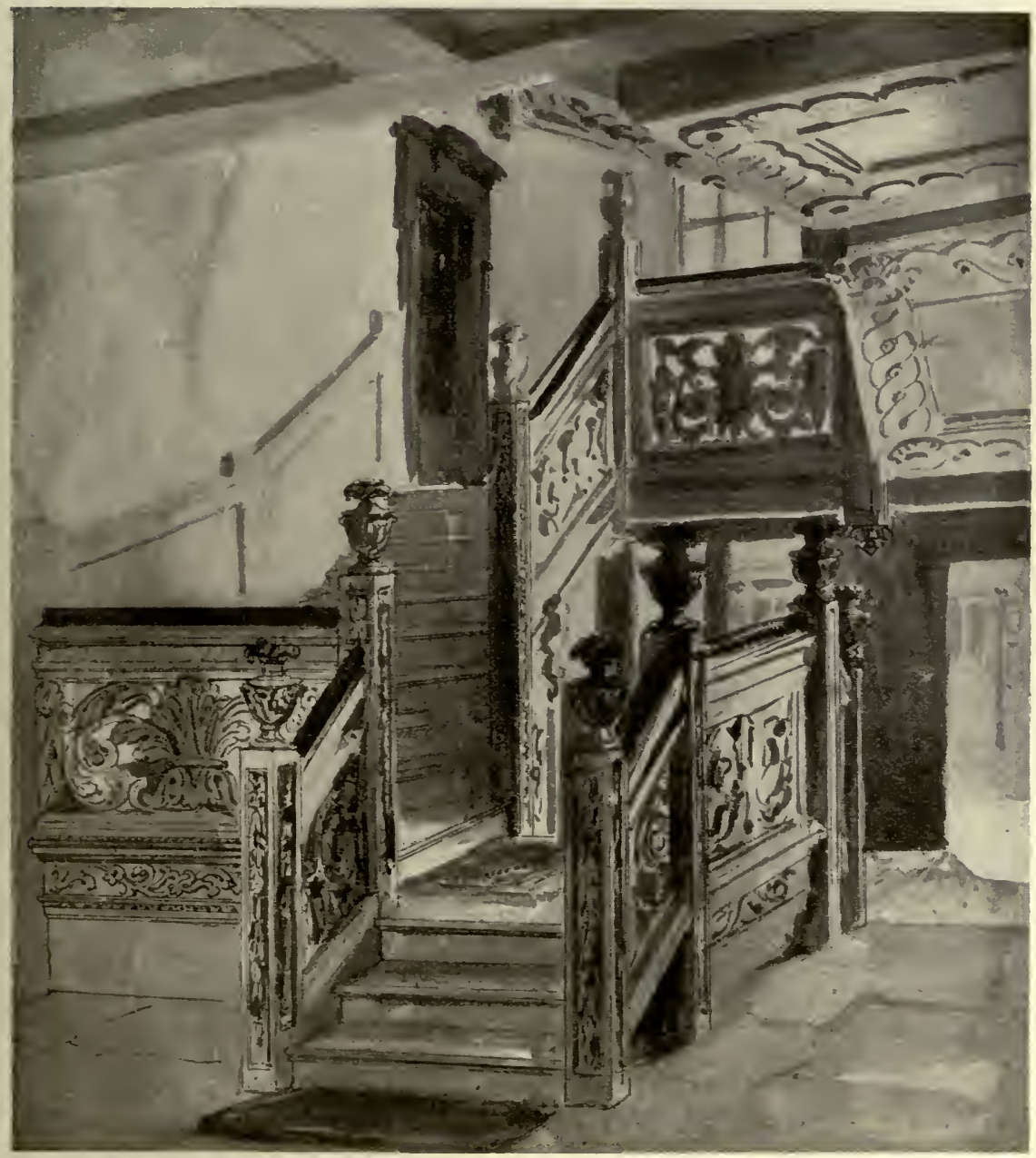

FiG. 82.-The Staircase at the "Old Palace," Greenwich (now destroyed).

From a Sketch by C. J. Richardson.

learned hands there were intermediate stages of development between the Jacobean type and the full classic. Such a one may be seen in the library door at St John's College, Oxford (Fig. 85), and in an external door at Brasenose College (Fig. 84), part of the work already referred to. The library at St John's was built in I63 I by Archbishop Laud, who was at that time Bishop of London and Chancellor of the University of Oxford. It is said that he obtained the help of Inigo 


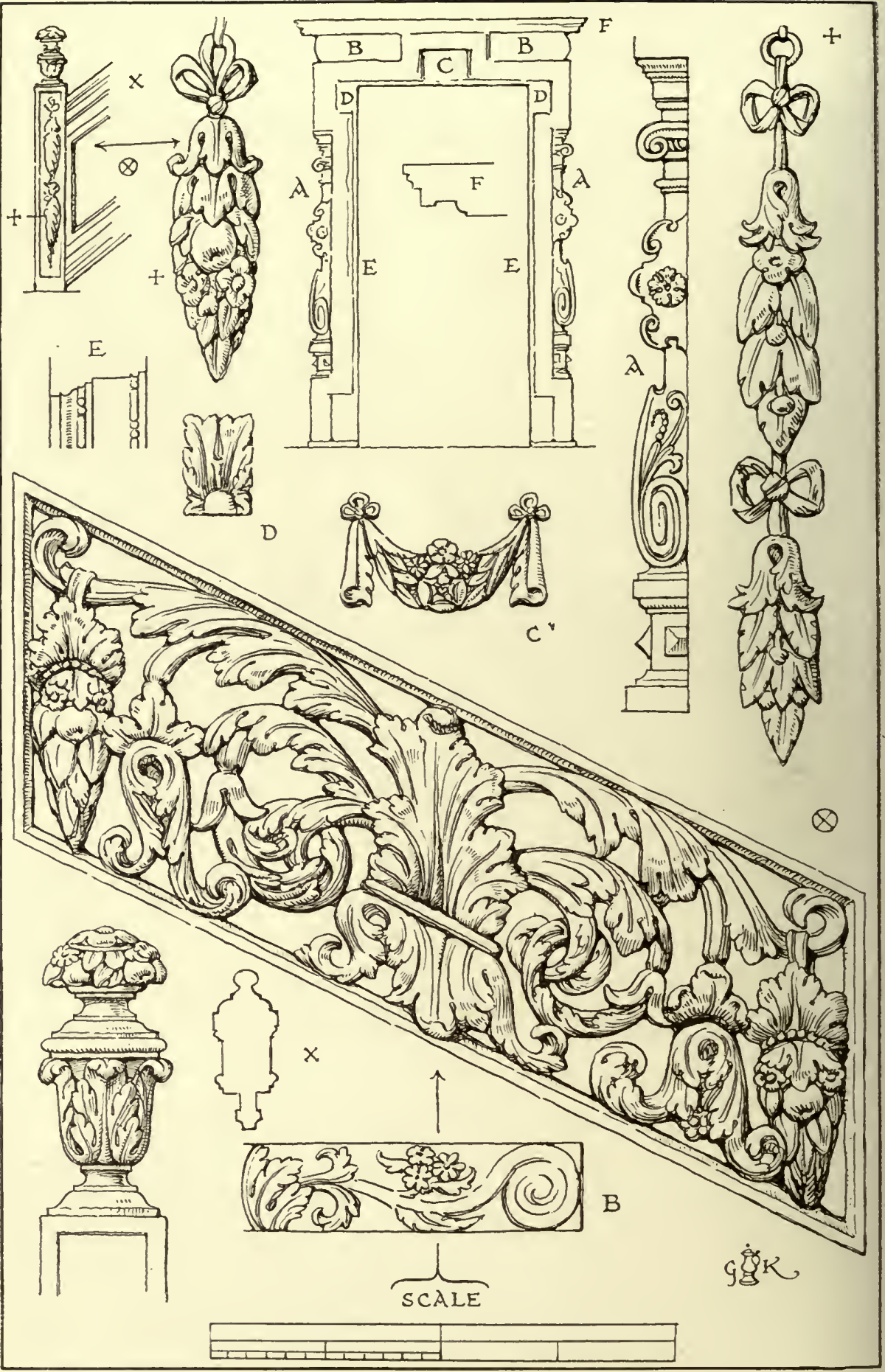

Fig. $8_{3} .-$ "Old PAlaCE," GREenivich. . Staircase Detalls and Door. 
Jones, but the detail of the work is so unlike anything which remains of Jones's own draughtsmanship, that the correctness of the attribution is very doubtful. The stonework of this particular door, however, is not unlike some of the doorways with which the name of Jones is connected, now preserved at the Royal Institute of British Architects. The woodwork has no counterpart among his designs.

If we want to see the scholar's idea of what a doorway should be, we must turn to Jones's drawing of one for the Banqueting House (Fig. 86), or to Webb's design for one in the palace at Greenwich, the block which he designed for Charles II. (Fig. 87). The former is entitled in Jones's writing, "Scitzo for the Great Doore Ban. Ho. I6I9." It has the logically indefensible broken pediment, making room for an unfinished cartouche which was doubtless to receive the royal arms. On the panel in the frieze is indicated an inscription commencing with the first letters of Jacobus Rex Magnæe Britanniæ; below it is an ornament in which the strapwork motif lingers. The whole effect is strong, handsome, and well proportioned. If it was ever actually carried out, it has now disappeared. WVebb's drawing is entitled in his own writing, "Greenwich. ffor the dore going out of the Cabinet into the gallery I663." The whole composition is not unlike Jones's, but it is larger, although the door itself is smaller. The draughtsmanship in both is somewhat alike, but the difference is just that which distinguishes the work of the one man from that of the other. Jones's is the more virile and direct. The figures on the pediment at Greenwich are named as "Liberality and Magnanimity," at the other end were to be "Religion and Justice." It must be admitted that their different attributes are not clearly indicated. A note at the side shows that this doorway was Webb's own design; it reads " $\mathrm{M}^{\mathrm{e}} \mathrm{I}$ must alter these measures and make them thus," then follow the altered dimensions.

It has already been pointed out how the mullioned window was gradually altered by the introduction of a wider light surmounted by an arch (Fig. 66), or by the introduction of an elliptical light (Fig. 70 ). But the mullioned window in any form was out of place in a truly classic design. Jones has an early drawing of 1616 in which he makes use of it, as well as of other Jacobean features, but it is doubtful whether any executed work of his can show a stone mullioned window. The type 


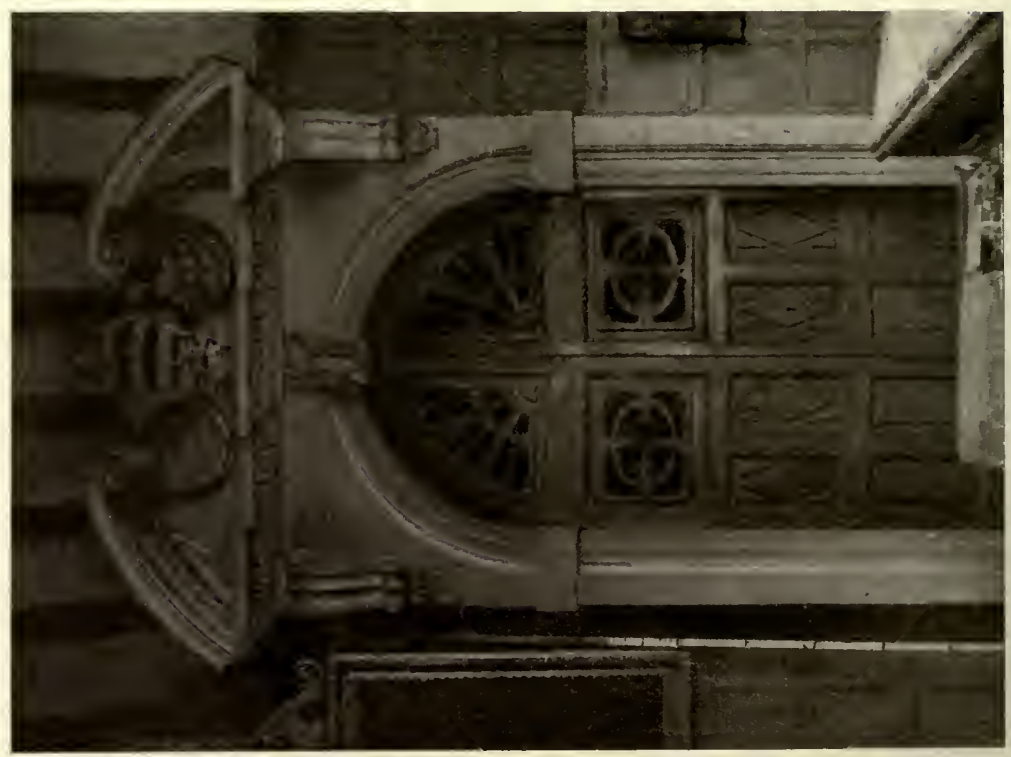

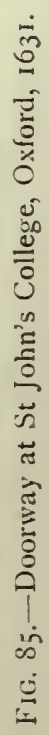

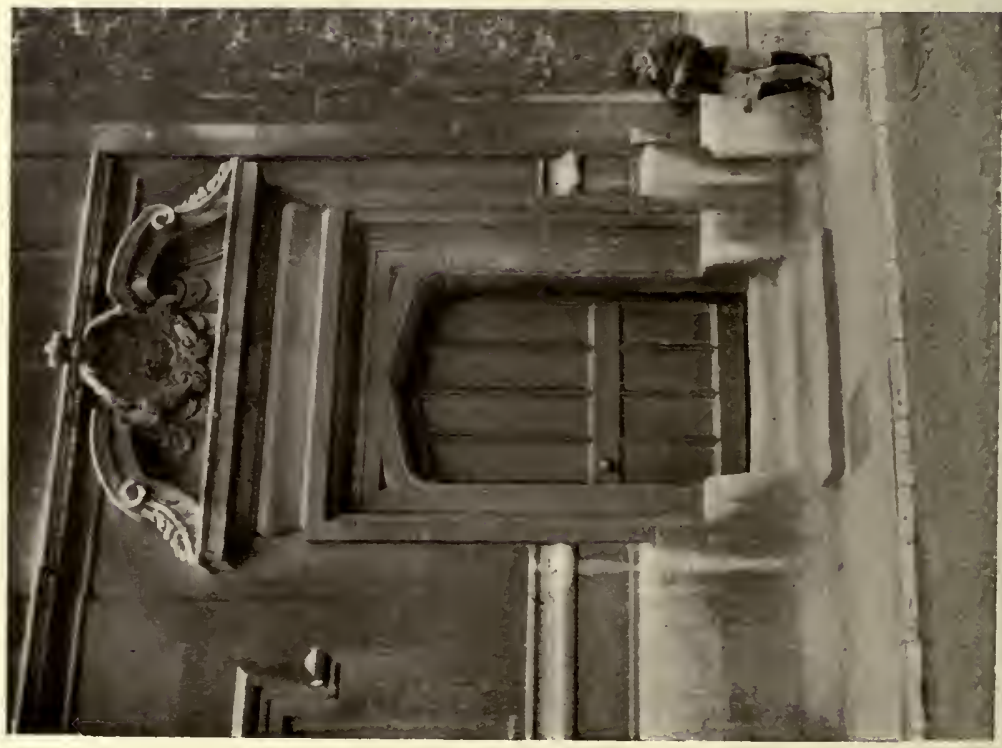

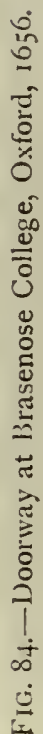




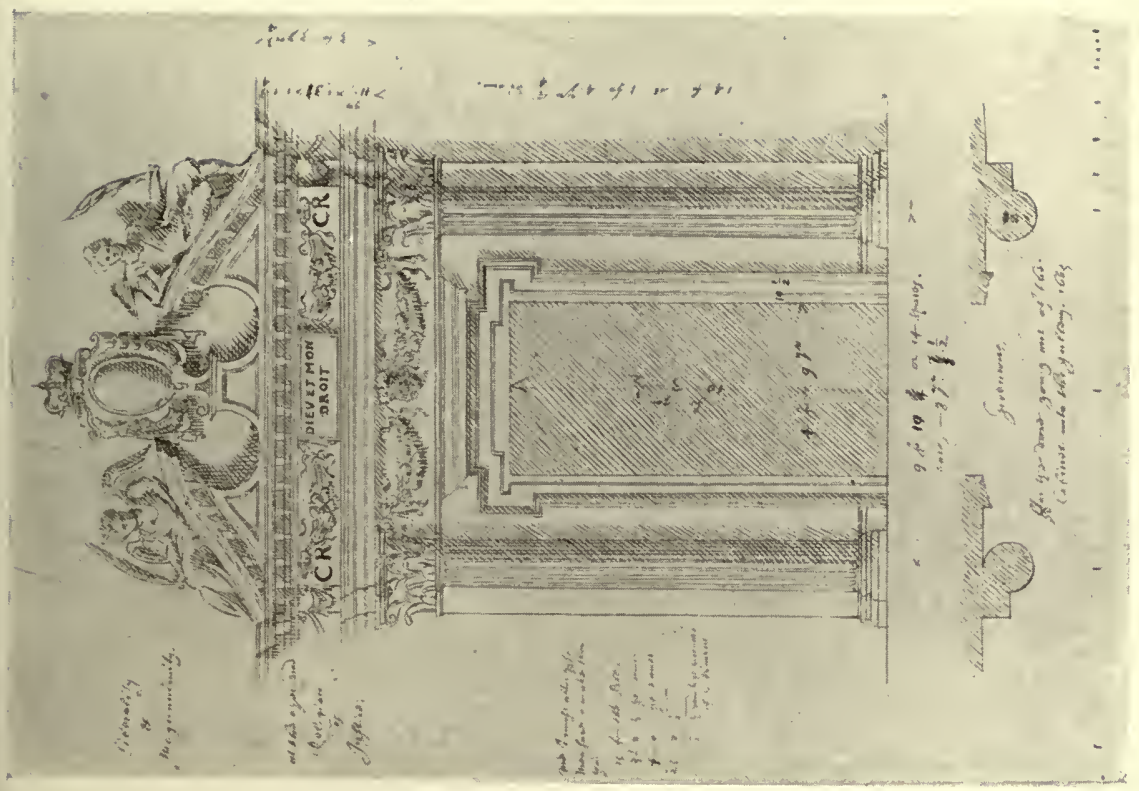

告

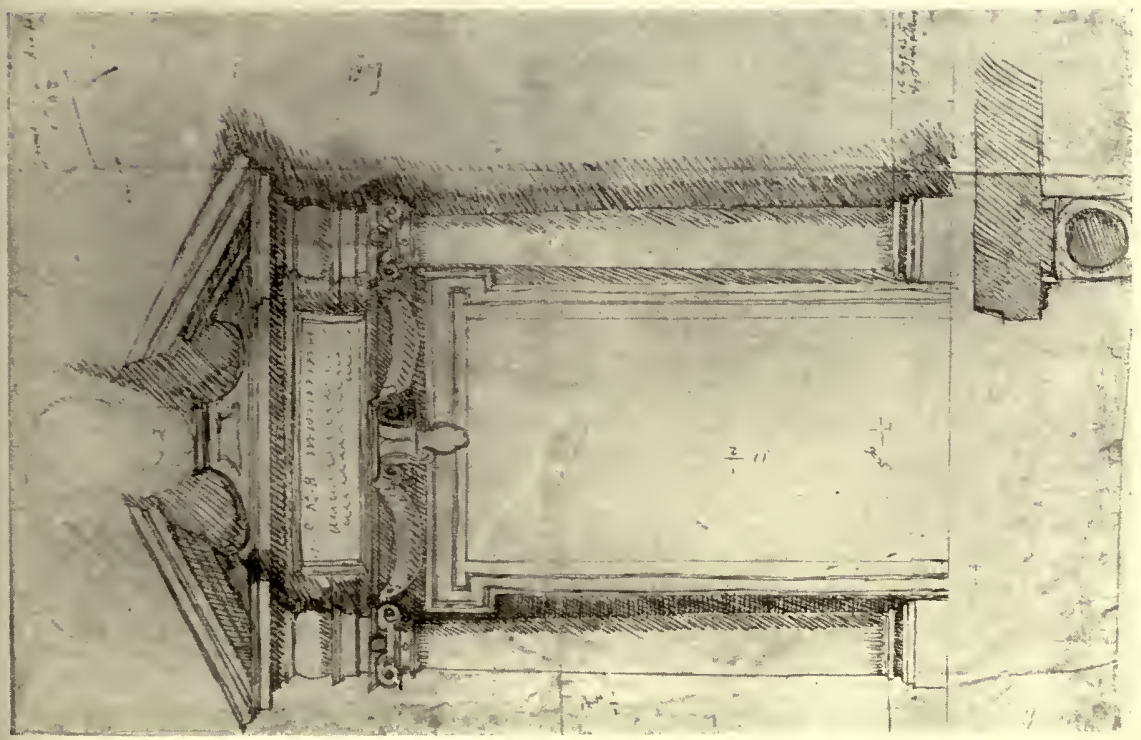

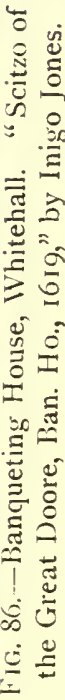




\section{THE CHANGE FROM HEADED WINDOWS}

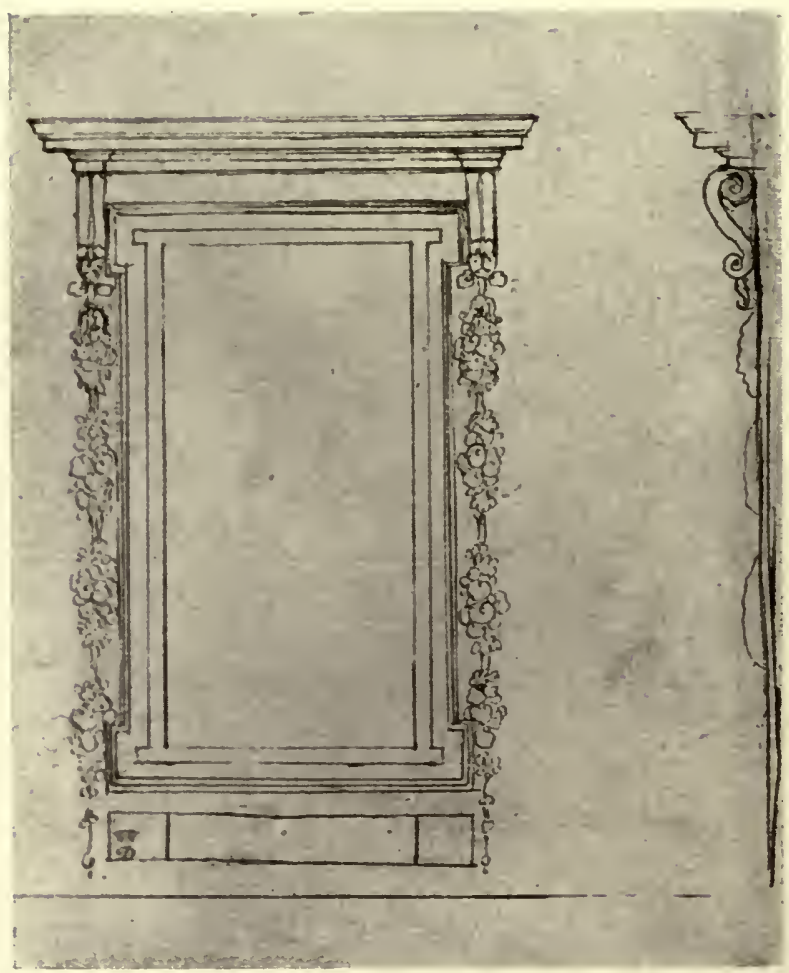

F1G. 88.-Banqueting House, Whitehall, "The upper windowe of $y^{e}$ Modell," by Inigo Jones. employed in the Banque t in $\mathrm{g}$ House is that which he favoured, and it is probable that a drawing entitled "The upper windowe of $y^{\text {e }}$ modell " (Fig. 88) is a sketch by him for the 'windows in the upper story of this build ing. By comparing this sketch with that of the Banqueting House (Fig. 36) the simi-

larity will be apparent. Jones, like Webb after him, was a student of Serlio, and he has a sheet of sketches of windows taken from Serlio with notes of his own appended. He and Webb do not seem to have concerned themselves with the filling of the window space, all they troubled about was the proportion and embellishment of the main opening. Yet the filling is of considerable interest. Mullioned windows were filled with lead lights, which only required glass of small size. Their successors, where the main opening was large, appear to have been filled with wooden frames having mullions and transoms of the same material, which reduced the actual openings to a size suitable for glazing in the old way. Later on the lead which held the glass was replaced by thick wooden bars holding glass of a larger size. But the opening part of all these windows was a casement, that is a 


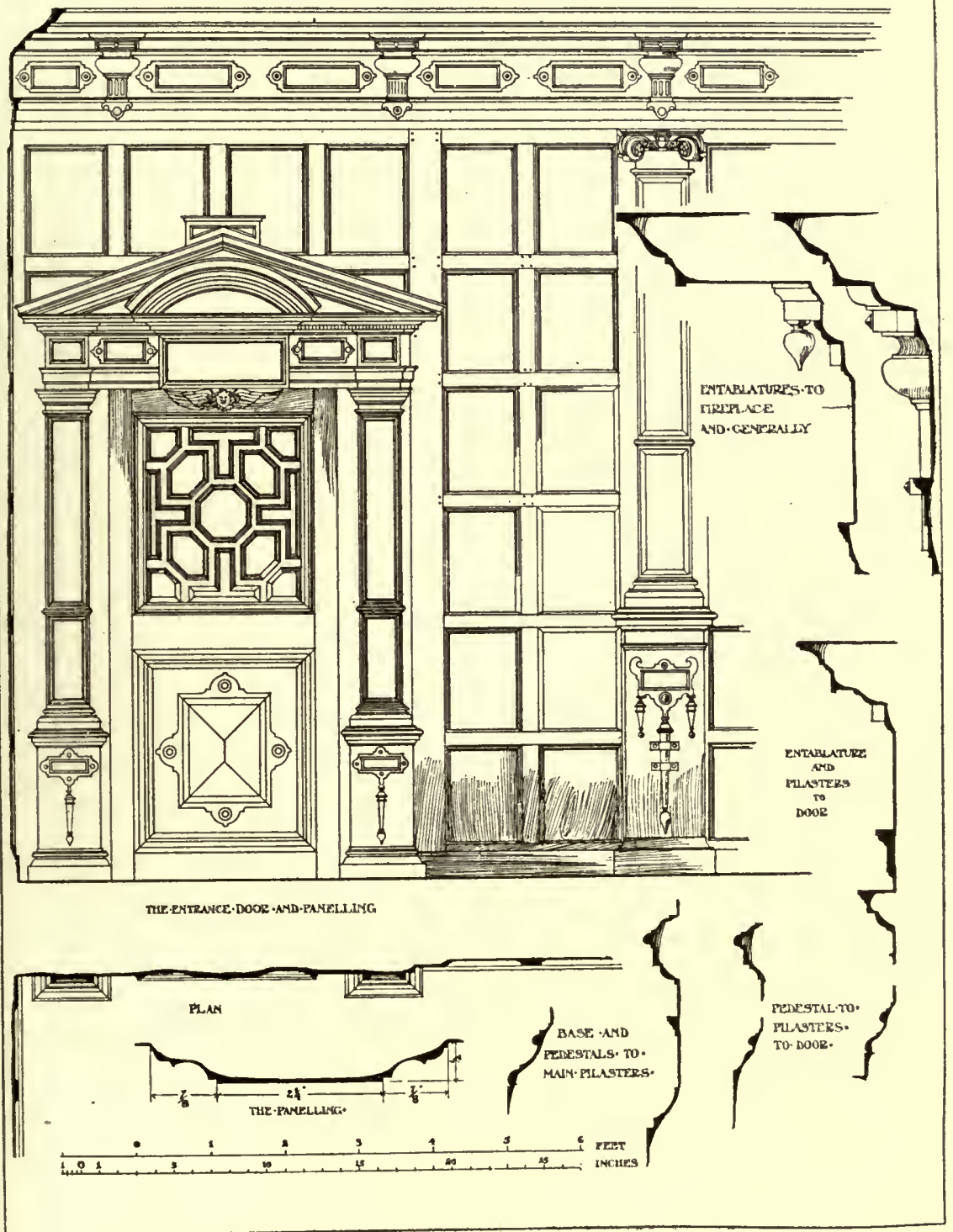

FIG. S9.-ST JOHN'S COLLEGE, ONFORD.

The PresIDEAT'S DRAWING-ROON. 


\section{MULLIONS SUPERSEDED BY SASH-WINDOWS}

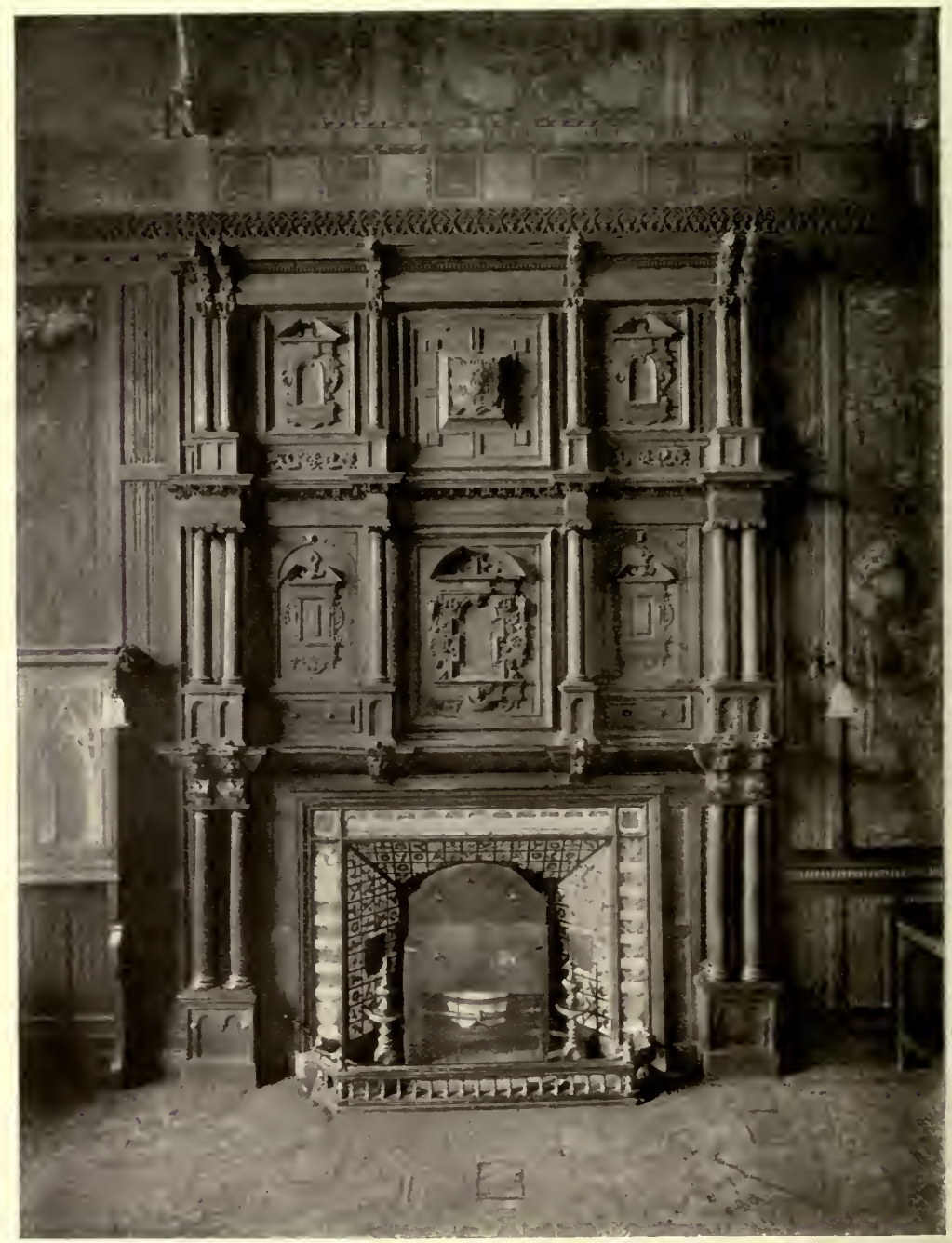

FIG. 90.-Chimney-Piece in the Jerusalem Chamber, Westminster.

framework (generally of iron) which was hung at the side and opened like a door. Then, from somewhere-but nobody knows exactly whence or when-came the ingenious sliding sash, which was hung with cords and counterbalanced by concealed weights, so that it could be moved up and down. This was really a remarkable change, although we are so accustomed to sash- 
windows as to take them for granted as part of the universal scheme of things. Their effect on the architectural treatment of windows was of the first importance. They made mullions impossible, they compelled window spaces to be of large size, and these large spaces necessarily influenced the design. They also rendered small bay-windows impossible, as well as large bay-ivindows with a narrow canted side. They practically put an end to any attempt at modified versions of the J acobean style, but they

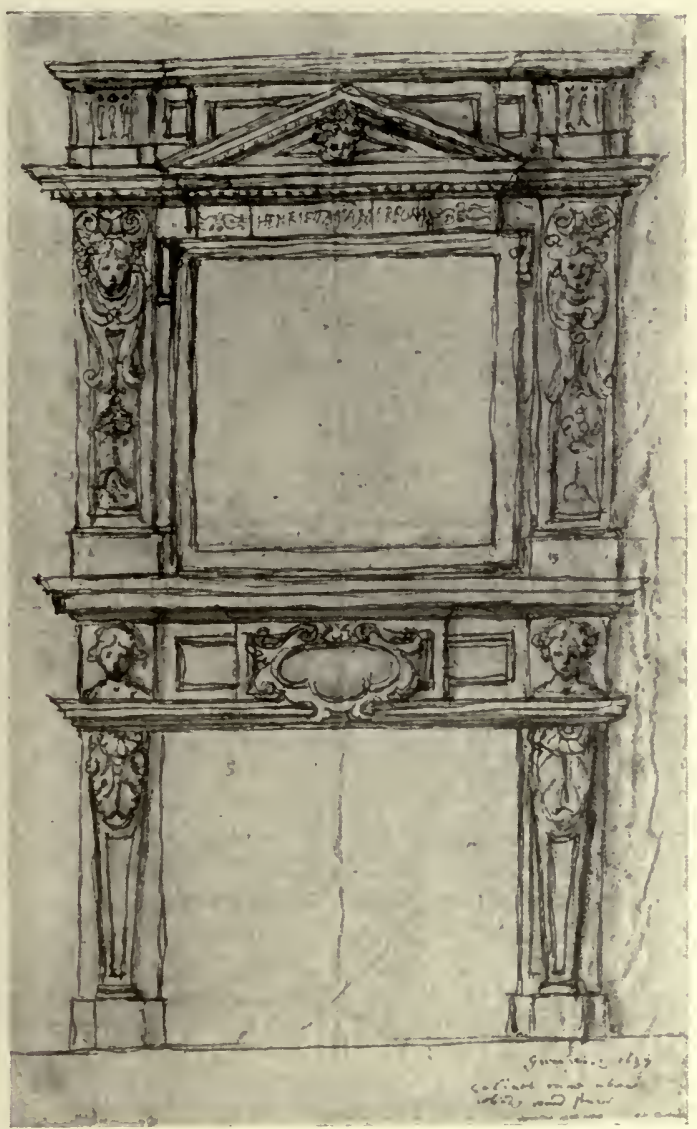

F1G. 91.-A Chimney-Piece for the Queen's House, Greenwich, 1619, by Inigo Jones.

From a Drawing in the Burlington-Devonshire Collection at the R.I.B.A.

were excellently

adapted to the larger, plainer, and more regular classic. Considering the effect they had on design it is to be regretted that we know nothing of their origin, or the date of their introduction. At present only one authenticated instance of their use can be cited before the time of IVilliam III. If they appear in earlier buildings caution would have to be exercised to ascertain whether they were not later insertions. Anyone who can settle this point would render a singular service in the byways of architectural history. The instance mentioned 
above occurs in the accounts for work done at Windsor Castle in I686-88:-1

Sarah Wyatt for a Sash Window and Frame with Weights Lynes and Pullyes and a Wainscott Window-board done in the Governor of the Castles Secretaryes office - $\quad-\quad-\quad-\quad-\quad-\quad-70^{\mathrm{s}}$

- The kind of panelling which corered the walls of Jacobean houses was retained in the houses of less importance till about the middle of the century, but there was a tendency for the panels to grow larger. Inigo Jones and Webb generally used large panels, and discarded the

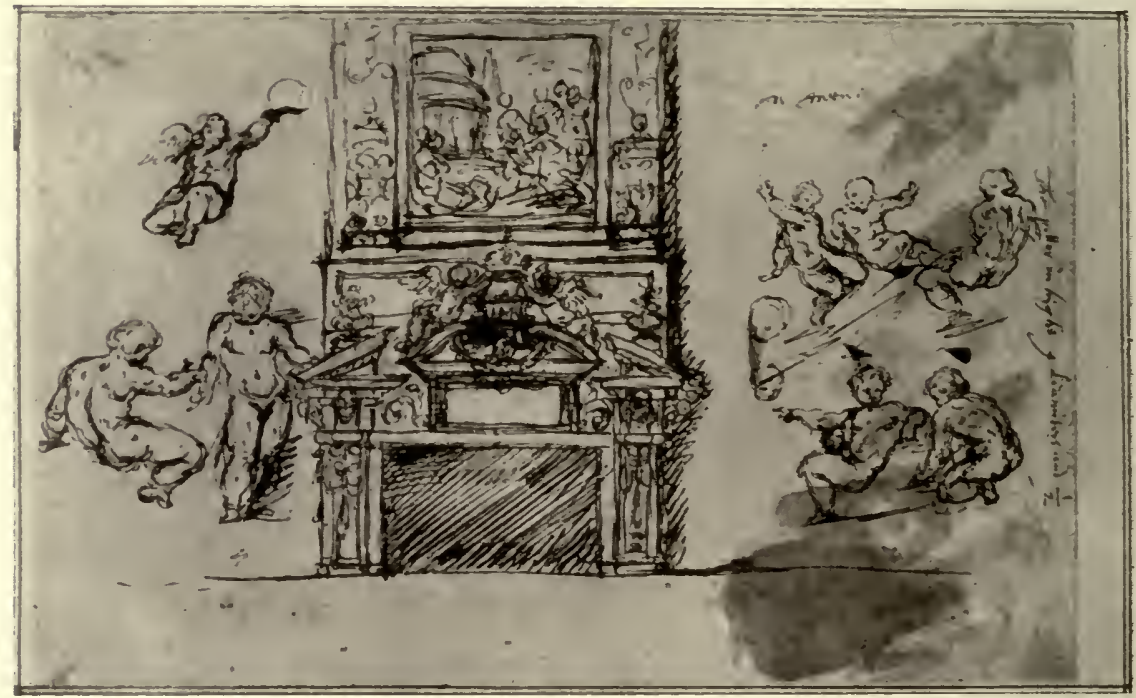

FIG. 92.-A Chimney-Piece for the Queen's House, Greenwich, by Inigo Jones.

From a Drawing in the Burlington-Devonshire Collection at the R.I.B.A.

small oblongs still favoured by local joiners. In the detail of woodwork generally greater refinement and simplicity became apparent, and more successful endeavours were made to adapt classic profiles. At St John's College, Oxford, the work of I63I illustrates this tendency (Fig. 89). The wood chimney-pieces in the same building are also handled with more restraint than in earlier examples, and a similar kind of treatment marks the fine chimney-piece in the Jerusalem Chamber at Westminster (Fig. 90), which must have been the work of John Williams, Bishop of Lincoln, who was Dean of Westminster

1 "Windsor Castle," by Sir W. H. St John Hope, p. 329. 


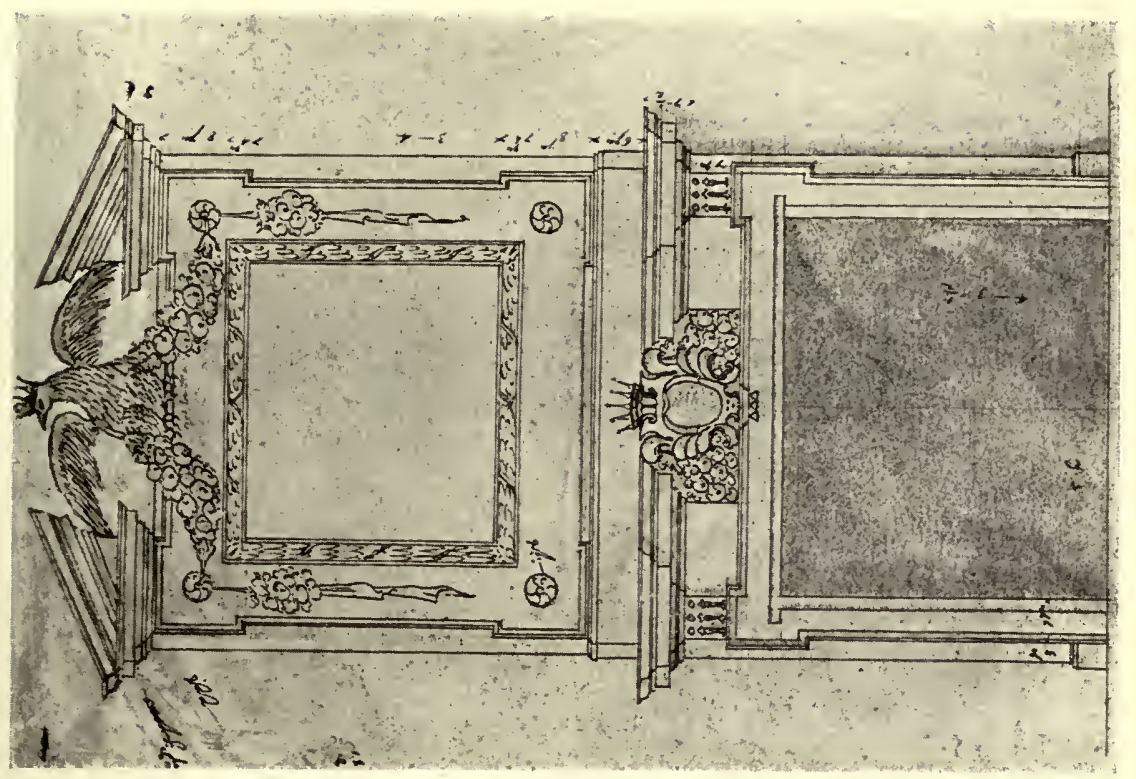

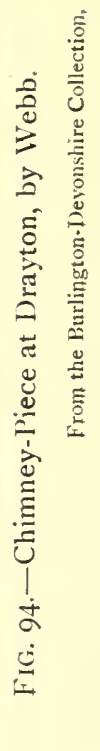

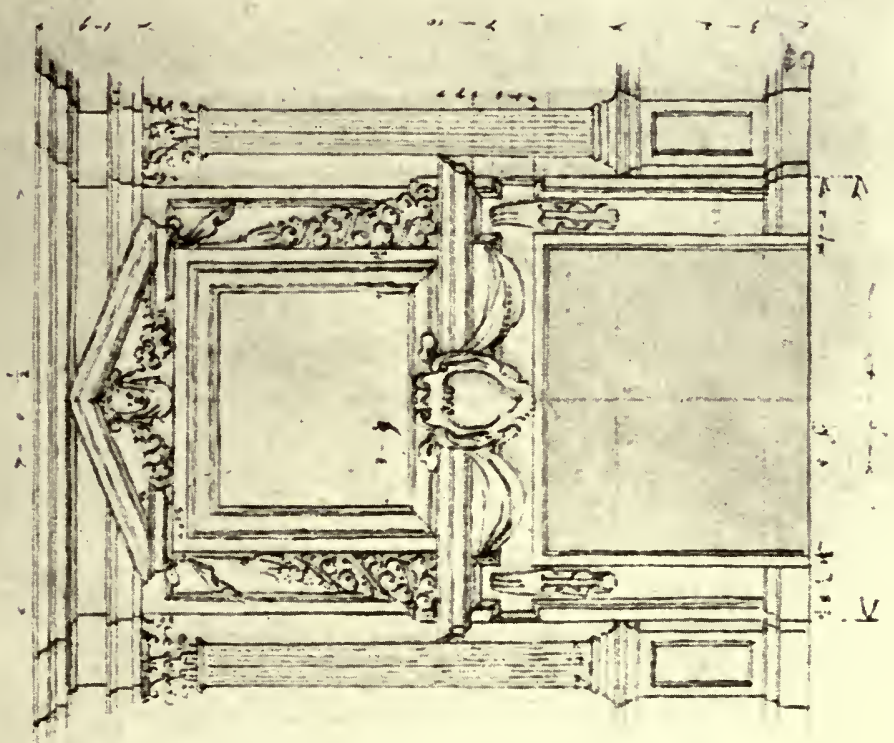

है

氙

$\frac{n}{=}$

U્

$=$

ㄴํㅇ

3

ड़े

Ư

$* \quad$ Uू

ఏ

$\varangle$

๙2

$\stackrel{3}{4}$ 
during a large part of the reign of Charles I. The excellent panelling by $\mathrm{Webb}$ at Thorpe Hall has already been illustrated (see Fig. 48). It embodies a still greater departure from the old manner.

This departure is also very noticeable in the designs of chimney-pieces which Jones and Webb have left behind them. Fig. 9I shows one of those designed for the Queen's House at Greenwich in 1637 : in the panel below the pediment is inscribed "Henrietta Maria Regina." Fig. 92 is "for Greenwich," and bears the cipher H.M.R. It is very characteristic of Jones's way of sketching his details; he has bestowed more care (and more affection) upon the little children at the side than upon the principal object itself. It is evident that the large panel over the chimney-piece was to be occupied by a picture, as also parhaps was that in the preceding example. In Jacobean times such a space would have contained the owner's arms. IVebb's chimney-pieces follow those of his master in general conception, and they are the precursors of the type prevalent in the eighteenth century, largely used by Kent, who had access to these very drawings. Of the examples selected, one was for Drayton House, in Northamptonshire, and it is signed by Webb and dated 1653 (Fig. 94); the other was for " $D^{r}$ George Price his great chamber" (Fig. 93). The whole series affords a good idea of the style of the period as compared with that of earlier times.

It is interesting to compare with these drawings of Jones and Webb a contemporary chimney-piece at Ford Abbey, in Dorset, attributed to Jones (Fig. 95). It must be confessed, however, that the treatment is widely different in the two cases. This is not to say that the Ford Abbey example has no merit; on the contrary, there is a refreshing playfulness about the way in which the staid classic detail is bent from its usual austere lines. 


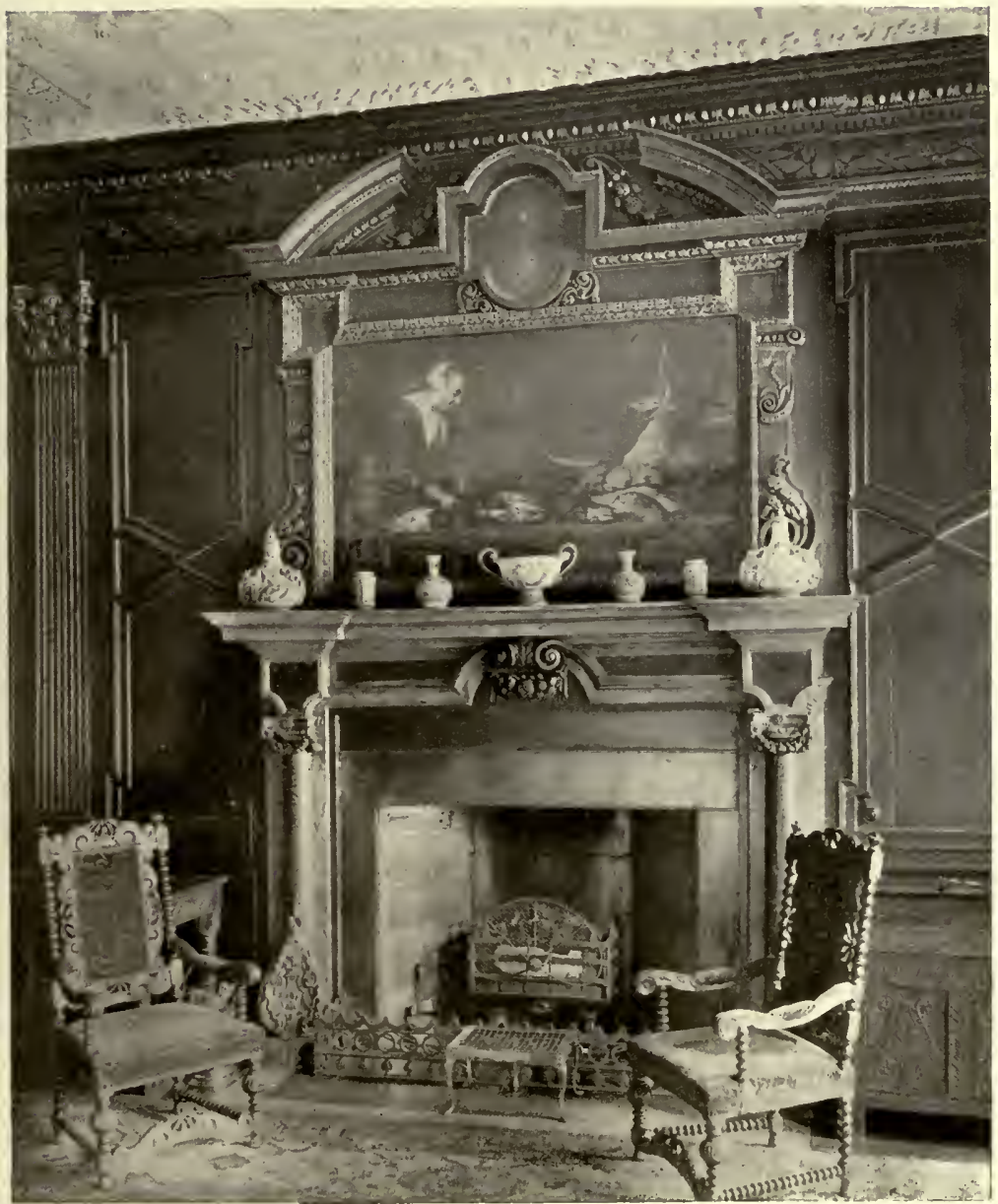

FIG. 95.-CIHMNEY-PIECE IN THE DINING-ROOM, FORD ABBEY, DORSET. 


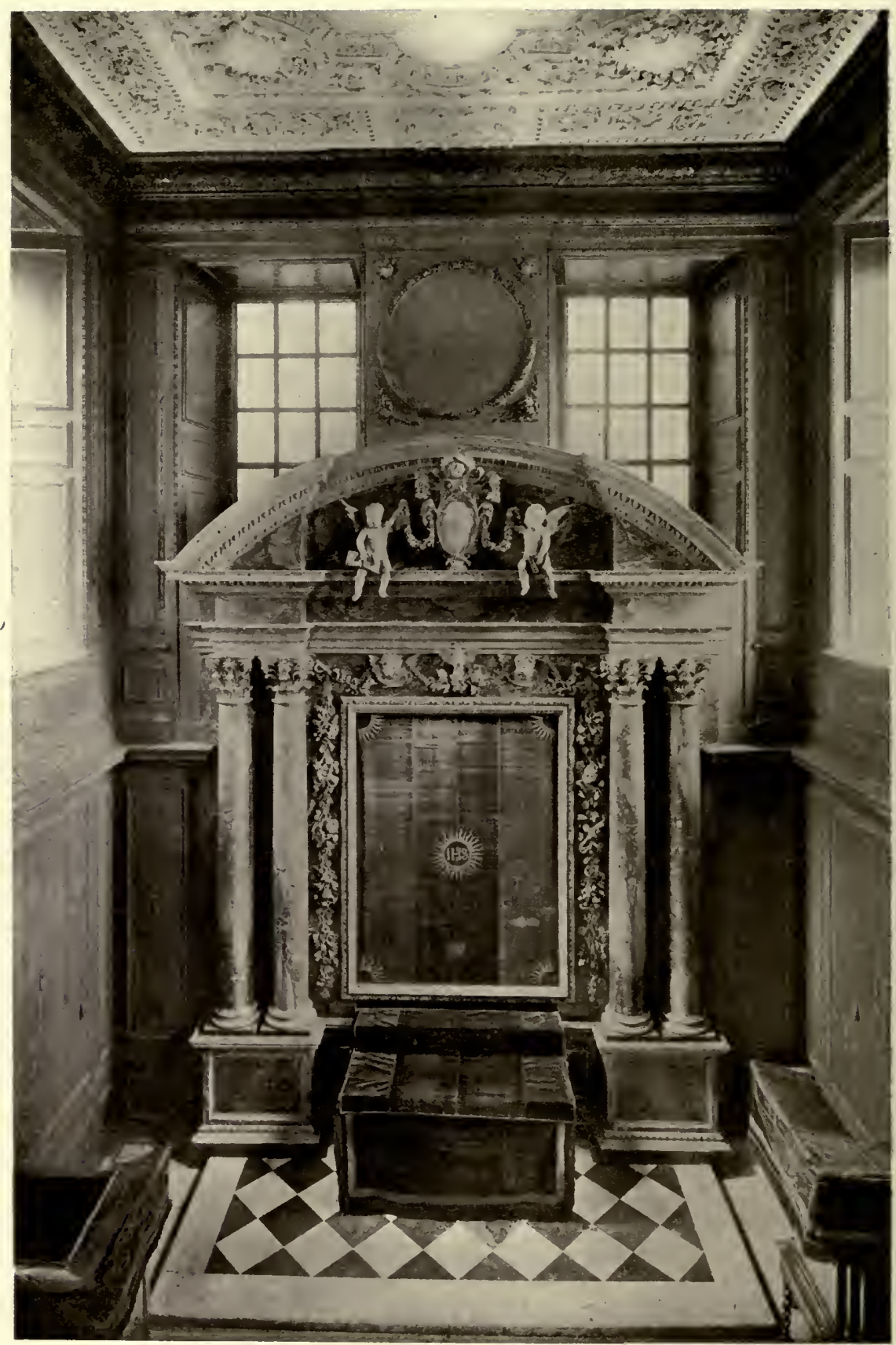

Fig, 96.-BELTON HOUSE. The Chatel. 


\section{SIR CHRISTOPHER WREN}

WHEN Charles II. was restored to his inheritance in 1660 , he evidently contemplated indulging in the royal pastime of fine building. At this time John IVebb was not only the veteran of architecture, but the most notable exponent of the art then living in England. His claims on the favour of the king were founded on his long and intimate connection with Inigo Jones, a name to conjure with both in relation to architecture and to the less stable factor of court influence. They were supported on the practical side by the work he had done, although fruitlessly, for Charles's father in the preparation of the great schemes for the palace at Whitehall, and by the assistance he had given both in architecture and the artistic hobbies of the time to many of the nobility and gentry. They were supported on the human side by personal services rendered to the late king, especially in furnishing to him, while at Oxford, full designs and particulars of all the fortifications round London, with instructions how they might be carried; and in conveying to the king, whilst at Beverley, his majesty's jewellery, which he took, concealed in his waistcoat, through the enemy's quarters, suffering, in consequence of the fact being discovered, close imprisonment for a month.

These claims, as we have seen, failed to gain for him the coveted post of surveyor to the king's works, but Charles employed him in resuscitating the idea of a new palace at Whitehall, which never came to fruition, and in actually erecting a considerable part of the projected palace at Greenwich.

Webb never succeeded in obtaining the official appointment for which he longed, for which he appears to have had the best qualifications, and of which he was actually promised the reversion on the death of Sir John Denham, who was preferred before him 


\section{APPEARANCE OF SIR CHRISTOPHER WREN}

at the Restoration. The reasons for his failure are obscure, but it may be that his active employment during the Commonwealth told against him, for his clients of that period were obviously not such devoted adherents of the royal cause as to be in exile, or suffering other great hardships. It may be that he lacked the support and patronage of John Evelyn, whose influence with Charles II. in all matters of culture was enormous. It may be that his age was against him, for when Wren was appointed on the death of Denham, Webb was fifty-seven years old. But whatever the cause, his failure was complete, and he eventually retired to his home at Butleigh where he died in 1672 . Although he missed the goal of his ambition, although the men who have had the ear of the world have not sounded his name in high notes, he was a remarkable man. The work conceded to him by general consent is noteworthy, and he probably did more to influence domestic architecture in England than any other man of his time, Inigo Jones not excepted. For any student, divesting himself of established prejudices, who will examine his original drawings, can hardly fail to come to the conclusion that it was his imagination and his hand which developed and prepared most of the designs which, published as the work of Inigo Jones, had so wide an effect upon English houses in the eighteenth century.

Charles II.'s interest in the pastime of building was but fitful. The Whitehall Palace got little further than Webb's old designs, nor did that at Greenwich go beyond the one block called after the king. He was preoccupied with matters of more personal interest, and what money he had for his own purposes was spent in directions other than that of architecture. Nevertheless incidental to the kingly rôle was the patronage of the arts, and when the necessity arose he bestowed his attention upon them and upon those, who were engaged in their pursuit. It was in this way that Wren was brought to his notice, and thereby obtained that official position which led to the development of his extraordinary powers. That Charles had no special acquaintance with architecture nor any consuming love for it, is sufficiently proved by his sanction of that design of Wren's for St Paul's Cathedral known as the "warrant" design, and by the spasmodic way in which he sought to house himself in regal fashion; for another abortive attempt at a palace was made in 1683 , this time at Winchester and with the help of Wren. 
Wren is even better known to the public as an architect than Inigo Jones, largely owing to the fact that he left behind him many more buildings which can be seen to-day than did his predecessor. But the admiration he has received, whether founded on knowledge or not, is no more than his due, for he was a truly remarkable man. He had achieved a European reputation as a man of science before he was thirty, and although, when he became officially connected with building for the first time, he had apparently received no practical training in architecture, he soon made up his deficiencies on the scaffold itself, amid the ring of the trowel and the thud of the hammer.

He came of good and cultured stock. His father, $\mathrm{Dr}$ Christopher Wren, was Dean of Windsor; his uncle, Matthew, was Bishop of Ely. His father was a man of considerable attainments in literature and science, and had a superficial knowledge of architecture. Christopher, who was born in 1632 , was his only son, and received a good education. His natural abilities enabled him to profit by his opportunities to such a degree that at the age of thirteen he invented a new astronomical instrument and a pneumatic engine, both of which he introduced to his father in elegant Latin, the one in verse, the other in prose. A year later he was entered as a gentleman-commoner at Wadham College, Oxford, where he continued to distinguish himself. It would be tedious to recount his juvenile essays in astronomy, mathematics, gnomonics, and Latin, but so great a reputation did he achieve that when Evelyn (who took a genuine interest in anything remarkable) went to Oxford in 1654, he made a point of going to see "that miracle of a youth, Mr Christopher Wren, nephew of the Bishop of Ely."

The youth was then twenty-two, and was already a Master of Arts and a Fellow of All Souls; three years later he was chosen Professor of Astronomy at Gresham College in London, and subsequently, in I66r, Savilian professor of the same subject in the University of Oxford. In the same year he was made D.C.L. by both Oxford and Cambridge. During- these years he was one of the most active of those "virtuous and learned men of philosophical minds" who, along with Dr Wilkins, Warden of Wadham, laid the foundations of the Royal Society. A whole page of the "Parentalia"--memoirs written by his son, and the chief source of information concerning his life-is occupied with a catalogue of the New Theories, Inventions, 
Experiments, and Mechanic Improvements exhibited by $\mathrm{Mr}$ Wren at the meetings in connection with the great movement. One or two examples will serve to show the wide range of his investigations: a weather clock; an artificial eye, with the humours truly and dioptically made; several ways of graving and etching; divers improvements in the art of husbandry; divers new musical instruments; easier ways of whale-fishing; ways to perfect coaches for ease. Indeed there seems to have been nothing in the heavens above, or the earth beneath, or the waters under the earth, about which he did not know something.

These things may be regarded as the by-products of a great imagination, an imagination which made him a skilled astronomer and a profound mathematician. He had an extraordinary aptitude for scientific research, and he was the first who experimented in the infusion of foreign liquid into the blood of animals, a process which, modified to the transfusion of blood from one person to another, has had remarkable results in medicine. He also established, by experiment, before the Royal Society in I668, the Third Law of Motion; and no doubt his study of the laws of motion subsequently stood him in good stead in his daring feats of architectural construction.

The remarkable thing about these studies and experiments is that, amid all their variety, not a word is said about architecture. He was a fair draughtsman, but he was primarily a man of science and a virtuoso, in other words, a man accomplished in the arts and sciences, but who had no need to bring his knowledge to any practical test involving responsibility. He was, however, soon to become more than a virtuoso, for in the year I66I he was appointed deputy surveyor of his majesty's works and buildings under Sir John Denham, and, after the latter's death in 1668 , he succeeded him in the office to the exclusion of the more experienced Webb.

Wren's early efforts in architecture show, as might be expected, considerable immaturity. One of his first was the Sheldonian Theatre at Oxford, on which he was engaged between 1663 and 1668 . It is interesting as the work of a man young in design, but it cannot be regarded as a masterpiece; its shape is ungraceful, and its detail crude. One of its principal claims to attention was its roof, which covered (with a flat ceiling) what was then considered a very wide span, namely, 7oft. Here Wren's scientific training must have helped him; he 
was also probably helped by his carpenter, one R. Frogley. The roof itself has been renewed, but drawings of it were published by Dr Plot in his "Natural History. of Oxfordshire," and were reproduced in "Parentalia." Its most remarkable feature was the long tie-beam of the principals, which being too long for one piece of timber, was made up of three pieces ingeniously jointed, or "scarfed," together. There are still tie-beams to the roof, but they are hidden in the thickness of the attic floor, and it is impossible to say whether they are Wren's or not. But as the disposition of all the visible timbers is quite different from those shown by Plot, the inference is that there is nothing left of Wren's ingenious roof. With the old roof went Wren's ugly dormers as well as his turret, which was replaced by that which exists to-day.

The other work at Oxford, attributed to Wren, rests its claims, except in the case of the Tom Tower of Christ Church, on little or no evidence. Even in the case of Trinity College, where letters show him to have been consulted, he appears to have done nothing beyond sending, in 1664 , to his friend, $\mathrm{Dr}$ Bathurst, the president, a letter with alternative plans and an elevation; and in criticising, in 1692, a design for the chapel. There is no evidence that he actually carried out any work here in the formal capacity of architect. About so notable a feature of Oxford as the Tom Tower it would be rash to say anything in disparagement. But this much may perhaps be said without offence. It is at least doubtful whether the designer of the lower part, which is the original Gothic work, would have been satisfied with Wren's completion. The scale is different, the detail is different; the whole conception is out of harmony with Gothic ideas. Yet it is still less allied to anything classic; the fact is that Wren was working in a style which he did not understand, and which he frankly disliked. We get much nearer to the heart of the man by studying another aspect of his work at Oxford, his drawings preserved in the library at All Souls. There are four large volumes of them, comprising designs for various works, including alterations to one or two large houses; but the most interesting are those connected with St Paul's Cathedral. In these volumes can be seen his weakness and his strength, and, taken in conjunction with other of his drawings preserved at St Paul's, they show how he felt his way in architectural design. They also indicate that the 


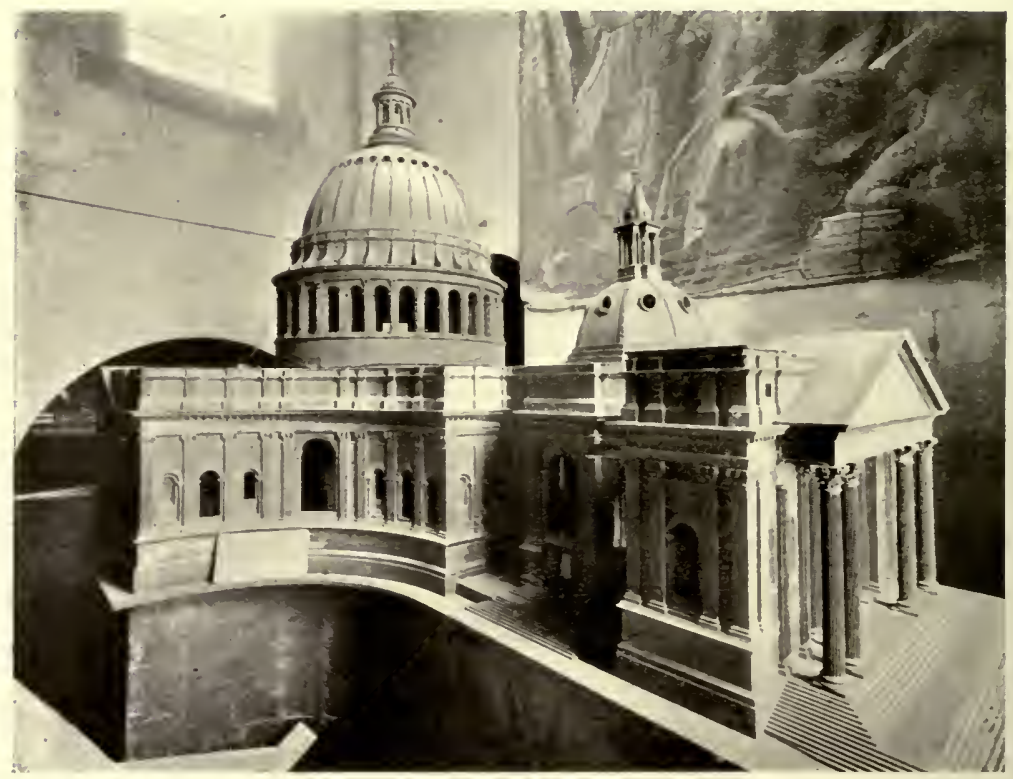

Fig. 97.- Model of Wren's first Design for St Paul's Cathedral.

old system still survived under which the architect relied in great measure upon his subordinates for the detail of his work; at the same time they prove that Wren worked out his general conceptions much more thoroughly than such men as Joln Thorpe and Smithson had done a century earlier.

The history of the reparation and rebuilding of St Paul's is too long and intricate to be set out in detail in this place, apart from the fact that it is outside the category of domestic architecture; but it stands for so much in Wren's life that a few words about it may, perhaps, be allowed.

During the years following the restoration of Charles II. much consideration had been given to the old cathedral, which was in a neglected and ruinous condition. The commissioners, of whom IVren was one, were divided in opinion as to the course to be pursued; some were for preserving it, others for rebuilding. Inigo Jones had already put a new classic west front to the Gothic building ; it was held to be one of the finest pieces of architecture of modern times. Wren's idea was to continue the classic casing and to replace the lofty spire by a classic dome. Some of the drawings at All Souls embody 
this idea, which fortunately was never carried out. Then came the great fire in I666, and the problem was simplified, for the fire had left but little to deal with, and it was decided to rebuild.

The fire wrought a great change in Wren: he was no longer the professor, the virtuoso, but the architect; for to him fell the duty of rebuilding not only the cathedral, but the numerous city churches which had been destroyed. It is fortunate that old St Paul's was so completely shattered as to compel its demolition, for although the force necessary to remove the ruins was such as would have elicited vigorous protests in the present day (gunpowder had to be employed, to the terror of adjacent occupants), yet it resulted in providing Wren with a vacant site whereon he could place a new building, instead of attempting either a mixture of Gothic and classic such as he had formerly contemplated, or his own version of Gothic which would have been even more unpalatable.

The new St Paul's is one of the finest and most impressive buildings of its kind in Europe; its dome is unrivalled for purity of outline and aptness of composition. How did a man, who had no practical acquaintance with architecture until he was thirty years old, conceive such a masterpiece within a few years from that time? Probably nobody but Wren could have done it: he had an extraordinary aptitude for mastering any subject to which he turned his attention. But even he did not produce this great result at one stroke; he felt his way through many attempts. There were two complete preliminary designs, neither of which had much in common with the other or with the building as erected, beyond the fact that the dominating feature was to be a dome. The first of these is known as Wren's favourite design, the other as the "warrant" design.

The first was worked out with much care and completeness, and a large model of it was made, which is now preserved in one of the towers of the cathedral (Fig. 97). 'The plan, however, was so great a departure from the type sanctioned by tradition, that it was rejected by the king and his advisers. Wren thereupon produced the "warrant" design, one of the most extraordinary ever made by a serious man, and one of the worst to which a great architect ever set his name. This is a mystery to which no satisfactory solution has yet been found. That a man with the capacity of producing St Paul's as we see it, should have produced the "warrant" design, and seriously submitted it 


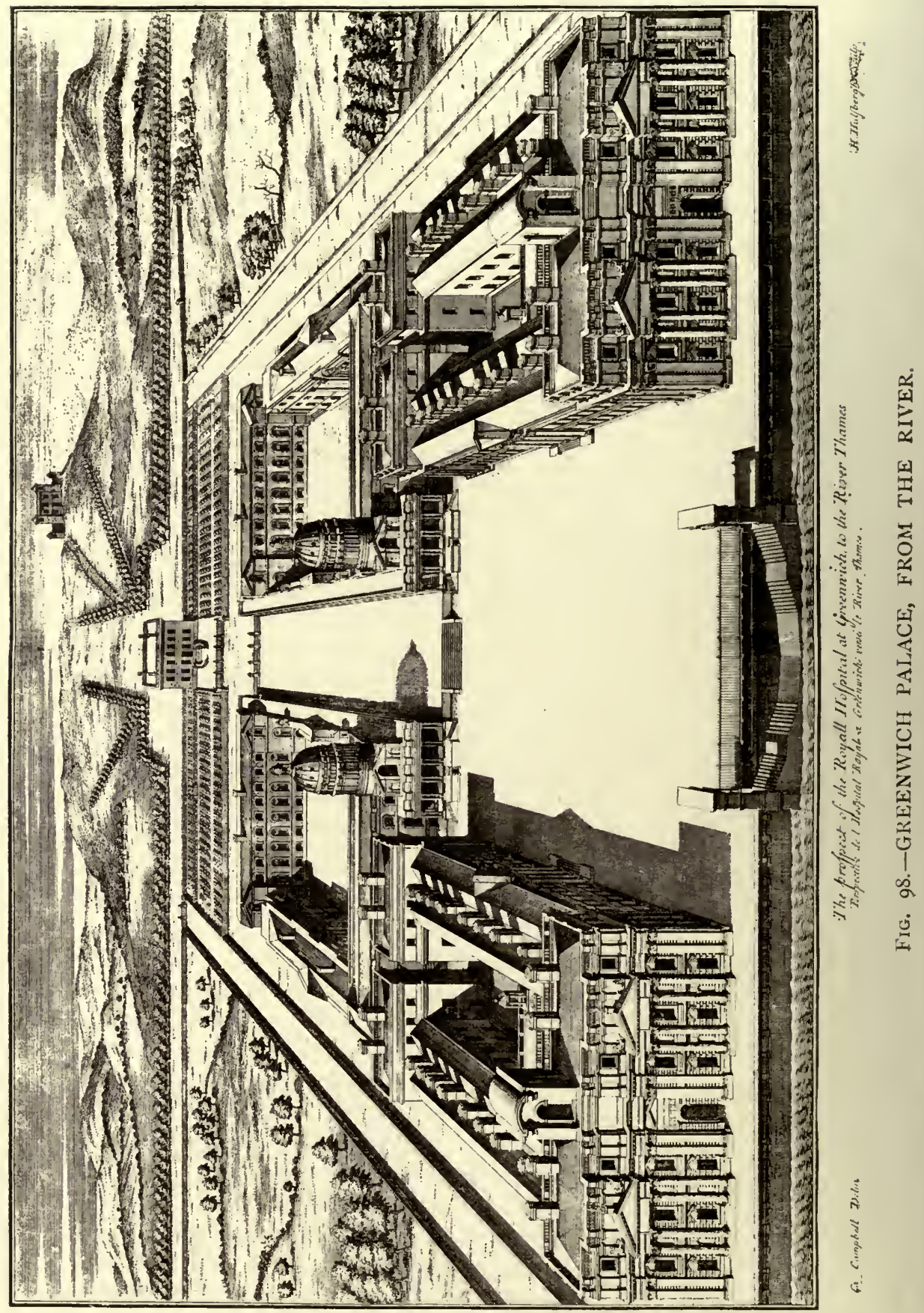


for acceptance, is astonishing; but apparently IVren knew his clients, for it was approved and ordered to be carried out under the warrant of the king, dated the I4th May I675, wherein it is described as "very artificial, proper, and useful." The slight change which time has introduced into the meaning of the first of these adjectives lends, for modern ears, a spice of humour to the description.

Fortunately, nothing more was heard of this design; it reposes among the drawings in the All Souls library, and there is nothing to show that any attempt was made to develop it. How IVren managed to drop it completely has not been explained. He had the king's leave to vary it in minor points; he varied it altogether. It is probable that, the matter being left in his hands, he quietly proceeded, as the years went by, to improve upon his early ideas. The dome of the "warrant" design is its ugliest feature; among Wren's drawings are many sketches of domes, none of them so bad as this, nor any so good as the final one, nor is there any special sequence of steps to show how the ultimate result was obtained. But it is easy to see that the result was his own work, and that it was only after numerous trials that he at last achieved it.

The building of St Paul's took many years. The first stone was laid on 2 Ist June 1675 ; the last stone of the cupola was laid by his son in the old man's presence in I7 10. During this period of thirty-five years Wren practically rebuilt the city churches, and was thus continually gaining experience. The great cathedral will always be his chief monument, but the fiftythree churches which he carried out would themselves have made his reputation. The sites were mostly irregular, but of so much value that it was essential to utilise them completely. IV ren covered them to the last inch, and yet contrived to get that classic treatment in which symmetry plays so important a part. In many hands symmetry would have meant extravagance in space and materials. The problem in planning was new in another respect, for the churches were all designed for the Protestant form of worship, requiring an arrangement different from that of mediæval churches, and, among other things, a suitable auditorium.

To his skill in planning he added a constant variety of treatment, both inside and out; and, given a departure from the simple straight lines of a Gothic spire, nothing could exceed the 
happy ingenuity and fertility of design exhibited in Wren's steeples.

Wren did not pass his whole time in designing ecclesiastical buildings. He had the chief share in the shaping of Greenwich Hospital which, originally intended for a palace, was begun and continued in a palatial manner, although diverted from its first purpose and made into a home for worn-out sailors (Fig. 98). $\mathrm{He}$ also began the rebuilding of Hampton Court, but happily did not proceed, as was at one time contemplated, to sweep. away the whole of the older portions of that fascinating place. These are both in a sense domestic work, but they are not domestic in the way that appeals to the ordinary person. People who live in palaces may well afford some sacrifice to grandeur. Wren's was the grand manner. His churches involved fairly simple planning. Their requirements lent themselves to this treatment much more readily than those of an ordinary house with its complicated demands, where an uncomfortable plan is not atoned for by splendour of appearance. If it be asked how Wren would have faced the difficulties of ordinary domestic planning, there is but little material for an answer. The work he did in the Temple does not help us much. Several houses in different parts of the country are attributed to him, but without much reliable evidence. At All Souls, however, there are a few drawings, either of new houses. or of alterations to old ones, and these do not go to prove that he had his usual masterful grip of the subject. Doubtless, had the necessity arisen, he would have acquired it, but his energies took another direction, and he has left no solution of how to build a house at once convenient, comfortabie, and grand.

He lived to be an old man-he was ninety-one when he died in 1723-yet he lived a strenuous life till within a few years of his death. He not only devised his own buildings, but superintended their erection, and it was largely on the scaffoid that he gained his experience. This did much to sober his judgment and make his work reasonable and sensible, more so than that of his immediate successors. Although at first an amateur, he became practical through being in constant touch with his work: they remained amateurs all the way through.

A slight but vivid picture of him at work was drawn by the lively Duchess of Marlborough, who, when expostulating with Vanbrugh for demanding $£ 300$ a year for looking after 


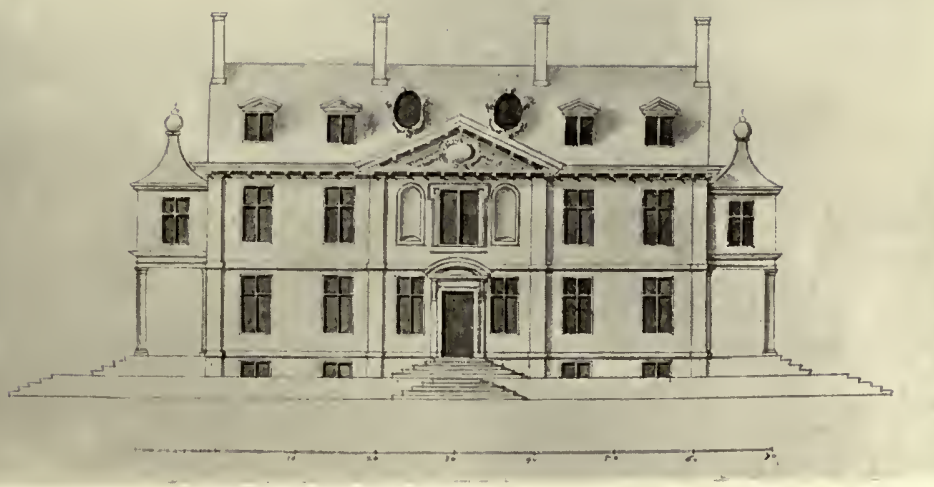

FIG. 99.-Elevation of a House.

From the Wren Collection, All Souls College, Oxford.
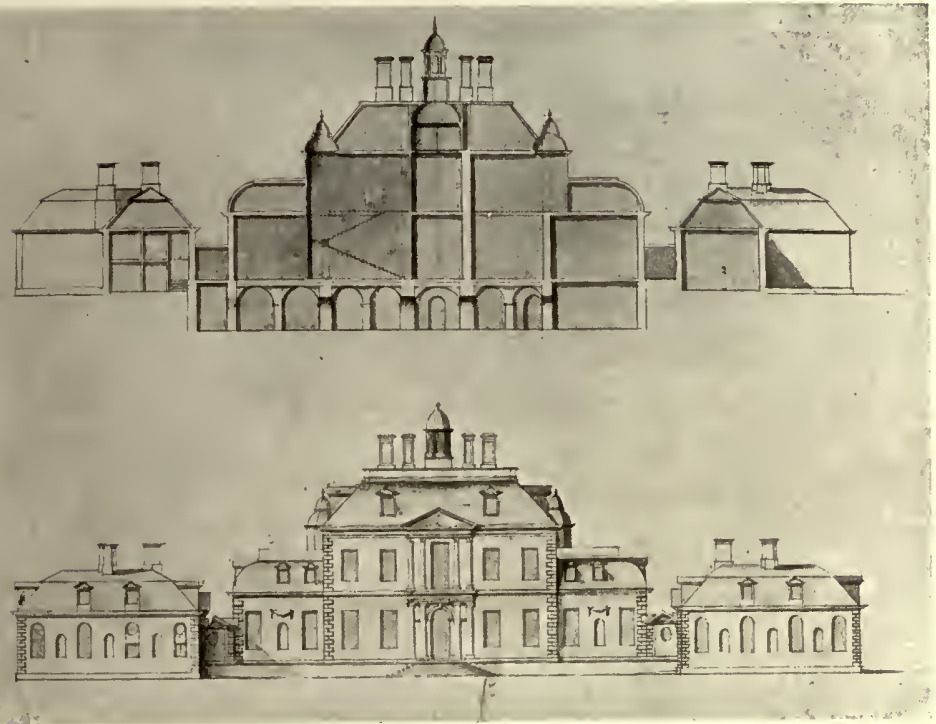

FIG. Ioo.-Elevation and Section of a House.

From the Wren Collection, All Souls College, Oxford. 


\section{WREN'S INFLUENCE ON ARCHITECIURE}

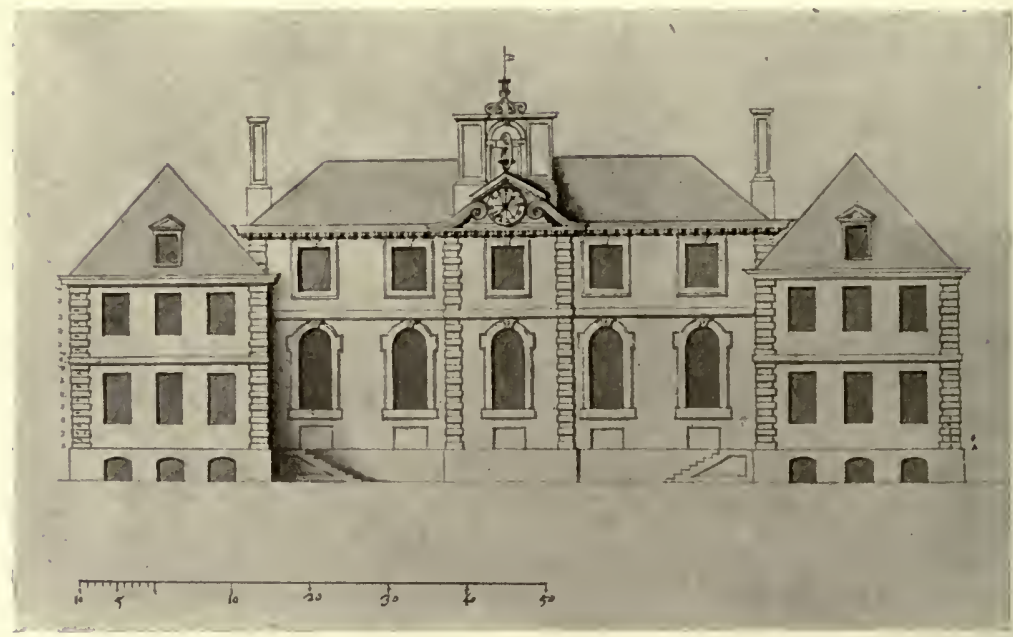

F1G. 101.-Elevation of a House.

From the Wren Collection, All Souls College, Oxford.

Blenheim, declared that Wren had been "content to be dragged up in a basket, three or four times a week to the top of St Paul's, and at great hazard, for $£ 200$ a year."

All through his busy years as an architect he maintained his interest in science, and was not only President of the Royal Society in 1680 , but continued to submit all sorts of inventions and suggestions for the consideration of its members. Curiously enough, these things had but little practical value, not even that one which showed how smoky chimneys might be cured: indeed none but futile specifics have yet been offered to the public with this end in view.

His later years were clouded by the intrigues of his opponents at court, who not only contrived to oust him from his office of surveyor to the royal works, but endeavoured to attack his character for probity. The latter attempt failed of course; but when he was already eighty-six and had held his office for nearly fifty years, he was superseded by an unknown and incompetent person.

Wren's influence on architecture was powerful while he lived, but he can hardly be said to have founded a distinctive school of domestic architecture which long survived him. Soon after his death new publications, amongst which the most 
influential was Kent's "Designs of Inigo Jones," changed the trend of design. His influence, however, continued to be felt in the treatment of interior decoration, particularly in regard to

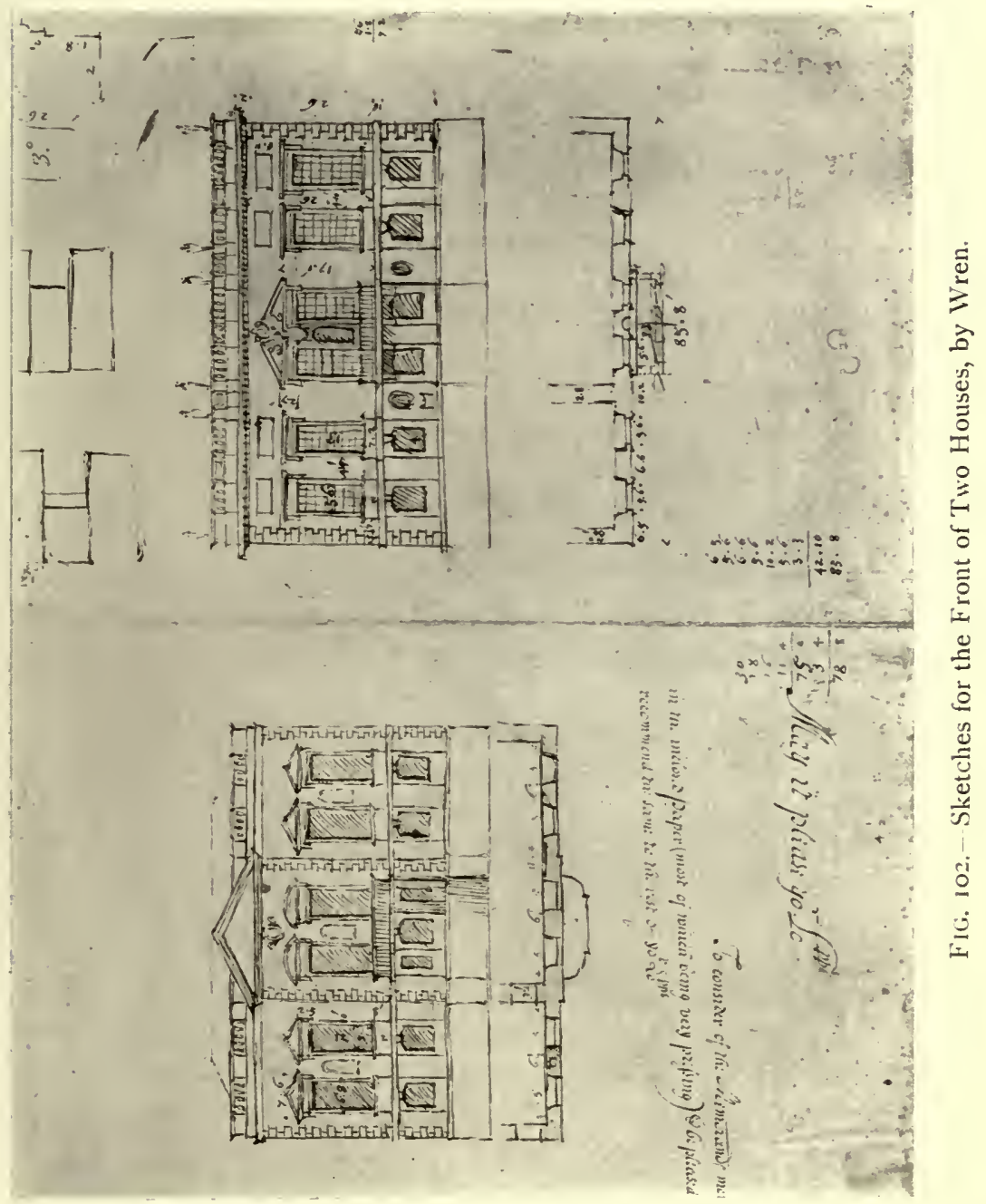

panelling and ornamental woodwork, down to the middle of the century. The exteriors of many small Georgian houses may owe something to him, but such houses as are obviously reminiscent of his manner were built during his lifetime. 
Most of his successors, while carrying on the style in which he worked, failed to impart to their work that vigour and reasonableness which distinguished his. The rules and regulations which served as guides to him became masters to them, and we look in vain among them either for his scientific equipment or his intuitive perception of what was fitting. The grandeur of manner which suited admirably the buildings with which he had to deal, was out of place when applied to ordinary houses; and the artificiality which sprang from the way in which architecture was then regarded, but which his genius enabled him to avoid, settled down heavily after his death.

Among the drawings at All Souls are the examples of house-design illustrated here (Figs. 99-102). They are not named, and have not been identified; it is not even certain that they were ever carried out. But they give some idea of Wren's notions as to the appearance he would have given to houses. In general disposition they conform to the type adopted by Jones and IVebb, but they have touches about them reminiscent of French architecture, ${ }^{1}$ more particularly those in Figs. 99, IOI. The others are two rough sketches for the front of a building (probably a house), drawn on a piece of waste paper, and apparently they show two methods of treating the same façade (Fig. IO2). They are characteristic of IVren's manner as displayed at Hampton Court (see Fig. 6), more so than the other examples illustrated, and they are certainly more pleasing in their proportions and in the simplicity of their handling. The design for part of a front for the new palace at Whitehall (Fig. IO3) is interesting in two respects; it is a specimen of IVren's treatment of domestic architecture on a grand scale; and it proves that Charles II. still harboured the idea of a great new palace at Whitehall, an idea which fructified as little under Wren's direction as it had done under Webb's. As a piece of design this is no advance upon what had already been tried before. There is a weediness and crudity of ornament about it which is out of keeping with Wren's actual work; but of him it may be said, as of Inigo Jones and other great architects, that his designs are less happy on paper than in execution. Indeed a study of all the important collections of architectural drawings inclines one to take the negative side in the interesting controversy, "Is fine drawing necessary to fine architecture?"

1 It was perhaps Pierre le Muet whose work most influenced Wren. 


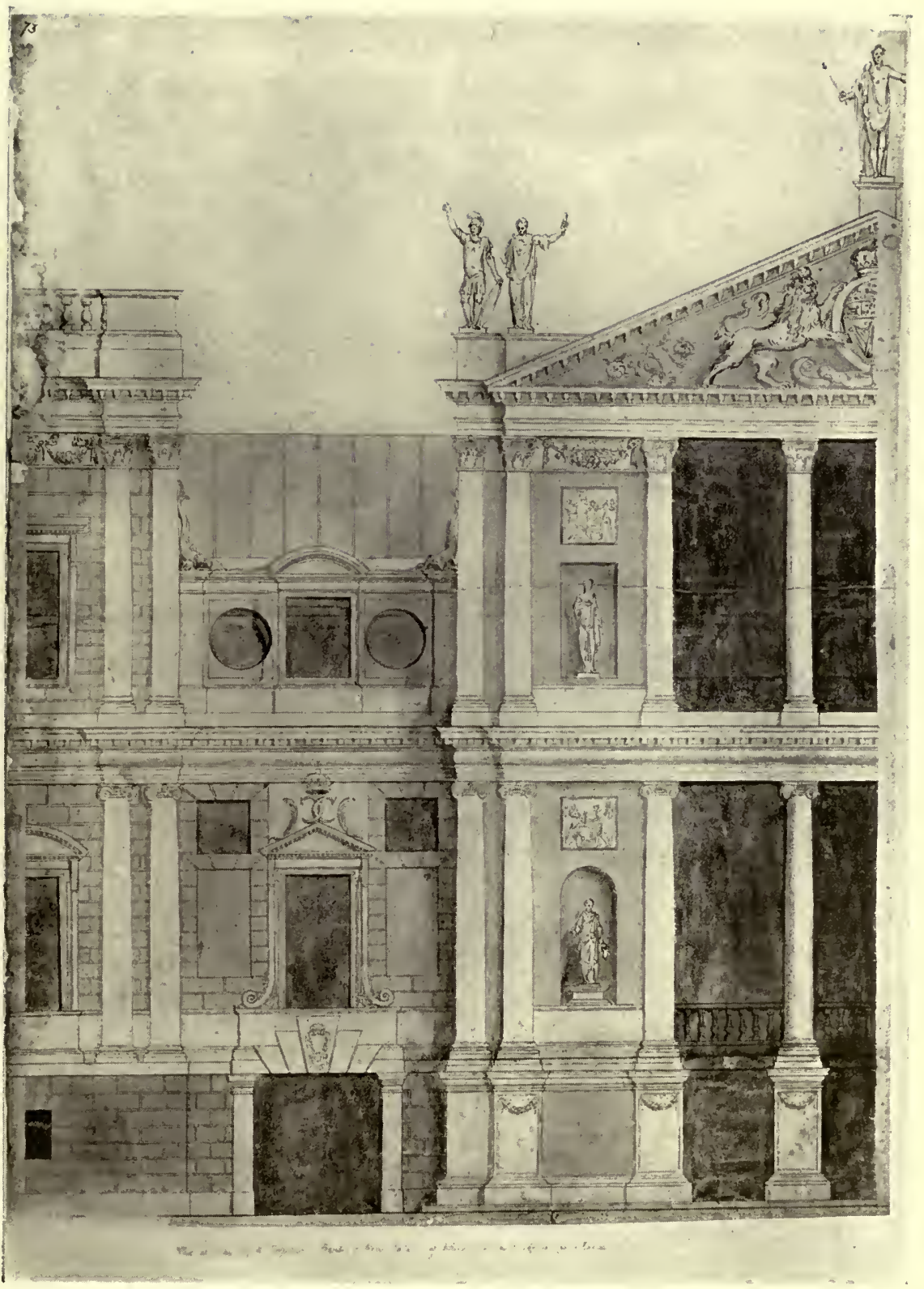

FIG. I03.-EIEVATION OF PART OF THE FRONT OF A PROPOSEI) PALACE AT WHITEHALL.

From the Wren Collection, All Souls College, Cxford. 


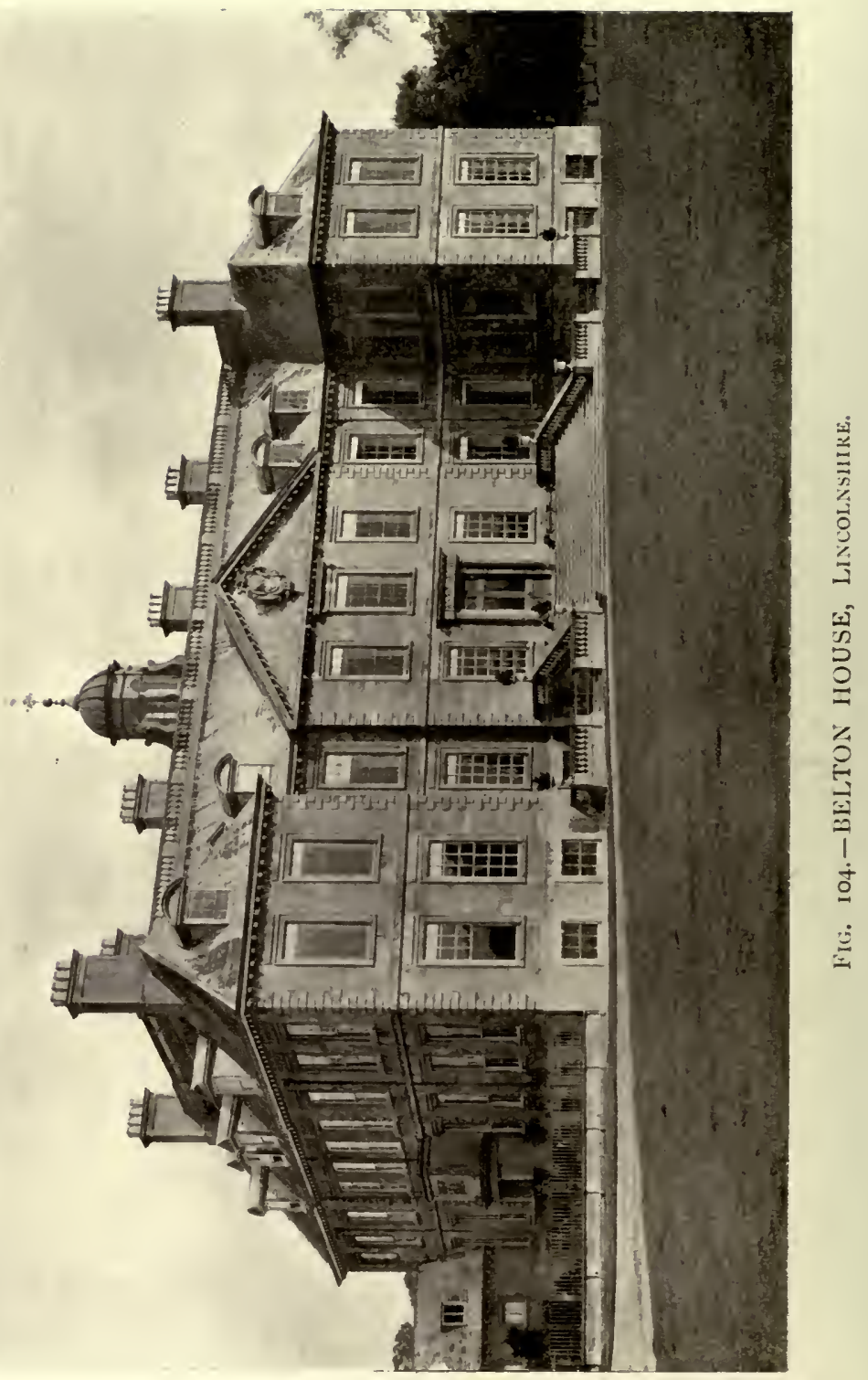


The indications of French feeling alluded to above may be accounted for by the fact that in the early days of Wren's connection with architecture, in $166_{5}$, he went to France for a few months. He was already enthusiastic in his new vocation, and like many an enthusiast in the same cause before him and after him, he wanted to see what was being done in foreign lands. He spent his whole time there in interviewing eminent architects and in visiting the most noteworthy buildings of Paris and its neighbourhood. He made so many sketches that he said in one of his letters that he bid fair to bring back "almost all France on paper." He had indeed caught the architectural fever ; and every architect knows that thenceforward it would never leave his veins.

Among the houses attributed, on insufficient grounds, to Wren is Belton House, near Grantham, one of the seats of Earl Brownlow (Fig. 104); it was built in the year 1689

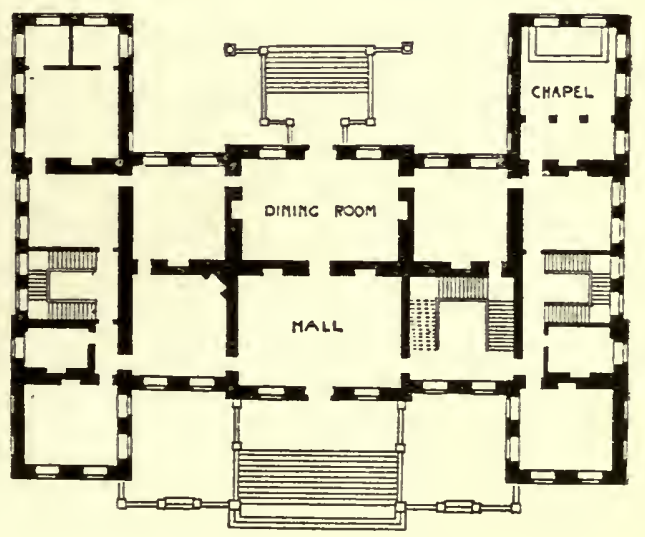

$\stackrel{510,}{+},+, 60$ FEET.

FIG. 105.-Belton House. Ground Floor. for Sir John Brown-

low: There is nothing particularly novel about it; it follows the type of what may be called the Webb house, both as to plan (Fig. IOj) and external treatment. It has the bold cornice, the hipped roof, and the balustraded flat out of which rises a cupola, which $\mathrm{Webb}$ had rendered familiar. In spite of its good proportions, however, it hardly hits the mark so fully and truly as WVebb's work, and it lacks in many respects the masculine vigour of Wren's. Nevertheless it is a notable building, and an admirable example of a dignified yet unpretentious country house, quite comfortable to live in.

The screen of ironwork which runs from the house to a subsidiary range of buildings contains a fine gateway (Fig. I06) and encloses a court of some architectural interest and one 


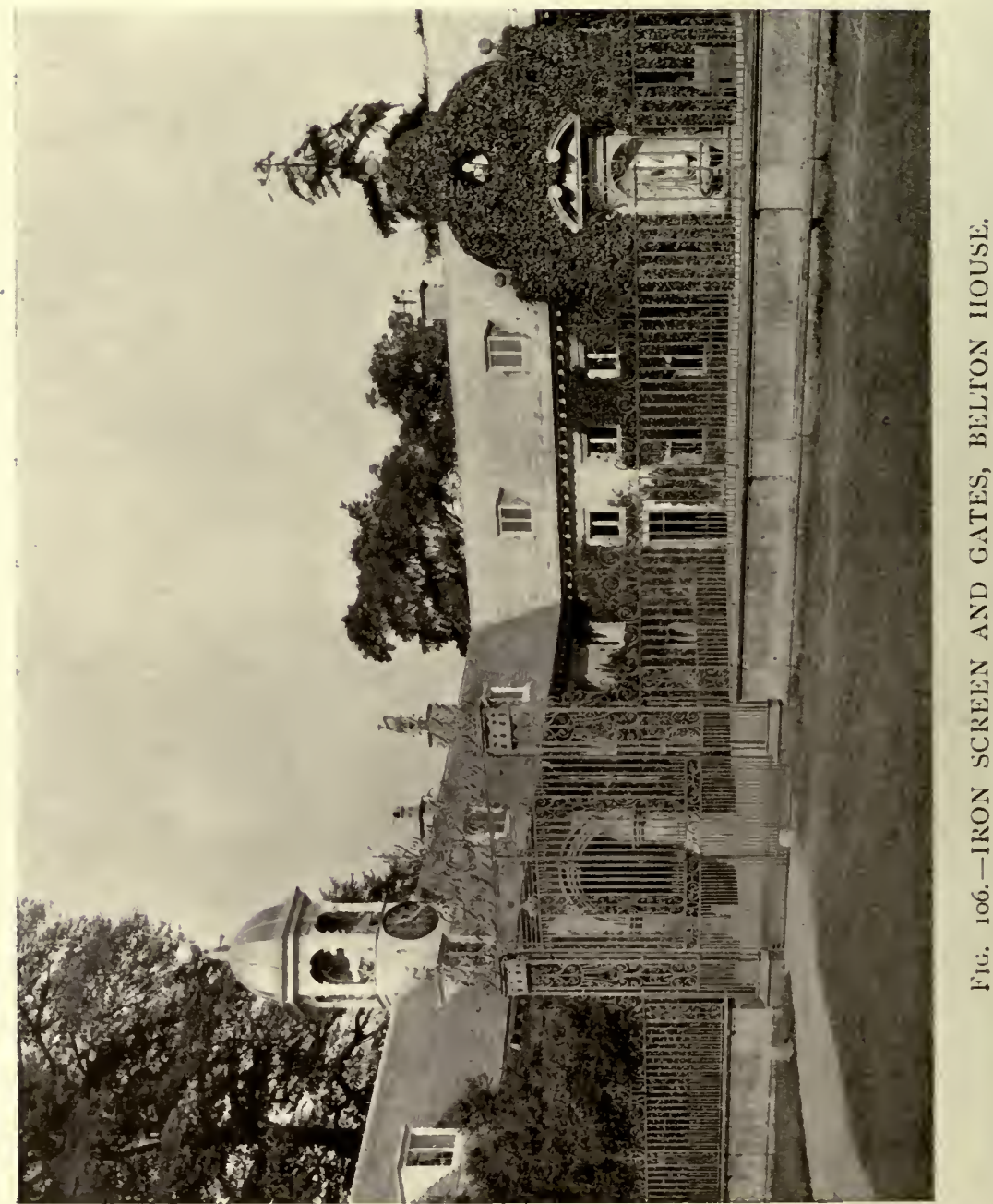


CARVING ATTRIBUTED TO GRINLING GIBBONS 159

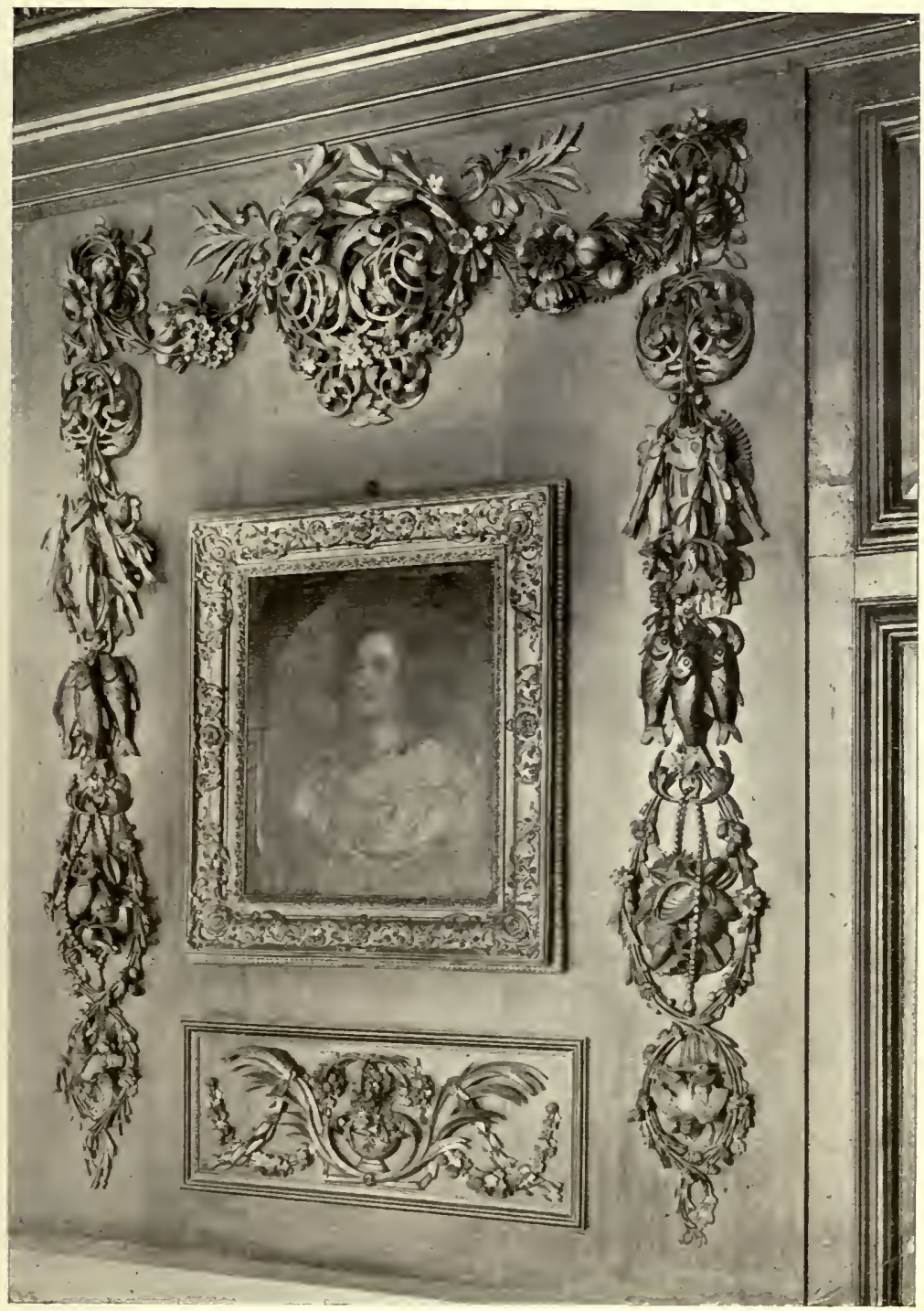

Fig. I07.-BELTON HOUSE, CARING IN THE GREAT HaL. 
which strikes a pleasing note, as it brings some of the minor accommodation into close relationship to the house. It is approached through an archway in the side opposite to what is now the front door. Being enclosed on one side by the open screen already mentioned, it has a cheerful outlook over the park. The present front door, with its porch, has been squeezed in among the windows; it probably replaces an original exit of small importance which led into the court for the sake of convenience. The principal entrance was formerly up the broad flight of steps in the middle of the façade; but the present access, although not so stately, is better adapted to modern requirements.

The interior has excellent decorative work of the period. In addition to the panelling there is a considerable amount of carving attributed to Grinling Gibbons (Fig. 107); and there are a few ceilings executed in high relief, with admirably modelled detail, of which the treatment corresponds with that associated with Gibbons' name. So charming are the figures and foliage that they prompt a desire to see them at close quarters, instead of on the inaccessible heights of a ceiling.

The chapel (Fig. 96) is interesting as an example of classic treatment applied to sacred purposes, and as one among the last survivals of the medireval idea that it was necessary for a large house to have a chapel within it. In the days when a household might be cut off for weeks from the parish church and when a daily exercise of religious observances was of the first importance, a chapel always accessible and close at hand was necessary. But the time was approaching, if it had not already arrived, when the religious fervour of distinguished people could easily be satisfied by attendance at places of public worship. 


\section{SOME FURTHER WORK OF THE TIME OF CHARLES II}

IT is needless to insist upon the fact that there was a large amount of work executed during the seventeenth century by men other than Jones, Webb, and Wren. Some of this has already been considered, in so far as it illustrates the gradual change of style in small buildings. But during the reign of Charles II. important work was done by men little known to fame, and much else by others whose names have either not survived or have not yet been disinterred from the ruins of the past. So few architects contemporary with Jones are known that it will be of interest to mention one who, if not intimately connected with architecture himself, wrote a book about it, and trained a pupil who merits more attention than his master.

This individual was Sir Balthazar Gerbier, to whom Horace Walpole devotes several pages in his "Anecdotes of Painting," where he treats of him as a painter. But Gerbier does not appear to have pursued any art with much application. He hung on the fringe of state affairs, and was a versatile adventurer of indifferent character, if Walpole does him no injustice. Among other things he dabbled in architecture. He was surveyor to the Duke of Buckingham, for whom he is said to have designed a temporary house on the site of old York House in the Strand. According to Gerbier's own account, in a letter to the duke dated 2nd December I624, Inigo Jones came to see this house, and "was like one surprised and abashed . . . he is very jealous of it." ${ }^{1}$ It may have been so, but it is certain that Gerbier was jealous of Jones, for he makes several slighting references to him in the little book which he published, "Of Counsel and Advice to all Builders." It is, indeed, this book which gives him a claim to be mentioned in connection with

1 "Lives of the British Architects," by E. Beresford Chancellor, p. 79. 


\section{GERBIER'S "COUNSEL TO BUILDERS"}

architecture, and that because of incidental allusions to matters of interest. In his dedication to Charles II. (the book was published in 1664) he advises the king to set the main body of his contemplated palace on the side of St James's Park, and the gardens along the river. This, no doubt, refers to the schemes upon which Webb, as already mentioned, was then engaged. Gerbier has several oblique as well as one direct thrust at Inigo Jones. He carps at those "who have marshald colombs," and have made them "like things patcht or glewed against a wall, and for the most part against the second Story of a Building . . . as if their intent were, that the weight of the colombs should draw down the IVall on the heads of those that passe by." Doubtless this was an allusion to the Banqueting House, about which he makes further and more definite criticisms. After cavilling at the elaboration of stage effects in masques, he roundly states that "Inigo Jones (the late surveyor)" found the Banqueting House unsuitable for such purposes, and that he "was constrained to Build a IVooden House overthwart the Court of Whitehall:" He then takes exception to the height of the room, alleging that the king and his retinue were lost in it because of its vastness; and goes on to say that he does not undervalue any modern works, "every good Talent being commendable," including, presumably, even the late surveyor's. At the same time there were some alive who knew that the king of blessed memory had graciously avouched, in the year 1648 , that a room near York Gate not above $35 \mathrm{ft}$. square (which was the one Gerbier had designed himself) was as apt for masques as the Banqueting House itself. Moreover judicious persons would not deny that the excellence of the Triumphal Arches erected in London (which Gerbier is said to have designed for the entry of Charles II.) consisted not in their bulk.

The book abounds in malicious and egotistical touches of this kind, both in the two treatises into which it is divided, and in the forty dedicatory epistles which he deemed necessary to the launching of his venture. But amid a deal of skimbleskamble stuff, he says a few things worth noting. Chimneys need only be carried about $2 \mathrm{ft}$. above the ridge; large and lofty stacks he deems unsightly and dangerous. Staircases should be easy of ascent and wide. Anyone who has sound limbs and a "gallant gate" naturally lifts his toes at least 
4 inches in walking; if, therefore, stairs be only 4 inches high and I 8 from front to back, the ordinary person can walk up them as easily as he can walk on the level. His reasons for these proportions are hardly convincing, but in regard to the width of staircases he is probably nearer the mark, when he says they ought to be so wide that the attendants on each side the noble person who is ascending may not be straitened for room.

His advice to persons contemplating building, that they should employ an architect and should not be constantly interfering with him, is undoubtedly sound: and one reason advanced for employing an architect, namely, that "the several Masterworkmen may receive instructions by way of Draughts, Models, Frames, etc.," is interesting as showing that architects were now accustomed to provide more minute details than in the time of Elizabeth and James. One more reference and this curious book, with its few noteworthy observations buried in pages of involved verbiage, may be left. In speaking of such as were concerned with building he says, "they may perchance have heard of rare buildings, nay, seen the Books of the Italian Architects, have the Traditions of Vignola in their Pockets, and have heard Lectures on the Art of Architecture." It is interesting to learn that in addition to books on architecture there were opportunities, so long ago, to hear lectures on the subject; but it is probable that, in his usual egotistical way, Gerbier is here referring to lectures which he himself had given at an academy which he founded in Bethnal Green, in imitation, Walpole suggests, of another established by Charles I. for instruction in arts and sciences, foreign languages, mathematics, painting, architecture, riding, fortification, antiquities, and the science of medals. ${ }^{1}$

The "Counsel" concludes with a lengthy schedule of prices at which all kinds of building work could be executed.

Little, if any, architectural work can with safety be attributed to Gerbier. Hamstead Marshall, which is said to be his, is more probably due to his pupil, IVynne, to whom, as Master IVilliam Wine, he addresses one of his numerous dedications.

Walpole says that Wynne, or Winde as he calls him, finished the house which had been begun by his master, making several alterations in the plan; but the history of the owner and of the house, as well as the character of the work, renders it doubtful whether Gerbier could have had anything to do with it. The

I Walpole's "Anecdotes of Painting." 
house was one of the seats of William, Lord Craven; it has been destroyed with the exception of some fine gate piers and part of the lay out, but Kip has an engraving of it in "Britannia Illustrata" (Fig. I08). There are also a few drawings of details in the Bodleian Library, including windows, gate piers, doors, and a ceiling. The windows and piers can be identified on Kip's engraving, as also can the general lay out, thus confirming the accuracy of Kip's view. His illustration shows the house with a front of Jacobean design as to its two lower stories. but of later character as to the third story and the return front. The windows of this later work agree in general appearance with the drawing at the Bodleian, which shows festoons above the windows and panels between them, decorated with Lord Craven's cipher, WV. C., and a baron's coronet (Fig. IO9).

By examining Kip's view in the light of the principal facts of Lord Craven's life, and of the dates on the Bodleian drawings, a shrewd guess can be made as to the history of the house. In his youth William Craven achieved such honour through "valiant adventures" in Germany and the Netherlands under Henry, Prince of Orange, that in the year 1626, when he was eighteen years old, he was knighted by Charles I. at Newmarket and was immediately afterwards created a baron, with the title of Lord Craven of Hamstead Marshall. In I63 I he returned to the scenes of his early glories, and continued to reside abroad. until the Restoration. Although absence prevented him from fighting for Charles I. he was a staunch loyalist, and helped. the king with considerable supplies. This brought him under the notice of the Parliament, and his estates were confiscated in $165 \mathrm{I}$, and sold to different persons. ${ }^{1}$ After the Restoration, however, Charles II. created him an earl in recompense for his services, and he must previously have regained possession of Hamstead Marshall, since the drawings for the new work bear a baron's coronet and various dates, of which the earliest is 1662 .

It would appear, then, that the original house was a Jacobean building, and from the fact that Lord Craven was a bachelor and was resident abroad for the greater part of his life previous to the Restoration, it is highly improbable that he did any building during that period; he had neither family nor leisure to induce him. On the sale of the property in $165 \mathrm{I}$, it is quite- 


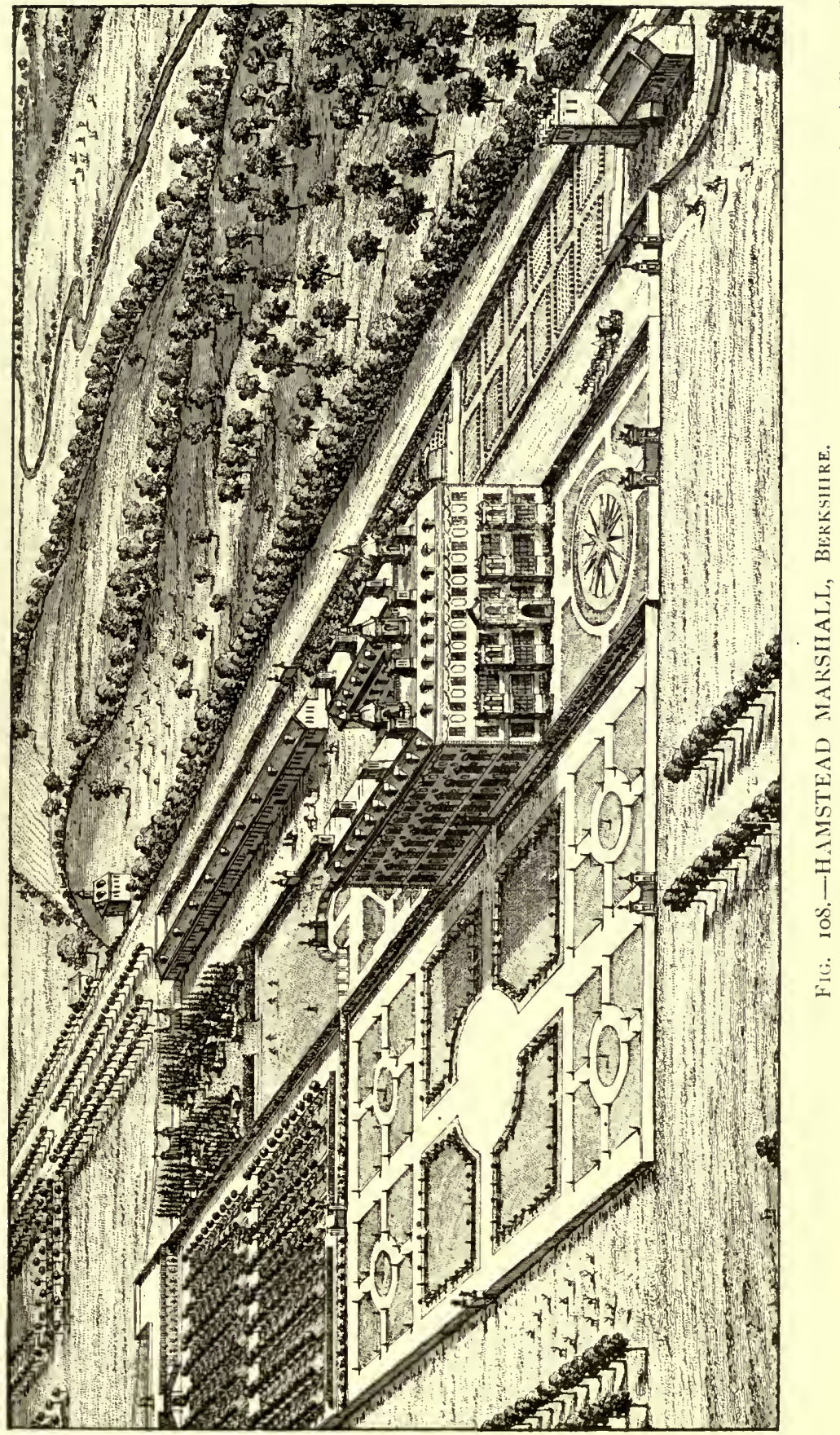




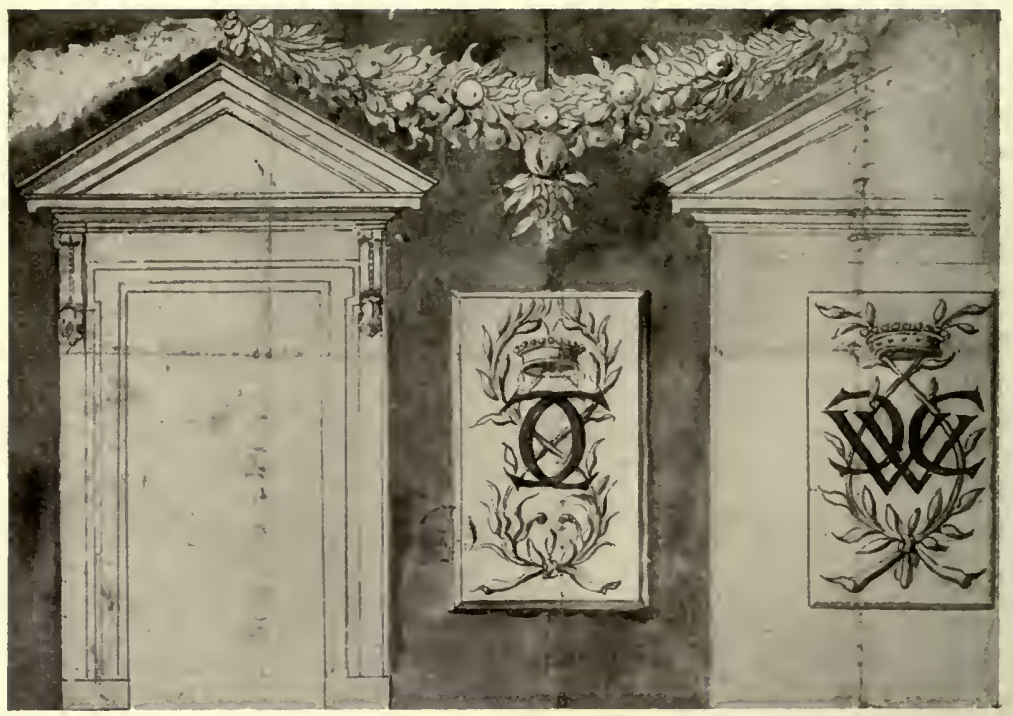

FIG. Io9.-Hamstead Marshall. "The Ornament of the Windows," by Wynne.

From a Drawing in the Bodleian Library.

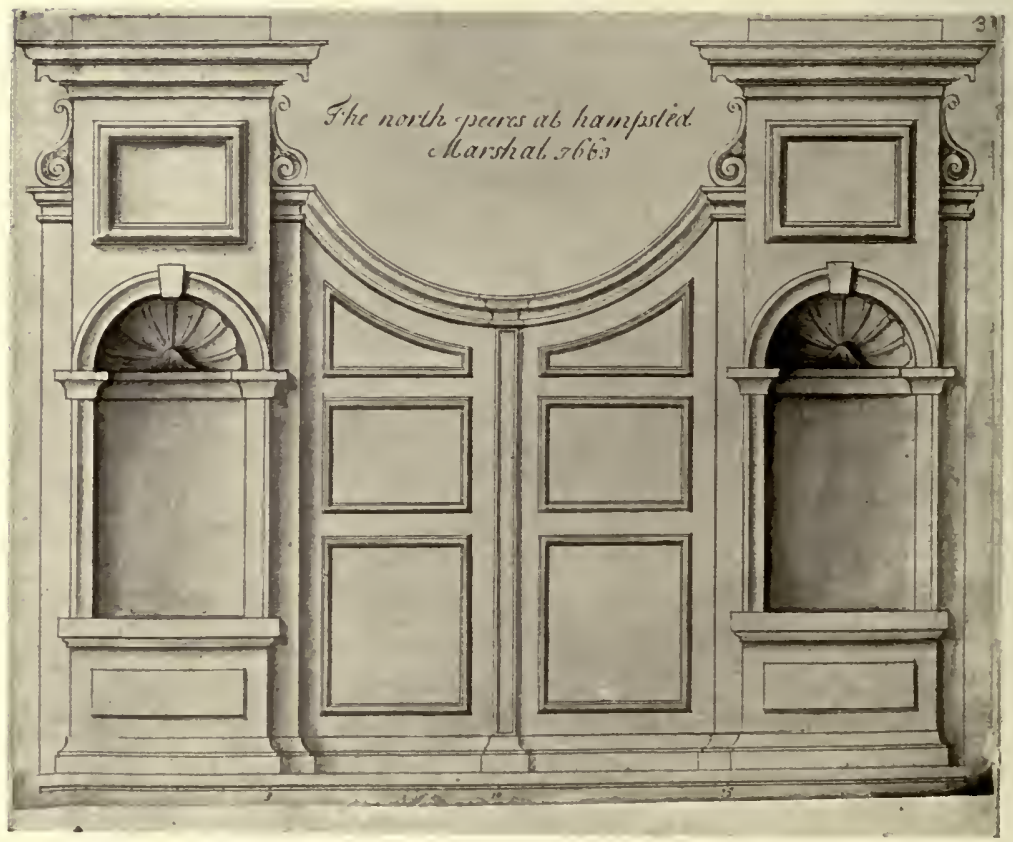

FIG. I 10.- "The North Piers at Hamstead Marshall, I663," by Wynne. From a Drawing in the Bodleian Library. 
possible that the house was partly dismantled, ${ }^{1}$ as were many others in similar circumstances, not a b I y Holdenby House. On his return in 1660 , or as soon afterwards as he could, he set about restoring his home. $\mathrm{He}$ preserved the Jacobean fron t, but added a new top story and new sides. The drawing of

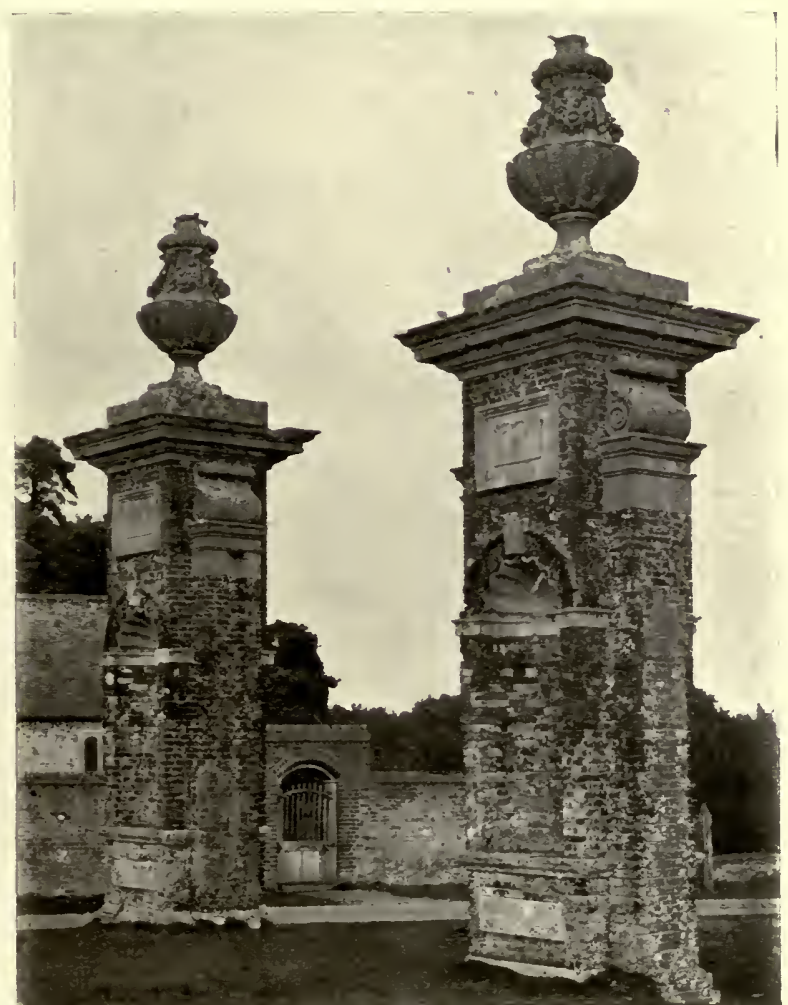

FIG. III.-Gate Piers at Hamstead Marshall. the portico, which would be at the back of the house shown by $\mathrm{Kip}$, is dated 1662 ; that of the gate piers in the front wall is dated 1663 (Fig. I Io), and those in the circular wall at the rear I673; a ceiling is dated I686. The baron's coronet indicates that the work was done before the earldom was bestowed, which was in 1663. The dates on the drawings suggest what one might expect, that the house itself was first taken in hand, then the garden walls and lay out, and subsequently the embellishment of some of the chief rooms.

If the history of the house is rightly conjectured, there

1 This conjecture is strengthened by a reference of Evelyn's, who notes that in going from Reading to Marlborough in June 1654 he saw "my Lord Craven's house at Causam now in ruines, his goodly woods felling by the rebels." 
would be no room for Gerbier in its design, for he is said to have died in 1662 when he was at least seventy years old, and there is no trace of senility in the Bodleian drawings. They are vigorous in design as well as drawing; the gate piers (Fig. III) are still in existence, some scattered, as it were, in a field, others still leading into a walled garden. It is only when the imagination restores the walls that once connected them that an idea is formed of the size of the original enclosures to which those piers were the noble entrances. The ceiling (Fig. I 12), dated I686 on the drawing, is of the type prevalent throughout the greater part of the seventeenth century, and usually employed by Jones, Webb, and Wren.

As Wynne-cthe learned and ingenious Captain Wynne" Campbell calls him $^{1}$-is the only other person whose name is connected with the designing of Hamstead Marshall, the credit may fairly be placed to his account. The character of the new work, as shown by Kip, accords with the treatment usually adopted by Webb; that is to say, the walls are fairly plain, there is a wide cornice at the eaves. The height of the roof is proportioned to the walls (not merely determined by the span of the building), it is crowned by cupolas and broken by dormers, and the chimneys are short and solid-perhaps, in this case; in consequence of the teaching of Gerbier, IVynne's master.

It is evident that the restoration of Charles II. gave a great impetus to building. Charles himself revived the project for a new palace at Whitehall; he built a large wing of another at Greenwich ; Lord Craven was among those who endeavoured to redeem the time; and Gerbier thought the occasion opportune to publish his "Counsel" to those who were contemplating new houses.

Too little is known of this learned and ingenious Captain Wynne. Campbell credits him with old Buckingham House in St James's Park, for the Duke of Buckingham, in I705. This duke must not be confused with either of the Villiers, Dukes of Buckingham. He was the first duke of a new creation, his family name being Sheffield. He was, in fact, the grandson of that "my lord Sheffield" whose house has already been illustrated in Chapter II. as one of the designs of John Smithson. To Wynne is also assigned Cliefden House for the same nobleman, and Newcastle House in Lincoln's Inn Fields, as well as certain

$$
1 \text { "Vit. Brit.," i. 43, } 44 .
$$




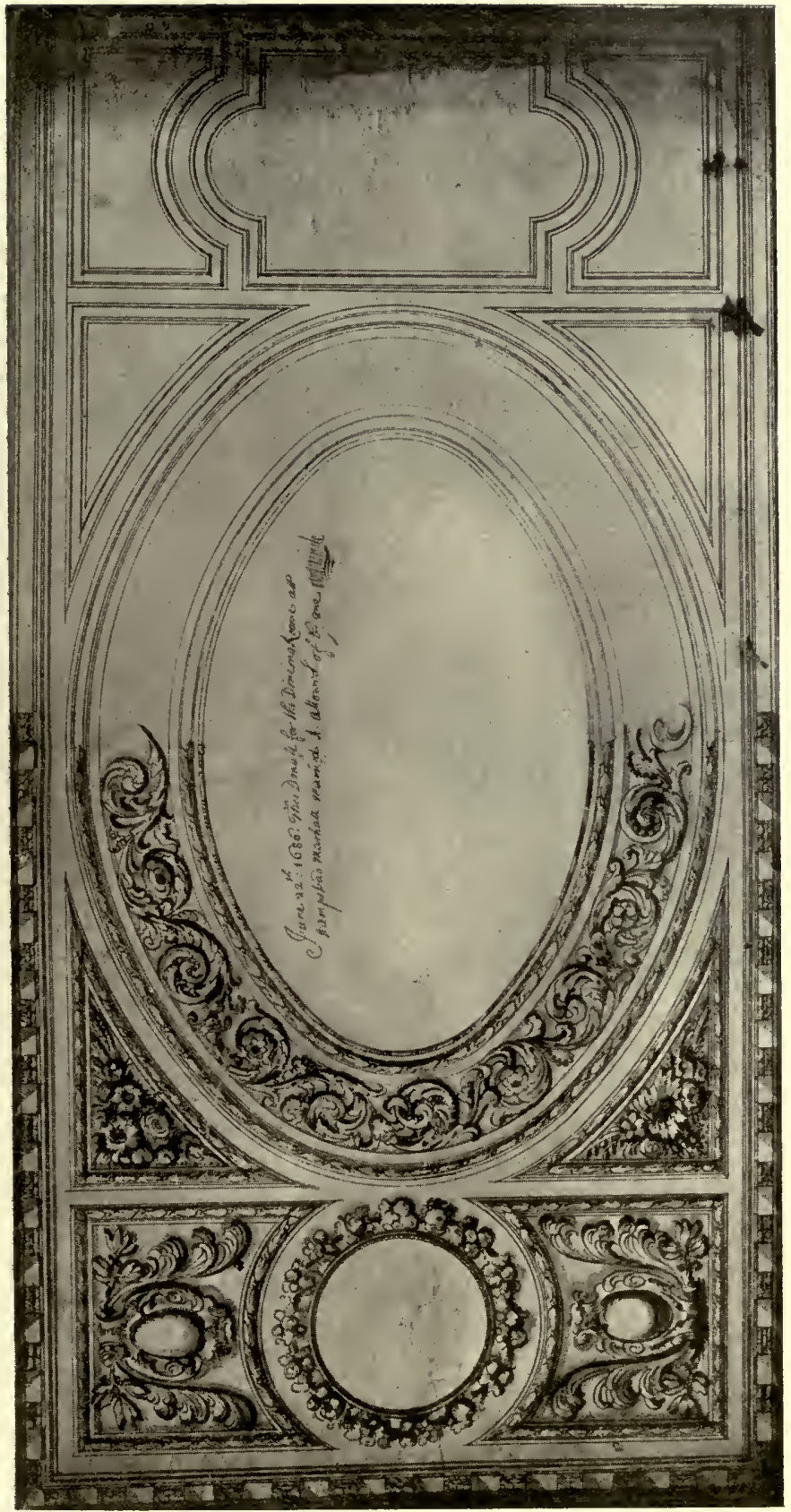

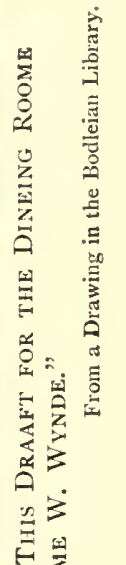

:

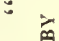

के

도 온

닌

는

类

त

5 웝

少

$\Xi$

एक

孚

至窇

需

왼

牙

$=$ is

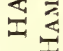

娄

项

7

$\stackrel{i}{-}$

$\dot{3}$ 


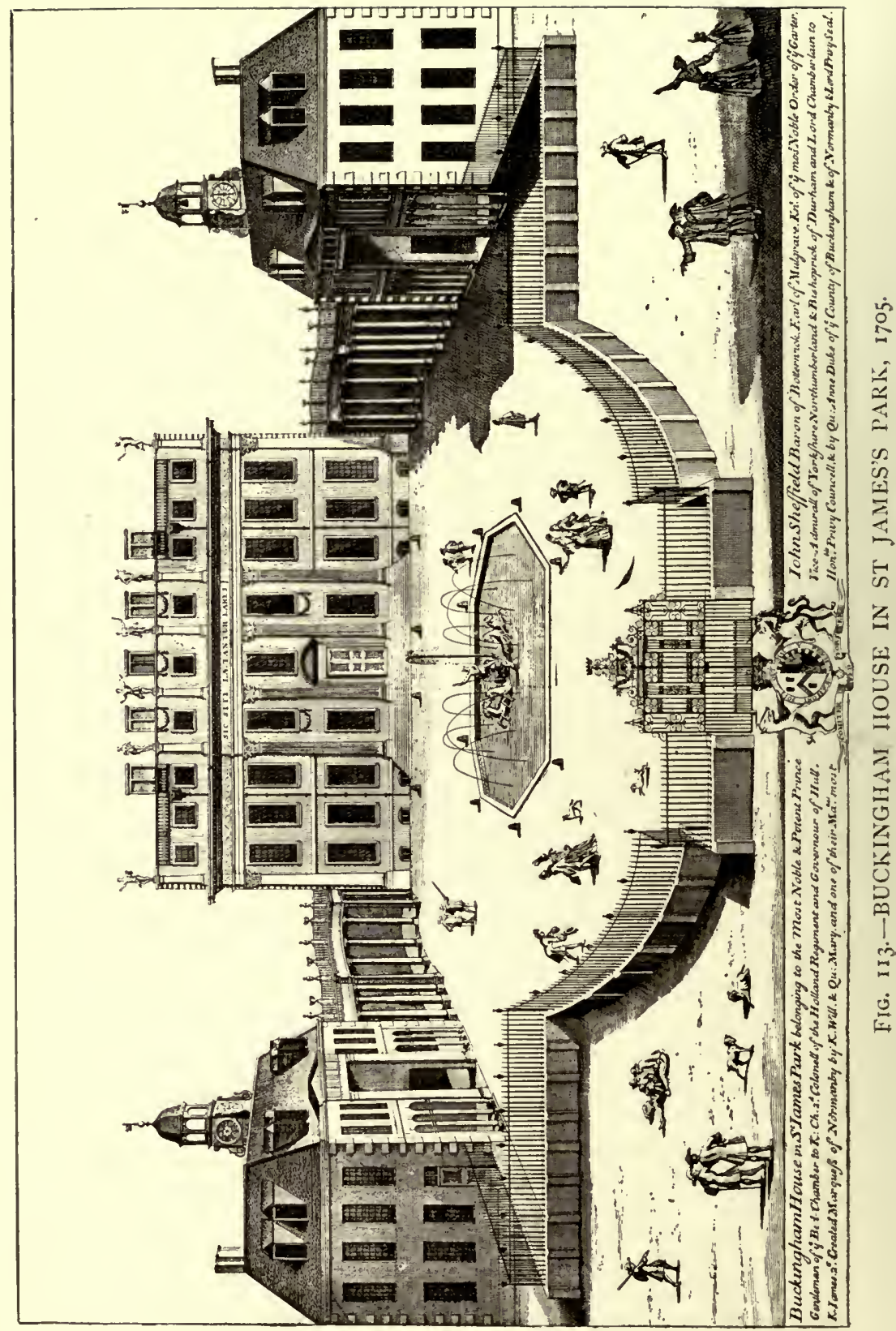


additions to Combe Abbey for Lord Craven. ${ }^{1}$ Hardly anything remains of all this work, but if it was of a standard equal to the remnants of Hamstead Marshall, Wynne would take a high place among English architects. Newcastle House, originally called Powis House after William Herbert, Viscount Montgomery and Marquis of Powis, for whom it was built in 1686,2 still stands at the north-west corner of Lincoln's Inn Fields, but it has been considerably altered; the loss through fire of the original fine wooden cornice has much diminished its effect.

Buckingham House (Fig. I I 3) stood where Buckingham Palace now is, and, judging by Campbell's elevation, ${ }^{3}$ was of much greater architectural interest than the present building before it was refronted. It was considered "one of the great beauties of London, both by reason of its situation and its building." + It fronted the Mall-the noblest arenue in Europe, according to Campbell - and at the back was a fine garden and a noble terrace, whence the eye roamed over a wide rural prospect, so free from obtrusive buildings as to justify the inscription placed by the duke on this front, "Rus in Urbe." The description of the entrance court is interesting as giving a good idea of the kind of lay out that went with all large houses of that time. "The court-yard which fronts the Park is spacious: the offices are on each side divided from the Palace by two arching galleries, and in the middle of the court is a round basin of water, lined with freestone, with the figures of Neptune and the Tritons in a water-work." Campbell's plan agrees with this description save that he makes the basin octagonal. The "arching galleries" were by this time a very usual feature which will be further described presently. His plan also conveniently illustrates the duke's own description of the entrance into the house itself. "After crossing the court-yard," he says, "we mount to a terrace in the front of a large Hall, paved with square white stones mixed with a dark-coloured marbie; the walls of it covered with a set of pictures done in

1 The curious volume of original drawings by Wyne, which is preserved at the Bodleian Library, and from which the illustrations 109, 110 , and 112 are reproduced, also contains drawings for work at Combe Abbey; it would appear, therefore, that $\mathrm{W}_{y}$ nne was the architect employed both there and at Hamstead Marshall.

"Wheatley and Cunningham's "London, Past and Present."

3 "Vit. Brit.," i. 44.

4 "Journey through England" (1722), by J. Mackay, quoted in "London, Past and Present." 
the school of Raphael. Out of this on the right hand we go into a parlour 33 feet by 39 feet, with a niche 15 feet broad for a Bufette, paved with white marble, and placed within an arch, with Pilasters of divers colours, the upper part of which as high as the ceiling is painted by Ricci." The roof of the house was flat and gave opportunity for obtaining a fine prospect: on the parapet fronting the park were four statues of MercurySecrecy, Equity, and Liberty, and fronting the garden were the four Seasons. This particular enumeration gives a touch of life and reality to the endless figures which break the sky-line of Campbell's elevations, and of John Webb's before him. The view reproduced in Fig. I I $3 \mathrm{~A}$ shows the house as it appeared in 1790 , when it was about a hundred years old. It not only suggests the rural surroundings, but gives a lively idea of the groups which frequented the Mall, down the length of which this front faced. The Mall, it will be remembered, was the principal walk in the royal park of St James, and apparently enjoyed the formality of being guarded by sentries.

Cliefden House, in Buckinghamshire, was another of these noblemen's "palaces," with "arching galleries" joining the offices to the house. It stood upon an enormous terrace described by Campbell as $433 \mathrm{ft}$. long and $24 \mathrm{ft}$. high, the front of which consisted of a series of alcoves or niches, flanked at either end by a flight of steps (Fig. I I 4 ). The original house has entirely disappeared, and has been replaced by one of excellent design by Charles Barry. Merely the terrace, somewhat altered, and the dwarf walls of the lay out remain, and Wynne's work can only be judged from Campbell's elevations and from old prints.

The consideration of these two houses brings vividly before the mind the completeness of the change that had come over domestic architecture during the course of the seventeenth century. The description of Buckingham House from contemporary pens (one of them that of the owner himself) gives an air of vraisemblance to Campbell's cold illustrations. The "arching galleries" indicate a disposition of plan which was being adopted in many large houses, and was for another half century employed in order to impart stateliness to what otherwise might have been a rather bald design.

The idea of this arrangement was to have a central block containing the principal rooms, and to flank it at some distance on each side by a subsidiary block connected to the main structure by curved colonnades-the "arching galleries" of 


\section{W.tis}

ars

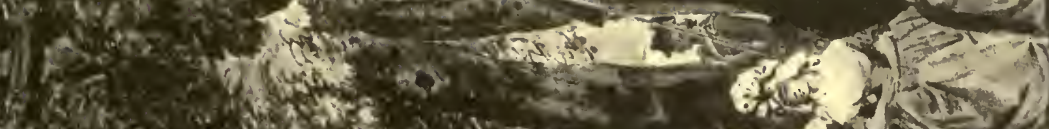

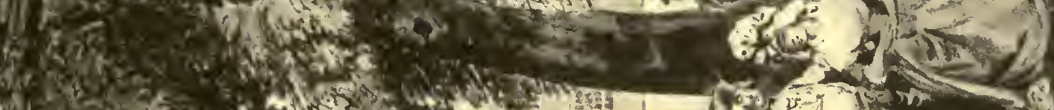

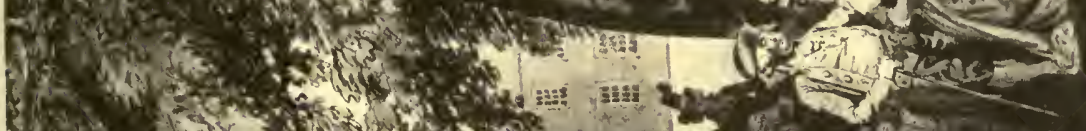

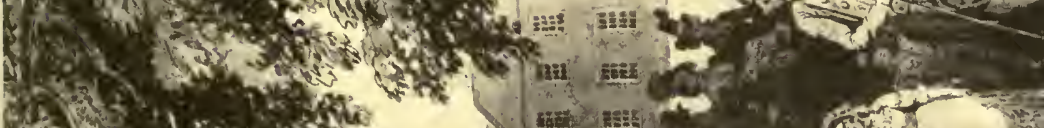
Q0.

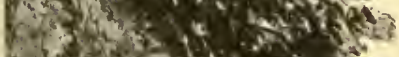
W.t.

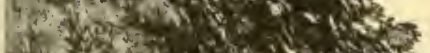

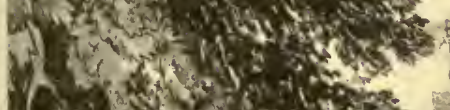
If

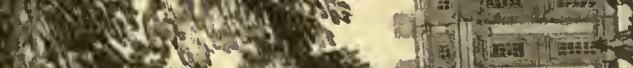
(2) x.M.

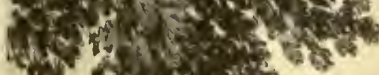
of

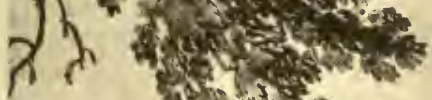

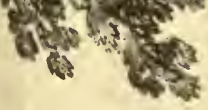

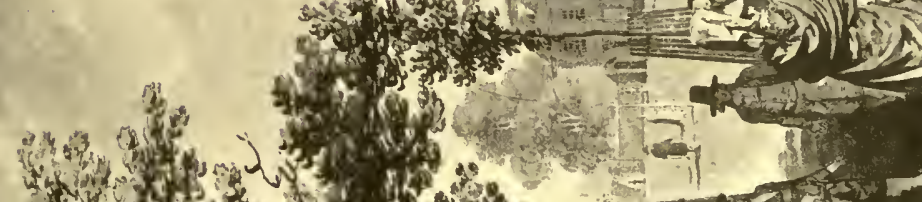

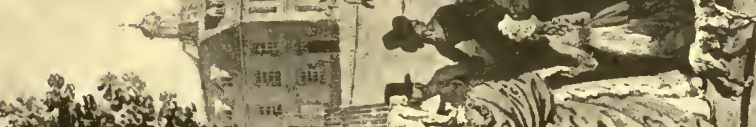

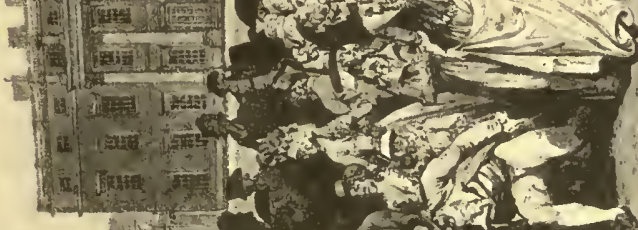

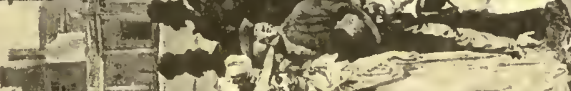

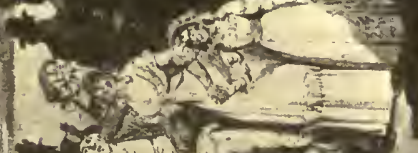
$\frac{1}{2}$

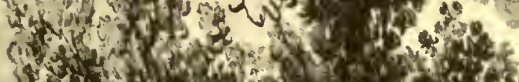

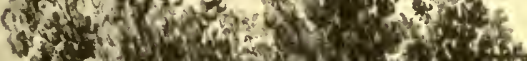

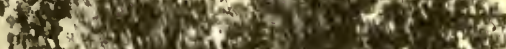

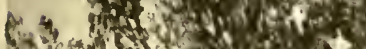

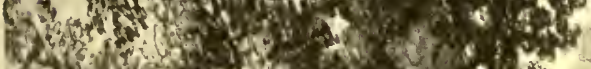

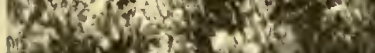
antras \&

$=1(x)=0.0$

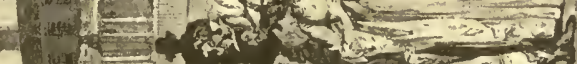

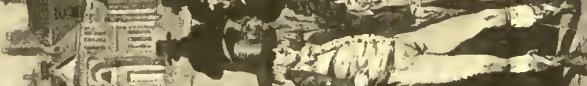





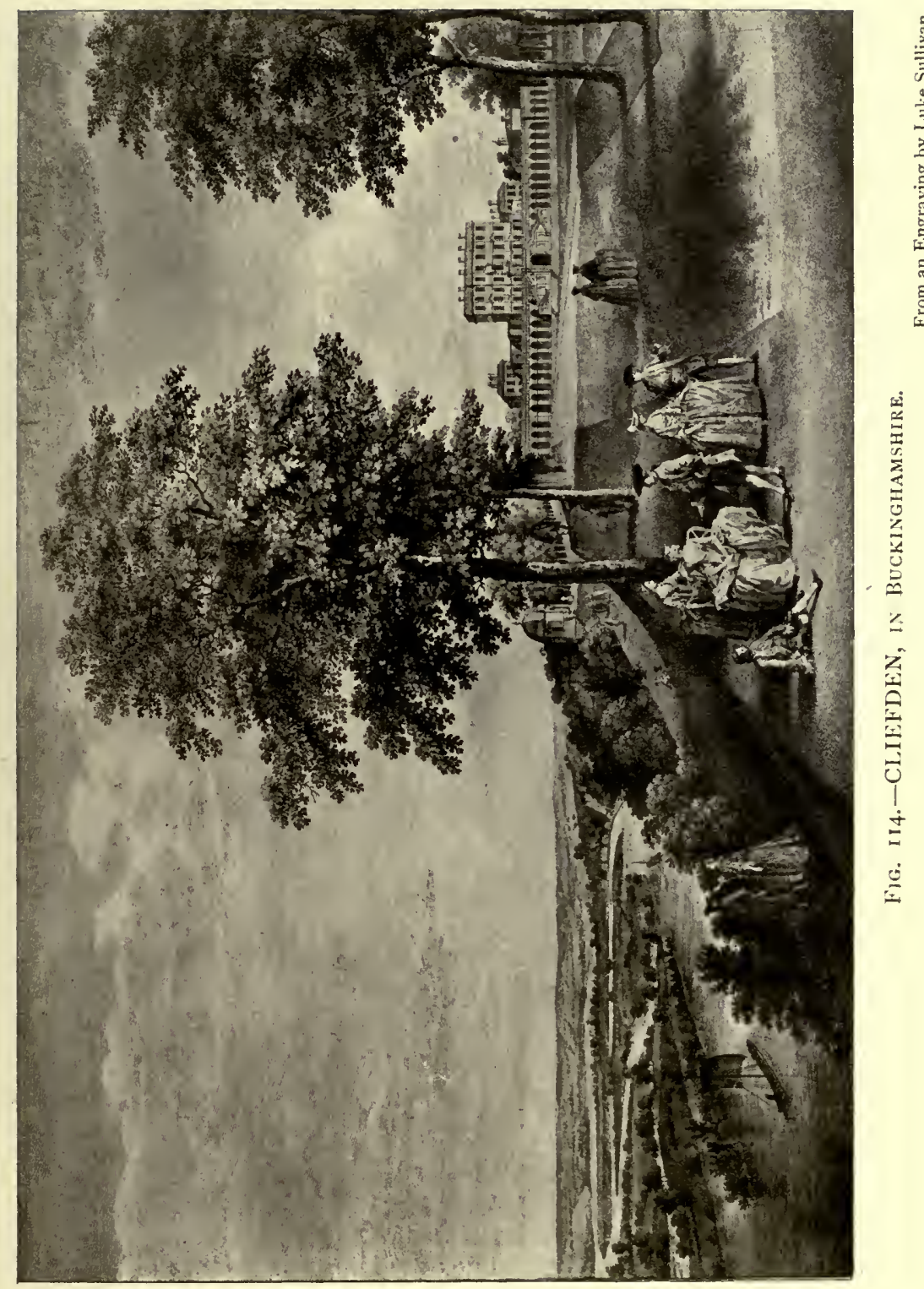




\section{PLANNING OF THE LARGER MANSIONS}

Buckingham House. These outlying blocks contained the offices, which were sometimes the kitchens, sometimes the stables, and occasionally the library or chapel. The inconvenience of the arrangement is ubvious; under it compactness was sacrificed to appearance. If these outliers looked out on to the approach, their windows embarrassed the access to the front door. If they looked the other way, they turned their dull backs upon the main approach. Windows suitable for a kitchen had to be balanced by similar windows in the stables which were not suitable; or, as an alternative, sham windows were employed. Designers found themselves obliged to resort to

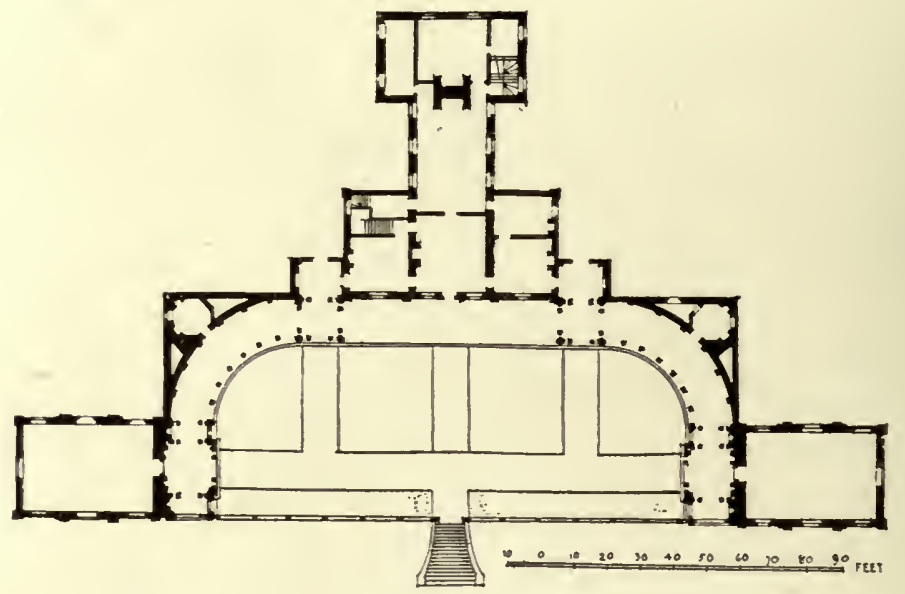

FIG. I I 5.-Plan of Stoke Bruerne, Northamptonshire.

devices of one kind or another, which sacrificed the convenience of one block in order to assimilate it in appearance to the other. Nor did the sacrifice stop here; it affected more or less the whole house. The mistaken claims of "architecture" led to the external appearance being considered as of the first importance; the internal convenience was modified to suit it. Not infrequently rooms were wrongly placed, wrongly lighted, awkwardly shaped, given a bad aspect, or otherwise ill-handled, in order to preserve the symmetry and proportion of the exterior. The placing of the kitchen in a distant block, connected perhaps by an open colonnade, must have been a great inconvenience both to the family and the servants. But inconvenience counted for little so long as an imposing edifice was secured.

The introduction of this particular form of plan, with a 


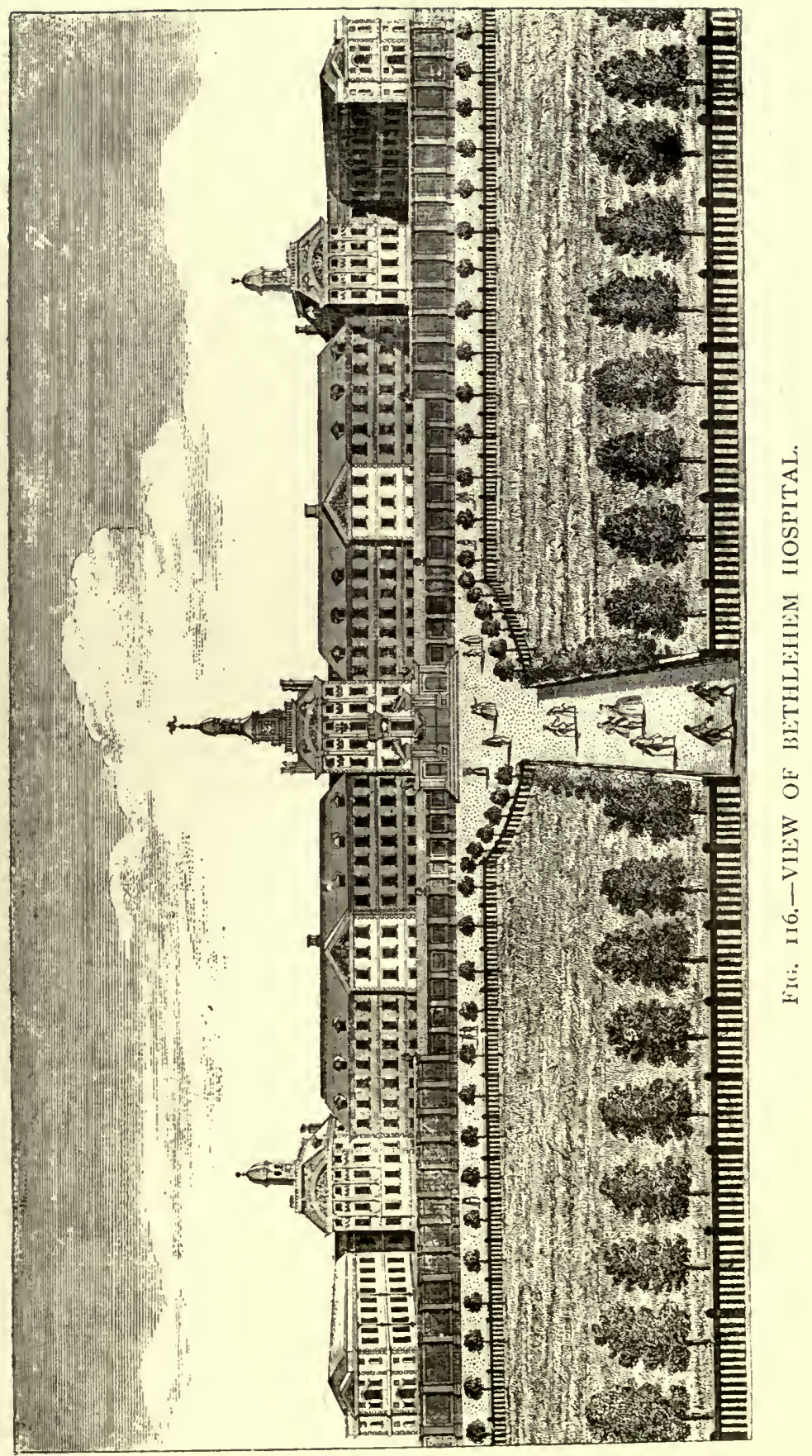


central block, two outlying wings, and connecting colonnades, is associated with the name of Inigo Jones and the house of Stoke Bruerne, in Northamptonshire. According to Bridges, the county historian, "the house was built by Sir Francis Crane, who brought the design from Italy, and in the execution of it received the assistance of Inigo Jones. It consists of a body and two wings, joined by corridores or galleries (see plan, Fig. I I 5 ). The pillars which support the galleries leading to the wings, are red and of a different colour from the house. ... The house was begun about the year 1630 and finished before 1636 , during which interval he gave an entertainment here to the King and Queen." I Colin Campbell, however, says that the building was begun by Inigo, who made the wings, colonnades, and all the foundations, and that owing to the interruption caused by the Civil War the front was designed by "another architect." $\mathrm{He}$ puts the date at I640. Bridges' account is circumstantial, and he was a careful historian; but Campbell's elevation shows the body of the house treated in a different manner from the wings, and so far supports his statement. Unfortunately this part of the building was burnt down in 1886 , and the opportunity of comparing the differences in the work itself is lost.

Both authorities concur in placing the date as early as somewhere between 1630 and 1640 , which was quite half a century before this type of plan became at all popular. Nevertheless among Webb's drawings, which cover at least thirty years of the half century, there are several instances in which it is employed; and even the practical and level-headed Wren has a plan of this type among his drawings at All Souls College, Oxford (see Fig. JOO). The genesis of this particular form is of interest inasmuch as it was widely adopted in the eighteenth century; so much so that Isaac Ware in his "Complete Body of Architecture," published in 1756 , lays down various rules for its disposition and proportions, and recommends its adoption as raising a house out of the commonplace and making it handsome without being necessarily pompous.

Among the more notable examples of this type of plan may be mentioned Burley on the Hill, in Rutland, where a low curved colonnade is thrust out on each side to a great distance without serving any particular object beyond that of obtaining an appearance of grandeur; this was one of the earlier applications of the idea, dating from late in the seventeenth century: Easton

${ }^{1}$ Bridges' "History of Northamptonshire," vol. i. p. 328. 


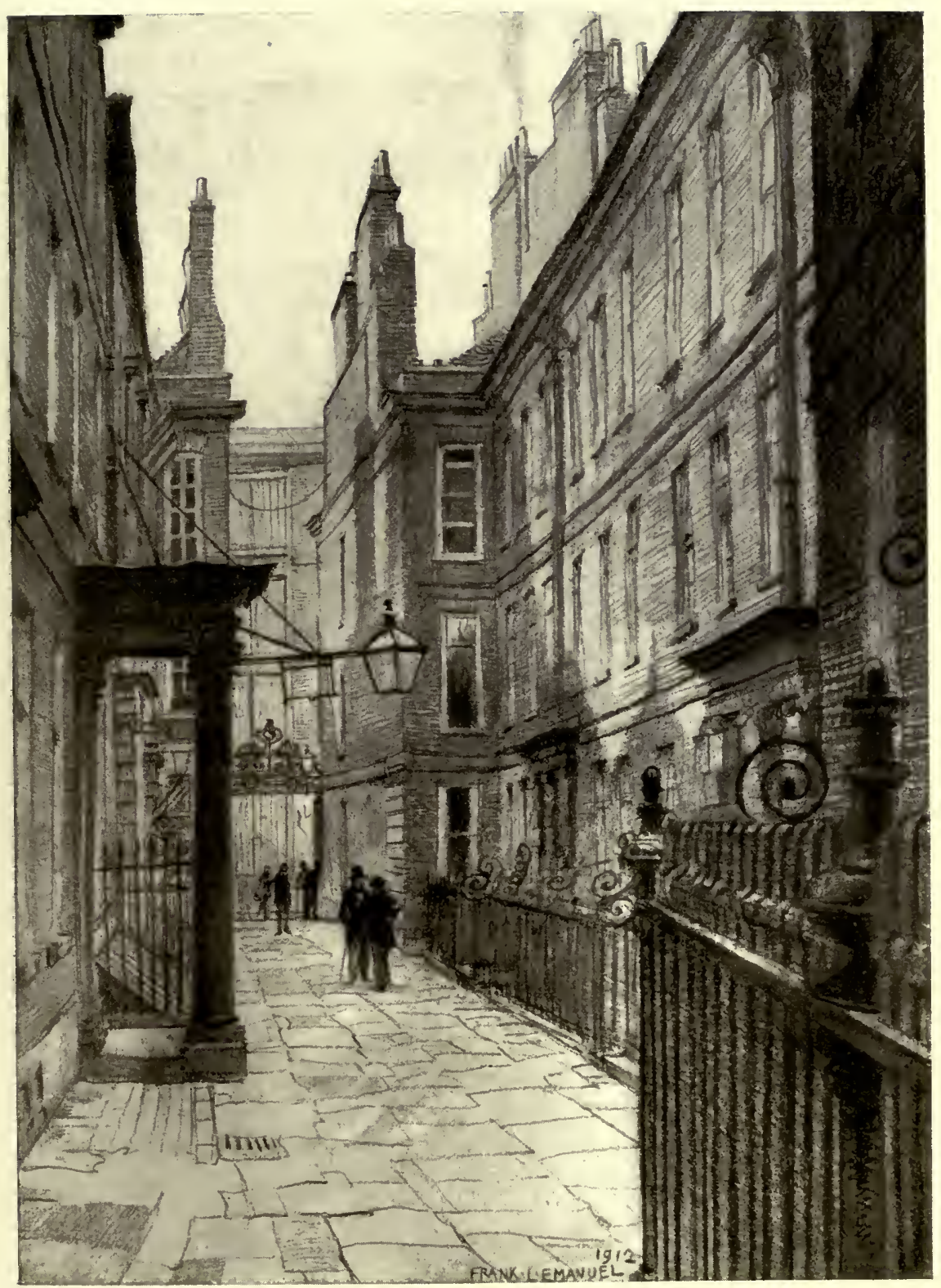

FIG. II7.-CATHERINE COURT, TOWER HILL, LONDON.

Drawn by F. I. Emanuel. 
Neston, in Northamptonshire, dated I 702, which will be described presently; Cottesbrooke, in the same county, built in the early part of the eighteenth century; Kelmarsh, a not very distant neighbour of Cottesbrooke, designed by Gibbs and replacing a picturesque Jacobean house ${ }^{1}$ Seaton Delaral, in Northumberland, designed by Vanbrugh about 1720 , of which the two wings alone remain in use; Houghton, in Norfolk, begun in I 722 ; Holkham, in the same county, begun in I 734 ; and Kedlestone, in Derbyshire, dating from 1761 ; the last three of which will be referred to at greater length in a subsequent chapter.

Wren was not the only man of science of his time who became an architect; there was his acquaintance, Robert Hooke, three years his junior, and, like himself, the son of a parson. Hooke was almost as versatile a genius as $\mathrm{W}$ ren, but it was as a mathematician that he achieved most reputation. He was connected with the Royal Society at its inception, and was appointed curator of experiments. The great fire of London appears to have turned his attention to architecture; indeed that event, owing to the necessity it imposed of a vast amount of urgent rebuilding, seems to have led into the paths of architecture men whose previous training, although not architectural, qualified them eren slightly for the work. Doubtless Hooke's mathematics pointed him out as being not unsuitable to become a city surveyor, besides which he had submitted a plan to the Royal Society for the rebuilding of London, which received much commendation from the lord mayor and corporation, who asked that it might be submitted to the king. In this direction, however, he had been forestalled by Wren with his fine scheme. In the end nothing came of either of the suggestions.

Hooke appears to have made a considerable fortune as a surveyor, and he is credited with the design of three important buildings, all of which have disappeared. One of these was Montagu House, in Bloomsbury, for Ralph, Lord Montagu, whose country house at Boughton is presently to be described. Hooke's house did not last long; it was begun in 1675 and burnt down in I686, its successor being designed by the French architect, Puget, whom Lord Montagu may have known during

1 The curious can compare the appearance of the old house with what Gibbs put in its place by referring to the plates in Bridges' "History of Northamptonshire"; whether the newer design was an improvement, either in appearance or convenience, is open to question. 

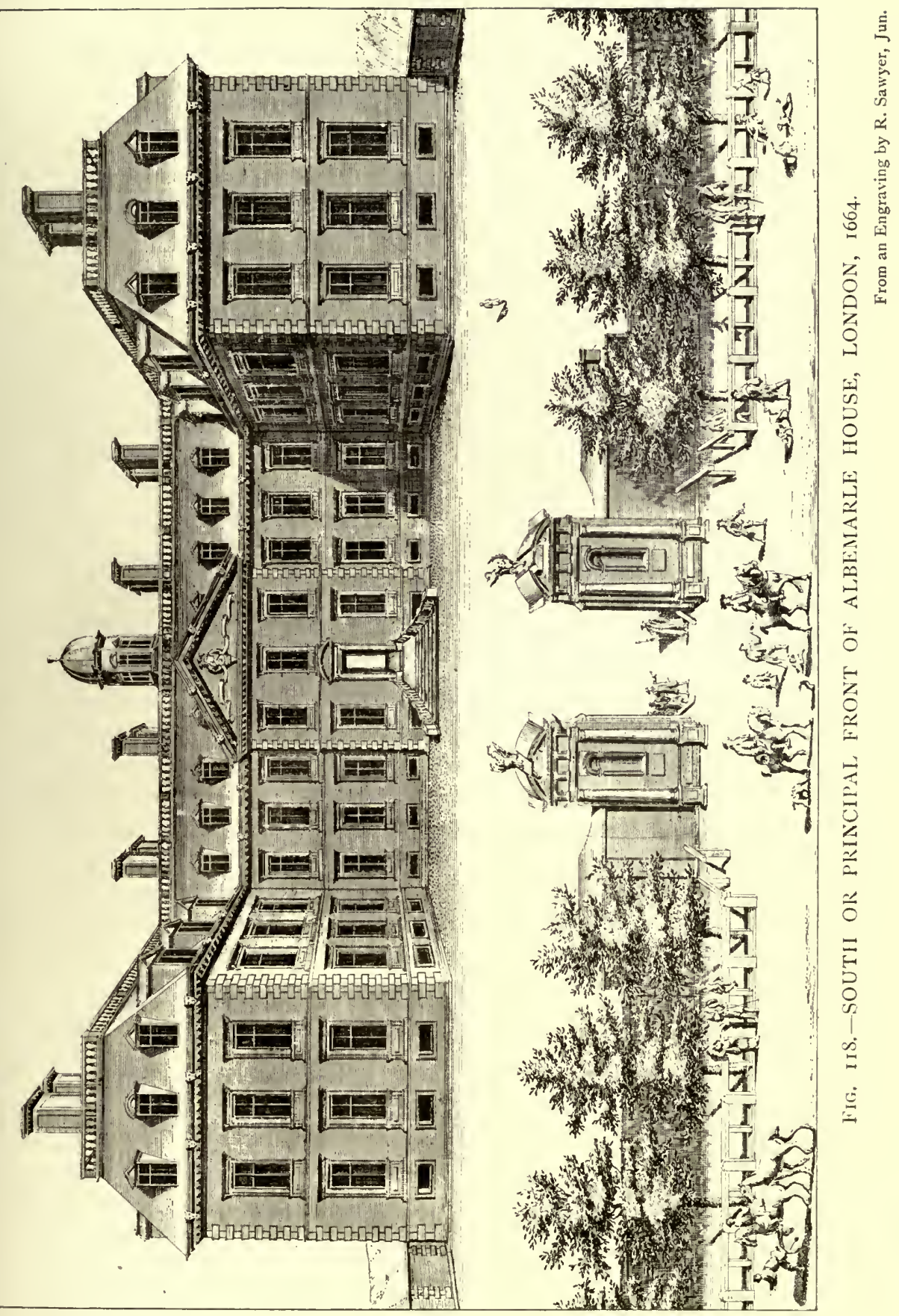
his long residence in France. The second building ascribed to Hooke is the old Bethlem Hospital, likewise begun in 1675 and pulled down in I8I4 (Fig. I I6); and the third is Aske's Hospital at Hoxton, begun about 1688. Engravings of the last two buildings (there is no record of the first Montagu House) do not lead to the opinion that Hooke was a great master of architecture, although it is true that the long front of Bethlem Hospital is handled in a simple, straightforward manner. $\mathrm{He}$ was far behind Wren, but he is interesting as being another whose training led him, under the special conditions of the time, into active practice.

Lord Chancellor Hyde, Earl of Clarendon, built a fine house during the heyday of his prosperity, on a site in Piccadilly, opposite the top of St James's Street (Fig. I I8). It was highly extolled by Evelyn (especially when writing to Lord Cornbury, the chancellor's eldest son), and after him by Pepys, who went to see it, "hearing so much from Mr Evelyn of it." He declared it to be the finest pile he ever did see, and on a subsequent visit he climbed with some trouble to the top, and there found the noblest prospect that ever he saw, Greenwich being nothing to it. The engraving hardly bears out this extravagant praise, but it must have been a stately house. The architect was Roger Pratt, afterwards knighted, another of the men whom the great fire appears to have brought into the service of architecture. ${ }^{1}$ Evelyn mentions him more than once; he was a fellow commissioner of his in the inquiry as to the rebuilding of St Paul's, and Evelyn had met him years before in Italy. The house was begun in 1664, and was approaching completion in November I666. But misfortune dogged it from the outset. The populace, with whom Clarendon was no favourite, dubbed it Dunkirk House, in allusion to his supposed connection with the sale of that town to the French. The chancellor occupied it but a single year before he fled the country; his son occupied it for another year or two, and it was then let on lease to the Duke of Ormond. After Clarendon's death at the end of 1674 , it was sold to the second Duke of Albemarle, and became known as Albemarle House; he again sold it some three years later to a kind of building syndicate, who in a few years pulled it down and laid out its site and the surrounding land in streets, one of which was called Albemarle Street, and another Bond Street, after Sir Thomas Bond who was one of the principals concerned in the transaction. The house was regarded as an 


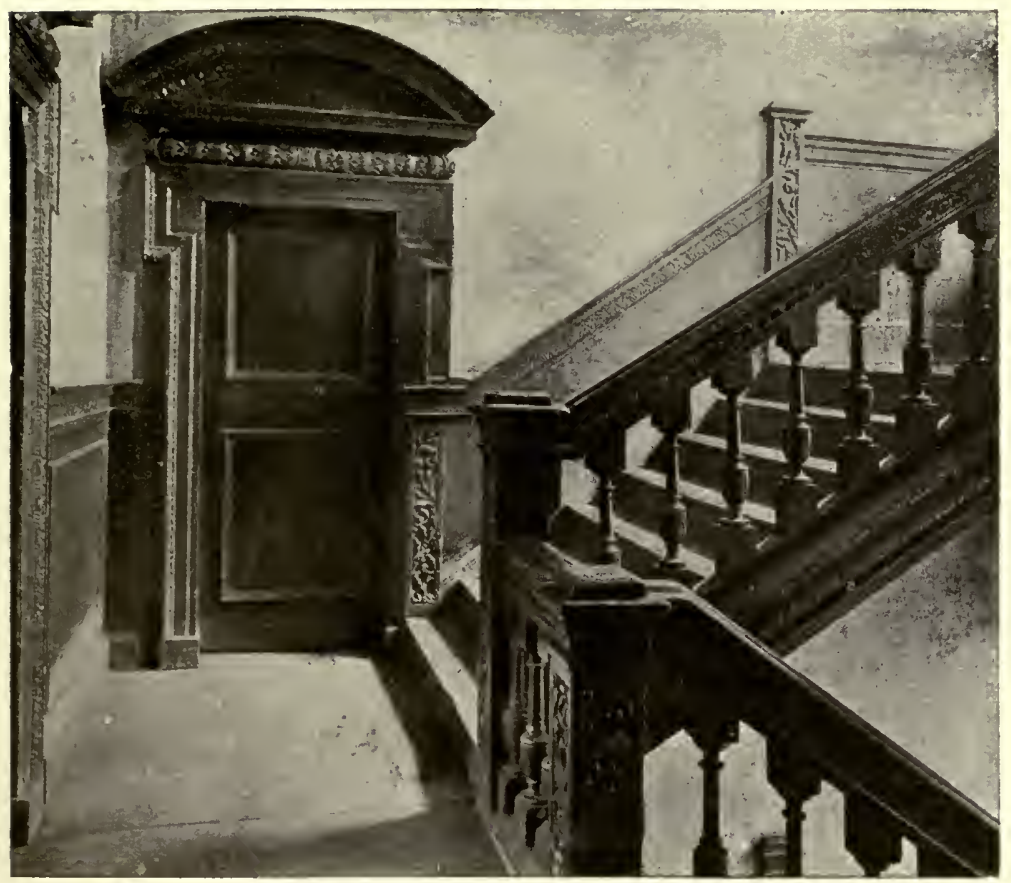

FIG. I I 9.- Staircase of a House between Love Lane and Botolph Lane, London (demolished in 1906).

unwarrantable extravagance, and Clarendon himself is reported to have eventually looked upon the building of it as a "vanity and folly." But after all it only cost $£ 50,000$, which was a small sum compared with the cost of many houses both before and since. It is interesting because of its short life-less than twenty years from foundation to demolition-and from the character of the design, which follows the lines laid down by Jones and Webb.

Apart from the large houses which were built for wealthy persons, the new London which sprang up after the fire must have been widely different from the old. The houses which were burnt down were, many of them, built of wood and plasterrelics of mediæval times. Their fronts leaned across narrow lanes, each story projecting over the one beneath it, after such a fashion as may still be seen, though ever less frequently, in some of our ancient country towns. The houses which replaced them followed in most cases the old frontage lines, but their fronts were vertical and admitted as much light and air as the width of the street allowed. Nevertheless, the width was fre- 


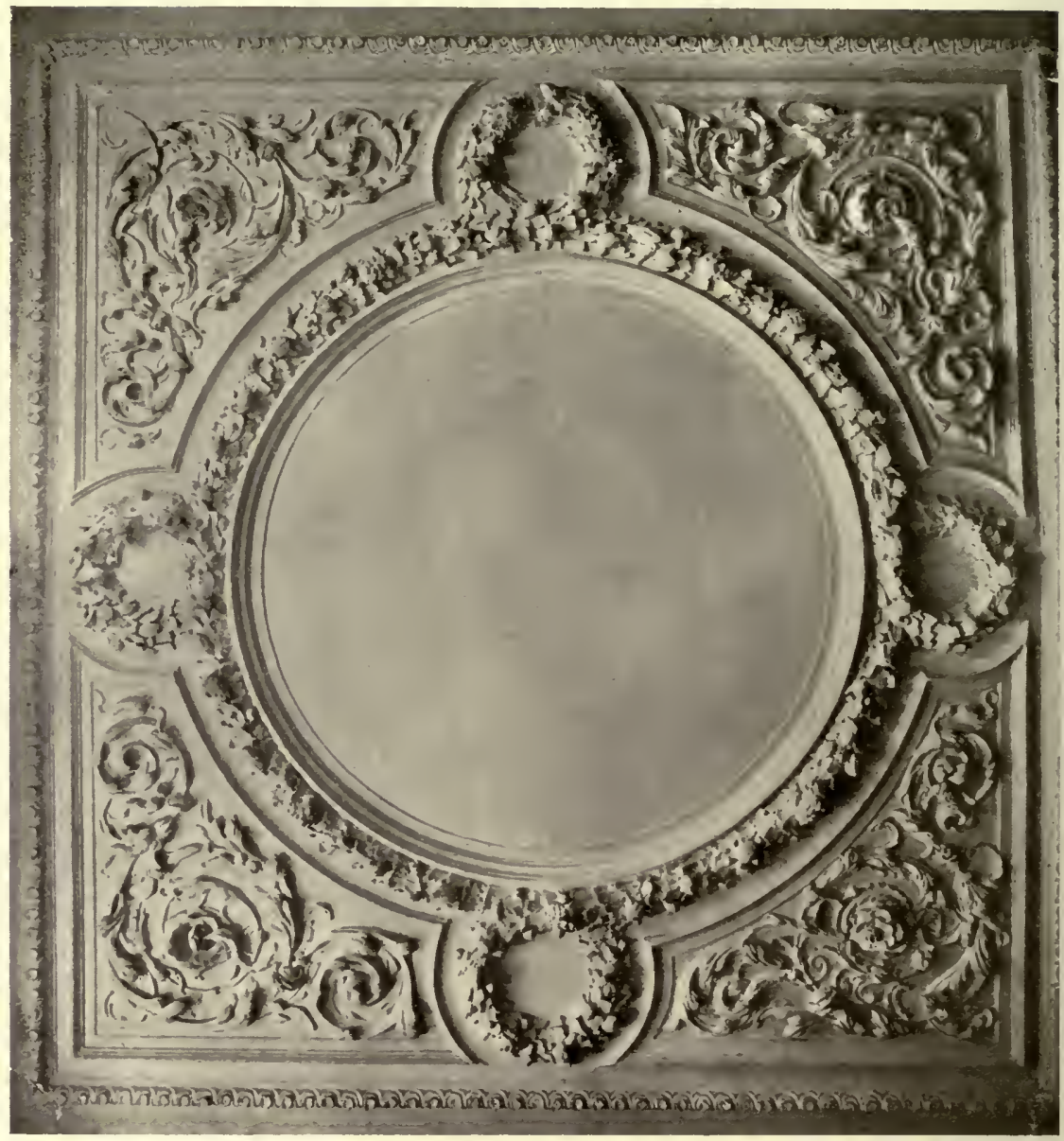

FIG. I 20. - Ceiling in a House between Love and Botolph Lanes.

quently but little, and houses of great size and finely treated within, were built in streets and lanes which in the present day we should regard as mere alleys, and which, indeed, would not be permitted under any modern by-laws. London still preserves many of these old houses (Fig. I I7), although they are gradually being improved away. They are generally built of brick, with very little relief to their fronts save a good doorway and a good cornice, and perhaps a few touches in some ironwork. The same general treatment prevailed for half a century or more, with a tendency, however, to even greater simplicity; the result was that, although in the city where the narrow lanes were crooked and had here and there unexpected projections, the effect was 

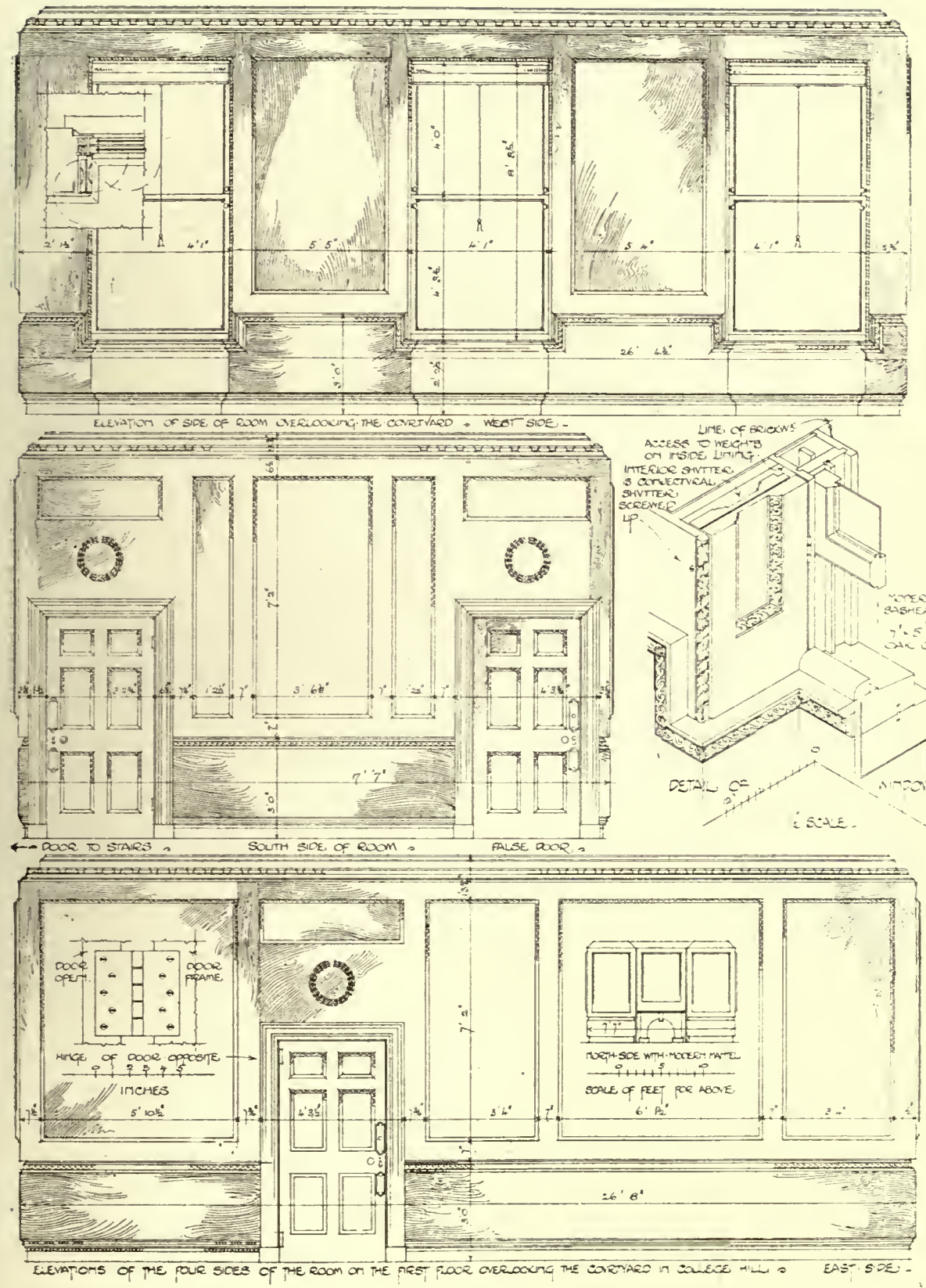

Fig. I2I.-HOUSE IN COLLEGE HILL. DETAIIS.

Lawrence Furniss, del.

Illustration reproduced by permission of Messrs Technical Journals, Ltd. 

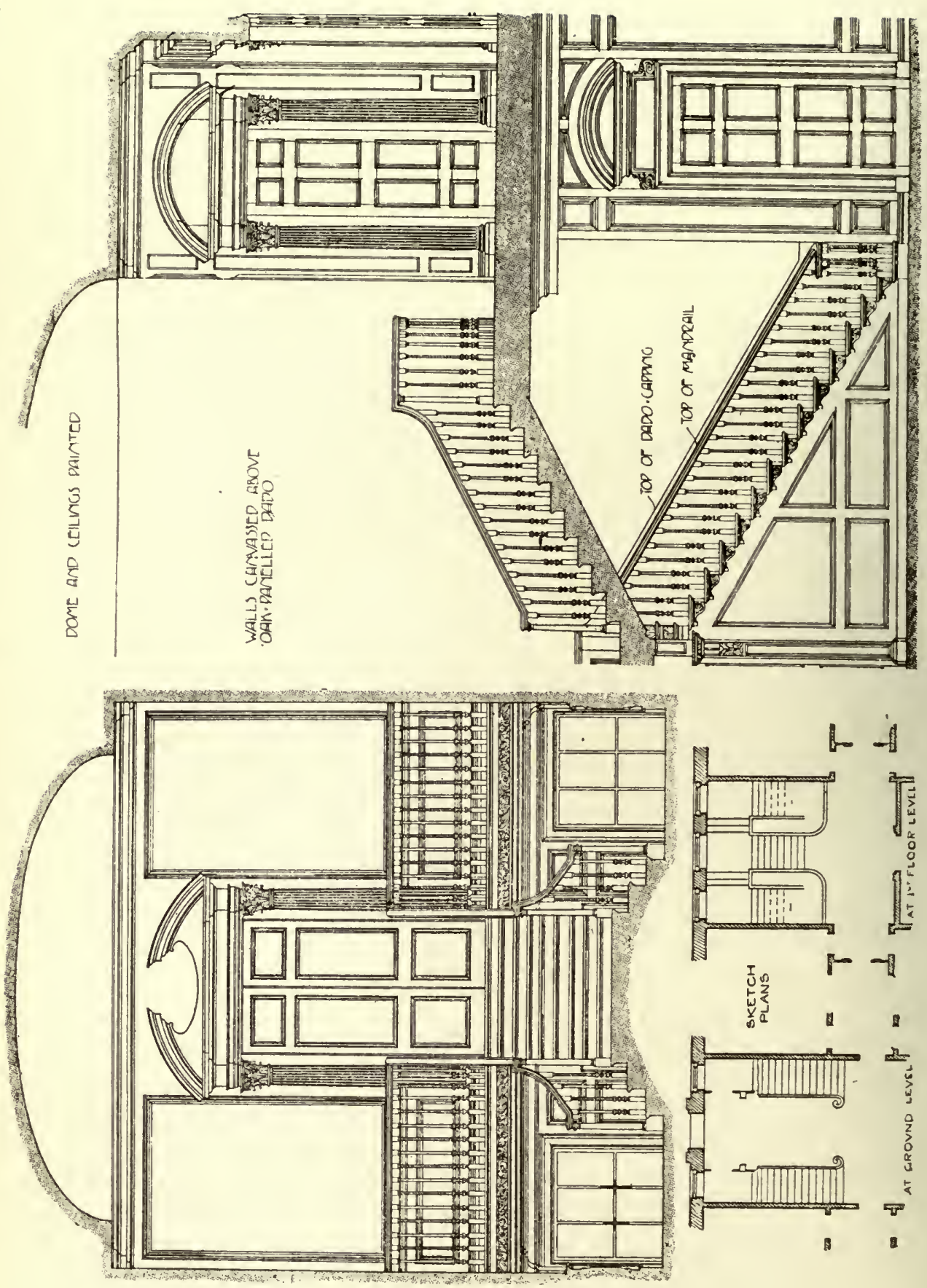
interesting, yet where the same plain treatment was applied to long straight streets, the effect became dull and monotonous. Most of these houses had interesting detail within them, many of them were actually sumptuous, and of a richness suitable to the merchant princes who dwelt there. They had fine staircases and ceilings like those in a house in Botolph Lane (Figs. I I9, I 20), and good doorways and panelling like that in a house in College Hill (Fig. I2I).

A fine example of the treatment, prevalent at this period, of a staircase and hall was to be seen, before its destruction, at the Great House at Leyton, in Essex, not far from London (Fig. I22). It is designed in a broad, simple, yet monumental manner, which, however, has led to the dividing of the lower part of the staircase into two separate flights, which merge into a single flight of the same width at the half-landing. The treatment is not quite logical, but_which was held to be more important-it is symmetrical. The Great House was built by Sir Fisher Tenche, Bart., whose father was an Alderman of London, and it is a good example of the houses built by wealthy citizens out in the country, but within reach of the city. ${ }^{1}$

Although, strictly speaking, rather outside the subject of domestic architecture, the city halls and churches should not be overlooked, as they contain splendid specimens of decoration in wood and plaster of the same kind as those to be found in houses. At the period under consicleration, as in former times, the same sort of embellishment was applied to churches as to houses; it is quite a modern idea, born of revivals and restorations, to consider it necessary that a church should be Gothic in style; to think of Gothic as essentially ecclesiastic and of Classic as secular. Accordingly in Wren's churches there are admirable bits of woodwork, which illustrate the methods of design then in vogue in houses. So, too, in the halls of the great city companies. All this work was the consequence of the destruction of the older buildings by the great fire. The new church of St Lawrence, Jewry, was begun in $167 \mathrm{I}$, Wren being the architect, and it was opened in 1677 . The woodwork of the interior is as fine as anything that this age of fine woodwork produced, and that of the vestry is designed after the same fashion as the panelling and doorways of a large house (Fig. I 24); it is, if anything, more

${ }^{1}$ See "The Great House, Leyton," by Edwin Gunn, published by the Committee for the Survey of the Memorials of Greater London, 1903. 


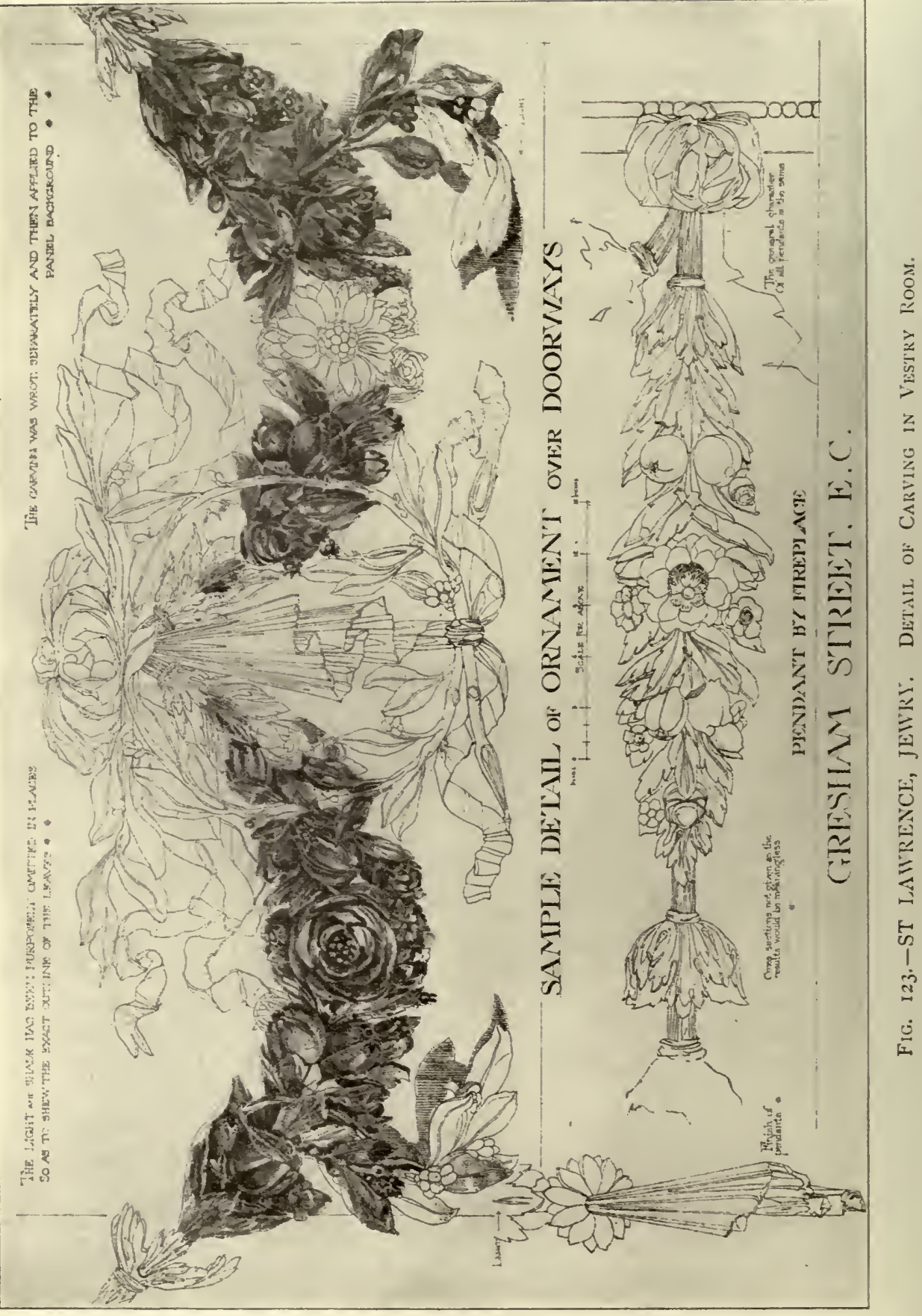




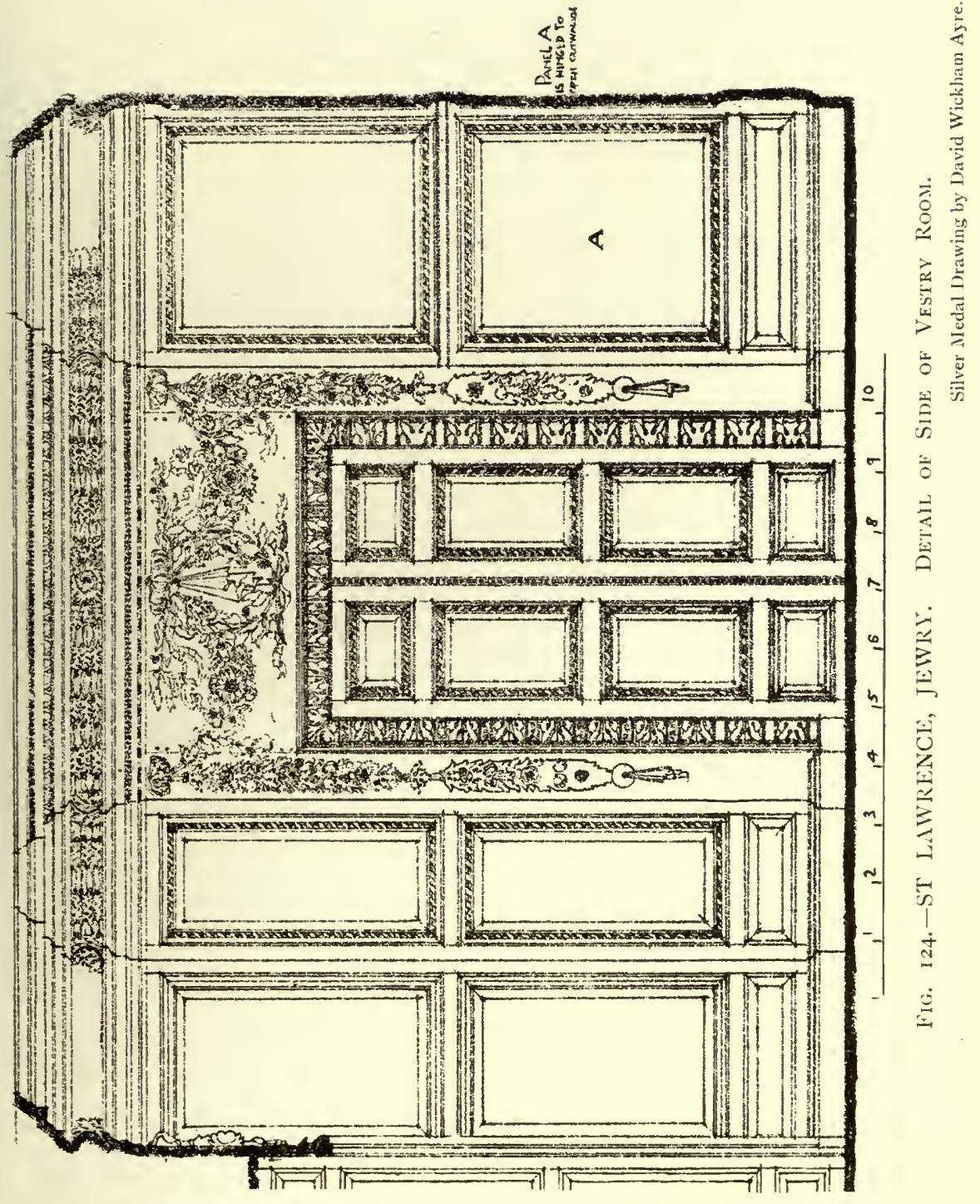




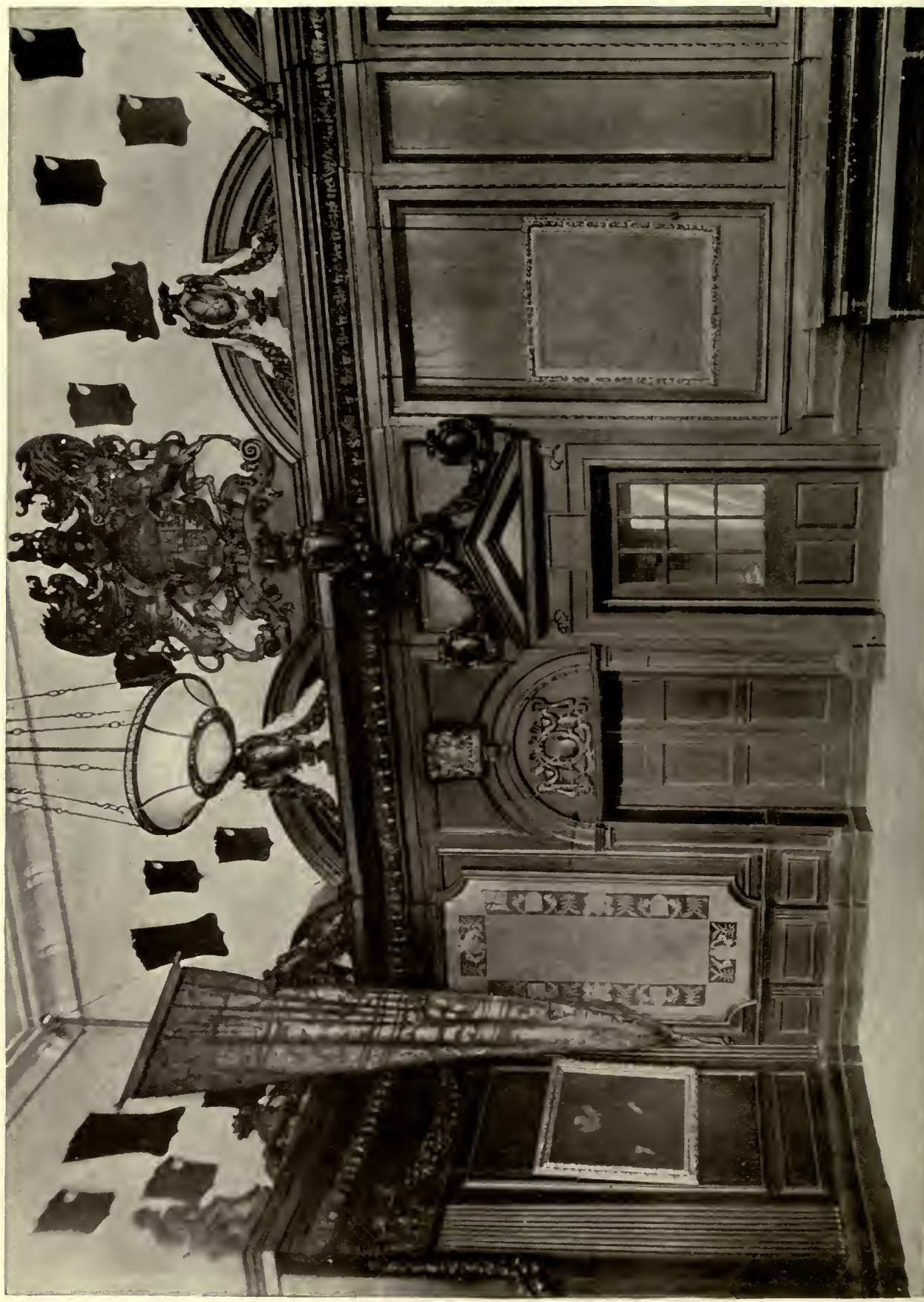

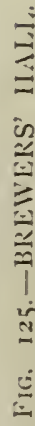




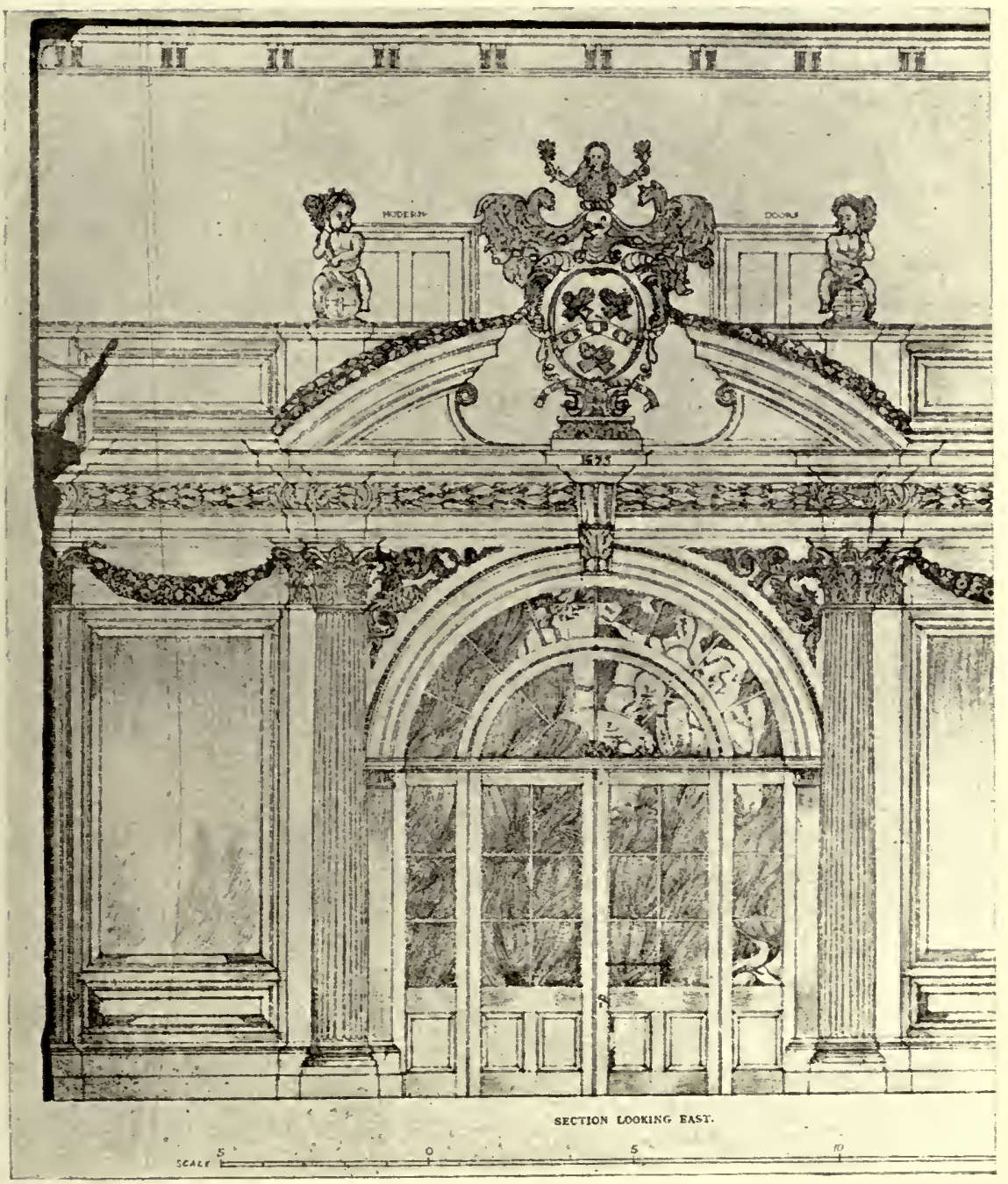

- FIG. I26.-Brewers' Hall.

superb. The carving (Fig. I23) is almost certainly the work of Grinling Gibbons. St Lawrence is one of the best furnished of Wren's churches, but many others possess admirable fittings such as pulpits, pews, organcases, galleries, and doorways, boldly designed and richly decorated, which show what a high excellence the joiner's art had achieved under Wren, Gibbons, and their chief craftsmen. 


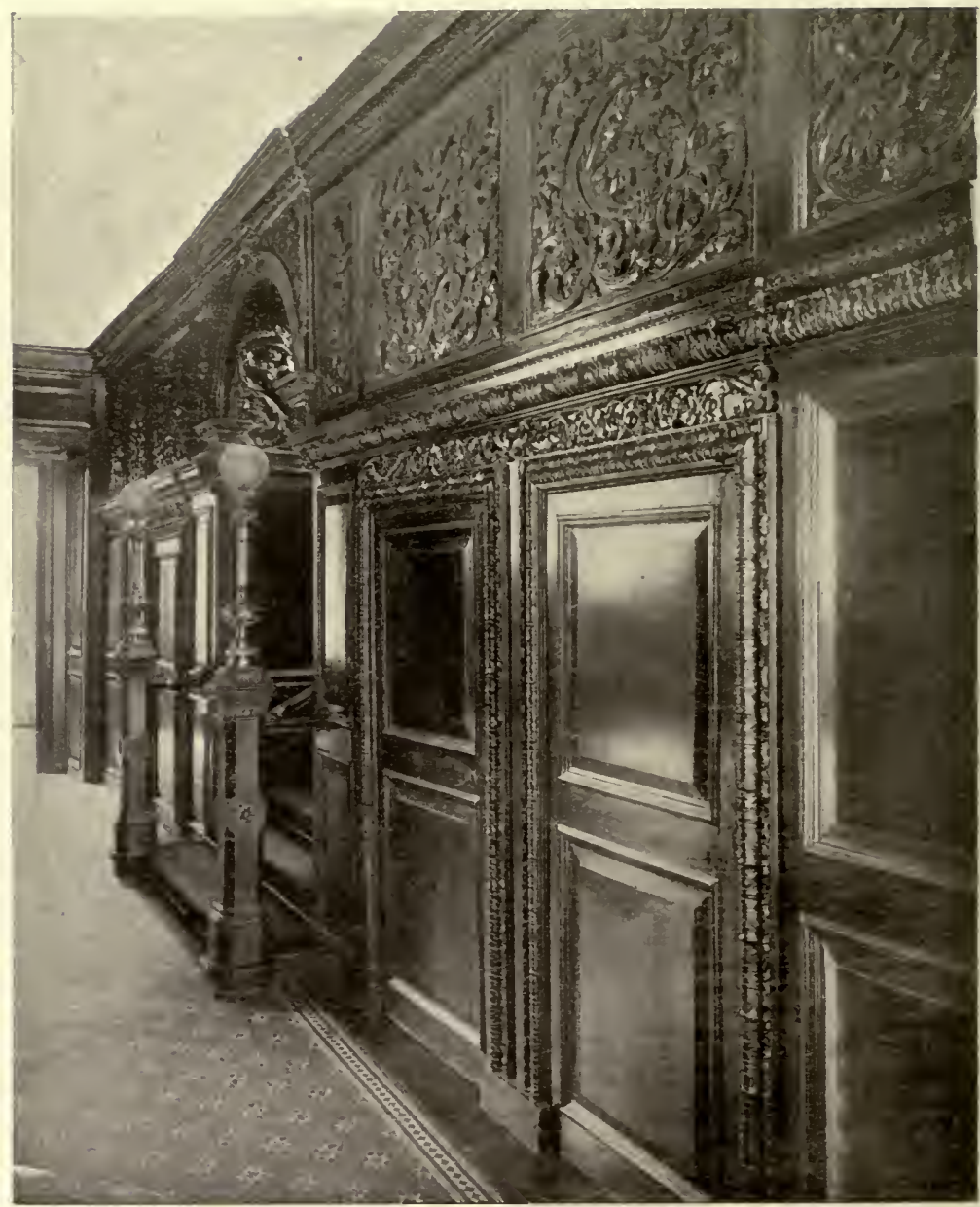

FiG. 127.-Girdlers' Hall, London.

One of the most interesting of the city halls is that of the Brewers' Company, in Addle Street. It has undergone restoration and some amount of alteration, but the principal floor, which contains the hall and council chamber, still retains much of its original flavour. The walls are panelled in large panels (Fig. I25), the hall is entered through a screen with a splendid doorivay (Fig. I26), and the council chamber has a fine fireplace. This is as good an example as could be found of the manner 


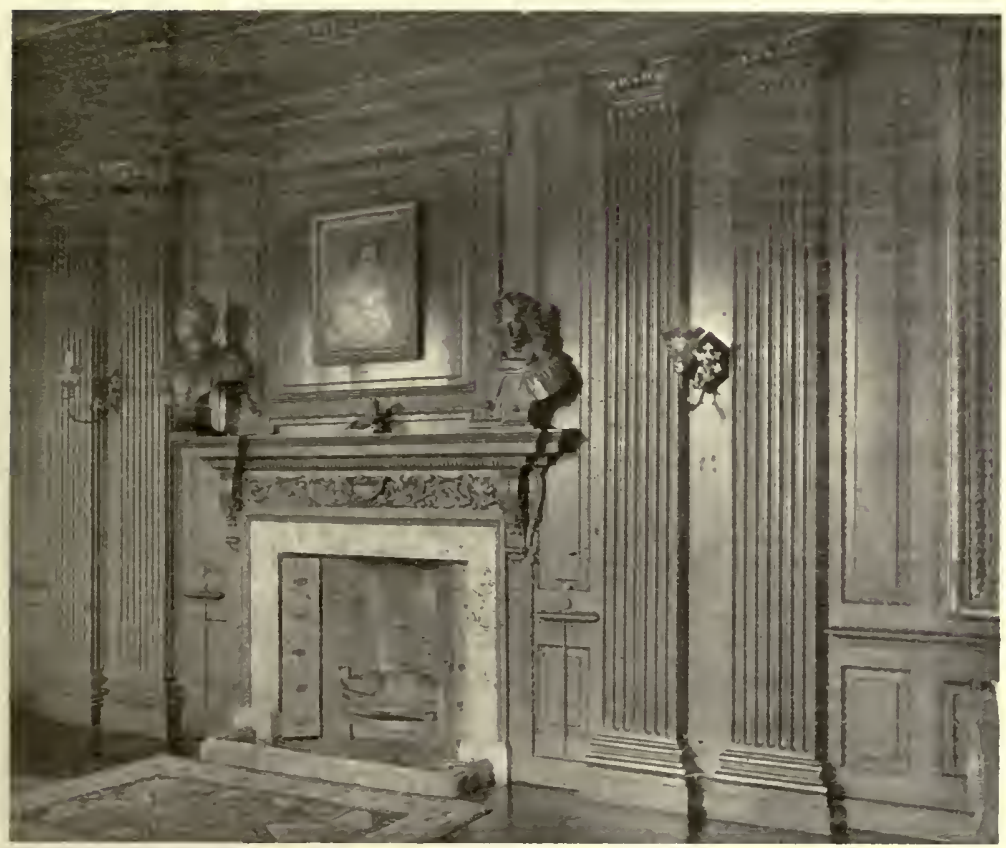

FiG. I28.-The Deanery, Wells.

of panelling and decorating large rooms which prevailed at the time it was built, namely, 1673. The Stationers' Hall has as fine a screen and doorway as those of the Brewers, and indeed most of the city halls, in spite of modern renorations, retain good work of this period, among the less known examples of which is the rich panelling at Girdlers' Hall, in Basinghall Street (Fig. I 27).

Outside London there was a large amount of work done during this period, much of it fresh and interesting. Stapleford Park, in Leicestershire, a house with a long history and possessing some unusual deftail of the date of 1633 , was considerably altered and enlarged about the time of Charles II. by Bennet, Lord Sherard, who was in possession from I640 to I700. The exterior is plain, but in the interior are two rooms, with charming woodwork; the door of the dining-room is illustrated in Fig. I 30, and that of the library in Fig. I 29. The two doors differ, but they are alike in that each is placed on a slight projection which causes a break in the main cornice of the room. The 


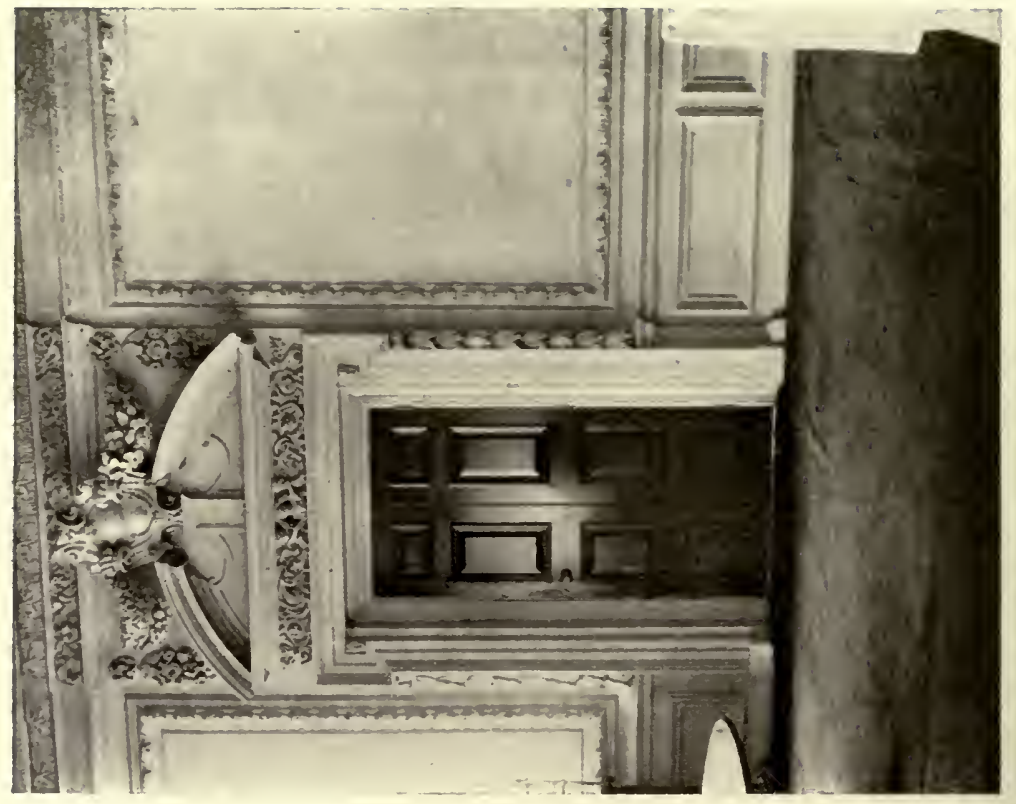

$\stackrel{2}{8}$

:

:

产

는

บ.

路

웅

in

$\stackrel{3}{3}$

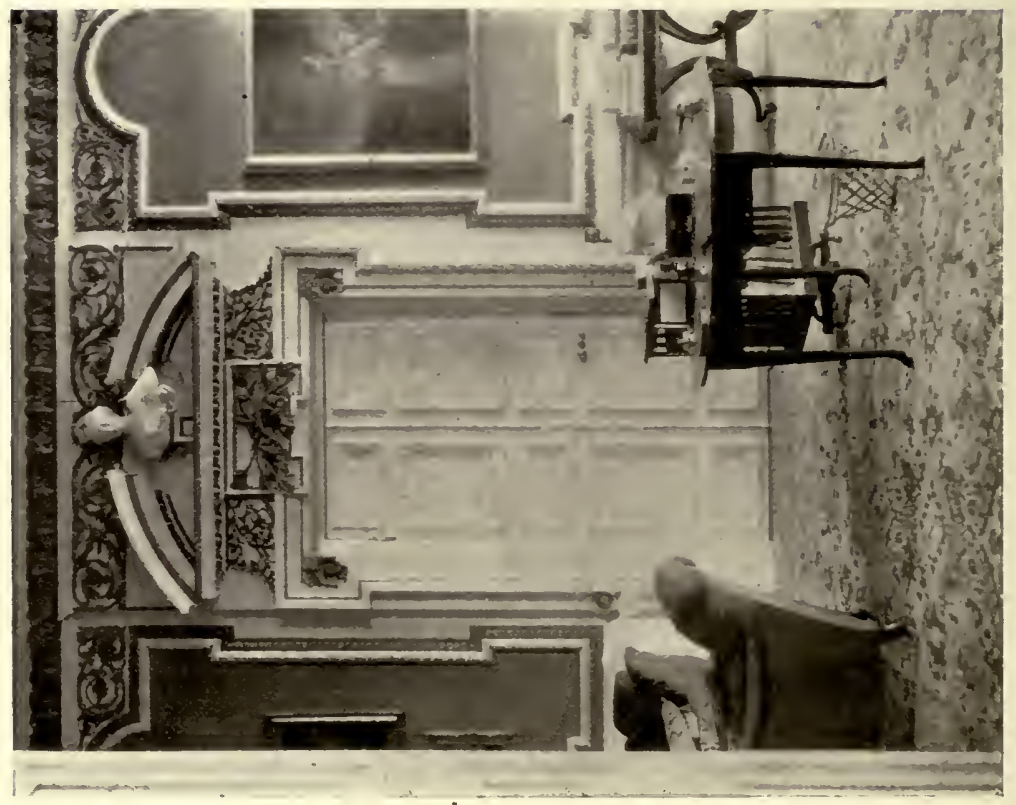

อ 造 สำ

$\approx \equiv$

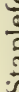
荥

$\stackrel{1}{3}$ 
dining-room has large panels with a boldly carved bolection moulding. The door has a broken pediment in the gap of which is placed a shield connected by heavy swags to the surrounding work. This was a common feature of the period. The library door is of much the same type, but instead of a shield there is a bust. The panels on the walls are formed by a bold moulding, which is broken backwards and forwards into a pattern that recalls the busy treatment of Jacobean work.

In the Deanery at Wells is a fine panelled room attributed to Sir Christopher Wren, and certainly wrought after his style if not actually designed by him. The walls are divided into bays by heavy Ionic pilasters, the spaces between which are filled with large panels. Here, too, the bolection moulding is carved, as well as several other members, the whole effect being rich and handsome (Fig. I 28).

Melton Constable stands in a park amid the undulations of the western part of Norfolk. It is a fine simple house of about the year I680 (Fig. I3I). The eaves cornice gives it its chief character; the rest of the detail is correct, but strikes the modern eye as being a little hackneyed; but this is the fault, not of the original architect but of his successors, who, if they did not copy this actual work, drew, one after the other, upon the same well of inspiration.

These examples serve to illustrate the progress of house design during the later years of the seventeenth century ; they show how the fully dereloped classic manner had superseded the homely treatment of Jacobean times. Its further career of grandeur and stateliness demands a fresh chapter for its consideration. 


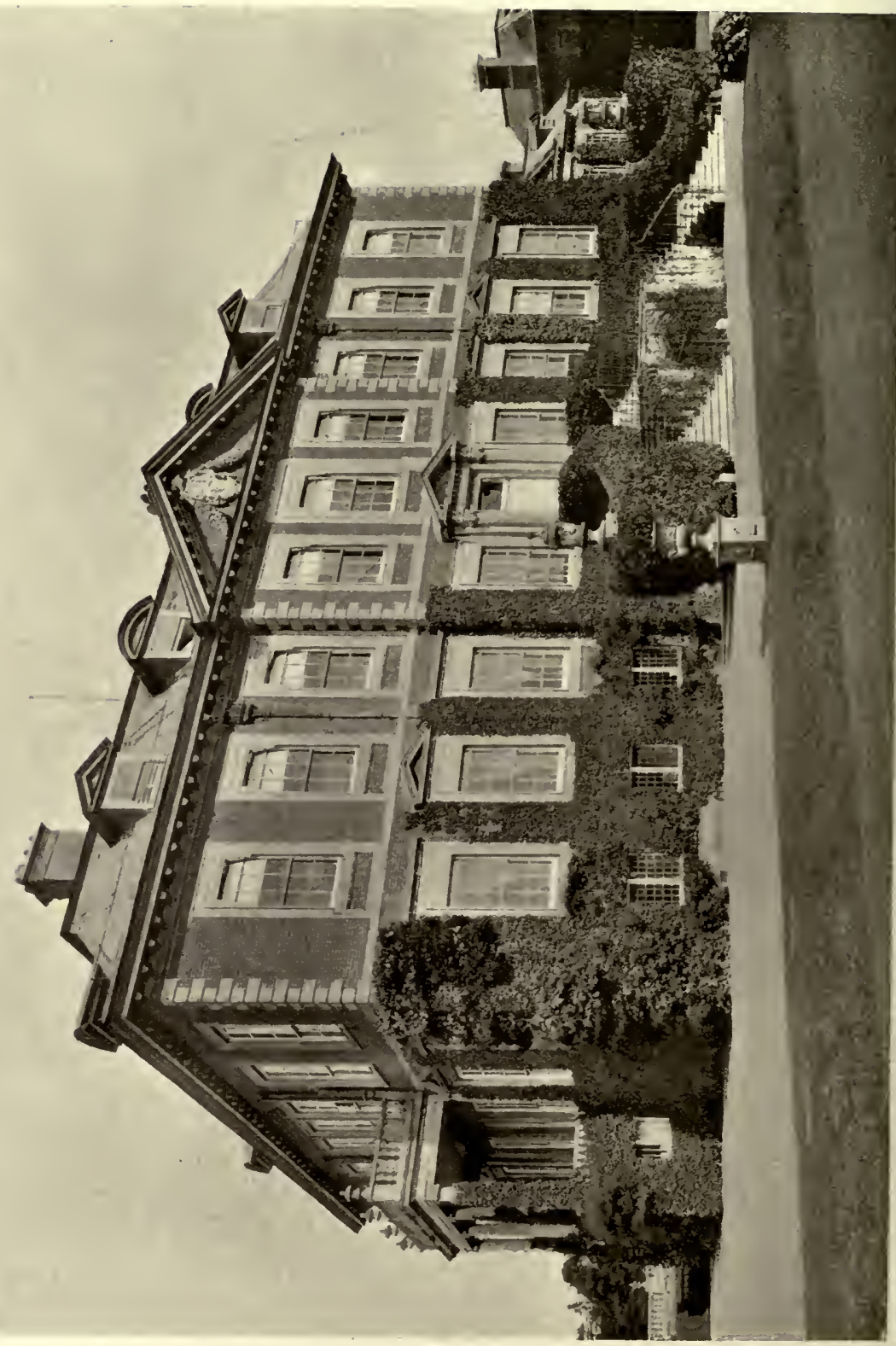

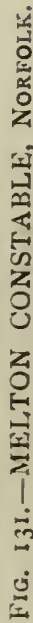




\section{VIII}

\section{GREAT HOUSES AND GARDENS OF THE EARLY EIGHTEENTH CENTURY}

TwENTY-FIVE years after his restoration Charles II. died; James II. passed uneasily across the scene to his inglorious exit, and William and Mary succeeded him on the throne. But it is not to the sovereigns that we must look as pioneers in house building, although at Greenwich and Hampton Court fine work was accomplished. It is rather to the great nobles, or at least to aristocratic and wealthy families, that we owe the most notable specimens of domestic architecture of the time. At this period the gulf between the upper and lower classes was wide and deep: its widening was perhaps one of the reactions from the conditions of the Commonwealth when many persons of humble origin fought their way to eminence. The distance between the heads of a great household and their retainers had been increasing all through the century; the increase has already been indicated in the type of plan adopted by Jones and V'ebb. The great hall, where the whole family used to meet on common ground and with common objects, had disappeared. The great noble of Elizabeth's time lived among his retainers; the grandee under William and Mary relegated his servants to a distant part of the building or to the basement. The great ones of the land now housed themselves in splendid buifdings, and surrounded themselves with splendid gardens. Nobody grumbled; the whole community concurred in this exaltation of birth combined with wealth. Men whose names to us are household words sought the patronage of others whose names and doings are hardly. recorded outside the pages of the "Complete Peerage." Manners, customs, dress emphasised this condition at the time; architecture reflects it to-day. 
Boughton House, near Kettering in Northamptonshire, is a good example of a home of one of the great nobles of the time of William and Mary. Ralph Montagu (afterwards Duke of Montagu) succeeded his father as Lord Montagu of Boughton in I68I. In 1669 he had been appointed ambassador extraordinary to France, and during his stay in that country he lived for a considerable period at Versailles. One of his biographers ${ }^{1}$ says that "here it was his Grace formed his idea

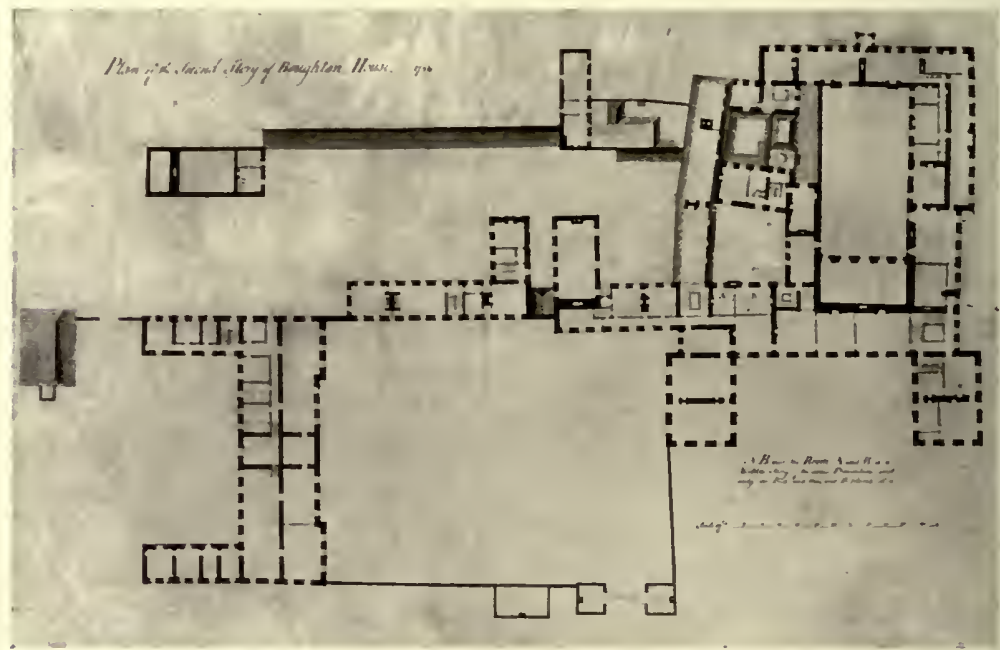

F1G. 132.--Boughton House, Northamptonshire. Plan of the Upper Story, 1736.

From a Plan preserved in the house.

The front at the bottom of the plan faces north. The house lies to the right of the plan, the stables to the left. The entrance to the house is between the two wings on the north front. Remains of the original house are to be found in the great hall situated at the north end of the oblong court, and in the two sides of the same court.

of building and gardening, erecting his seat at Boughton, in Northamptonshire, after the pattern, and as his Dimensions would allow, after the very model of Versailles." In I695 he entertained King William and Queen Mary at Boughton for fifteen days. He had been created Earl of Montagu by William in 1689 , and in 1705 he was created Duke of Montagu by Queen Anne. He was, therefore, a great personage, and he 


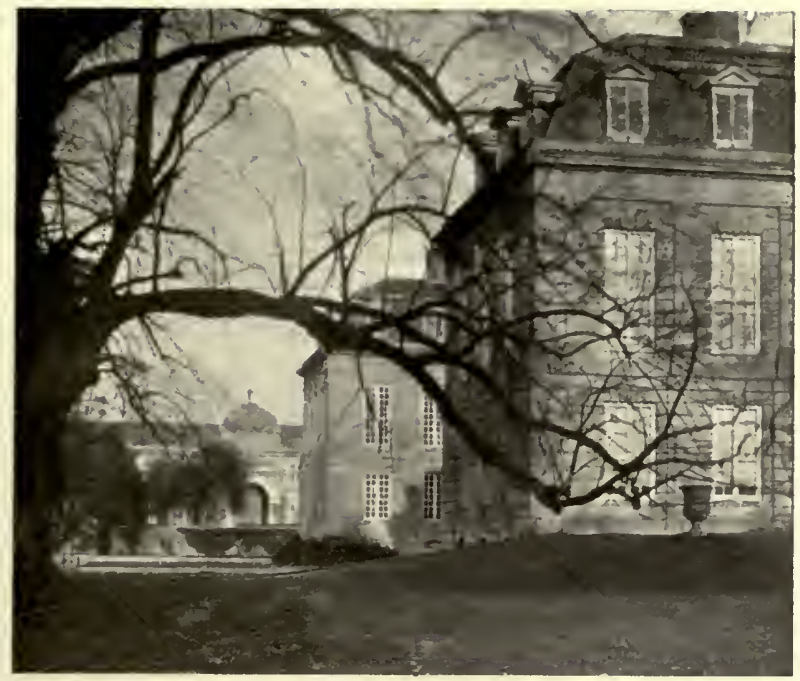

FIG. 133.-Boughton House. North-Front of House, with Stables beyond.

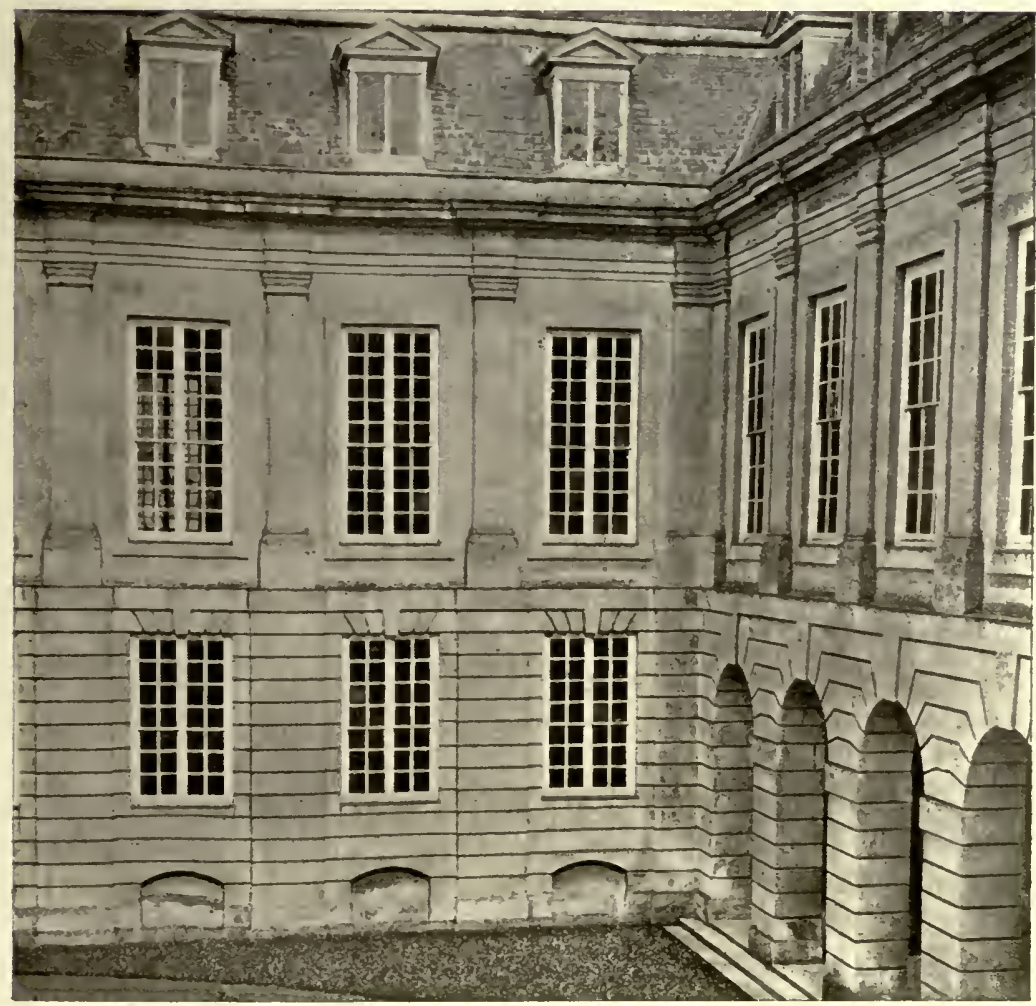

FIG. I34--Boughton House. A Corner of the Entrance Front. 


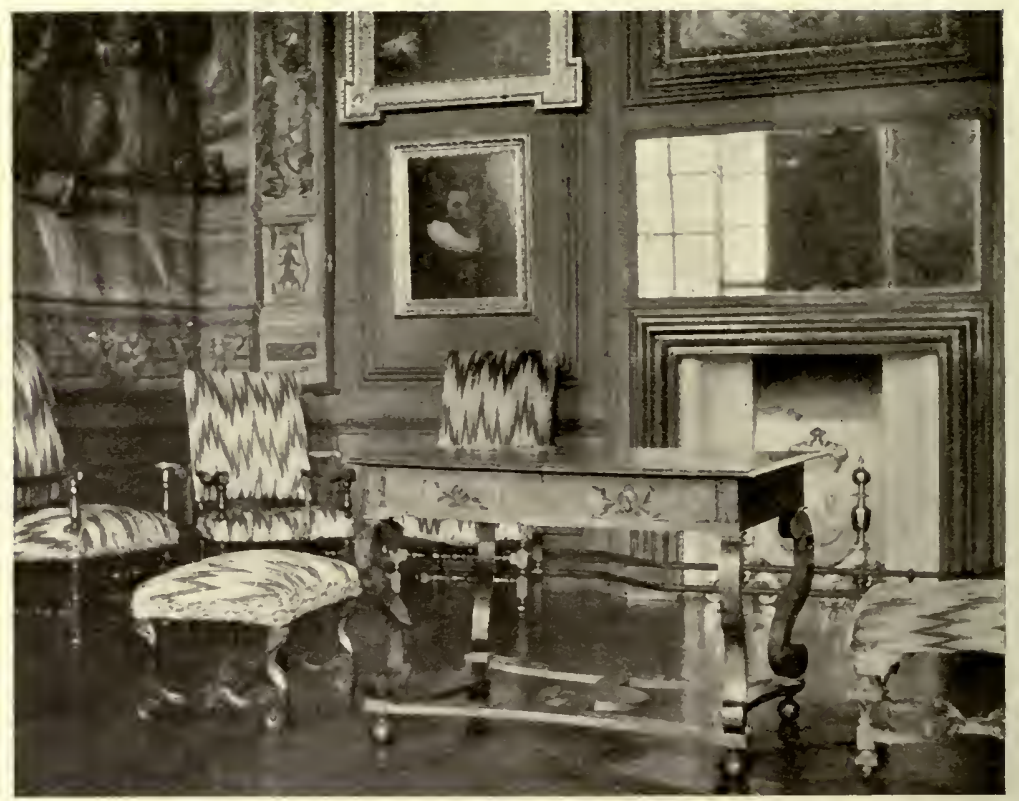

FiG. 135.-Boughton House. One of the State Rooms.

made his house and its surroundings of a magnificence suitable to his dignity.

An ancestor had already, in the middle of the sixteenth century, built a fine house at Boughton, with a great hall covered by a roof of unusual beauty and excellence, and with wings and adjuncts of considerable extent. Ralph, Lord Montagu, proceeded to overlay this old house with his new work so completely (see plan, Fig. 132) that it is only here and there, on the removal of panelling, or in the course of some minor alteration such as must from time to time occur in these old houses, that traces of the original building can be found. Fortunately the roof of the hall was preserved, but it was hidden, and remains hidden, by a new plaster ceiling on which Cheron painted a large and elaborate composition. The old house was taken as the nucleus of the new, but it was extended in various directions, especially on the north side, where a range of state rooms was erected with two boldly projecting wings (Fig. 133). It is this part of the house which is reminiscent of Versailles, if the lofty windows and Mansard roofs can really be said to remind one of that vast and 
much more ornate palace. But the style of this particular work bears a certain resemblance to the grand stable buildings at Versailles; it is large in scale, sober and dignified in treatment (Fig. I 34). Indeed, it is so severe as to be thought dull by the casual visitor.

This reproach is not brought against the interior. The rooms are large and stately; their walls are panelled with the great, boldly moulded panels of the period (Fig. I 35); their ceilings are painted with the gay mythological subjects of Verrio and his school (see Figs. 3IO, 3II); the floors are filled with the tables, chairs, settees, cabinets, and bedsteads of the time. Portraits of the family ${ }^{1}$ hang on the panelling, there are mirrors in which their glories were reflected, and knick-knacks which they handled. In other wings are rooms of less stateliness, intended for daily use; in the attics are long rows of still plainer rooms intended for the servants.

At the time it was built the house, no doubt, answered its purpose admirably; but times change and we change with them ; and eventually the rooms were found to be cold, draughty, and inconveniently arranged-one leading, as a rule, out of another. There was space enough, but there were none of the comforts of modern life; no baths nor even any supply of water laid on; it all had to be carried long distances. The house became less constantly in use, and to this fact is largely owing the preservation of its ancient character. Nothing brings home to the mind the changes that have taken place in manners and customs during the last two centuries so forcibly as an attempt to live in an old unaltered house, where even the cooking appliances, although on a grand scale, are ill-adapted to modern needs; and it is only by drastic alterations in some of the less notable rooms that Boughton has been fitted for modern occupation.

Ralph was succeeded in I 708 by his son John, the second duke, who carried on such work as his father had left unfinished. He is responsible for several fireplaces, among other things, on which he made a considerable display of heraldry. The difference between the motif of Duke John's heraldry and that of a hundred years earlier is that in the earlier work

1 An excellent annotated catalogue of the pictures has been prepared by Mr C. H. Scott and privately printed. The Boughton estates passed to the Dukes of Buccleuch (Montagu-Douglas-Scott) by marriage with an heiress of the Montagus. 
the aim was as much decorative as historic, while in the latter it was mainly historic. In James I.'s time the family arms were found to be excellent objects for ornamenting important panels, and if at the same time they ministered to family pride, somuch the better. In Duke John's case the aim of the heraldry is not so much to provide decoration as to set forth the descent of the ducal family and its alliances, especially the last alliance of all, the marriage of the Duke of Montagu with a daughter of the great Duke of Marlborough. It not inaptly illustrates the attitude of mind of the nobles of the time, their assumption of qualities which placed them on a plane above the rest of mankind, where "grandeur hears with a disdainful smile the short and simple annals of the poor." The rest of mankind, howerer, concurred in the assumption, especially those who stood in need of patrons, and the literature of the eighteenth century makes it clear that noblemen and persons of quality wielded an influence which made their goodwill worth cultivating.

It was only fitting that such notable personages should be worthily housed, and at Boughton the first two dukes surrounded themselves with suitable magnificence. The splendour was not confined to the house, it pervaded the surroundings as. well. The first duke planted a grand double avenue as wide as the whole façade of the house. He laid out the gardens on a large scale with parterres and wildernesses, long canals and jets d'eau (Fig. I 36). The water of the canals fell over a cascade of five stages into an ornamental pond. Intricate walks, somecurved and some straight, were left among the young trees. Statues gave point to the vistas. The second duke carried on the work both inside and outside the gardens. He planted a network of avenues extending for many miles in all directions; some of them centred on the house, others pointed to neighbouring churches, yet others converged upon an ancient oak marking the spot where, according to tradition, the last wolf in England was killed. They all linked up the ancient woods, remnants of the old forest of Rockingham. Many old plans are preserved at the house showing the growth of the scheme. There is also. an ancient plan of St Cloud in France showing the forests and avenues with which it was enclosed, and from the strong likeness. between the English maps and the French, it is not difficult to guess whence the duke's inspiration was derived.

The grandeur of the gardens has long been dismantled; the 


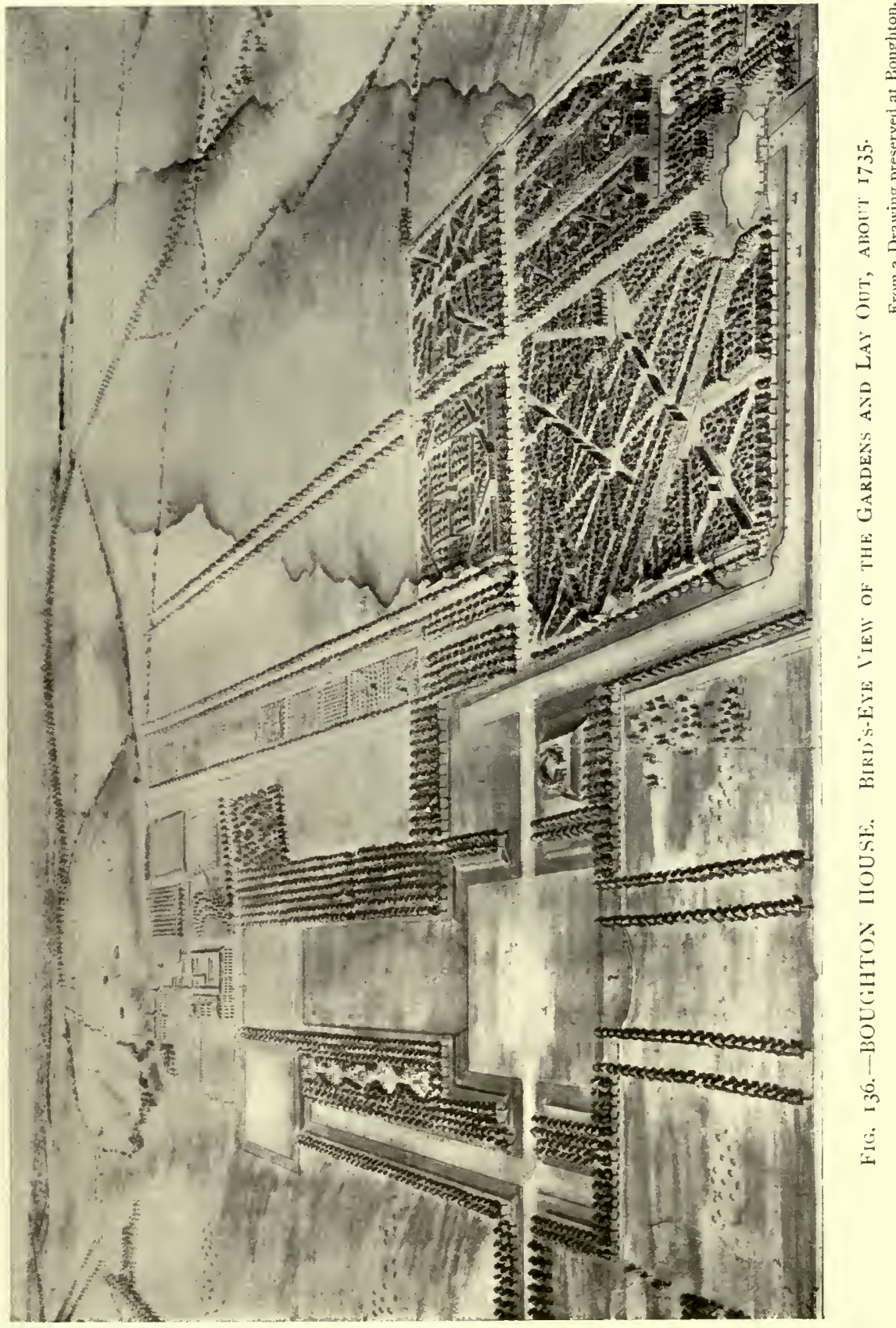




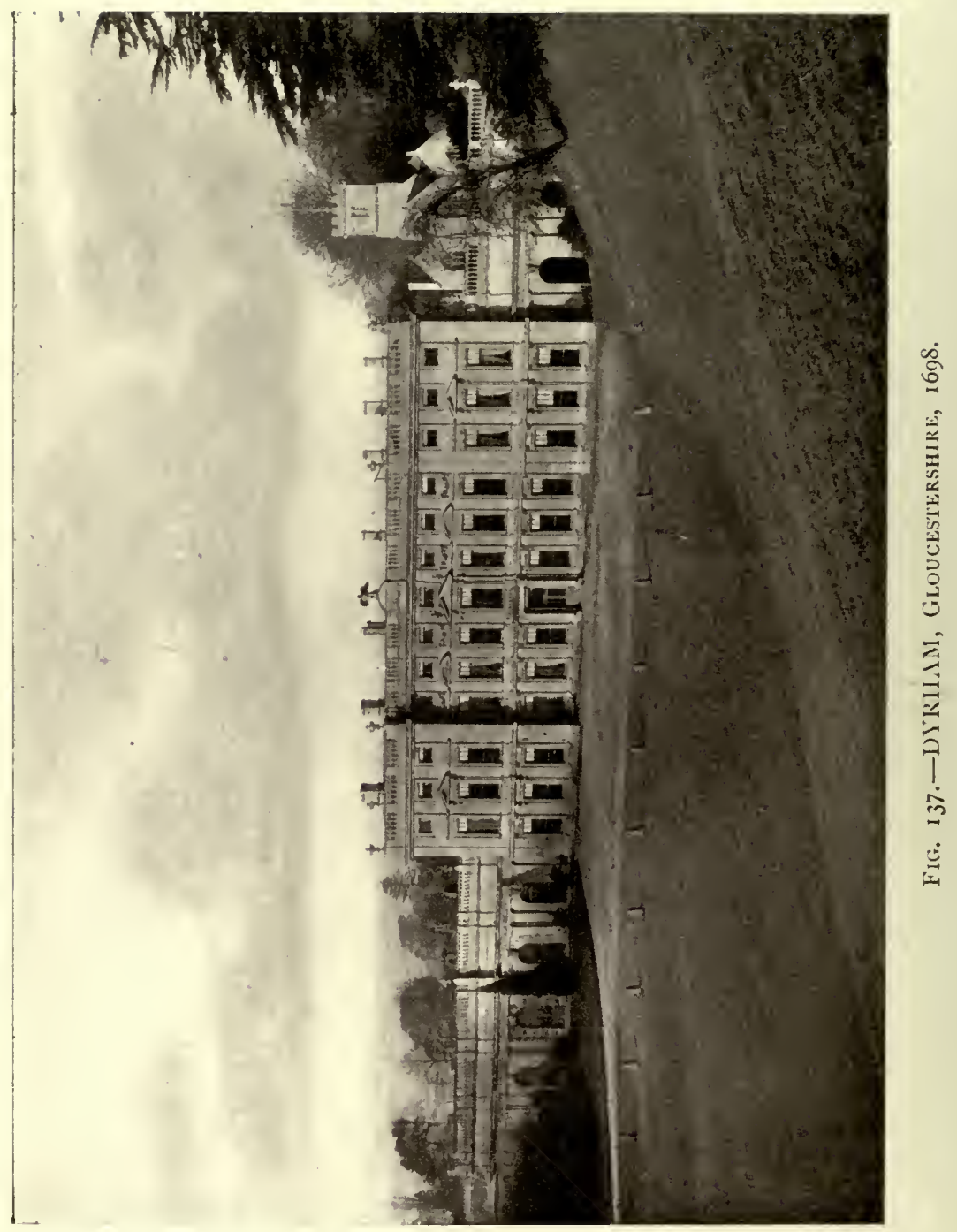


statues have disappeared, and some may be seen adorning other people's fields. The parterres are obliterated, and the intricate walks can no longer be traced; indeed time alone would have rendered them an overgrown tangle. But the great avenues still remain, still centre on the house, still point to the churches, still converge on the ancient oak, still link up the ancient woods. The canals are there, and would yet fall over the cascade were the floodgates lowered. Many of the little trees which formed
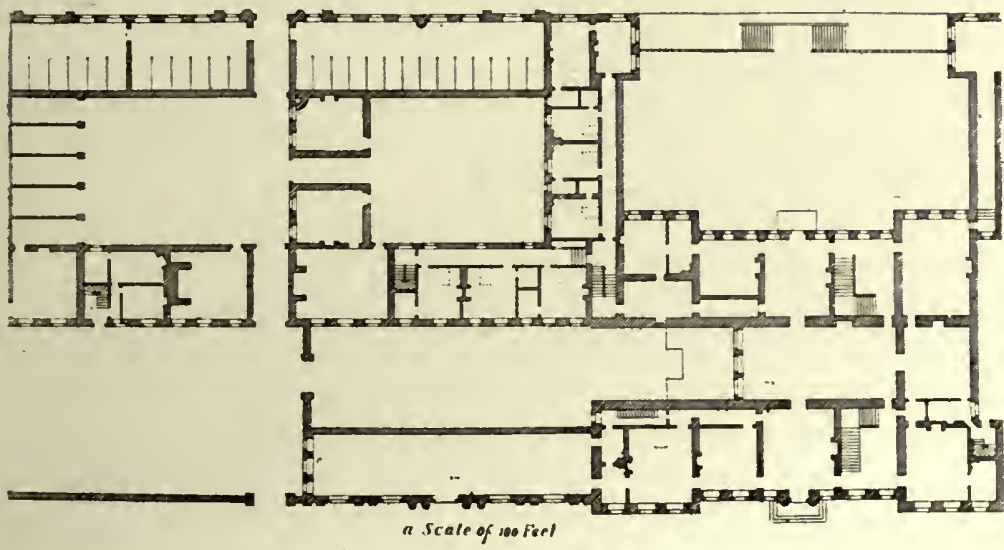

FIG. 138.-Plan of the Ground Floor of Dyrham.

curious patterns on the plans have grown into giants. Here and there a path survives, following part of its allotted route, enough to show that the original design was not merely a visionary scheme but was actually carried out.

Dyrham, in Gloucestershire, is another but somewhat smaller house of this period; it wa's built in 1698 from the designs of "the ingenious Mr Talman," as Campbell calls him, for William Blaythwayt, who was Secretary of State to William III. The property had come to him some thirty years before by a marriage with the heiress of the IVynters, whose ancient house was removed to make way for the new one. The site lies towards the base of a steep hill down which the road winds through a park, presenting a bird's-eye view of the house for some time before it is reached. The buildings stand on a level platform contrived among the declivities of the park, and from a terrace at the back a fine flight of steps leads down to the gardens. 
The entrance front (Fig. 137) is lengthened by the adjoining orangery, forming a façade of some $220 \mathrm{ft}$., of which the house itself occupies $130 \mathrm{ft}$. In the middle of this part is the front door, which opens into a hall (see plan, Fig. I 38 ). Immediately opposite is the door into the saloon, beyond which is a second hall, which leads out to the terrace. A vista is thus formed through the house and on to the gardens. The terrace is flanked on one side by the stable buildings and on the other by a corridor leading to the ancient church. The whole arrangement is symmetrical, stately, and interesting. Being on a reasonable scale the effect is dignified without being overpowering. Time has dealt kindly with the place, and there are no modern restorations to interfere either with the tone or the sentiment of the surroundings.

There is nothing particularly striking about the architecture of the interior, charming though this is; most of the rooms are panelled with the large and boldly moulded panelling of the period (Fig. I39), and there is one in which the effect is very happily enhanced by rich, though subdued gilding. The unusual charm of the house springs from the fact that very few alterations have been made, and that it retains its old furniture, books, and pictures, which combine to produce a fine feeling of old-fashioned comfort and culture.

From the plan (Fig. I38) it will be gathered that many of the rooms communicate with each other and are, in fact, thoroughfare rooms; and in this respect it must be granted that the comfort of those days differed from that of our own. It will also be seen that the saloon is lighted from one end only, an arrangement which, although rendering the room by no means dark, yet detracts somewhat from its cheerfulness and deprives it of all prospect.

An important point in the external treatment, differentiating this house from most of those hitherto mentioned, is that the roof is not visible. Webb made his roofs an important feature, bestowing much care upon their proportion and pitch; here the cornice is surmounted by an open balustrade, and the chimneys, instead of being made to attract the eye, are as inconspicuous as possible.

Talman had adopted the same treatment at Chatsworth, which was being built at this time ${ }^{1}$ for the first Duke of Devonshire (Fig. 140). Chatsworth is on a much larger scale than

1 It was begun in 1687 and finished in 1706. 


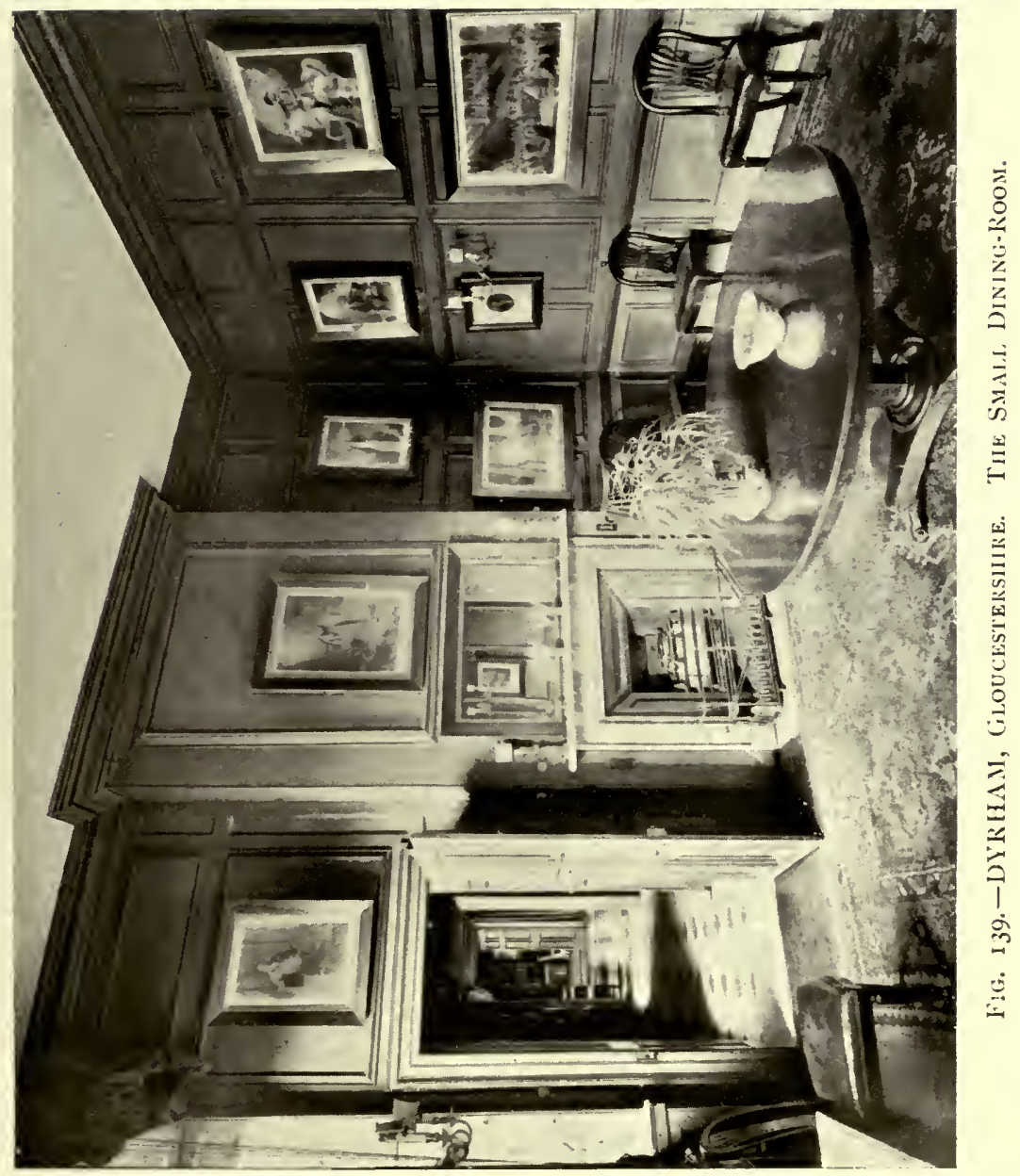




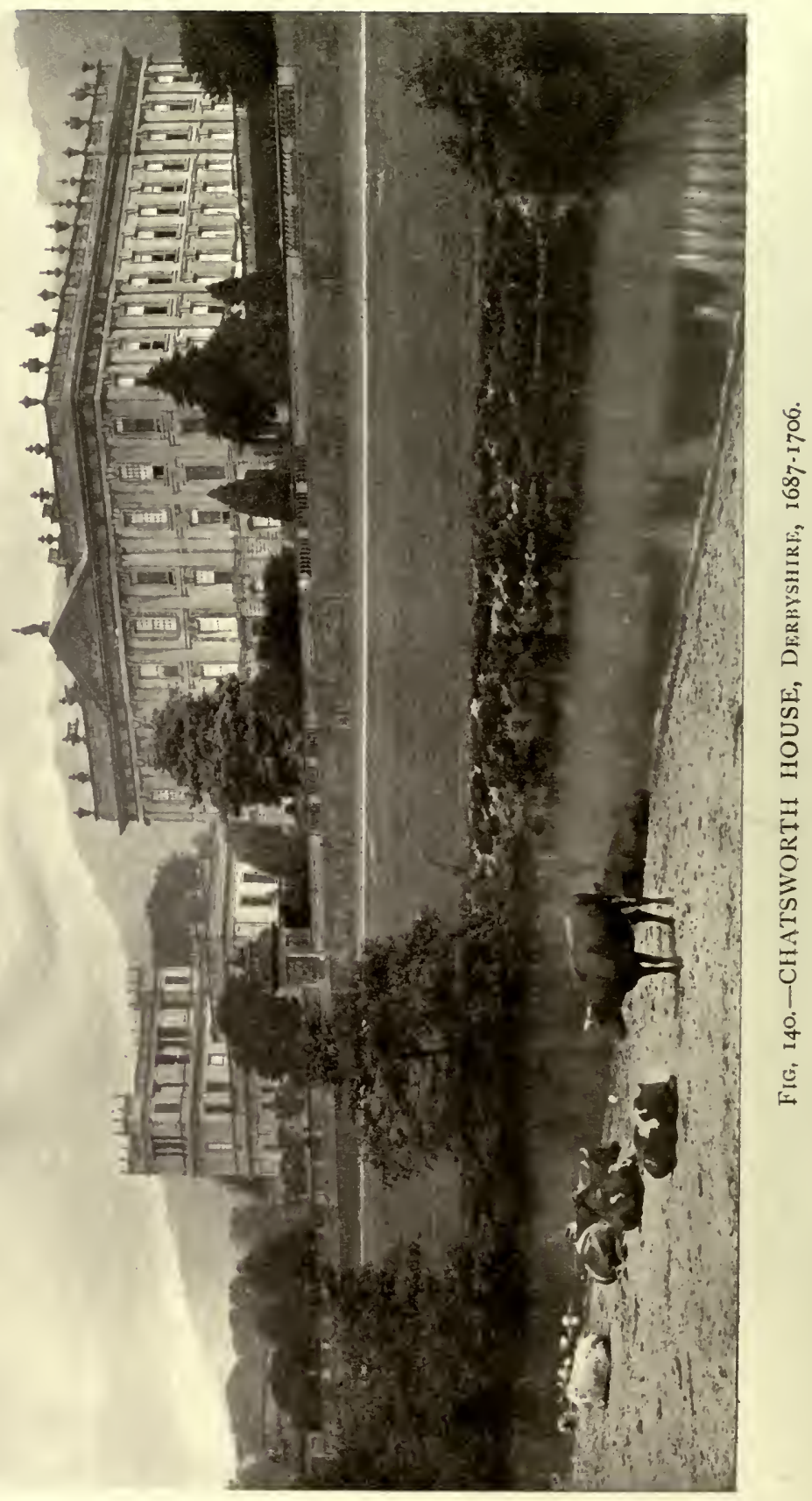


Dyrham, and is far better known to the public. Indeed to many persons it presents itself as the model of what a great nobleman's seat should be. This is owing to its simple and dignified treatment, and to its admirable situation and the lordly nature of its lay out. When examined closely, it lacks interest and variety in its detail. Some of the rooms, however, are finely proportioned and are decorated with beautiful woodwork and plasterwork; and there are two or three doorways with alabaster mouldings and pediments of remarkable interest. Much of the wood carving, from its style and workmanship, was ascribed for many years to Grinling Gibbons, but the building accounts show that it was in fact executed by a Derbyshire man of the name of Samuel Watson, of Heanor. This is another illustration of the tendency to attribute, in the absence of definite knowledge, any remarkable work to the best known master of the time.

It might have been expected that IVren's manner would have been continued in the work of his assistant, Nicholas Hawksmoor, and to a certain extent it was; but Hawksmoor was influenced largely by Vanbrugh, who infected him with some of his own passion for the grandiose. The most notable work of Hawksmoor in domestic architecture is Easton Neston, in Northamptonshire, built for William, Lord Lempster, of which a plan (Fig. 142) and elevation are given in "Vitruvius Britannicus." The principal block, containing the state rooms, is flanked on the plan by outlying wings occupied by the stables and offices, and beyond them the court is widened out, and eventually completed by a monumental arcade or corridor, which obviously could never have been of any practical use. There are no less than five important approaches to the courtyard, through the wings and the arcaded portion; the whole arrangement is designed for stateliness. It is said that the wings were designed by Wren, and that Hawksmoor added the house itself in 1702, some twenty years later.' Campbell's elevation certainly does not confirm the idea that Wren's hand was employed; there is nothing of his gracious dignity about the portion of the wings there shown. Campbell says that the building was finished in I 7 I 3 , and that he was indebted to Hawksmoor himself for the original drawings of the house; he does not mention IVren. The central building itself bears

${ }^{1}$ Bridges' "History of Northamptonshire," i. 289, repeated by Baker in his history of the same county, ii. $14+$. 


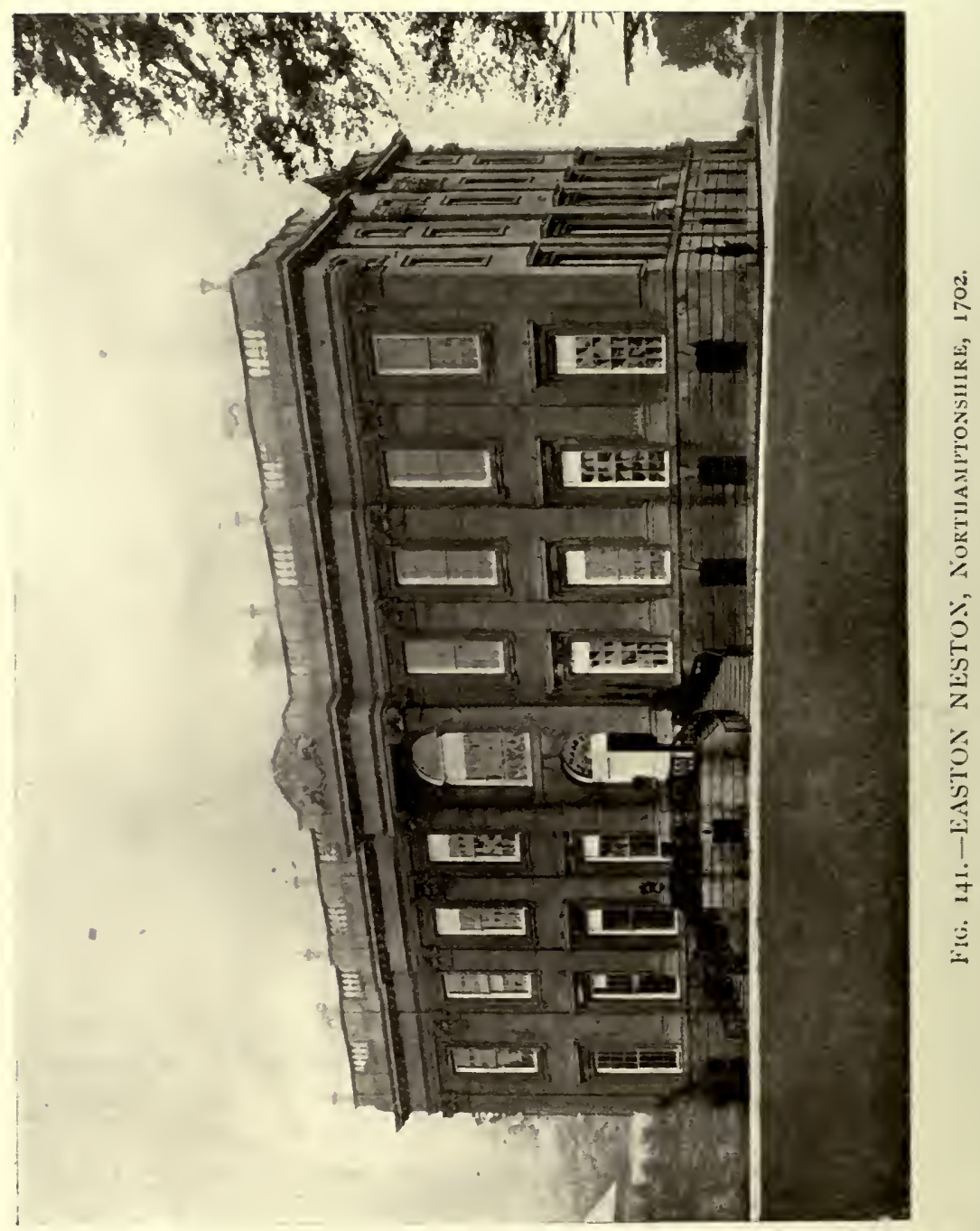


the date "A ${ }^{\circ}$ Sal. MDCCII" on the frieze, so there is evidently some confusion as to the wings. These might have been built after the house and finished in 1713 , but in that case they could hardly have been the work of Wren.

It is noteworthy that the whole of the wings and courtyard were subsequently pulled down, ${ }^{1}$ and nothing remains of the original house but the central block. The reason of this destruction was presumably that they were found to be useless and extravagant, as indeed might be expected. The effect has been somewhat spoiled, for the house, unsupported by anything but some buildings wholly unworthy of it, looks gaunt and abrupt; it seems too grand for its size (Fig: I $4 \mathrm{I}$ ). It suffers in fact from its grancleur; the large windows are suitable enough for the large rooms, but where the exigencies of the plan bring them into small rooms or passages, they are overwhelming. It is interesting to find that Hawksmoor felt this himself, and that in the two ends of the house

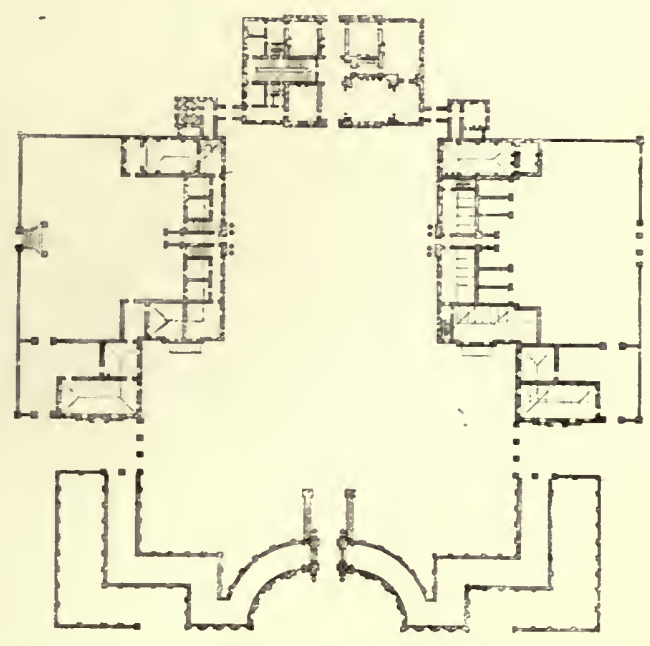

FIG. 142.-Plan of Easton Neston.

he departs from the large scale of the main façades. He has collected as far as possible his small rooms at the two ends, and has given them smaller windows, contriving two floors here in the height of one along the front. The plan of the house follows the stately ideas of the time, which took little count of domestic comfort. The hall was treated in an unusual way; it was formed of three portions, but whereas the middle bay was carried up to the height of two stories, the two end bays were of but one story. The effect was rather fine, as may be seen from the view in Fig. 143. A large floor space was obtained, and also the effect of noble height without the 


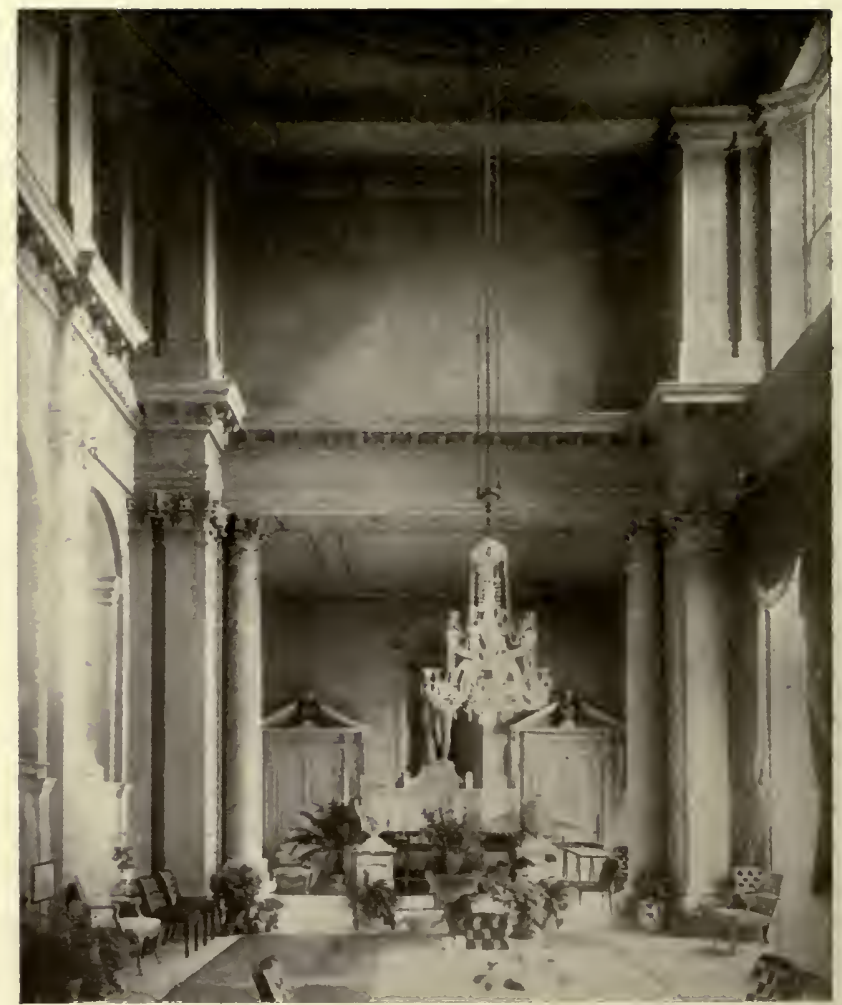

FIG. 143.-Easton Neston. The Dining-Room (now altered).

overpowering result which would have followed from carrying the whole of the hall to the height of two stories. But even this restraint left a greater void than suits modern comfort, and the more lofty portion has now been divided by a floor at the level of the cornice. Other alterations, both of disposition and of decoration, have been made. The original hall has become the dining-room, and a new hall has been fashioned to the left of the entrance. The drawing-room, however, retains much of its original treatment, including the elaborate ceiling with figures in high relief in the middle panel, and the walls, which are occupied by panels with rather extravagant frames (Fig I44).

The bulk of Hawksmoor's work was concerned with churches, and therefore lies outside the scope of the present inquiry. $\mathrm{He}$ was a trained and skilful architect, but contemporary with him. 


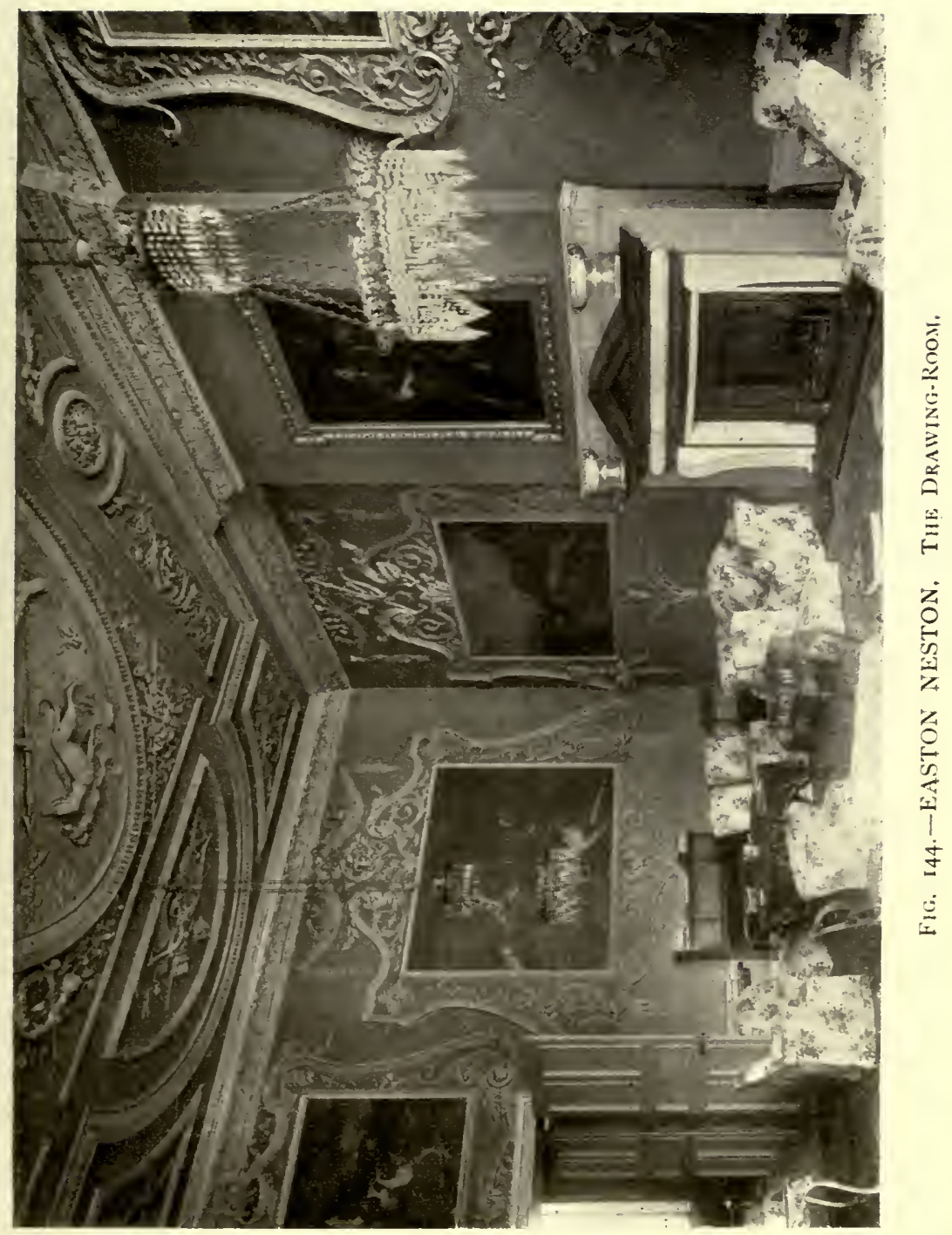




\section{AMA'TEUR INTERES'T IN ARCHITECTURE}

figure others who had not received the practical teaching which he enjoyed.

Almost cver since the publication of books on architecture had begun, a certain number of wealthy Englishmen had taken an interest in the subject. Lord Burghley had procured books from abroad in the time of Elizabeth; and as the years went by more and more people studied such publications as were procurable. IVebb, it will be remembered, referred to the fact that "most gentry in England at this day have some knowledge in the theory of architecture," and by the end of the seventeenth century, it had become the fashion among the great and wealthy to take an interest in the subject-that is, in the classic architecture of the books. It is hardly necessary to say that the interest was somewhat superficial, and concerned itself with appearance more than with convenience; it was still the theory rather than "ye practique," as Webb phrases it, that was studied. The pursuit of the most technical and utilitarian of the arts was thus taken up by amateurs. Wren himself was an amateur when he first began to design. His chief, Sir John Denham, was reckoned by Evelyn "a better poet than architect," but to do Sir John justice, he does not appear to have advanced a claim to be an architect of any kind. Evelyn was a patron of the arts, and especially of architecture, about which he wrote a book. After him, in the eighteenth century, came Lord Burlington, the most distinguished patron of architecture of that age. He was a patron of architccts, too; many of the best known men of the century owed their start in life to the earl. He dabbled in design himself. We are probably justified in calling it dabbling, but it was not so considered at the time, and Horace Walpole, himself a dabbler, speaks of him as a distinguished architect. It was through the munificence of Lord Burlington that many designs of Palladio were published, as well as those drawings left behind him by Webb, which, under the title of "Designs by Inigo Jones," had so great a vogue at this period.

Of the work usually attributed to Lord Burlington, it may fairly be surmised that the practical part was done by one or other of the men who were profiting by his generosity in their endeavours to become architects. The theoretical part was really not very difficult, for designers had a short way with architectural problems in those days. The general purpose of a building having been considered, its external appearance was 


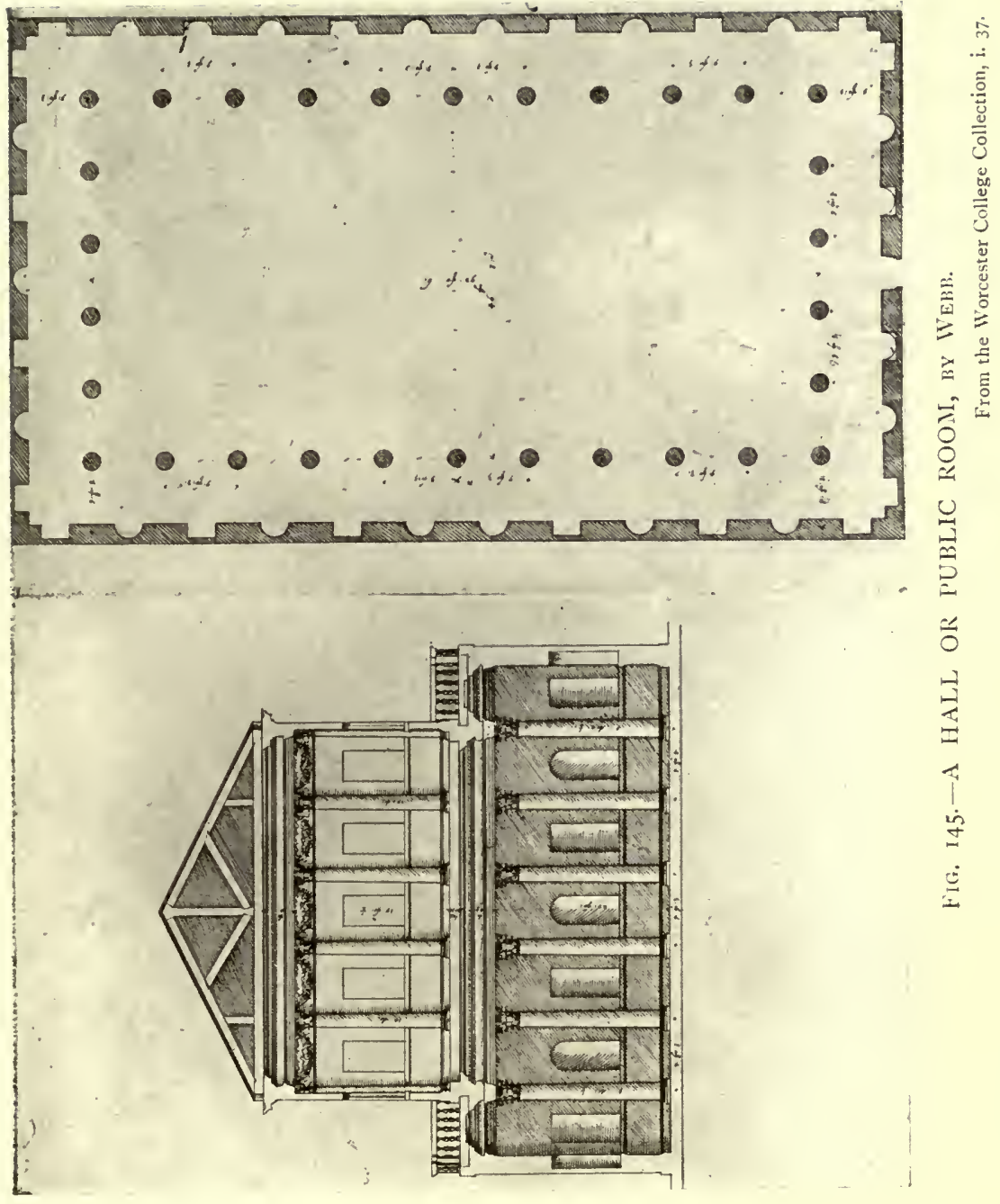


then more or less suitably designed. When the elevation was perfected according to the rules of art, the plan was made to fit it, and if the plan did not answer all the purposes for which it was intended, those concerned had to put up with the deficiency. The oft-quoted saying of Lord Chesterfield illustrates this, for when Lord Burlington had designed a beautiful but inconvenient house for General Wade, Lord Chesterfield advised the latter if he could not live in it to his comfort, to take a house opposite and look at it. It should not have been difficult for Lord Burlington to design this particular house, for he had all Webb's drawings to help him, and among them many examples of this type. So with the Assembly Rooms at York; the large hall is a crib from Palladio's illustration of a hall after the Egyptian manner, but influenced by a rendering of the same subject by WVebb. Webb's version consists of an oblong room, having a row of columns set some eight feet from the walls, thus forming an aisle all round the room (Fig. 145). The columns carry a wall which is pierced with windows, and which in its turn carries the roof. The outside walls of the ground floor stop short below the windows, and are crowned with a balustraded parapet masking the flat roof over the aisle. Lord Burlington adopted this idea wholesale (Fig. I47), but he made his room much narrower than Webb's, although of about the same length, and he kept to the general proportions of Palladio. When, however, the treatment of the end of the hall (which was the source of inspiration) was lengthened nearly fourfold to do duty for the sides, the effect became monotonous and poverty-stricken; this is apparent on Burlington's section (Fig. 146). To the main room he added others of less account, but they are nearly all too long and too narrow, whether for appearance or for use.

Another well-known work of his is his villa at Chiswick (Fig. I48), which was copied from a design of Palladio's for a villa near Vicenza, but spoilt in the process. Here again there is no originality, and the practical drawbacks are so great as to arouse even Walpole's criticism, to which, however, he adds the illuminating observation that its faults were condoned by the fact that here, without any trouble, might be obtained picturesque views better worth seeing than many of those fragments of ancient grandeur which travellers sought with infinite labour-an interesting testimonial to scenic architecture. 


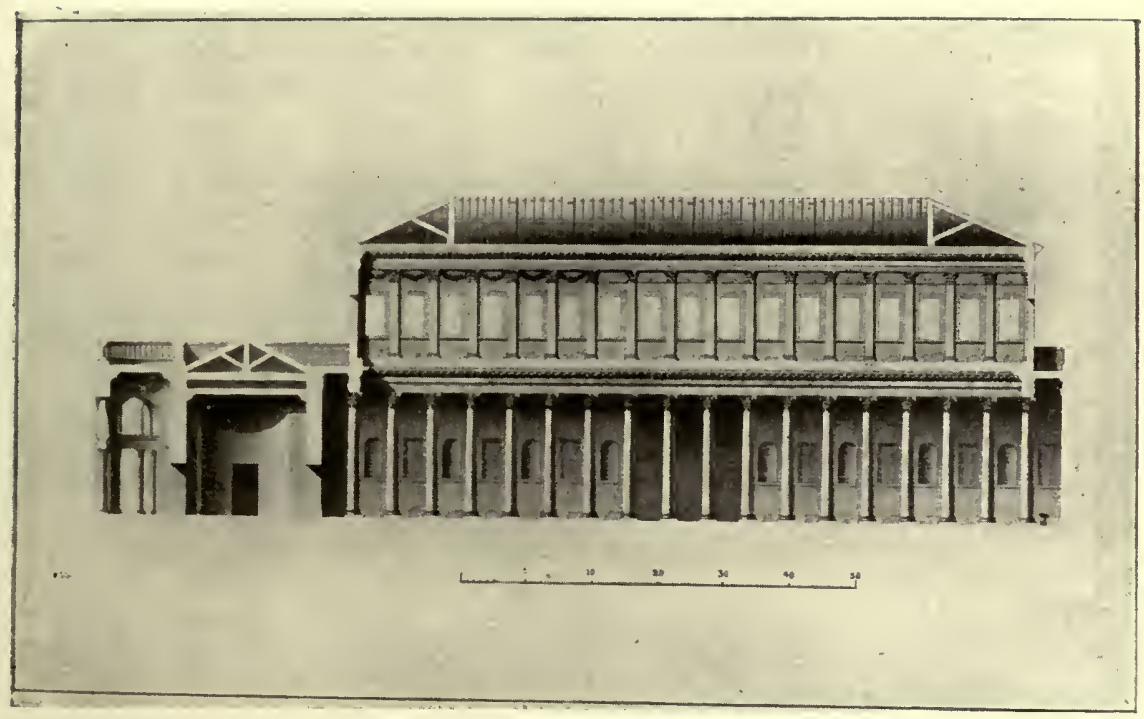

FIG. I46.-Section of the Assembly Room, York.

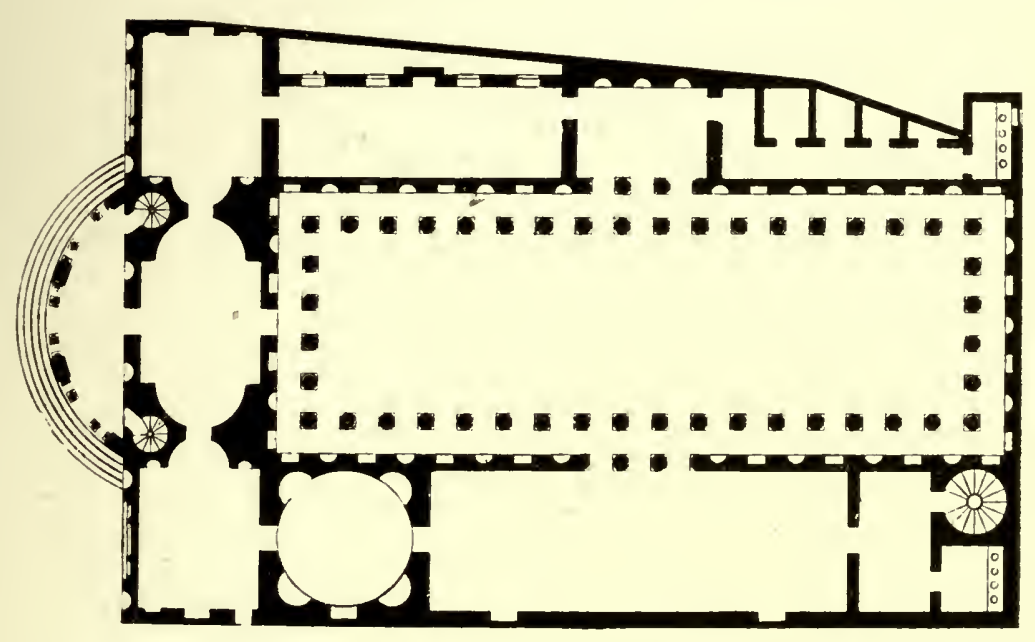

as

FIG. I 47.-Plan of the Assembly Room, York. 
The other works attributed to Lord Burlington are the dormitory at Westminster, a school and almshouses at Sevenoaks, both illustrated by Kent in his "Designs of Inigo Jones," and Burlington House, Piccadilly. Of these the dormitory at Westminster was a bald and mutilated version of a design by Wren, and Burlington House was probably designed by Campbell. ${ }^{1}$

But although Burlington cannot be regarded as an architect who did anything great in design, he was a munificent patron of the art and of those who pursued it more practically.

Contemporary with him, and indeed starting a little before him, was another well-known but more skilful amateur, the witty dramatist, Sir John Vanbrugh, who has left behind him some of the largest and most ponderous houses ever built in England. His patrons and friends among the nobility were all esteemed good judges of architecture, and to their judgment he submitted at least one of his largest designs.

Among the noblemen who employed him was the third Earl of Carlisle, who conceived the idea of making himself a magnificent home at Castle Howard, in Yorkshire, to replace the ancient castle of Hinderskelf, which had been brought into the family by marriage with one of the co-heiresses of Lord Dacres. The scheme embraced not only a new palace, but a large lay out of plantations, vistas, lakes, temples, obelisks, lodges, and other objects of interest, such as had been employed by Le Nôtre at Versailles and elsewhere. The completion of his scheme is recorded in verses too bald (one would imagine) to be any but his lordship's, engraved on an important obelisk. They give the date of commencement as 1702 , the inscription is dated $173 \mathrm{I}$, so that year may be held to have witnessed the fulfilment of the main project.

But the house had been occupied long before this; for in I714 Lady Mary Wortley Montague wrote from Yorkshire to her husband, professing to be "in a great fright " about attempts from Scotland in favour of the Pretender. "The four young ladies at Castle Howard," she says, were as much alarmed as she was, for their father had gone away and was not likely to return for months. They had asked her to join them, a suggestion which she was inclined to comply with, since Castle Howard would be a safe retreat, although rather like

1 Mr R. Blomfield's "History of Renaissance Architecture in England," p. 224 . 
a nunnery, as no mortal man ever entered its doors in the absence of the father.

It must have been early in the year I699 that the earl called Vanbrugh to his assistance, for the latter writes on the 25 th December that he had been that summer at Lord Carlisle's, and had visited most of the great houses of the North. Amongst

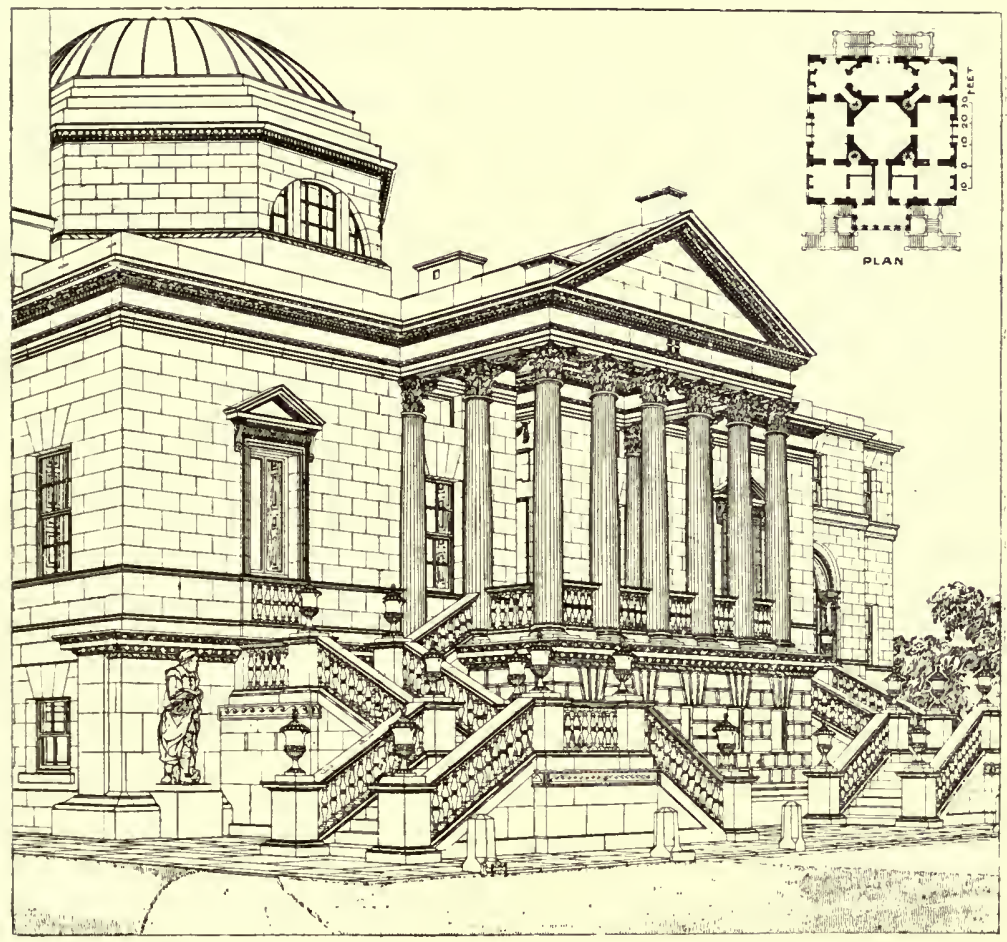

F1G. 148.- Lord Burlington's Villa at Chiswick.

I) raw! by A. C. Bosıom..

others he had been to Chatsworth, where he stayed four or five days, and had shown to the duke all the designs for Castle Howard, which he "absolutely approved." Since then they had been submitted to a great many other critics, and as no objection had been raised to them, the stone was already being quarried and the foundations were to be laid in the spring. A model of the house was being prepared in wood, which was tobe sent to Kensington for the criticism of the king. ${ }^{1}$ Thus.

1 "Court and Society from Elizabeth to Anne," edited from the papers at Kimbolton, by the Duke of Manchester, London, 1864, p. 56 . 
fortified with general approval the design was carried out, the works extending over some thirty years. The cost must have been very great, and in a later letter Vanbrugh tells how it was met in part, for in July 1707 he says that Lord Carlisle had "won $£ 2,000$ from the Sharpers, and is gone down to lay it out in his buildings." 1

Although the whole of Vanbrugh's design was not carried out the house is of great size and of palatial magnificence (Fig. 150). Indeed no modern person can be incessantly as grand as the grandeur of the building demands. It requires innumerable servants to keep it in order, innumerable guests to make it cheerful. It involves a great drain upon the owner's resources, both of temperament and of purse, to fill it with enough people to prevent its being dull, and to maintain it in suitable repair and tidiness. From a practical standpoint the corridors are too many and are out of all proportion to the rooms they serve. There are indeed no rooms of a size commensurate with the outside grandeur; most of them appear small and narrow, their height is as great as their width (Fig. I 52), and this must have tended, before the introduction of modern heating, to make them cold. The finest apartment is the hall (Fig. I $5 \mathrm{I}$ ), so large and lofty as to occupy an undue proportion of space compared with what is devoted to domestic use. Its effect is more nearly allied to what we are accustomed to associate with a large museum or other public building than with a house.

The view in "Vitruvius Britannicus" does more justice to Vanbrugh's conception than does the building itself. The house is there shown with a subsidiary court on each side, one being devoted to laundries and so forth, and the other to stables. In front there was to have been a forecourt enclosed by a monumental fence with the main entrance gates on the axial line. Actually but one of the side courts was built, and the forecourt was not carried out. The road, instead of approaching the house directly opposite to the centre of the façade, thus giving the visitor a coup d'cil of the whole vast composition, approaches it laterally, close to the end of one of the wings, and it is only on passing the corner of the wing that the visitor is suddenly aware at close quarters of the recessed entrance front.

The one subsidiary court which was built contains the laundries, and it is in the nature of a shock to see laundry-maids 


\section{新}

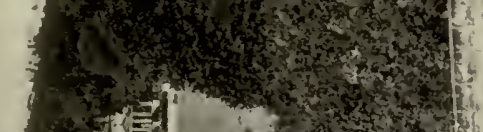

$8=1$ (E)

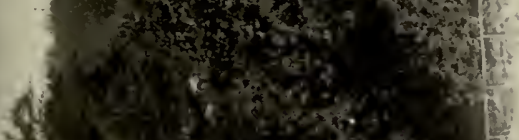

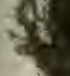

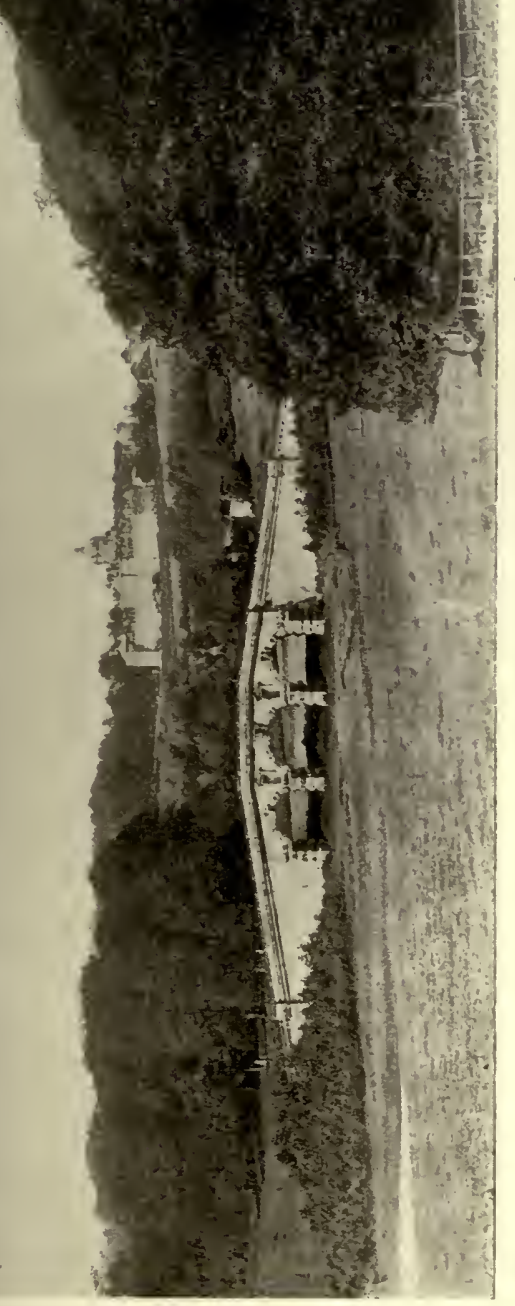

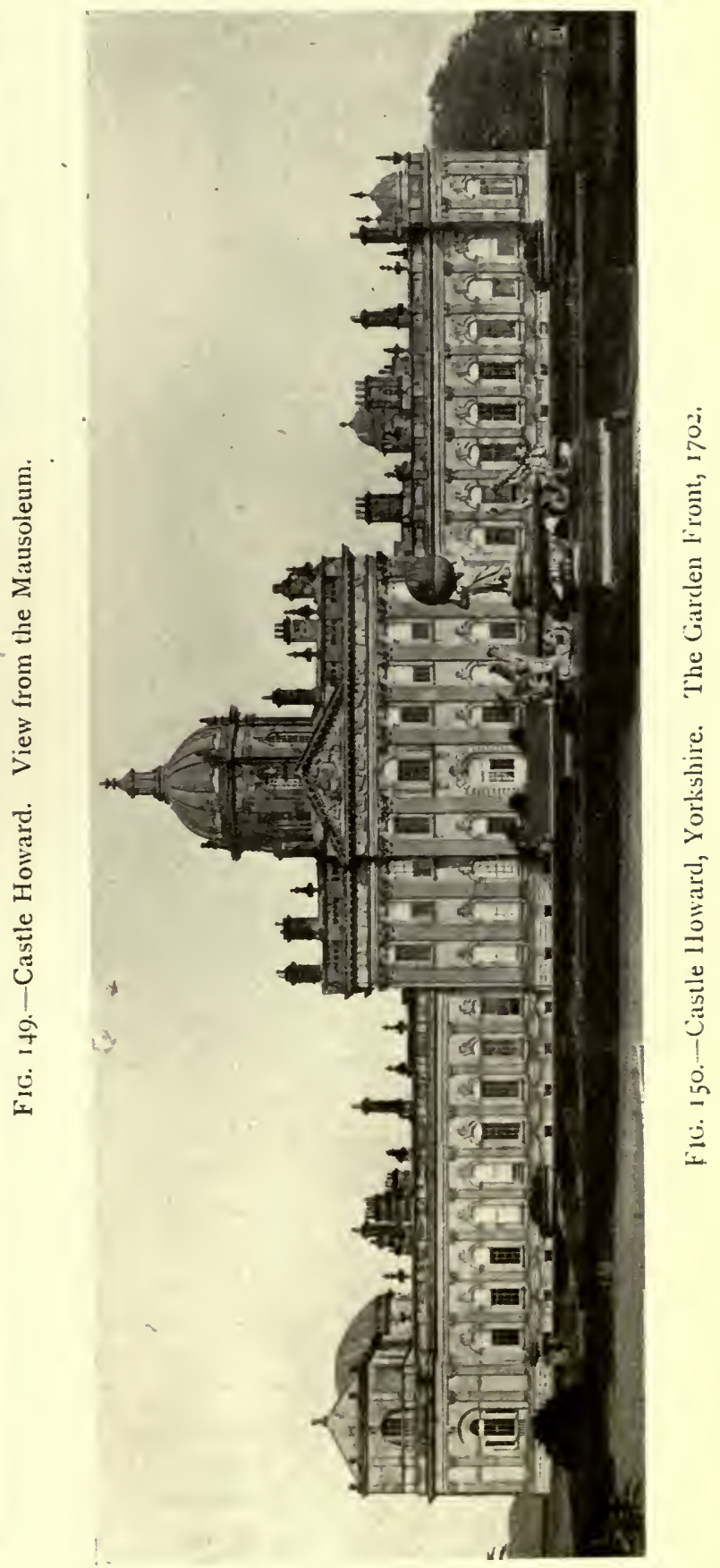




\section{CASTLE HOWARD_GARDENS, MAUSOLEUM}

at work amid surroundings almost massive enough for Diocletian himself.

The lay out is of corresponding scenic magnificence. From one direction the house is approached along a far-stretching avenue, which leads up hill and down dale, then beneath a gateway in a long, symmetrically designed range of building crowned with a sturdy pyramid, and so onwards towards a lofty obelisk, the meeting-point of several roads, one of which leads to the house. The formal gardens close to the house surround a large basin, in the midst of which is Atlas bearing up the world, amid the encouragements of four huge tritons who raise great horns towards him across the water. The broad gravel walk along the garden front leads in one direction to the walled fruit gardens; in the other to a smooth grass track which slopes upwards to a copse of beeches. Curving away from this is another grass track which, passing an ordered row of lead figures, comes eventually to a classic temple. Beyond are undulating fields skirting an artificial lake, across which is flung a massive bridge which deserves, even more than that at Wilton, Walpole's epithet of "theatric," for it serves no purpose but to adorn the landscape. It spans a sheet of water contrived for little else than to provide the opportunity to build it. Its roadway, deep-grown in grass, leads from nowhere to nowhere. The Palladian bridge at Prior Park, near Bath, illustrated in Fig. I 54, is almost an exact replica of that at Wilton.

Still further on, crowning an eminence, stands a huge mausoleum, a noble building designed by Hawksmoor (Fig. 153). It rests on a lofty and spacious platform of irregular symmetry; whereon the friends and tenants of deceased earls may have gathered to await the arrival of the funeral procession as it made its slow way along the grass walks, and after halting at the temple, wound across the rolling fields. Long stone benches suggest the scores of horsemen who dismounted and left their horses to be tended on the ample spaces of the platform. The mausoleum itself is a circular domed building, surrounded by disengaged columns; within it are two chambers; the lower. level with the platform, contains the vaults; the upper is the chapel. The latter is approached by long flights of steps, and is itself circular and covered at a great height with a coffered dome. The sweep of the walls within is relieved by eight recesses for an altar, the clergy, and the chief mourners. The vaulted apartment below is massively constructed, and in the 


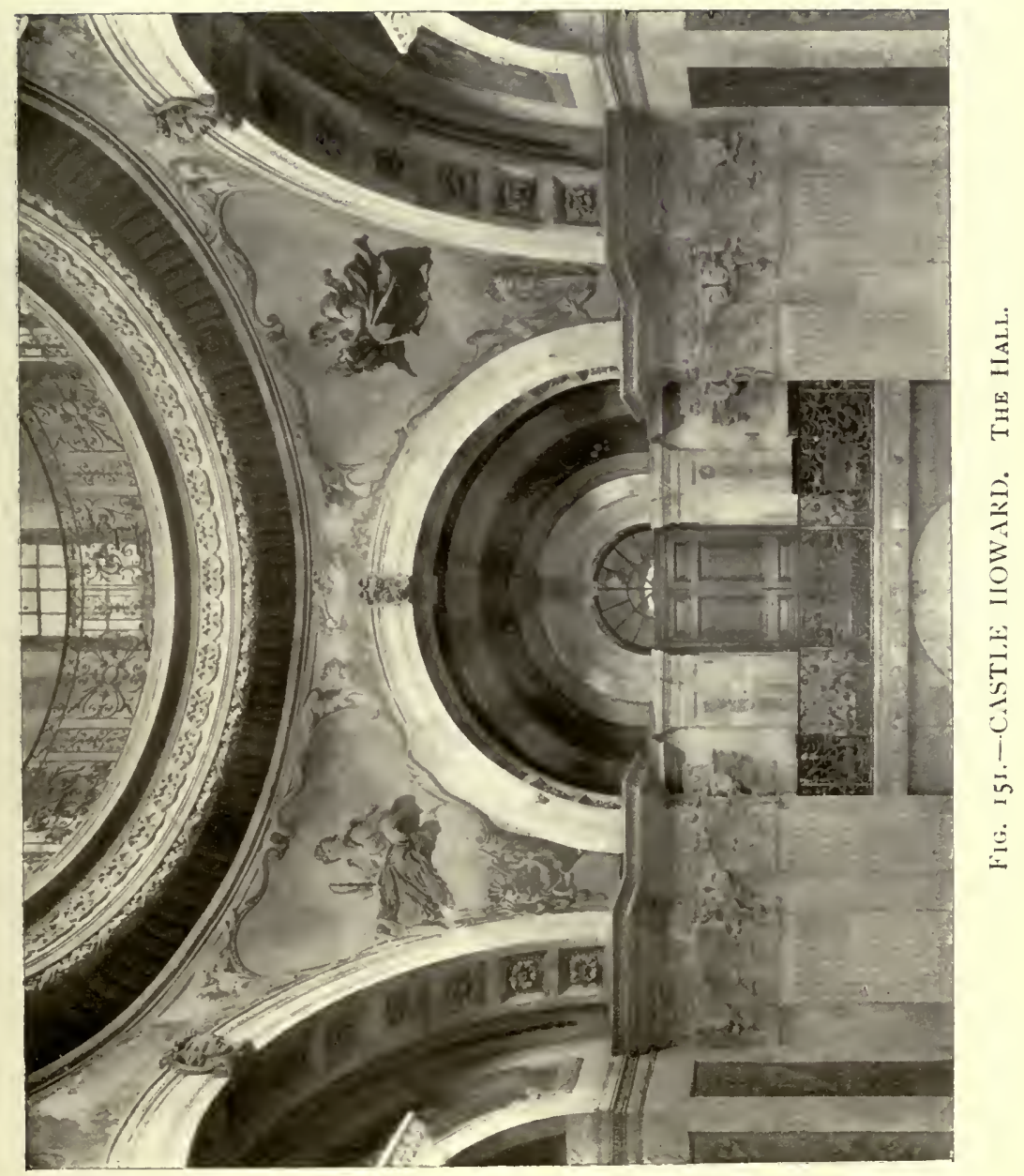




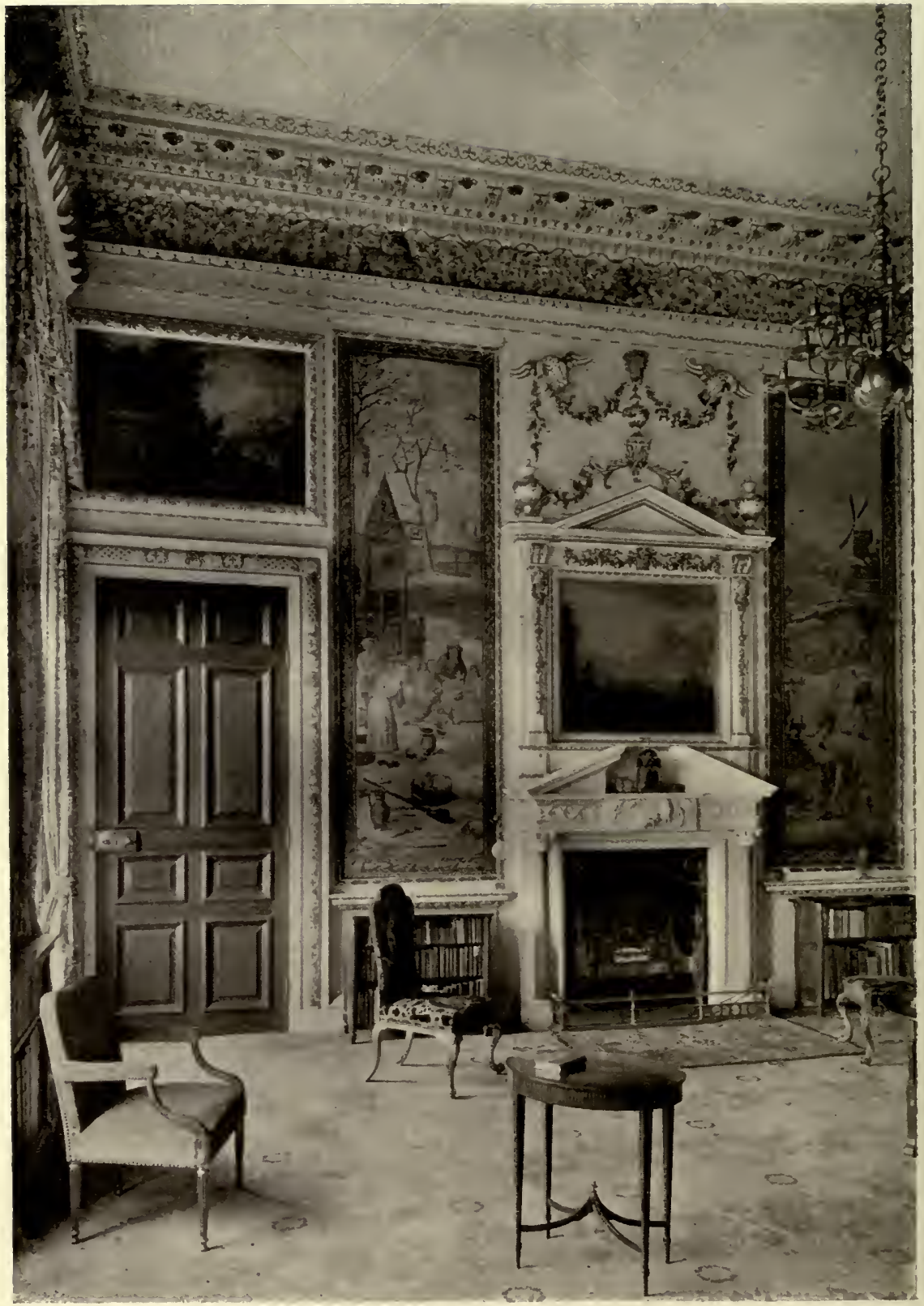

Fig. I52.-CASTLE HOWARD. THE TAPESTRI ROOM. 


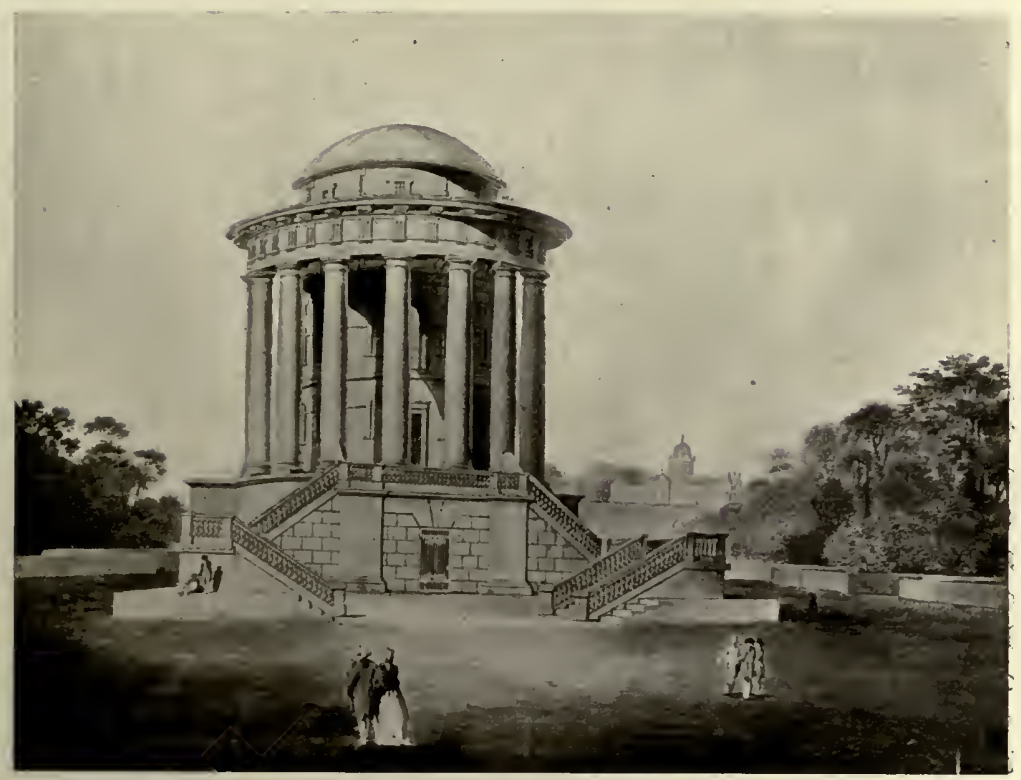

FiG. 153.-The Mausoleum at Castle Howard, as seen from the Platform on which it stands.

thickness of the masonry are contrived many recesses for the reception of coffins. But few hate been utilised, and, as the visitor discovers by the light of his taper cavern after cavern. still unoccupied and unlikely ever to be filled, as he stands inthe chilly spaces of the chapel with its dome soaring far overhead, as he gazes from an angle of the platform across the fields. and the grass-grown bridge on to the distant house (Fig. I49), he realises how vastly things have changed, how entirely this fine conception has lost its point, how empty is the pomp of architecture when the habits to which it ministered have ceased.

Castle Howard was a private undertaking. Immense though it was-its total length was to have been $660 \mathrm{ft}$. had both its courts been built-it was exceeded in size by the palace. of Blenheim, which was a national monument to the glory of the British arms, although actually a gift to the Duke of Marlborough. Here Vanbrugh must have been in his element. There was presumably to be no unreasonable limit to the cost; the result was to be monumental. Convenience of arrangement, internal effect, the amenities of daily life were minor considerations. The nation wanted a monument; it should 
have something which should impress the thousands who would see the exterior, rather than the scores who might possibly see the interior. The house itself was flanked, as at Castle Howard, by two huge courts, one for the stables, the other for the kitchens ; the total façade was $850 \mathrm{ft}$. in length. The approach was along the axial line over a splendid bridge, finer in every way than that at Castle Howard; indeed, it is the most satisfactory piece of design at Blenheim. The house is overwhelmed by its own size (Fig. I 55). The eye cannot grasp it in its entirety, and when it studies isolated portions they do not suggest thoughts of domestic pleasures; the colonnades and the turrets are not consecrated by daily use, they are there for scenic effect; the statues are cold abstractions, they are no more germane to Blenheim than to any other grand house. How different is this effect from that of even the largest of the Elizabethan palaces. There grandeur itself was homely. The difference cannot be attributed to increase in size; the absence of homeliness springs not even from the inevitable difference between a palace and a manor house. It is inherent in the changed views prevalent both as to life and as to architecture. The aloofness of the great noble accounts for something, but the desire to produce scenic architecture in preference to creating a home, accounts for more. It underlay nearly all Vanbrugh's efforts, as indeed it did those of his contemporaries and successors. At Stowe House, near to Buckingham, it is apparent in the sacrifice of the bedroom windows on the south front to the desire for an appearance of solidness and simplicity; it is still more obvious in the treatment of the gardens, presently to be described. Seaton Delaval, in Northumberland, is perhaps Vanbrugh's most pleasing production, but even here convenience and common sense gave way to display, and the house itself, having been burnt down some few years after it was built, no one has thought it worth while to reinstate it. No one could be comfortable in it if he did.

In one of his houses, at any rate, Vanbrugh did not resort to his usual devices for producing his effects. This was Kimbolton Castle, in Huntingdonshire, which, except on one front which has a great columnar portico, is as gaunt and plain as anyone could desire; and it was made so of set purpose, for Vanbrugh writes to his client, the Earl of Manchester, in July I707, "I thought it was absolutely best to give it something of the castle air, though at the same time to make it 


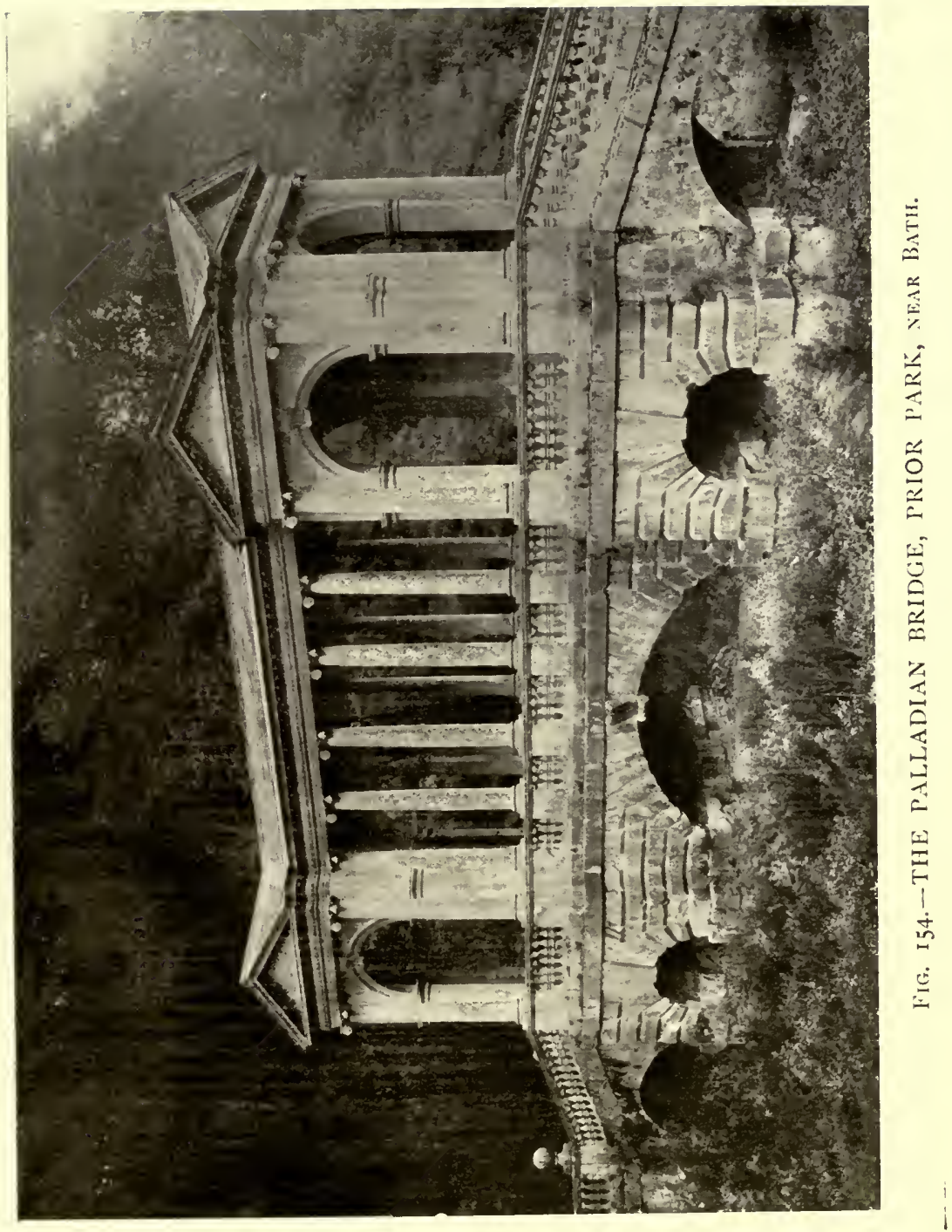




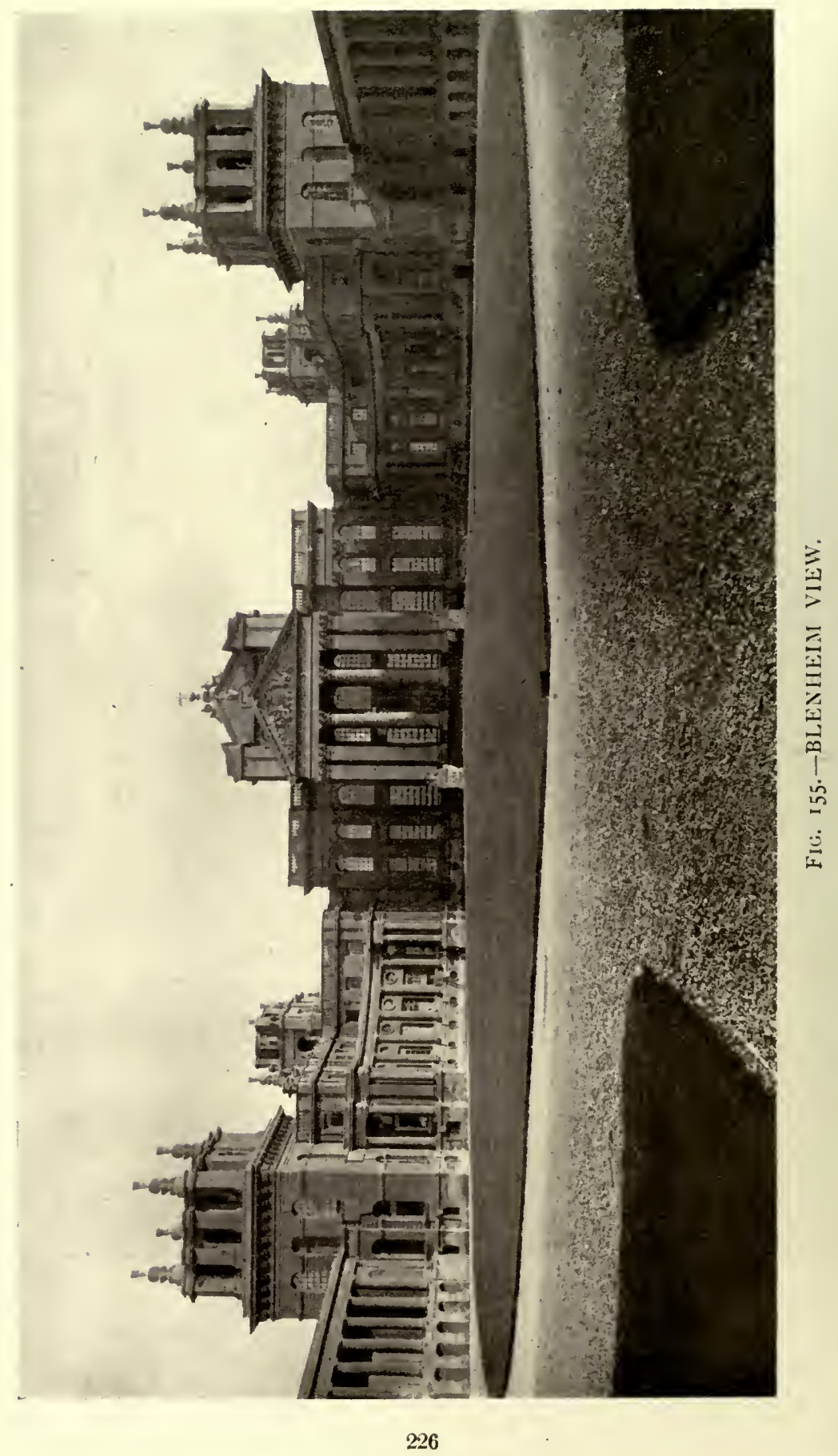


regular, . . . so I hope your Lordship will not be discouraged if any Italian you may shew it to, should find fault that it is not Roman; for to have built a front with pilasters and what the orders require, could never have been done with the rest of the castle. I am sure this will make a very noble and masculine show." And again in the following September, "I shall be much deceived if people do not see a manly beauty in it, when it is up, that they did not conceive could be produced out of such rough materials; but it is certainly the figure and proportions that make the most pleasing fabric, and not the delicacy of the ornaments, a proof of which I am in great hopes to shew your Lordship at Kimbolton."

There is much sound sense in all this, and every architect will agree that no amount of ornament can redeem a badly proportioned building; but Vanbrugh's reason for the omission of pilasters, and what the orders require, would have had more point if there had been anything preserved of the ancient castle beyond its name. So far as can be seen there is nothing older than the house itself, and although it was built of the old stones, as Vanbrugh says (and this may be the real reason for so plain a treatment), there is no evidence of earlier working visible upon them.

A casual remark in another letter is of interest, as showing what people thought of some of these large houses. He is speaking of Blenheim in a letter of July I 708 . "He (Sir John Coniers) made mighty fine speeches upon the building, and took it for granted no subject's house in Europe would approach it, which will be true if the Duke of Shrewsbury judges right in saying, "There is not in Italy so fine a house as Chatsworth,' for this of Blenheim is, beyond all comparison, more magnificent than that." He is certainly right as to magnificence, if not also as to the general pleasurable effect.

Vanbrugh's houses may be taken as the highest manifestation of the spirit of the age in house-building; the exaltation of social grandeur, the scenic magnificence of architecture. That they rather missed the mark in respect of comfort and convenience, as we understand those qualities, was not held to be a great drawback. Yet even contemporary voices were raised in protest, as may be gathered from Pope's verses on "The Duke of Marlborough's House at Woodstock," wherein, after listening to an admirer's description of its splendour, he suddenly interrupts him:- 


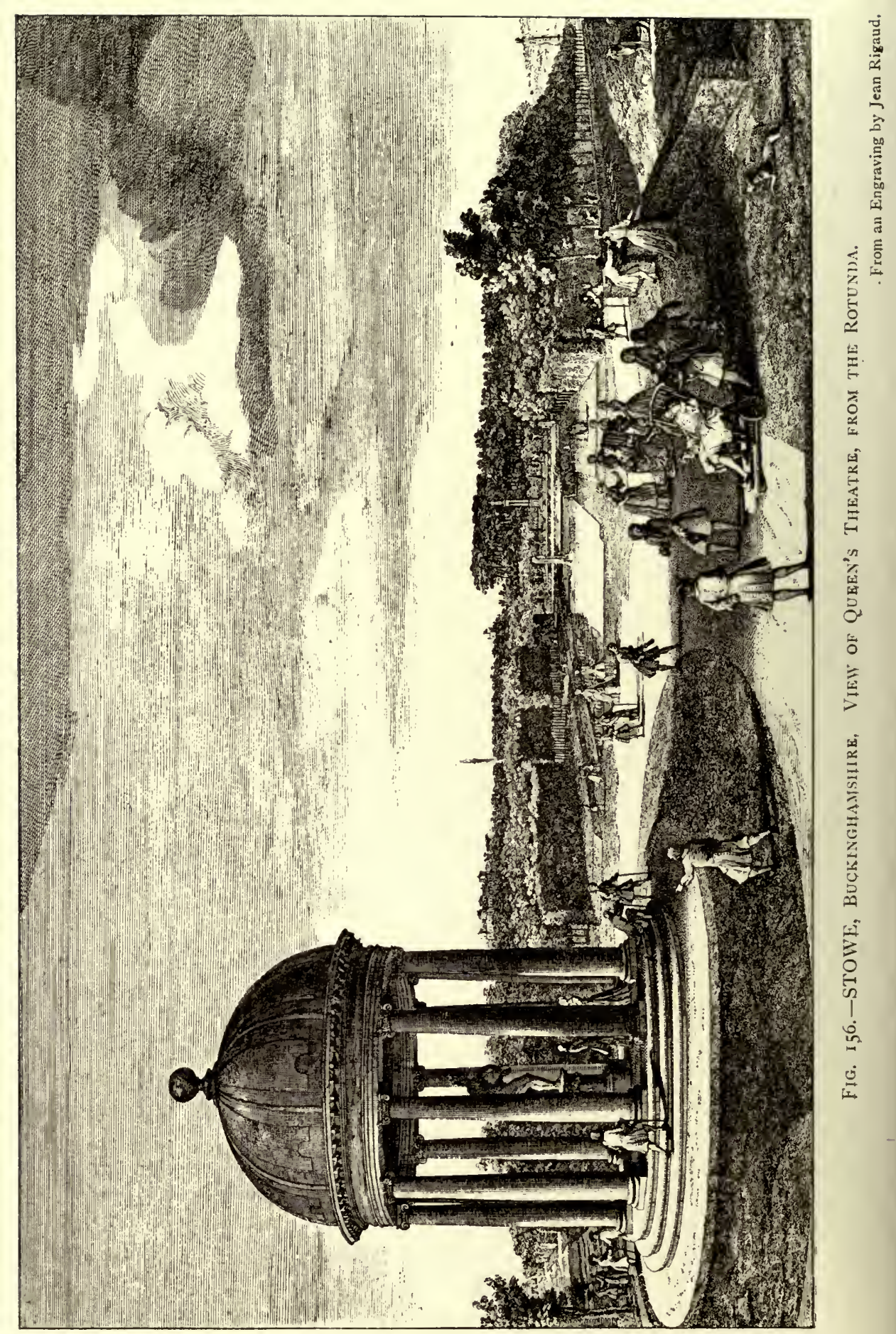


"Thanks, Sir, I cried, 'tis very fine, But where d'ye sleep, or where d'ye dine?

I find by all you have been telling, That 'tis a house, but not a dwelling."

Sir Joshua Reynolds, in the thirteenth of his admirable Discourses, remarks that Vanbrugh "was defrauded of the due reward of his merit by the wits of the time"; and we can heartily concur in his opinion as a painter, that Vanbrugh, "had originality of invention, he understood light and shade, and had great skill in composition."

In all these great houses the lay out helped the general effect; the gardens and the groves were designed in the same spirit as the houses which they surrounded. Those at Stowe were the most famous of their time. There was but little formality about them, although they were traversed by a few straight walks and vistas (Fig. I 56). They embodied, indeed, the new idea which eschewed formality, and sought to gain the help of nature without apparent effort (Fig. 157). They covered a considerable amount of space, and were diversified by undulations of varied steepness, and by great masses of trees. The landscape thus provided by nature was improved by art. A stream was made to fall here, to wind there, to broaden out into a lake elsewhere. Paths were contrived to pass through thickets, to descend a dell, to curve beneath a lofty mound crowned with a "temple," to undulate along the edge of a copse and overlook meadows sloping down to the lake. The whole was studded at intervals with buildings, each of which had a character of its own. There were grottoes, temples, arches, rotundas, and columns, designed by Vanbrugh, Leoni, Kent, and others. They were so placed amid the trees, the meadows, and the water as to remind the spectator of pictures of Italian scenery. Half Italy was squeezed into two hundred acres of English countryside. A Corinthian arch admitted the principal approach from Buckingham. There were many temples; among them one to Venus, one to Bacchus, others to the Ancient Virtues, to the Modern Virtues (in ruins-a costly piece of satire which must speedily have palled), to British worthies, to Concord and Victory, to Friendship and to other deities and abstractions. There was Dido's cave in one place, and St Augustine's in another, a Fane of Pastoral Poetry elsewhere; there were monuments to people of more or less eminence, archways com- 


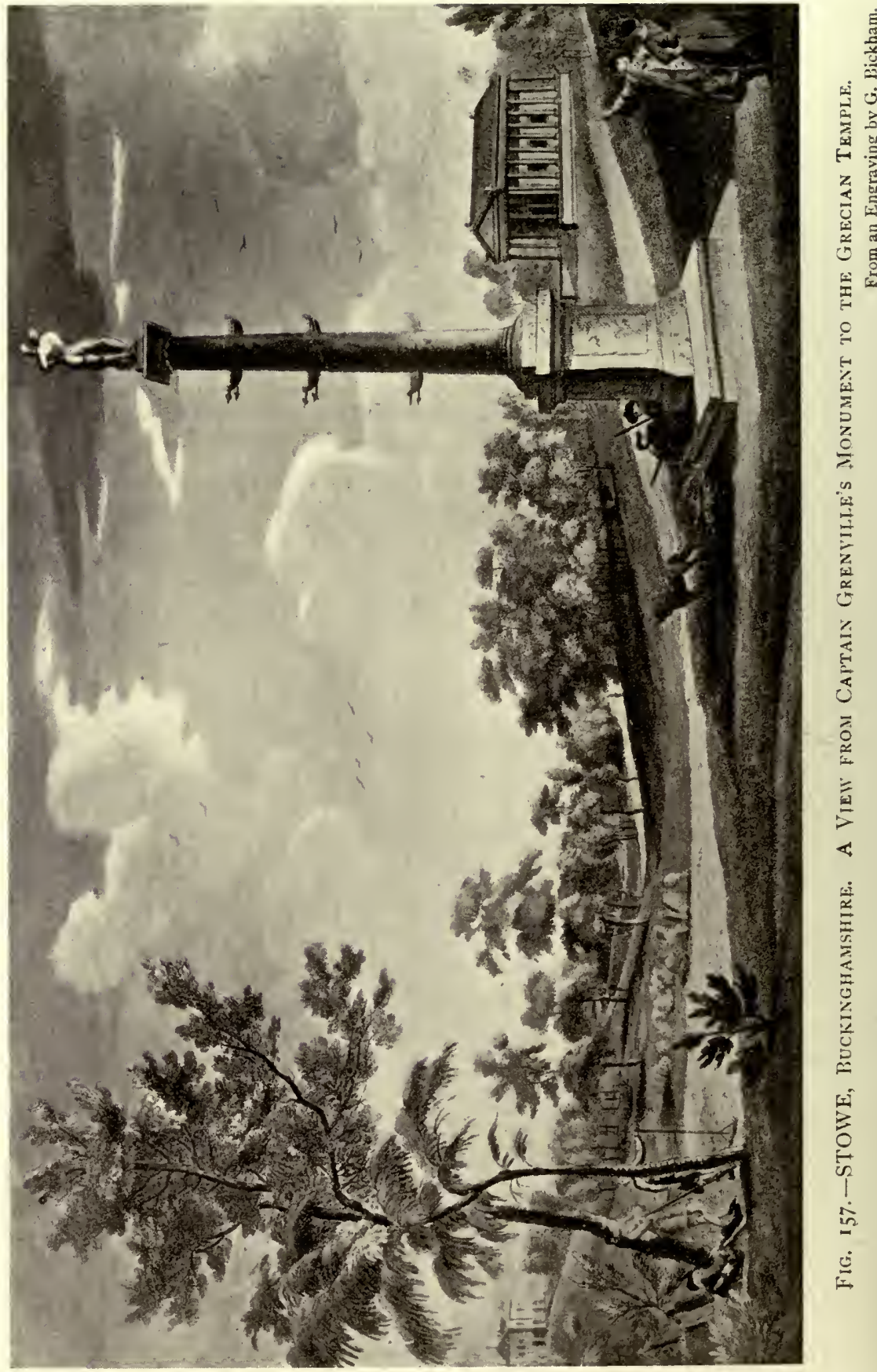


memorative of royal visitors, artificial ruins, bridges over artificial waters, a Gothic temple, and a large tablet to a dead dog.

Most of these buildings were furnished with inscriptions on which were bestowed much ingenuity, scholarship, and neatness of versification. For thirty or forty years monuments were added as occasion arose, either to commemorate the death of a distinguished acquaintance, or the visit of some royal personages. Horace IValpole was half repelled, yet wholly attracted by this curious panorama. The modern visitor is filled with much the same emotions. The mere catalogue sounds inane, yet the whole idea is carried out with so much skill, the buildings themselves are so charming that, once we accept the artificial atmosphere of the place, we wander from point to point with unabated interest and admiration. Nowhere else can we gain so vivid an insight into the laborious elegance of the age.

Walpole's lively account of his visit to meet the P'rincess Amelia, in July 1770 , gives an excellent idea of the impressions the place made upon him. The view through the archway, erected in honour of her royal highness, he describes as "a tall landscape framed by the arch and the embowering trees, and comprehending more beauties of light, shade, and buildings, than any picture of Albano I ever saw." 1 "Twice a day we made a pilgrimage to almost every heathen temple in that province that they call a garden; and there is no sallying out of the house without descending a flight of steps as high as St Paul's." He describes an al fresco supper, which they attended in state, in one of the grottoes on a cold evening. It reduces to very human dimensions the lordliness of the great scheme. A large concourse of people from Buckingham and the district came to behold the distinguished company at their revels. Before this crowd the house party descended the vast flight of steps leading from the house. "I could not help laughing as I surveyed our troop, which, instead of tripping lightly to such an Arcadian cntertainment, were hobbling down by the balustrades, wrapped up in cloaks and great-coats for fear of catching cold. The earl, you know, is bent double, the countess very lame; I am a miserable walker, and the princess, though as strong as a Brunswick lion, makes no figure in going down fifty stone stairs."

Stowe, and Hagley in Worcestershire, which both owe much

1 Letter to George Montagu, 7th July 1770 ; also to H. S. Conway, 12th July 1770 . 


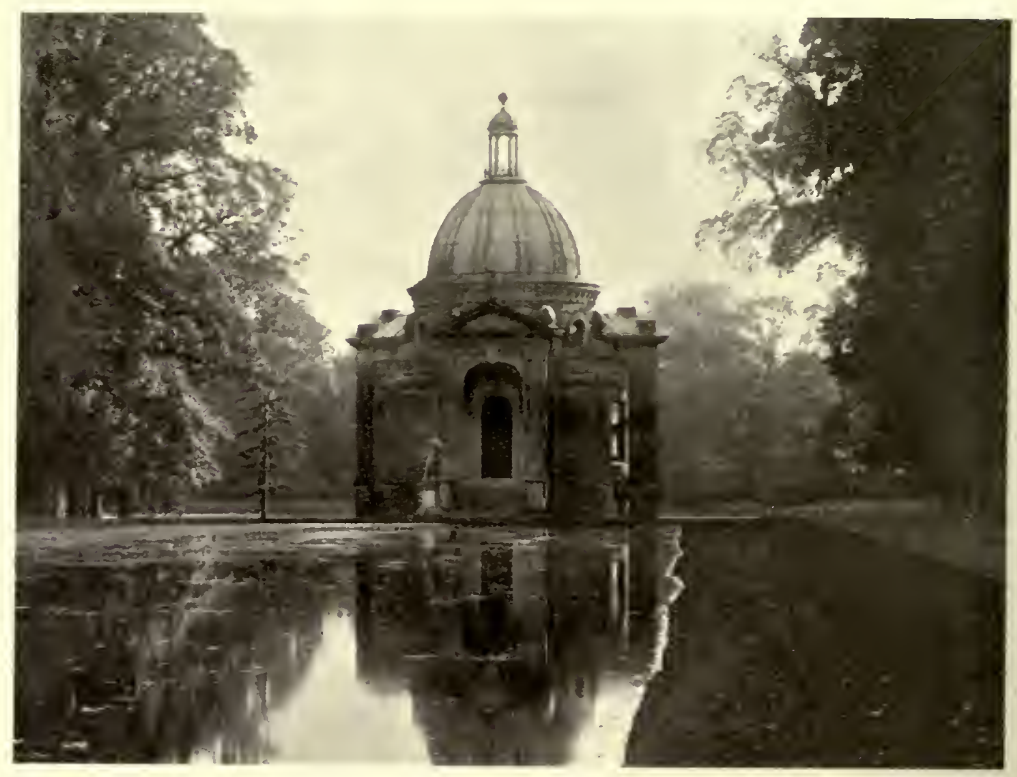

FIG. 158.-In the Gardens of Wrest, Bedfordshire.

of their character to the taste and judgment of Lord Chatham, are perhaps the best examples of lay outs which are not so much gardens, as a collection of landscape pictures to which interest was imparted by the introduction of classic buildings, and from which symmetry and formality were excluded.

In contrast to the free treatment at Stowe, which brought a tract of countryside into the curtilage of the house, is the formality at Bramham Park, some ten miles from Leeds, which carried the ordered symmetry of the house into the gardens. Of the two methods, the formal was the earlier, but during the eighteenth century it gradually gave way to the other.

The gardens at Bramham are among the most satisfactory of the large lay outs of the period (Figs. I62, I63). They were devised for ${ }^{\circ}$ Robert Benson, afterwards Lord Bingley, about the year 17 IO. $^{1}$ There are the usual vistas converging upon the house; there are various buildings in imitation of the antique, both classic and Gothic; there are memorials to pet animals; but the number is reasonable, and the scheme is more easily grasped than that of Stowe. The principal walk runs parallel to the garden front of the house, near which it ends against a 1 "Vitruvius Britannicus," ii., pl. 8I, 82. 


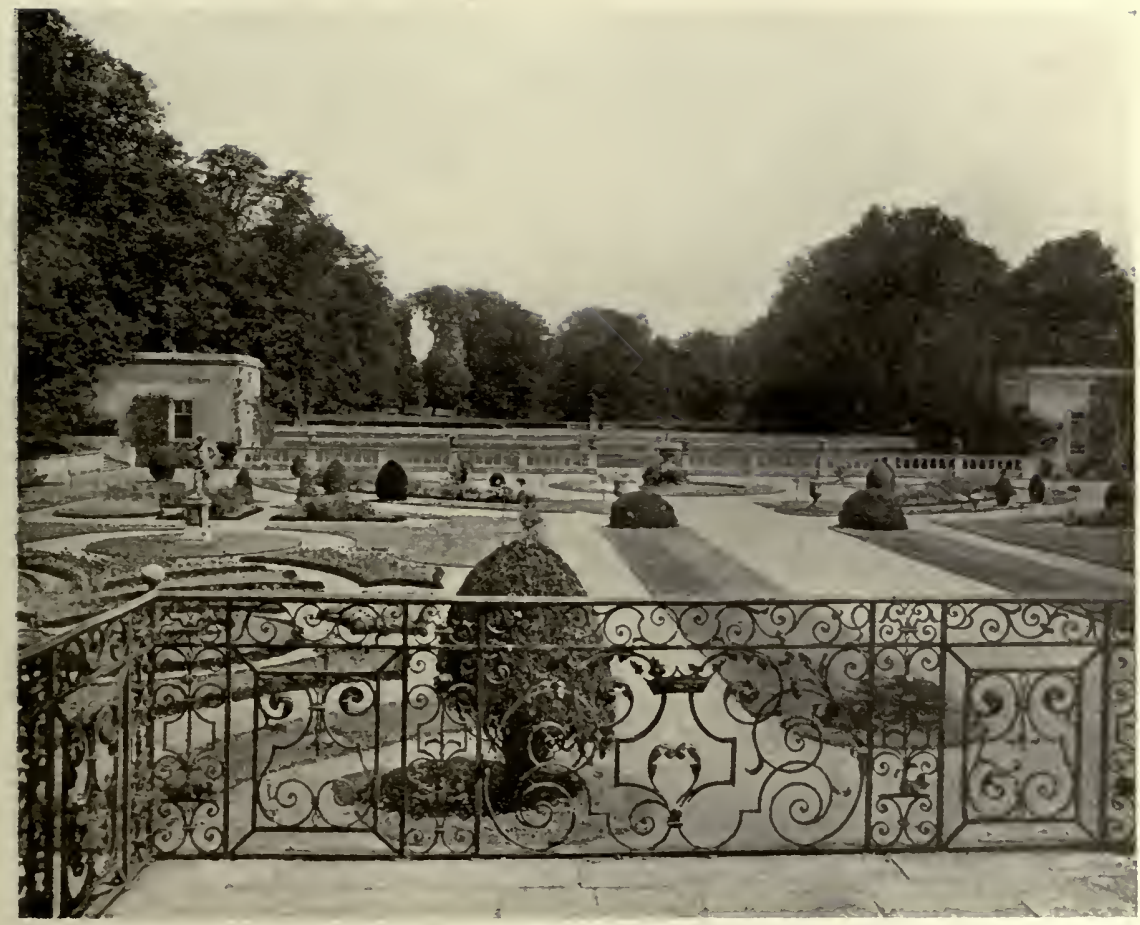

FIG. I 59.-The Gardens at Drayton House, Northamptonshire

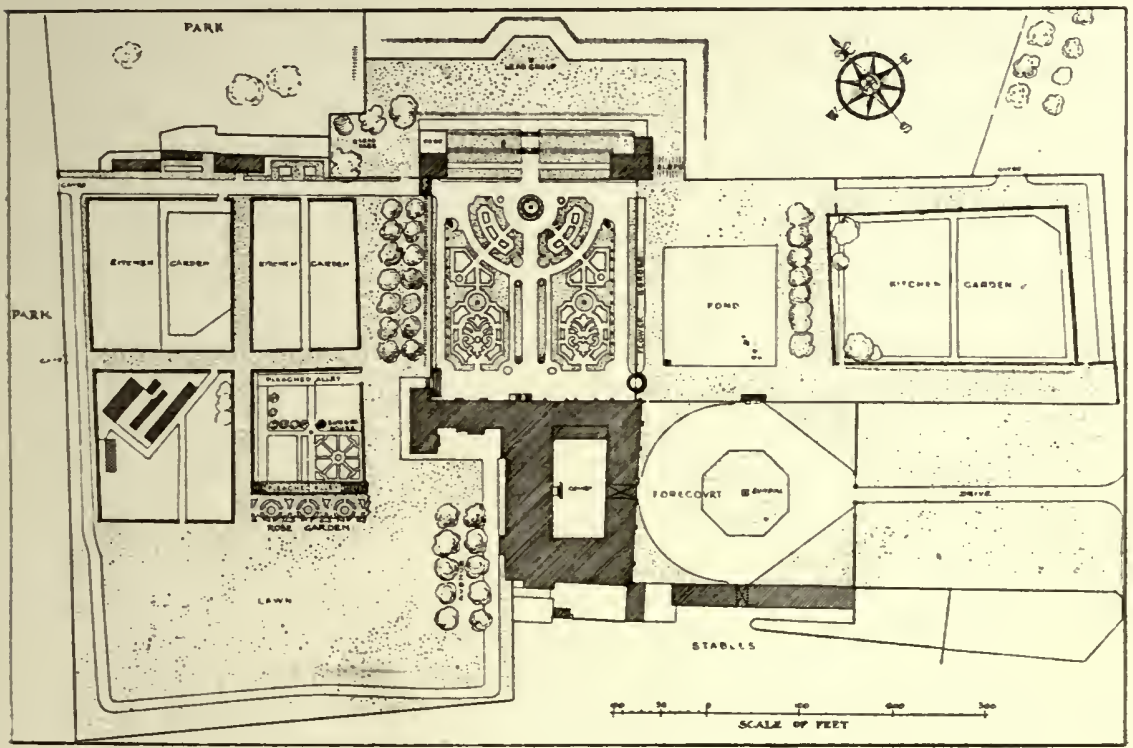

FIG. 160.- Plan of the Gardens at Drayton House, Northamptonshire. 


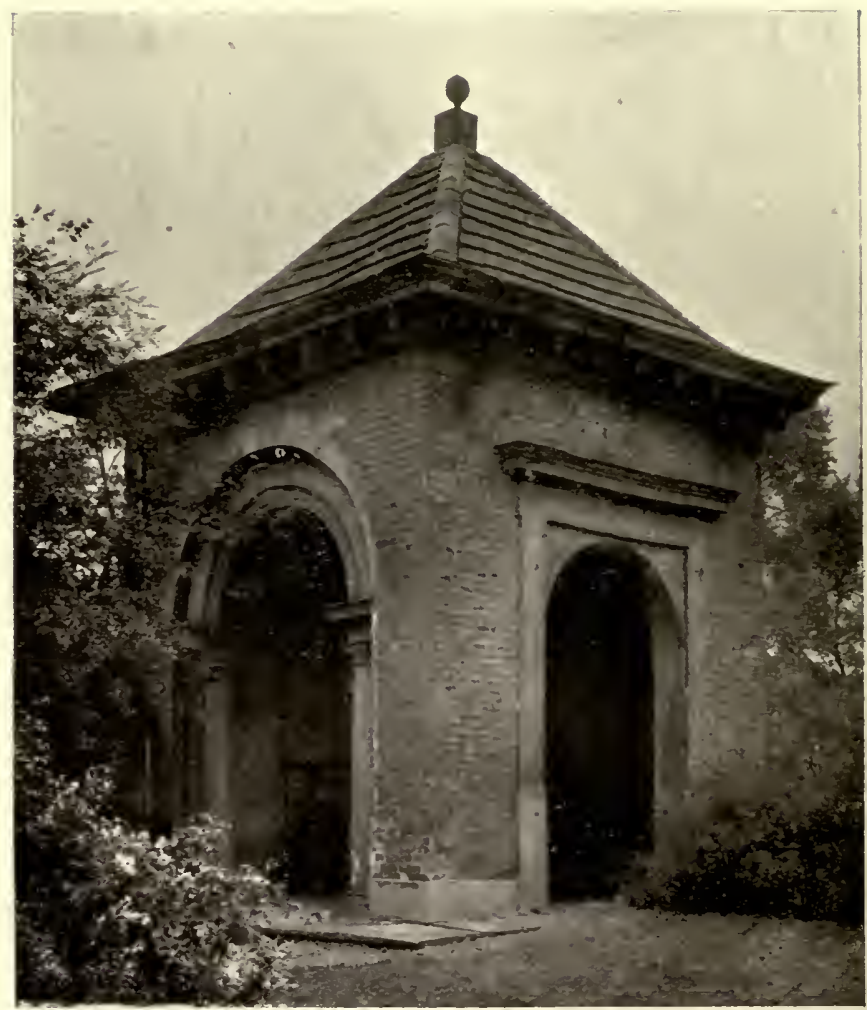

F!G. 161.-Garden House at Croom's Hill, Greenwich.

"temple," which is the chapel of the mansion. In the opposite direction it merges into an avenue which leads the eye across the park to a distant monument. Just before quitting the garden the vista crosses an elaborate arrangement of ornamental water, comprising a large basin flanked by subsidiary pools and cascades, all symmetrically planned. The walk is led from one level to another by monumental steps, producing picturesque groups of garden architecture, and the large water basin is the starting-point of fresh vistas.

The garden buildings form an interesting commentary on the architectural literature of the time, for whereas those in the classic style are quite good, owing to the numerous examples in books, those in the Gothic style are lamentable, since there was nothing to guide the designer but his own study and observation; and nobody at that period had any but the merest nodding acquaintance with Gothic work. 


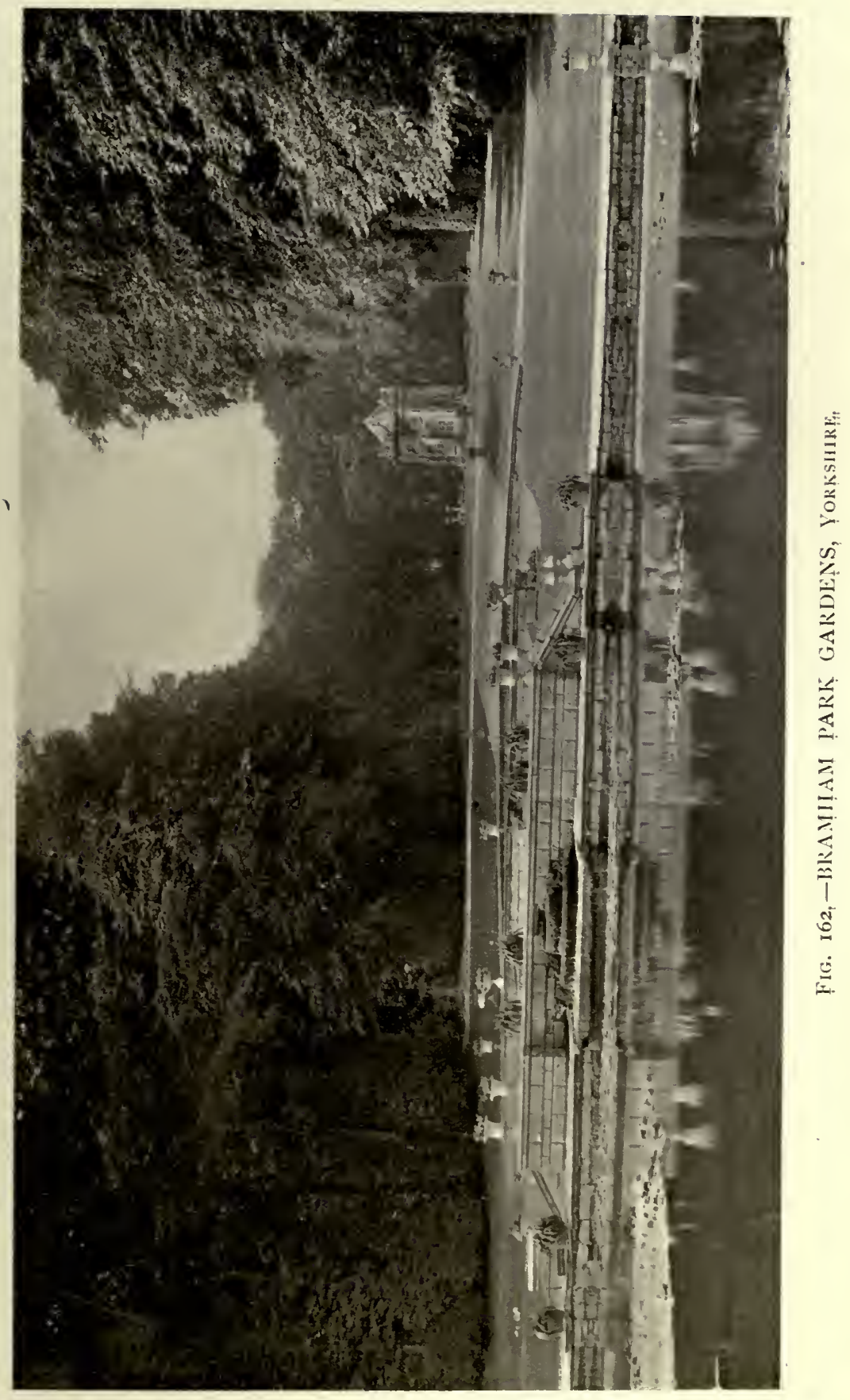


The adoption of a dignified lay out, large or small, to every house of any pretensions at this period, is exemplified in many contemporary prints and books, notably in Kip's "Britannia Illustrata" and Campbell's "Vitruvius Britannicus." Many of these formal gardens have been destroyed, submerged by the wave of landscape gardening, on which "Capability" Brown floated to fame; but there still remain admirable examples besides those already mentioned. There are the placid canals of Wrest, in Bedfordshire (Fig. I 58 ); the sloping vistas of Melbourne, in Derbyshire; the terraces of St Catherine's Court, in Somerset; and the pleached walks and broad parterres of Drayton, in Northamptonshire (Fig. 159), where the forecourt with its beautiful gates and screen of ironwork, the steps from one level to another, and the lead vases, placed on the terrace walls, or raised on pedestals as a dominating part of the scheme, all combine to render the lay out one of the most fascinating of its kind (see plan, Fig. 160). Indeed, examples may be found in every county, although not a tithe of what once existed; and on their terraces, amid their canals and straight walks may be found groups of figures, delightful temples, monuments, urns, and garden-houses, like that at Croom's Hill, Greenwich (Fig. I61), which are not only charming in themselves, but give point to the whole conception. And those conceptions are the most satisfactory which are on a scale moderate enough to enable the mind to grasp them on the spot, without the aid of a plan.

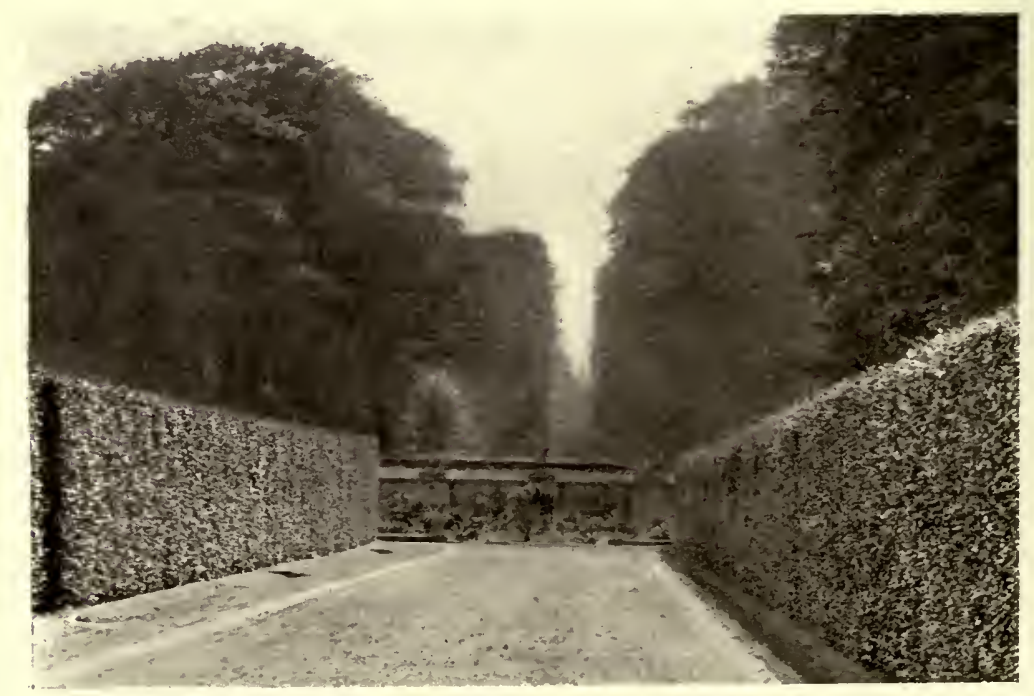

FIG. $16{ }_{3}$--Bramham Yew Hedge. 


\section{$\operatorname{IX}$}

\section{GEORGIAN HOUSES}

REFERENCE was made in the last chapter to the influence of architectural books in stimulating the interest of wealthy amateurs in the matter of building. The eighteenth century saw a considerable increase in the number published, and of these two of the earliest and most important were Lord Burlington's, or rather Kent's, "Designs of Inigo Jones," and Colin Campbell's "Vitruvius Britannicus." Kent put his name to the former, and no doubt rightly, as being the collector and editor of the materials comprised in the two volumes; but Lord Burlington was the "only begetter" as well as the paymaster of the venture. The first volume is devoted almost entirely to one of the designs for the palace at Whitehall, which have already been dealt with in Chapter IV. The second volume consists of designs for houses of all sizes, nominally by Inigo Jones, but actually by Webb. Plans, elevations, and some sections are given, but there is an air of unreality about them, and, as a matter of fact, very few of them were actually built. They are mostly exercises in design in which the convenience of the plan is a secondary consideration. The Thorpe collection is very different in this respect. There most of the plans have the rooms named, a genuine effort being made to get a workable design, with all its parts suitably related one to the other. In Kent's book none of the rooms are named; there appears to be no effort to achieve a workable result. The space enclosed within the outside walls is divided into rooms, and the rooms are carefully proportioned; but so far as the designer is concerned any room might be put to any purpose at the fancy of the occupant. The relation of the dining-room to the kitchen, for instance, is held of no account; aspect and prospect are alike neglected. Sanitary provision there is none. Bath-rooms, of course, were unknown: indeed, from the few allusions to such 


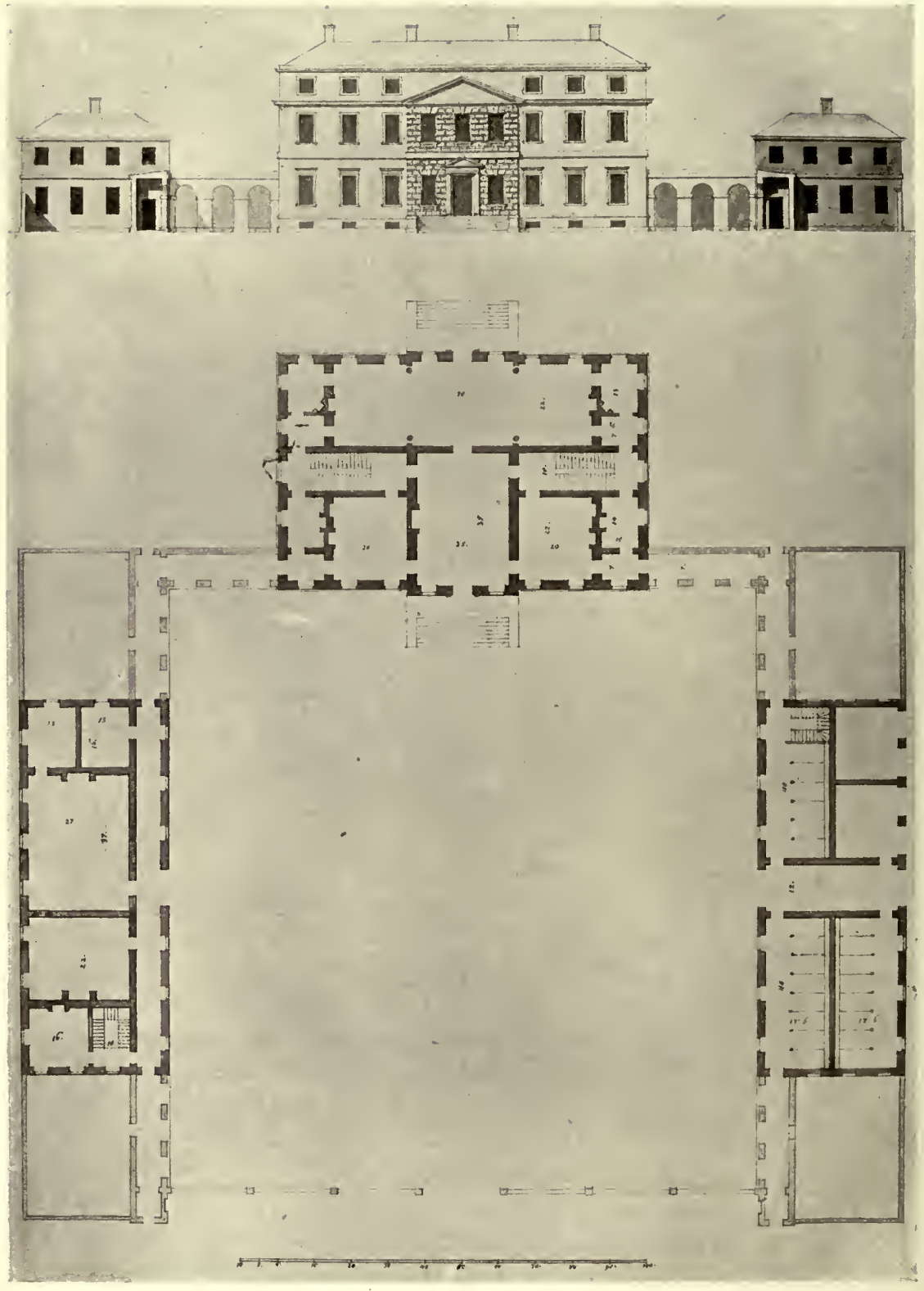

FIG. I64.-DESIGN FOR A HOUSE.

From Gibbs's "Book of Architecture," pl. 57. 


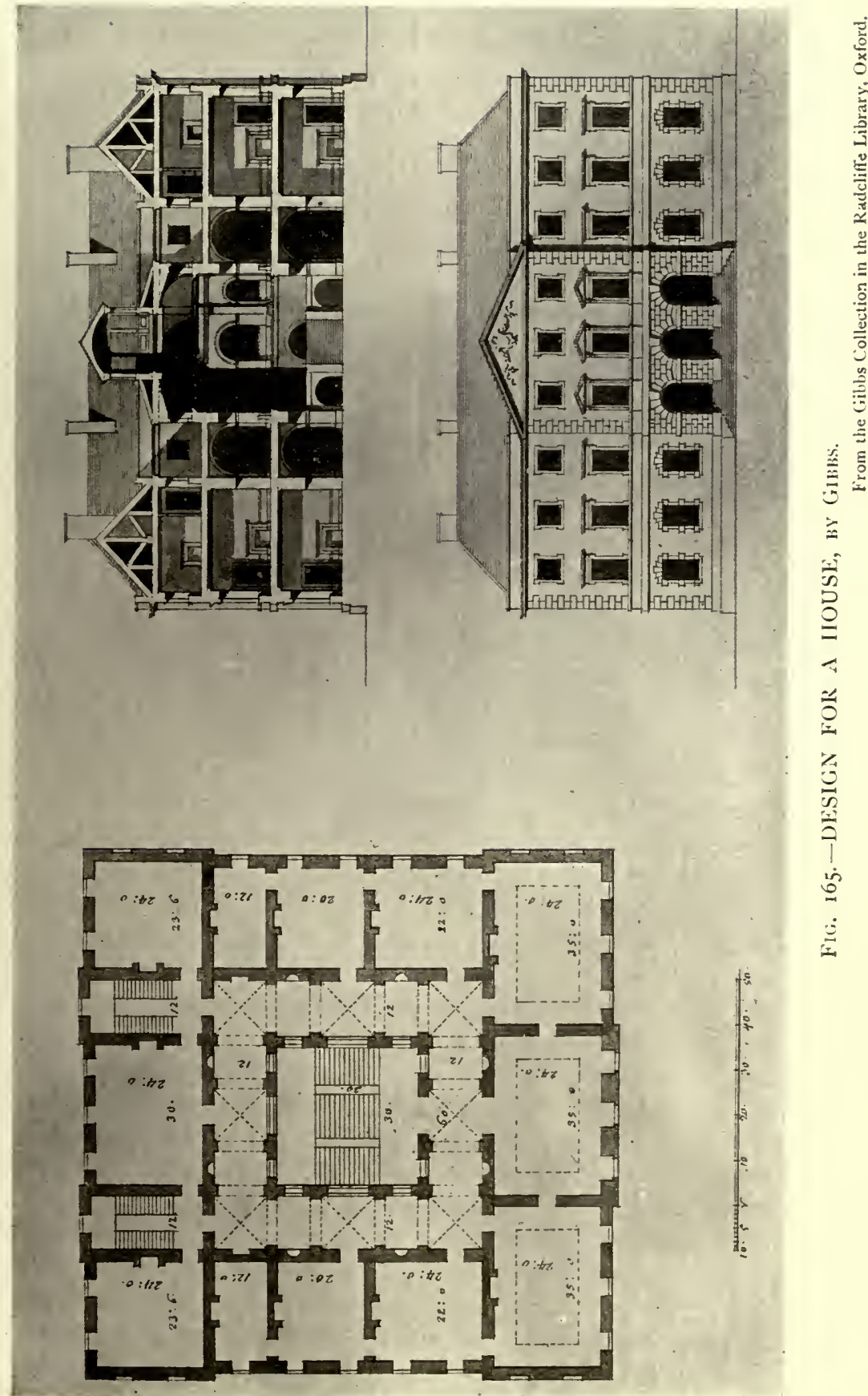




\section{CHARACTER OF XVII. CENTURY HOUSES}

matters as occur in the literature of the time, it is evident that our ancestors of the eighteenth century had deplorable ideas as to cleanliness and sanitation; and the provisions now made in these respects, which are one of the pivots upon which a modern plan turns, were then undreamed of. When all practical considerations were left to take care of themselves, planning a house was a very simple matter, and one which an amateur could undertake with a light heart. The principal aim of designers was to achieve a scenic success. The rooms were to be well proportioned, and so arranged as to produce a stately effect, both in themselves and in the passing from one to the other. They were also so disposed as to result in a fine exterior, where the length should be duly proportioned to the height, the windows should be regularly placed and of a size agreeable to. the eye. Every part was to be symmetrical, and the whole was to be a neat piece of architecture. There seems, in looking through these designs, to be no essential reason why one should have differed from another, except for the sake of variety. Yet every modern architect knows that a house properly planned to meet one set of circumstances can never be utilised for another without drastic alterations; that every fresh house presents a fresh problem. But this springs from the modern way of looking at house-designing, namely, that a house ought to satisfy the wants and even the idiosyncrasies of the owner, and that its disposition must be modified by considerations of aspect, prospect, soil, surroundings, and a score of other things.

But the outlook of the eighteenth century being what it was, the designers were successful in compassing their object, and they produced many charming houses, often stately and always dignified. This result was owing in a large degree to a study of Kent's "Designs of Inigo Jones."

Campbell's "Vitruvius Britannicus" is an epitome of the more important houses of the last twenty years of the seventeenth century and first twenty of the eighteenth. ${ }^{1}$ The ideas underlying it are those which have already been mentioned. There is a short descriptive account of each subject. In these, Campbell dwells on the proportions of his rooms, on the truly classic treatment of the elevations; he explains how one subject. is treated in the "palatial" style, another in the "temple" style ; another in the "theatrical." The principal rooms are all stately,

1 The first series, in three volumes, is here referred to. 

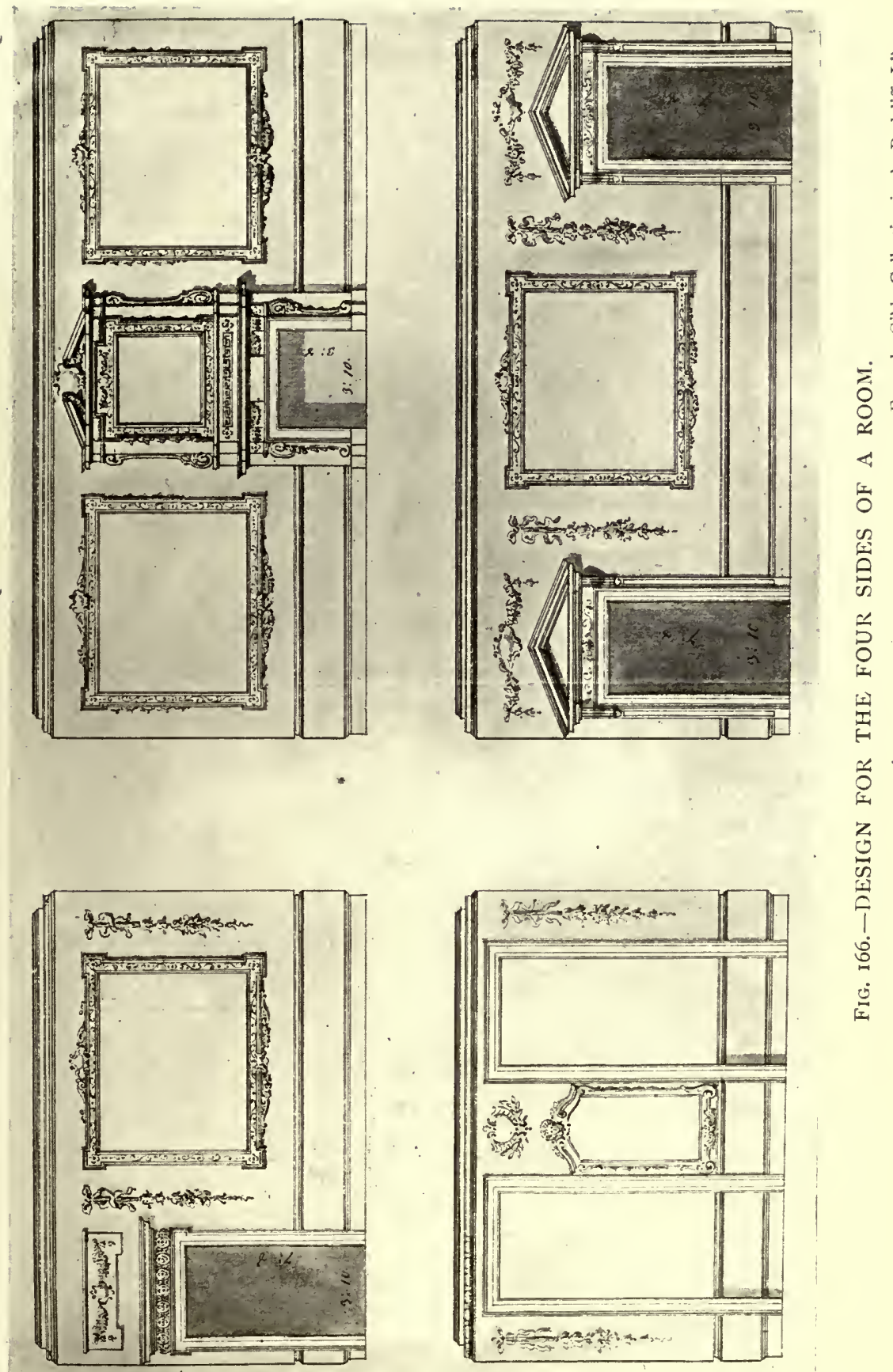

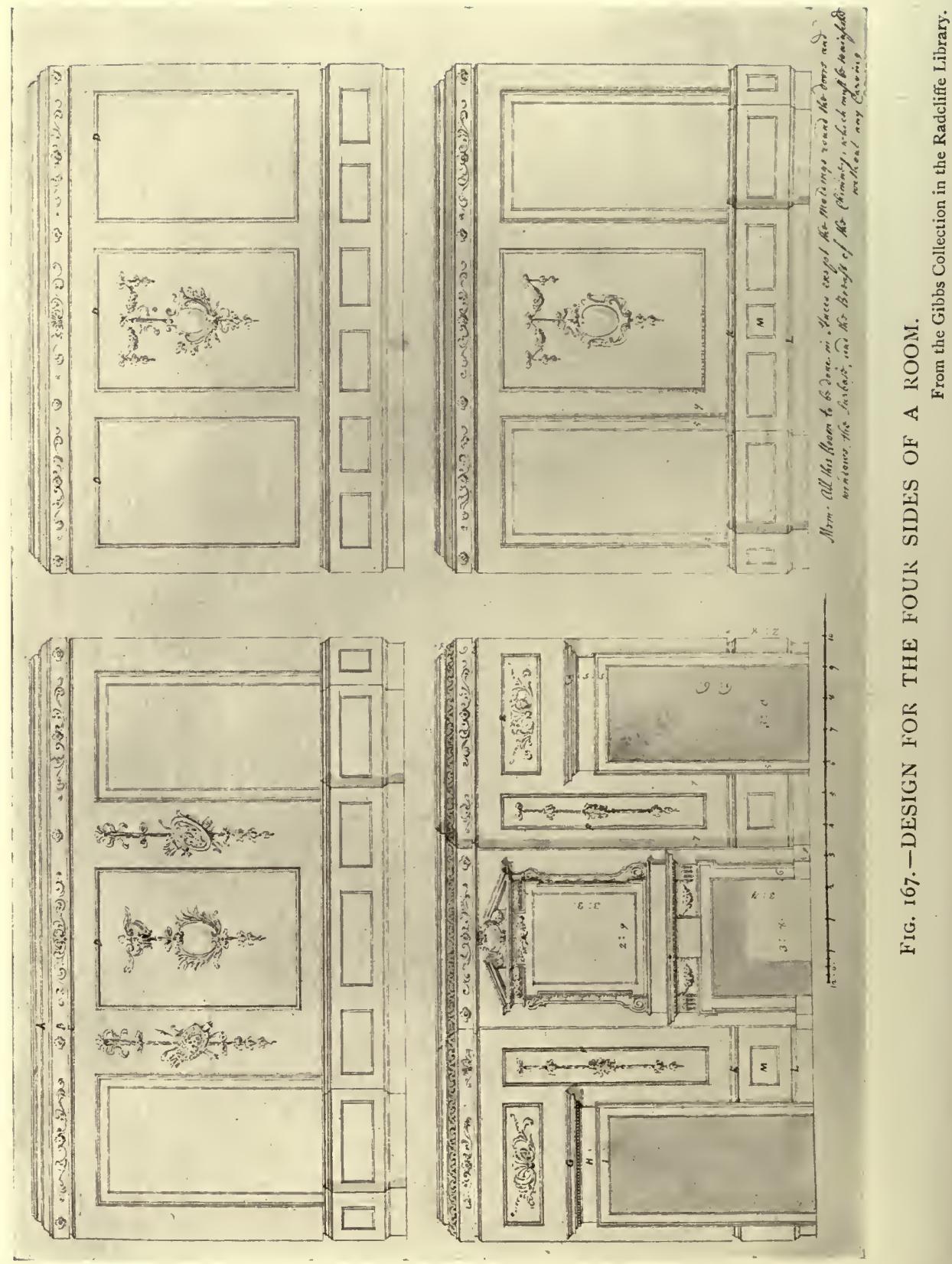
the family rooms in some cases are in the attics, lighted from the leads. In one design he plumes himself on not having his windows "crowded"; and indeed the amount of wall space between the lower and upper windows is so ample that either the lower must be far below the ceiling, or the upper far above the floor. It would be tedious to multiply instances; anyone can find them for himself by looking through his volumes. The point is that many important houses of that time were built for state and show, rather than for coinfort and convenience; and they afford a striking commentary on the difference in outlook on daily life between that period and our own among the wealthy classes.

These particular manifestations were not merely a passing fashion; they were too widespread and too lasting for that; yet that they were in fact the outcome of fashion is proved by Pope's Epistle to Lord Burlington (the fourth of the "Moral Essays") which is in effect a vindication of common sense as opposed to extravagance in buildings, gardens, and entertainments. Pope credits Lord Burlington with the qualities he commends, yet in none of the buildings attributed to that nobleman is common sense very conspicuous.

Another book on architecture was published by James Gibbs, a contemporary of Hawksmoor and Vanbrugh, but somewhat younger, and who was one of the numerous architects encouraged by Lord Burlington. He deservedly enjoyed a large practice, and designed many churches and houses. He was skilful and ingenious, and showed more originality than most of his contemporaries, particularly in his churches; his houses go very little outside the lines which were universally accepted as being appropriate for gentlemen's residences. Like several of his fellows he commended himself to the public by publishing (in I728) a large folio volume of his designs. These are well worth study, for they were all either actually built or were intended to be built, the erection of some being prevented by the death of the client or by some other cause. They have therefore a more vital interest than most of those in Kent's "Designs of Inigo Jones."

His Introduction is interesting. The work was undertaken, he says, at the instance of several Persons of Quality, who were of opinion that it "would be of use to such Gentlemen as might be concerned in Building, especially in remote parts of the Country, where little or no assistance for Designs can be pro- 
cured." He suggests that, furnished with his book, these remote gentlemen can employ any workman who understands lines to build them a house, and even make alterations in his designs if guided by a person of judgment. But he (very rightly) warns his readers against employing only ignorant workmen in the management of buildings of great expense, lest they undergo the mortification of finding the result condemned by persons of taste, entailing even the drastic remedy of pulling the building down. He also warns them against extravagant and misapplied ornament, "for it is not the Bulk of a Fabrick, the Richness and Quantity of the Materials, the Multiplicity of Lines, nor the Gaudiness of the Finishing, that give the Grace or Beauty and Grandeur to a Building; but the Proportion of the Parts to one another and to the Whole, whether entirely plain, or enriched with a few Ornaments properly disposed." It is to be feared that his readers must have felt that what he gave with one hand in offering them his book, he took away with the other by showing how hazardous it was to use it without training and experience.

He concludes by saying that his designs had been done in the best taste he could form upon the instructions of the greatest masters in Italy, supplemented by his own observations upon the ancient buildings there during many years' study; adding, as a sly dig at the amateurs, "for a cursory View of those August Remains can no more qualify the Spectator, or Admirer, than the Air of the Country can inspire him with the knowledge of Architecture."

It is a characteristic pronouncement, with its reliance on the authority of the Italian masters, its insistence on proportion, its omission of any reference to domestic comfort, its intention that the book should help the unlearned, coupled with the warning that unless the user had taste and judgment of his own, he must seek those qualities in an expert.

The illustrations give a good idea of what was expected in a country house in those days. The plans are all symmetrical, and each front is regular and intended to be seen; there was no thought of giving the house a back for the use of servants and tradesmen. Indeed there were hardly any tradesmen to be considered. Every house was self-sustaining and provided its own bread, meat, and vegetables. This is an important point to bear in mind; it accounts for the numerous outbuildings which 

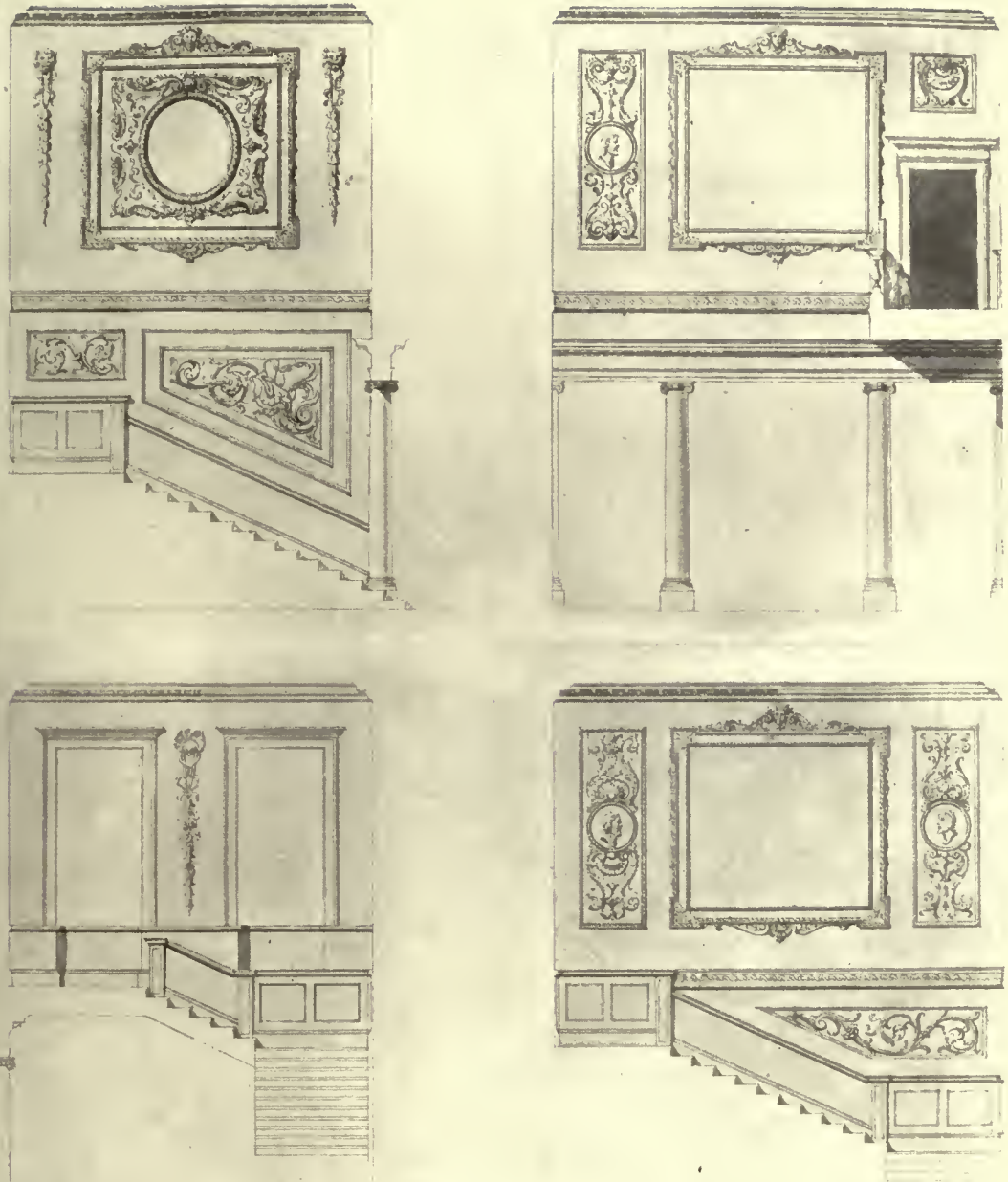

FIG. 168.-DESIGN FOR A STAIRCASE.

From the Gibbs Collection in the Raccliffe Library. 


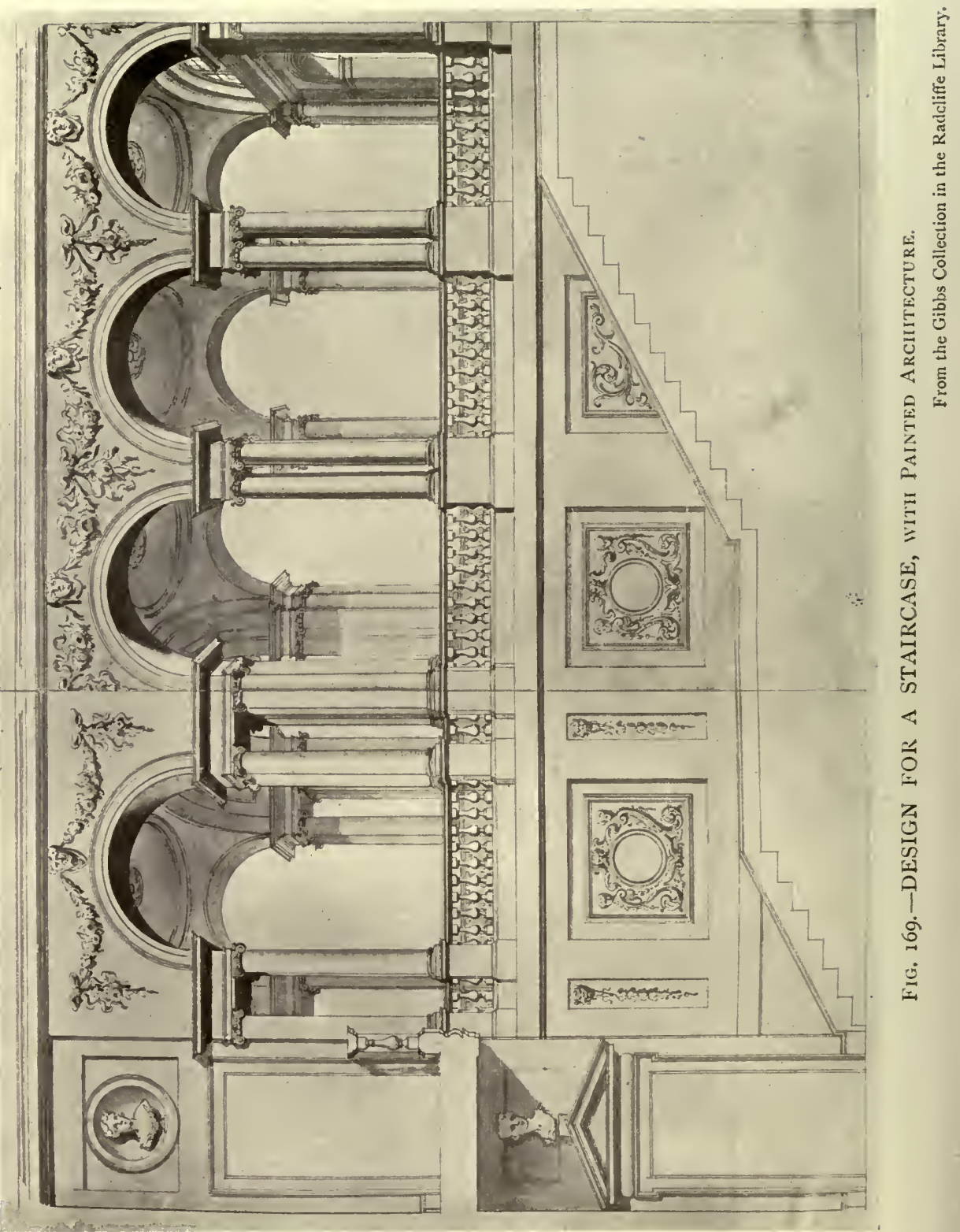


form part of old houses, inasmuch as places had to be provided for storing most of the things which are now retained by the shopkeeper until his carts take them to his customers. It also partly explains how it was possible to have each side of the house a show-front, for there was less outside traffic when there were no tradesmen's carts, although there was always a staff of servants going in and out. The servants are placed either in a basement or in an outlying wing, never in proximity to the principal rooms; at the same time, in order to gain their rooms in the attics, they generally had to cross either the hall or one of the rooms intended for the family. The effect of this was that they were less conveniently placed for service than they are in the present day, and yet they could not gain their bedrooms without the risk of intruding on the family.

In many instances the kitchen with its dependencies occupied an outlying wing, and the food had to be brought a long distance, and frequently through an open corridor. The inconvenience of this arrangement must have outweighed the advantage of getting the smells and noise of the kitchen away from the house. The family rooms were the chief concern of the designer, and his aim was to make them stately. The arrangement most often adopted was to have a large entrance hall, and beyond it a dining-room; on either side were two or more rooms with a staircase between them. The hall occupied two stories in height, being as much as $30 \mathrm{ft}$. or $36 \mathrm{ft}$. high, and it must have been cold and cheerless, if grand. The principal rooms were lofty, and over each was another of the same size; in some instances small rooms of less height were placed next to the staircases, thus enabling others over them to be reached from a landing half-way up- "intersoles," as Gibbs calls them. The same device had already been adopted by Hawksmoor at Easton Neston. The symmetrical disposition of the rooms favoured the placing of their doors in a straight line so that long vistas could be obtained, and although Gibbs prides himself on providing passages which rendered every room private, there were usually doors of intercommunication, and many of the rooms suffered from a multiplicity of entrances. The passages were evidently a concession to modern ideas, and were often ill-lighted from openings into the hall. The observance of strict symmetry sometimes led to the provision of two equally important staircases where 


\section{GIBBS:S DRAWINGS IN RADCLIFFE LIBRARY}

one would have been enough for practical purposes. It also resulted in the stairs crossing windows, the outside harmony of which was held to be sacred; and a further consequence was the introduction of many sham windows for the sake of uniformity.

In spite of such drawbacks, which sprang from the formality of the treatment, Gibbs's plans are ingenious and well devised. He attaches great importance to privacy, and frequently introduces a number of "apartments," as he calls them, each apartment comprising a bedroom and dressing room, with occasionally a third or ante-room. The demands of those times were, of course, far simpler than our own, and Gibbs was as skilful as any of his contemporaries in satisfying them. He was able to do this within walls which were treated in a strictly classic manner, founded on instructions of the Italian masters. Whether he could have met the complex wants of the present day in so simple a fashion is open to question.

Many of Gibbs's original drawings are preserved in the Radcliffe Library at Oxford, some of these being included in his "Book of Architecture." Two of them are reproduced here, one (Fig. I64) is plate 57 of his book, the other (Fig. 165) has not been published. The first is an example of a house with a forecourt and wings connected by open corridors to the central block; in the left-hand wing are the kitchens, in the right the stables. The house is entered through a large hall beyond which is a gallery, with small rooms at each end. To the left of the hall is presumably the dining-room, as it lies nearest to the kitchens, to the right is a room of the same size. There are two large staircases resembling each other in all respects, that on the left being probably the back stairs. Grouped on each side of the staircases are small rooms over which might have been the "intersoles," although Gibbs does not expressly mention them. In this instance the hall was but one story in height with a room over it, and there were three rooms over the gallery. The same disposition obtained on the top floor, which may have been devoted to guest chambers, as it would appear that the servants were lodged in the kitchen wing, judging by the size of the staircase.

The other and unpublished design (Fig. 165) is of a somewhat different type. The centre of the house is occupied by a vast and lofty staircase mainly lighted from a cupola. Round this 


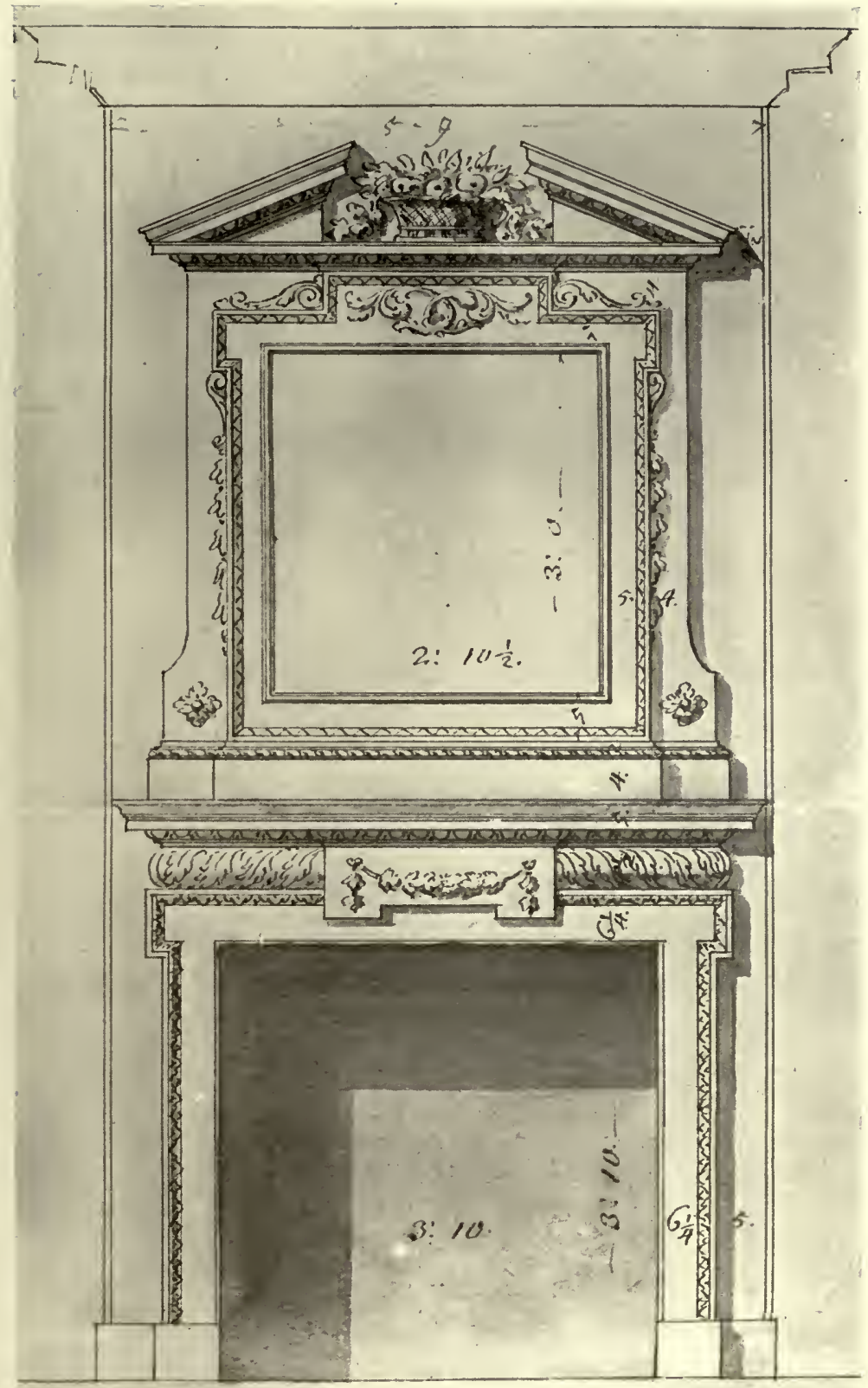

Fig. 170.-A CHIMNEY-PIECE, By Gibbs.

From the Gibbs Collection in the Radcliffe Library. 


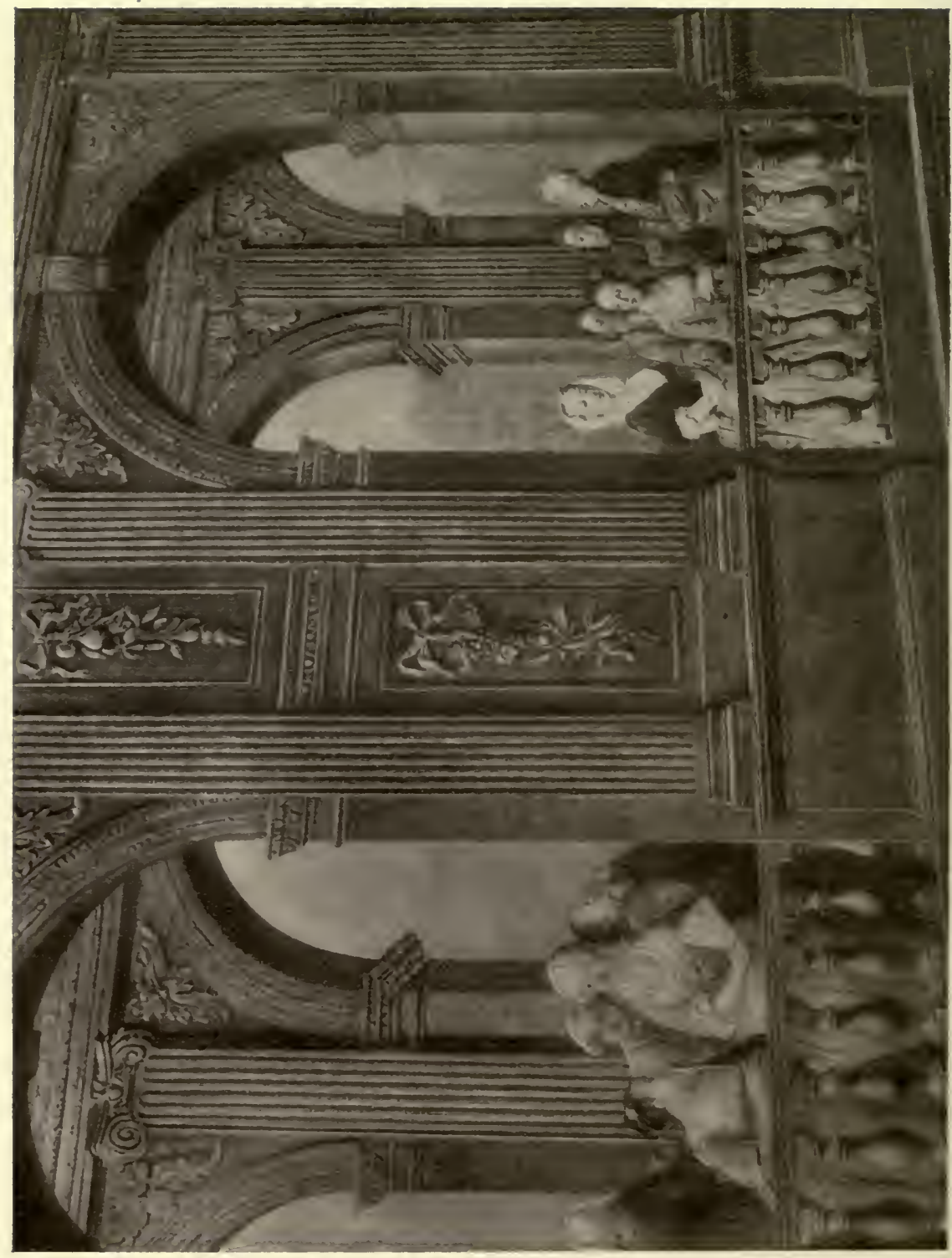

年 
is a broad corridor giving access to the various rooms, which are of fine dimensions. The same disposition appears to apply to all three floors, save that on the topmost the corridor is omitted, and thus an open space is provided which gives light to the hall on one side and to a passage on the other, which is taken off the width of the rooms. There is no indication where the kitchens lie; the section shows no basement, and there are no indications of separate wings.

The section gives an adequate idea of the internal treatment; it shows the great hall and its lighting, as well as the very simple decoration of the rooms, far plainer in this case than in most of those published in his book. The rooms are usually panelled somewhat after the manner shown in Figs. 166 and 167. This gives an air of distinction to them, but it severely limits (and perhaps not unhappily) the number of pictures and prints which can be hung on the walls. A very similar treatment is applied to the staircases (Fig. I68). In one instance the walls were apparently. to be painted with an architectural composition, which introduces a touch of poetry into the practical prose of Gibbs's ordinary handling (Fig. I69). There is a house in Dean Street, Soho (Fig. I 7 I), where the staircase walls are decorated with figure subjects by Hogarth, somewhat after the fashion of Gibbs's drawing, but more elaborate in design. The decoration of the rooms already illustrated includes in each case the chimneypiece, but a further example, to a larger scale (Fig. I 70), will serve to show the kind of design which was widely adopted, not only by Gibbs but by most architects during the first half of the eighteenth century.

Campbell was also a practising architect as well as an illustrator of the art, and he was consulted in the erection of Houghton Hall, in Norfolk, which is one of the finest examples of the great houses of its period, a period when nobles and wealthy gentlemen were vying with one another in building fine homes in the fashionable Italian manner, and surrounding them with equally fine gardens. It was the celebrated Prime Minister, Sir Robert Walpole, who built Houghton; and Colin Campbell supplied him with the design in the year I722. It would appear, however, that Campbell did not carry out the work himself, but that his designs were handed over to Ripley, who altered them in many respects while following the general idea 
pretty faithfully. The sizes and disposition of the rooms were varied, both in the central block and in the wings. The proportions of the windows were altered, and Campbell's projecting portico was omitted, the columns being attached to the wall instead of standing some fifteen feet in front of it. The attic stories of his corner pavilions were also changed into domes. On the whole these slight alterations tended to improve the appearance, but in spite of these variations, Campbell must have

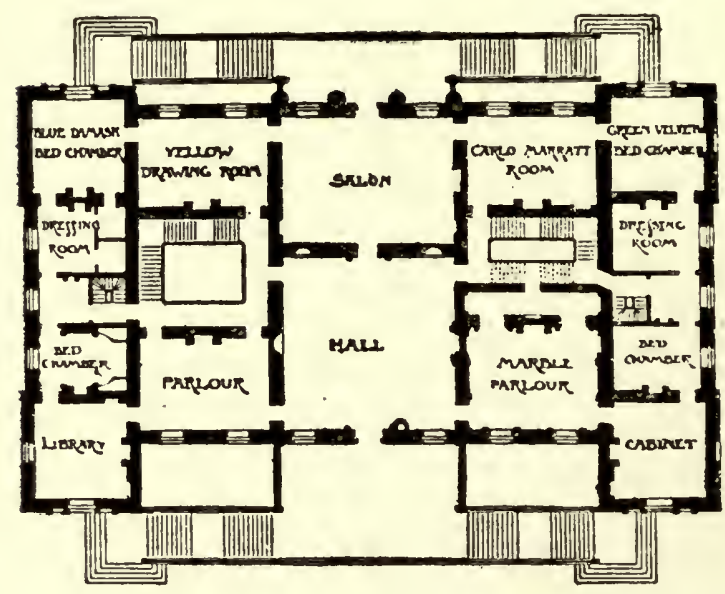

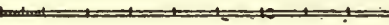

FIG, 172.-Houghton, Norfolk. Plan of Principal Floor, I722. the credit for the design (Fig. I 73).

The whole arrangement is of the prevalent type. There is a noble main building flanked on each side at some distance by a subsidiary block, connected to the house by colonnades which arecurved on one face and rectangular on the other. The south wing contains the kitchen and servants' quarters; the north wing is occupied by a picture gallery and chapel, but much of this particular building has been destroyed by fire.

The house itself is of three stories, including the basement, which is used in part for domestic purposes, but serves in the main to raise the principal floor well above the ground. This floor (see plan, Fig. I72) contains the fine stone hall, a cube of $40 \mathrm{ft}$., a saloon somewhat smaller and less lofty, a dozen fine rooms and some staircases, of which the chief one is magnificent. All these rooms are symmetrically arranged, and the doorways are so disposed as to produce long vistas when the whole series is opened. The four rooms in the corners can only be gained by 


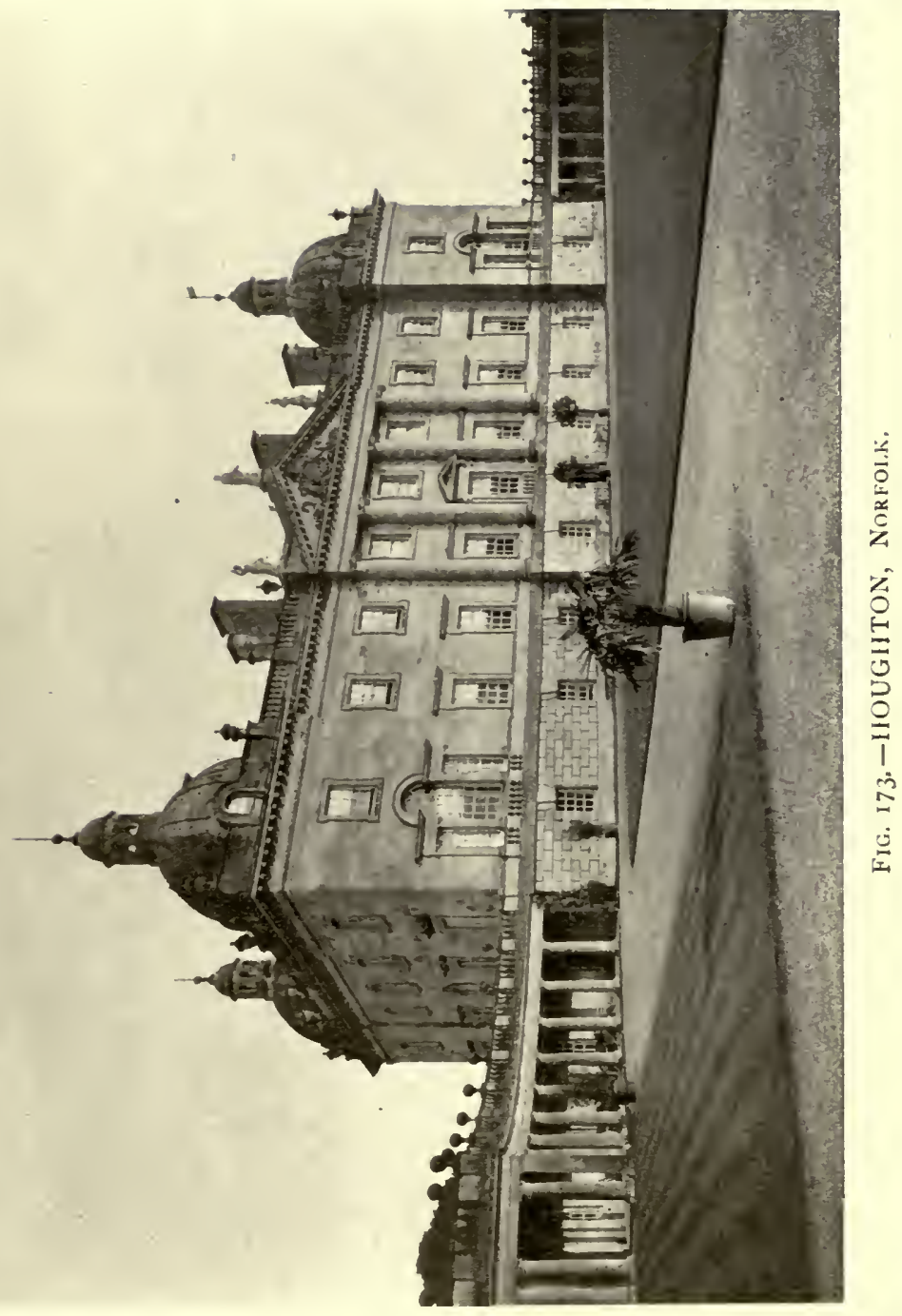




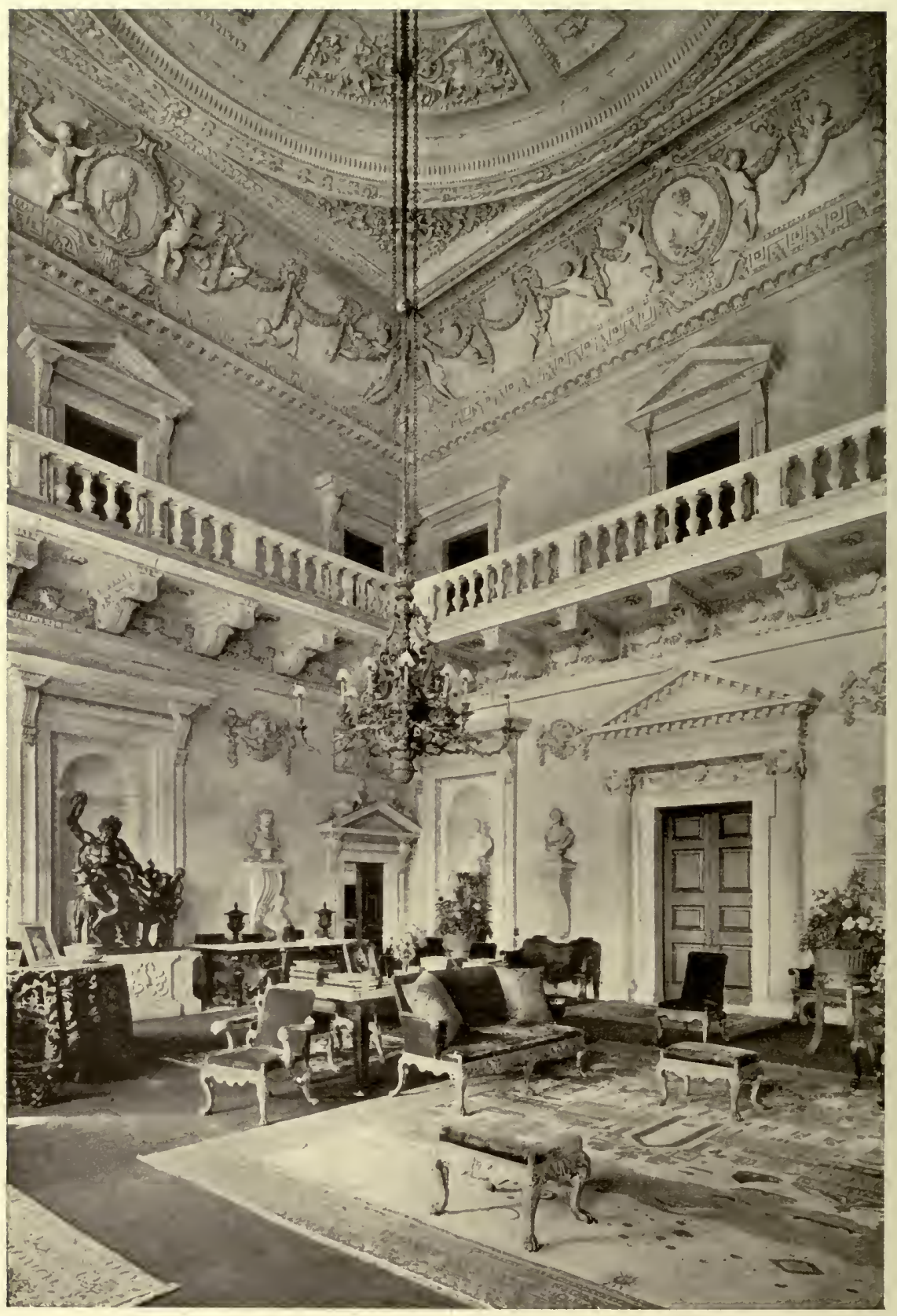

Fig. i74.-HOUGHTON. The Stone Hall. 
passing through other rooms. The whole effect is stately both inside and out, and although in the present day there may be a certain lack of comfort, yet the house fully met the needs of the time when it was built, and it provided the atmosphere of splendour which was demanded by all great persons of the period. The whole façade is over $500 \mathrm{ft}$. long, the central block has a frontage of $165 \mathrm{ft}$., and the wings I IO $\mathrm{ft}$. These are handsome dimensions; they are indeed so large that it is not easy for the eye to include the whole group at once from any ordinary viewpoint. The illustration (Fig. 173) only shows the house and its colonnades, beyond which the reader's imagination must add the wings, which are strictly subordinated in height to the main building.

The interior decorations are attributed to Kent, who was assisted in the plasterwork by the Italian, Artari. But the stone hall (Fig. 174) follows Campbell's drawing in the main, as may be seen by comparing it with his sections in "Vitruvius Britannicus." The ceiling is a remarkable tour de force, and the cove, with its children disporting themselves among the wreaths, is much admired. There is plenty of movement and variety in it, but the figures are a little inclined to-obesity. The whole work perhaps suffers from being in too high relief, but its vigour and freedom of design are incontestably admirable. One of the principal rooms is called the marble dining-room, and it was intended to be lined with marble throughout, but one side only was carried out in this manner (Fig. 175). It includes a fine chimney-piece, characteristic of the grander type then in vogue; on either side of it are marble-lined recesses in which are placed marble sideboards to correspond with their surroundings. The panel of the chimney-piece contains a figure subject, a sacrifice to Bacchus, carved by Rysbrach, and the decoration, both here and in the ceiling, consists largely of grapes, a form of ornament highly appropriate to a room devoted to entertainments in which deep drinking played an important part. The woodwork throughout is exceedingly handsome; it is executed for the most part in mahogany, a precious wood which had not previously been used in great abundance. The doorway of the green state room is an example of a rich treatment (Fig. 176), and Sir Robert's dressing-room one of a plainer handling (Fig. I77). The principal staircase has an exceedingly massive mahogany 


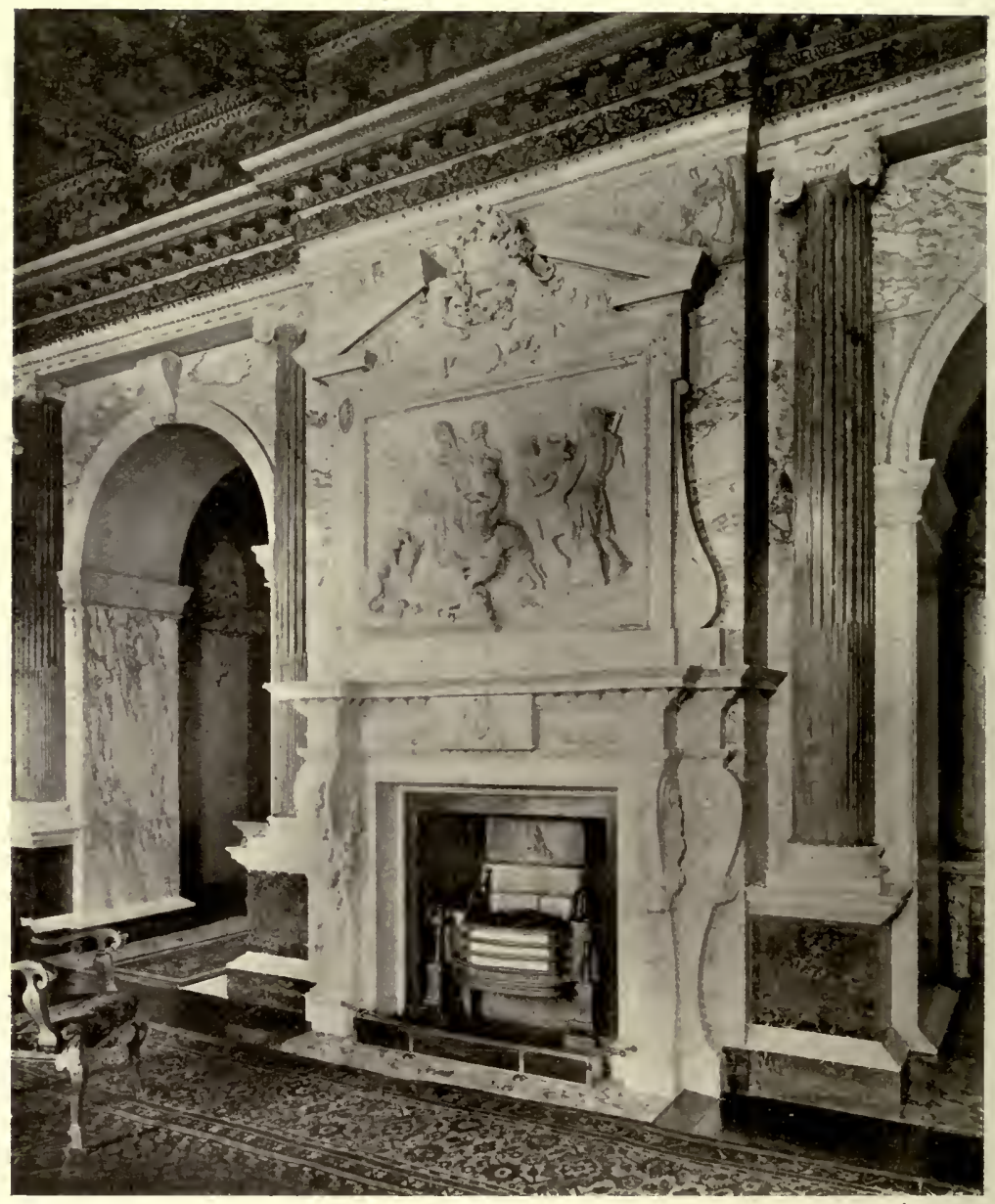

FIG. 175.-Houghton. The Marble Dining-Room.

balustrade (Fig. I78), and the walls are decorated with figures and subjects in monochrome, by the hand of Kent himself. Sir Robert is said by Walpole, in his "Anecdotes of Painting," to. have purposely restricted the artist to this vehicle, having lively misgivings as to Kent's exploits in brighter and more varied pigments.

Another of the imposing houses of the eighteenth century is Wentworth Woodhouse, in Yorkshire, a seat of the Earl 


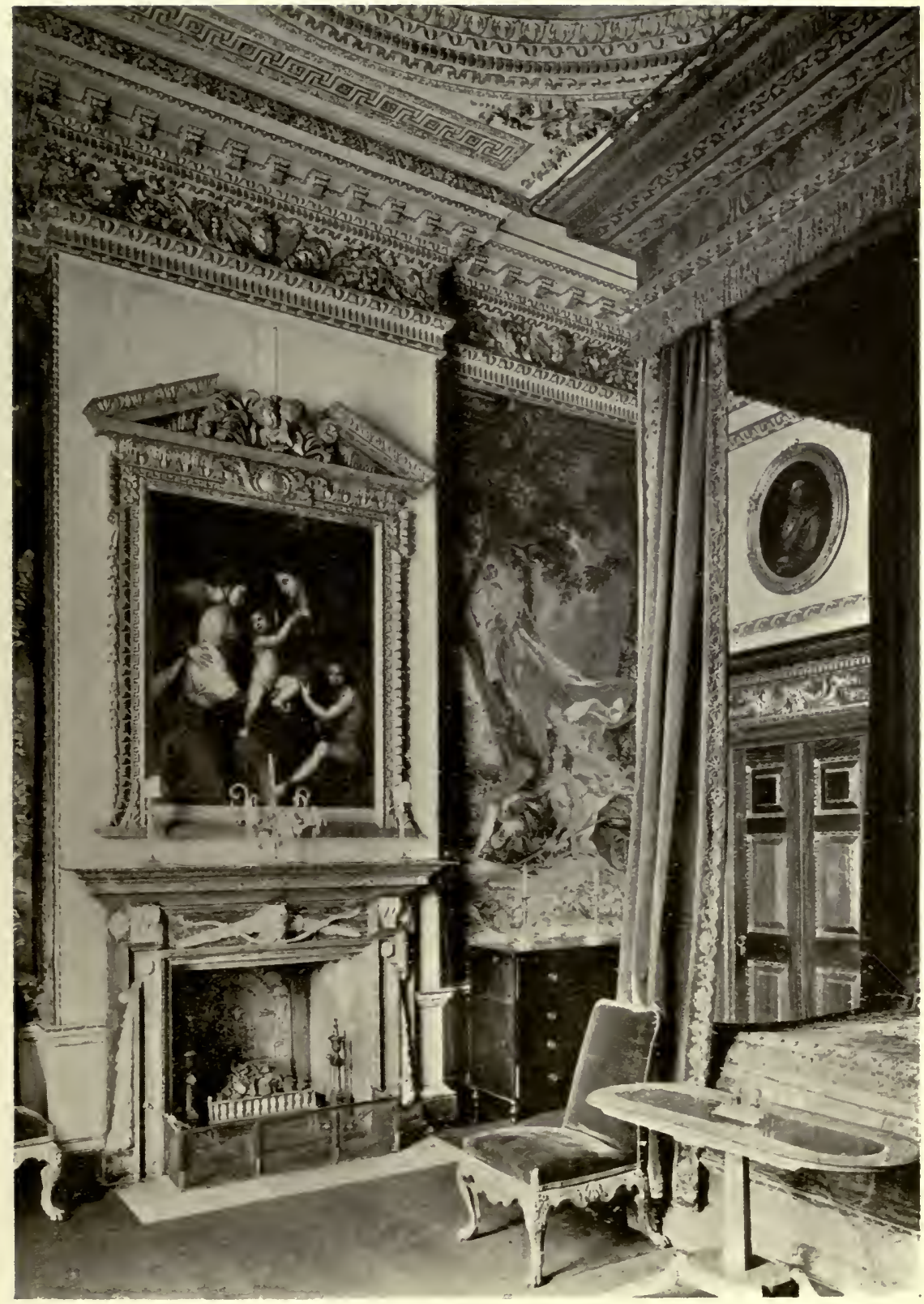

Fig, 176.-HOUGHTON. TIE GRenN State RoON. 


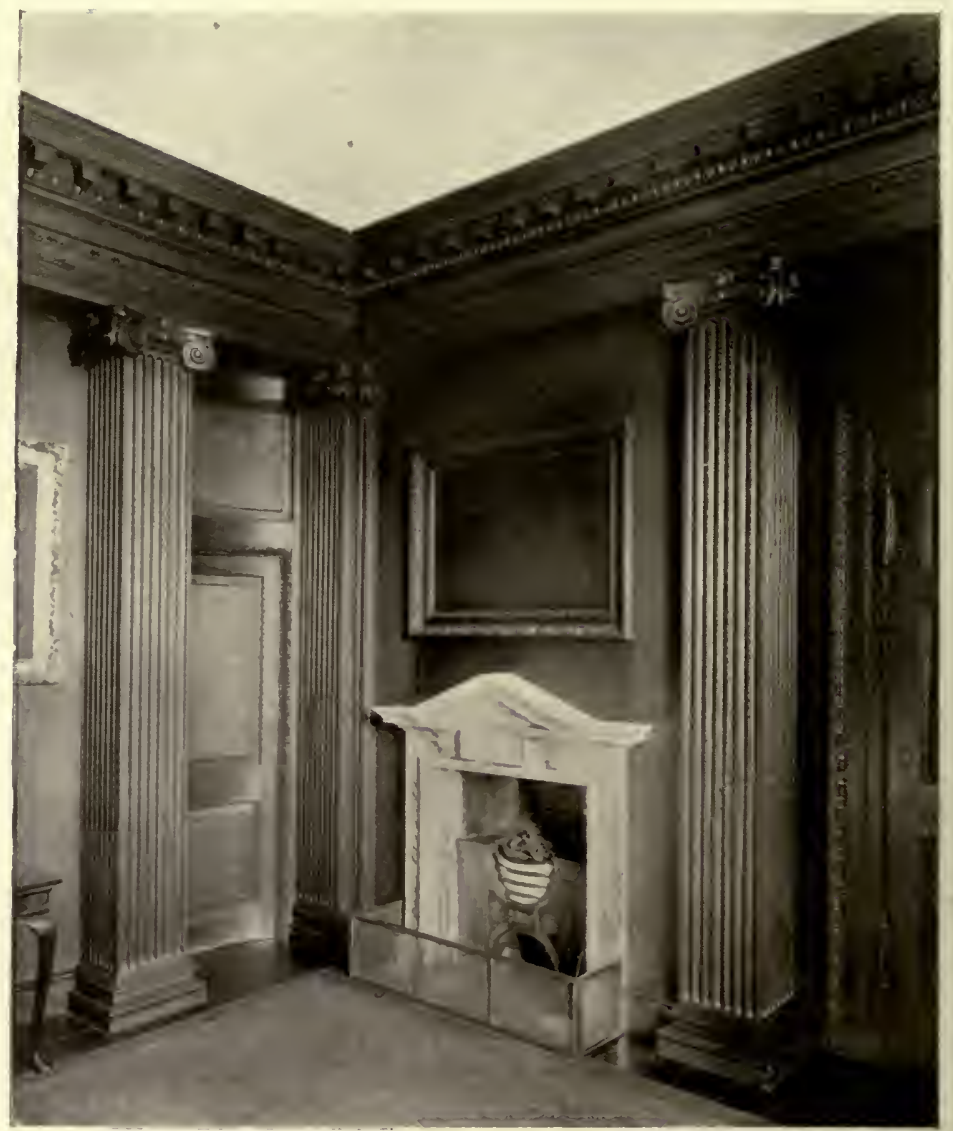

FIG. 177.-Houghton. Sir Robert Walpole's Dressing-Room.

Fitzwilliam, which must not be confused with Wentworth Castle, near Barnsley, a smaller house, but still a fine one, built by Thomas, Earl of Strafford, in I730. IVentworth Woodhouse was designed in the year 1740 by Henry Flitcroft for Thomas, Earl of Malton, who succeeded some six years later to the barony of Rockingham, and was thereupon created Marquis of Rockingham. His biographer ${ }^{1}$ says that he "rebuilt the ancient family seat, now called Wentworth House, in a very elegant manner, where he died on I4th December I750." His eldest

${ }^{1}$ Collins's "Peerage." 


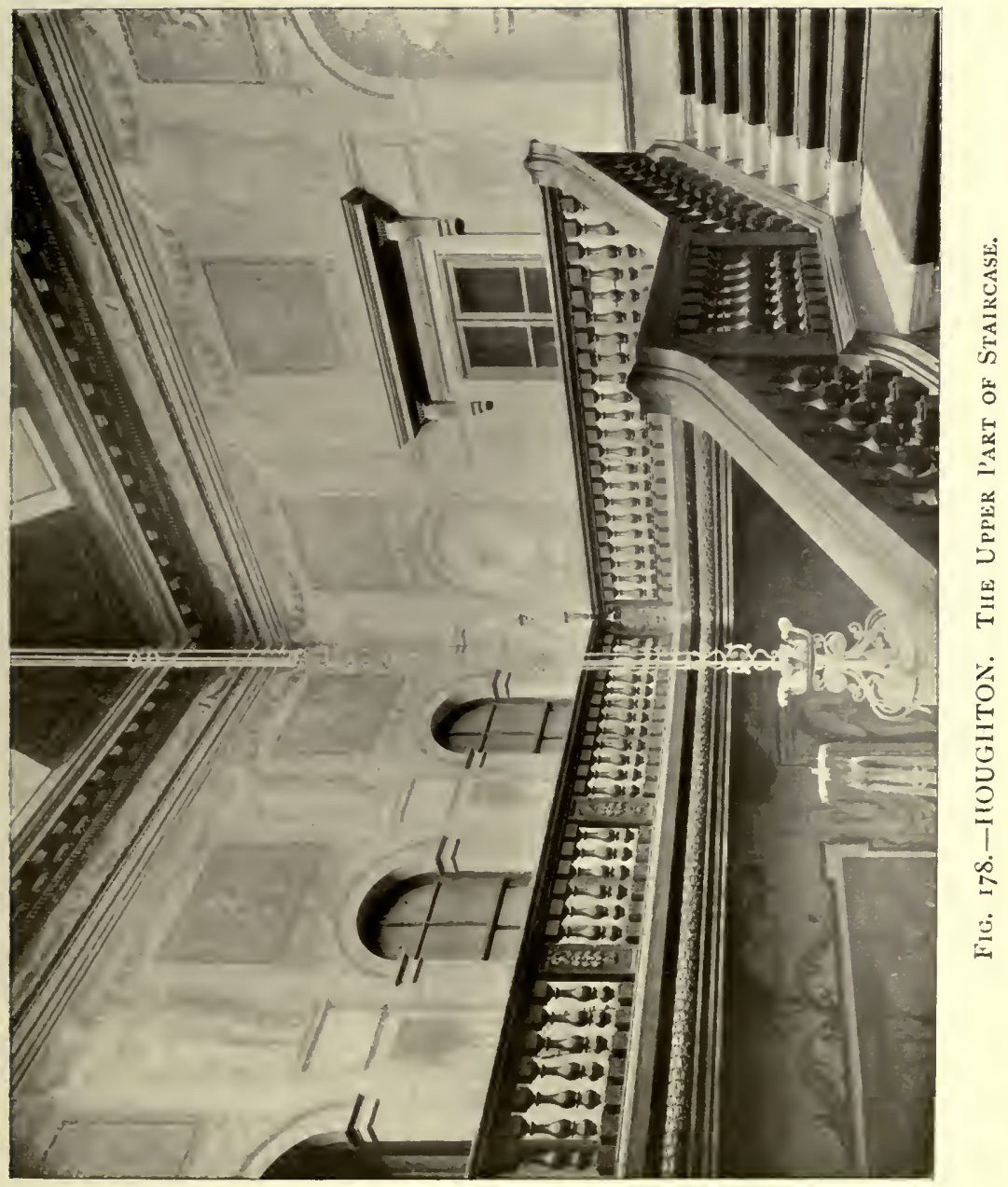


daughter, Anne, married Earl Fitzwilliam, and carried Wentworth House into her husband's family in 1769. Flitcroft published a drawing of the principal front of the house at the end of the I 770 edition of Kent's "Designs of Inigo Jones," and in the main this design was carried out. The central and chief part of the façade was executed as drawn, but the two wings, while preserving their original disposition, were considerably improved.

The stately front (Fig. I79) is some $600 \mathrm{ft}$. in extent, and is the more striking in that it is a continuous façade, and not broken up into the usual three parts, consisting of the house and two outlying wings. The memory of the old curved colonnades is preserved in the convex portions which connect the end towers with the front. The central block is not so much an adaptation as a copy of Campbell's second design for Wanstead ("Vit. Brit.," i. 24, 25), with the omission of the cupola and of one window in the length of the wings. It is rendered personal to the builder by the introduction of his arms in the pediment, and the Wentworth motto, "Mea gloria fides," in the frieze. To whatever extent Flitcroft may have borrowed his materials, it cannot be denied that he has blended them together with noble results.

In the interior there is a fine saloon (Fig. I 80), which recalls Campbell's stone hall at Houghton. Its variety of treatment is in strong contrast to the cold-looking hall which contains the staircase (Fig. I8I). Both these apartments have the defect of their qualities. There is so much architecture that there is scarcely room for those homely touches which endear a house to its occupants. The architect is more in evidence than the family. The splendour which stimulates the admiration of the stranger palls upon the eye that sees it daily; the feelings cease to answer to the stimulus. Grand rooms like these seem to demand an impossible series of grand functions, or at the least that oldfashioned custom of keeping open house which once prevailed at Wentworth Woodhouse.

Another of the great mansions built about the same time as Wentworth Woodhouse was Prior Park, near Bath, and here again the result would appear to owe something to Campbell's second design for Wanstead in so far as the great hexastyle portico is concerned. The architect was John WVod, of Bath, 


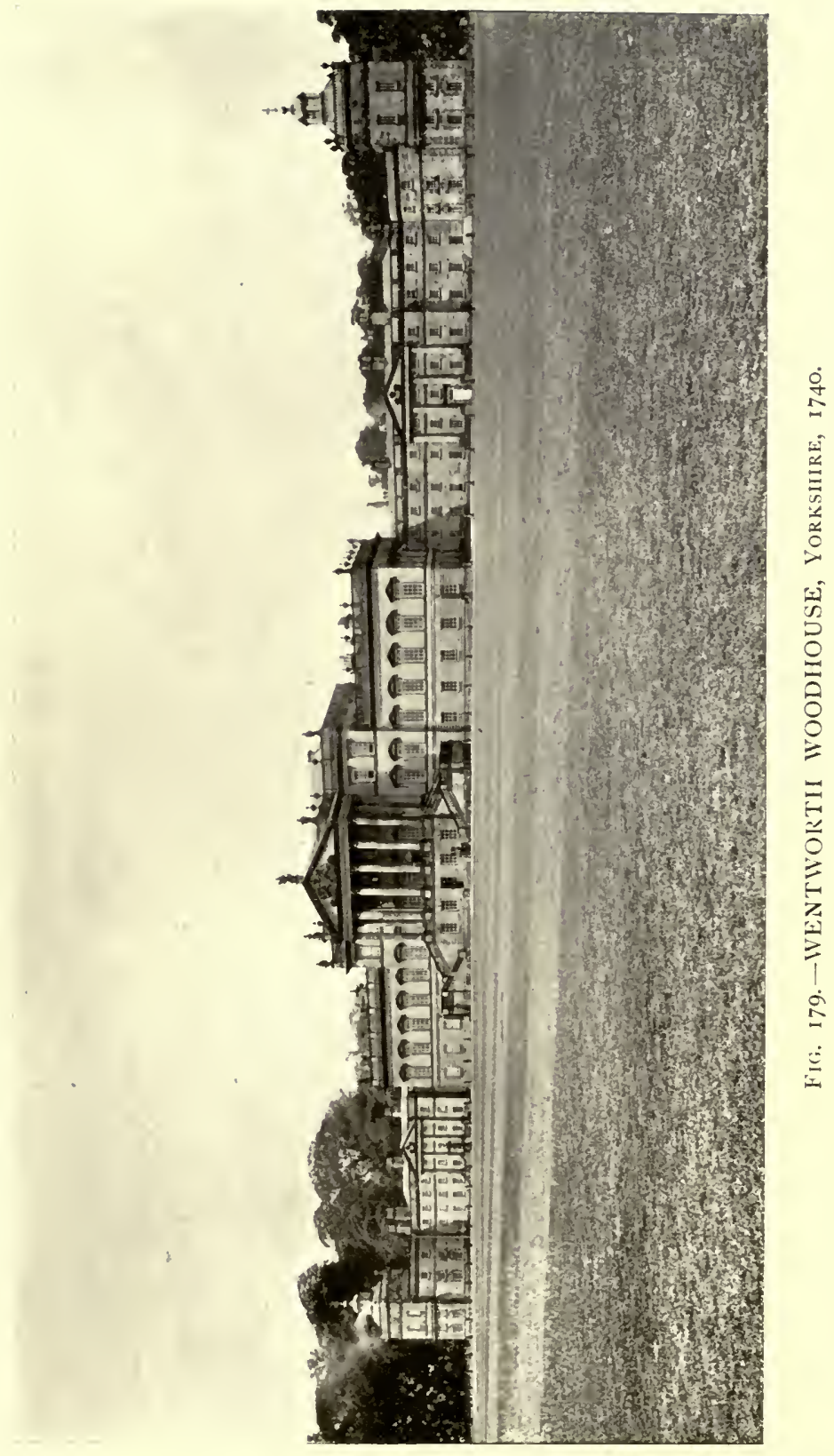




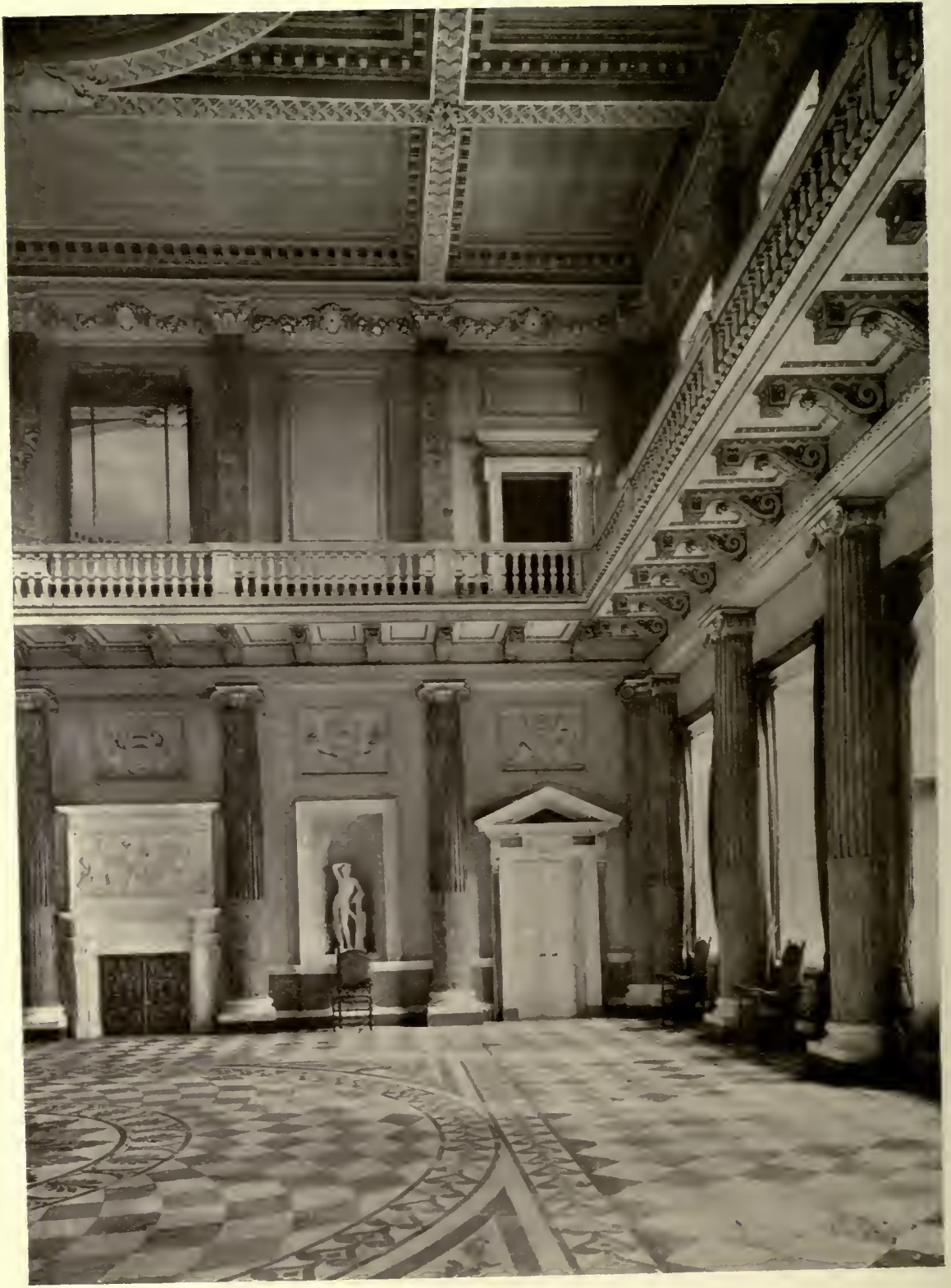

Fig. iso.-Wentworth WoOdhouse. The Saloon. 


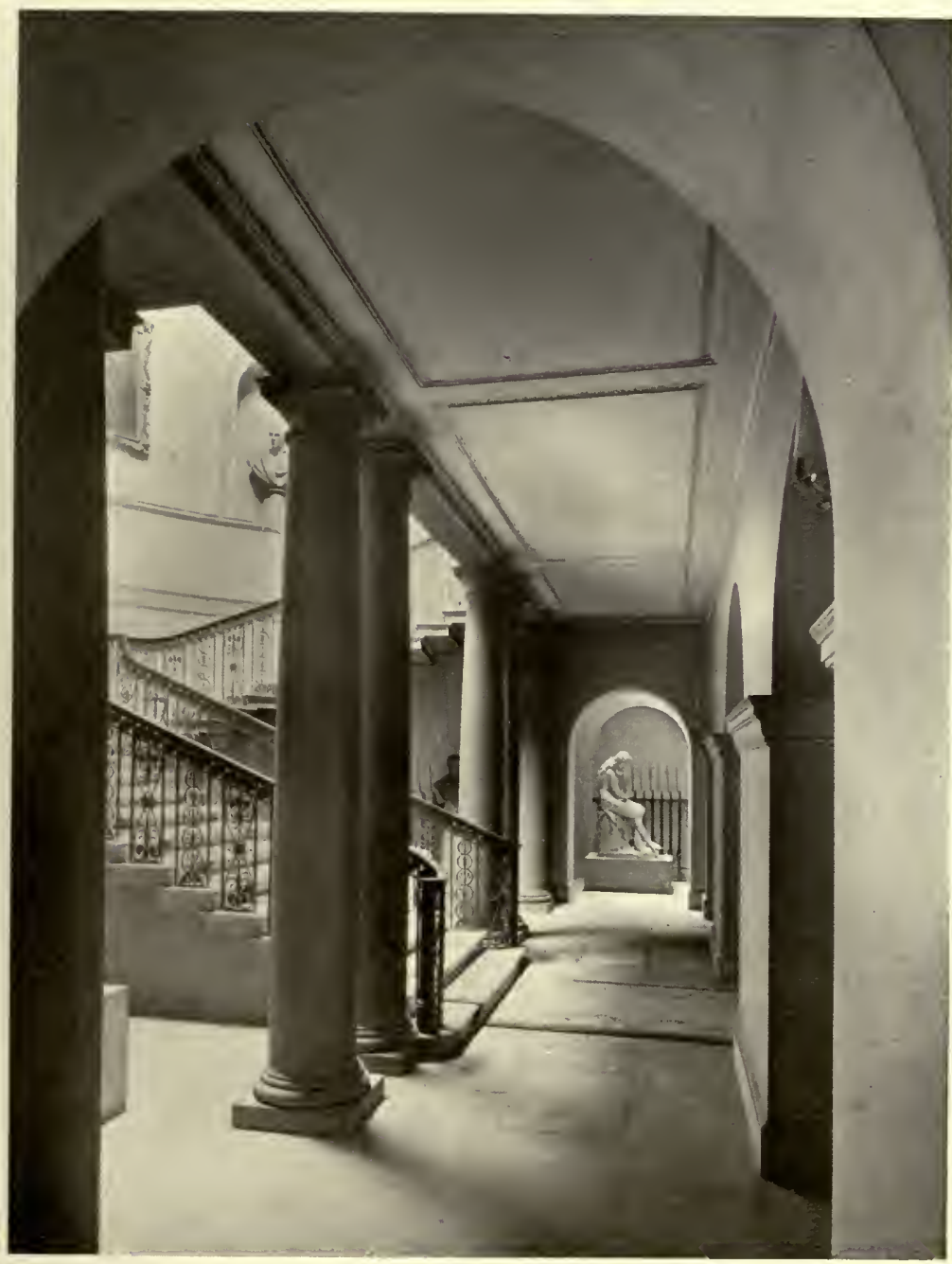

FIG. I8I.-Wentworth Woodhouse. The Staircase Hall.

who designed it in 1736 for Ralph Allen, an extremely capable man, who, from being a clerk in a Bath post office, became one of the wealthiest men of his time. He established a lucrative system of posts, and he exploited the quarries of the district. It is said, incleed, that Prior Park was built in order to advertise 


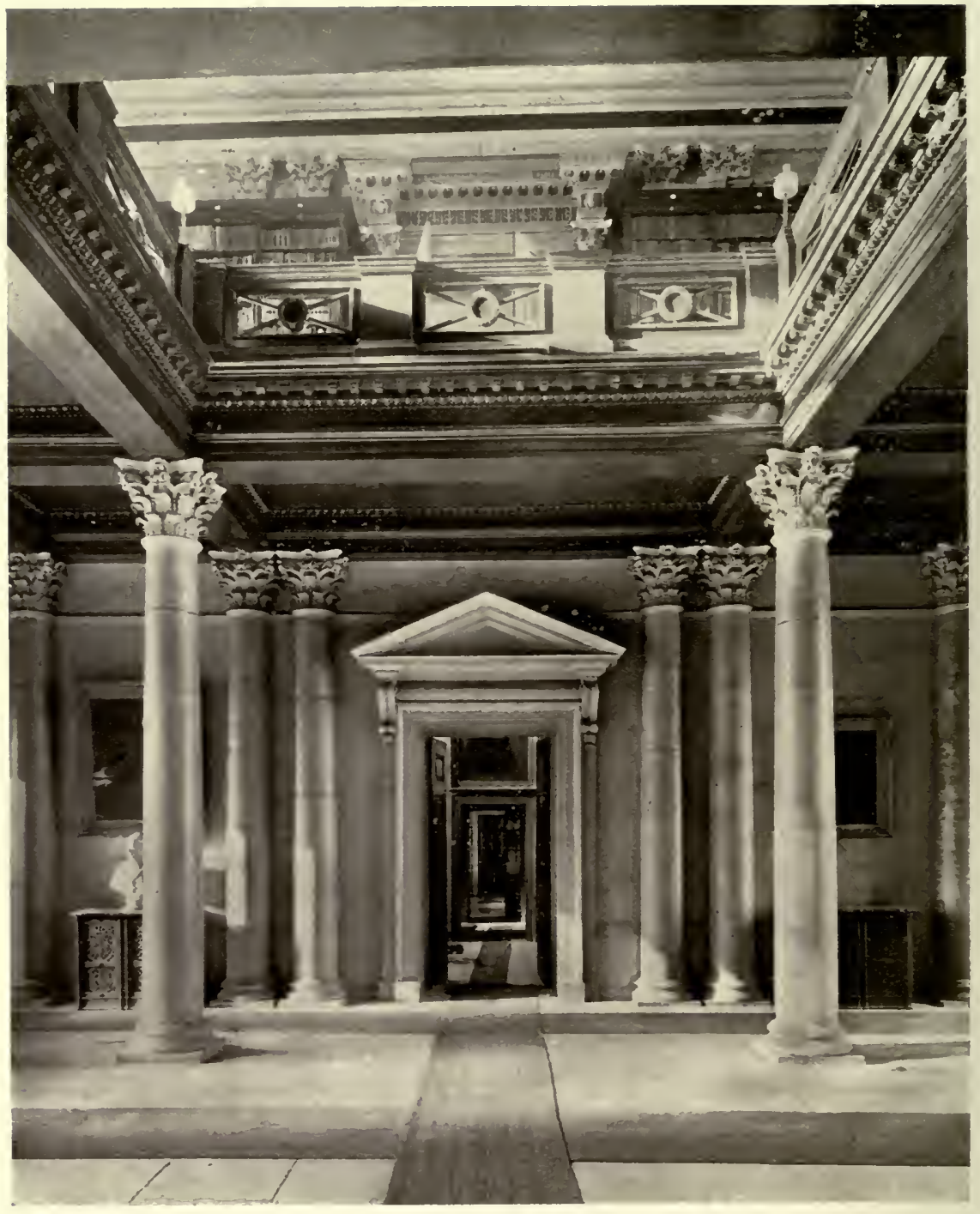

FIG. I82.-PRIOR PARK. THE HALL.

The ceiling of the hall was opened up by Goodridge, who added the balustrade in 1829 . 


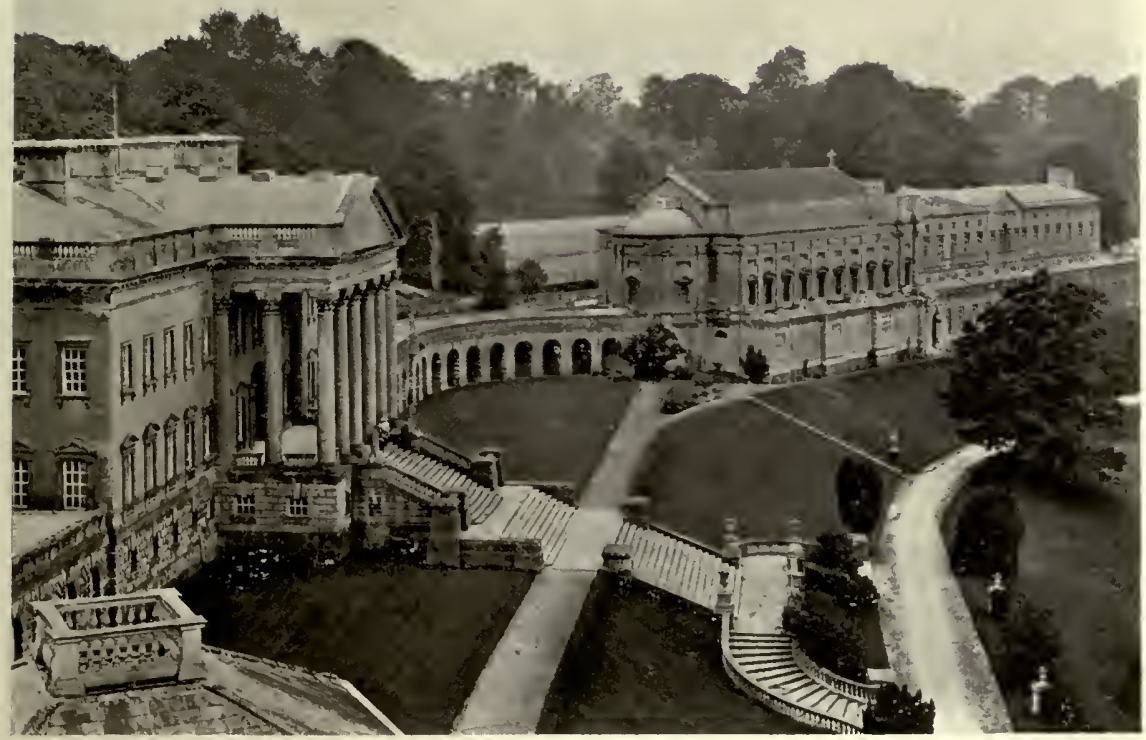

FIG. 183.-Prior Park, near Bath, 1736.

the excellence of Bath stone; if true, it was a noble form of advertisement. The house stands high up on a hillside, and is flanked at a distance by stables and other buildings to which it is joined by low rusticated arcades of the same height as the basement story (Fig. I 83). The whole façade is slightly curved concavely in order to follow the conformation of the ground. From the terrace on which the house stands a fine flight of steps, partly straight and partly curved, leads down to a lower level, but this is a later addition, carried out by H. E. Goodridge, of Bath, in the year i 825 .

It is interesting to find so splendid a house built for a self-made man, but as Allen left no family, it has not acquired the intimate charm of most great houses; it was for many years a Roman Catholic college, but has now been taken over for purposes connected with the war. The interior has suffered from fire, but the great hall retains its imposing appearance (Fig. I82). Like most halls of the period, it is, perhaps, too grand to be home-like, but it is admirably suited for the present uses of the house. If, as is said, Allen was the prototype of 
Fielding's Mr Allworthy, he must have been an amiable as well as a capable man. The man himself may have stood for the portrait, but Fielding placed Allworthy in circumstances of his own invention. He was made of ancient descent, and although his seat was in Somerset, and occupied a site comparable to that of Prior Park, the house itself was a noble product of the Gothic style; "there was an air of grandeur in it that struck you with awe, and rivalled the beauties of the best Grecian architecture; and it was as commodious within as venerable without."

Do we not see in this description signs of a revolt from the prevailing worship of the classic type? Fielding published "Tom Jones" about 1744 , but there were still many years to run before the classic idea ceased to dominate domestic architecture.

Wood himself certainly did nothing to divert architectural design from its accustomed channel. He, and his son after him, stamped Bath with its particular character, and made it the finest city in England. It had become a fashionable resort early in the eighteenth century, largely owing to the exertions of Beau Nash, and it is a fortunate circumstance that when it had to expand there was so accomplished a man as John Wood on the spot to control the expansion. He it was who first designed streets and squares and rows of houses as definite architectural conceptions. There is much to be said for this idea, especially when the work is new and the design still retains the colour and disposition intended by the architect, and while the buildings are occupied for the purposes for which they were built. But with the lapse of time inevitable changes occur. The property falls into different hands; each owner treats his portion after his own will. It may be that one paints his part of the façade one colour, while another paints his of a different tint, the lines of demarcation having no relation to the architectural treatment. Some of the tenements may become business premises, with large indications of their purpose exposed to catch the public eye. Others may even be rebuilt in a fashion wholly out of keeping with the original design. In short, although a square may be built as one architectural conception, it is impossible to preserve it as such in perpetuity; and when once the original idea is destroyed by the march of events, the effect is worse than if it had never been conceived. 


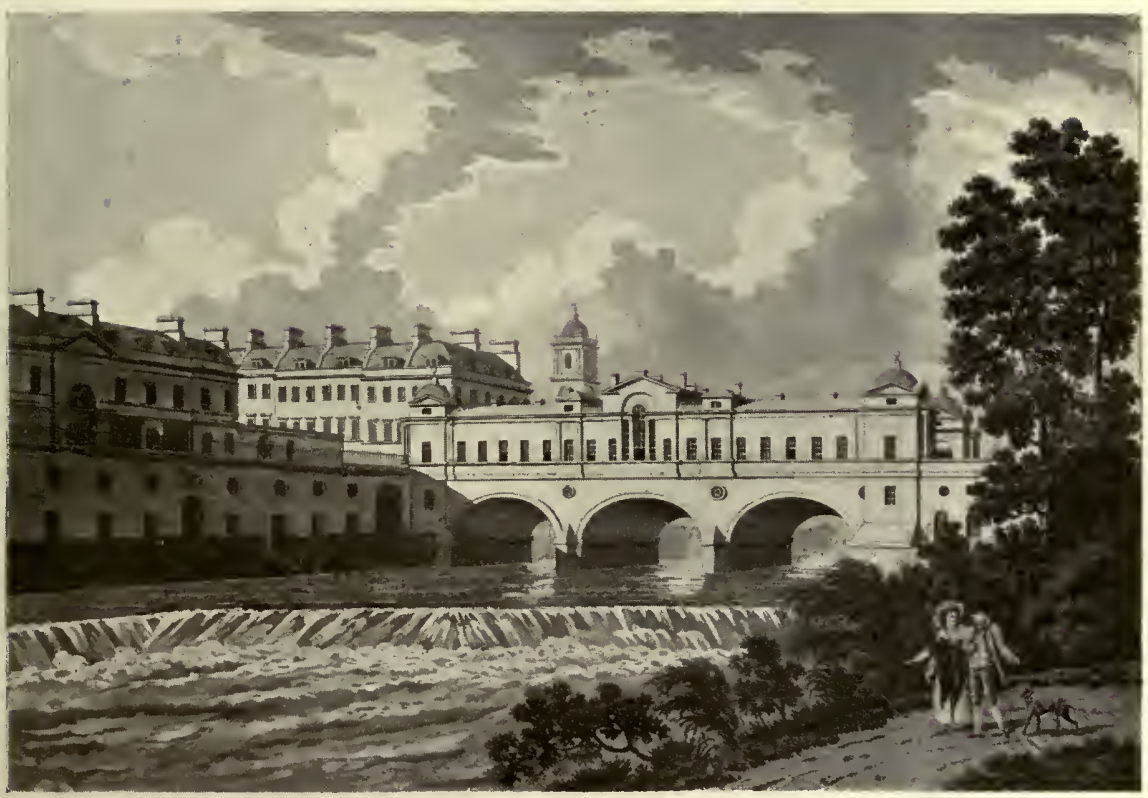

FIG. I 84.-Pulteney Bridge, Bath.

From an Aquatint by Thomas Malton.

Town-planning on architectural lines can be studied at Bath better, perhaps, than anywhere, but all towns are not equally fortunate in preserving the original character of their buildings. Pulteney Street, attributed to Thomas Baldwin, was laid out about 1780 with good residences, and to close its vista there was a carefully designed house, pleasant to look upon. Eventually, however, this house fell into decay, the character of the street changed, and its general aspect, instead of being fine, became depressing. Its very virtues emphasised its decline. The house has now been restored, and the whole street has once more become cheerful. But local enterprise is not everywhere so vigorous as at Bath, and decay in a scheme of this kind cannot always be arrested. Pulteney Bridge, which leads to the street of the same name, carries a row of narrow shops on each side, and presents much the same appearance as shown in Fig. I 84. But the shops are necessarily small, low, and shallow, and they can have no chance of expanding or of keeping pace with other premises not thus restricted. Their relative importance is therefore much smaller than it was at the time when they were built. An 


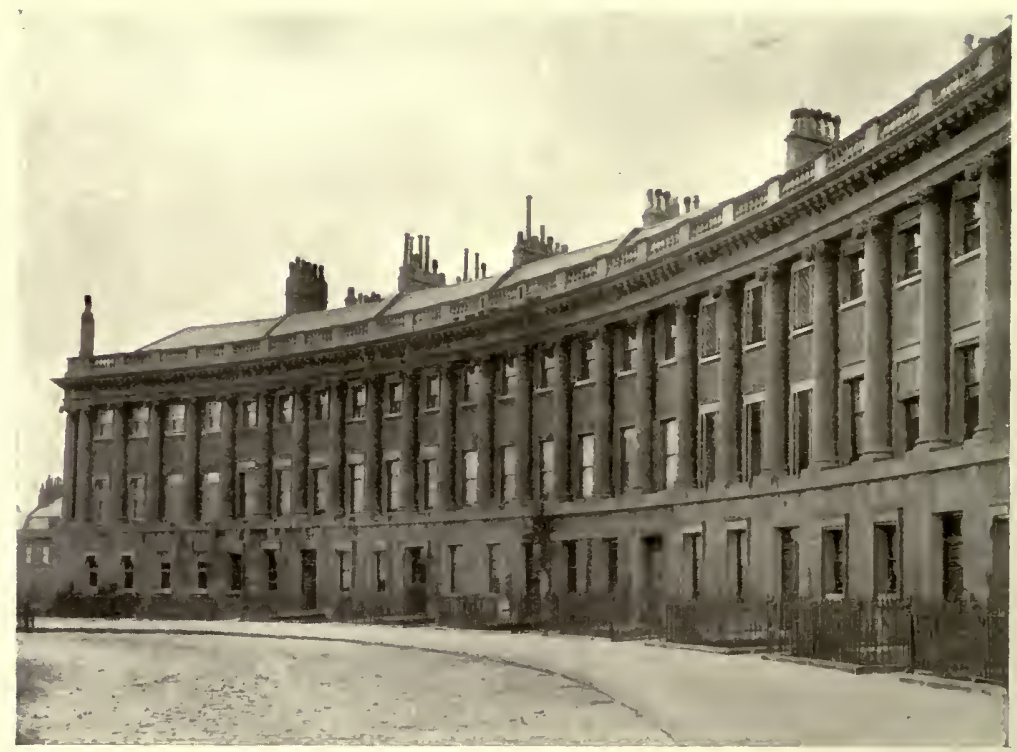

F1G. I85.-The Royal Crescent, Bath, 1769.

example of a row of houses dealt with as a piece of architecture, and one which has suffered little, if at all, from change, is the Royal Crescent (Fig. I85). It was designed by the younger IVood in 1769 .

The abundance and excellent quality of the stone in the Bath district greatly facilitated the erection of new houses both in the city and the neighbourhood. It was susceptible of delicate detail, and lent itself admirably to the classic work then in vogue, which indeed could never have obtained a footing save through the medium of stone. Throughout the district there are to be found good houses of the time of the Woods, houses which are not large, which have no pretensions to vie with Prior Park, yet which are handsomely treated, and have had considerable skill and some learning bestowed upon their design. Such a one is Widcombe Manor House (Fig. I87), of which, however, it must be observed that it would be useless to undertake such a house unless one were prepared to spend a considerable amount for the sake of architectural effect. "It is interesting to contrast with this product of the stone district a house in the adjoining county of IVilts.-Reddish Manor, Broad Chalk (Fig. 186). The 


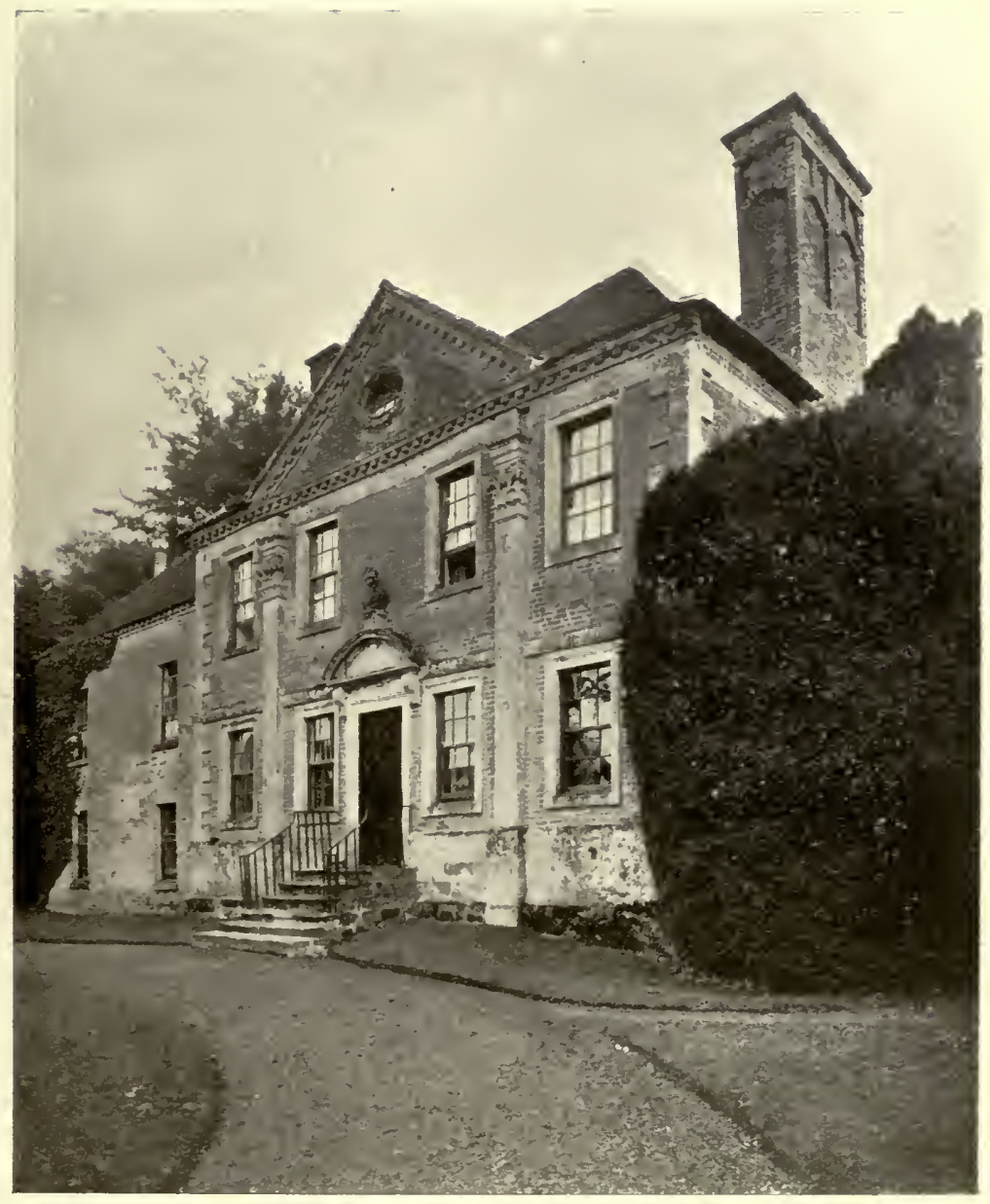

Fig. I86.-REDDISH MANOR, BROAD CHALK, WIITS. 


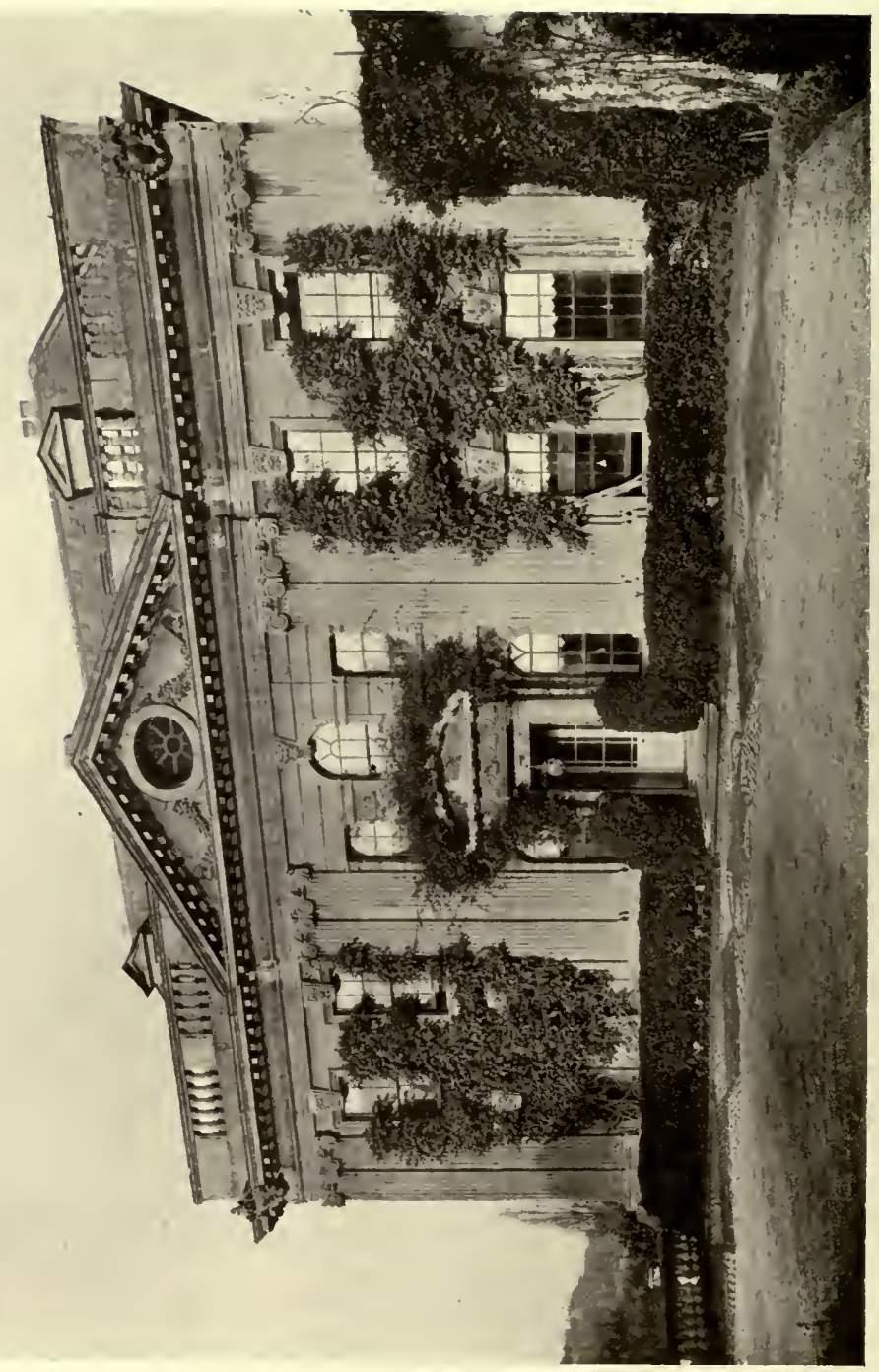

岕

;

อ

$=$

-

3

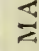

s

ڤ్ర

交

$\stackrel{5}{1}$ 
walls here are of brick and the ornament is of stone, but apparently either the stone or the money gave out by the time the roof was reached, for the cornice and the pediment are of brick, and it is seen at once how impossible it was to carry out classic detail in the ordinary brick of the district, and with the limited skill of the ordinary workman. Nevertheless the result is attractive, and it prompts the somewhat disconcerting question, whether the fancy is not as much tickled by the efforts of the obscure and half-educated designer, as by the correct and skilful handling of the trained architect? Accidents of colour and situation, the effects of time and weather, and above all, individuality of treatment, are as potent factors in impressing the imagination as booklearning and careful adherence to rules of proportion; and in admiring the great houses of the eighteenth century, and Campbell, Gibbs, and the hierarchy of architects who produced them, one longs to meet some unexpected difficulty successfully surmounted, some state of things not contemplated in the books, which should prove that the man had an invention, an imagination, one might almost say a soul, of his own.

The custom of building large houses with detached wings survived well into the middle of the eighteenth century. It will be remembered that Isaac Ware, in his "Complete Body of Architecture" (1756), gives elaborate rules for the proportions and disposition of such edifices; Holkham Hall, in Norfolk, designed by Kent about 1734, and Kedleston Hall, in Derbyshire, designed by James Paine in $176 \mathrm{I}$, are two notable examples still in existence.

Holkham is the most important piece of domestic work of the fashionable architect, IVilliam Kent, who was the favourite protégé of Lord Burlington. Like most of his contemporaries, Kent passed several years in Italy before doing any work in England. He was of lowly origin, as were many architects of the time. As a start in life he was apprenticed to a coachpainter; Ripley walked to London at the onset of his career, and obtained work with a journeyman carpenter; Carr, of York, began as a working mason; all three were Yorkshire men. Kent early impressed men of position with his unusual capacity, and it was through their kindness that he was enabled to study in Italy, where he appears to have lived from I7 Io to I7I9. At this time he was studying painting, a pursuit 
in which, by general consent, he achiered no distinction-at any rate no enviable distinction. Sir Robert Walpole's opinion of his powers in this direction has already been indicated (p. 256). During his stay in Rome he became acquainted with Lord Burlington, who, according to Horace Walpole, "discovered the rich vein of genius that had been hid from the artist himself." He came back to England with his new patron, and thenceforward his success was assured. An apartment was assigned to him in Burlington House as long as he lived, and on his death

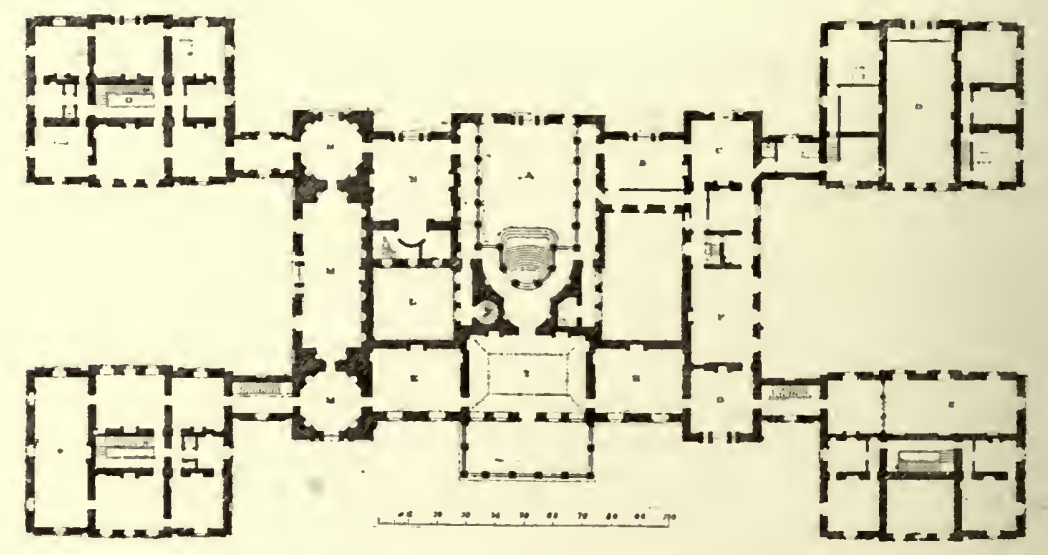

FIG. I88.-Holkham Hall, Norfolk, 1734. Plan of the Principal Floor.

"he was buried in a very handsome manner in Lord Burlington's vault at Chiswick." 1

Endowed with natural abilities above the average, which had been cultivated during nine years in Italy, and fortified by the most powerful patronage of the age, it is no wonder that Kent was able to cut a good figure in the world of art. He became the fashionable decorator of the time in many directions, especially in relation to great houses and their surroundings: IValpole had a poor opinion of him as a painter, admired him as an architect, and praised him highly as a garden designer. To us in the present day he appears as a man of considerable ability and culture, who seldom rose above mediocrity, especially in his architecture, which, however sound and correct, is wanting in

1 Walpole, "Anecdotes." 


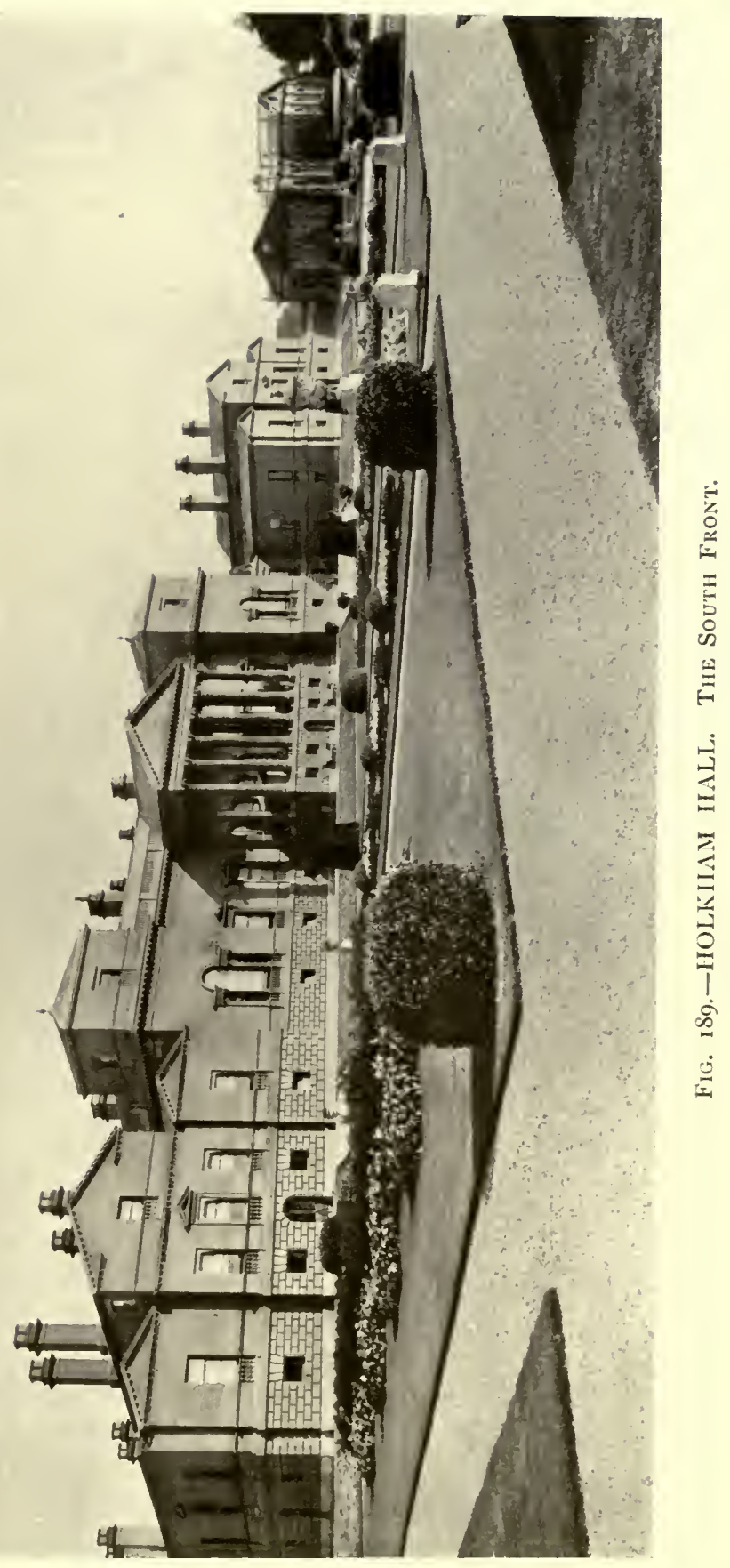


vivacity. Holkham is a case in point. There is nothing novel about the plan (Fig. I88), save that the wings are closer to the main building than usual; but in spite of this the kitchen is a long way from the dining-room. The rooms are not particularly striking: the finest are the entrance hall, and the sculpture gallery or "statue gallery," as it is called on the plan in "Vitruvius Britannicus." The house was designed for the reception of the numerous works of art which the owner and builder; Thomas Coke (afterwards created Earl of Leicester), collected in Italy. The collection of pictures, statues, antiques, books, and manuscripts ranks among the finest in England. The opinions of critics on the house are by no means unanimous. Sir IVilliam Chambers, for instance, remarks how difficult it is to give pleasing proportions to rooms of differing sizes, but which are all of the same height, and so to arrange the smaller as to contrive suitable mezzanines above them. "Holkham," he says, "is a masterpiece in this respect, as well as in many others. It deserves much commendation, and does credit to the memory of $\mathrm{Mr}$ Kent, it being exceedingly well contrived both for state and convenience." 1 Ferguson, on the other hand, says: "IVe are left to conjecture whether the noble host and hostess sleep in a bedroom $40 \mathrm{ft}$. high, or are relegated like their guests to a garret or an outhouse, or perhaps may have their bedroom windows turned inwards on a lead flat." He goes on to say that although the house may be "a monumental whole, yet the occupants would probably prefer rooms of appropriate dimensions, where they could get fresh air and a view of the park." ?

Both opinions are, or were, probably right. At the time it was built, and for the wants of that period, Holkham was no doubt both convenient and stately. But Ferguson's criticisms find a ready echo in our own bosoms, and they are a measure of the difference between the ideas of the eighteenth and nineteenth centuries as to domestic comfort.

The exterior of Holkham (Fig. I 89), although a departure from the customary treatment, is hardly an improvement upon it. It is a little monotonous, and the large extent of plain wall abore the windows of the principal floor has a dull

1 "Treatise on Architecture."

2 Ferguson's " History of Architecture," Book IV., 1873 ed., p. 328. 


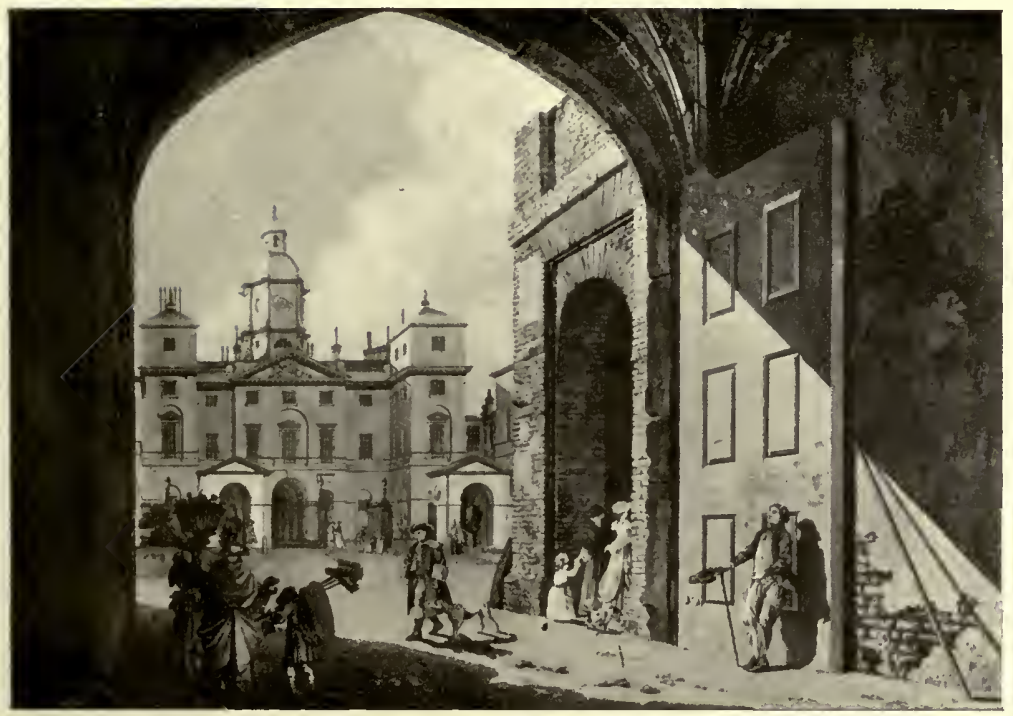

FIG. I90.-The Horse Guards, Whitehall

effect. The plain turrets and the thin cornice of the wings impart a meagre appearance, which is heightened by the fact that the walls are of white brick, a material which remains triste to the end, although centuries may have endeavoured to mellow it, as they have in vain at Hengrave Hall, in Suffolk.

Kent's versatility is evidenced at Holkham in the furniture, most of which was designed by him. It is characterised by a solidity and massiveness, both of construction and decoration, in striking contrast to the attenuated elegance of his successors.

Kent died in 1748 , long before the house was finished; the Earl of Leicester died in 1759 , still leaving much to be completed. The manner of his death brings home to us the changes which have taken place in habits and ctistoms even more vividly than does his house. Lord Leicester had spoken slightingly of the militia at his own table, a topic of general comment at the time; his remarks were taken ill by George Townshend, his neighbour at Rainham, who challenged him to a duel. Townshend was young and a practised duellist; Lord Leicester was a staid 
gentleman of sixty-five. The result was a foregone conclusion, and the older man died of his wound. ${ }^{1}$

Lady Leicester carried on the works at Holkham with the help of Matthew Brettingham, of Norwich, who had been a pupil of Kent's and had acted as his assistant and clerk of the works. After the work was ended he published the plans and elevations of the house in a book dedicated to Lady Leicester, and claimed the whole credit of the design. But it belongs in reality to Kent, and Holkham is an interesting example of the work of one man, alike as to the house, its decoration and its furniture.?

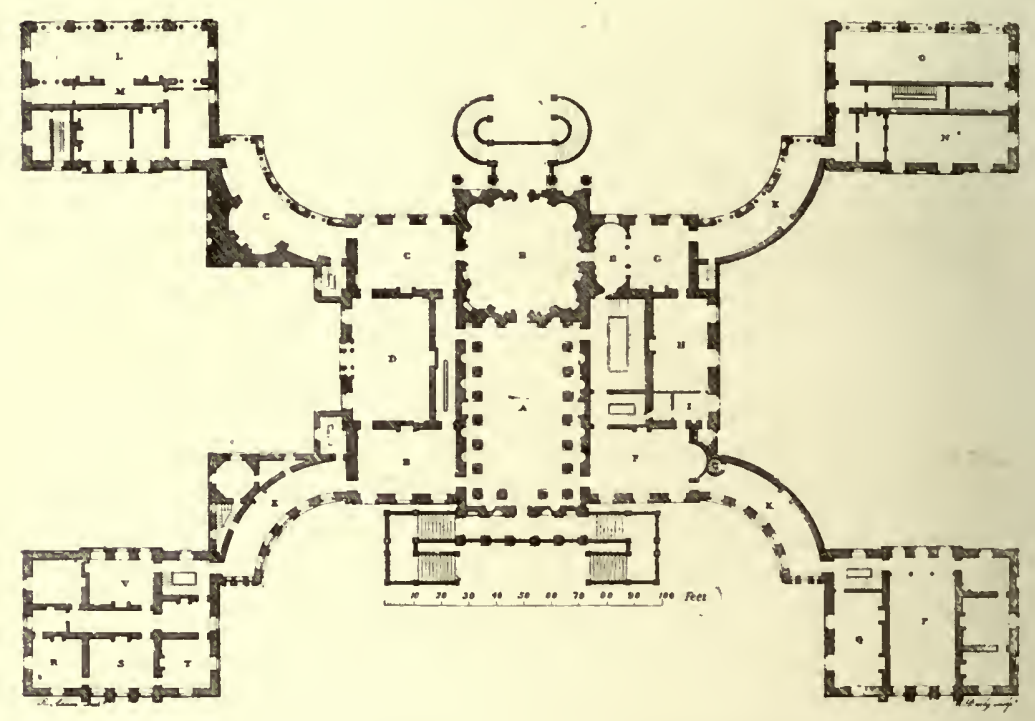

F1G. 191.--Kedleston, Derbyshire, 1761. Plan of the Principal Floor.

Although Holkham is his most notable achievement-unless we except the Horse Guards, which has some resemblance to it in general treatment (Fig. 190)--Kent was fully employed during his thirty years of active work. He designed many houses and many gardens. One of the most pleasing of the buildings at Stowe, the Temple of Ancient Virtues, was his. His help was obtained in directions other than architecture, and Walpole tells

1 "Memoirs of a Royal Chaplain," by Albert Hartsborne, pp. 318-320.

${ }^{2} \mathrm{Sec}$ an article on Holkham by M. Jourdain, "Interiors of English Mansions," in the Art Journal of July 19r I, and Lenygon's "Decoration in England" and "Furniture in England"(1660-1790), 2 vols. (Batsford). 


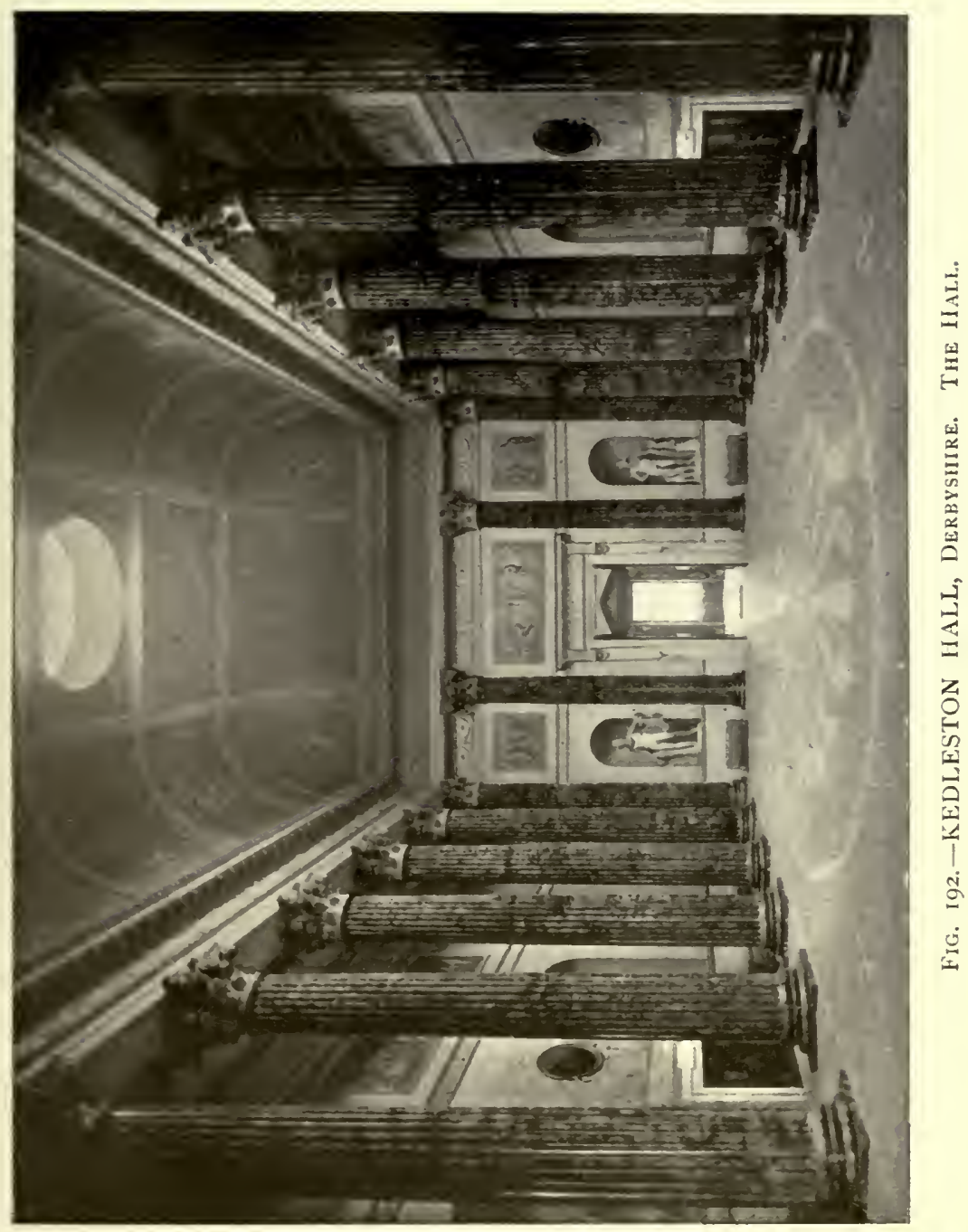


us that he designed birthday gowns for two ladies, to which he gave a decidedly architectural turn. He must have spent much time in producing "The Designs of Inigo Jones," and it is not improbable that he was the power behind the throne in respect of the architectural efforts of Lord Burlington.

Brettingham had a certain connection with Kedleston, as he seems to have designed and built one of the wings. He was succeeded by James Paine, to whom the general design is attributed, which followed the lines started by Brettingham. The house was to have had four outlying wings, much after the fashion of Holkham, but only two were carried out. The original plan looks very striking on paper (Fig. I9I), but it is one further proof of the way in which comfort was sacrificed to grandeur by the architects of that time. All the principal rooms are noble, those, that is, which were to be used on grand occasions; the others are quite subordinate. The basement, which contains rooms in daily use, seems overweighted by the superstructure, and is in fact too low to allow the light to penetrate freely to the remoter parts of the entrance. The bedrooms were, in the opinion of Dr Johnson, who visited the house with Boswell in September 1777, "but indifferent rooms." The hall is a lordly apartment with a row of lofty columns down each side (Fig. I92). Some of the columns are monoliths, and one is of alabaster from the locality. Dr Johnson thought the house "would do excellently for a town-hall; the large room with the pillars would do for the judges to sit in at the assizes; the circular room for a jury-chamber; and the room above for prisoners." It is quite true that many of these large houses produce an impression similar to that created by public buildings.

The situation of the house is in keeping with the ideas prevalent at the time. It is not, as of old, the centre of a formally disposed lay out, with vistas stretching away from its principal windows. It stands, indeed, askew with all points of view, on a slope of the park, backed by a long range of trees which crowns the summit of the hill; behind another group of trees lie the stables, connected to the house by a sunk way. A contemporary bridge in the park, over which the approach is carried, lies in haphazard relation to the house. But this was 

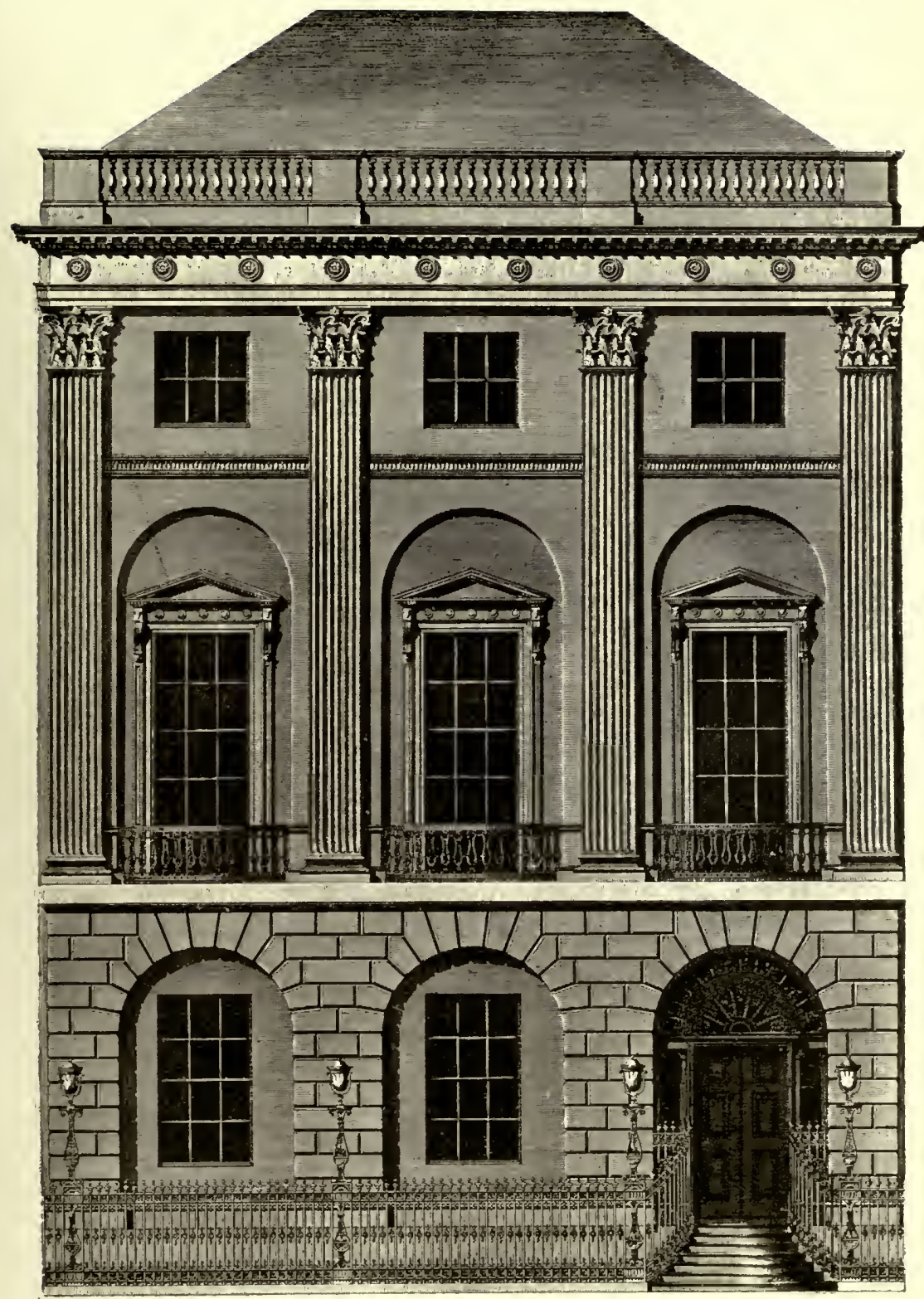

FIG. I93-ELEVATION OF SIR WATKIN WYNN'S HOUSE IN ST JAMES"S SQUARE, LONDON. 


\section{THE BROTHERS ADAM AT KEDLESTON}

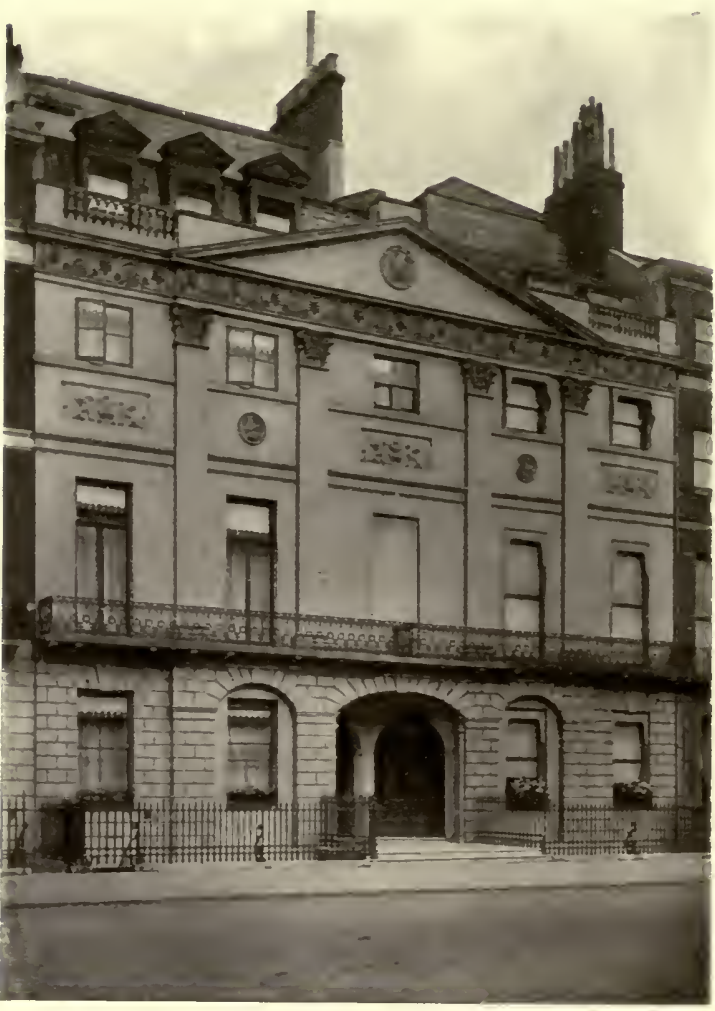

FIg. 194.- Houses in Portland Place, London.

all part of the design, which aimed not at any formal lay out, but at a result which should convey the impression that everything was unstudied, and that skill was bestowed not in makingan effect, but merely in seizing on the effects supplied by nature and using them to the best advantage.

Paine did not finish the house. Before it was completed he was replaced by the brothers Adam, who carried out all the decoration of the interior and also designed much of the furniture.

Of the brothers Adam (there were four of them), Robert was the most gifted, and it is his work which gave rise to the well-known "Adam" style. He, too, had a training of several years in Italy (from I 754 to 1758 ), but, more adventurous than other students, he paid a visit of some weeks' duration to Spalato in Dalmatia, where he occupied himself, with the help of companions, in taking measurements and making drawings of Diocletian's palace. According to one authority ${ }^{1}$ these studies were the foundation of his future style. Much of the furniture at Kedleston, however, is more nearly allied to the type

1 Mr Percy Fitzgerald, M.A., F.S.A., in his "Robert Adam." 


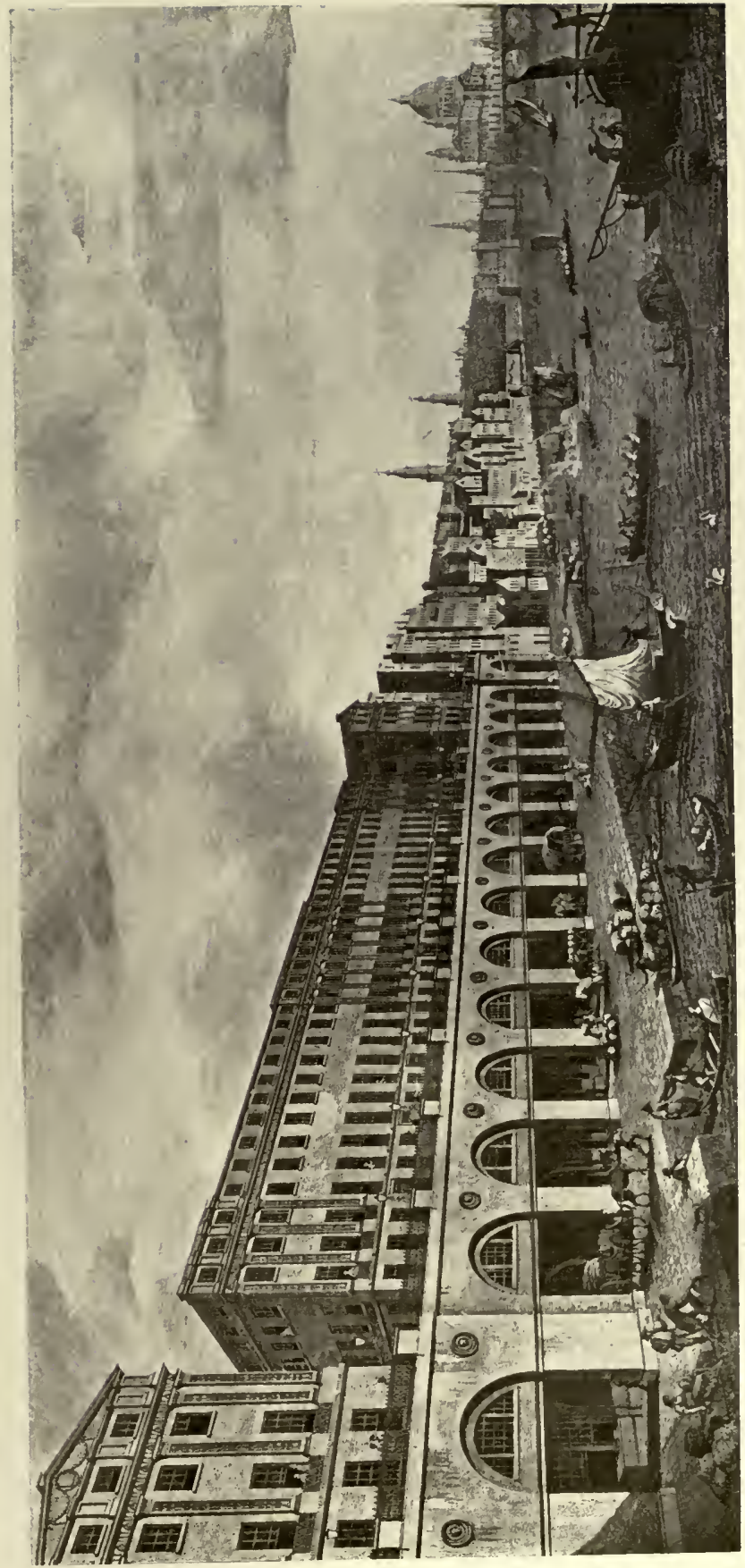

 
established by Kent than to that which we are accustomed to associate with Adam; presumably he had not yet established his own individuality. In his architectural work he had a great idea of obtaining "movement" by giving rhythmical projections to a façade, and a picturesque but ordered variety to the skyline. This was his intention, and the adoption of the word is his own; it is doubtful whether observers and critics would have discovered enough of the one to have adopted the other of their own accord. Indeed the exteriors of his buildings are often tame. He broke away, it is true, from the conventions of the preceding half-century, but although the result was to a certain extent novel, it can hardly be deemed more attractive. The fact is that he laboured under the same drawback which beset all the architects of the eighteenth century, the glorification of architecture at the expense of practical building. Instead of making his architecture reflect the requirements of the persons who were to use the edifice, he made the interior arrangements to fit the preconceived exterior. This is exemplified in a small instance in the fact that, having designed two houses to form one architectural composition, he was obliged to make the party wall cut a window in two, a mutilated half of which lighted a room in each of two separate houses. IV'e have already seen how the same sort of difficulty beset Wood's houses in Bath; and exactly the same fault in regard to windows is to be found in Grainger's work at Newcastle. The absurdity is only fully realised when one of the houses has to be remodelled or rebuilt, when, among other odd results, it is found that a window has to be shorn in two, one half removed and the other left.

Adam's excellence lies in his eye for proportion, in the refinement of his detail, and in the fastidious handling of his ornament. A house in St James's Square (Fig. 193) and another in Portland Place (Fig. I94) are characteristic examples of his work. At first sight they appear insipid, and might easily escape the eye ; but when the attention is once caught it is arrested by the detail which appeals to the cultivated taste; the intellect is charmed with the extreme care bestowed upon every part of the ornament, or rather, considering the enormous amount of work which occupied Adam's time, by the wonderful intuition which produced such harmonious results.

He can hardly be said to have made a permanent mark in 


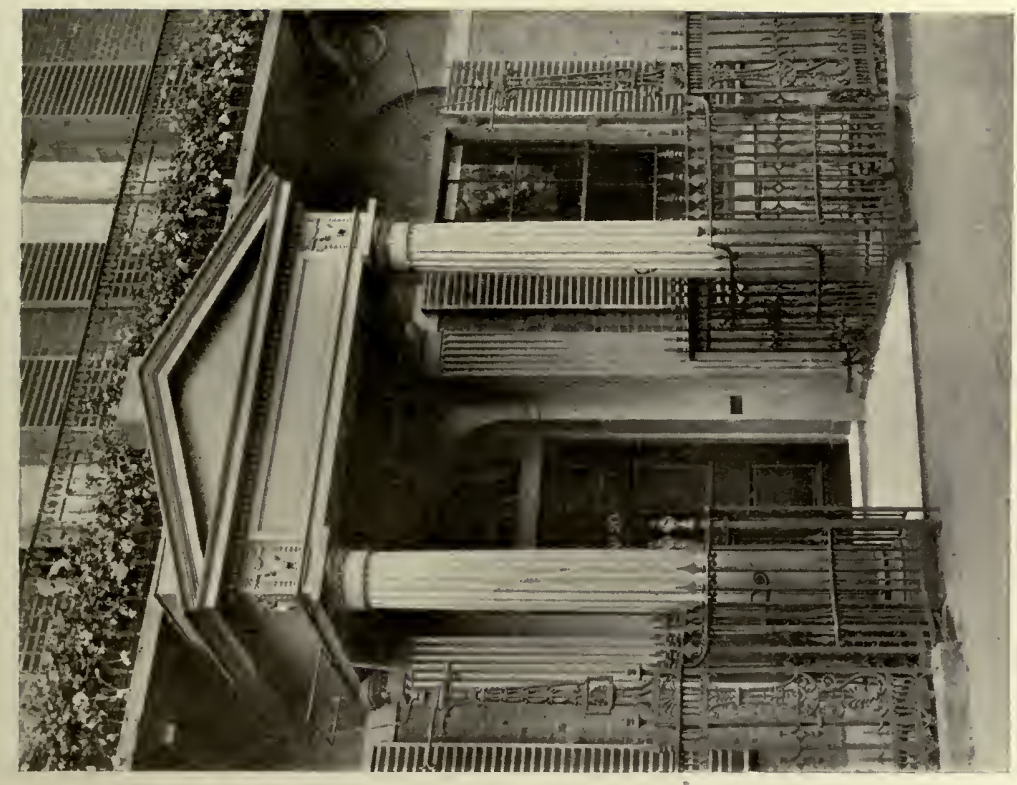

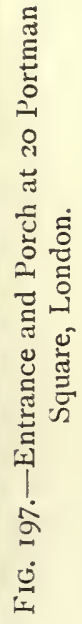

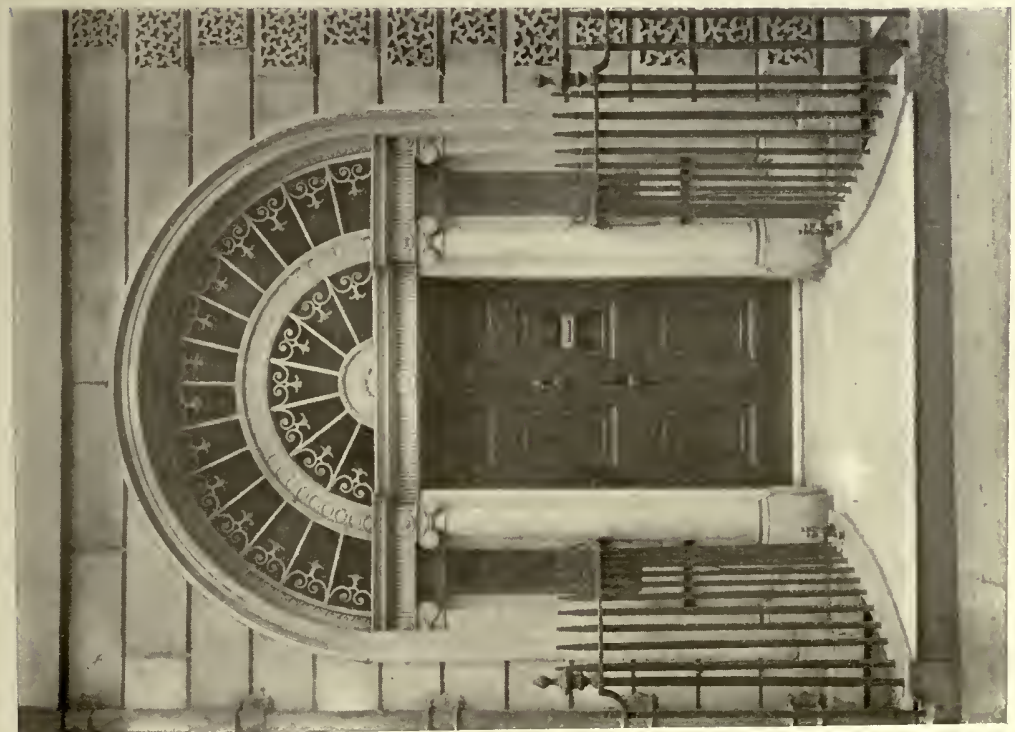

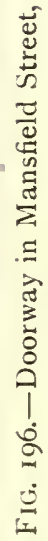




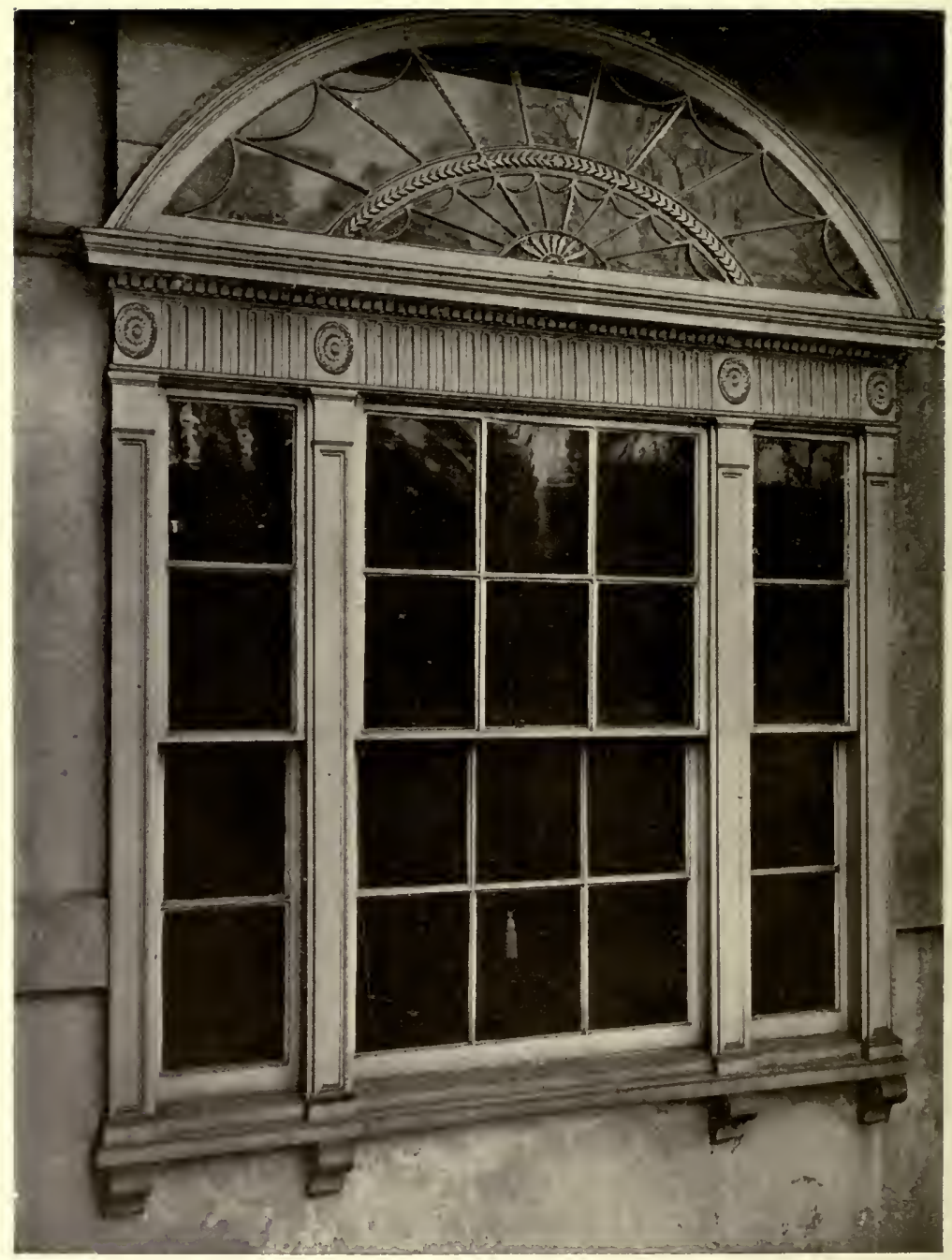

FIg. I98.-WINDOW AT SUTTON COURT. 
his large architectural conceptions. With the help of his brothers he rebuilt a whole district of London which was called after them, "the Adelphi." 1 The long terrace on an arcaded basement was much admired, and it has been claimed for him that he planted by the side of the Thames a worthy version of the splendours of Spalato, but the building (Fig. 195) hardly bears out this contention. It is Spalato much diluted. The lesson to be learnt from this as from most of the architecture of that period is that no reproduction of ancient glories, whether direct or modified, can be of abiding interest. Architecture to be interesting must meet certain definite wants, must refect the needs of the hour and of the individual, and as these must of necessity be ever changing, so must architectural expression. Each work of every architect presents a fresh problem which ought to be solved in its own way.

It is in particular features, such as doorways, windows, balustrades, and panels, that Adam's gift of design shows to the best advantage. A doorway in Mansfield Street (Fig. 196), with its large fanlight, is characteristic of one treatment; the projecting porch from Portman Square (Fig. 197) is equally so of another. The window from Sutton Court (Fig. I98) would be a prosaic affair, but for the fanlight and the detail imparted to the surrounding woodwork. It should be noticed that, in keeping with his delicate mouldings, the sash-bars are thin, in complete contrast to the more vigorous handling of his predecessors.

The delicacy of his detail was more appropriate to the inside of a house than to the outside, and nothing pleased him better than to design the whole decoration of a room-doors, chimney-piece, ceiling, plaster wall panels, lockplates and door handles, grate, and the whole of the furniture. Pretty, graceful, and refined, but rarely virile, his work appeals to the less tumultuous emotions; indeed he made his mark not so much by his architecture as by his decoration, which exhibits extraordinary fecundity and fertility of design.

1 A Latinised version of the Greek word for "Brothers." 


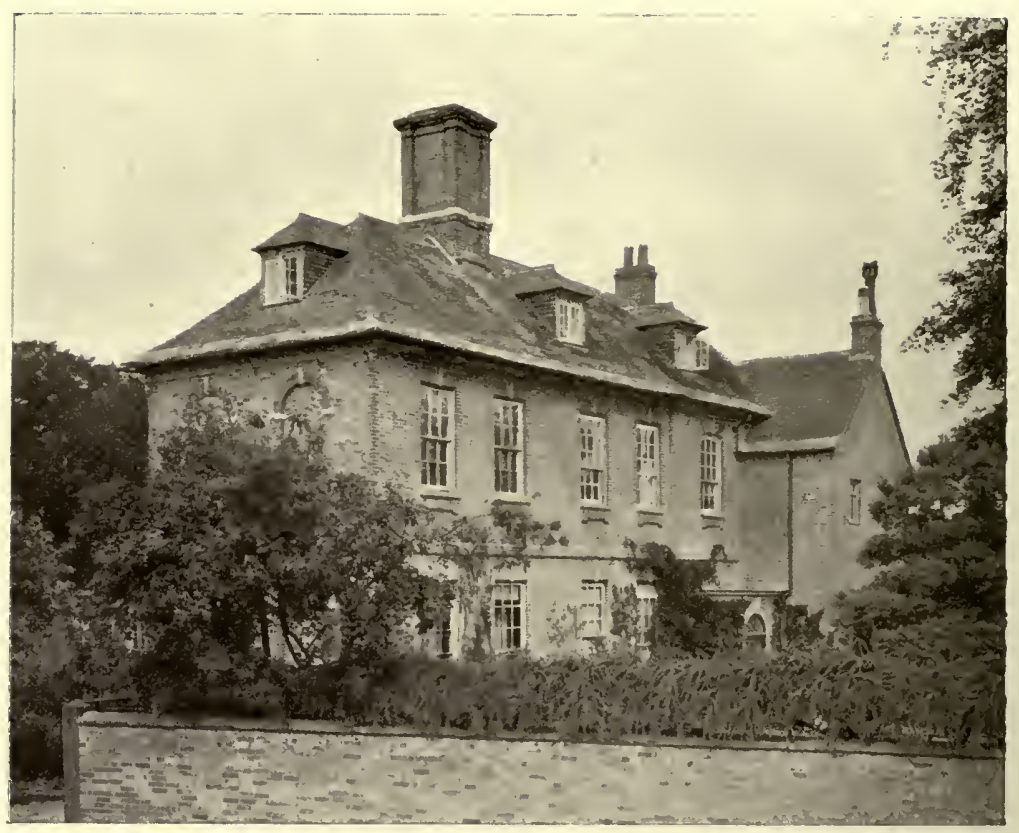

FIG. I99.-Vicarage at Puddletown, Dorset.

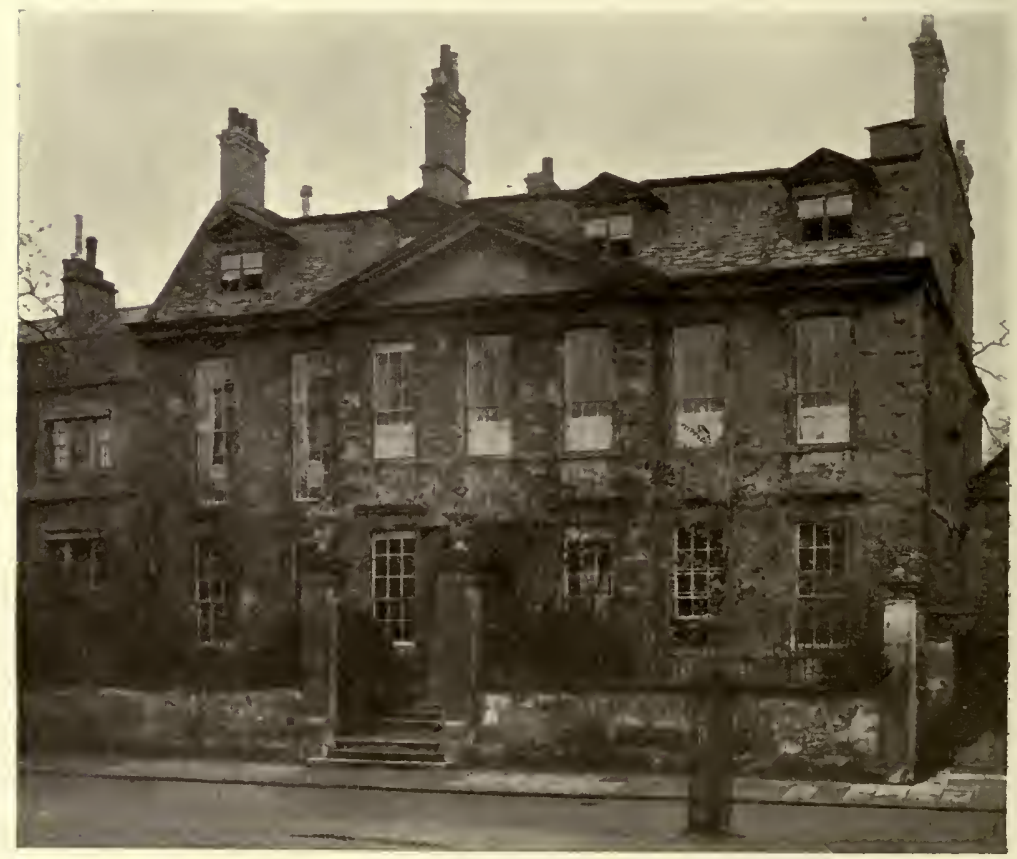

FIG. 200.-House in St Giles, Oxford. 


\section{$\mathrm{X}$ \\ SMALLER HOUSES, TOWN HOUSES, EXTERIOR FEATURES}

In the large houses which have been described in the preceding chapters, it has been impossible to avoid passing a certain amount of adverse criticism upon the manner in which comfort and convenience were often sacrificed to the claims of fine architecture, as the term was understood during the eighteenth century. When we turn to the smaller houses this drawback is much less in evidence; not because better architects were employed, for doubtless the unknown designers of these smaller buildings would have sinned equally with their more famous brethren, had the opportunity to do so come their way, but because the occasion demanded no great display, and there was no money wherewith to make it. Nothing more was wanted than a handsome-looking house with rooms of suitable size and number. It was very seldom that any great ingenuity was required of the designers. Two, three, or in the larger houses, four sittingrooms, a hall and staircase, a kitchen, back kitchen, and pantries usually completed the accommodation of the ground floor; the floor above was occupied by bedrooms, which, if insufficient, were supplemented by others in the attic. There were no bathrooms, cloak-rooms, or other sanitary conveniences; it was not necessary to provide a fireplace to each room. The problems of design were therefore much simpler than those of the present day. There was no group of small rooms requiring a convenient yet inconspicuous situation: there was no need to struggle with single flues from isolated bedrooms, which could not be led to the main stacks; this difficulty was met by leaving the rooms without a fireplace. Nothing is commoner in old houses than to find two or perhaps three chimney-stacks, the position of which is determined by that of the sitting-rooms and kitchen, and to find that the bedrooms adjoining these stacks 


\section{CONVENIENCES OF THE SMALLER HOUSES}

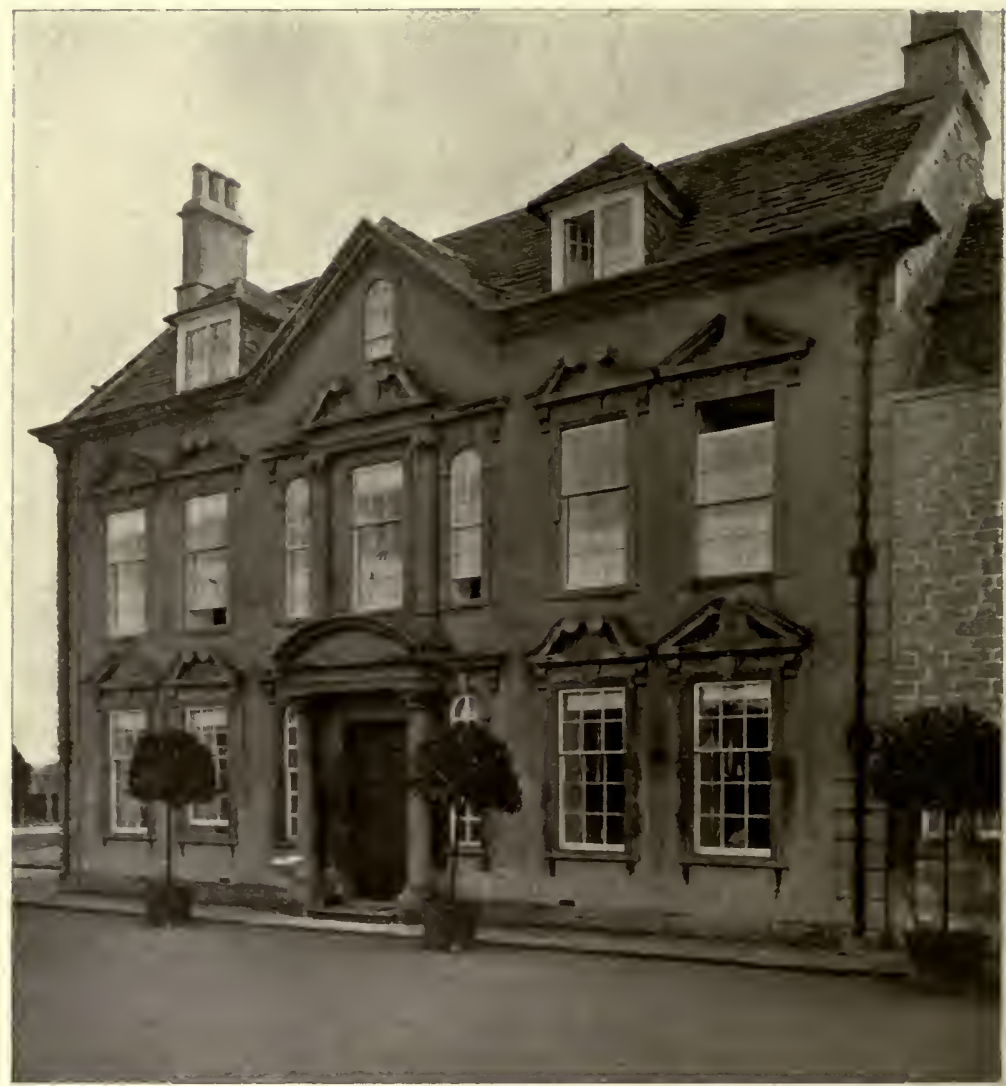

FIG. 20I.-The Court, Holt, near Bradford-on-Avon.

have fireplaces, while those away from them have none. As to sanitary conveniences, with the crude means of sewage disposal then in use, it was impossible to have them in the house; it was only after the introduction of water-carriage that this could be done. In the ancient days of fortified houses it was of course necessary for them to be within the walls, and considerable skill was often displayed in placing them so as to be as innocuous as possible. On Elizabethan plans they were sometimes retained indoors, but they were obviously a source of annoyance and danger; in later times they were removed outside, and in old houses, here and there, may still be found evidence of the handsome treatment provided for the family as distinguished from 


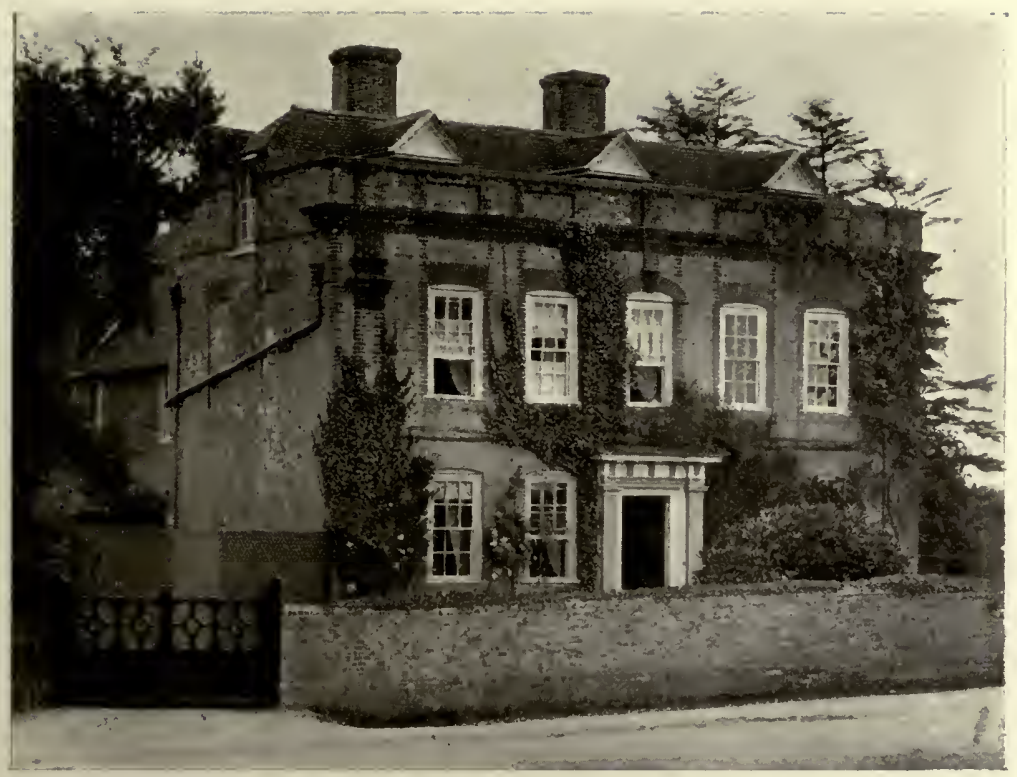

FiG. 202.-The Church House, Beckley, Sussex.

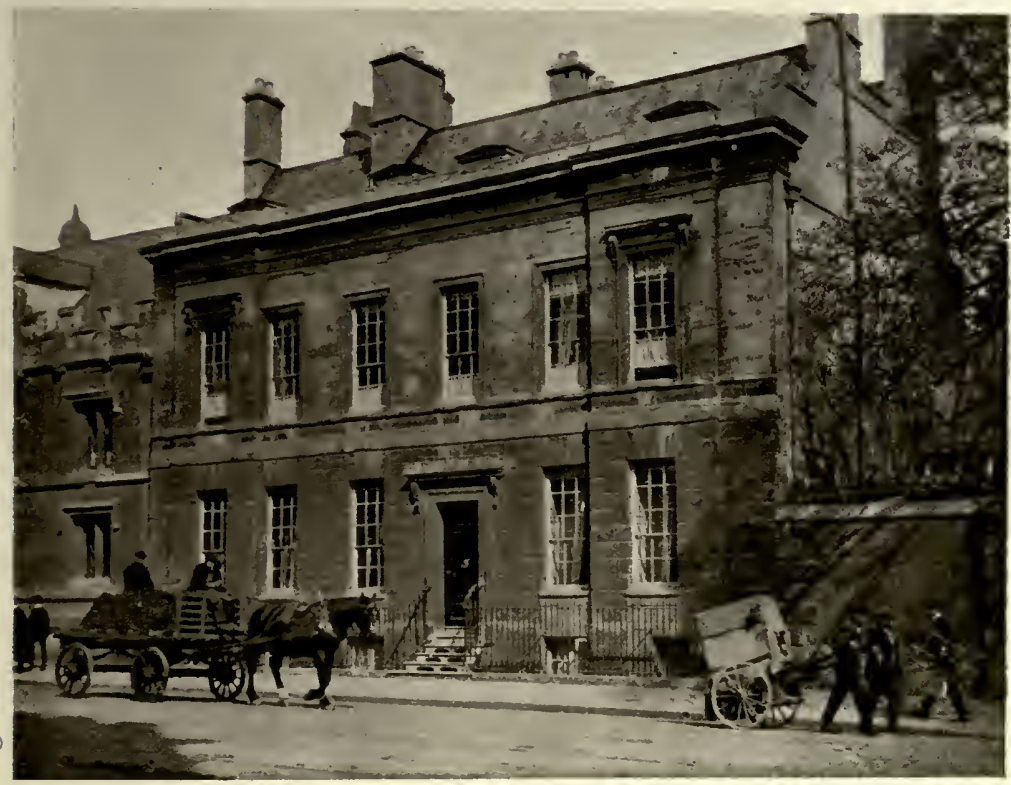

FIG, 203.-House in the High, Oxford. 


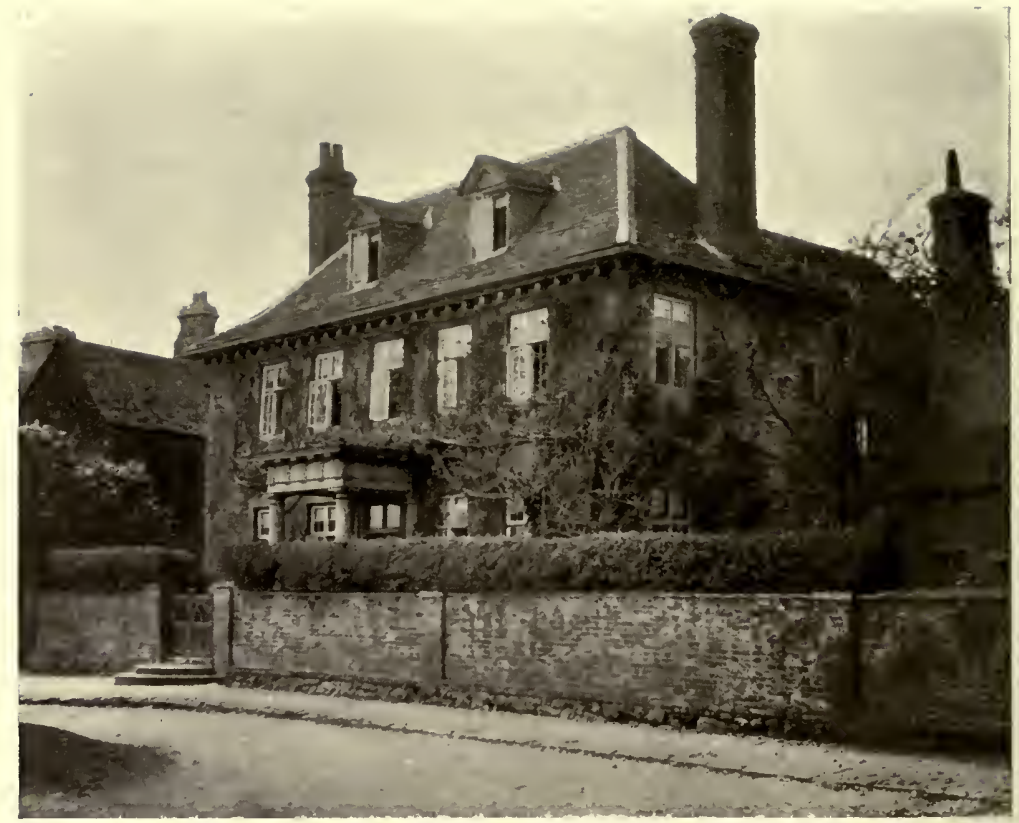

FIG. 204.--House at Shrivenham, Berkshire.

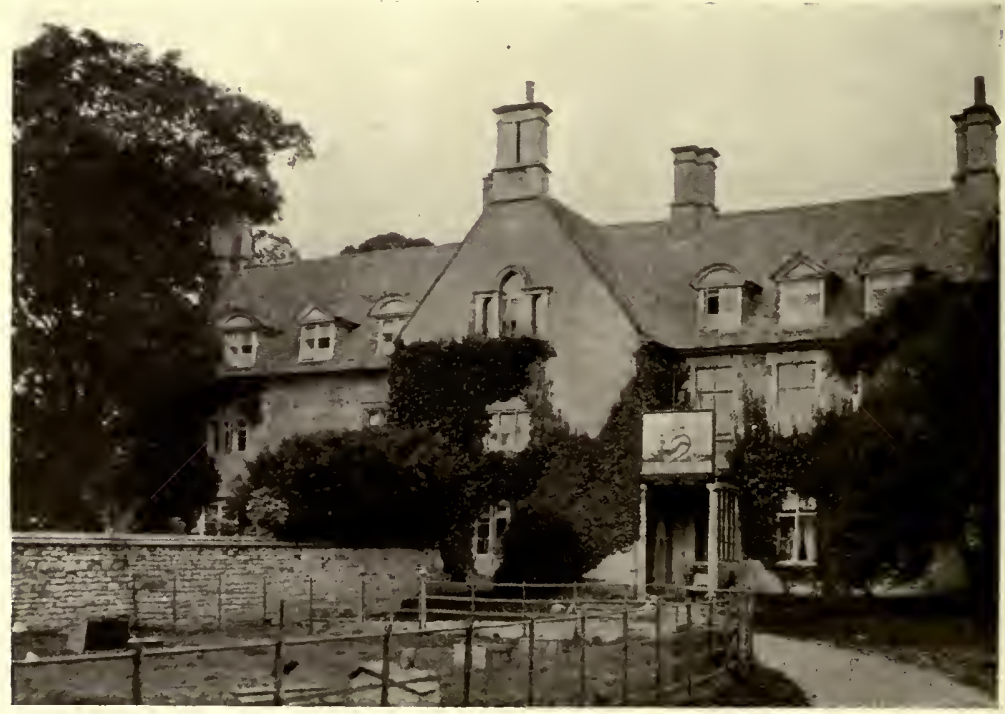

FIG. 205.-House (now the "Sea-horse" Inn) at Deene, Northamptonshire. 
the servants. The bedrooms, as many old houses still testify, were provided with some variation of the chaise percée.

The rooms, therefore, which had to be provided, could all be of a fair size, and they could be so disposed as to allow their windows to fall into the symmetrical arrangement, which the exterior treatment required. The results can be seen in most of our old-fashioned villages and towns: small manor-houses and parsonages in the former; houses for the doctor, the lawyer, the well-to-do tradesmen in the latter. The vicarage at Puddletown, in Dorset (Fig. 199), is an example of the early years of the century. It has one large chimney-stack in the main part of the house, and two smaller, and probably later stacks in the adjoining wing; its wide eaves give it its distinctive character, and further touches are added by the cut brickwork under the window-sills and the circular panels in the end. Beyond these there is nothing to raise emotions either of praise or blame. There is considerably more attcmpt at design in the Court at Holt, near Bradford-on-Avon (Fig. 20I). This place is in the midst of a district abounding in stone, and the builders availed themselves of the opportunity to impart a more pretentious character to their work. The older methods make themselves felt in the manner. in which the eaves cornice is bent up to form a gable, steeper than classic handling usually permits. Here, again, there are but two chimney-stacks, one at each end of the house.

The house in St Giles, Oxford (Fig. 200), is rather more imposing. It is of the period of $\mathrm{Wren}$, and is, indeed, attributed locally to him. The treatment is large, simple, and dignified, and the effect is enhanced by the handsome gate-piers which give access, up a few steps, to the front door. It is evident that here, at any rate, more rooms have fireplaces than those at the ends of the house. There is another house at Oxford, in the High Street (Fig. 203), of a later date, which is quite admirable in its simplicity and careful proportions, and the front is relieved from baldness by the slight projections at each end. Compared with the more famous pieces of architecture by which it is surrounded, this house is insignificant, and may well escape the attention it deserves. Dating from early in the century is the dower house at Deene, in Northamptonshire (Fig. 205), now occupied as a public-house under the sign of the sea-horse, which is the crest of the family owning the village. It presents 


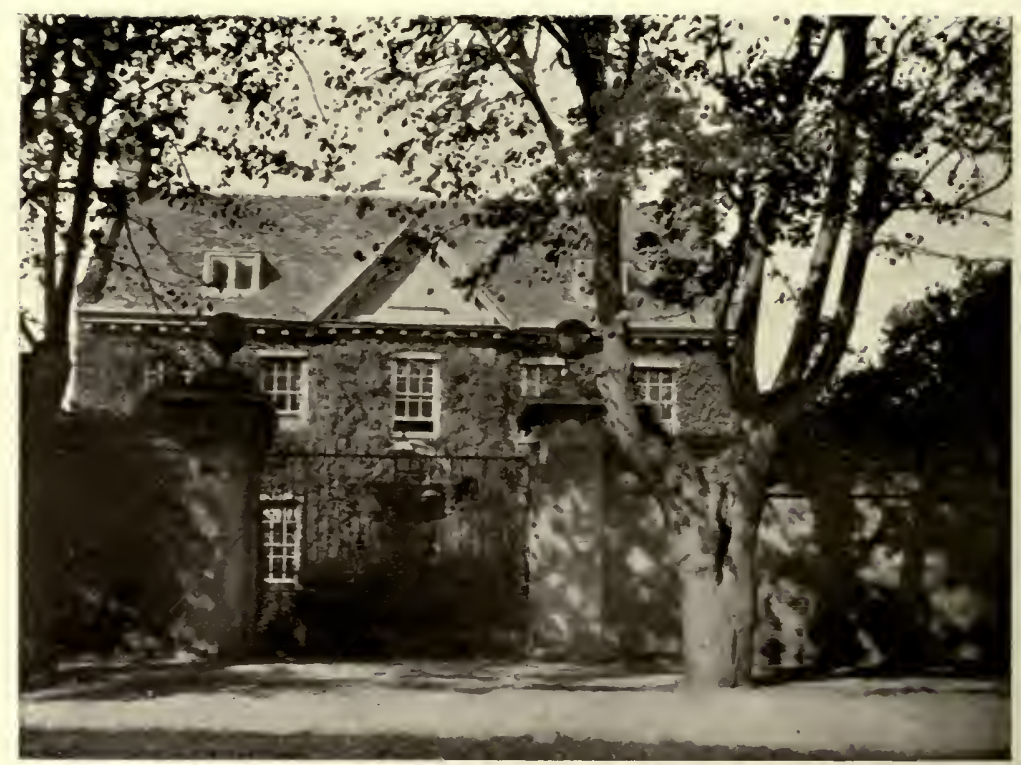

FIG. 206.-House at Ely, Cambridgeshire.

a quaint combination of the steep coped gables of the district prevalent in earlier times, with the wide eaves, sash-window's, and dormers fashionable when it was built. It has quite a large number of chimneys, but the dowagers who came from the great house no doubt looked for the comforts to which they had always been accustomed. Several of the rooms are decorated with good panelling and plaster-work, and have had skill and knowledge bestowed upon their proportions and design.

The Church House at Beckley, in Sussex (Fig. 202), has no projecting eaves, but above the cut-brick cornice rises a parapet which effectually blocks the outlook from the dormer windows. The usual plain treatment of the walls is here varied by the introduction of a pilaster at each end of the front, and by carrying up a slight projection from the keystone of the middle window. The pilasters are surmounted by a piece of architrave and frieze of the same width as the pilaster, a device which displays a misconception of classic features. The two main chimney-stacks are placed at the back of the principal block 


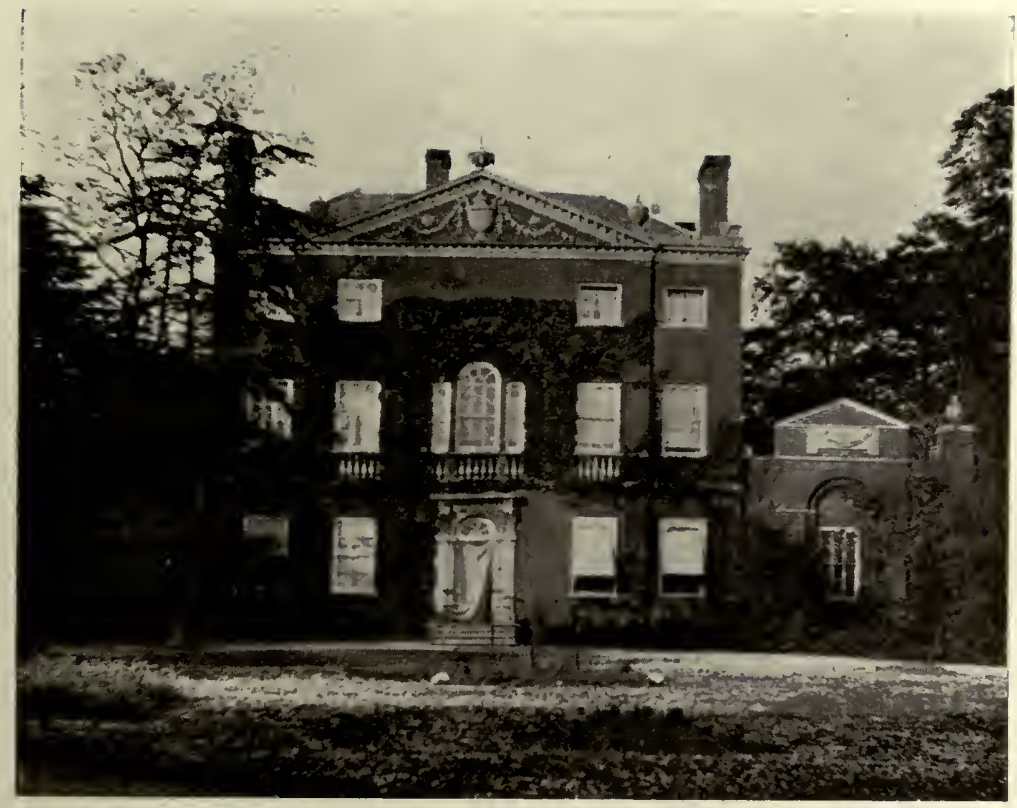

FIG. 207.- Rectory at Church Langton, Leicestershire.

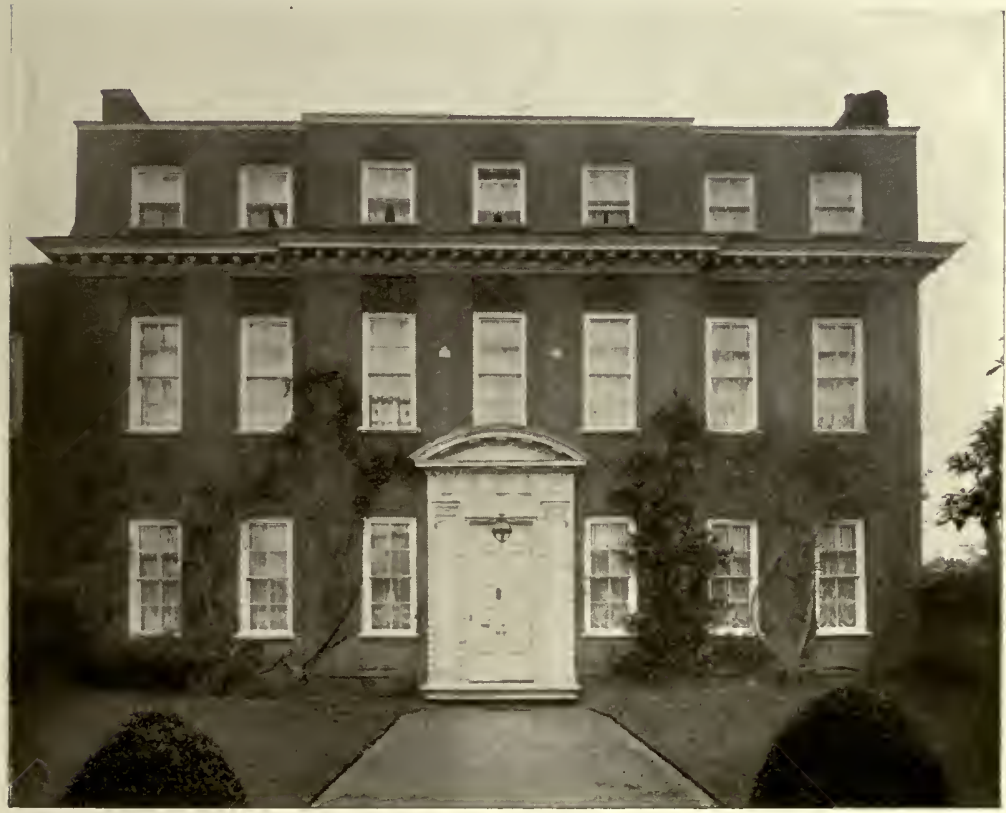

FIG. 208.-House at Petersham, Surrey. 


\section{AVERAGE SMALLER HOUSE OF THE PERIOD}

instead of at the ends, thus giving them an opportunity to serve rooms behind as well as those in the front.

The house at Shrivenham, in Berkshire (Fig. 204), is of the more ordinary type. It has a good eaves cornice, and the usual two chimney-stacks: the projecting porch forms a pleasing variation, and the whole house gives the impression of comfort and respectability. So, too, does the house at Ely (Fig. 206) which faces the green opposite the west end of the cathedral. It has a chimney-stack at each end, and a pediment of unusuallysteep pitch. Like several of the other examples, it has five windows along the front; the middle one lights the landing, and the two on each side light the rooms with fireplaces. Additional importance is given by the large gate-piers, and the whole effect is dignified and restful, eminently in keeping with the atmosphere of an old cathedral town. The house at Petersham (Fig. 208) is of larger size, having seren windows along the front; the three in the middle are placed in a slight projection round which the cornice breaks. This projection, together with the bold cornice, the rather large front door, and the wide window margins, is all there is in the way of design to give interest to the house. The rectory at Church Langton, in Leicestershire (Fig. 207), is of somewhat later date, probably about the beginning of the nineteenth century. Here there is a decided attempt at architectural effect in the ornamented pediment, the central arched recess, and the low buildings at the side; but the house itself is not more commodious inside, nor has it larger rooms than other houses of the same type. The adjuncts, too, are added for effect rather than for use.

Houses such as these abound in country districts. There is nothing particularly notable about them, and very little effort at design. But as a rule their proportions are pleasing, and the very absence of any attempt to achieve striking effects is itself one of their charms. They seem the natural expression of the quiet, uneventful lives led by the inhabitants, who, like the Vicar of Wakefield, had no adventures save by the fireside, and no migrations save from the blue bed to the brown. Their interest varies not so much through difference in design as by reason of their surroundings, and the variety of creepers which climb up their walls, and are the less objectionable in that they hide no architectural detail. 


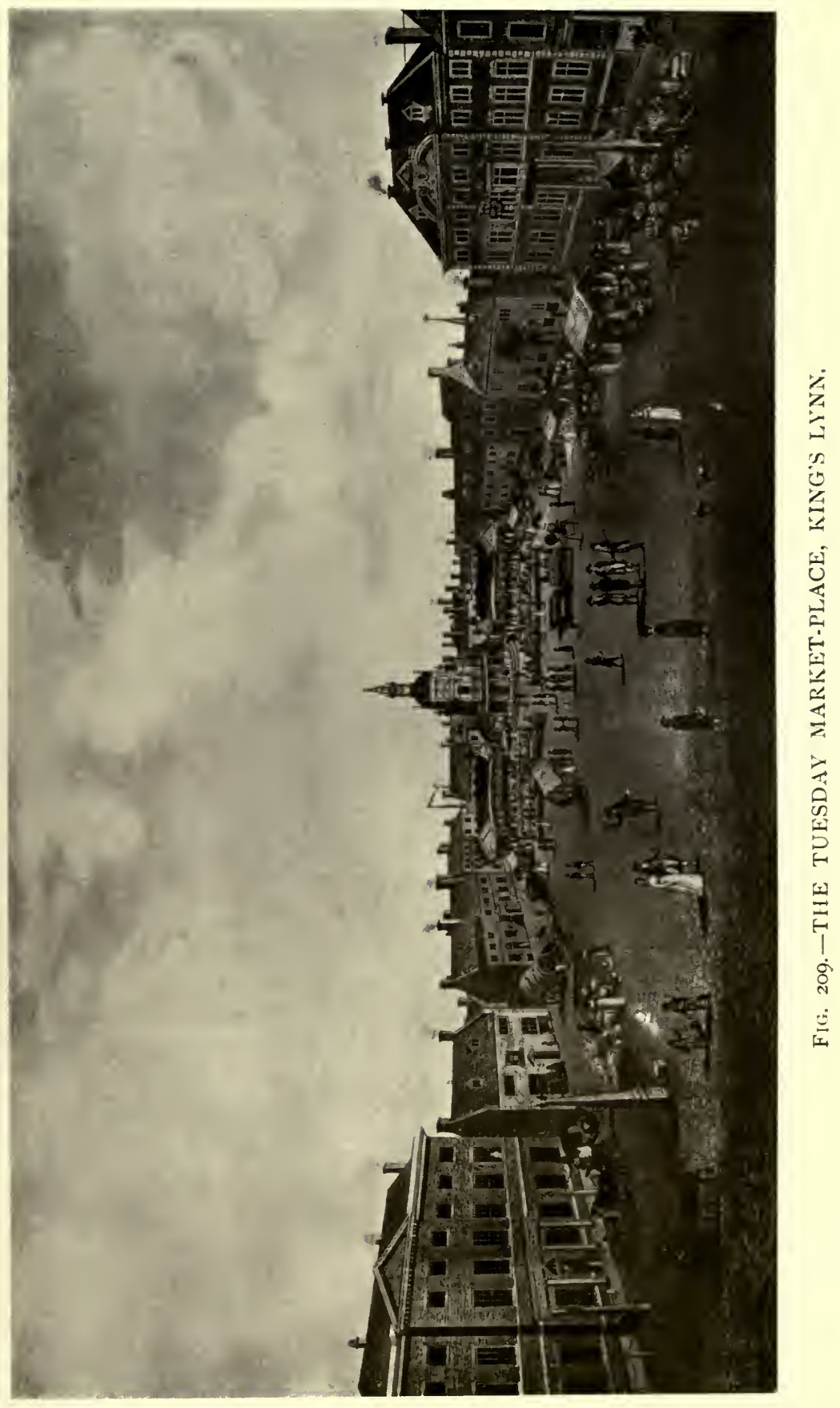




\section{LAY OUT OF XVIII. CENTURY STREETS}

In the towns, of course, the surroundings did little to help the appearance of houses; there they had to rely on their own merits. Nevertheless the disposition of the streets often lent picturesqueness to the houses that formed them. It is one of the charms of most English towns that their appearance is the result of fortuitous causes, or of some necessity which is no longer obvious. In some towns, like Marlborough or Dunstable, it is the width of the main street which gives character to the place; in others, like York, Canterbury, and (in a less degree) Warwick, it is the narrowness which strikes the visitor. In the one case the open spaces of the country are embodied in the town; there is room enough and to spare. In the other it is clear that every foot of room was utilised. Yarmouth has a very interesting lay out, evidently the result of premeditated design and not of chance. The river upon which it is built turns suddenly to the right as it approaches the sea, and runs for some distance parallel to the sea front, leaving a certain space between itself and the shore. L'pon this restricted space the town was built; streets of no great width were formed parallel with the river, next to which was a broad quay; then at right angles to the streets a series of narrow passages were formed, called "rows." Although these "rows" are not more than 4 or $5 \mathrm{ft}$. wide, they were formed of good houses, and it is surprising, in traversing them to-day, when they have become degraded into slums, to find remains of houses which must have been the residences of wealthy people. But the circumstances of Yarmouth were peculiar. At King's Lynn, another ancient port in the same county, although most of the old streets are narrow, judged by modern standards, there is a very fine open space known as the Tuesday market-place, which still retains much of its old-world flavour. The old print of it which is reproduced in Fig. 209 rather exaggerates its size, owing to the perspective of the draughtsman; the market hall and its circular adjuncts have disappeared, but the Georgian buildings in the front and on either side still remain, and that on the left retains its steps and obelisks. Another old print-one of Chelmsford (Fig. 2 IO)-gives a good idea of that town in Georgian times. Most of the houses are of the eighteenth century, and must have been quite modern at the time when the print was published; others are of an earlier date. Their disposition is the result of a long period of growth, and could never be achiered under a scheme 


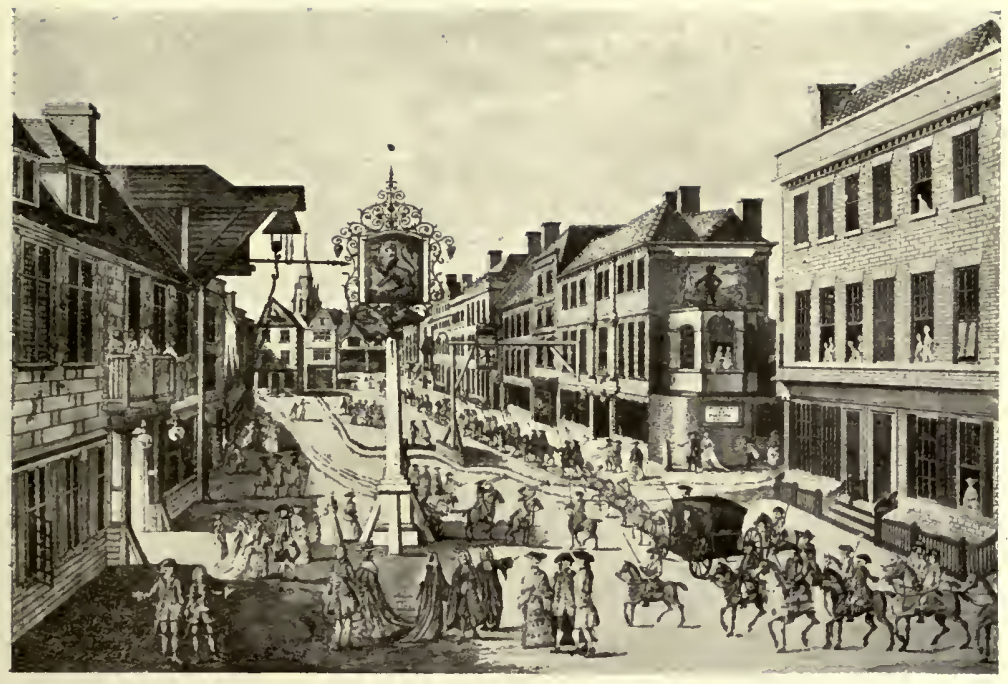

FIG. 2 Io.-Chelmsford, Essex.

From an Old Pint.

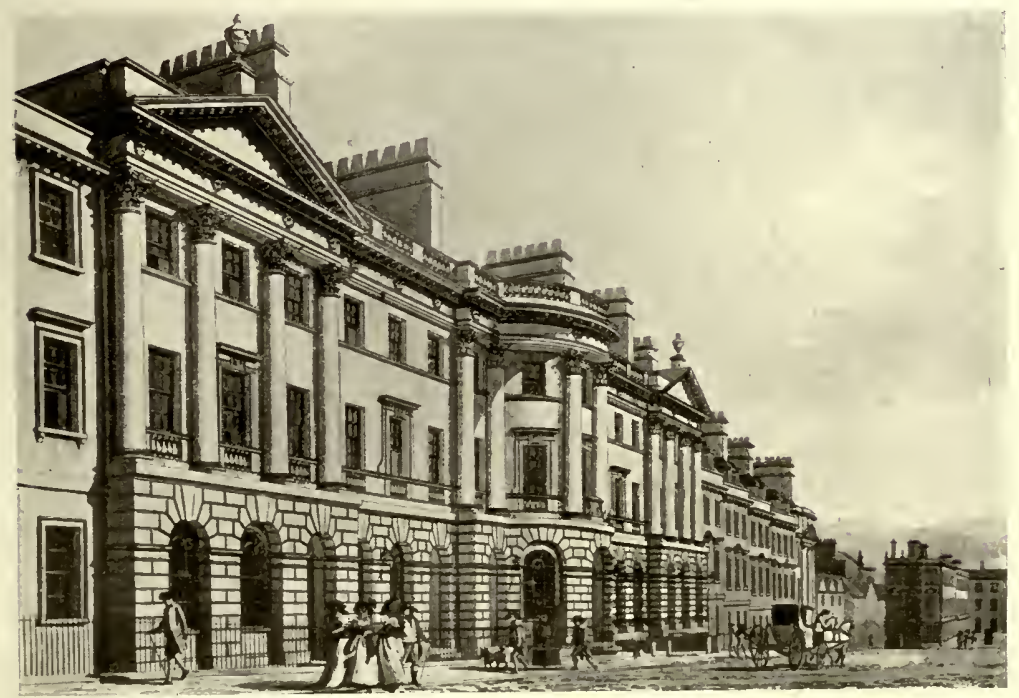

FIG. 2I I.-Somerset Buildings, Milsom Street, Bath.

From an Engraving by Thomas Malton. 


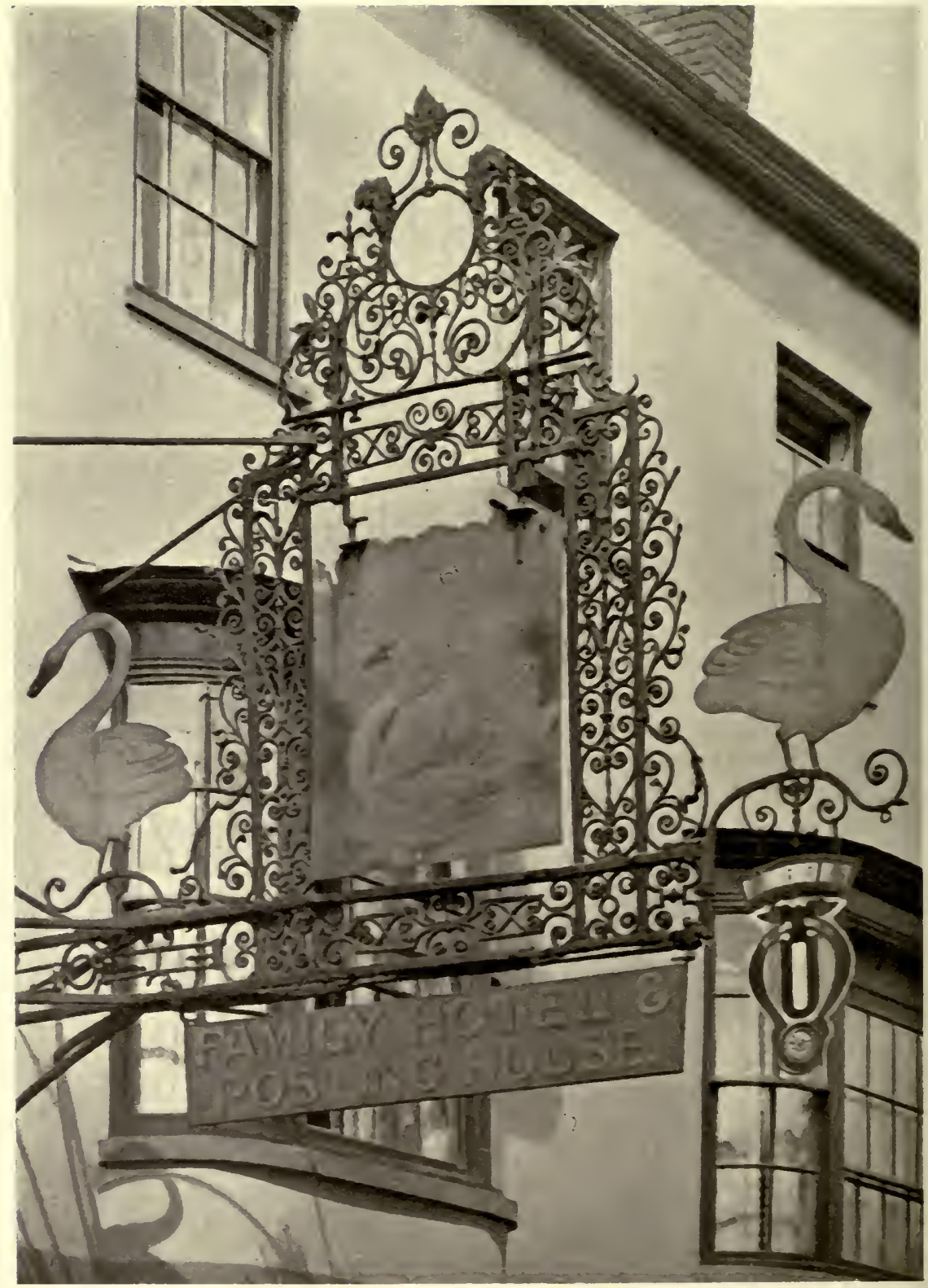

FIg, 2I2, -SIGN OF THE SWAN HOTEL, MARKET HARBOROLGGH. 
of town-planning. One of the most prominent objects in the view is the inn sign, a good solid structure, thrust well out into the public way; it is characteristic of the times, both in its size and in the wrought-iron scroll-work which surrounds the swinging lion; indeed bits of fanciful ironwork such as this were prodigally used during the eighteenth century, and give interest to a house or a street which otherwise would attract no attention. In the middle distance is another sign typical of many which used to exist, but which are seldom found in the present day. Here it stretches across a large part of the public road, but in many cases these signs were made to span the whole width of the street. An example of an elaborate sign may be seen at the Swan Inn, Market Harborough (Fig. 2I2),

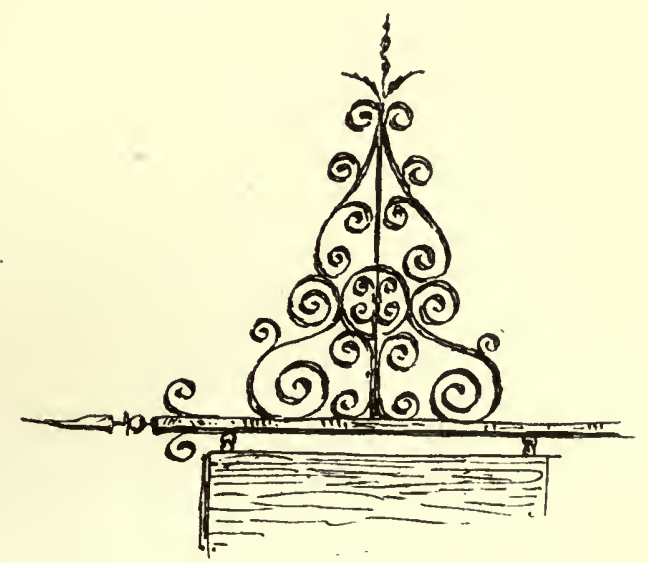

FIG. 213.-The Sign of an Inn at Salisbury. and an unpretentious but effective specimen is shown in Fig. 213.

In most of the county towns the gentry of the district used to have their winter residences, to which they repaired when the state of the roads rendered locomotion difficult. It must be remembered that the roads in those days, except the most important, were little more than tracks across the country; nothing was done to make them hard or permanent - they merely traversed the natural soil. "Where there is good land there is foul way," was a saying of the time; and conversely, where the ground was stony the roads were fairly hard. Horace Walpole, among other writers, recounts the difficulties he experienced on country roads in bad weather, and this condition of things accounts for the number of horses which, according to old prints, were harnessed to family coaches. These in their turn were built in a strong and heavy fashion, in order to withstand the shocks to which they were inevitably subjected. When the wet weather came on, families who lived in country houses betook 


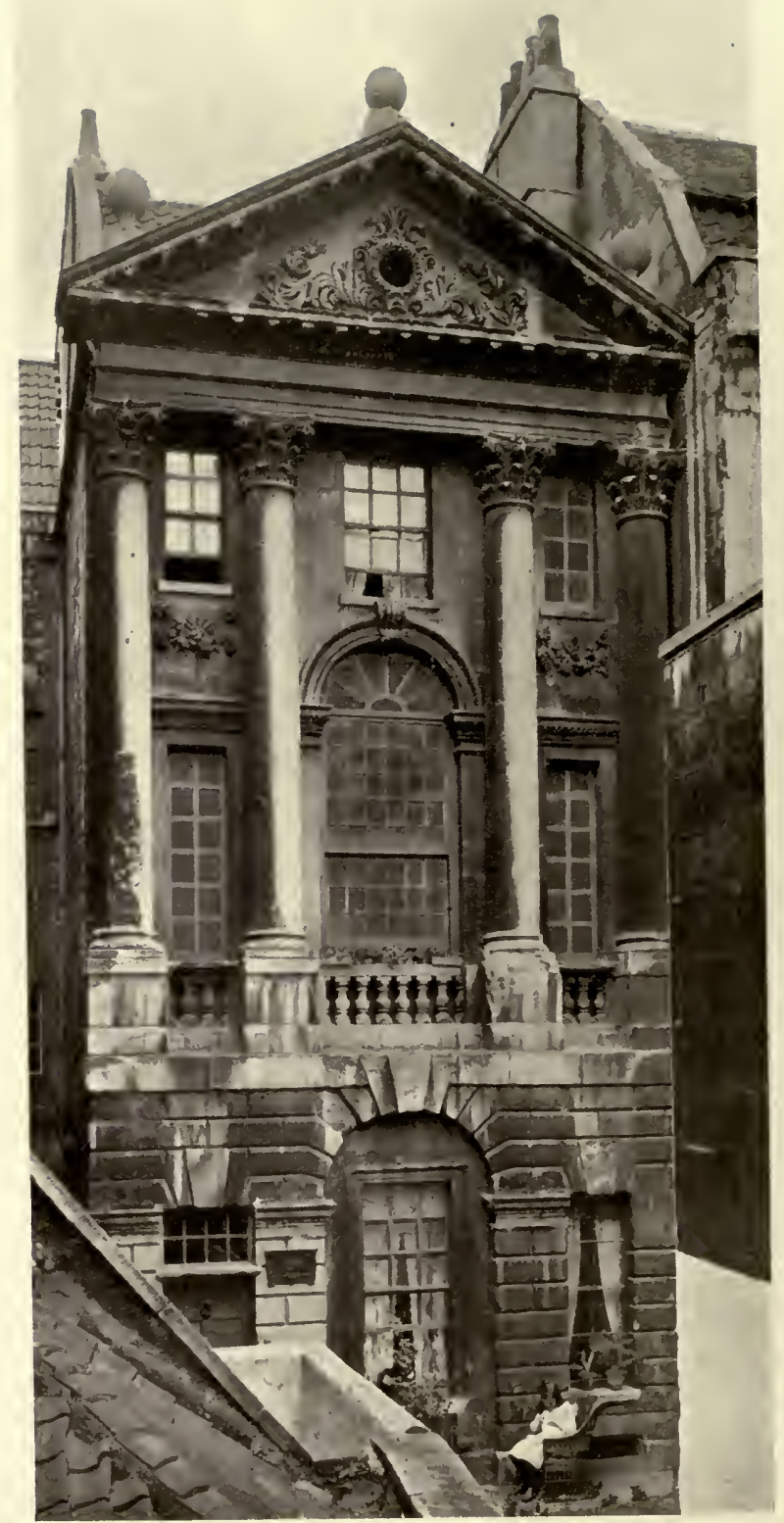

FIG. 214.-RALPH ALLEN'S HOUSE AT BATII. 


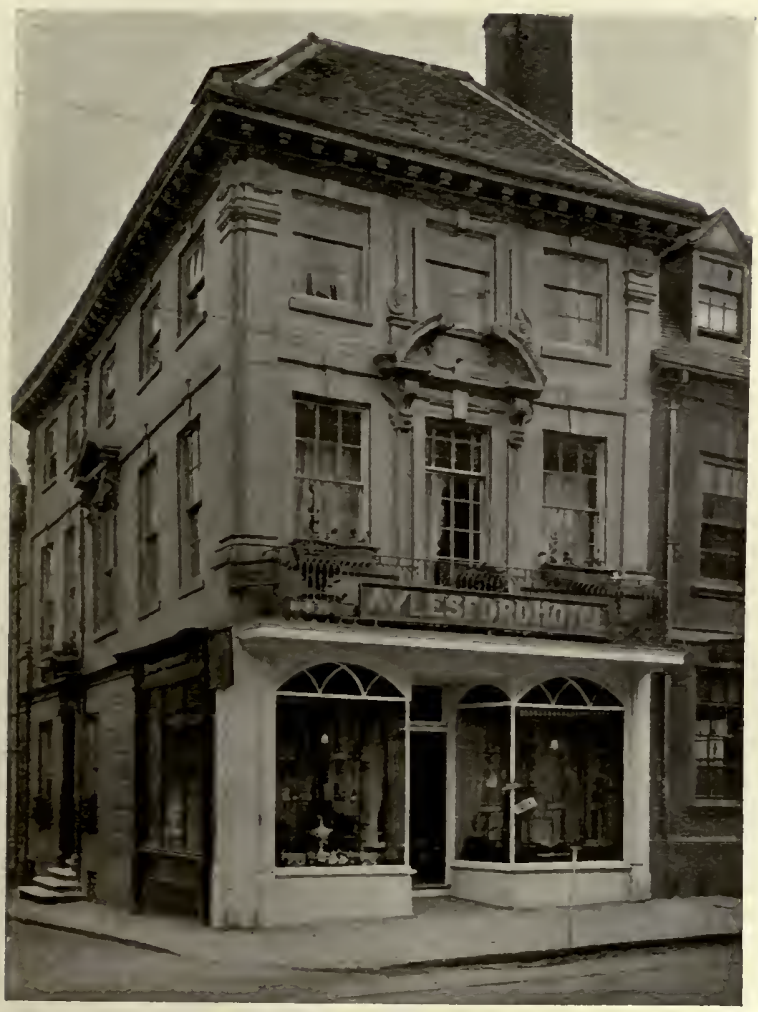

F1G. 215.--The Aylesford Hotel, Warwick.

themselves to the town for society and amusement. In places like Nottingham and Derby there still remain a fair number of houses which were built for county magnates, but in every instance they have been diverted from their original purpose and have become business premises. This affords another proof, if such were needed, that no lay out can be expected to retain in perpetuity its original character. Half the squares of London point the same moral.

No doubt the house at Warwick, which, for the time being, is the Aylesford Hotel (Fig. 2 I 5), was built for some such purpose as has just been indicated; it is a handsome and interesting example of the early part of the eighteenth century. Just outside the east gate is the house where Walter Savage Landor was born in 1775 . Another house of the same kind is that of 


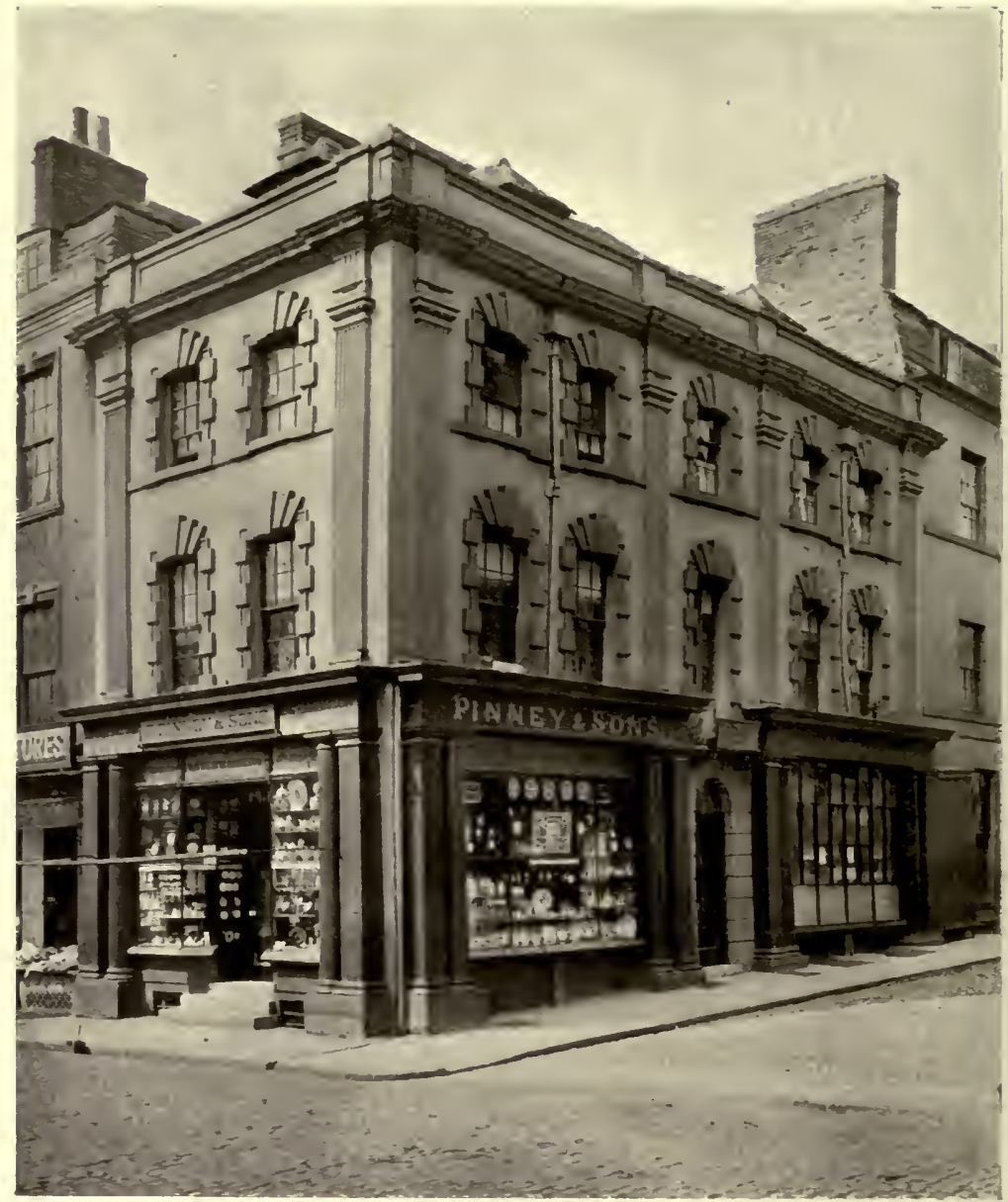

F1G. 216.-Shops at Cirencester.

Ralph Allen at Bath (Fig. 214), which is an architectural composition of much greater pretensions, now almost hidden from public view. It will be remembered that his country house was Prior Park.

Bath, of course, is full of good examples of town houses; but Bath was much more than a town to which the neighbouring gentry resorted for the winter. It was a fashionable watering place, and provision had to be made for visitors throughout the year. Some of its buildings have already been mentioned, but 


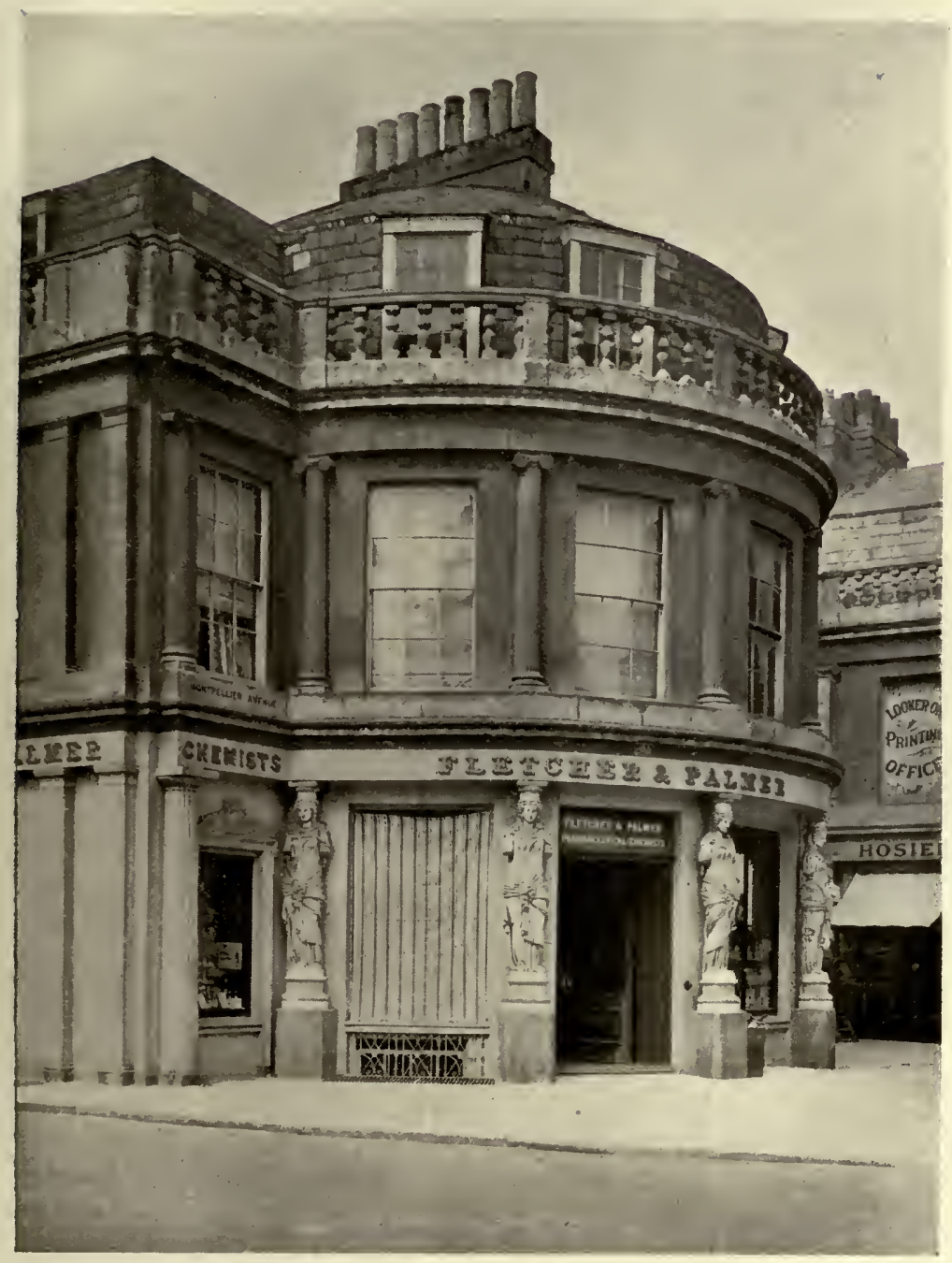

FIG. 2I7.-Shops, Montpellier, Cheltenham.

the accompanying engraving of Milsom Street (Fig. 2I I) gives a good idea of its street architecture, devoted partly to residential purposes and partly to business premises. This mixture of dwellings and shops is still met with in old-fashioned towns, where the principal streets are made up of houses-some large and some small-interspersed with shops and inns. But in places 


\section{COMBINATION OF SHOP \& DWELLING-HOUSE}

where factories are introduced and the population increases, the universal tendency is towards the multiplication of shops and the diminution of houses. Every growing town experiences this change. As the houses part with their tenants, whether through death or otherwise, they are either converted into shops and offices, or they are pulled down to make room for tradesmen seeking the best situations for their business; the tradesmen

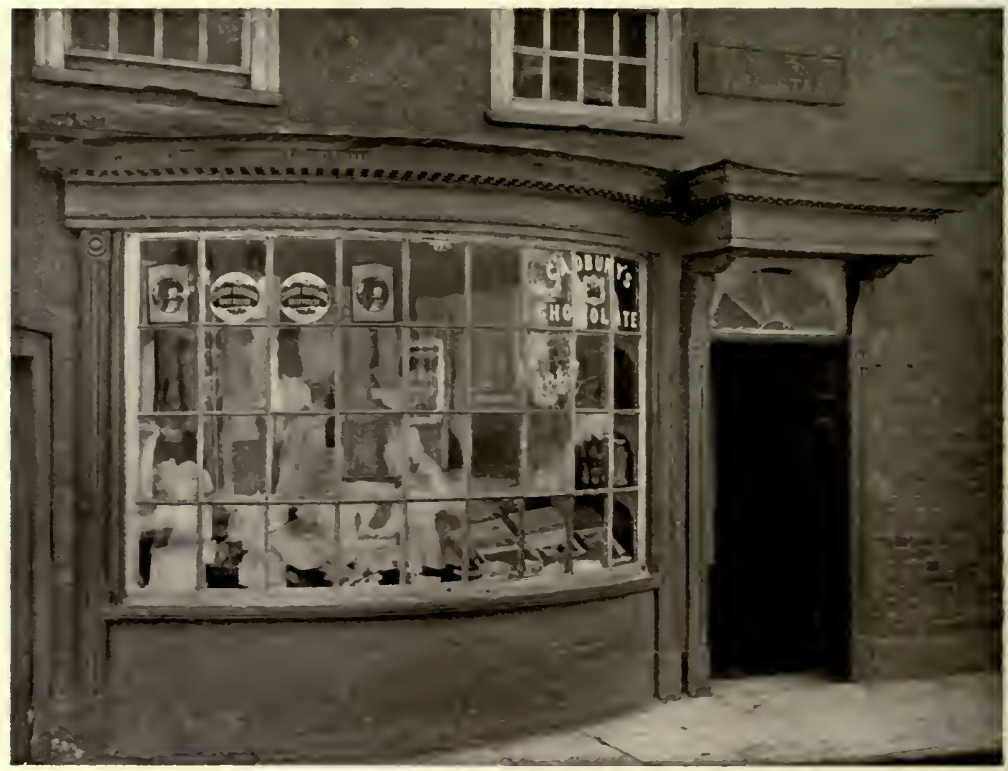

FIG. 218.-Shop in East Street, Wareham, Dorset.

themselves seek the cheaper and larger spaces of the suburbs for their own dwellings. The intentional combination of shop and dwelling, such as those at Cirencester (Fig. 216) or Cheltenham (Fig. 217), seldom occurs in the present day, when by-laws require for a house a certain amount of open space which can be more profitably used for business pure and simple. In the example from Cirencester the ground story, if not actually of the same date as the superstructure, has been skilfully designed to harmonise with it, and appears sufficiently sturdy to support it. But most tradesmen of the present day require so much room for the display of their goods, that they grudge every inch given to the purposes of support, and they would regard with equal 


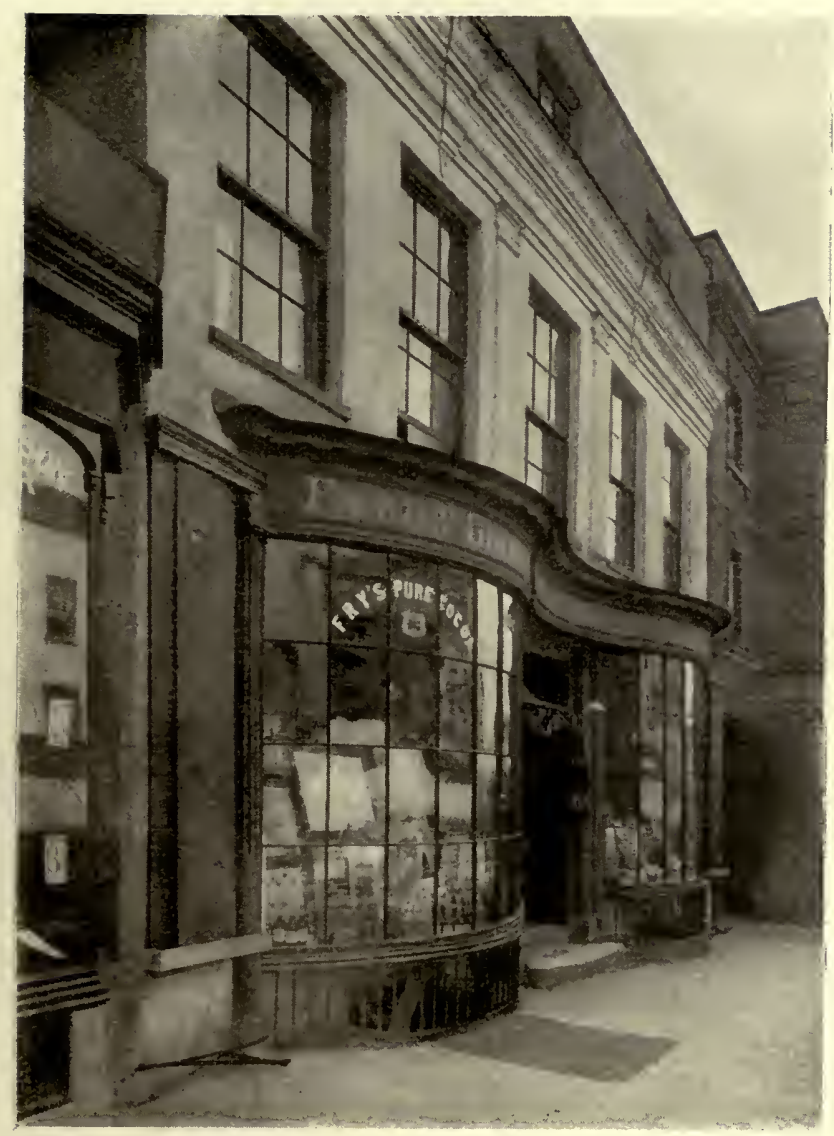

FIG. 219.-Shop Front at Dorking, Surrey.

disfarour the columns employed at Cirencester and the caryatides at Cheltenham.

Needless to say, the little old-fashioned shop fronts with small panes are quite out of the question in the present day, except for a very few trades. They would fill a modern shop fitter with contempt, yet there is something quite refreshing about such a front as that at Wareham (Fig. 218 ) or that at Dorking (Fig. 219). The outward curve, according to the simple ideas of the time, brought the goods into prominence, and when as yet it was unnecessary for rivals to shout each other down, the modest depth of the frieze was sufficient to display the name and calling 


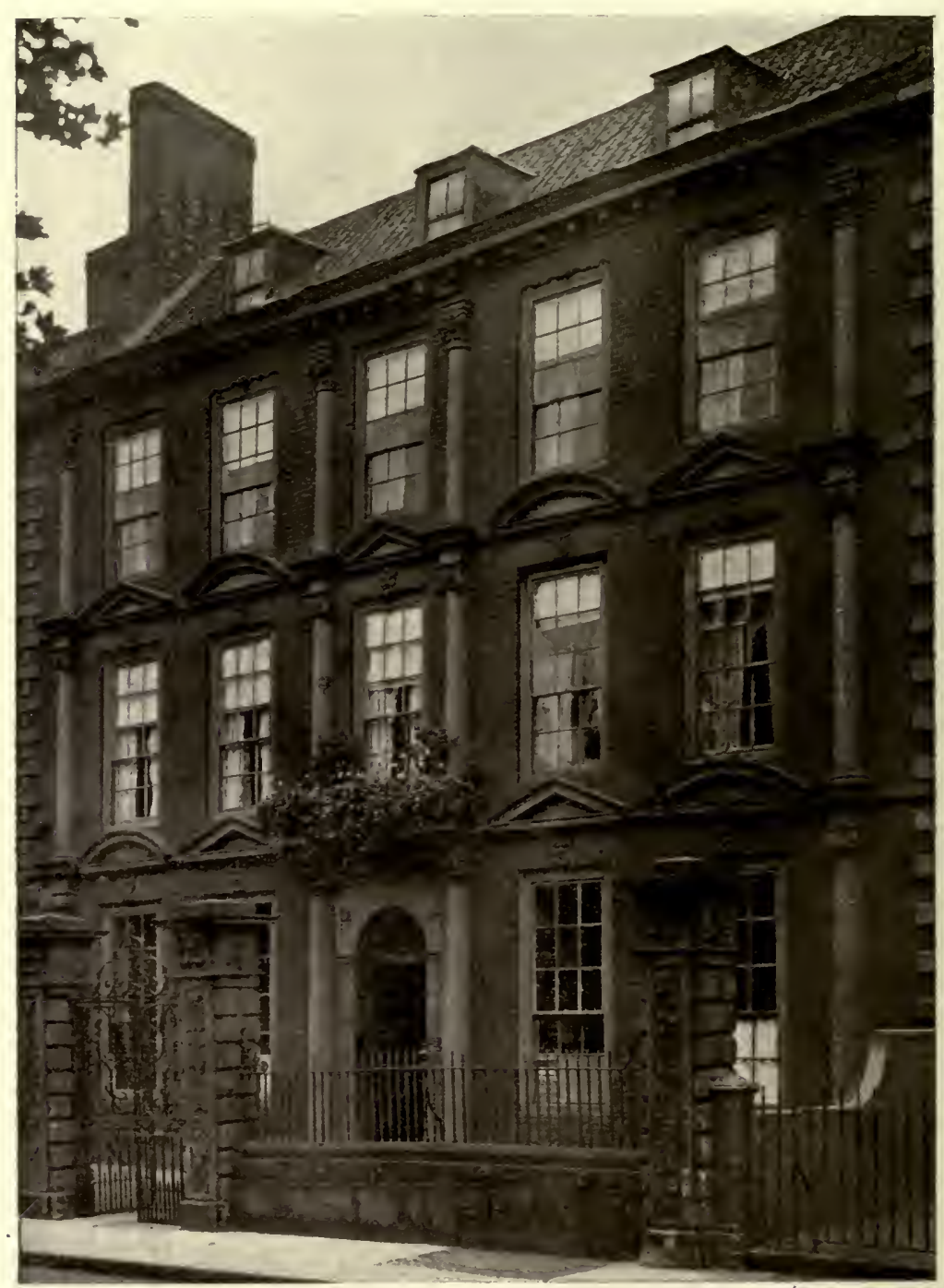

FiG. 220.-Houses at Bristol.

of the occupier. The delicate ornament in the cornice is in scale with its surroundings, but it would be out of place on the top of a sheet of plate glass two or three hundred feet in area, or surmounting a name board with letters two feet high.

Bristol still retains many interesting old houses, some dating 
from the early seventeenth century, and bearing witness to the wealth of its inhabitants at that period. These are to be found within a short distance of the quays, where the trade of the town centred. As the town spread further out more good houses were built, and there are still to be found in the outlying parts of the old town such houses as that shown in Fig. 220. It has a handsome, substantial front treated with more than usual richness; but if the pediments over the windows and the pilasters were removed, the residue would resemble one of the ordinary plain brick houses of the time. That is to say, the ornamental features are merely applied, and have no vital connection with the structure. The house is set a little way back from the street, thus leaving a narrow forecourt, which is enclosed by a railing abutting at each end on a handsome stone pier; two similar piers carry a pair of elaborate iron gates in the middle of the front. The piers lend an air of dignity to the whole. In some instances, where a good house was built in a crowded strect, it was set back some sixteen or twenty feet, thus forming a forecourt; and high walls were built at the sides of the court from the house up to the street, thus providing screens to mask the ends of the adjoining houses, which were built on the actual street front. There is such a case in Eastgate, Gloucester, but the forecourt is now filled with a shop, above which can be seen the front of the house and the screen walls. Nearly all our old towns retain relics of ancient grandeur such as this, but they are gradually disappearing before the march of modern improvements.

London, as may well be supposed, has innumerable examples of late eighteenth-century houses in such districts as Bloomsbury and Piccadilly. Bedford Square was built about I780, and presents to the world some inoffensive, although not very exciting fronts. The central feature of one side is shown in Fig. $22 \mathrm{I}$; there is nothing of striking originality in its design, but enough to break the monotony of the general treatment, and give a little interest to this rather dull though highly respectable square. Contemporary with this is Finsbury Square, which was laid out by George Dance, the younger, between 1777 and I79 I. ${ }^{1}$ A part of it is illustrated in Fig. 222. By simple expedients the designer has imparted variety to his front, and has emphasised the principal floor, where, according to custom, the drawing-room 


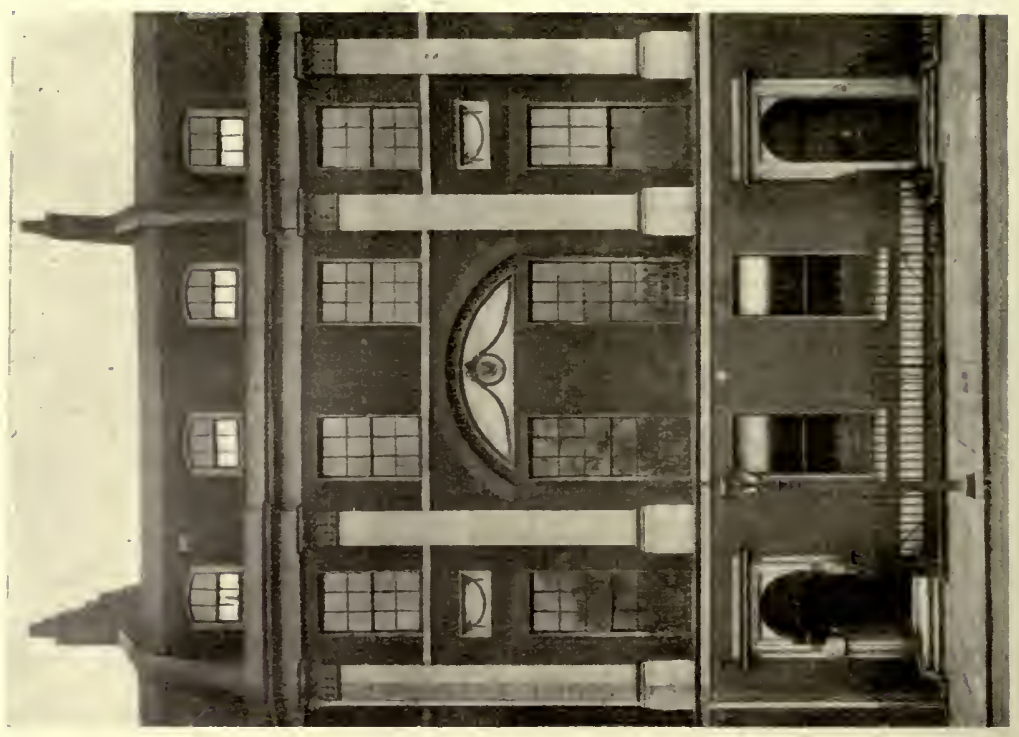

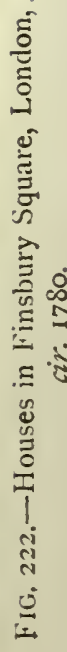

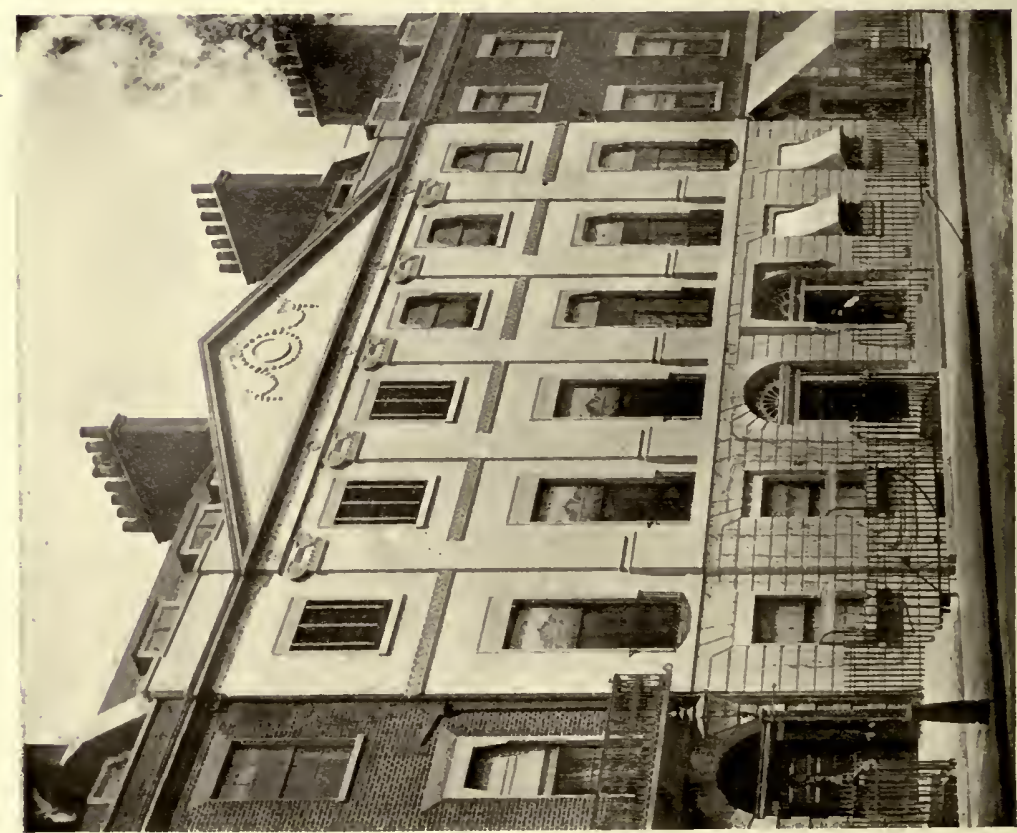

I 
is placed. The difficulty attending on the ornamenting of a row of houses with architectural features is illustrated here by the fact that one of the pilasters, which belongs in common to two houses, has been painted of two colours, which meet in a vertical line down the whole length of the pilaster-an effect certainly not contemplated by the architect. All these London houses have their kitchens in the basement, which is lighted from a sunk area between the house and the pavement. The plan generally adopted consisted of two rooms on each floor, one lighted from the front, the other from the back. Alongside the front room on the ground floor was the entrance passage, and next to the back room was the staircase, with its gangway of communication from flight to flight (Fig. 223). On the first floor the drawing-room occupied the whole of the front, behind it was a bedroom; the other floors repeated the arrangement. Sometimes the drawing-room

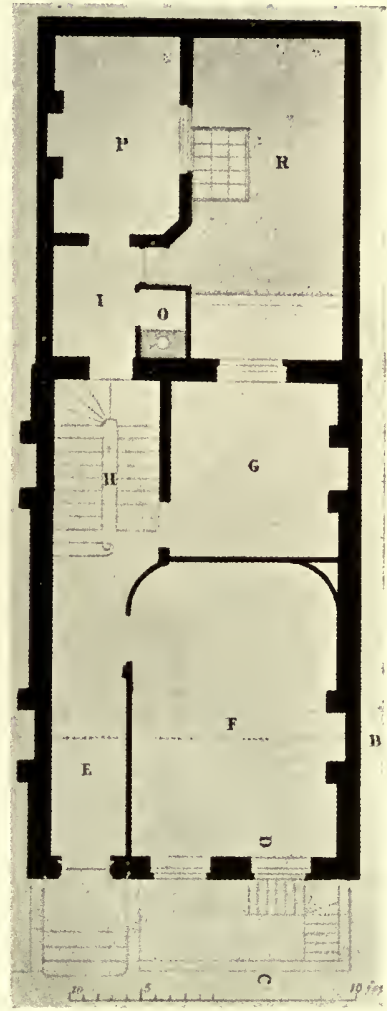

FIG. 223.-Plan of a London House. included the space elsewhere devoted to the bedroom, thus making a large L-shaped room. This plan was used for houses of fair size and also for artisans' dwellings; it is still the staple plan for houses in the long streets which make up the modern extension of growing towns, with the important exception that the kitchen and scullery are not in a basement, but on the ground floor, occupying the back room and the annexe. Of the London examples here illustrated this arrangement applies only to the houses in Finsbury Square ; the others are double-fronted. It is said to have been brought from Holland with IVilliam III., and this at least is tolerably certain, that no plan of this type is to be found in any collection of English drawings before this period, although there are plenty of plans with underground kitchens and offices. Thorpe has 


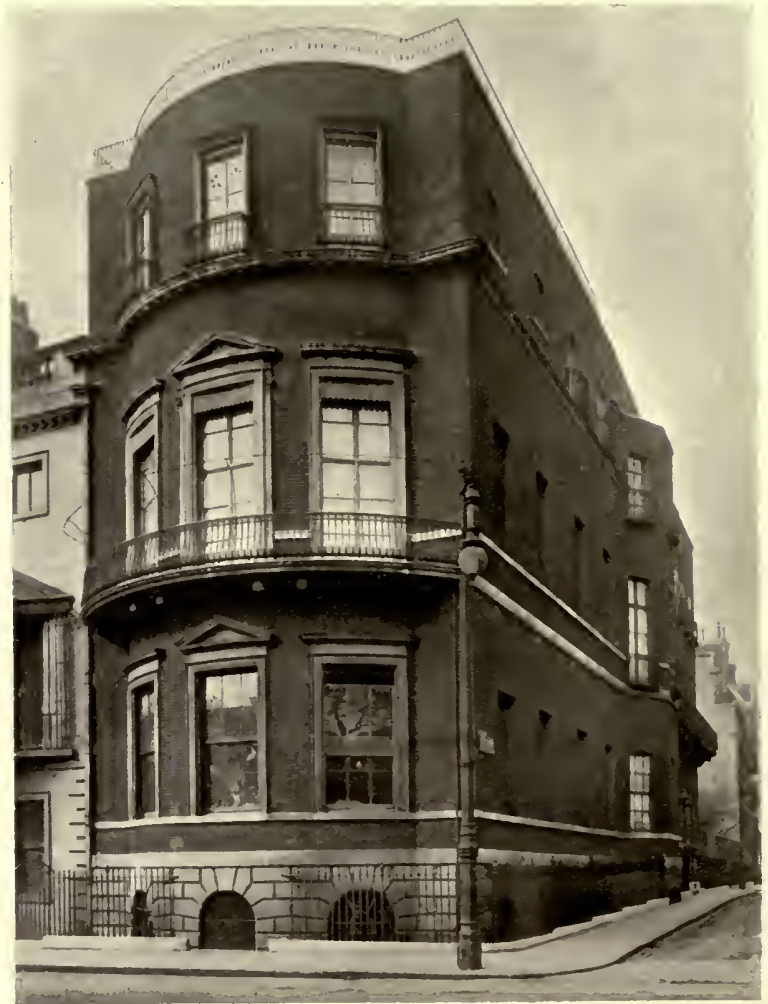

FIG. 224.- House at the Corner of Stratton Street, Piccadilly, London.

some plans for small houses in the city, with four rooms on the ground floor, one of which is a kitchen; he also has a house occupying the space of "three ordinary tenements," from which we gather that an ordinary tenement had a frontage of $\mathrm{I} 7 \mathrm{ft}$.

The house at the corner of Stratton Street, Piccadilly (Fig. 224), is typical of many of its contemporaries in London. It is plain to baldness, the most interesting things about it being the iron balustrades. This appears to be an early example of that method of designing which works on the supposition that the various faces of a building are as distinct in execution as they are on the drawings, and that a rich treatment of the front need not be continued along the side, nor even find an echo there, although the side is equally visible. 
At the beginning of the nineteenth century a much plainer and duller type of house was in vogue than had been the case at the beginning of the eighteenth. The trend of design had been always in this direction, always towards a more severe treatment. This severity was endurable in large buildings where variety could be obtained by a skilful grouping of the masses, but in rows of small houses, or even in small detached houses, it resulted in a baldness that can only rouse admiration when other means of enjoyment are exhausted. Tennyson's "long unlovely" street consisted of buildings thus plainly treated. Another cause of this lack of interest was the erection of houses by speculative builders and owners. Such houses had of necessity to be cheap, and where cheapness is the first consideration the amenities of design are generally the last. Design indeed had lost itself; the traditions which had been its guides were worn out; in looking for help it appealed for a time to Greece, and with its assistance planted a copy of the Temple of Erectheus in St Pancras and of the Choragic Monument of Lysicrates in Regent Street. Upon many a country garden it bestowed a Grecian temple, set amid winding shrubberies, towards which some heroine of Jane Austen would steal to indulge her love-sick fancies.

Such pagan architecture eventually roused protests in this Christian country, and Pugin initiated the Gothic revival. But the consideration of this development is beyond our present scope, and it is only mentioned in order to show how completely design had lost its way. Its last effort in the old paths was to cover in part the plain front of a small house with a verandah enclosed by trellis-work, in which originality is still to be found. There is a good example in Finsbury Circus (Fig. 225), which was built about ISI4. Others may be found in Kennington Park Road (Figs, 226, 227), somewhat more elaborate in treatment. Kennington Park was at that time a common, and was the place where malefactors from this part of Surrey expiated their crimes on the gallows. The progress of civilisation has not only reduced the number of crimes for which the penalty was paid on Kennington Common, but has withdrawn the last scene from public gaze. Doubtless, however, balconies such as these were often crowded by persons eager to watch the irrevocable punishment of offences now adequately purged by a few months' imprisonment. 


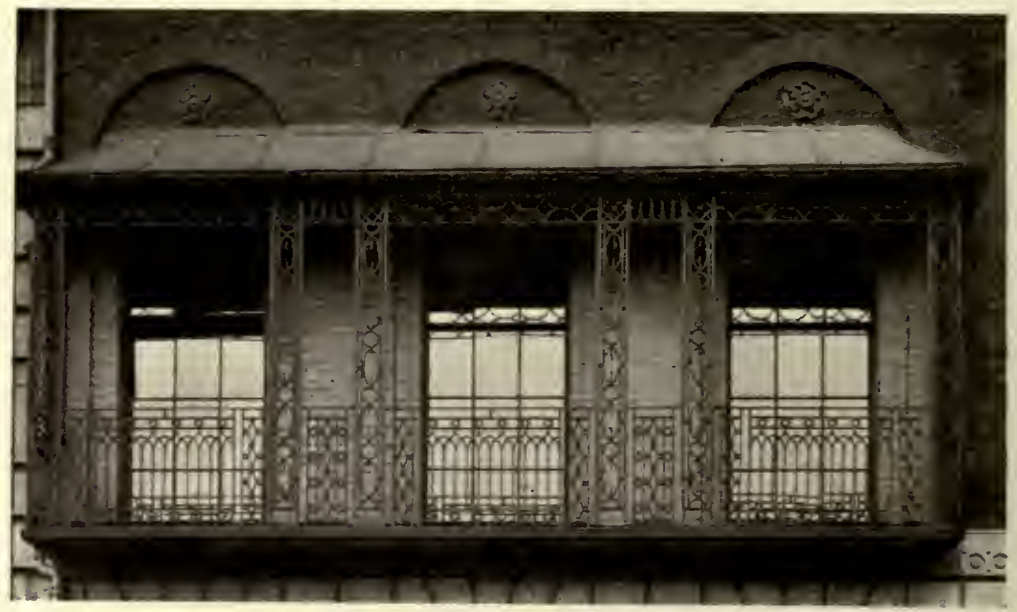

FIG. 225.-No. I 8 Finsbury Circus, London, 1814.

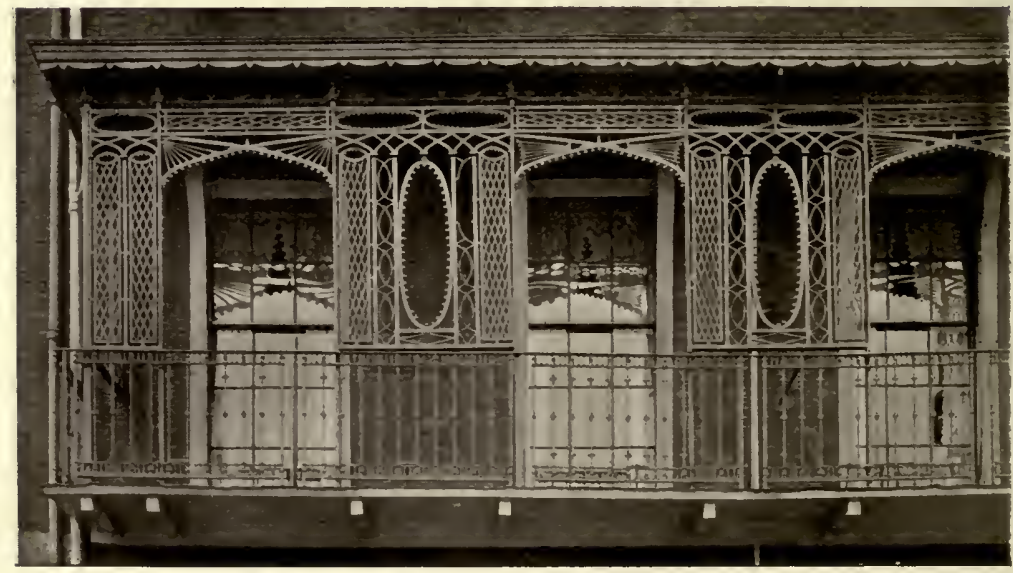

FIG. 226.-From a House, No. 272 Kennington Park Road, London. 


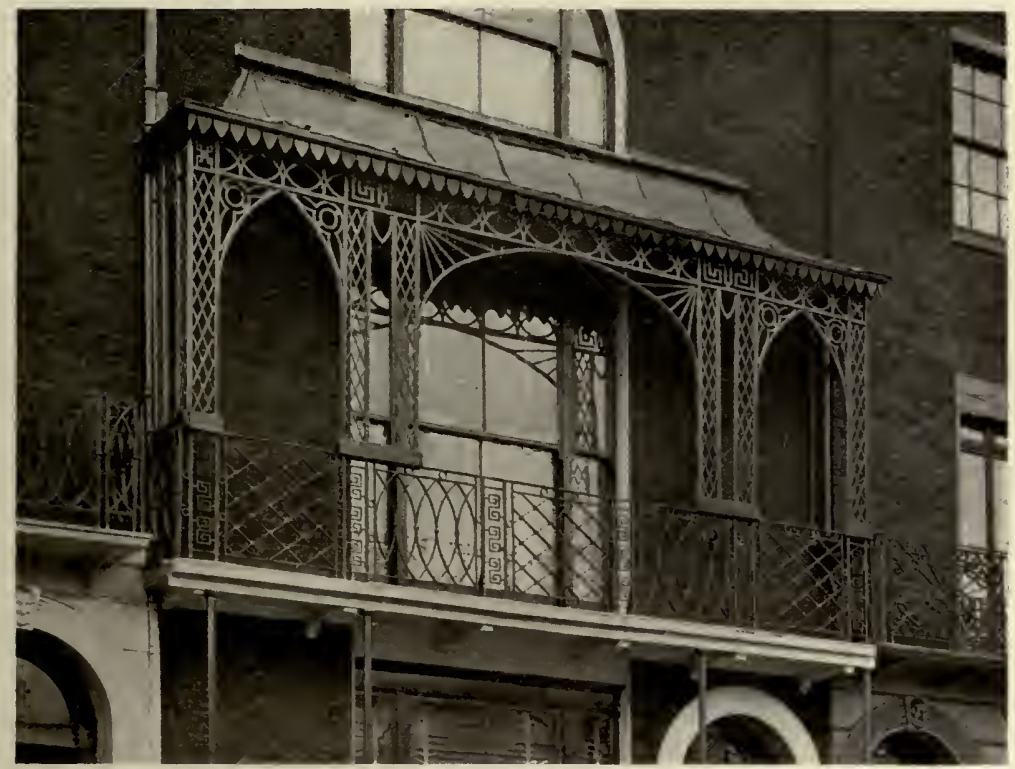

Fig. 227.-From a House, No. 282 Kennington Park Road, London.

With the improved methods of road making which were adopted at the end of the eighteenth century, there came greater inducements for citizens to retire to the suburbs of London after finishing their labours in town. Probably no great city had such beautiful suburbs as those which surrounded London a hundred years ago. They were full of fine trees embowering large houses which stood in their own spacious grounds. But year by year these remains of the past are disappearing, and their sites are being covered with dwellings of a humbler kind, towards which an immense population gravitates every evening. Yet in spite of these changes there still remain, along most of the great roads which lead out of London, houses of moderate size dating back to some period of the eighteenth century or the early years of the nineteenth.

During the eighteenth century, especially as it grew older, the play of fancy which marks the work of earlier times diminished more and more. Consequently less interest attaches to particular features than was the case in the days of Elizabeth, James, and the Charleses. Chimneys and parapets had but slight variety, and so also the windows, for the sash-window has very little elasticity compared with the mullioned. Bay- 


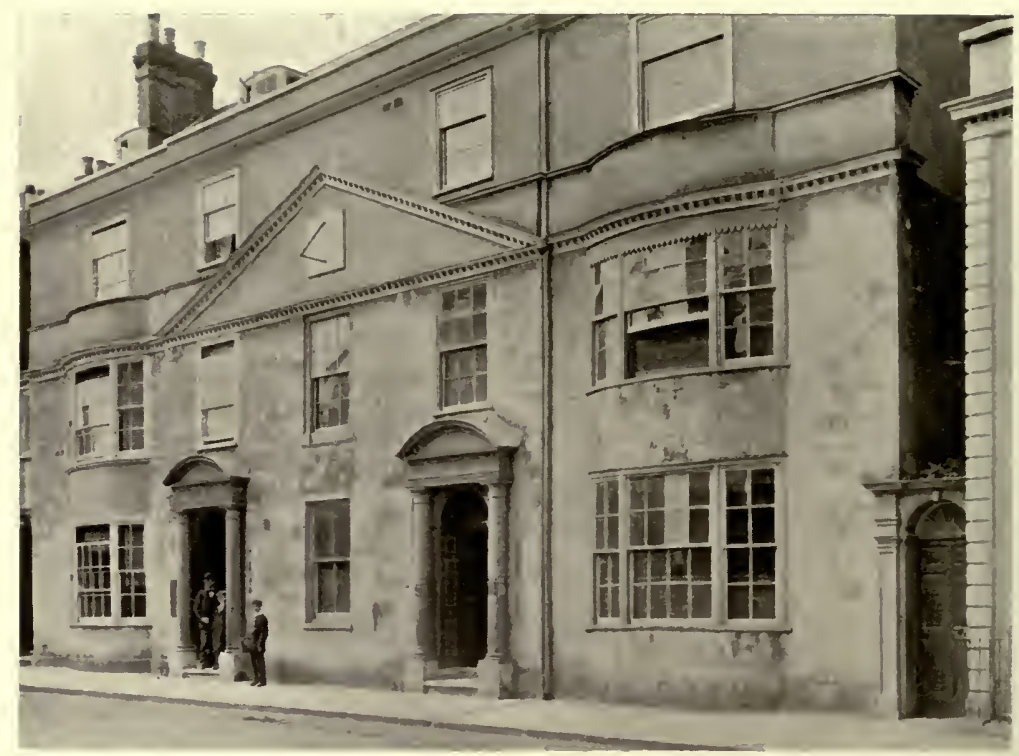

FIG. 228.-- House in the High Street, Lewes, Sussex.

windows went almost out of fashion, so unyielding were the sashes with which they would have had to be fitted. In small houses a bay-window is sometimes to be found, such as those in a house in the High Street at Lewes, in Sussex (Fig. 228). Chimneys grew plainer and plainer, and came to be regarded rather as a necessary evil than as a means of adorning the house. Nearly all those on the houses illustrated in this chapter are of the simplest character, far removed, for instance, from that on the north front of Kirby Hall, in Northamptonshire (Fig. 230), which is part of the work attributed to Inigo Jones. The dormer window included in the same group is allied to the Jacobean type, inasmuch as it is in effect part of the wall, whereas from Webb's time onwards dormers were part of the roof, and were susceptible of very little variety of treatment. The stone chimney from a house at Wansford (Fig. 229, 2) dates from the end of the seventeenth century, and although much plainer, it is clear that pains have been taken with its design. So, too, with the four brick examples in Fig. 229; they are all interesting, though not elaborate. In later years even the touches which gave these their character were withheld, and chimney-stacks became mere oblong masses with the scantiest of caps. 


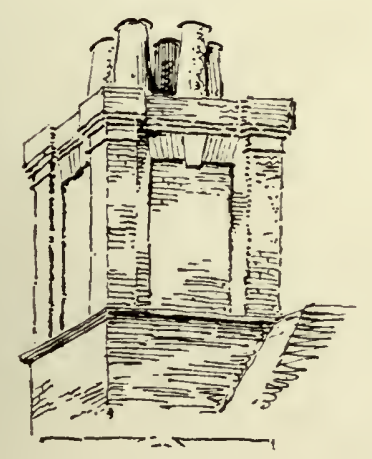

I.

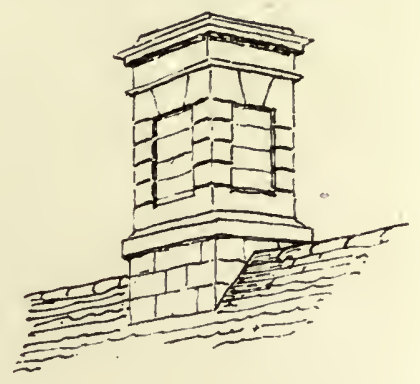

2

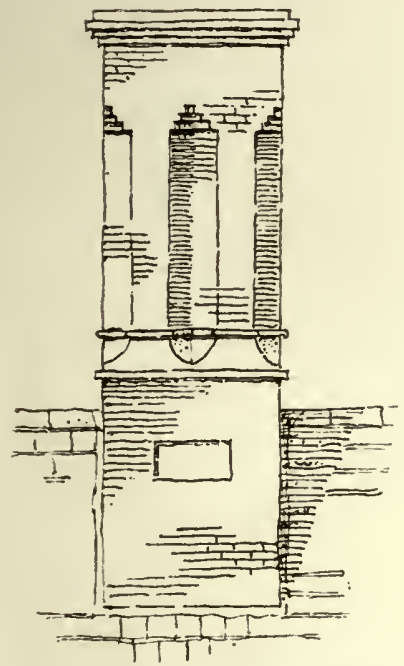

4.
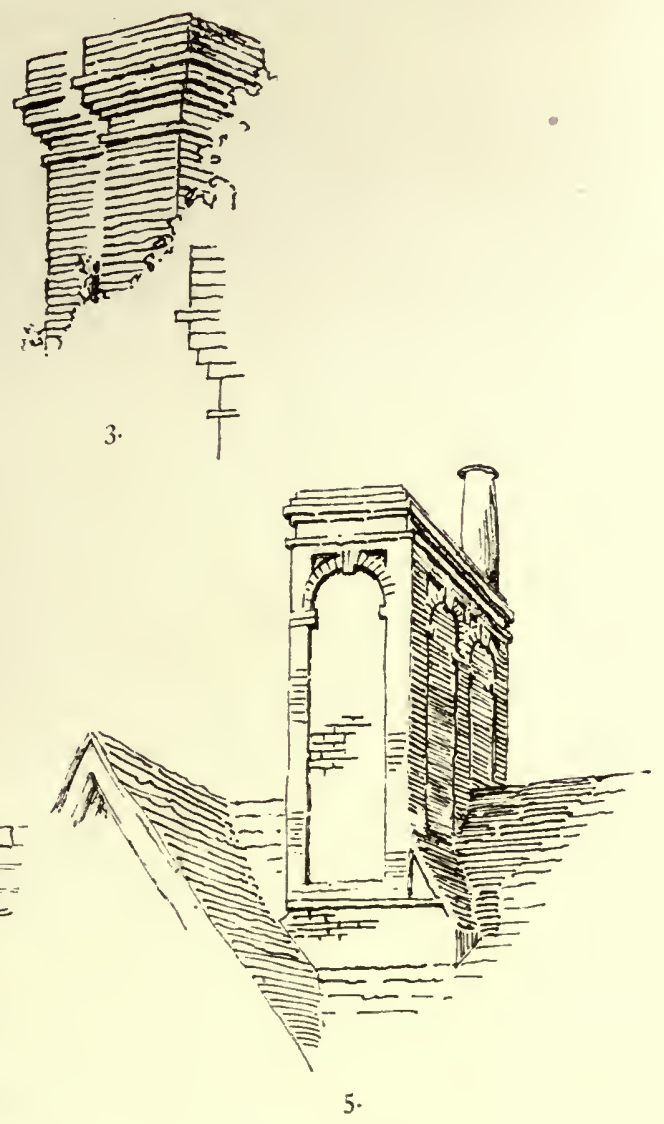

FI1. 229.-EIGHTEENTH-CENTURY CHIMNEXS. 


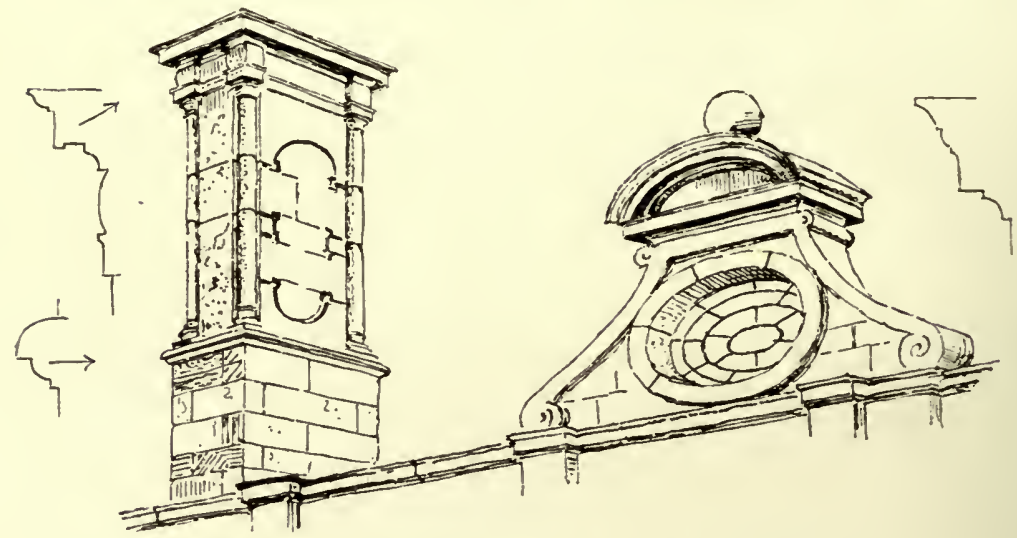

FIG. 230.-Chimney and Dormer Window at Kirby Hall, Northamptonshire.

Some compensation was afforded, however, by the introduction of the cupolas or lantern lights which were prevalent during the last half of the seventeenth century and the. first few years of the eighteenth. There is an interesting drawing of such a feature for Whitehall by Inigo Jones in the Worcester College collection (Fig. 232). It is entitled in Jones's writing- "June I, I627, for the Cloke house Whight hall." Webb made use of the same kind of feature, and so did Wren and his contemporaries. There is a fine example on the stables at Neville Holt, in Leicestershire

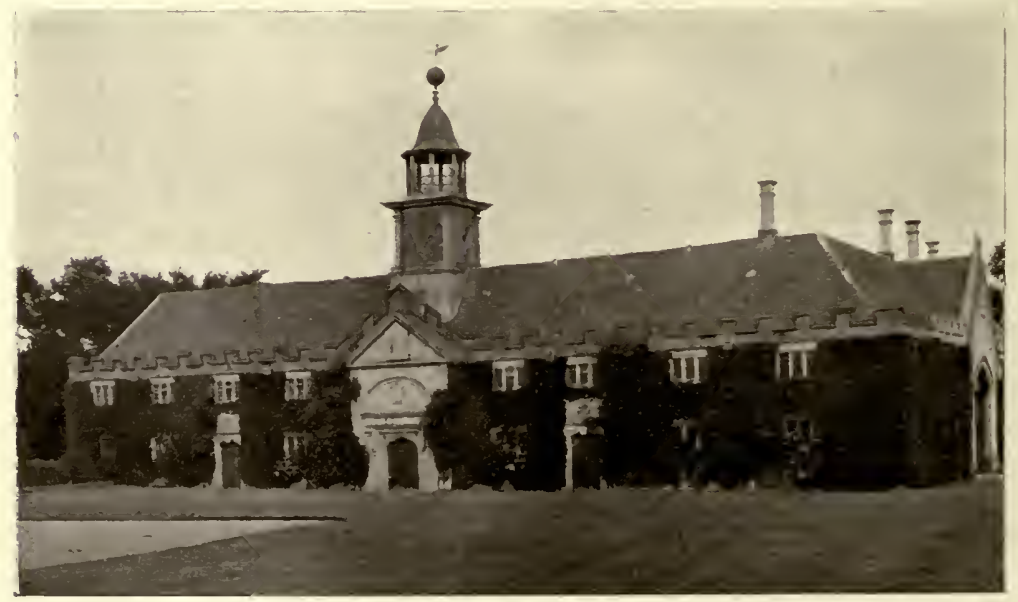

FIG. 23I.-The Stables, Neville Holt, Leicestershire. 


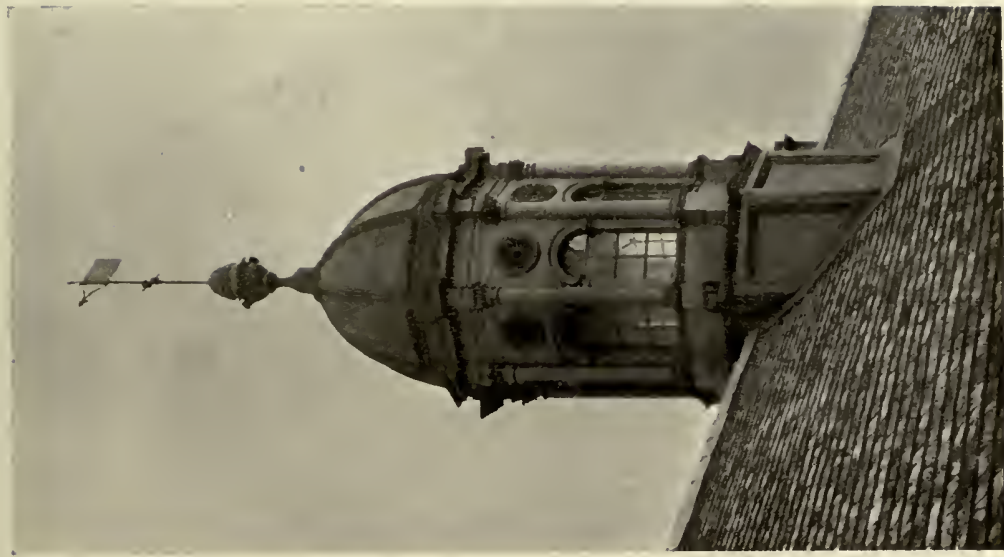

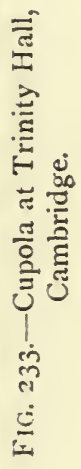

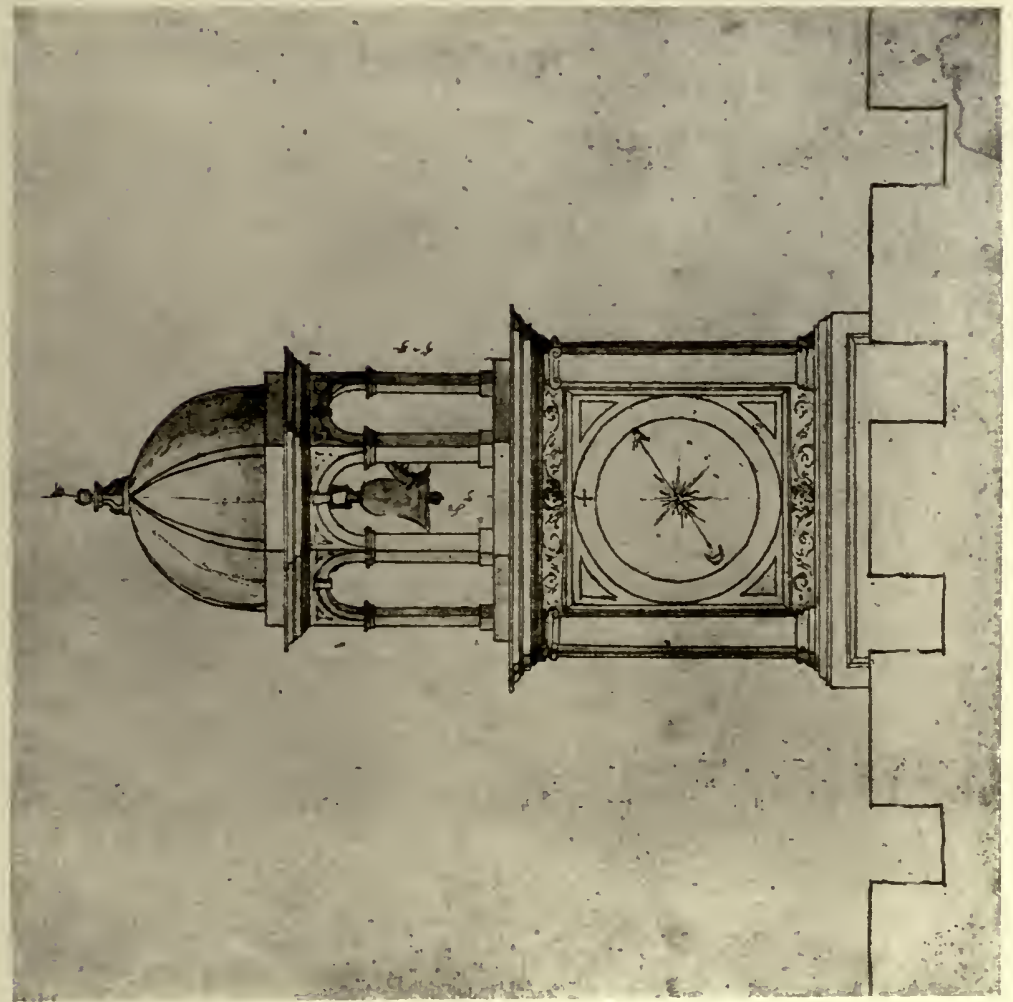

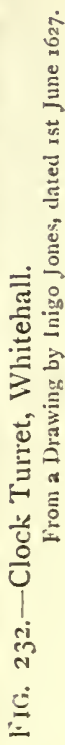




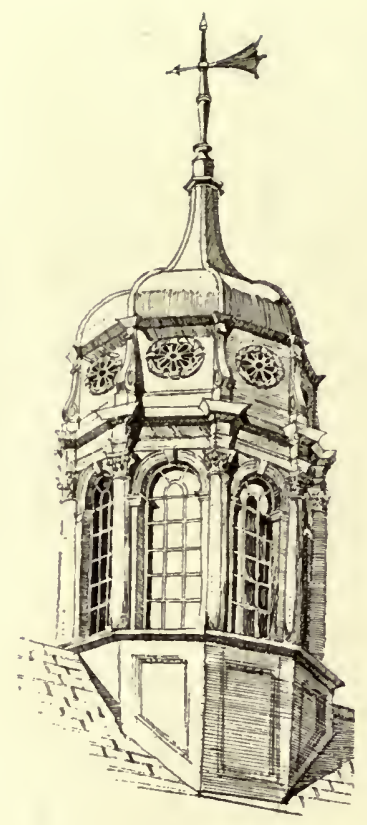

FIG. 234.-Cupola at Caius College, Cambridge.

(Fig. 23I), a building of great interest, possessing doorways of curious seventeenth-century detail; and another good specimen is at Trinity Hall, Cambridge (Fig. 233). The old hall was altered about the year 1742 , when it was described as "very gloomy and dark," and as being "roofed with old Oak Beams, very black \& dismal from $y^{\mathrm{e}}$ Charcoal $\mathrm{w}^{\mathrm{ch}}$ is burnt in $\mathrm{y}^{\mathrm{e}}$ middle of $y^{\mathrm{e}} \mathrm{Hall}$; and over it in $y^{\mathrm{e}}$ middle of $y^{\mathrm{e}}$ Roof was an old awkward kind of Cupulo to let out $y^{\text {e Smoak." } 1 ~ T h e ~ n e w ~ c u p u l a ~ w a s ~ c o n-~}$ sidered, presumably, more elegant and less awkward than the old one. The reference to the ancient method of warming the hall by a fire in the middle of the floor is interesting, as showing how long the old practice lingered in places where those in authority were averse to change. A further example is shown in Fig. 234.

While fancy still played a part in the work of local masons, the little date-stones shown in Fig. 235 were built into some unpretentious houses in the Midlands; but a hundred years later the diligent pursuit of correctitude had banished such touches from the work of architects, and masons had lost the feeling which gave rise to them. They are, however, quite suggestive, and provide ideas for the perpetuation of the owner's name and the date of his work-facts which are of interest in respect of all buildings. The cxample from Amersham is rather more ambitious, but hardly more successful (Fig. 236).

Another feature of interest to be found on many an eighteenthcentury house is the sundial. A specimen from High IVycombe is shown in Fig. 237, but almost every market town, and not a few villages, can produce examples as good. Sometimes an appropriate sentiment or an apt quotation was inscribed on the dial, but the number of cases where this occurs is not quite so

1 From a description by Cole, quoted in Willis and Clark's "Architectural History of the University of Cambridge." 
great as the literature on the subject would lead one to suppose. In those days, when no cheap watches were to be had, when indeed a watch was handed down from one generation to another as a valuable possession, sundials were of real use, even though they told none but sunny hours. "The Art of Dialling "was a recognised branch of polite learning, and an intricate subject it was; dealing not only with horizontal and vertical dials, but with those which faced in some other direction than due south. Dial stones may sometimes be seen with one side brought slightly forward, so that the face is not quite parallel with the wall in which it is set. This is an expedient to make the face look due south, in order to simplify the setting out of the lines. Needless to say that when the sun was relied on to tell the hour of the day, the introduction of "Summer time" would have been impossible; for the power to set back the shadow on the dial, as it was set back on that of Ahaz, has never been given to man.

From the earliest days it had been customary to give importance to the entrance of a house. When means of defence were a necessity, the access was through a portion of the main building, and so into a courtyard. The portal was flanked with turrets which at first were devised for its protection, but in later times were retained as handsome architectural features. Then came the period when defence was no longer necessary, and the forecourt was merely surrounded by a wall. Access to this 

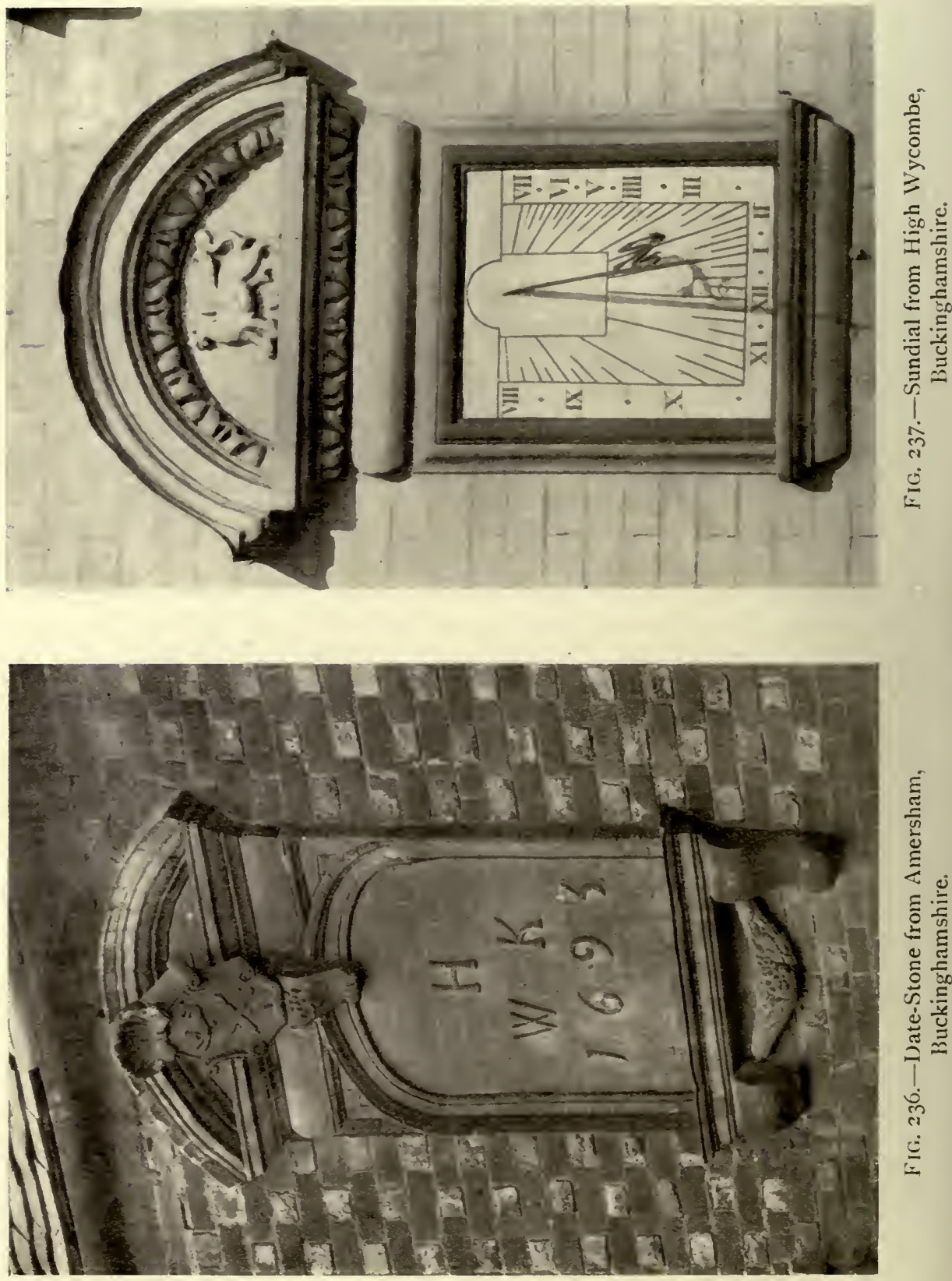

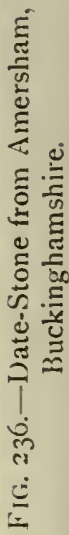




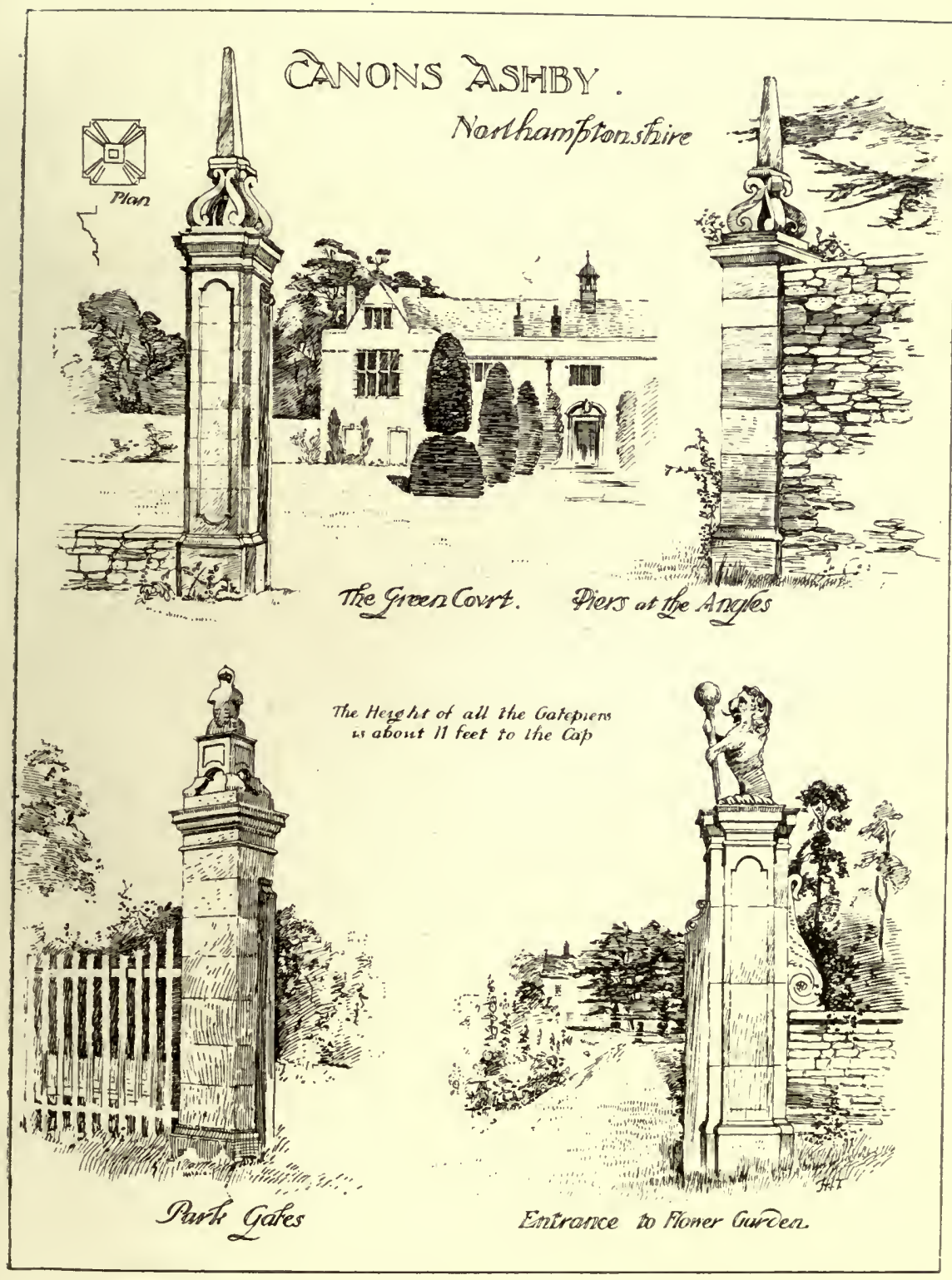

FIG. 238.-GATE-PIERS AT CANONS ASHBY, NORTHAMPTONSHIRE.

Drawn by H. Inigo Triggs. 
court was generally obtained through a gate-house, and Elizabethan and Jacobean houses have innumerable examples of these charming buildings. In the smaller houses an archway replaced the gate-house, and in course of time the archway gave place to gate-piers. But through all the changes, the desire to give emphasis to the entrance remained, and every house with architectural pretensions had gate-piers more or less handsome. At Canons Ashby, in Northamptonshire, there are several good types (Fig. 238); those between the green court and the park

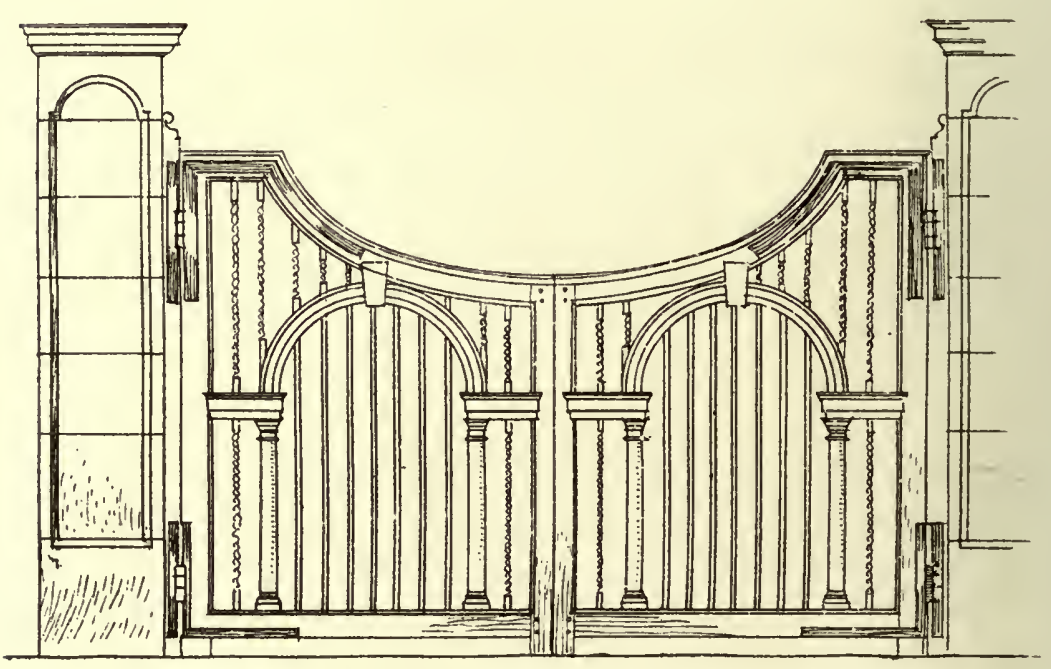

FIG. 239.-Wooden Gates, Canons Ashby.

have a Jacobean flavour about them, while those at the bottom of the garden are surmounted by the family crest in the shape of a demi-lion holding a sphere. The gates which formerly hung between these piers (Fig. 239) are probably the earliest example of garden gates in wood which survive, but they are so unconstructional in design that they threatened to fall to pieces, and were replaced by something plainer, but more convenient. Among the drawings by Jones and Webb are many of gateways, some rich in appearance, and some quite plain. The finest which remains is the well-known York water-gate at the foot of Buckingham Street (Fig. 35). There are some careful 


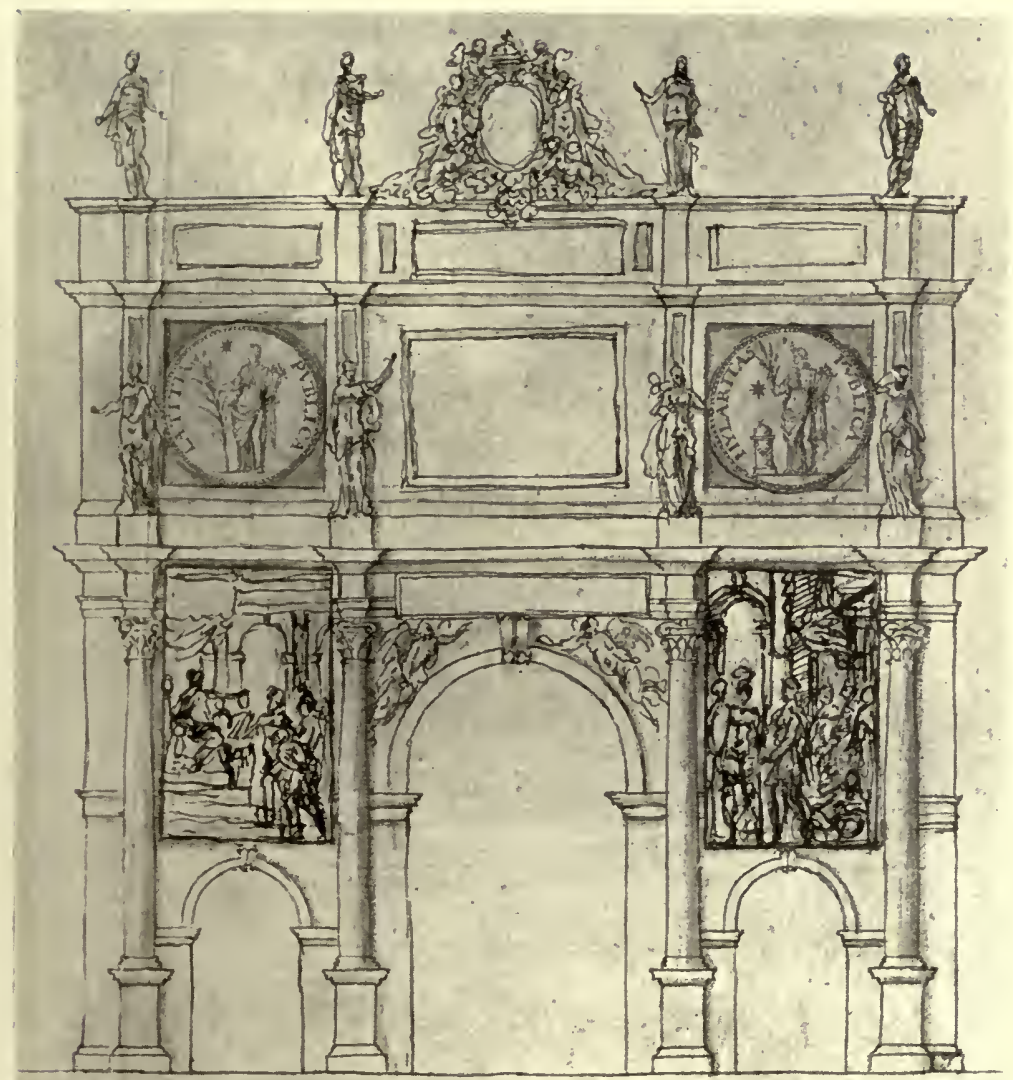

FIG. 240.-Design for Temple Bar, London, by Inigo Jones, I6 36 .

From the Burlington-Devonshire Collection at the R.1.B.A.

drawings of this by Webb in the Burlington-Deronshire collection at the Royal Institute of British Architects. In the same collection is a design for Temple Bar by Jones (Fig. 240), never carried out; a drawing of the constructional brickwork for the same, signed by him and dated ${ }_{16} 68$; and a drawing by Webb dated 1636. The two large circular panels represent "Lætitia Publica" and "Hylaritas Publica." If this design had been carried out, there would have been a grim irony in the custom of exhibiting rebels' heads just above roundels of such cheerful 


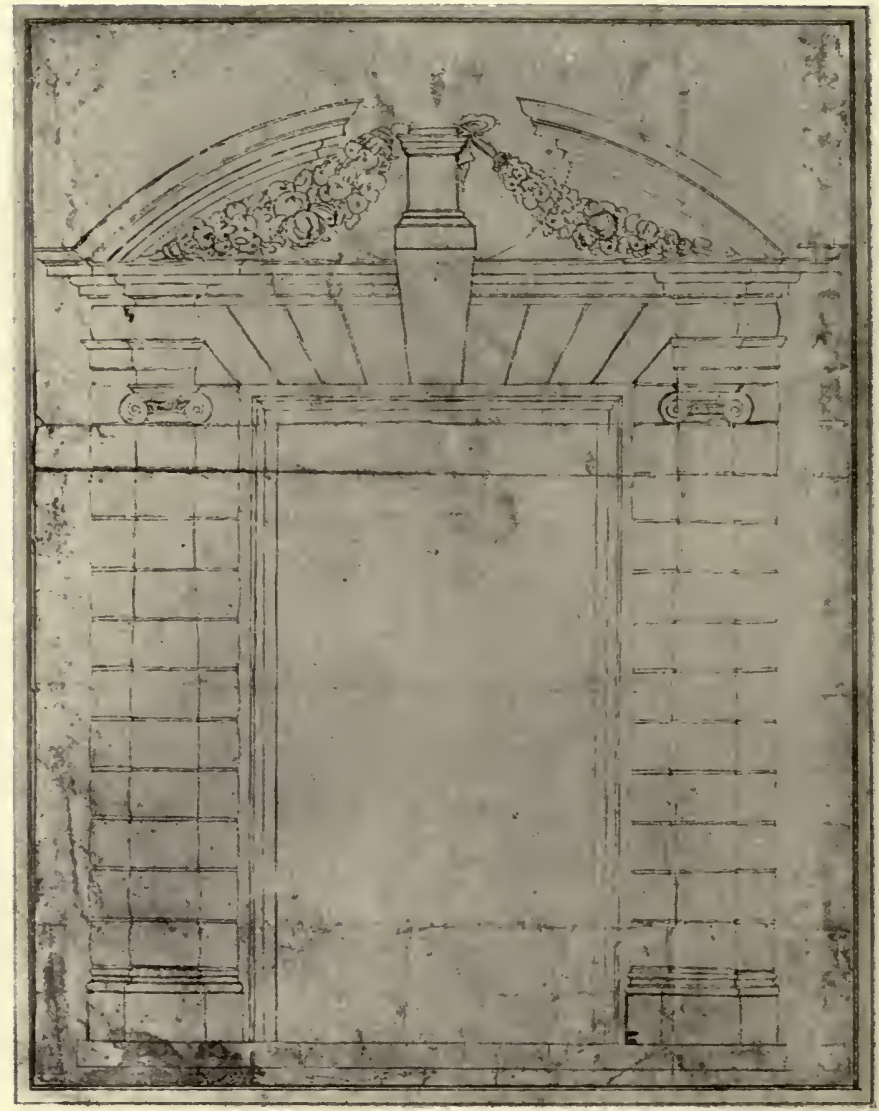

FIG. 241.-Drawing of Gateway by Inigo Jones.

intention. Among the numerous designs for gateways is the original by Jones of the little doorway which was once at Beaufort House, Chelsea, but is now at Chiswick, and an unnamed example illustrated in Fig. 24I. By the same master, in all probability, are the splendid piers at Coleshill, in Berkshire (Fig. 242). Next in order of date are the gate-piers at Thorpe Hall, in Northamptonshire, by John WVebb, shown in Fig. 50, and shortly after them is the fine series at Hamstead Marshall, of which some have already been illustrated in Figs. I IO, I II. These bring us down to the time of Wren, and at 


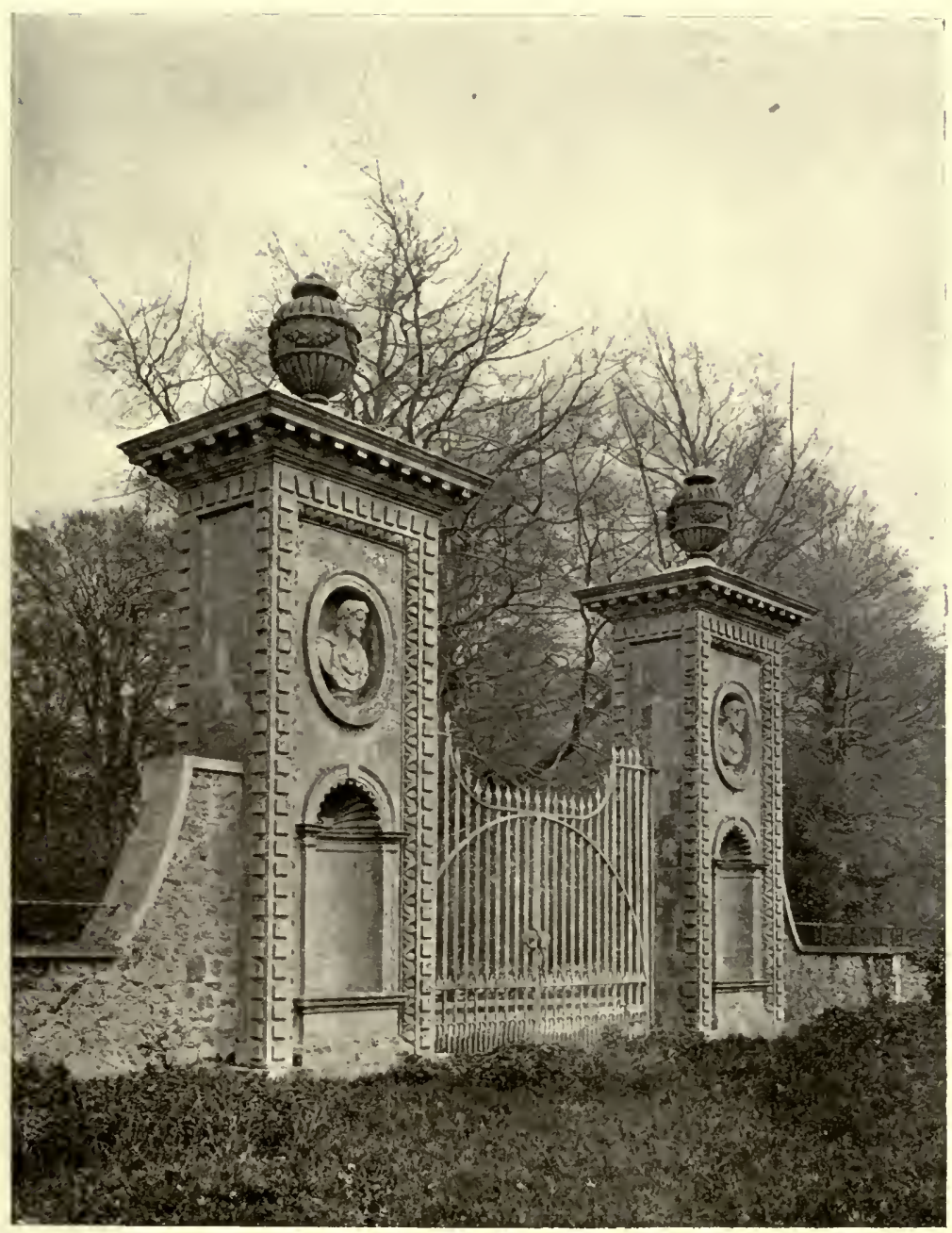

F1G. 242.-Gate-Piers at Coleshill, Berkshire.

Hampton Court is the lordly pier shown in Fig. 244. At St John's College, Cambridge, the piers shown in Fig. 243 form part of the bridge built between 1696 and I712. They perpetuate to some extent the feeling of Tudor work in the rose, the portcullis, and the heraldic animals on their summits. All the large houses of the early eighteenth century, and many of 


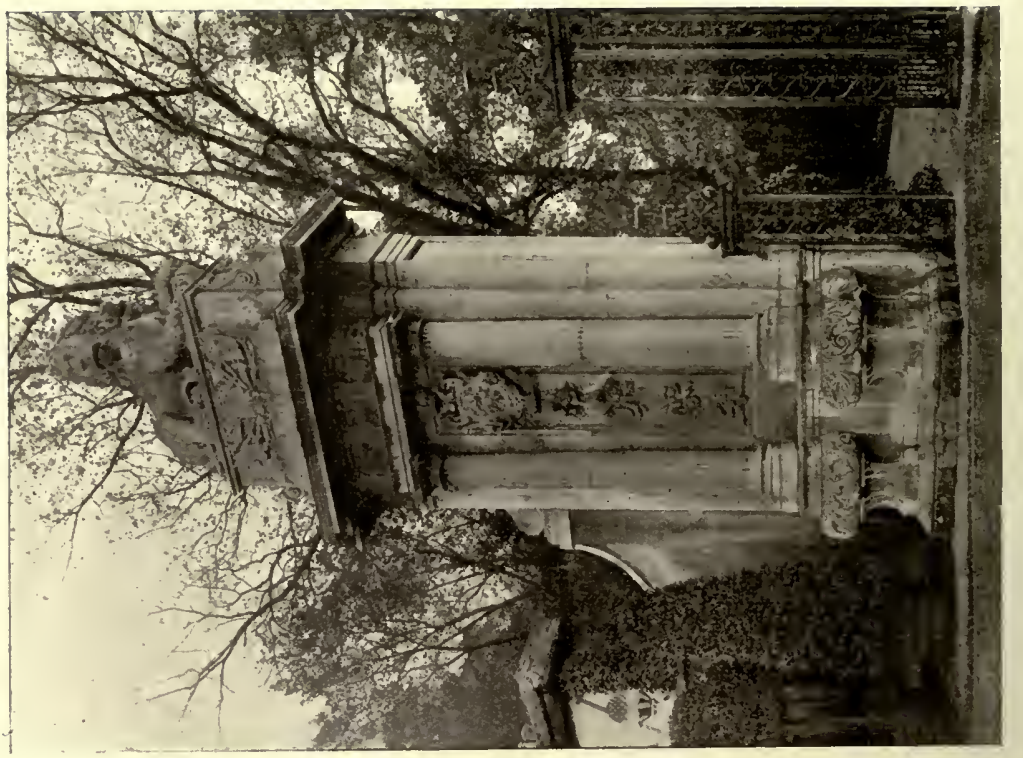

Uं

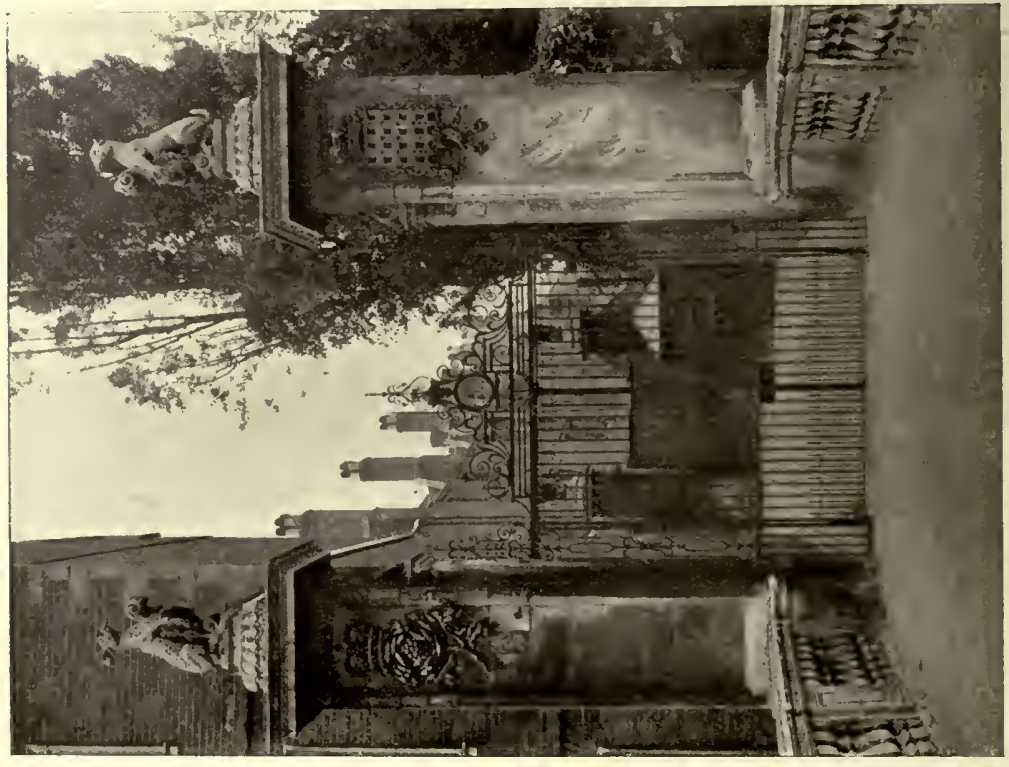

ט 


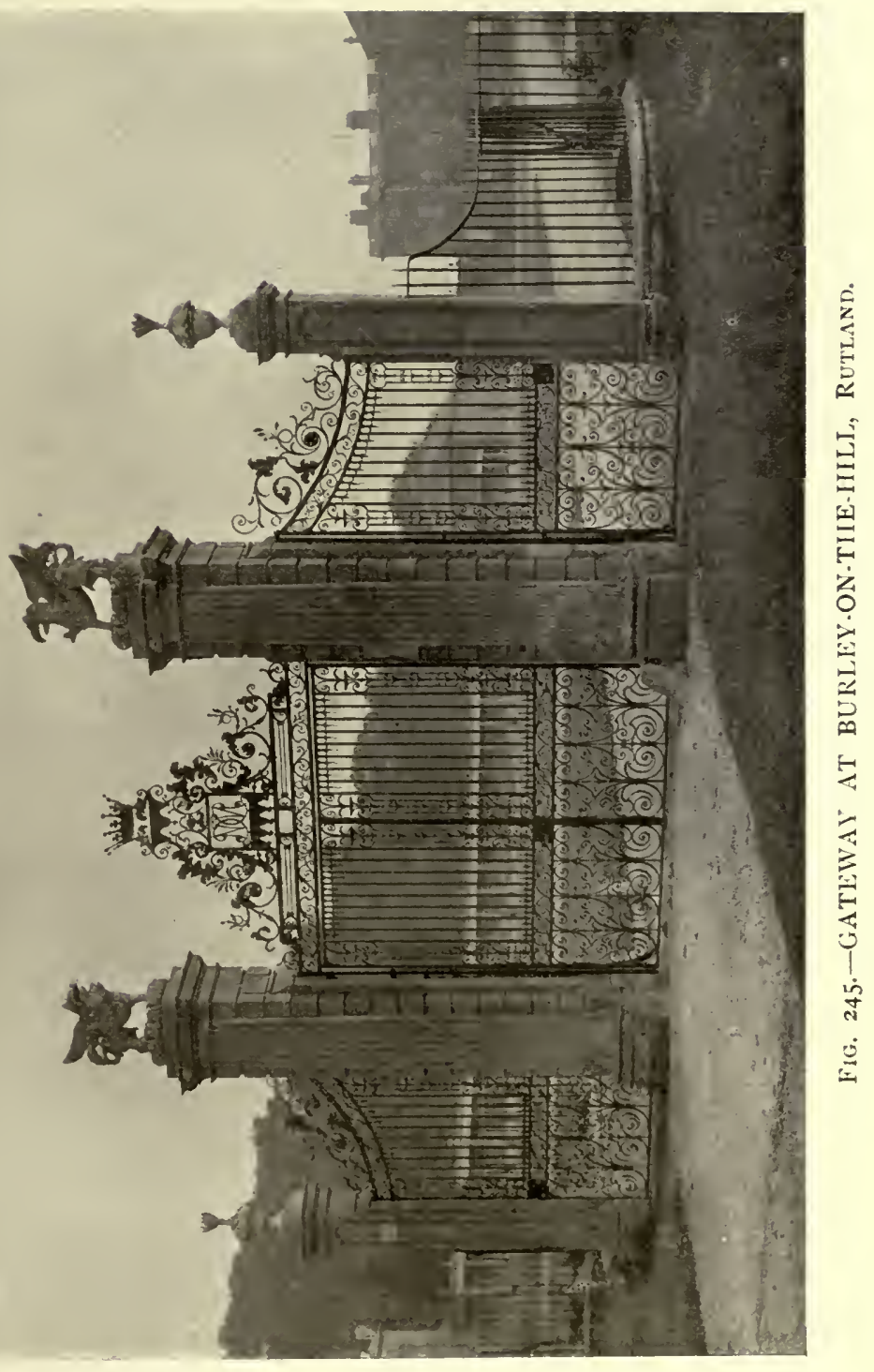




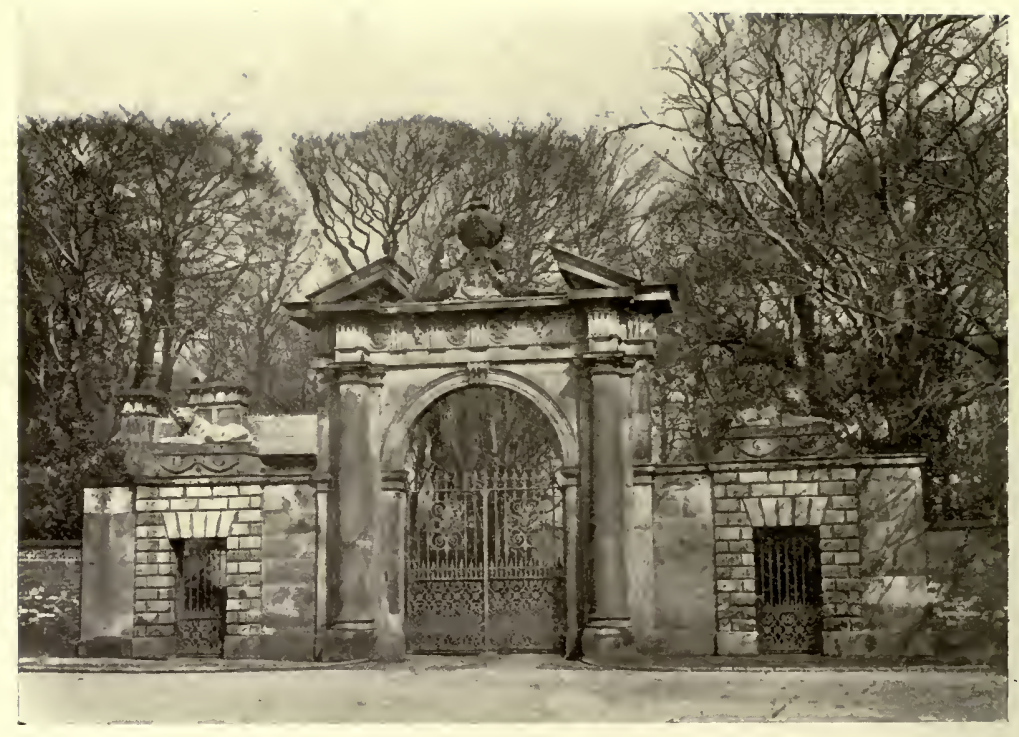

FIG. 246.-Lion Lodge, Ince Blundell, Lancashire.

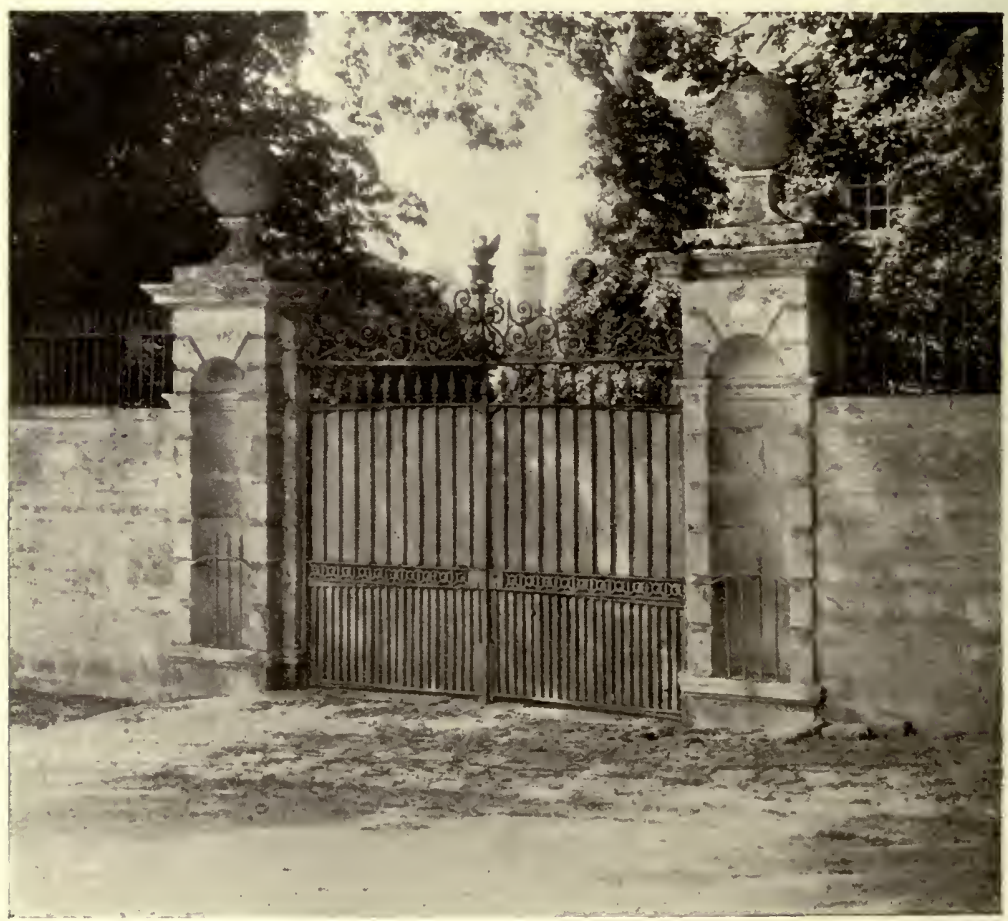

FIG. 247.-Gateway at Castor, Northamptonshire. 
the small ones, had noteworthy gates and gate-piers. There are hundreds of examples up and down the country, and that at Burley-on-the-Hill, near Oakham (Fig. 245), is typical of the larger kind. This treatment, with lofty stone piers and iron gates of more or less elaborate design, is more frequent than that adopted at Ince Blundell Hall, in Lancashire, where an archway forms the main entrance, and is flanked on each side by a length of wall containing gates for foot traffic (Fig. 246). Many smaller examples might be cited, but their general effect can

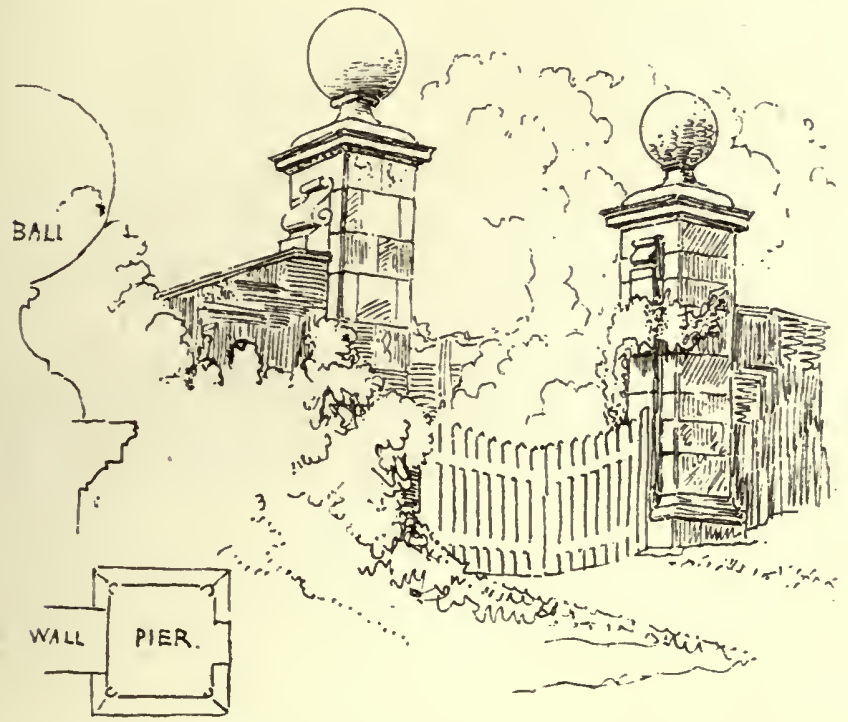

FIG. 248.-Gate-Piers at Rundhurst, Sussex.

J. A. Gotch, del.

be gathered from the three illustrations in Figs. 247, 249, and 250 , one of which is at a house at Castor, in Northamptonshire, another at a little house in Barrow Gurney, Somersetshire, and the third at one of the delightful houses in the Close at Salisbury. They are all quite unpretentious, but they impart a pleasant amount of interest and a certain degree of dignity to the houses which they serve. Another simple example is taken from a derelict house at Rundhurst, in Sussex (Fig. 248), and at Uffington, in Lincolnshire, is the more important example in Fig. $25 \mathrm{I}$, one of a pair of stone 


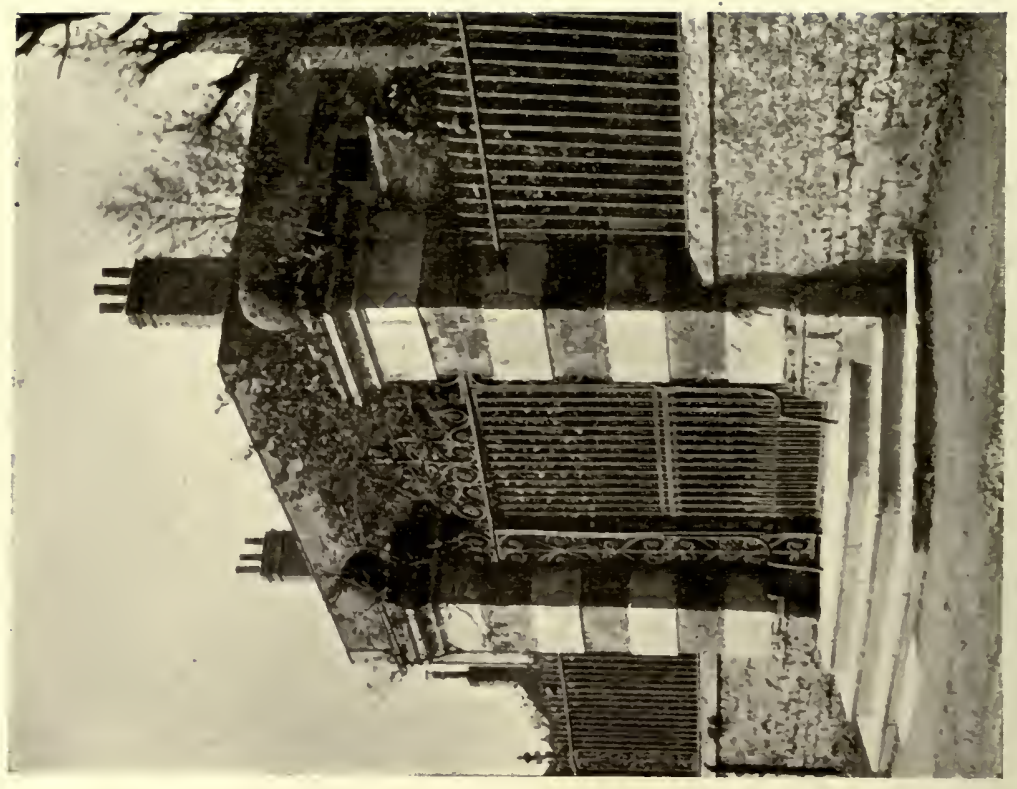

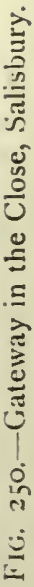

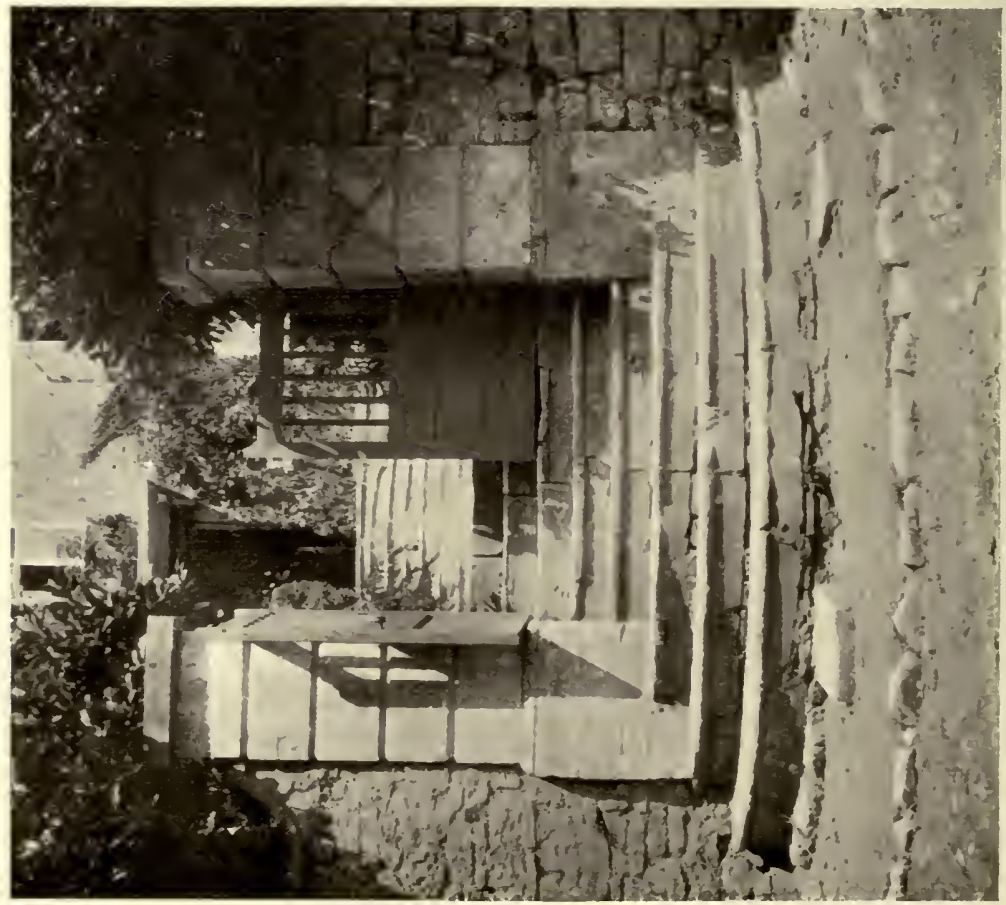

ปే 
piers which support some good iron gates, through which, standing on the village road, a glimpse of the hall gardens can be obtained.

The tendency being, as already pointed out, towards a plain treatment of the exterior, largely owing to the substitution of sash-ivindows for mullioned, some amount of relief was imparted by a rich treatment of the principal door, but there came a time

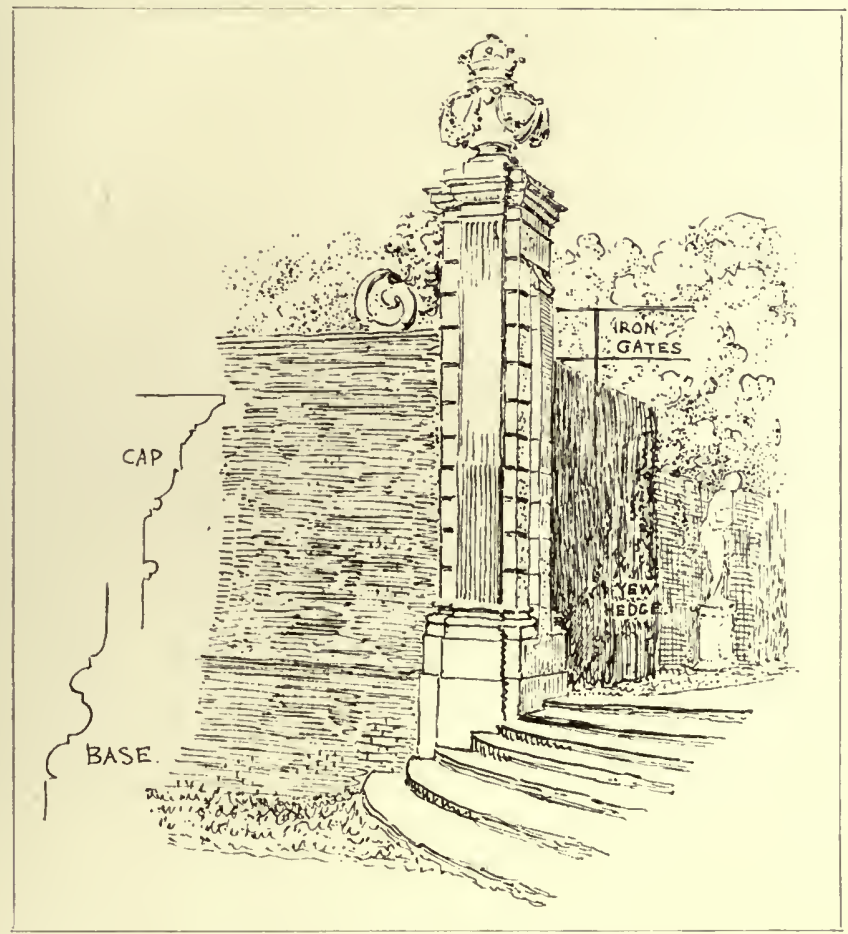

F1G. 25I.-Gate-Pier at Uffington, near Stamford.

J. A. Gotch, del.

when even this modicum of decoration was abandoned, and the exterior of a house was dealt with on purely utilitarian principles, the necessary openings being provided, but devoid of any attempt at ornament. But before this last stage of imaginative poverty, or inertia maybe, was reached, doorways were provided which gave a touch of fancy to an otherwise bald front. The form of circular hood, supported by carved brackets and filled with a fluted cove, usually described as a shell, is a common 


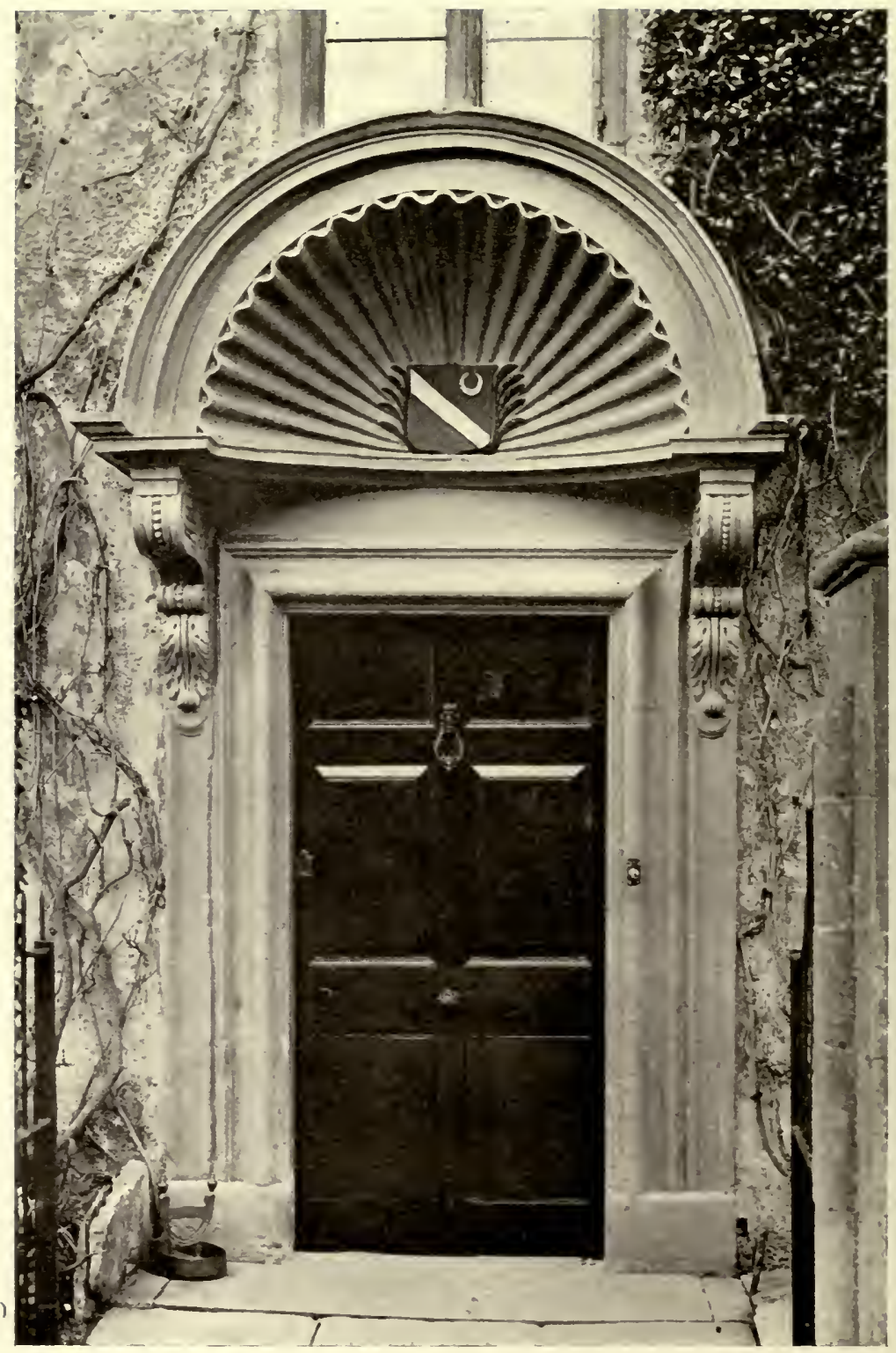

Frg. 252.-DOORWAY AT CASTLE COMBE, Wiltshire. 
feature of the work of the end of the seventeenth century and twenty years later. An example from Castle Combe, in Wiltshire, is shown in Fig. 252. The centre from which the flutings radiate is here occupied by a small shield of arms. There is a rather plainer rendering of the same idea at Oundle, in Northamptonshire (Fig. 253). Another rich form of hood, with straight outlines, may still be found in out-of-the-way streets and lanes in London, where the necessity for radical changes has not yet arisen. A simple form of this idea is shown in Fig. 257, where one hood covers two contiguous doorways. A treatment very commonly adopted was that shown in the example from York (Fig. 255), where the circular-headed doorway is covered with a pediment supported by pilasters; the semicircular space over the door is filled with a fanlight divided by thick bars. In this case the bars are simple in form, but they were often curved into curious patterns, surprising in their variety, and suggesting that the designers of the time had no lack of ingenuity had circumstances allowed them to display it. The extinguisher to the left

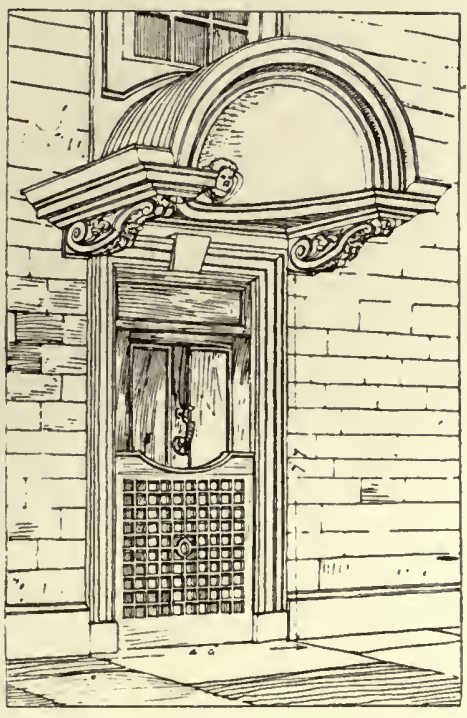

FIG. 253.-Doorway at Oundle, Northamptonshire. of the doorway should be noted. It is a reminder of the times when there was no public lighting of the streets, when indeed the casual illumination from shops and from houses, private and public, was of the feeblest, and citizens had to find their way home through thoroughfares where no scavenger was employed, by the light of torches, which they extinguished as they entered their houses. ${ }^{1}$

Of the same type as the last is the doorway at No. 33 Mark

1 London in the eighteenth century was even darker than it has been since the lighting has been minimised as a protection against air-raids. 


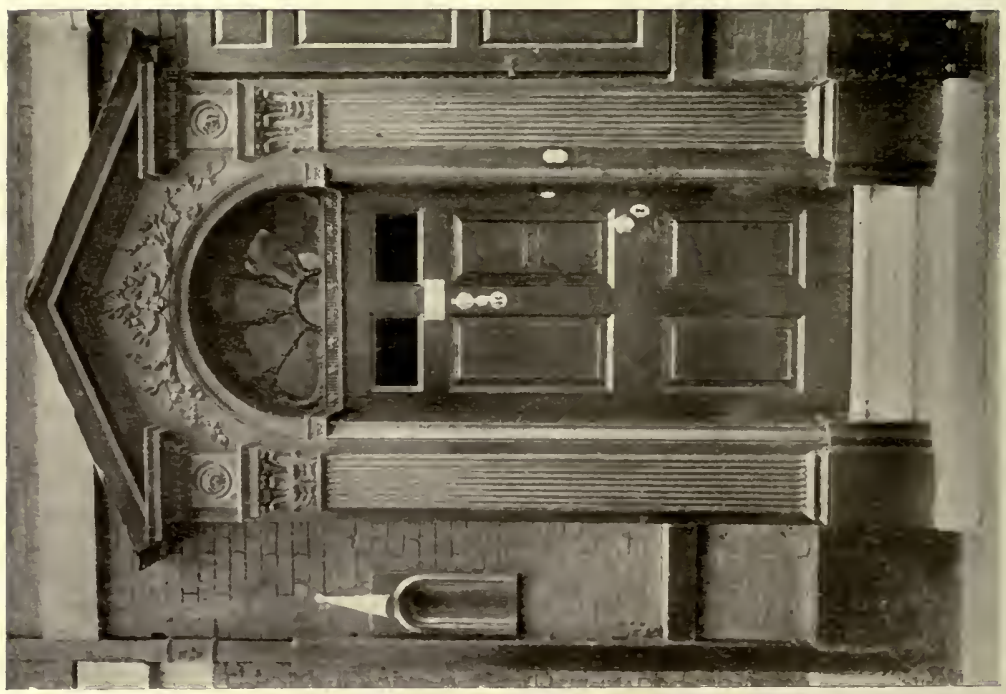

๕

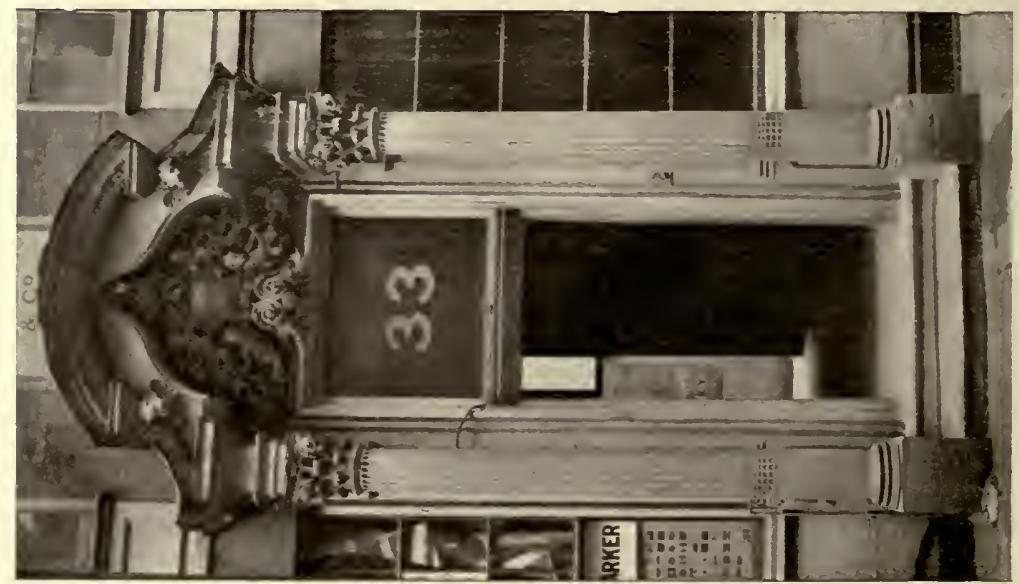

है 

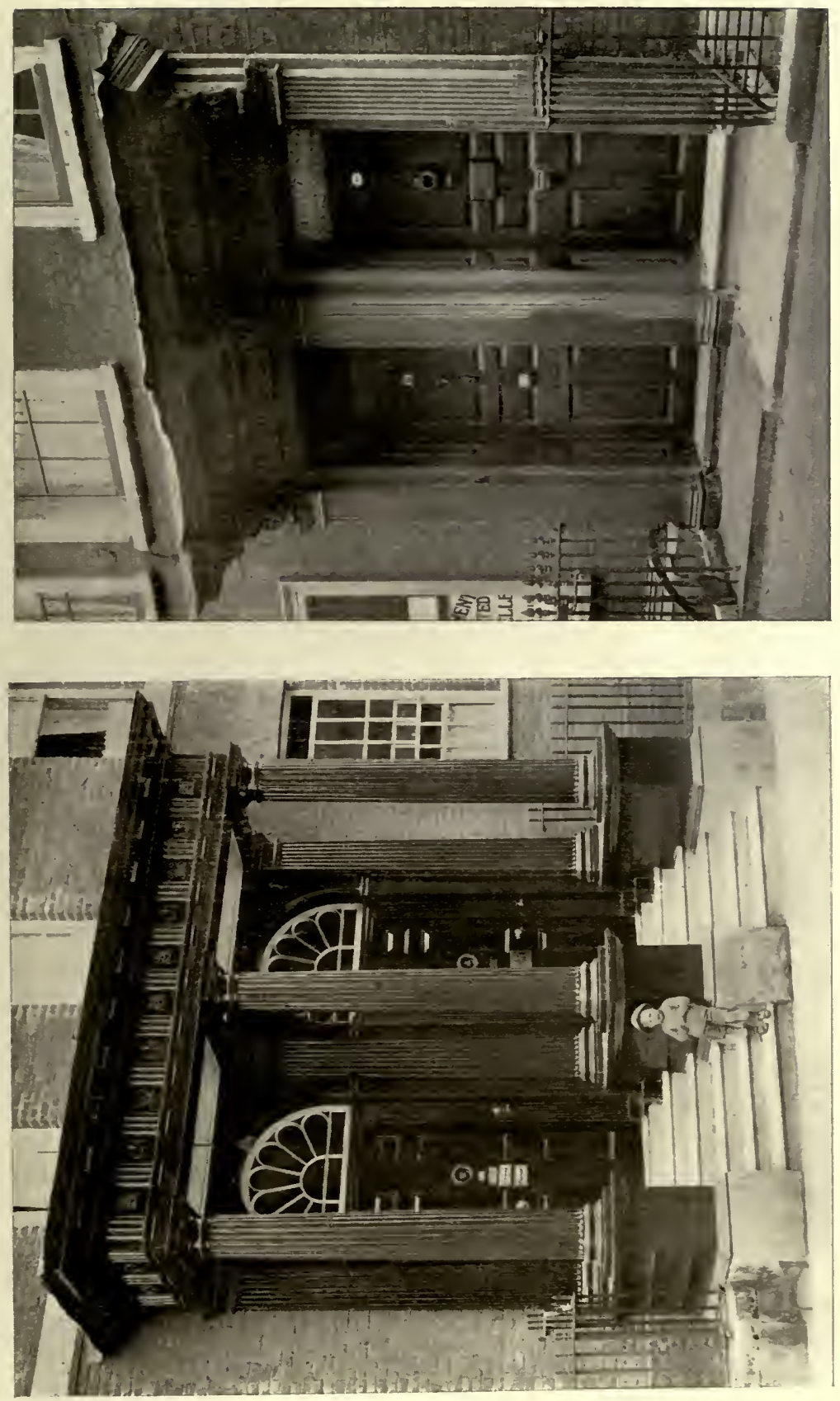

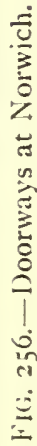



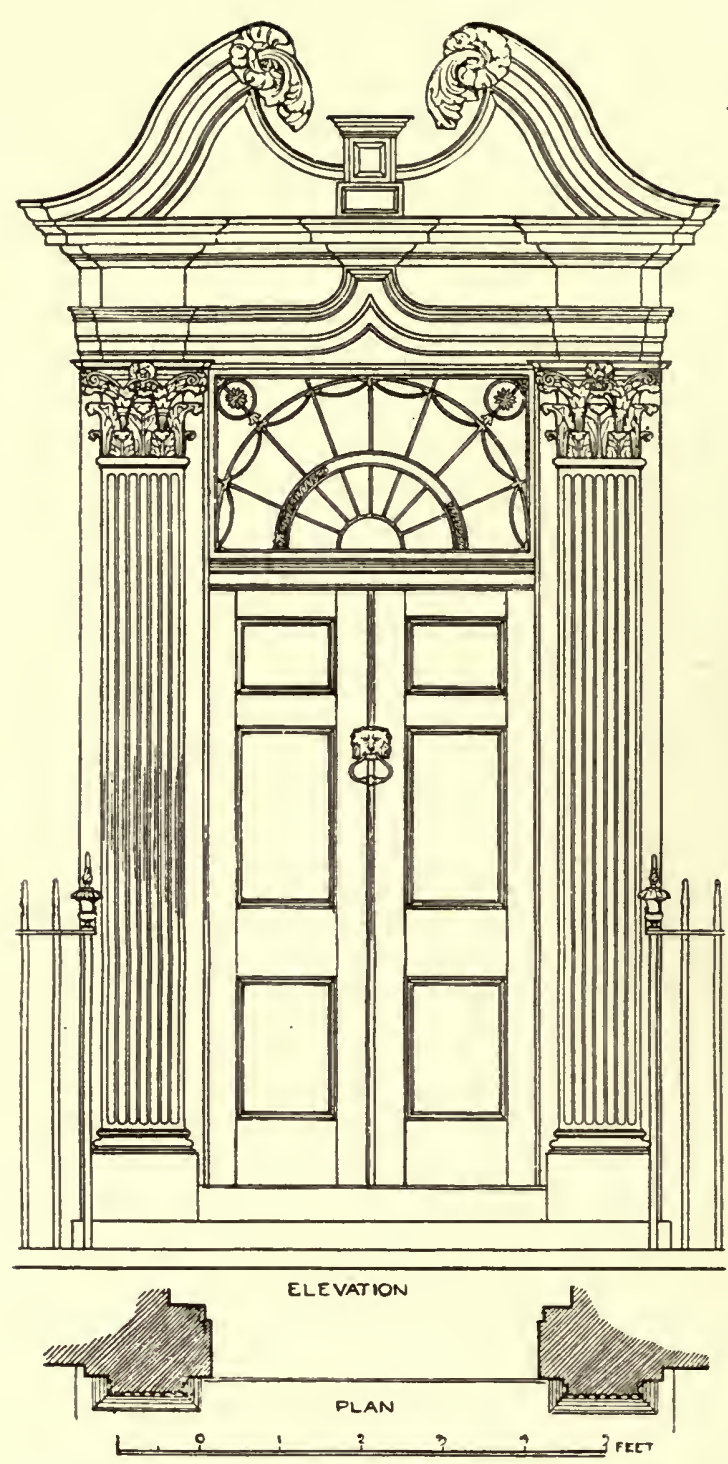

FIG. 258.-Door, 22 Buckingham Street, Strand.

Lane, London (Fig. 254), but it is far more elaborate, and served as the entrance to one of the fine private houses which lined Mark Lane, but which now are utilised as offices, if by chance they have escaped the wholesale demolition and rebuilding which expanding commerce entails. Another good example is to be seen in Buckingham Street, Strand (Fig. 258). Of later date is the double porch at Norwich . (Fig. 256), which is simple and dignified, and will so remain as long as the two occupants are of the same mind as to the colour it should be painted. It will be noticed that in all these examples the doorway is the only feature of interest; the surrounding work is quite plain. At 


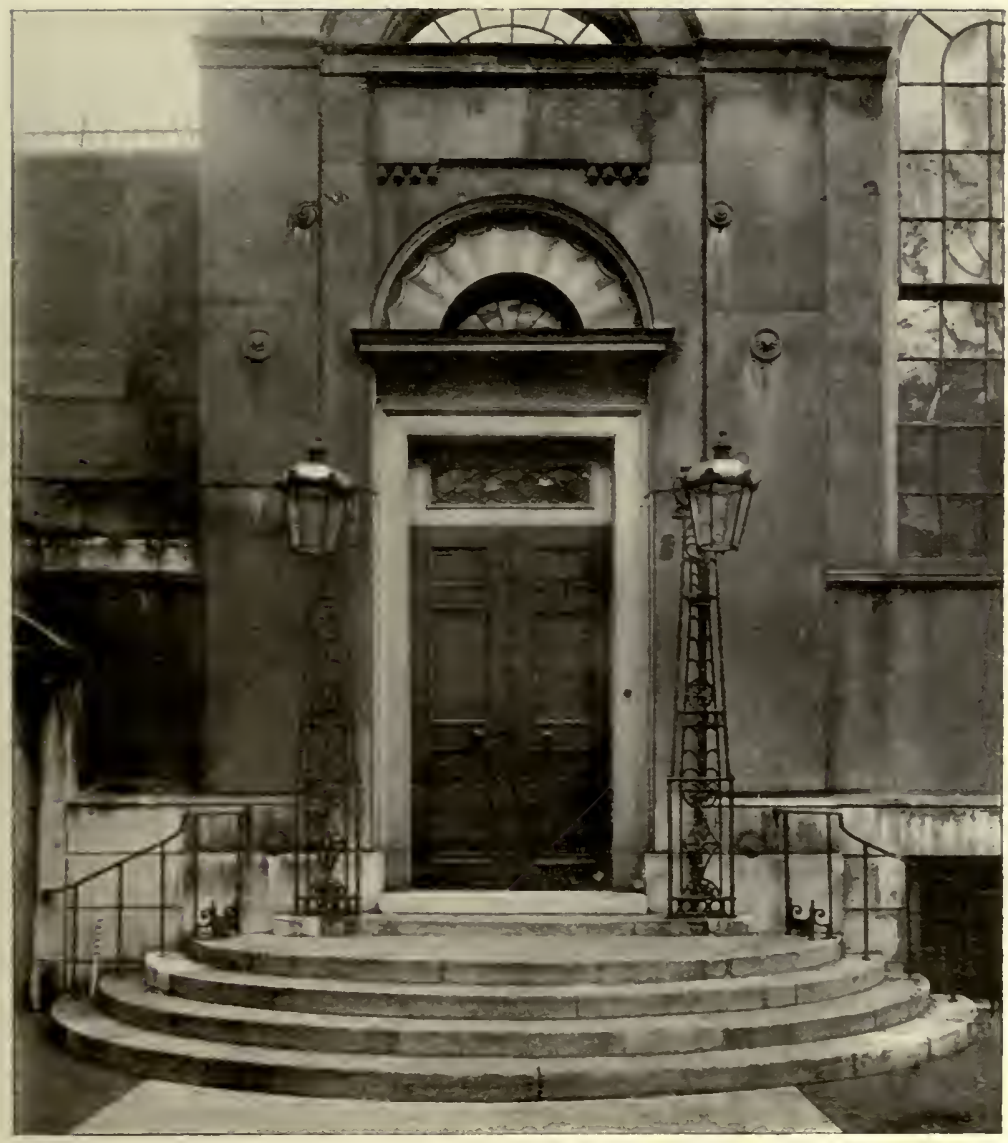

FIG. 259.-Doorway at Stationers' Hall, London.

the Stationers' Hall, in London (Fig. 259), we get a still later treatment, dating from the year I 800 , when Robert Mylne cased the building with stone. The iron standards were probably devised to carry lamps, which shed enough light to help incomers up the steps; but all things are relative, and doubtless, at the time, two oil lamps were considered a brilliant illumination.

Here and there in old towns are to be found twostoried porches projecting from the face of a house like that at Yarmouth (Fig. 260), which is the central feature of a front rather more elaborately treated than usual. In this case 


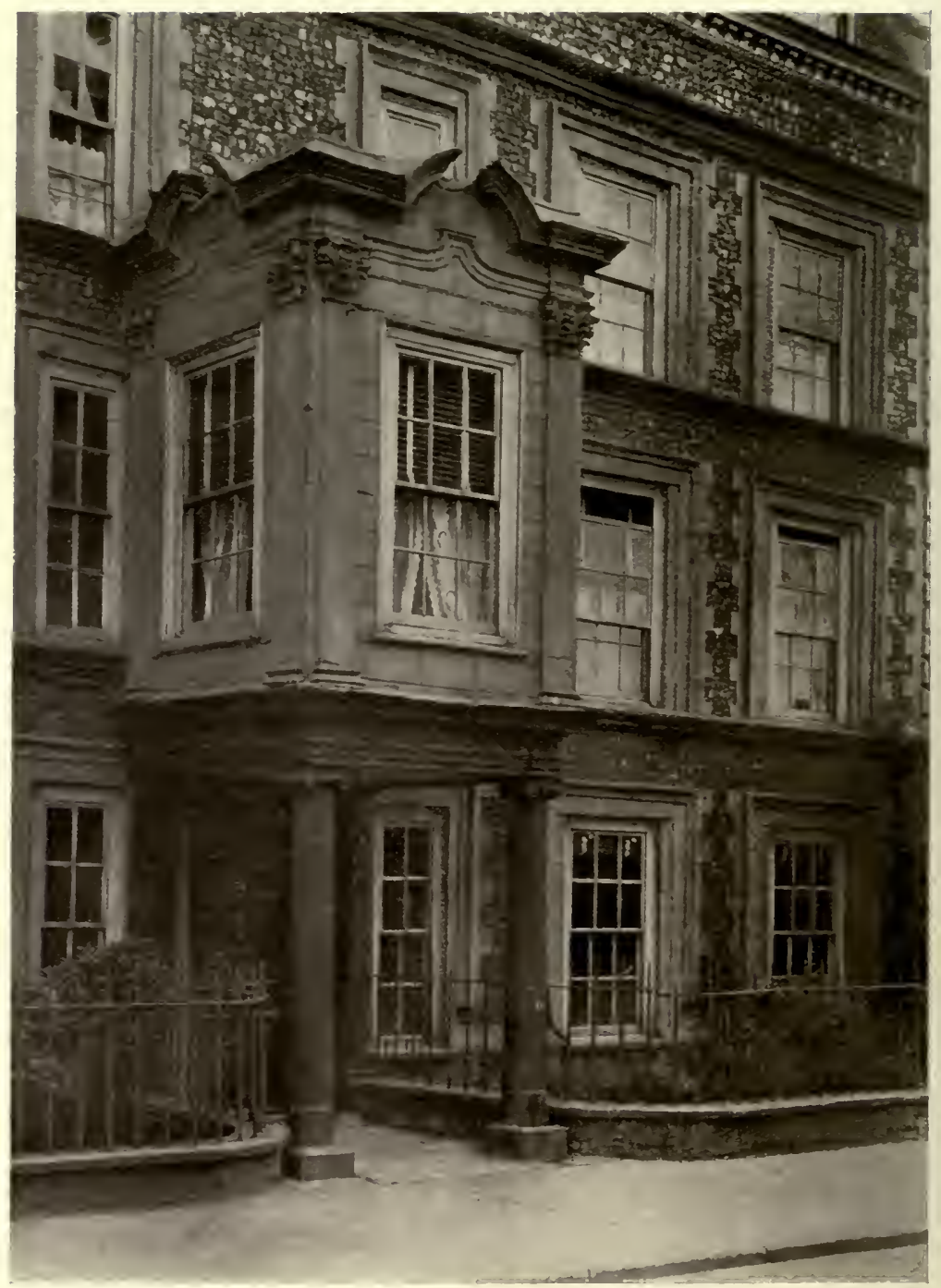

FIG, 260.--House at Yarmouth.

the porch stands on its own ground, but occasionally porches were built over part of the pavement, and the public traffic passed through them. It would be impossible for a private owner to take such liberty in the present day, when plans have to be submitted to the local council; but in those far-off 
times men of influence did many things which nobody was bold enough to stop; and while heartily agreeing that private interests must be subordinated to public, we may, perhaps, indulge. in feelings of secret gratification that among our ancestors individuality had more play than is possible in these well ordered times. Another picturesque but, strictly speaking, intolerable effort at design is to be seen at The Martins, Chipping Campden (Fig. 26I). The great truncated corner pilaster, the porch with its cornice running into the window, can be defended on no grounds save that there they are. But so imperfect is our nature that this bit of haphazard composition gives more pleasure than many a more correct attempt at design ; a pleasure allied, perhaps, to that cynical satisfaction we experience in watching shortcomings in our friends from which we ourselves are free.

The ironwork of the early eighteenth century is one of its most remarkable productions. In England ironwork design seems to have burst suddenly into full splendour, without any gradual preparation. There are no elaborate specimens to be found throughout the seventeenth century until its close, nor are there any drawings by Thorpe, Smithson, Jones, or Webb, which lead one to suppose that they treated ironwork in any but the simplest way. But with the advent in 1689 of Jean Tijou, a native of France, who was probably brought over from the Netherlands by Queen Mary, consort of William III., the whole aspect was changed, and a school of clever blacksmiths grew up who filled the country, and more especially London and its suburbs, with beautiful bits of design in gates, fences, sign-boards, mace-holders in churches, balustrades of staircases, screens, and other objects where iron could be employed. Their work is marked by great judgment in varying the sizes of the iron bars and scrolls, by the variety and elaboration of the design, and by the judicious introduction of thin sheet iron, hammered and modelled into foliage or some heraldic device. The craftsmen seem to have known exactly how to handle their material so as to combine strength with lightness, vigour with delicacy, the open effect of scroll-work with the solid effect of foliage. The due mixture of the curved line with the straight, the growth of one from the other, the repetition of straight lines in suitable positions, all seem to have come to them by intuition which seldom erred. Of the immense amount of work 
which still survives, the proportion of weak, unmeaning, or illadapted design is infinitesimal. Something, no doubt, they owed to France, but they worked largely on their own lines, and established a school of design which is essentially English.

Tijou worked for Queen Mary at Hampton Court, where he

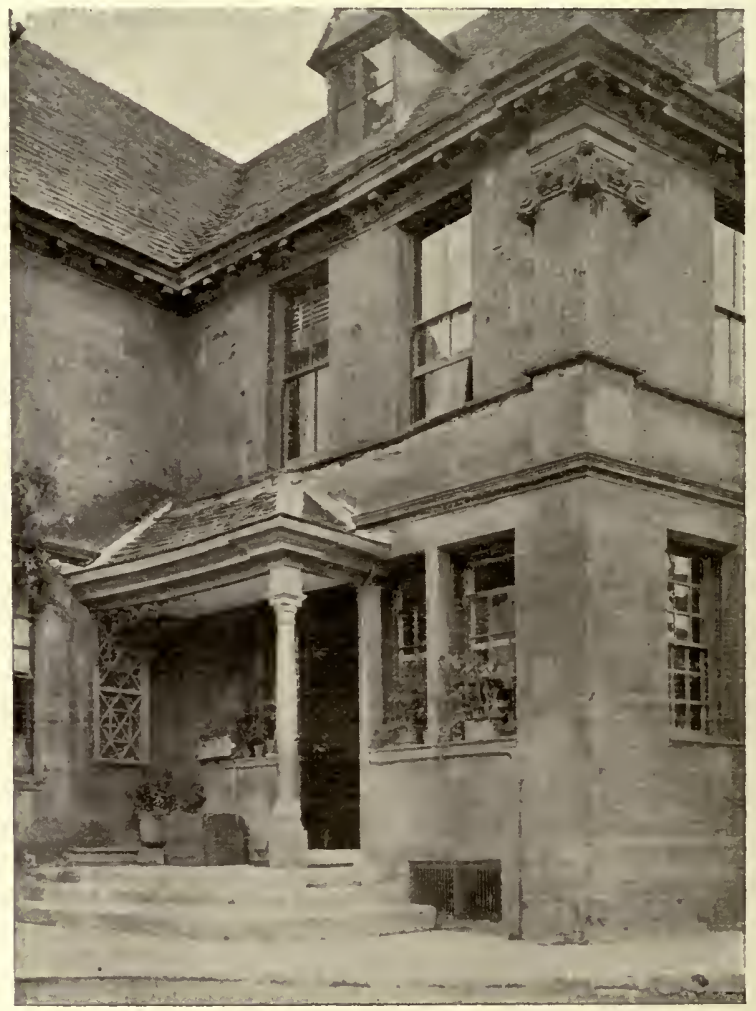

F1G. 261.-The Martins, Chipping Campden, 1714.

placed some of the richest screens and gates which the country can boast. A portion of his work is illustrated in Fig. 262. $\mathrm{He}$ also executed some splendid ironwork at Chatsworth, Burghley, and St Paul's, London. The balustrade to the king's staircase at Hampton Court (Fig. 264) may also in all probability be assigned to him. He must have had assistants, among whom Huntingdon Shaw, of Nottingham, has been reckoned the chief, and indeed the actual work on the screens at Hampton Court 


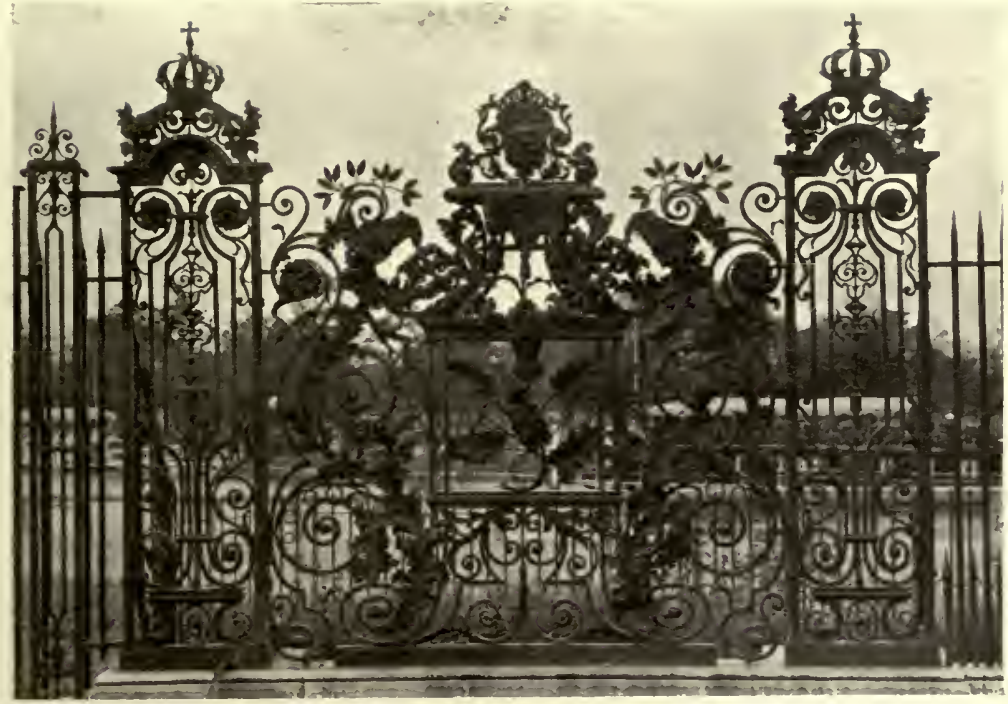

FIG. 262.-Part of Iron Screen, Hampton Court Palace.

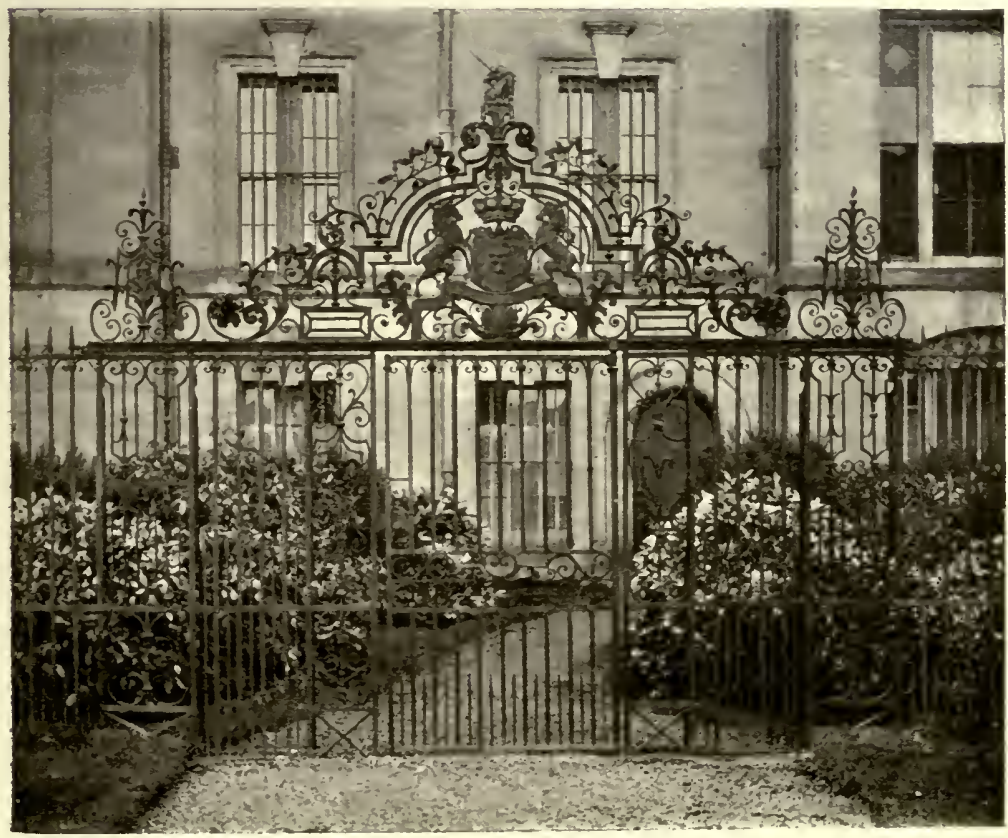

FIG. 263.-Iron Gateway, Stoneleigh Abbey, Warwickshire. 


\section{THE WROUGHT IRONWORK OF TIJOU}

has been claimed as his; but recent investigations show conclusively that the claim cannot be sustained. ${ }^{1}$ Another of Tijou's assistants was Robert Bakewell, who settled in Derby and was widely employed in the Midlands. To him, perhaps, we owe the gates at Stoneleigh Abbey, illustrated in Fig. 263, although tradition says that these were brought here from Watergate, a dismantled mansion beyond Southam. ${ }^{2}$ The ironwork in and round London may be largely attributed to

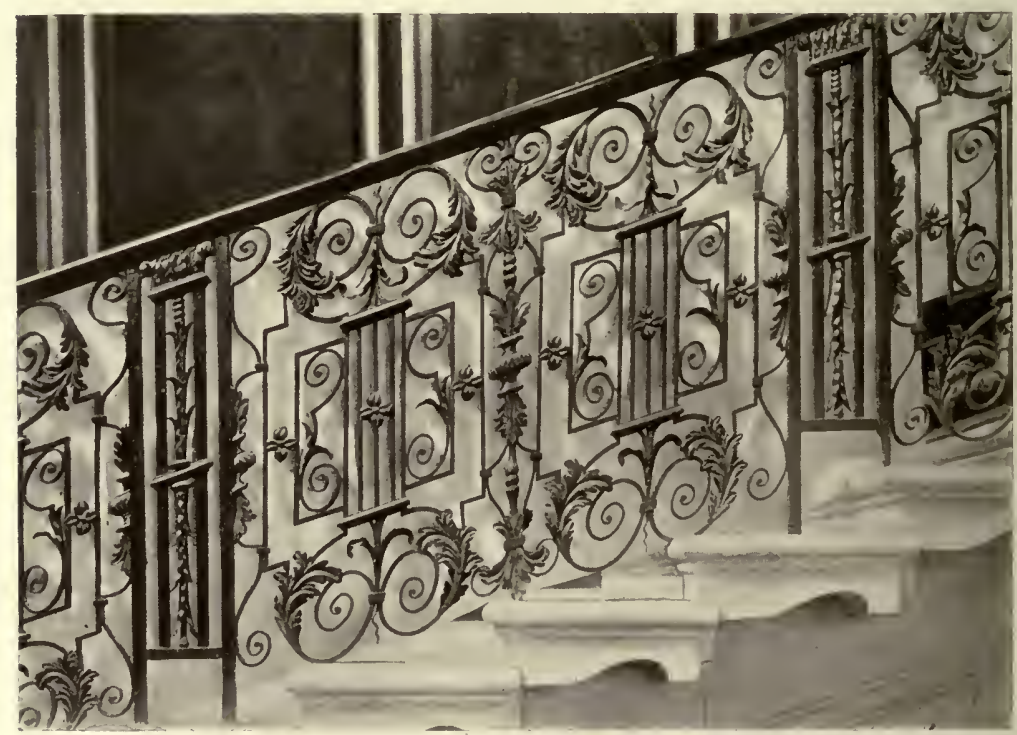

FIG. 264.-Balustrade to the King's Staircase, Hampton Court.

Thomas Robinson and his successors, and it would appear that skilful smiths settled in different centres in England, round which they influenced the work over a wide area. Bristol was the home of such a man, William Edney by name, and that he was an accomplished craftsman is proved by the magnificent gates at St Mary Redcliffe (Fig. 265), which date from I 710.

1 See two articles on Huntingdon Shaw by R. Garraway Rice, F.S.A., in the Archaological Journal, June 1895, and the Home Counties Magazine, January 1902, vol. iv., No. I3.

${ }^{2}$ See "English Ironwork of the XVIIth and XVIIIth Centuries," by J. Starkie (iardner. (Batsford.) 


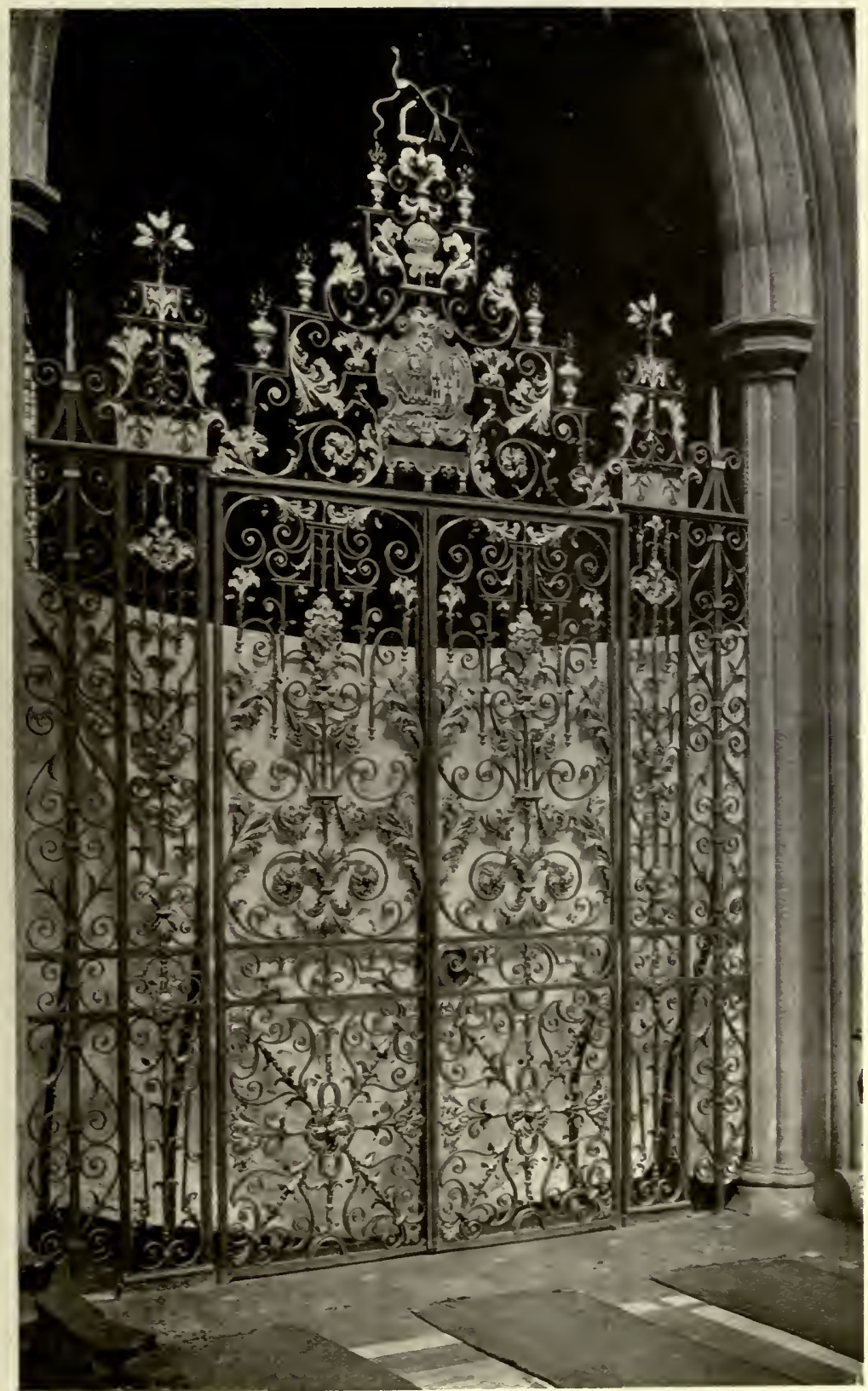

FIG. 265.-IRON GATES AT ST MARY REDCLIFFE, BRISTOL. 
344 WROUGHT-IRON GATES AND PIERS

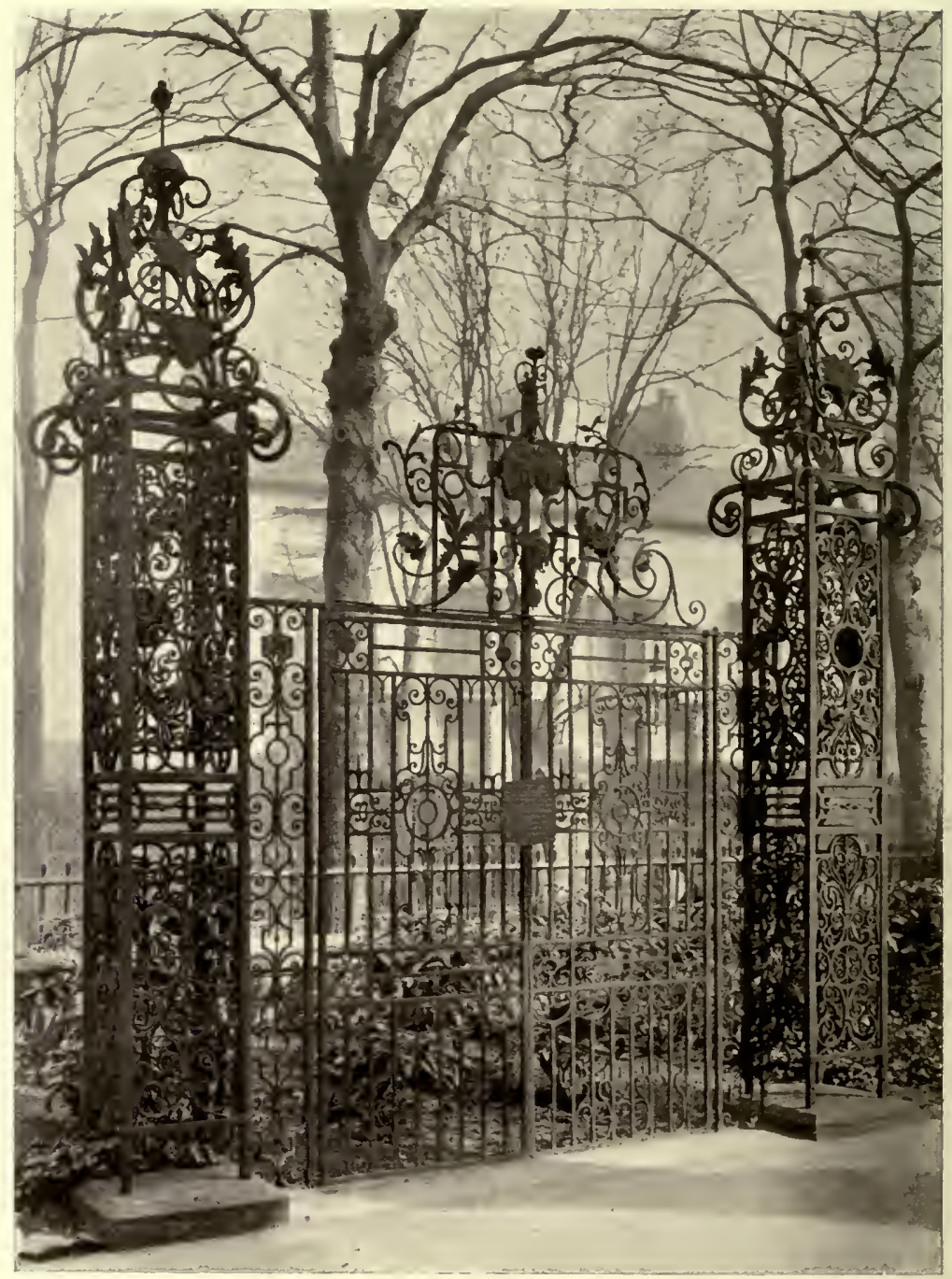

FIG. 266.-Gateway formerly at Quenby Hall, Leicestershire.

Museum, Leicester.

Examples without number could be produced of English ironwork of this period, but space forbids any but a few specimens being cited. There was a splendid gateway at Quenby Hall, Leicestershire, with elaborate iron piers, now in 


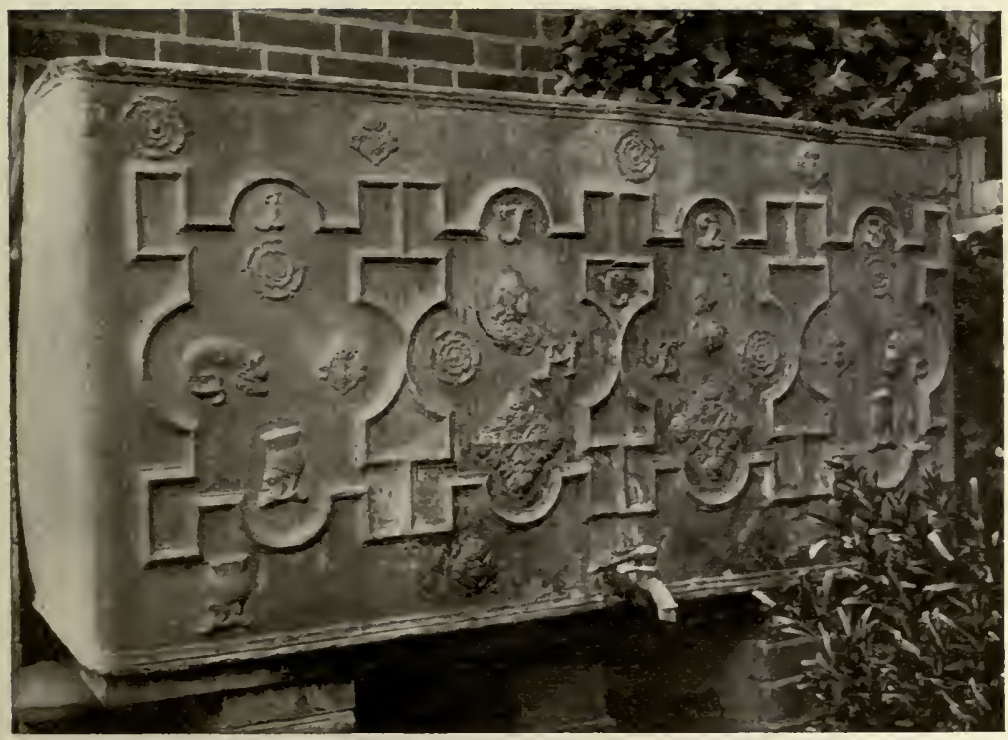

F1G. 267.- Lead Cistern in the possession of Mr L. A. Shuffrey.

front of the museum at Leicester (Fig. 266). ${ }^{1}$ The four examples shown in Figs. 268-27 I are of far simpler design, but they are worth careful study, and are typical of the ordinary work of the time. In the gate from Acton the solid work is aptly introduced and gives it richness and importance; the others exhibit a judicious combination of simplicity and richness which is quite admirable. Indeed the ironwork of the early part of the eighteenth century has never been bettered either in design or execution.

Ornamental leadwork was a characteristic feature of English houses as early as the time of Elizabeth, and many beautiful rain-water heads of that period still survive. They had worthy successors all through the seventeenth century and well into the eighteenth. Some of the rain-water heads at St John's College, Oxford, of the time of Charles I., are splendid things of their kind. Many houses built during the next hundred years retain fine examples of similar features (Fig. 272), and indeed, as long as it was necessary to fashion such things by hand, the

1 This work is attributed by Mr Starkie Gardner to a skilful smith named Robert Davies. 

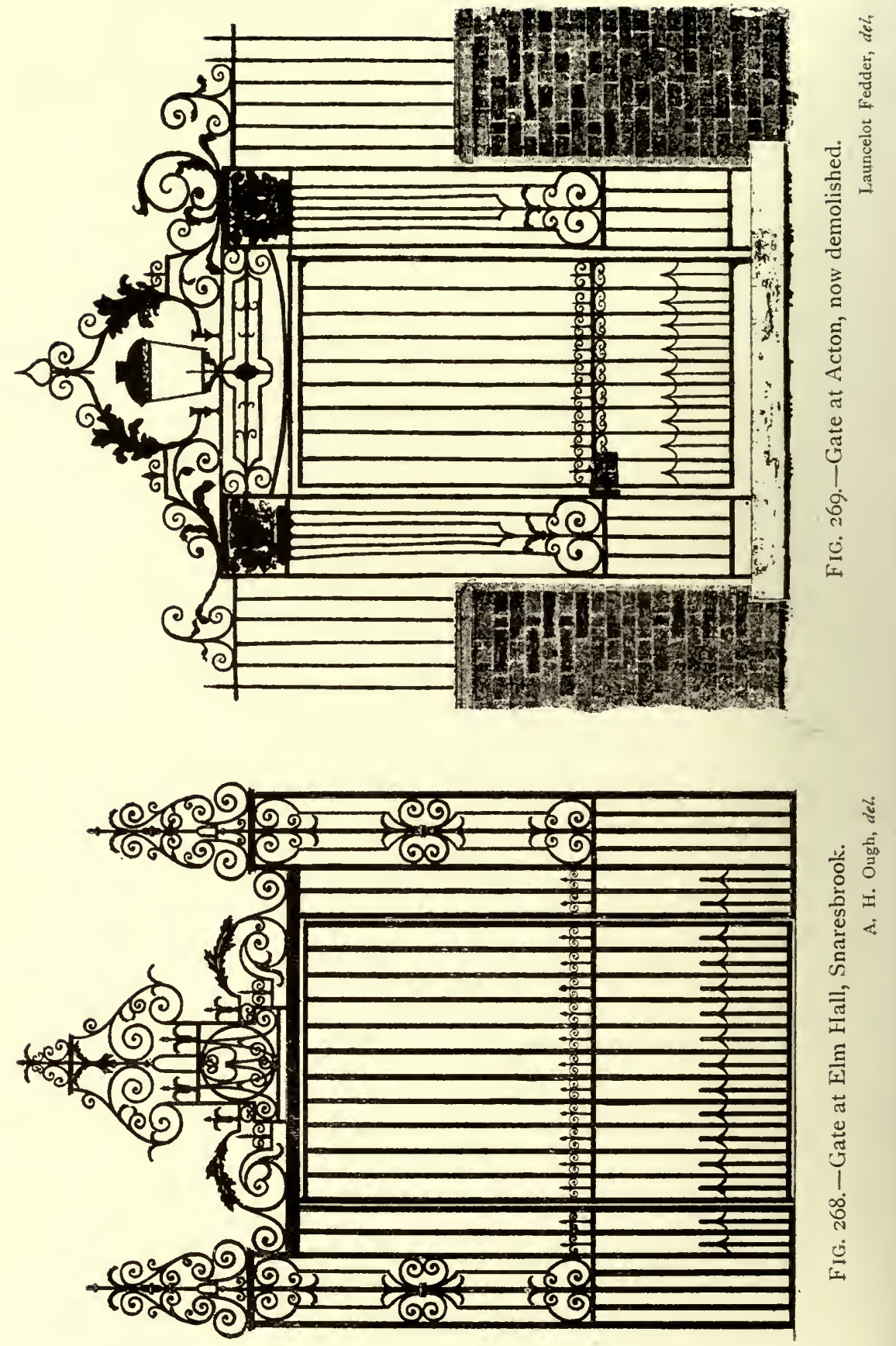

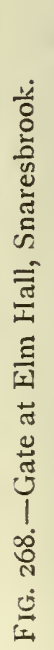




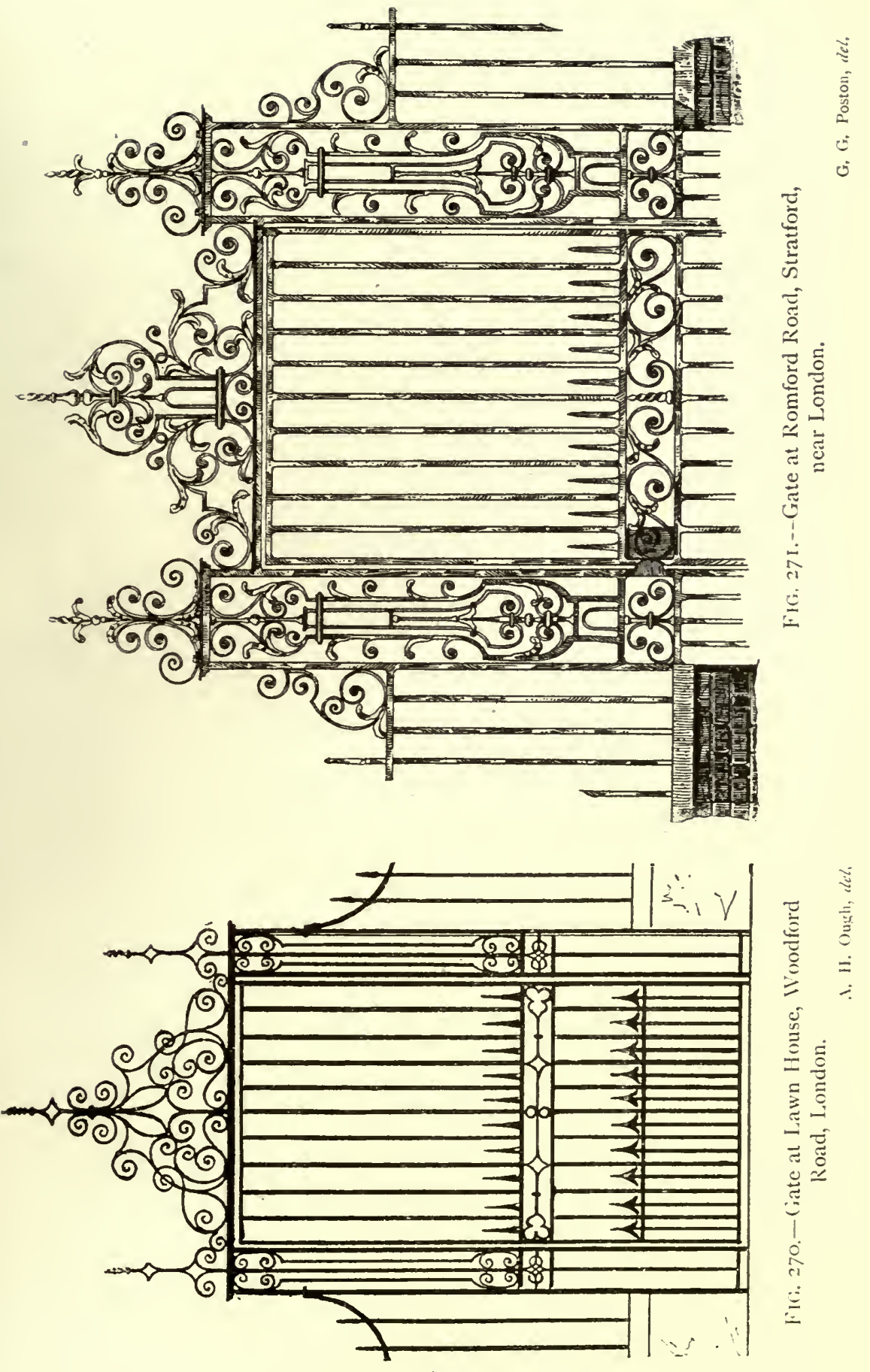




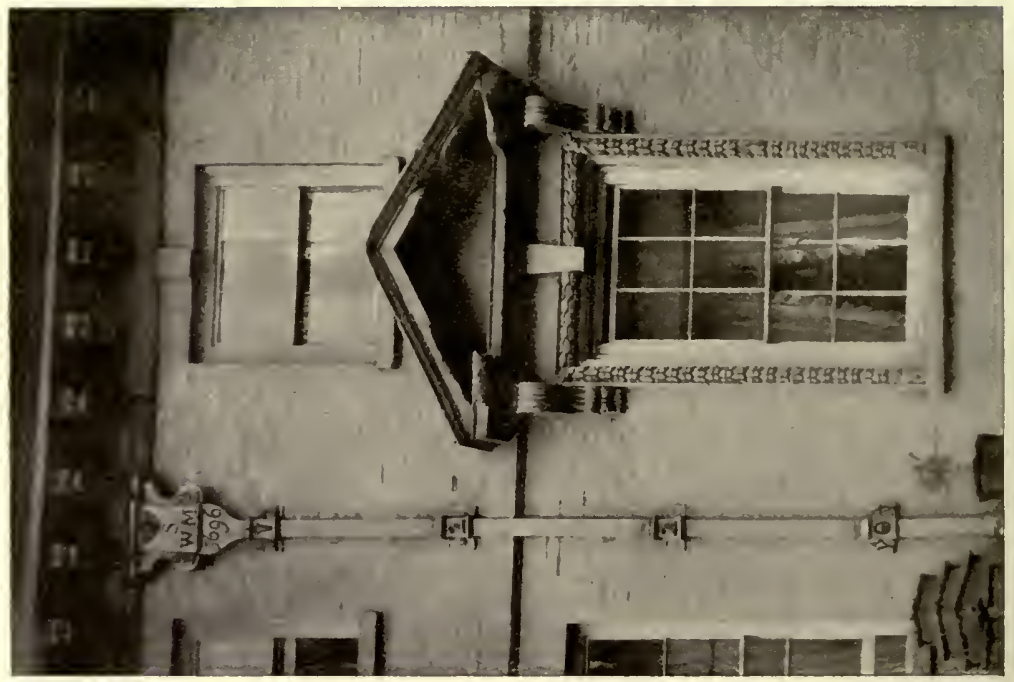

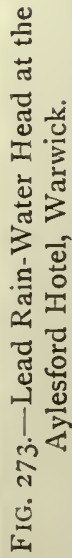

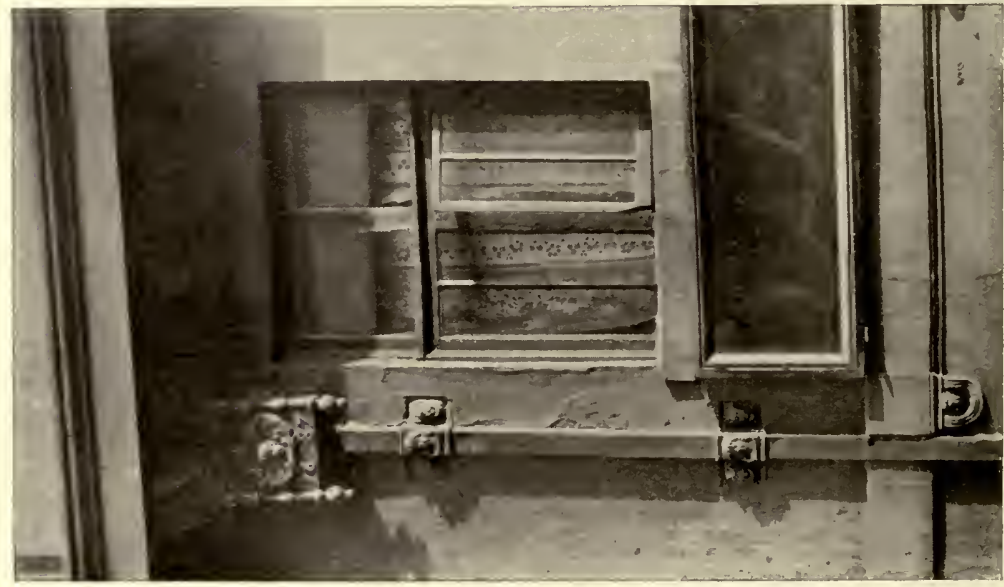

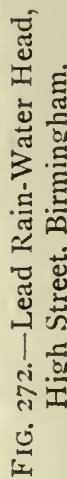


craftsman imparted character to his work even if it was of a simple and unobtrusive kind (Fig. 273); but with the advent of the speculative builder, the number of such things required, and the necessity of a rapid and cheap supply, led to more expeditious methods, and with the advent of cast-iron heads a general level of dullness and monotony was reached. The scope of lead ornament was necessarily restricted, it was only here and there that it was applicable; the other direction in which

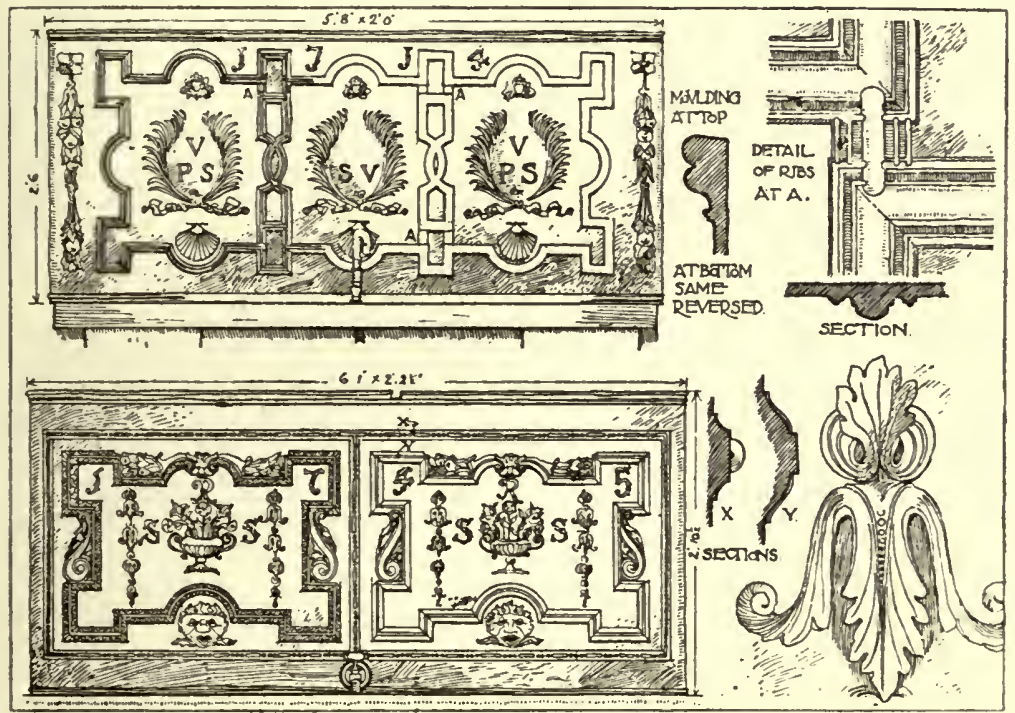

FIG. 274.-Two Examples of Lead Cisterns.

it was largely used was in cisterns or troughs of which examples occasionally occur, but lead being always a marketable commodity, most of these objects, when once out of use, were sold for melting and re-use. Some good examples dated I728, I 7 I4, and 1755 are shown in Figs. 267, 274.

The English craftsman has always been able to do good work when he has had the opportunity. Even during the period when house-design may be held to be void of interest. there are numberless examples of fittings, or furniture, or household articles which show his skill, and if a free and reasonable view of design is maintained, there is every prospect of his doing as good work in the future as he has done in the past. 


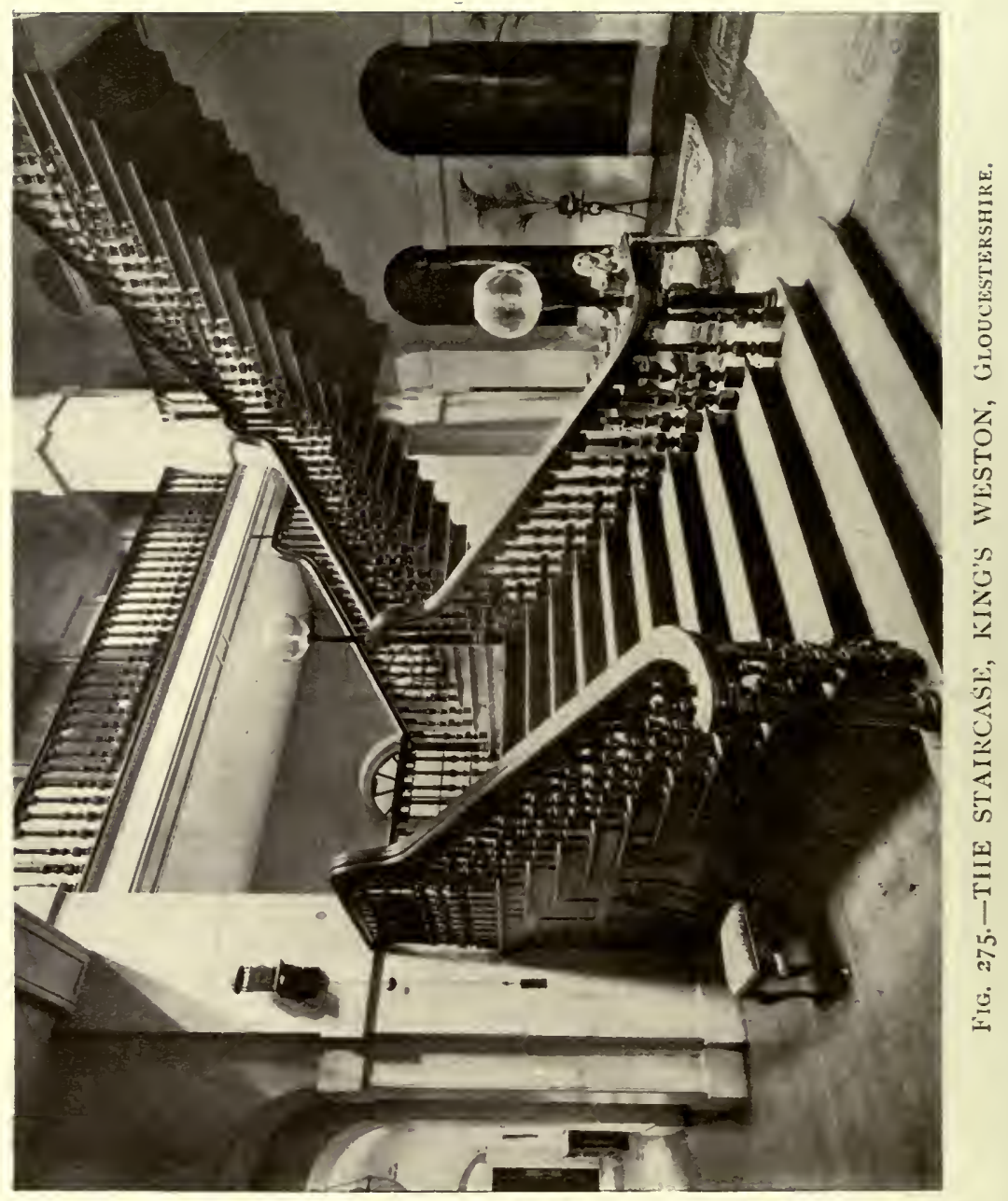




\section{XI}

\section{INTERNAL FEATURES (EIGHTEENTH CENTURY)}

THE internal decoration of houses of the seventeenth century has already been described, and incidentally a considerable number of examples have been given of the treatment of later houses; but it is desirable to treat the subject a little more fully than has been possible in former chapters.

In entering an eighteenth-century house the visitor found himself in a large vestibule or hall-not the old-fashioned hall of the early seventeenth century, which was itself one of the principal living-rooms, but a hall which was merely a vestibule or ante-room leading to the living-rooms. Sometimes it had a fireplace, but sometimes not; in either case it was not regarded as a room for constant use. In houses of the middle size it contained the staircase, and the same held good in many of larger size; but in the largest the hall was frequently the most striking apartment in the house, as for instance at Houghton (Fig. I74) and Prior Park (Fig. I 82).

The staircases were always handsomely treated. As a rule they were of wood, but a few. instances occur of marble steps and balustrades, and of stone steps with iron balustrades. The typical English staircase is of wood, with turned wood balusters. For a short time during the seventeenth century foliated balustrades had been the fashion (see Figs. 80-82), but towards its close the turned baluster reasserted itself. Massive handrails and solid strings were still retained, as in the example from the Ashmolean Museum, Oxford (Fig. 277); and many examples of simple staircases of this type are to be found in the Temple, London, and the surrounding neighbourhood. 
An important development in design occurred when the oldfashioned solid string was abandoned, and the balusters rested upon the steps themselves. This change took place about the beginning of the eighteenth century, and there is an early example at King's Weston, in Gloucestershire (Fig. 275). The steps are very deep from back to front, so much so that each step overlaps the second one above it. The nosings are carried along the end of every step and returned back to the wall under

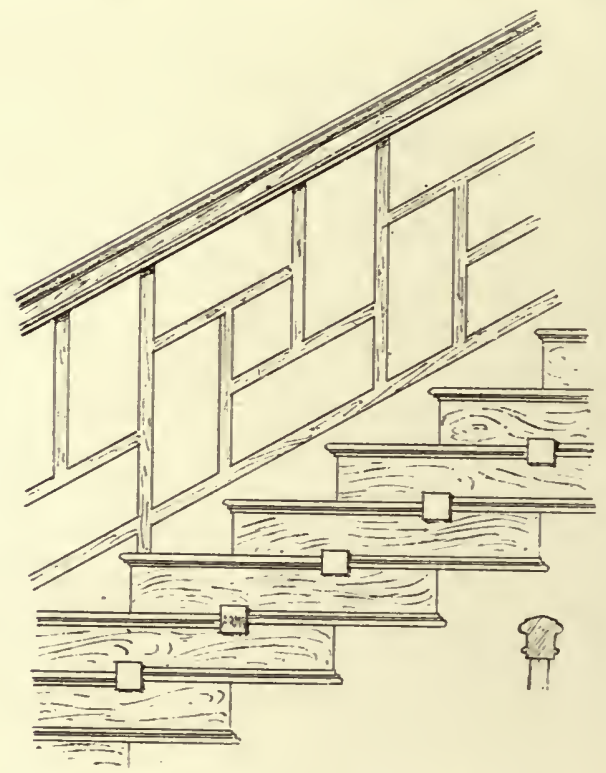

F1G. 276.- Staircase at Boughton House, Northamptonshire

J. A. Gotch, del. the step above; the bottom edge of this is finished with a moulding which returns and rests on the nosing of the step below. A very similar treatment is adopted at Boughton House, in Northamptonshire (Fig. 276), but here the edge of the soffit has a moulding like the nosing, but reversed: the junction of the two is masked by a wood block. These blocks are all painted with arms of the Montagus and their alliances, which prompted Horace IValpole to inquire whether the chief staircase at Boughton was intended for the "descent of the Montagus." Another point to be noticed in the King's Weston example is that the two bottom steps are carried out sideways beyond the others and rounded off with a bold sweep, and that the handrail is wreathed round instead of finishing against a large newel. This is a treatment which only became possible on the abandonment of the oldfashioned newels and strings.'

A variation of the treatment adopted at Boughton may be seen in an old house in Salisbury (Fig. 278), where the nosings are still carried back some distance, but are supported by carved 

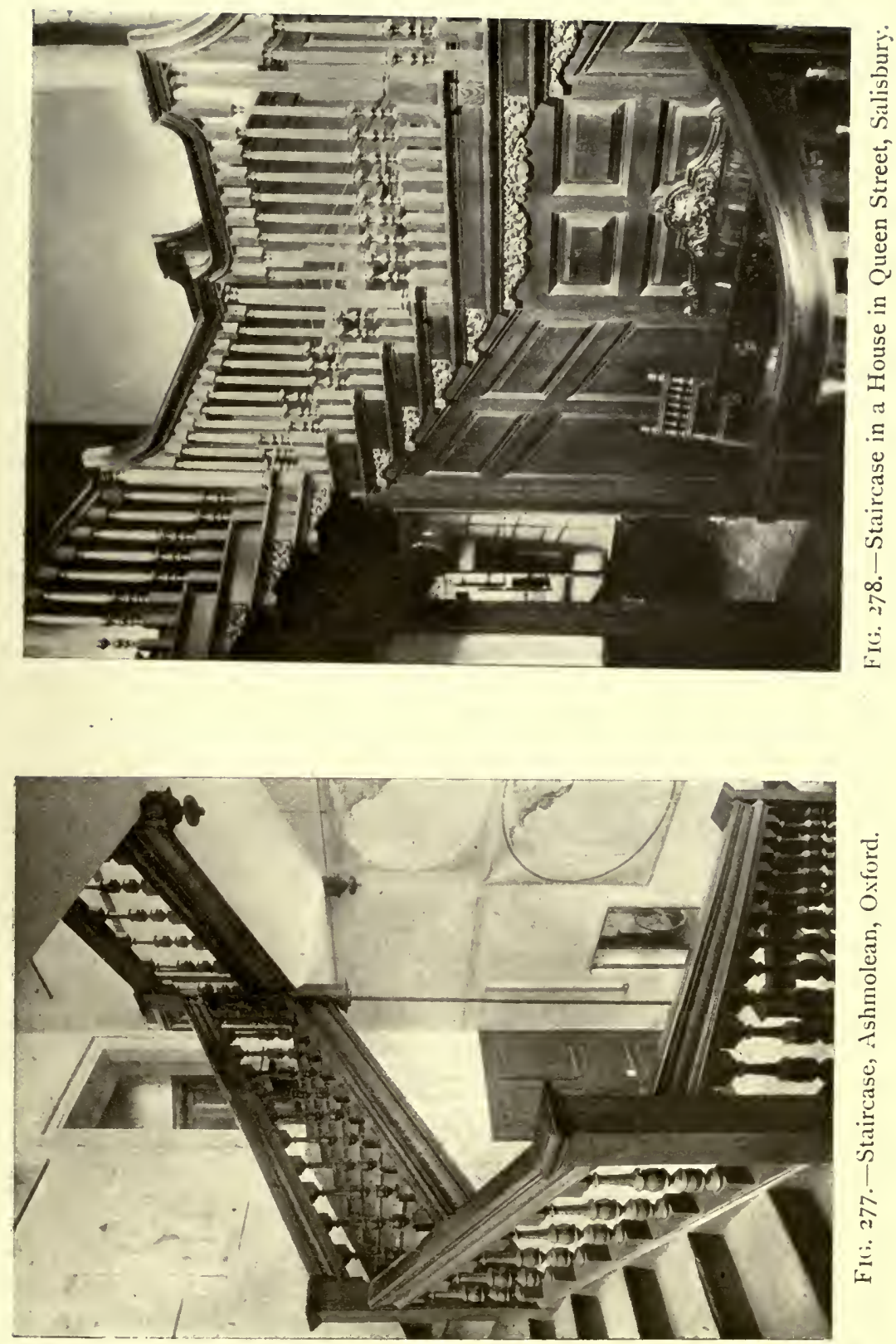


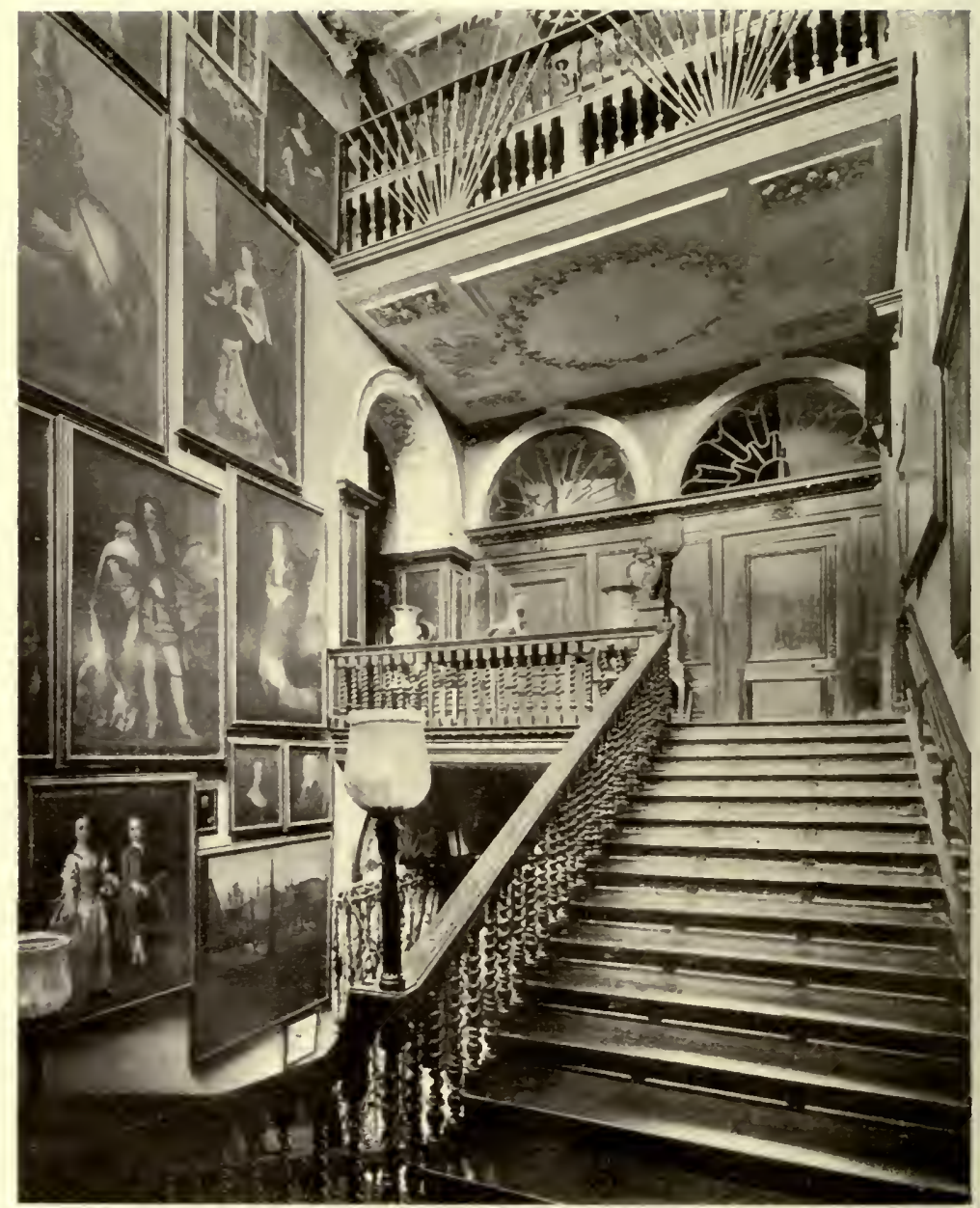

FIG. 279.-Staircase at Melton Constable, Norfolk.

brackets. It will be seen that the old stout newels have been replaced by small columns slightly larger than the balusters, and that the handrail is continuous, being bent upwards in a ramp where it has suddenly to attain a higher level. It is curved at the bottom in a large sweep similar to those at Kings Weston. At Melton Constable (Fig. 279) the same ideas are adopted, but here the risers of the stairs are panelled. It is clear from this 


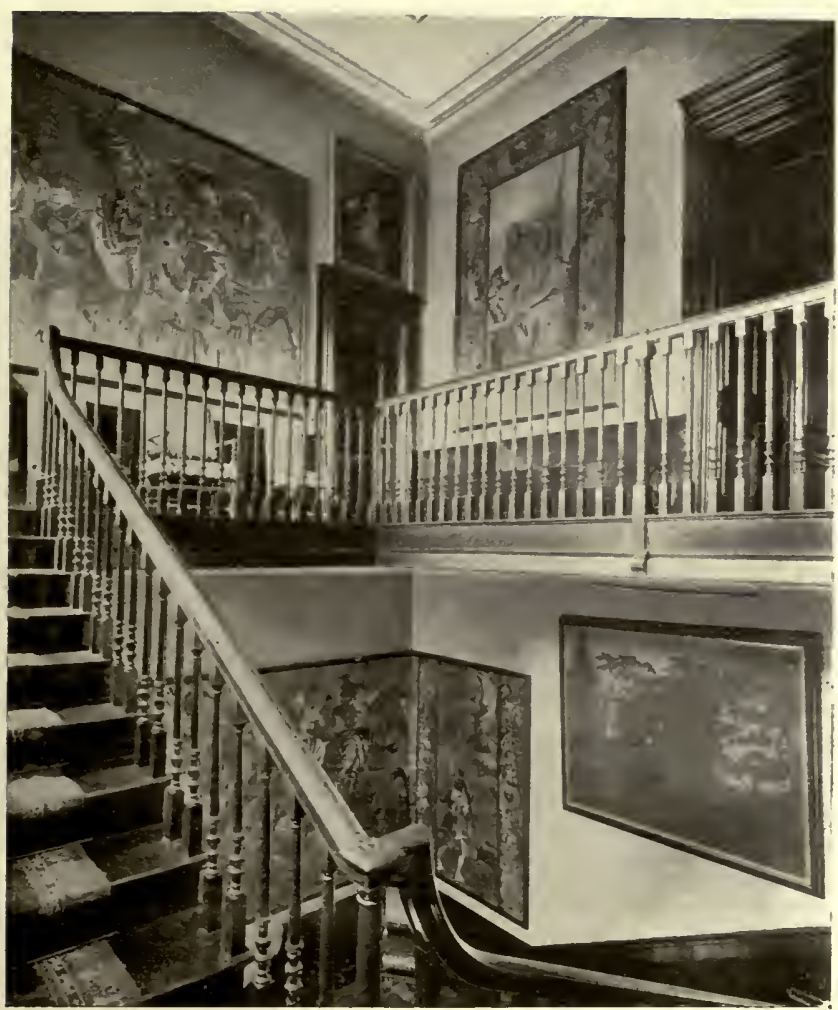

FiG. 280.--Staircase at Denham Place, Buckinghamshire.

that no stair carpets were contemplated, a point which is emphasised elsewhere by the fact that the landings and treads were often inlaid with different woods cut into patterns. Most of the staircases of the time were broad and of easy gradient, the balusters were short, and were either turned in graceful outlines or were twisted as at Melton Constable. At Denham Place, in Buckinghamshire (Fig. 280), the effect is quite satisfactory, although the stairs are narrower and steeper than usual, and the balusters are longer. This effect is obtained by the care bestowed upon the proportion and outline of the balusters.

Towards the close of the eighteenth century another form of staircase came into vogue. This consisted of a continuous 


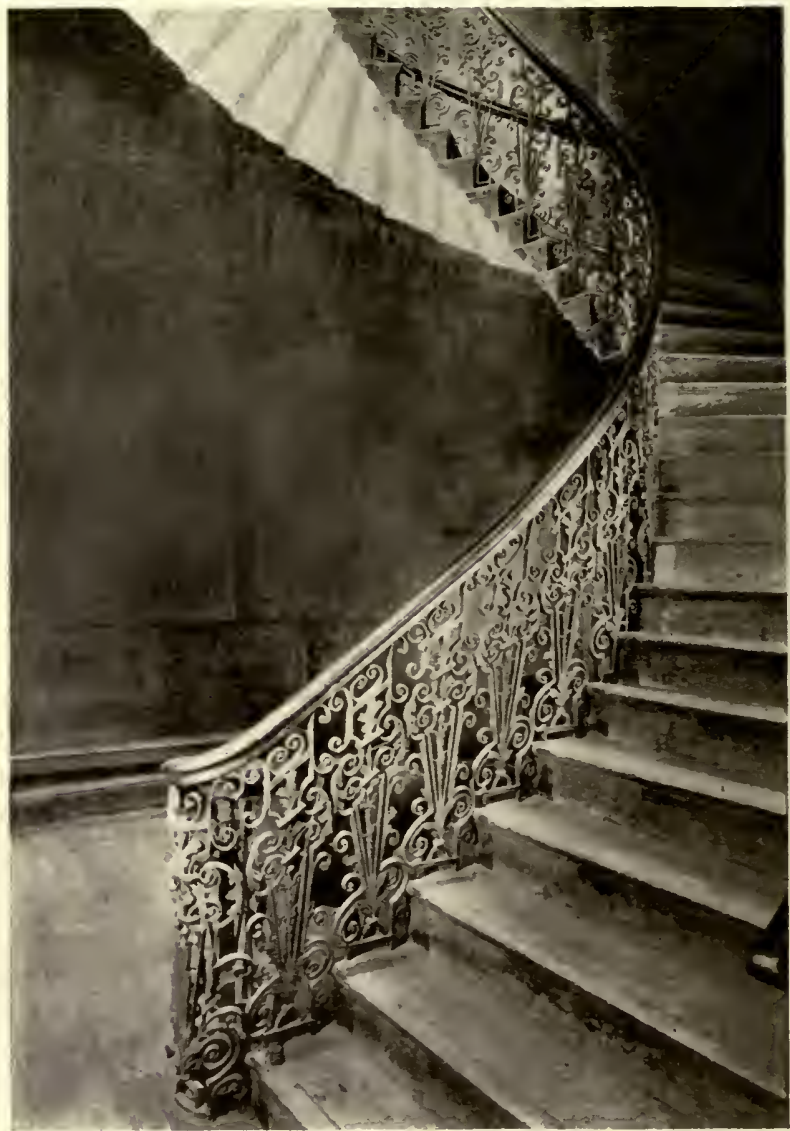

F1G. 281.-Staircase at No. 35 Lincoln's Inn Fields.

flight of stone steps, often oval in plan, leading from floor to floor in one sweep. Each step rested on that below, and one of its ends was built into the wall, thereby obviating the necessity of any expedient for supporting the other end. By this means a free space was obtained beneath the staircase. The general effect, although light and sometimes graceful, was a little cold and meagre; but it was quite in character with the rather severe schemes of decoration prevalent at the time (Fig. 28I).

In the larger houses much attention was bestowed upon the doorways : there is a good example at Godmersham Park, 


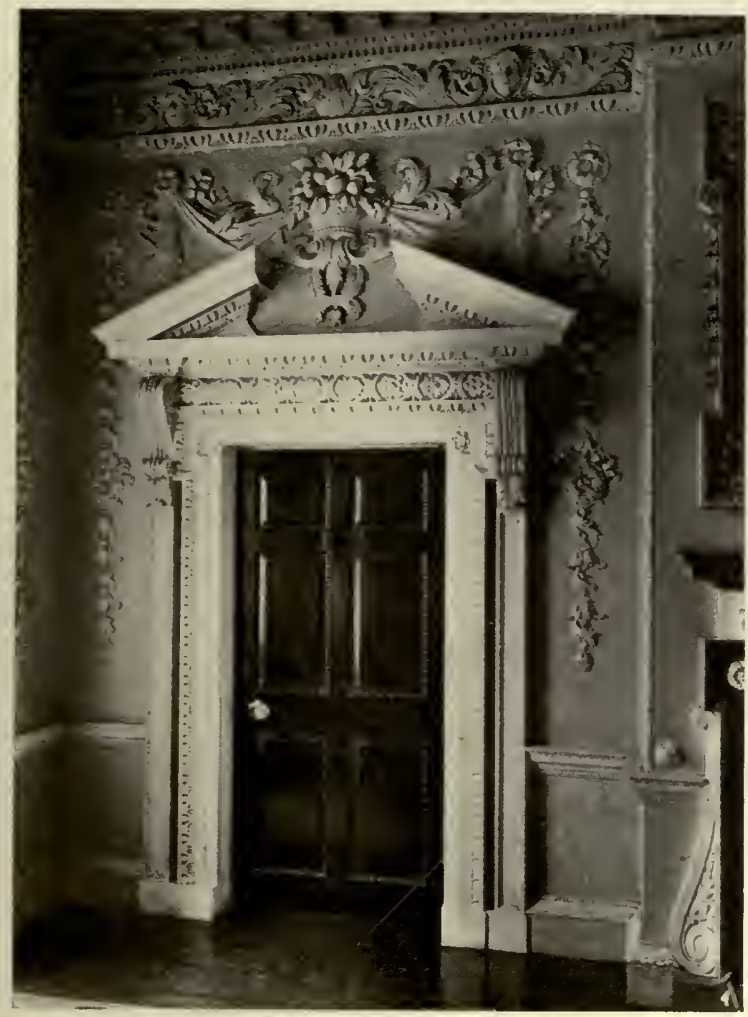

FIG. 282.-Doorway at Godmersham Park, Kent.

in Kent (Fig. 282), where the broken pediment affords space for the central feature of a design modelled in high relief. As here, so in many other instances, the door is of mahogany and the surrounding woodwork is painted white. The example from Honington Hall, in Warwickshire (Fig. 283); not only shows an important doorway, but also the domed and coffered ceiling of a lofty room, as well as walls with panels of plaster, and large pendants of fruit and birds in the manner of Grinling Gibbons. In houses of the early part of the eighteenth century there was often one room occupying two stories in height; sometimes it was the hall, sometimes, as in this case, a saloon or drawing-room.

In smaller houses were such doorways as that at Bourdon 


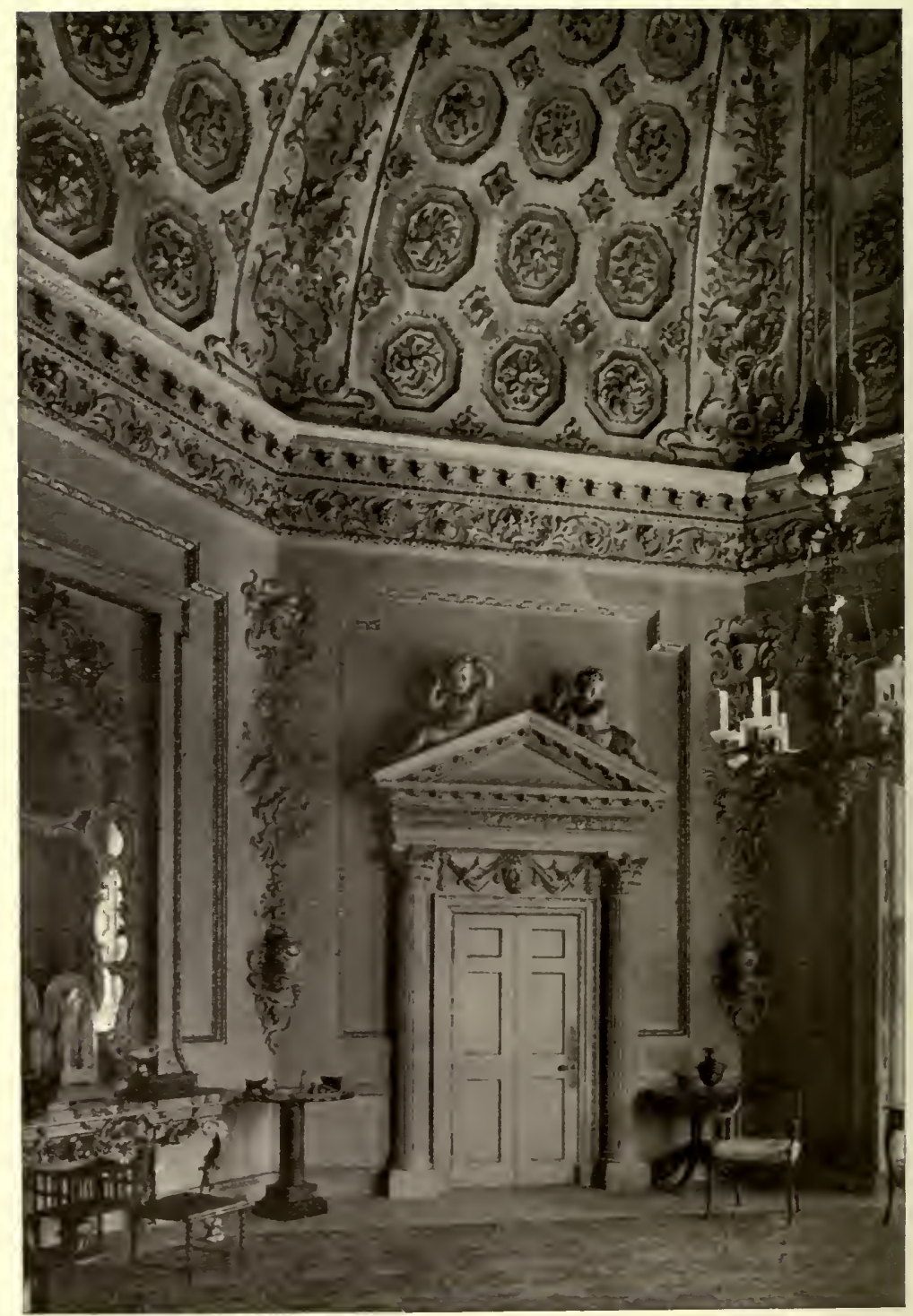

Fig. $28_{3}$. -HONINGTON HALL, WARWICKSHIRE. 


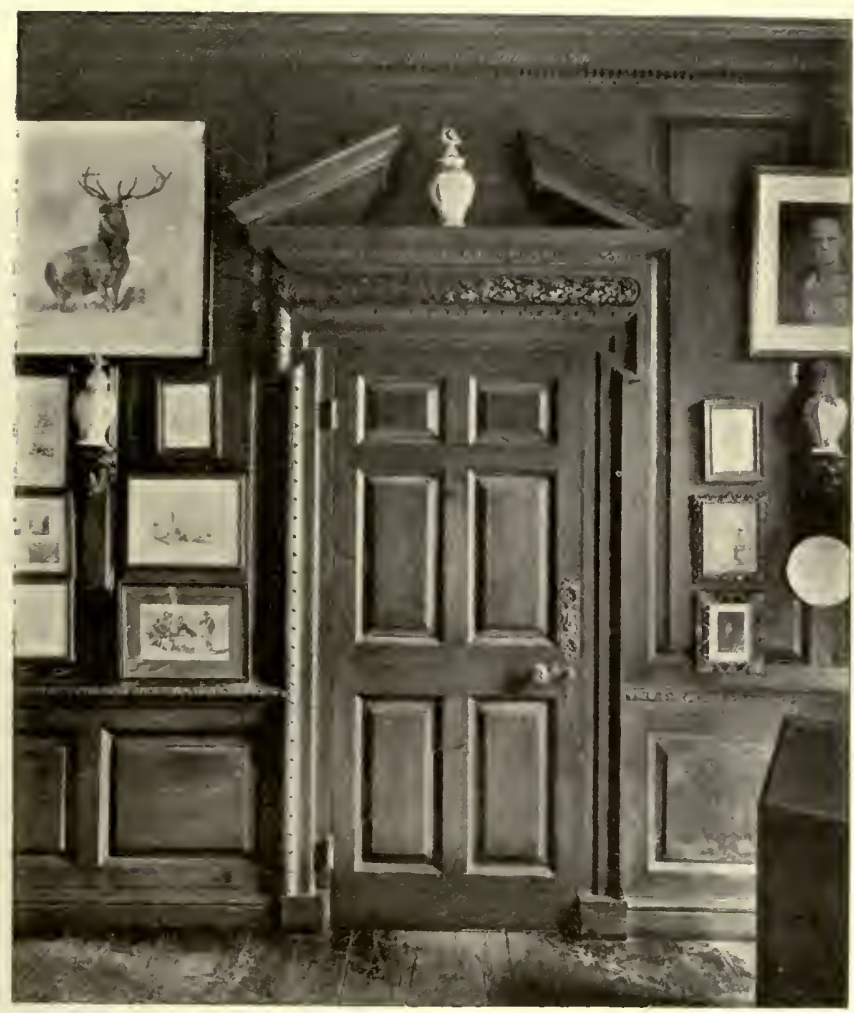

F1G. 284.-Doorway at Bourdon House, Mayfair, London.

House, London (Fig. 284), where there is carving enough to impart interest to the design without over-weighting it; and at Seckford Hall, in Suffolk, is a simple but effective treatment (Fig. 285) which is well within the compass of an ordinary joiner. A great variety of effect can be obtained at small cost by dint of a little thought and a determination not to be too much bound by correct precedents. It is one of the failings of the ordinary eighteenth-century designer that he feared to depart from the patterns published in books.

Very great changes in the manner of treating the walls of a room occurred during the course of the century. At first they were panelled with wood-not with the small panels of Jacobean times, but with large panels surrounded by bold mouldings, such as those at Denham Place (Fig. 287). Here 


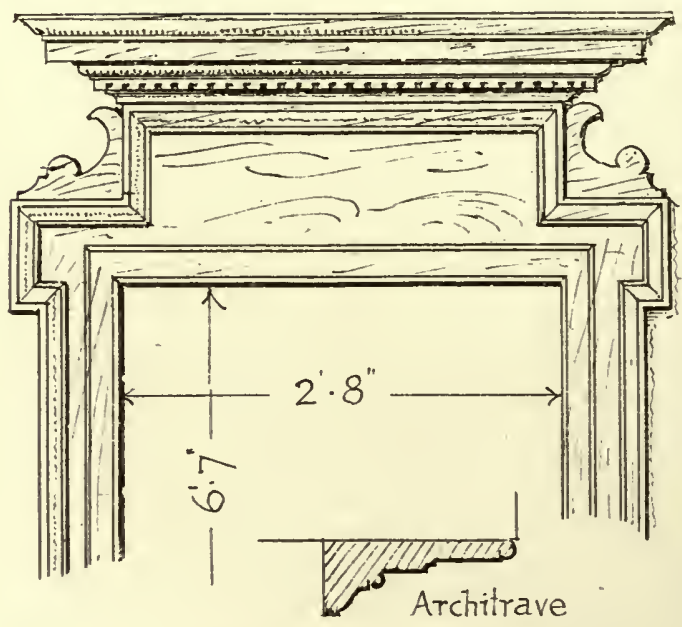

FIG. 285.- Head of a Doorway, Seckford Hall, Suffolk.

the mouldings are enriched with carving, which adds considerable richness, but as a rule the mouldings were plain; various examples have already been given in Figs. 122, 126 , I 35, I 39. There was usually a low dado with long horizontal panels, and above the dado rail were lofty vertical panels reaching up to a massive cornice. The effect is always simple and dignified, whether the material is oak or painted deal. Of course the panels very much restrict the freedom of arrangement of pictures, but in those days pictures were not so plentiful as they became later, prints were few, and so were the amateur artists who bestow the fruit of their elegant leisure upon their friends. The panels therefore hampered nobody, and they were in themselves a sufficient decoration. Family portraits or notable pictures were sometimes framed into them as part of the scheme.

The backgrounds of engravings published during the first half of the eighteenth century often show these large panels, as well as sash-windows' with stout bars. They seem to harmonise with the flowing wigs, the wide coat skirts

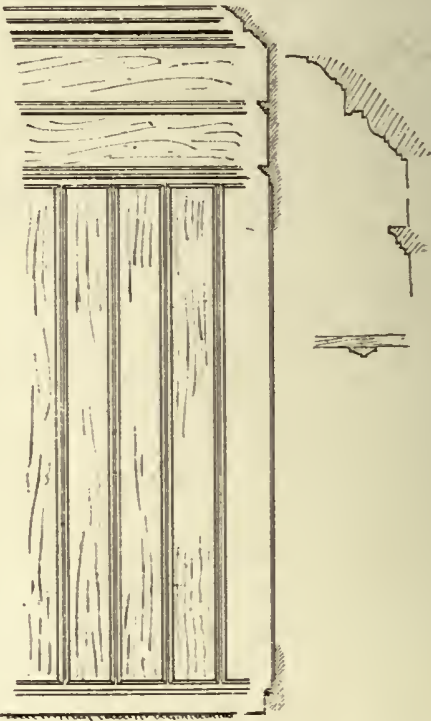

FIG. 286.-Panelling in the Audit Room, Boughton House, Northamptonshire. 


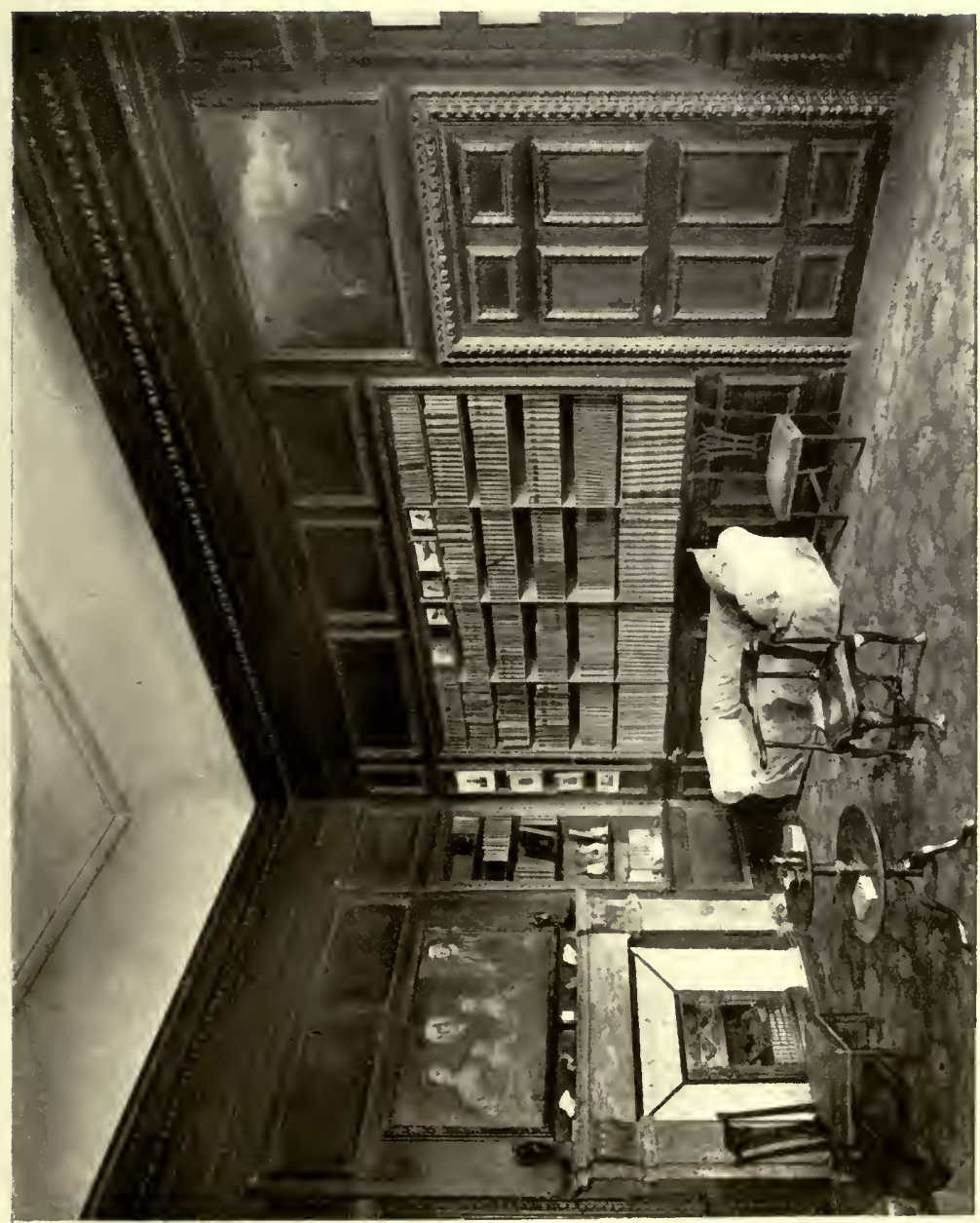

告 


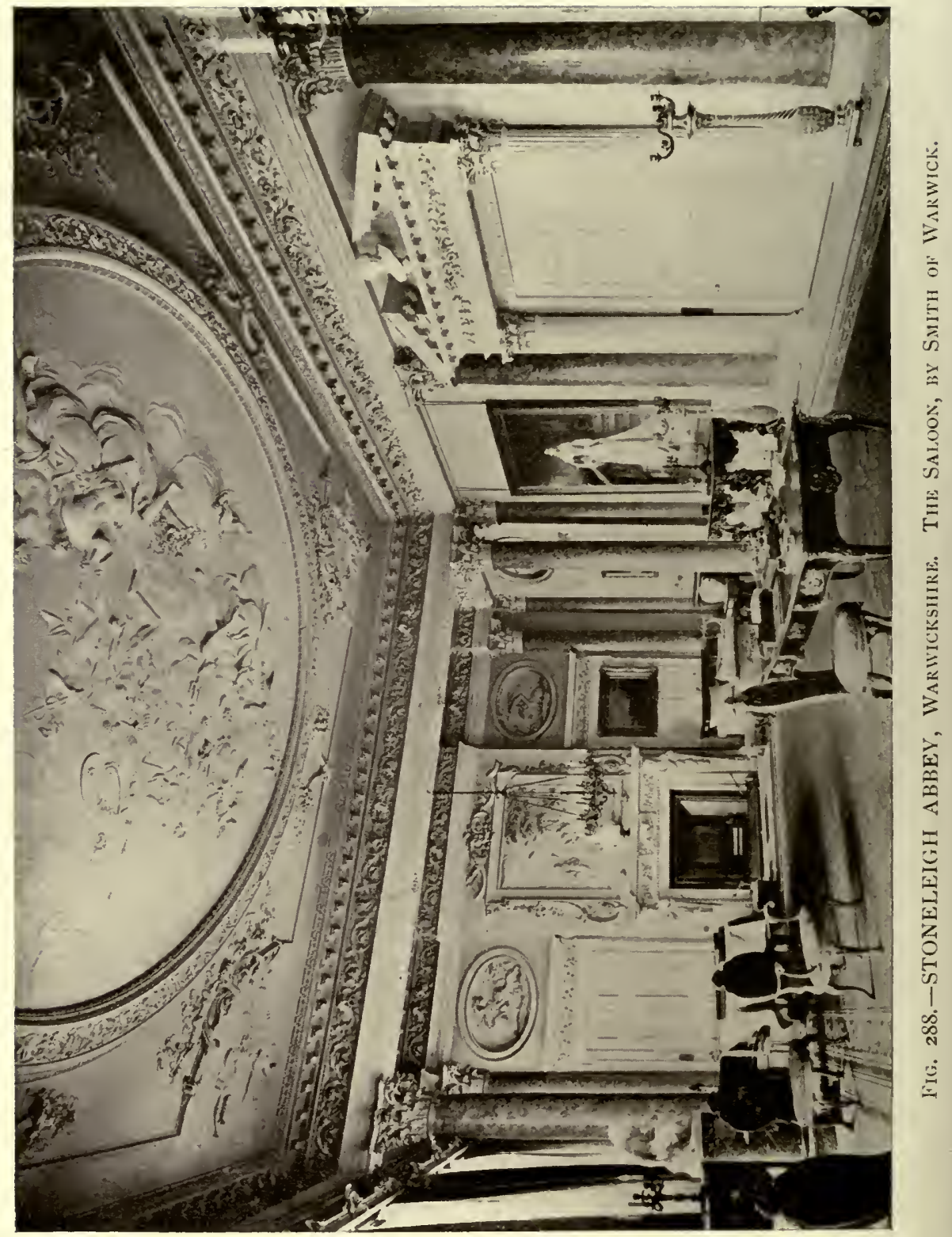




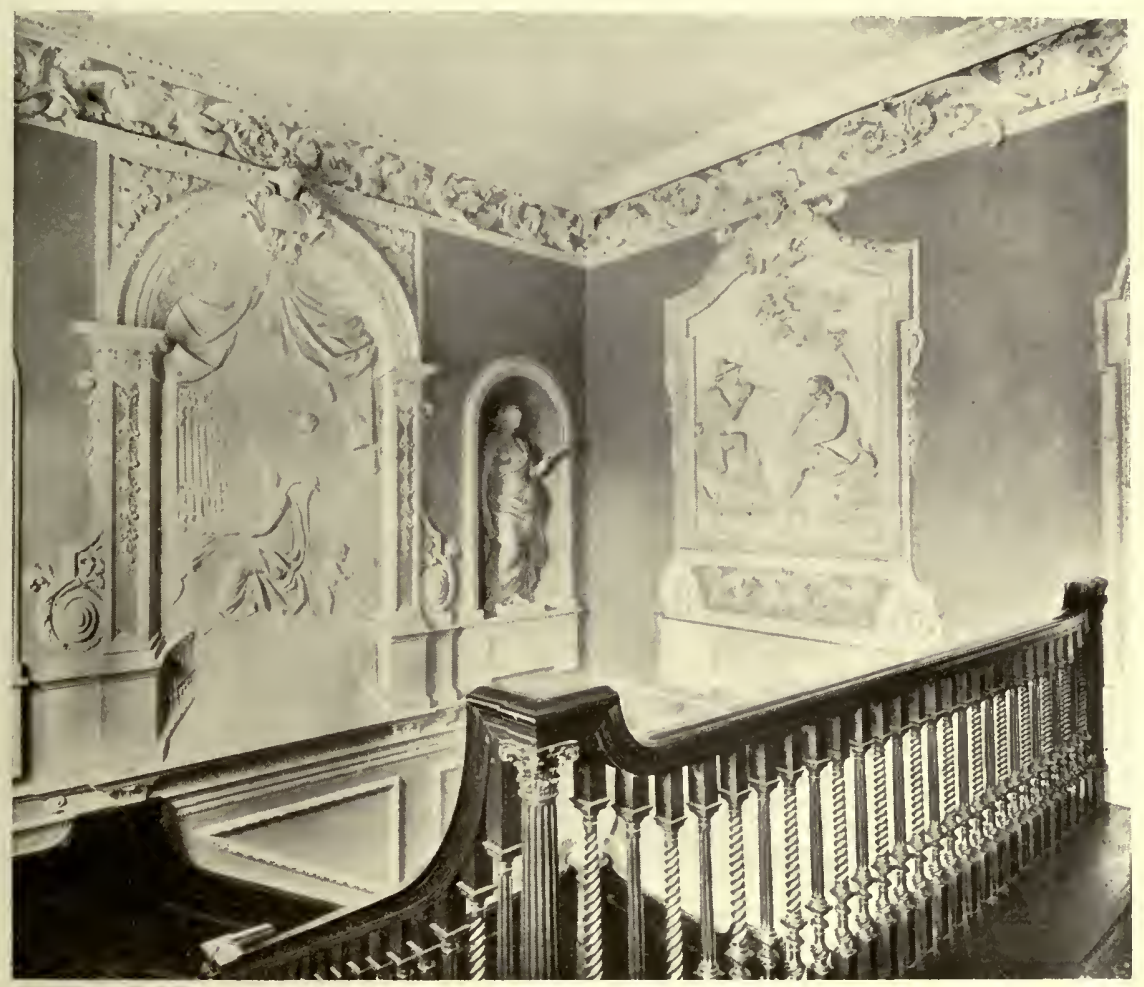

FIG. 289.-House in Queen Square, Bath.

and knee-breeches of the actors in the incidents which the prints are intended to record.

An unusual form of panelling, but one which is both cheap and effective, is to be seen in the audit room at Boughton House (Fig. 286). It consists of boards nailed vertically to the wall, having the joints covered with a moulding; below is a skirting, and above is a frieze and cornice.

IVood panelling was gradually superseded by panels formed in plaster on the plastered walls. Gibb's drawings have already afforded examples of this treatment (Figs. 166-169), and any book of the eighteenth century on house design will supply others. Stoneleigh Abbey, Kenilworth, has panels of unusual richness (Fig. 288), and a house in Queen Square, Bath, by one of the Woods, has some delicately modelled panels on the staircase (Fig. 289). The drawback to this method of decoration is that, being rather ambitious in aim, it challenges criticism much more definitely than does simple panelling. It is conceivable that 
one eventually might tire of seeing the same youth piping to the same old man, and the same lady for ever playing the same organ without looking at her notes.

But a more radical change in wall decoration was to come in the shape of wall papers. The early history of this method of adorning rooms has not been fully explored, but it seems clear that already in the seventeenth century sheets of paper covered with stencilled patterns had been pasted on to walls, or perhaps on to the panels into which they were divided. This was a laborious and by no means cheap process, but it contained the germ of the procedure which is so widely adopted to-day. Another and even more effective step was taken when Chinese papers were introduced (Fig. 290). These papers consisted of rolls, each printed with a portion of a large design, which required some five or six pieces to complete it. It was probably of such sets that the vivacious Lady Mary Wortley Montague, most celebrated of blue stockings, wrote to her daughter from Louvere, in I749, to say, "I have heard the fame of paper hangings, and had some thoughts of sending for a suite, but was informed that they were as dear as damask is here, which put an end to my curiosity." In some cases curiosity outweighed thriftiness, and the suites still remain in a few old houses; here and there some of the original rolls still exist, rolls which for some reason or other were not used, and which have luckily escaped destruction. Chinese papers became fashionable, and it is not difficult to imagine the process of evolution from rolls-each bearing part of a large design either of trees and flowers, or of a landscape or a figure subject, after the manner of tapestry-to other rolls all printed alike and forming a continuous pattern, with the parts duly repeated, which should cover the whole walls with decoration of a sort. The advantages of the new method were obvious: it was cheap; and although at first the paper was applied to canvas nailed to battens on the wall, yet eventually it was placed on the wall itself, and thus did away with the spaces between the walls and the panelling or tapestry: where dirt or spiders or more noxious insects could harbour; rough surfaces were rendered smooth, joints between wood frames and stone or brick walls were filled with plaster, and draughts were lessened. Most of these advantages were obtained by plastered walls ornamented with panels, but plain surfaces 


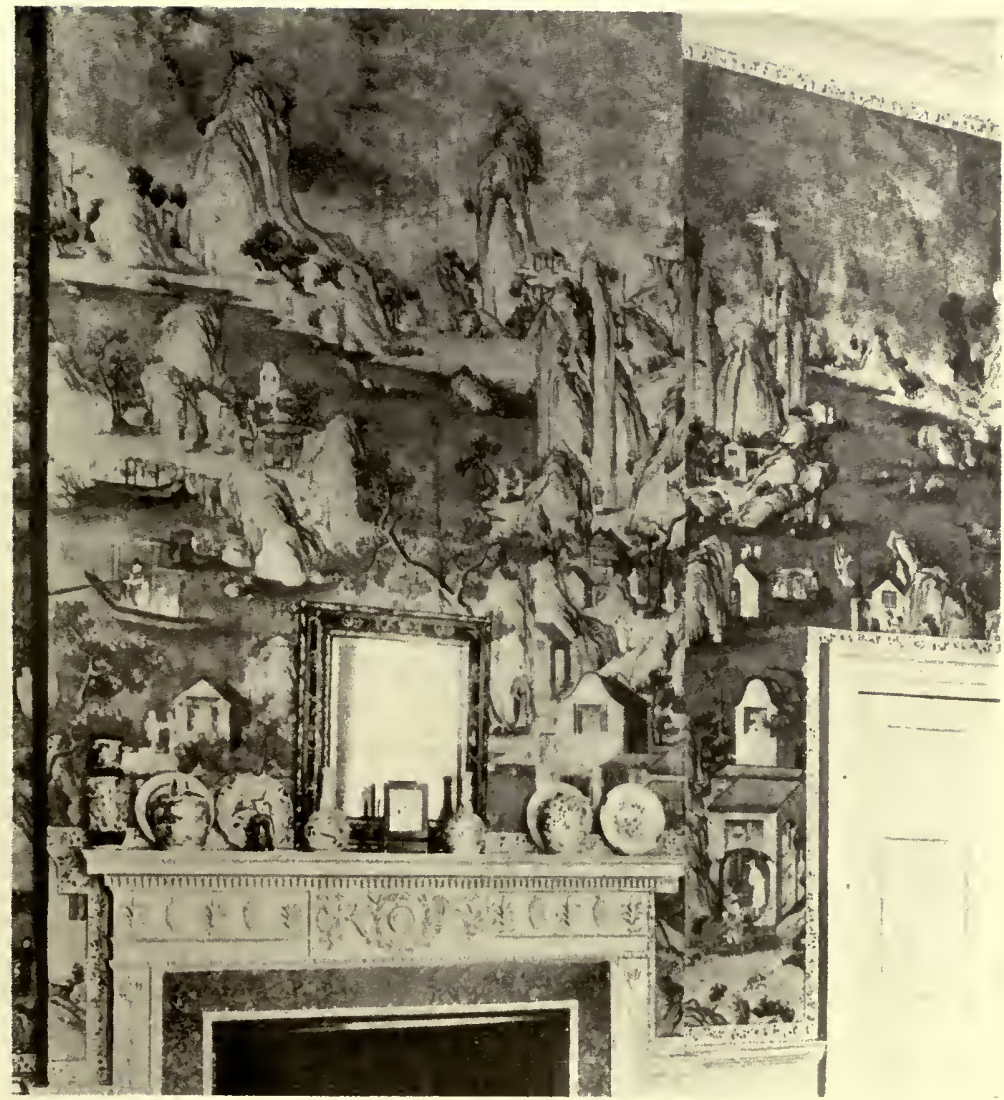

F1G. 290.-A Chinese Paper, Ramsbury, Wiltshire.

covered with paper were cheaper, and gave greater scope for the unrestricted hanging of pictures and prints as the taste for such things developed. Then, again, more and more people lived in hired houses, and with every fresh tenant new papers could readily be pasted over the old. There was no idea in those days of stripping off the previous papers; and in dealing with ancient houses as many as twenty layers of paper have sometimes been found. But our notions of sanitation have improved, and in the present day everything is removed down to the plaster before the new paper is hung.

The Chinese papers, as already observed, had some affinity 

13 (1)

18

al

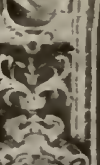

$5 x=0$

of $-4,3$

$6 x=2$

int

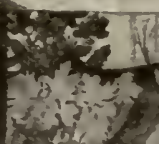

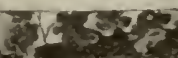

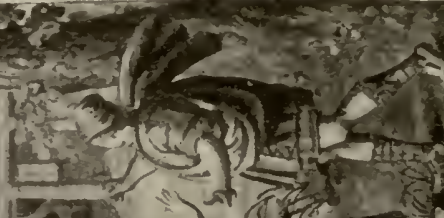

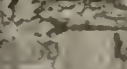

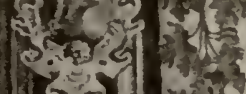

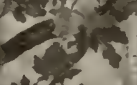

(दि)

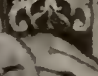

$16+2=3$

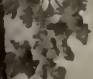

ras

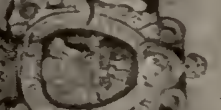

$\rightarrow x^{2}+2$

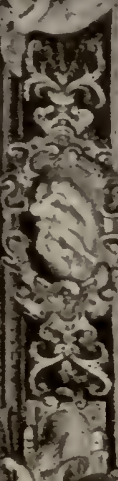

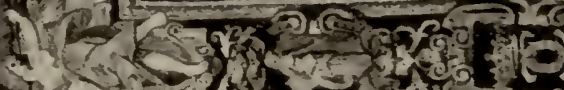

$l^{3}<2=2$

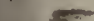

man
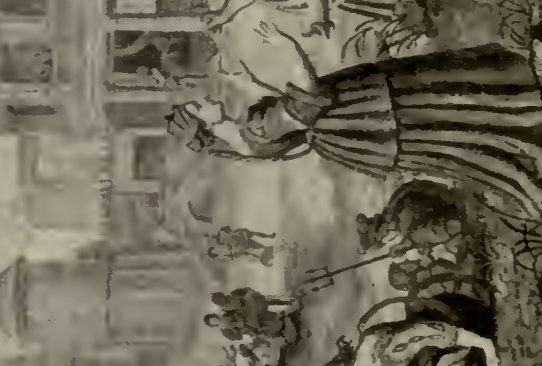

xis 3
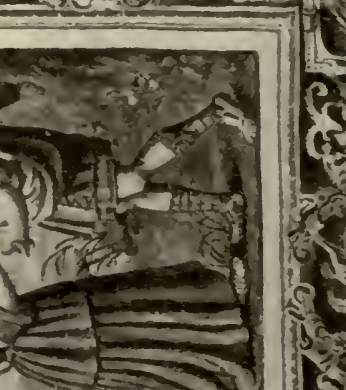

$\frac{1}{2}+2$

and?

ton 13

Q

is 50 ?

(fic)

$5 \rightarrow-2$

(1)

पर 4 की

min $\begin{aligned} & 3 \\ & \text { mat }\end{aligned}$

$x=4$ ह

i)

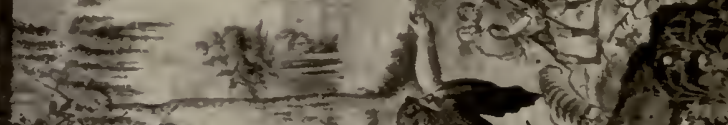

$\frac{4-26}{2+2}$

to $2 x$

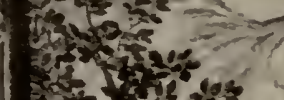

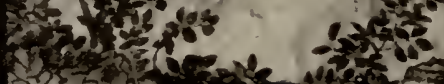

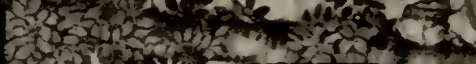
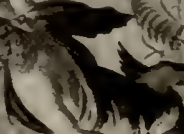

ifis
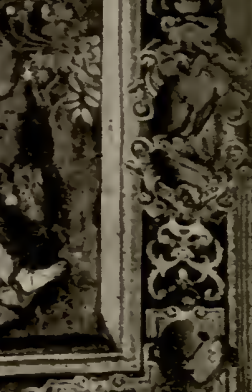

tisto

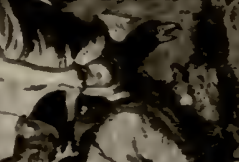

3

$\underline{z}$

$\frac{1}{3}$ 
in their subjects to tapestry, and tapestry had been a favourite means of covering walls from very early times (Figs. 29I, 293). In the seventeenth century it was much in vogue among the rich, both on the Continent and in England, and a noble form of decoration it is. It would be beside the mark to recount the history of tapestry weaving at any length, but it is of interest to know that during the seventeenth century the English factory at

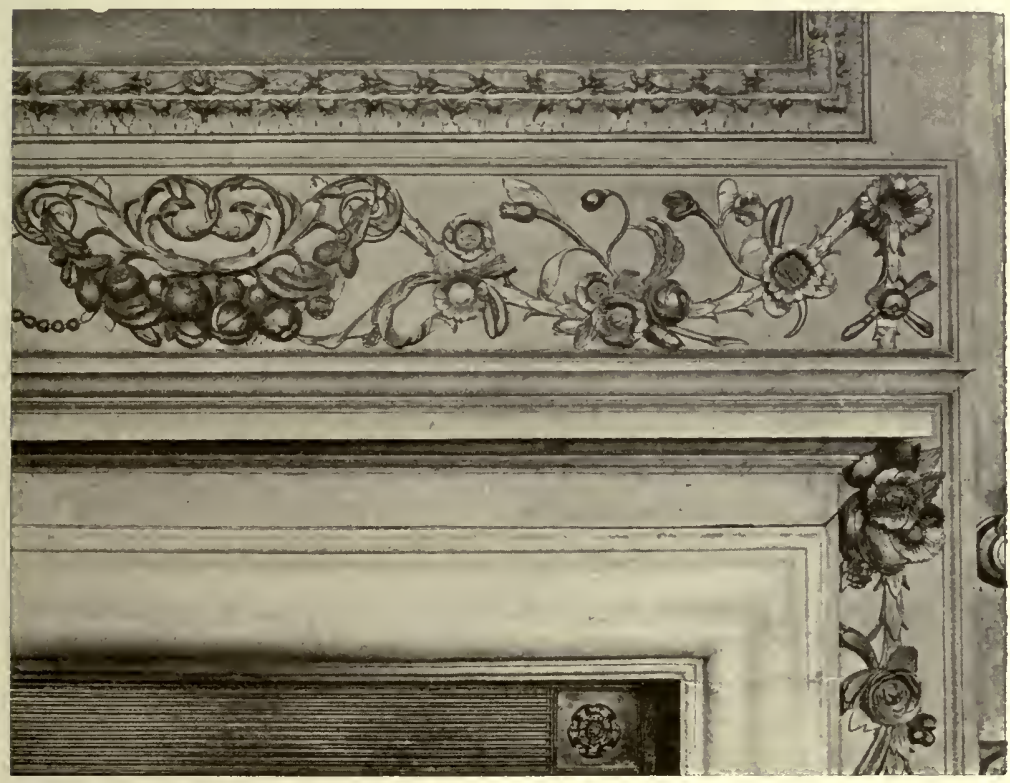

FIG. 292.--Chimney-Piece in the Mayor's Parlour, The Town Hall, South Molton, Devonshire.

Mortlake was the most renowned in the world, and produced some of the finest tapestries that have come down to us. The factory was founded in 1619 by James I., and with it are connected the names of two families who have already been mentioned in these pages. The first was that of the Cranes, the other the Montagus. ${ }^{1}$ Sir Francis Crane, who built a house at Stoke Bruerne, in Northamptonshire (sce pp. 174, 176), managed the factory for many years on behalf of the king, and made a considerable fortune. The factory flourished under James I. and Charles I., but declined under the Commonwealth. After

I See "Tapestry Weaving in England," by W. ( $\mathrm{r}$. Thomson. (Batsford.) 


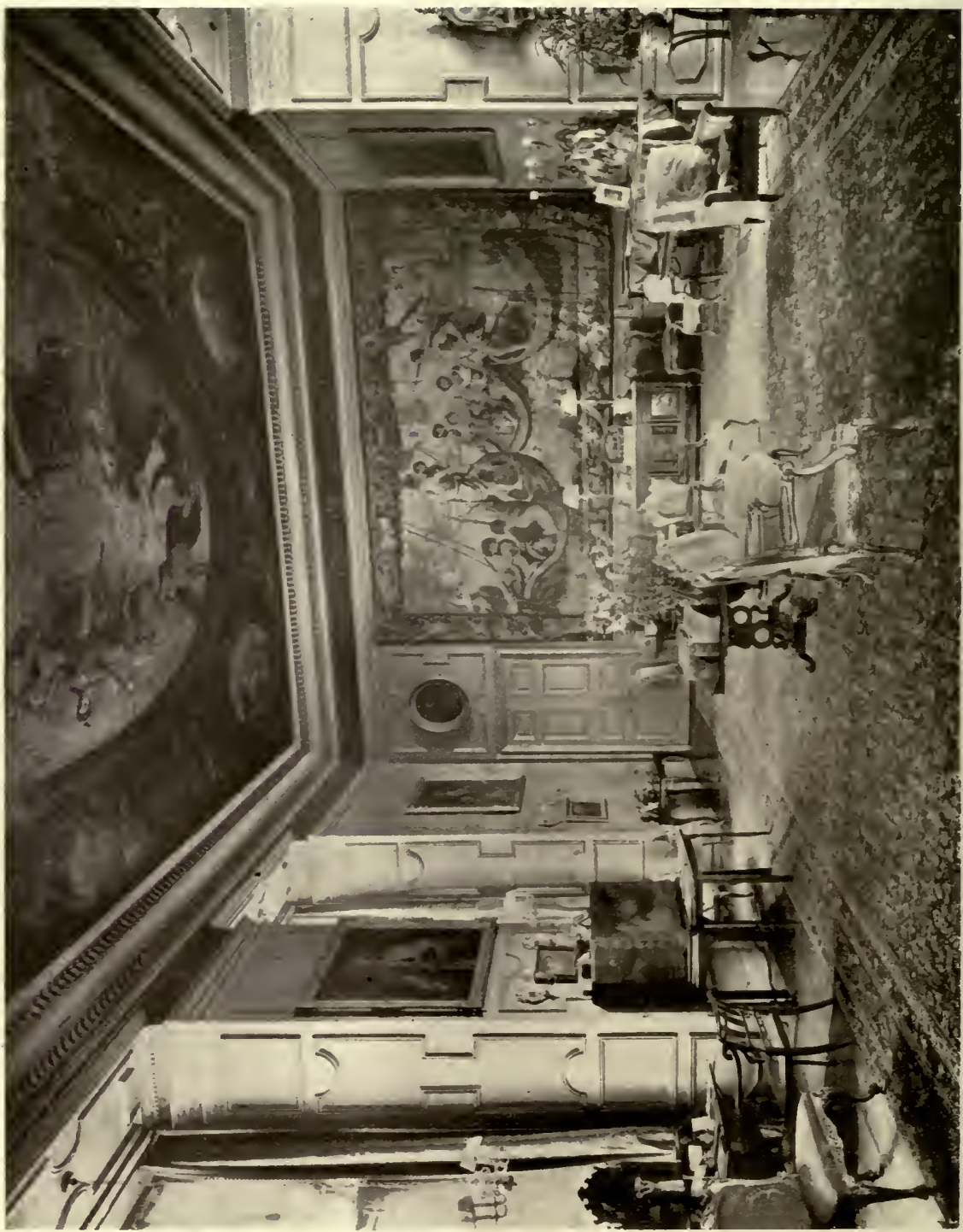

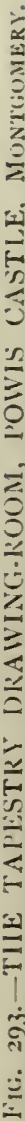


the Restoration new vigour was imparted to it; it passed from the direct patronage of the king and was acquired in 1674 by the Montagus, whose house at Boughton (see pp. 196-199) retains many splendid examples from its looms. But by this time the factory at Gobelins was producing work as fine as that at Mortlake, if not finer, and this circumstance, together with the declining taste for tapestries, brought the Mortlake venture to an end in 1703. ${ }^{1}$ Tapestries were at all times chiefly for the wealthy, but early in the eighteenth century they began to go out of fashion, and were superseded by the other modes of decoration already described.

At the beginning of the eighteenth century fireplaces were, as a rule, still contrived for the burning of wood logs. They were wide and deep, and were generally surrounded by a very bold moulding of stone or marble, like that in the Town Hall at South Molton (Fig. 292). The panelling of the room

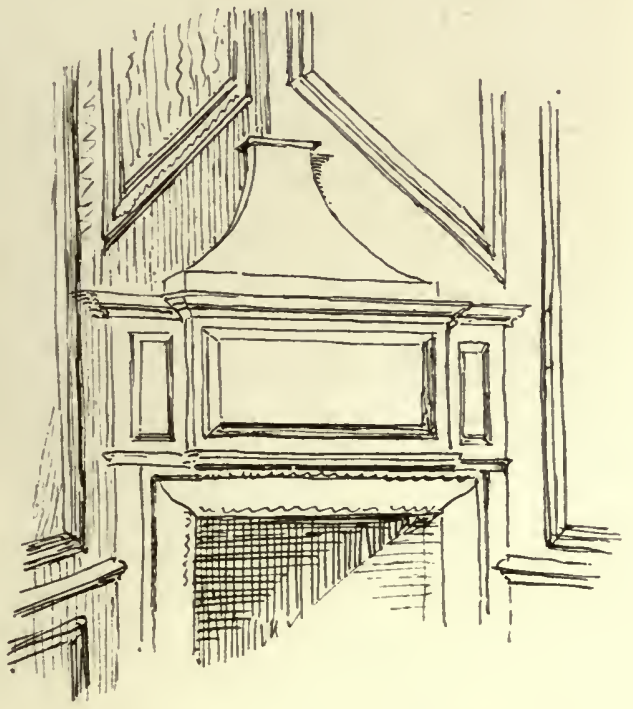

F1G. 294.-Corner Fireplace at Boughton House.

was often brought up to the marble, and continued above it with an additional richness over the fireplace; but sometimes there was a special margin provided round the large moulding, as in the case of South Molton. Occasionally it was found convenient to place the fireplace in a corner of the room, which led to some such ingenious treatment as that in Fig. 294, which is from a room at Boughton House.

Open fireplaces like these required fire-dogs on which to place the logs for the increase of the draught, and a great variety

1 "Guide to an Exhibition of Tapestries, Carpets, and Furniture, lent by the Earl of Dalkeith to the Victoria and Albert Museum," by A. F. K., 1914. 
of such dogs or andirons were produced, varying in character from rich and admirably modelled specimens like that in the queen's guard chamber at Hampton Court (Fig. 295), down to the simplest forms. It was also necessary to have fire-backs of cast iron to prevent the fire from eating away the brickwork against which it was

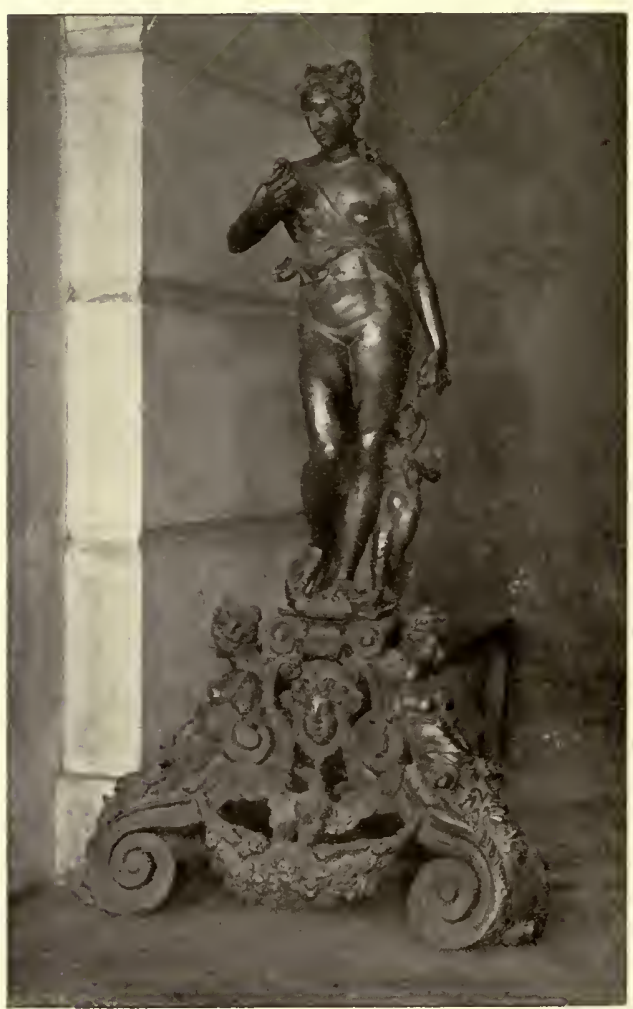

FIG. 295.-Fire-Dog at Hampton Court, in the Queen's Guard Chamber. piled. The various iron works in Sussex and elsewhere produced a great quantity of these backs of all degrees of elaboration. The ornament most frequently adopted was. a shield of arms, either those of the sovereign, or those of the family who usually warmed themselves at the fire; but the range of design was considerable, and. included floral and. figure subjects (Figs. 296-298), as well as patterns of extreme simplicity. Other accessories were tongs, bellows, and sometimes a fire shovel. The tongs were sufficiently stout to enable the $\log s$ to be handled; the bellows produced life in an almost dead fire with wonderful celerity; the shovel was used to bank up the ashes, which were allowed to accumulate in a great heap, and thereby preserved warmth during the night.

But early in the eighteenth century a rapid change took place in the kind of fuel consumed, and coal superseded wood. Sea-coal, that is sea-borne coal, had been in occasional use for 


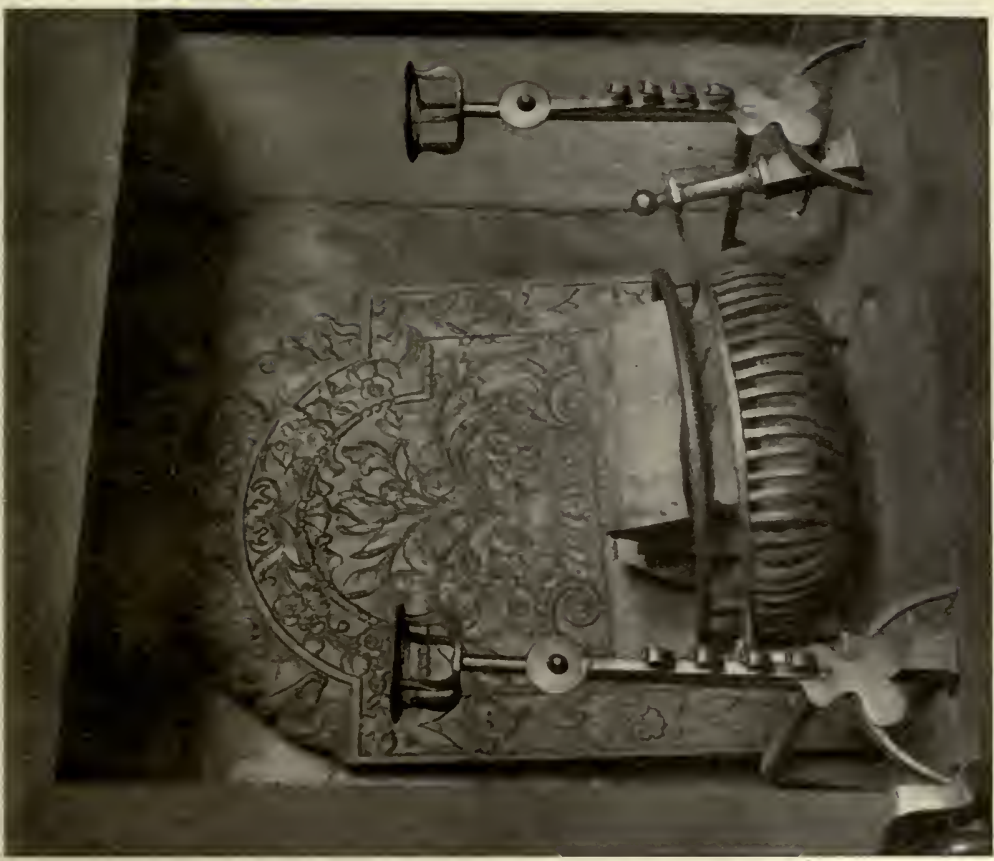

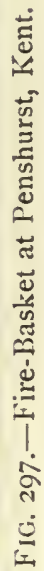

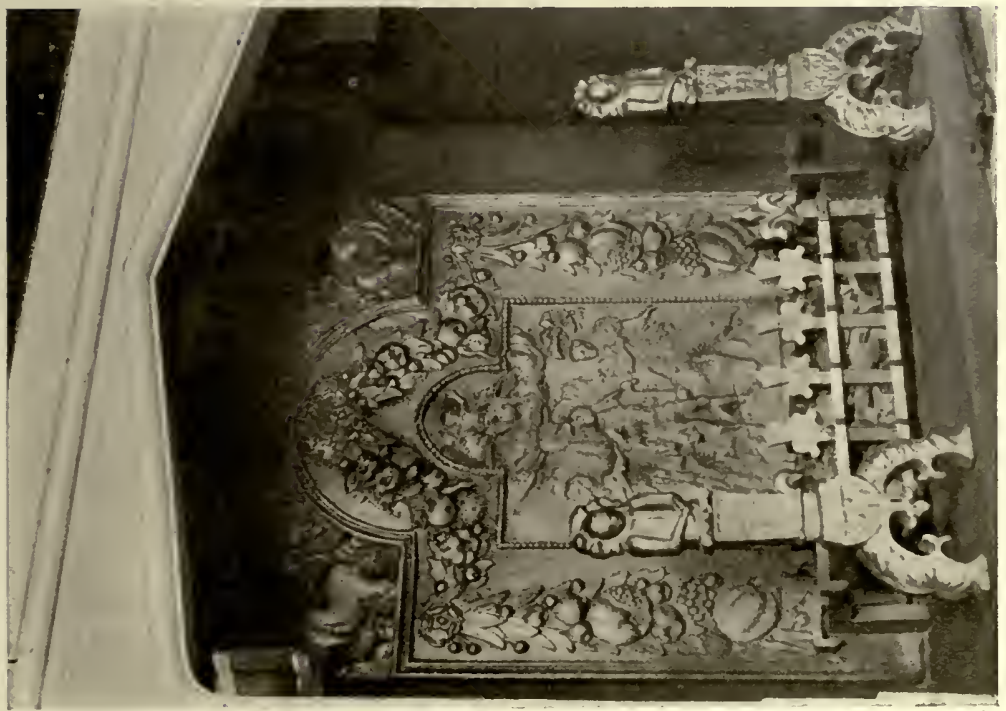

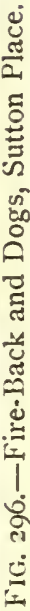




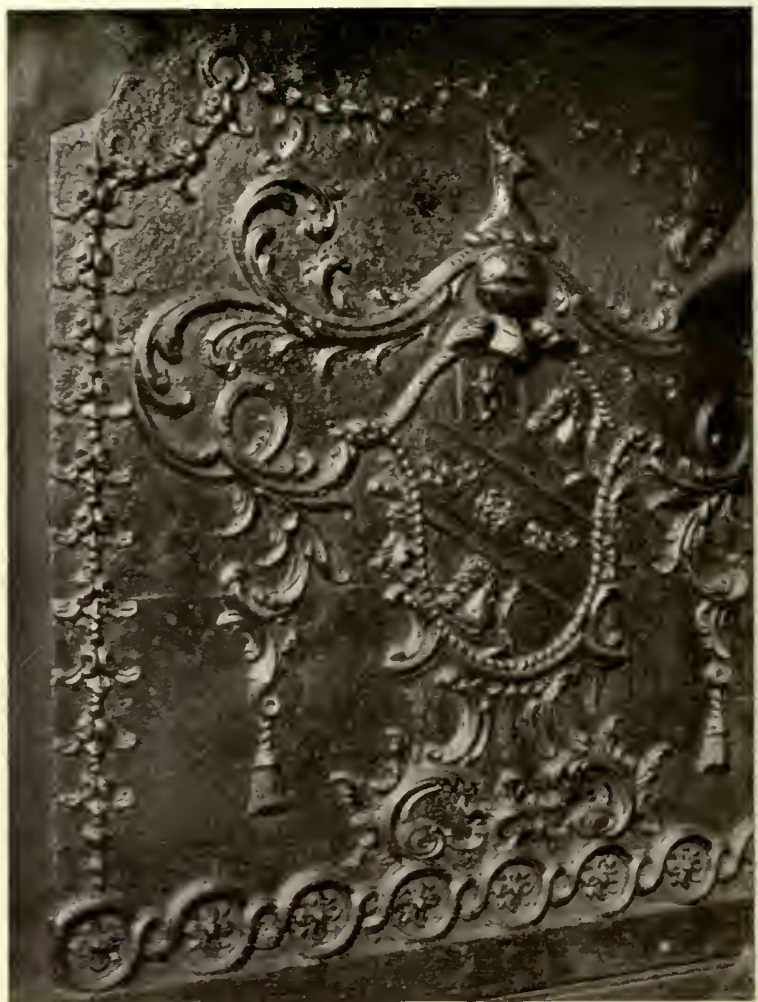

FiG. 298.-Jamb of Fireplace, Abbot's Hall, Battle Abbey, Sussex.

many years; now it was to become universal. The change is curiously indicated in some inventories of 1720 , made for one "Francis Hawes, of London, Esq., one of the late directors of the South Sea Company." When that great bubble burst Francis Hawes had to be sold up, and in consequence a complete statement of his affairs had to be prepared. It includes three inventories, two of manor-houses in the country, and one of a house in IVinchester Street, London. In regard to the point under consideration, some of the rooms, especially the bedrooms, had iron hearths, dogs, tongs, bellows, and fire shovels, which were requisite for the old-fashioned wood fires; others, including the parlours and hall, had the grates, shovels, tongs, pokers, and fenders requisite for coal fires. 


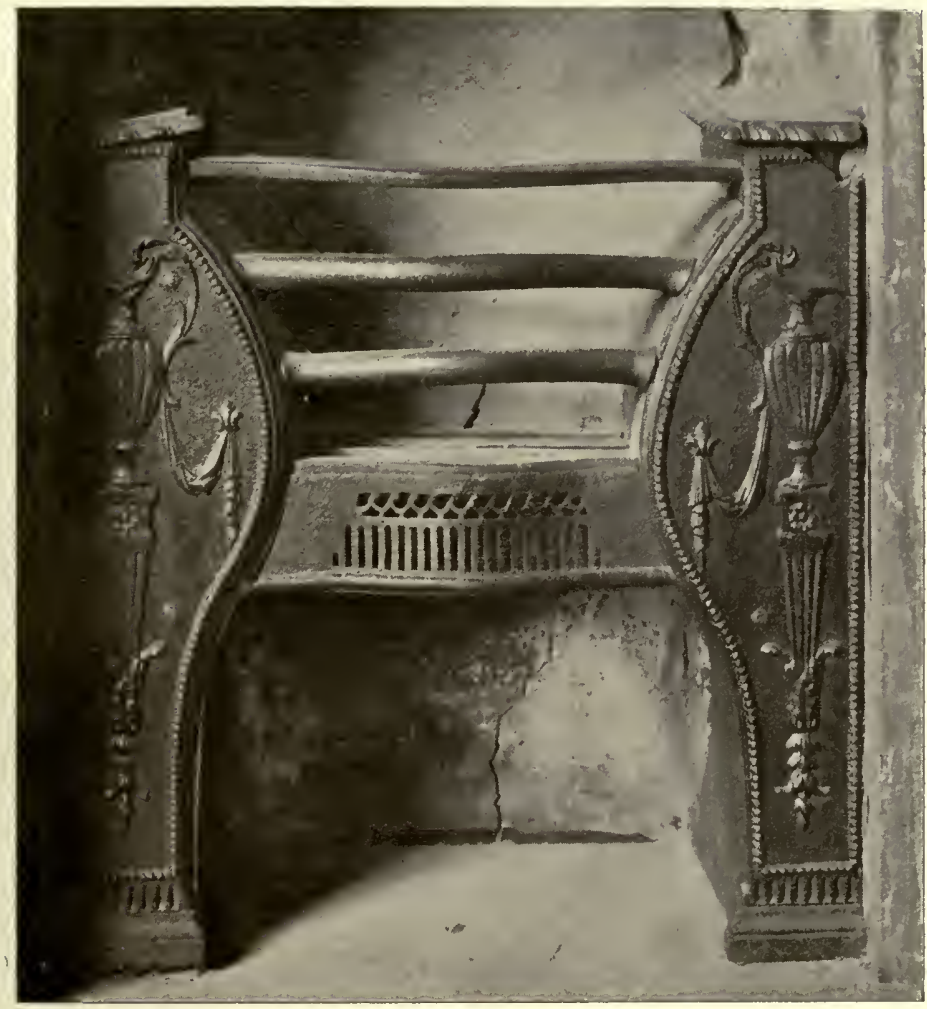

Fig. 299.-Fire-Grate at Kew Palace.

So, too, had the servants' hall, whereas the drawing-room had an open fire. We may, therefore, conclude that the rooms in most frequent use had the newer contrivances, the most noteworthy of which were the grates, the pokers (for breaking the coal, and quite unnecessary with a wood fire), and the fenders. It is clear that in I720 Francis Hawes had only partially adopted coal as his fuel, but the use of it quickly spread, and henceforward we find grates of various kinds in common use. Some of these were in effect baskets to hold the coal (Fig. 297), and they were placed in the old openings. Others were so large as to hold either wood or coal, an intermediate step of which there is an example at Dyrham, in Gloucestershire. In later years the basket grates gave way to cast-iron grates which filled the whole width of the recess, and were built 
in as fixtures (Figs. 299, 300). Some of the patterns were delicately modelled and charmingly designed, but as heatproducers these grates were crude to a degree. They merely held the coal. No attempt was made to regulate its consumption, or to direct its heat into the room; a large proportion went up the chimney, and chimneys were still built of the generous dimensions which had been customary in the days

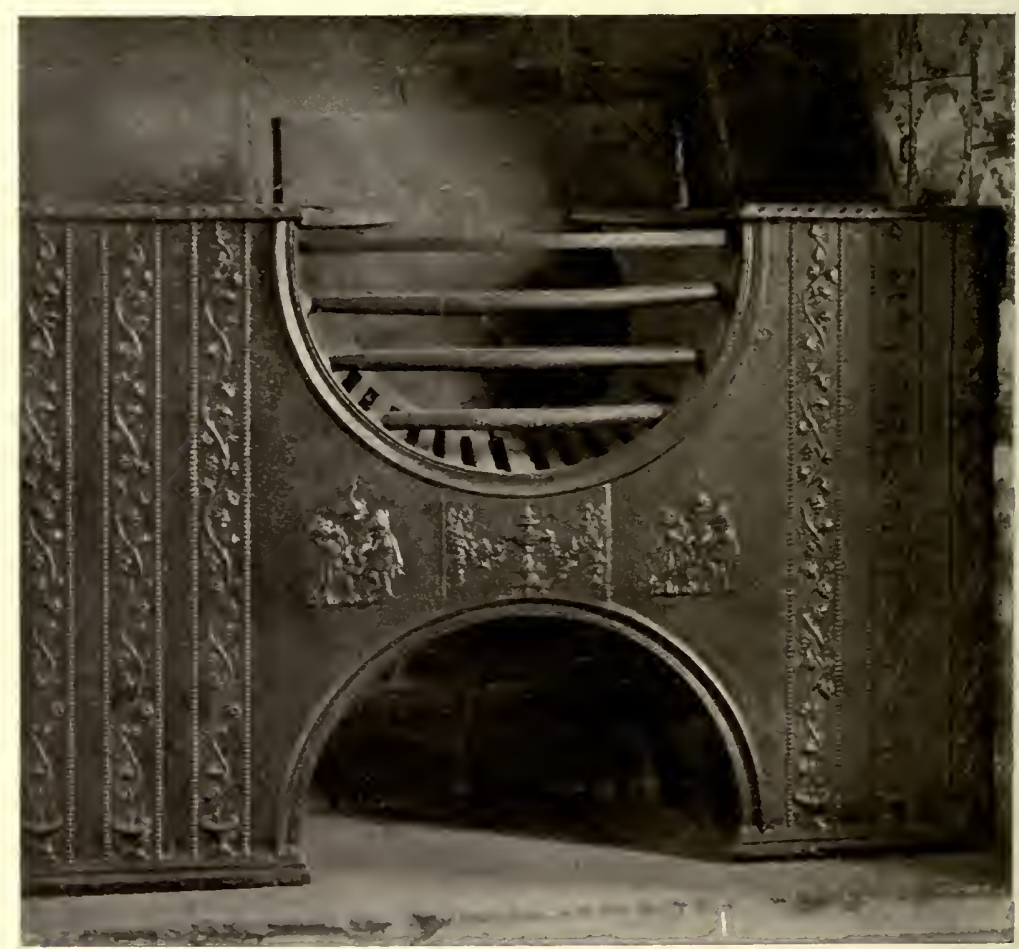

F1G. 300.-Fire-Grate at Kew Palace.

of wood fires. These generous dimensions were a length of four or five feet by a width of two or three at the base, gradually diminishing towards the outlet above the roof. IVhere the flues passed through the bedrooms they occupied a large amount of space, but generally left room at the sides for those deep cupboards which are often to be found in old houses. The only way to sweep such enormous shafts was for somebody to clamber up them with a brush. This dirty and dangerous task 
was usually imposed upon the chimney sweep's boy, until it was prohibited by legislation, but modern fires have flues of such small size as not to admit the most diminutive boy.

When huge fires were customary, they warmed the huge flues above them, and down-draughts were prevented; but when the same huge flues were warmed only by a basketful of coal, there was no longer the same upward draught, and the fires began to smoke. To remedy this, new fireplaces were made rather smaller, and the flues were slightly contracted; but the remedy was not effectual, and the next step, taken towards the end of the eighteenth century, was to fill up the large opening, and thereby restrict the access of air to the space occupied by the fire, and thus came into being the first of our modern fire-grates, which carry no suggestion with them of the ancient open fire on the hearth. This form of grate was an improvement, but it was wasteful and inefficient, and was at length superseded by the numerous modern contrivances which minimise the consumption of fuel, and direct more of the heat into the room and less up the flue. It would be rash to say that they have done away with smoky chimneys, but at any rate they have made them the exception rather than the rule.

The inventories of Francis Hawes are interesting in other ways than in marking the change from the ancient wood fires to the modern coal fires: they tell us of the manner in which his rooms were adorned and furnished. It would be outside the scope of the present inquiry to enter into these details at any length, but a few of the words thus spoken direct from the past may be worth listening to. The parlours of the London house were apparently panelled or otherwise decorated with some fixed material, since no mention is made of hangings. They had chimney-glasses, sconces of brass or glass, and curtains to the windows: of furniture one had two card-tables, ten red Turkey-leather chairs, a leather screen, sixteen pictures, and a painted cloth for the floor-not a very elaborate furnishing. The other parlour had a pier glass and marble slab, a scrutoire, six cane chairs, two Dutch chairs, a leather dressing-chair, two tables, a small nest of drawers, eight pictures, and a small carpet. The effect must have been rather bare according to modern standards, but these have gone to the other extreme, with the result that many rooms are now overcrowded with furniture. 
Upstairs one of the rooms must have been a gallery, for it had no chairs, but was full of curios and objets d'art. The bedrooms of all the houses were also sparsely furnished. They nearly all had large bedsteads, evidently four-posters, with furniture of different kinds, camlet lined with silk, yellow mohair, green or crimson harratine, green serge, and other materials. The walls were hung in most cases with materials of the same kind, blue china, crimson harratine, tapestry, mohair, or Irish stich and Dutch matting. There were curtains to the windows. One of

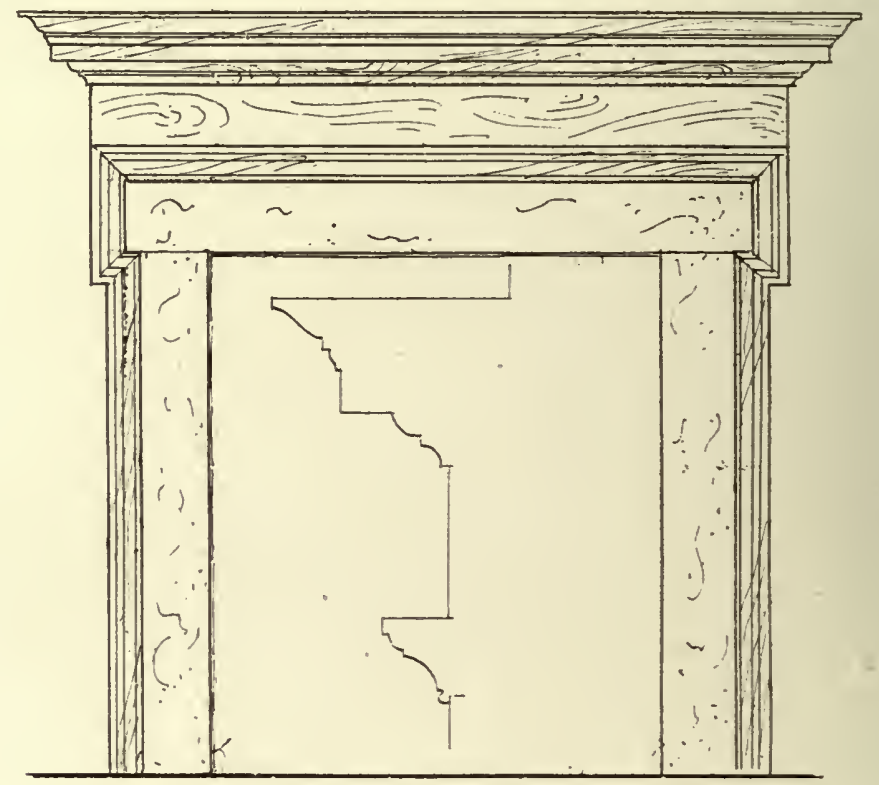

F1G. 3or.-Chimney-Piece in the George Inn, Winchester.

the smaller bedrooms had but a table and dressing-glass, a couple of chairs and a box ; another had a "bewreau" and a card-table in addition. The larger ones had two tables, half a dozen chairs, stools, a nest of drawers, a bookcase, and a number of pictures. It is noteworthy how seldom mention is made of a basin or even of a-dressing-table with a glass. This confirms what has already been indicated-that our ancestors of those days spent but little time upon their toilet. Very few rooms had a carpet but nearly every one had a hand-bell, some had as many as four. 


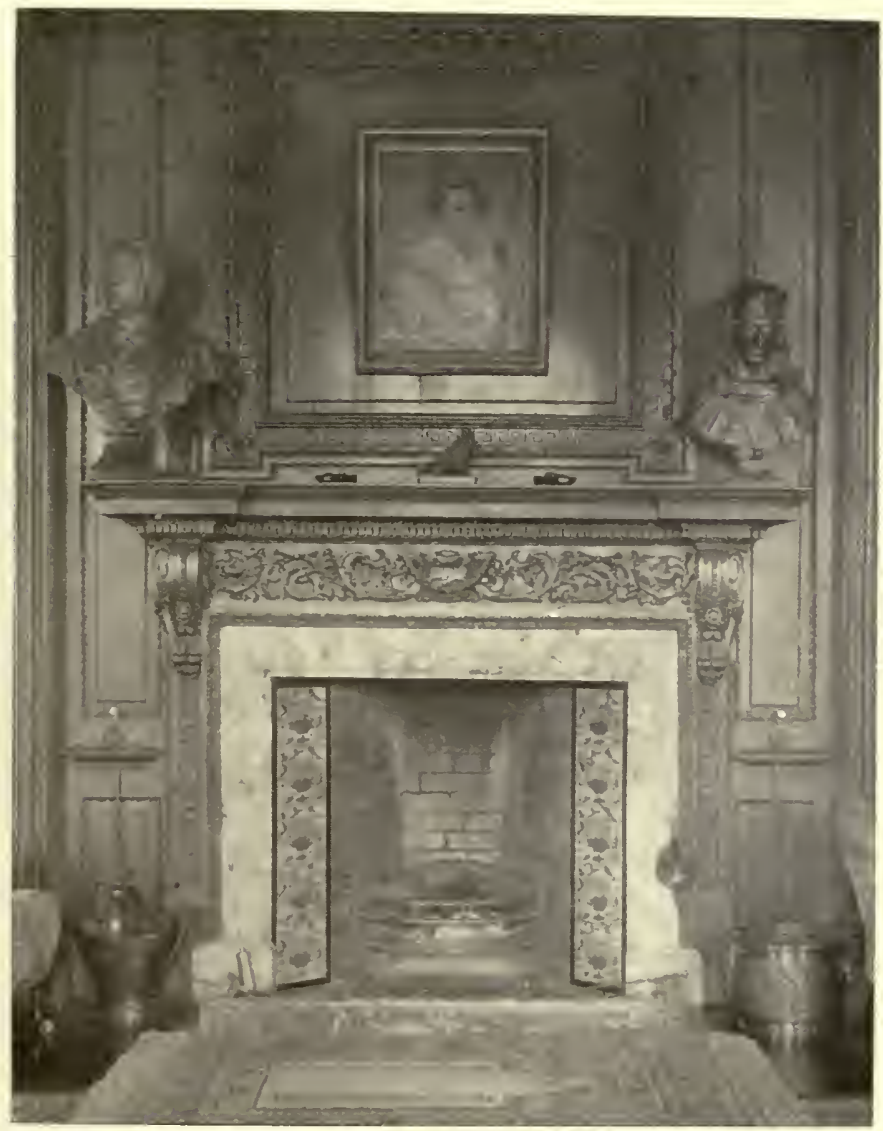

FIG. 302.-Chimney-Piece in the Deanery, Wells.

But to return to the question of fireplaces, and more particularly to the chimney-pieces which surrounded them. The method adopted in William III.'s time of having merely a bold moulding round the opening, tended to establish the practice of having chimney-pieces of one stage in height instead of two. In Jacobean time most of the large chimney-pieces reached from the floor to the ceiling; so they did in the mid-serenteenth century under Inigo Jones and John Webb, although a few of their designs show one stage only. When the "Designs of Inigo Jones" were published by Kent in 1727 , they gave an impetus again to the two-stage type, such as that shown in 


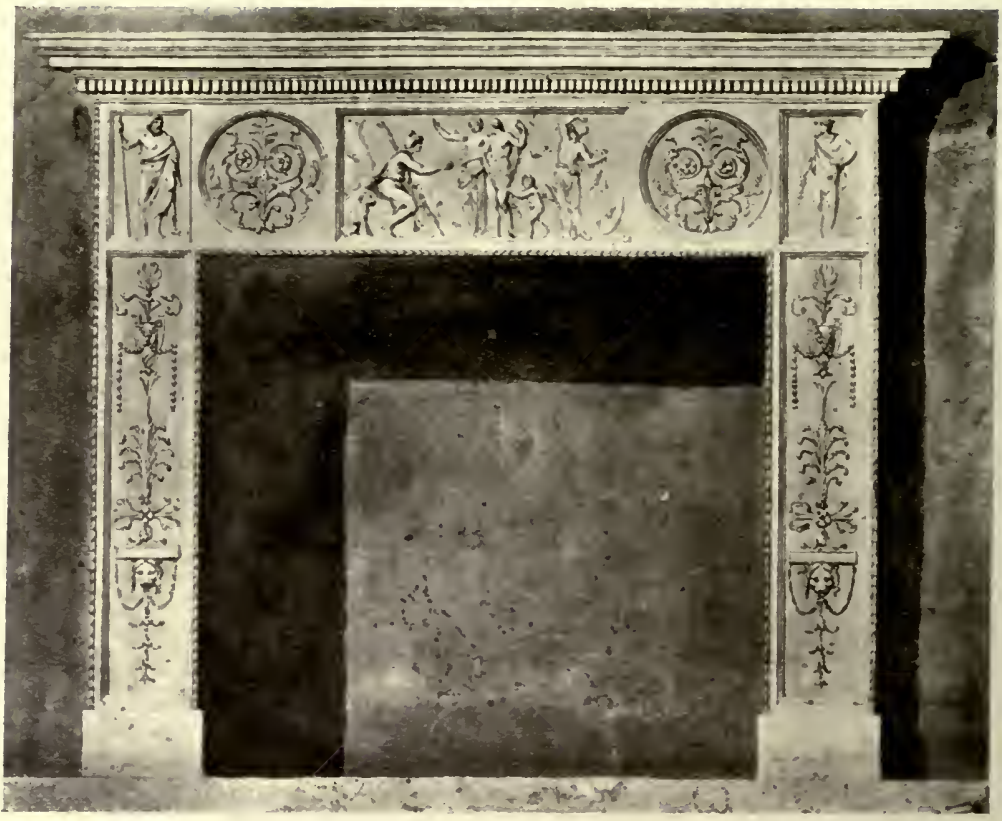

FIG. 303.-Design for a Chimney-Piece, by Flaxman.

From the Ionides Collection in the V. and A. II.

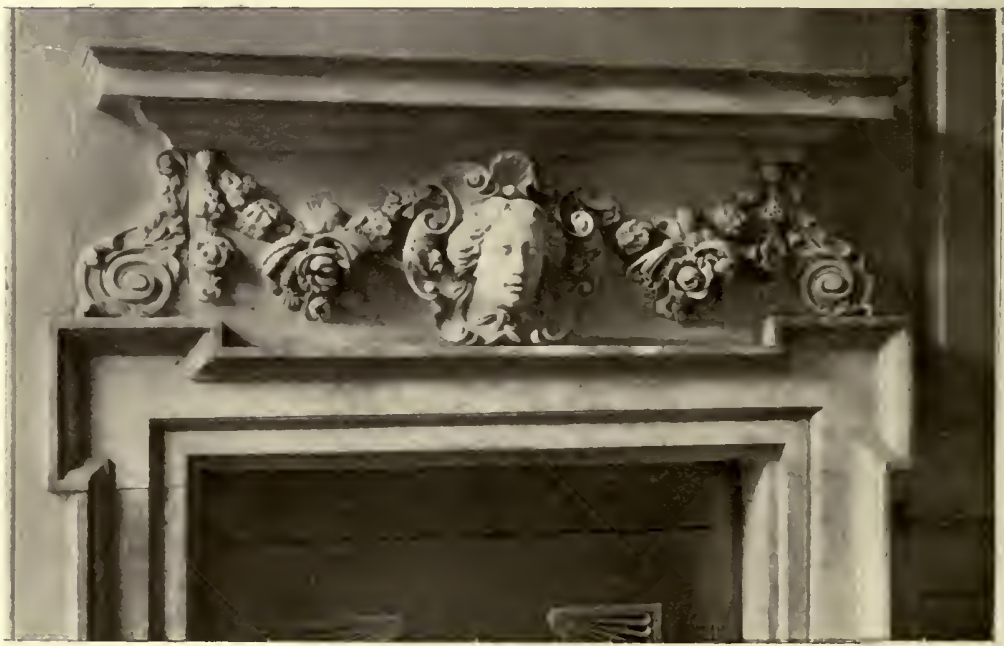

FIG. 304.-Marble Chimney-Piece, 6o Carey Street, London. 


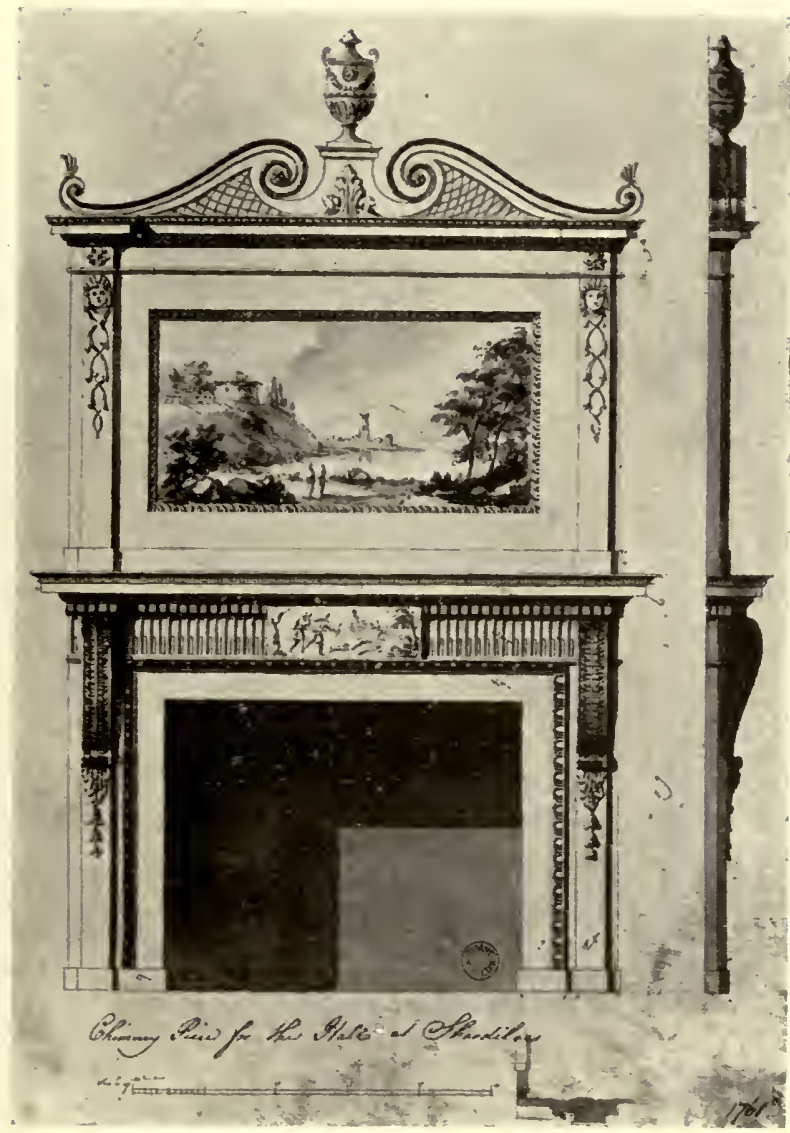

FIG. 305.-Design for a Chimney-Piece at Shardiloes House, 176r, by Robert Adam.

In the Soane Museum.

Fig. I 70; but smaller and less pretentious patterns were frequently adopted, of which a typical example is shown in Fig. $30 \mathrm{I}$; here a marble slab surrounds the opening, and is in its turn surrounded by a small wood moulding and surmounted by a flat frieze and a cornice which forms the mantel shelf. This type held the field all through the eighteenth century, sometimes plain, sometimes enriched, as in the example from the Deanery at Wells (Fig. 302). A variation, all in marble, is shown in Fig. 304, from a house in Carey Street. 


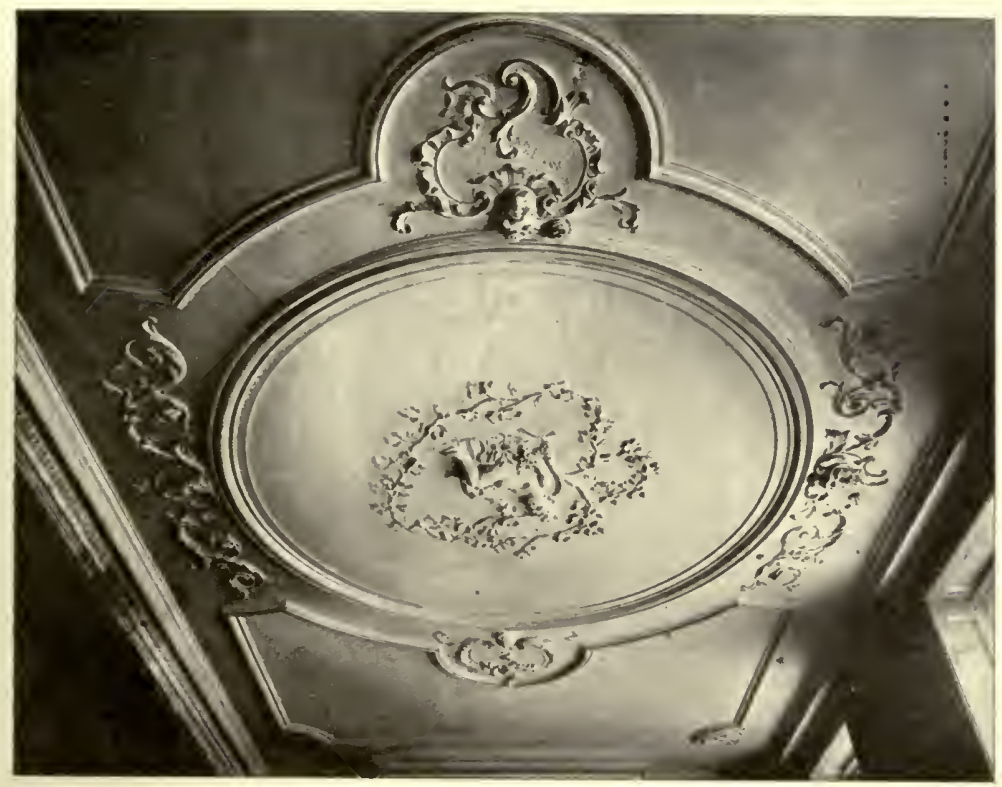

FIG. 307.-Ceiling at No. I6 Bishopsgate Street Without, London.

Now in the Victoria and Albert Museum.

Under the influence of the brothers Adam, detail of exquisite delicacy was introduced, including panels of well-modelled figures. This ornament was sometimes carved in marble or wood, but still more frequently worked in composition and applied to the woodwork. An example by Robert Adam is shown in Fig. 305, and a design by Flaxman in Fig. 303.

We have already seen in Chapter $\mathrm{V}$. how the busy ceilings of the Jacobean type changed into the coffered ceilings of Inigo Jones and Webb, who established a type which held the field, under Wren and his successors, well into the eighteenth century. The general tendency was to increase the relief of the plasterwork, to imitate nature instead of conventionalising it ; to work on the same lines which Grinling Gibbons was following with his carving in wood. The result was that the plasterwork had frequently to be modelled on wire which formed the stems of the leaves, and much of it was completely detached from the surface of the ceiling which it adomed. A very fine example of this treatment is to be seen in the Courts of Justice at Northampton (Fig. 306). 


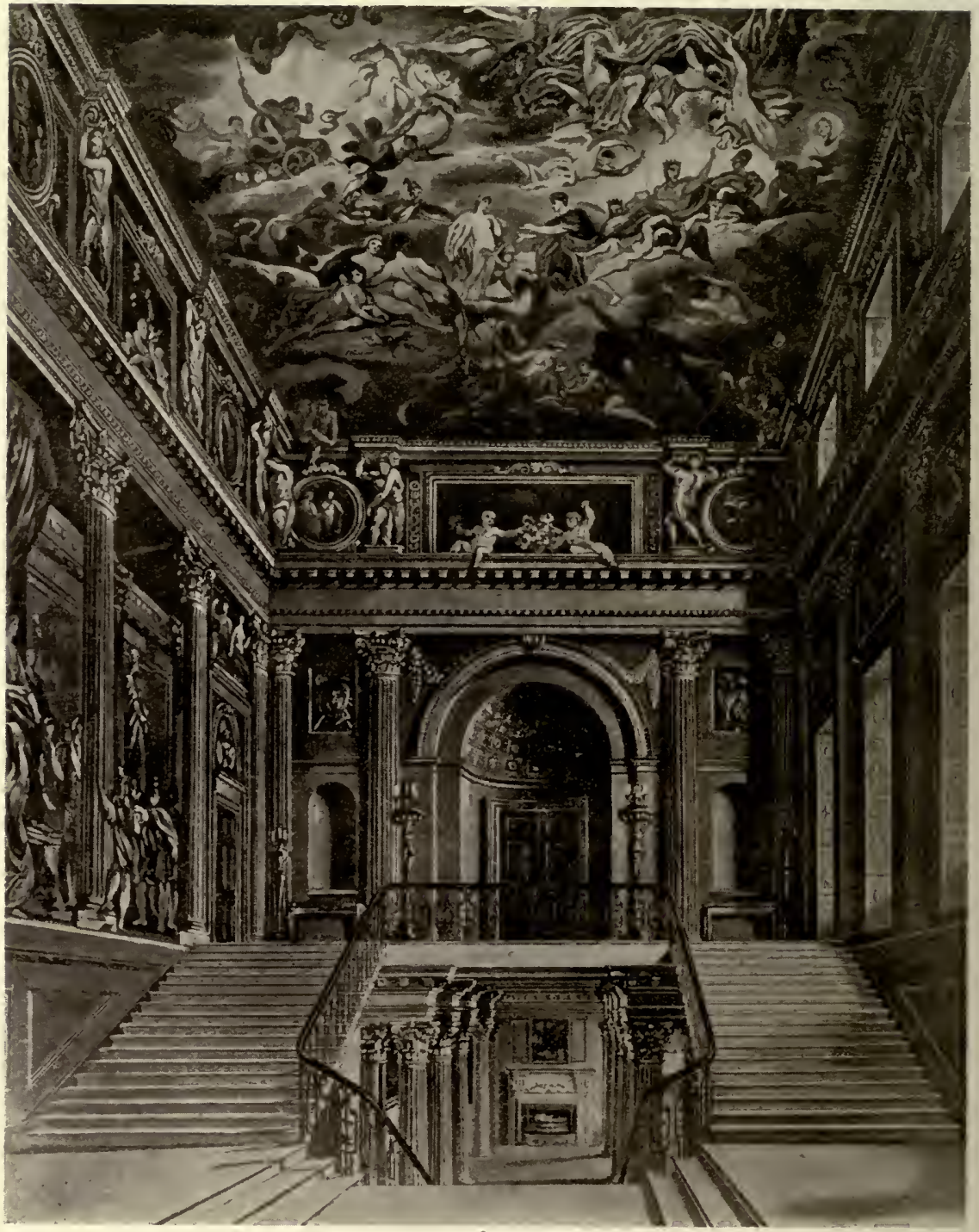

FIG. 308.-OLD BUCKINGHAM HOUSE. THE STAIRCASE, with Painted Cemixg and Wallo. 


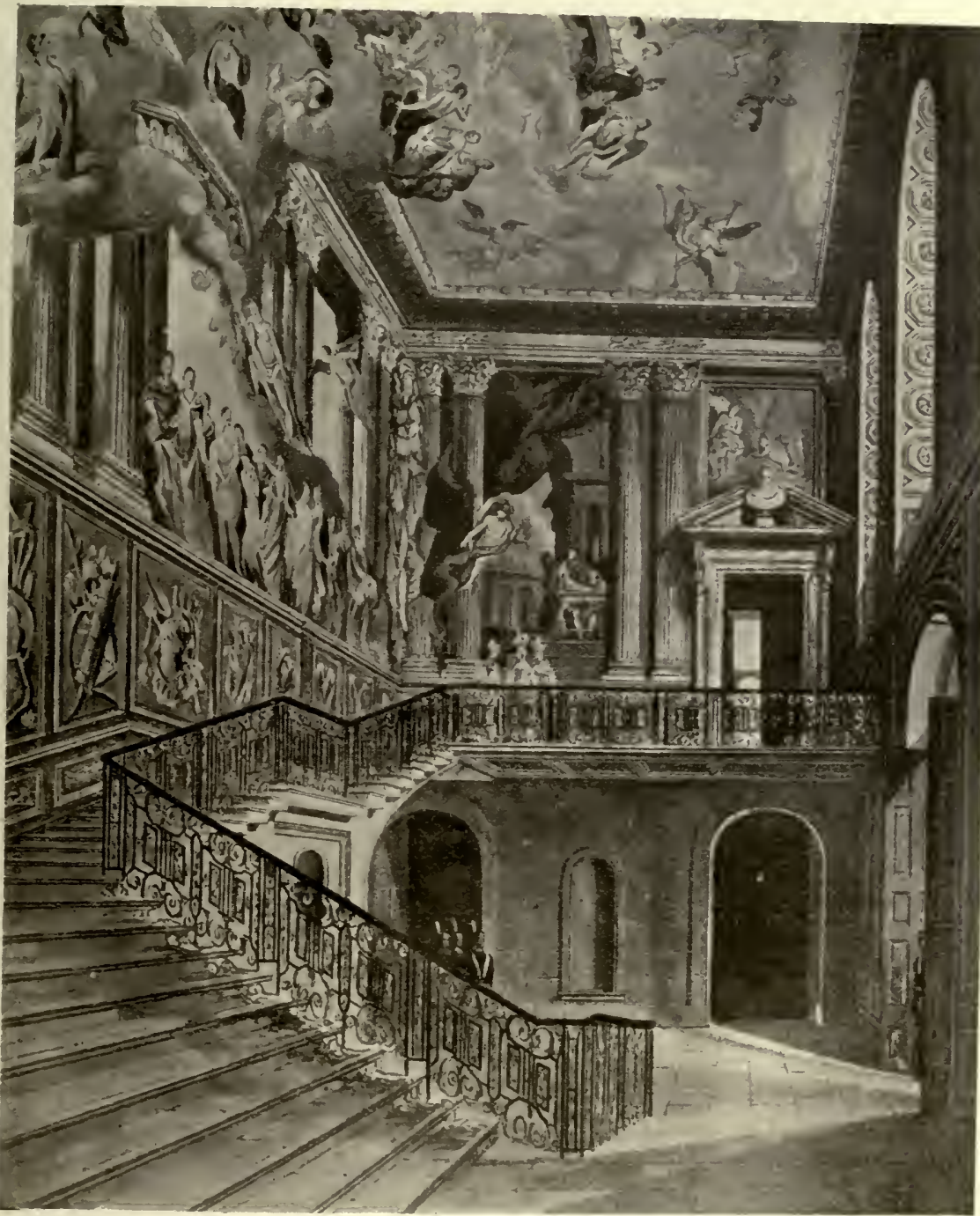

FIG. 309.-HAMPTON COURT PALACE. THE GRAND STAIRCASE, with Painted Ceilixg aNd Walls. 


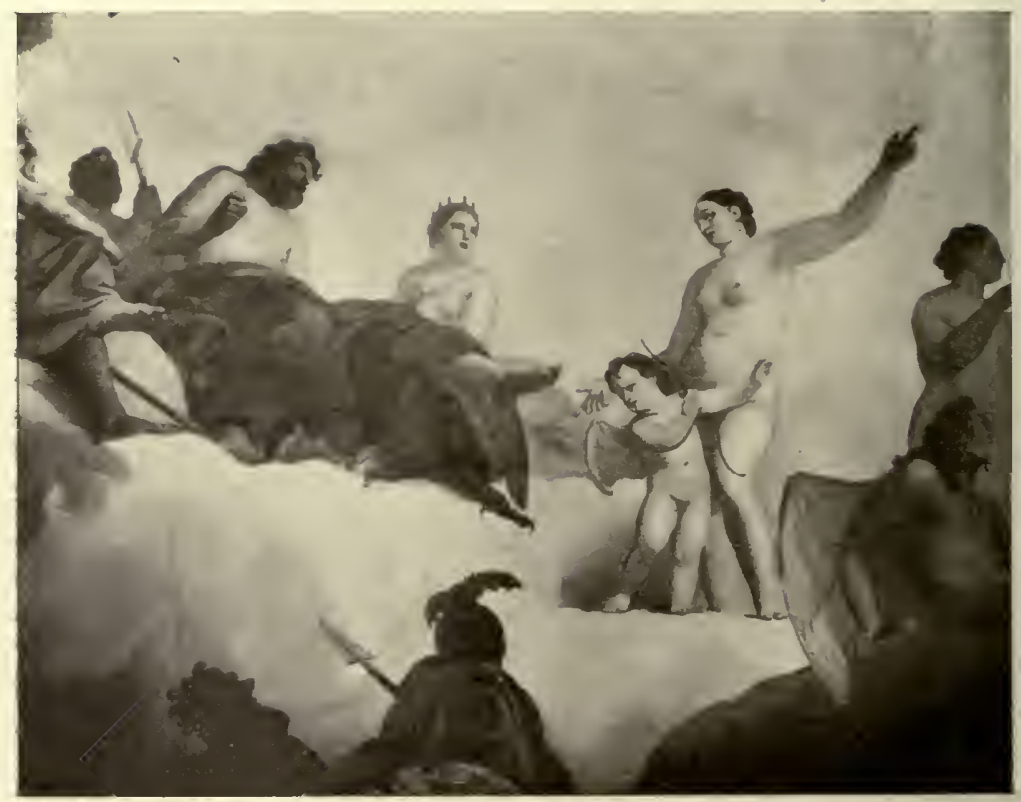

FIG. 3IO.-Part of a Painted Ceiling, Boughton House.

Contemporary with this kind of ceiling was a treatment entirely different, which was in vogue in great houses during the reigns of Charles II., James II., and IVilliam and Mary; this was the painting of immense plain surfaces with allegorical, mythological, and scriptural subjects. Old Buckingham House had a large ceiling of the kind over the principal staircase (Fig. 308 ); and the walls were painted so as to produce the effect of architectural perspective. This fashion is intimately associated with the name of Verrio, an Italian painter, who was brought to England by Charles II. He and his assistant and successor Laguerre are the best known of those who worked in this line of decoration, for they are immortalised by Pope, who describes how in a great house, being summoned "to all the pride of prayer" in the chapel-

"On painted ceilings you devoutly stare Where sprawl the saints of Verrio and Laguerre."

But there were several other artists engaged by wealthy noblemen to do similar work; among them was Cheron at Boughton House, and Lanscroo: 1 at Drayton, both in Northamptonshire. 


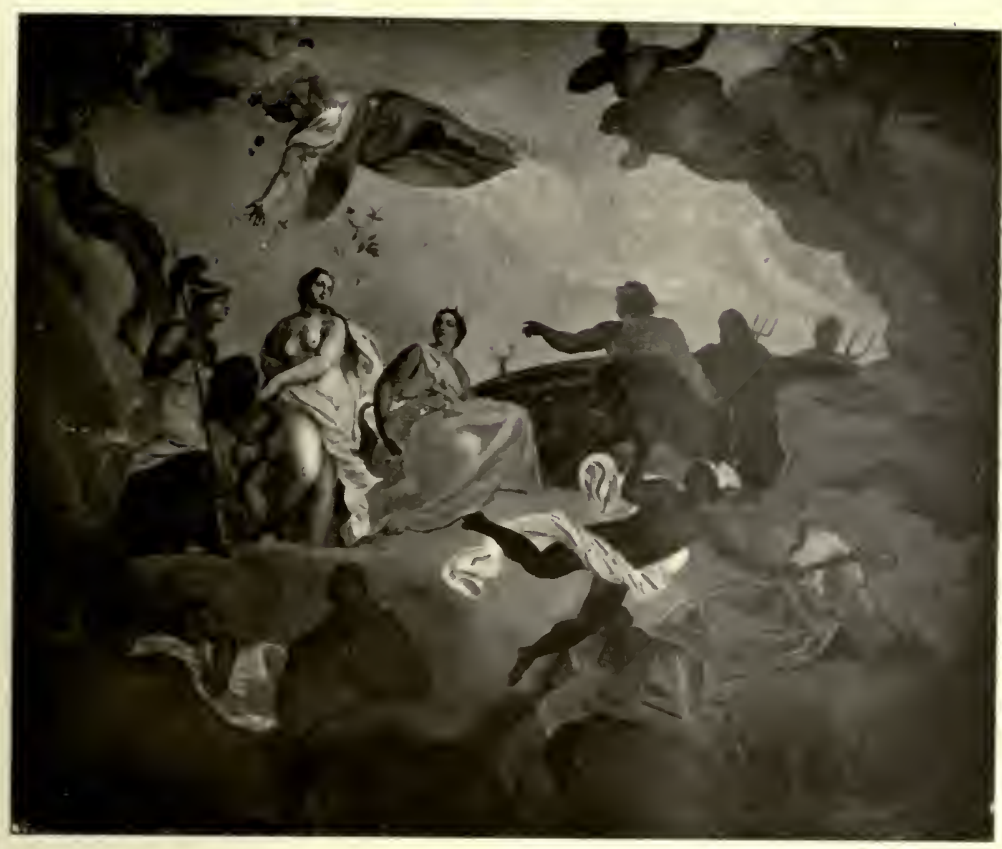

FIG. 3I I. - Part of Ceiling orer the Staircase, Boughton House.

But Verrio was by far the busiest of all, and did a vast amount of work at Windsor, Hampton Court, and Burghley House, among other places. Orer the grand staircase at Hampton Court (Fig. 309) the composition which occupies the ceiling is brought down on to the walls. This device was sometimes adopted with the view, apparently, of bringing ceiling and walls into one scheme; but although the technique is clever, the effect is rather confusing. The examples from Boughton House (Figs. 3IO, 3II) show a simpler and more intelligible treatment. Evelyn frequently mentions Verrio with high commendation, and his work and that of his school is extremely. clever, and were it more easily seen and with less physical discomfort, doubtless it would beget more admiration than it actually does. Verrio died in 1707 and Laguerre twenty years later. Their tradition was carried on for another ten or twelve years by $\mathrm{Sir}^{-}$James Thornhill, but it then died out, and painting on ceilings was confined to small panels.

It was chiefly in the larger houses that ornamental ceilings were now introduced. In those of ordinary size, and those built 
on speculation to let to tenants, the ceilings were for the most part plain. Where design was employed it became less ambitious, and during the second quarter of the eighteenth century it produced such comparatively simple work as that in a house in Bishopsgate Street Without (Fig. 307), or that in the Spenser room at Canons Ashby, in Northamptonshire (Fig. 312). Cottes-

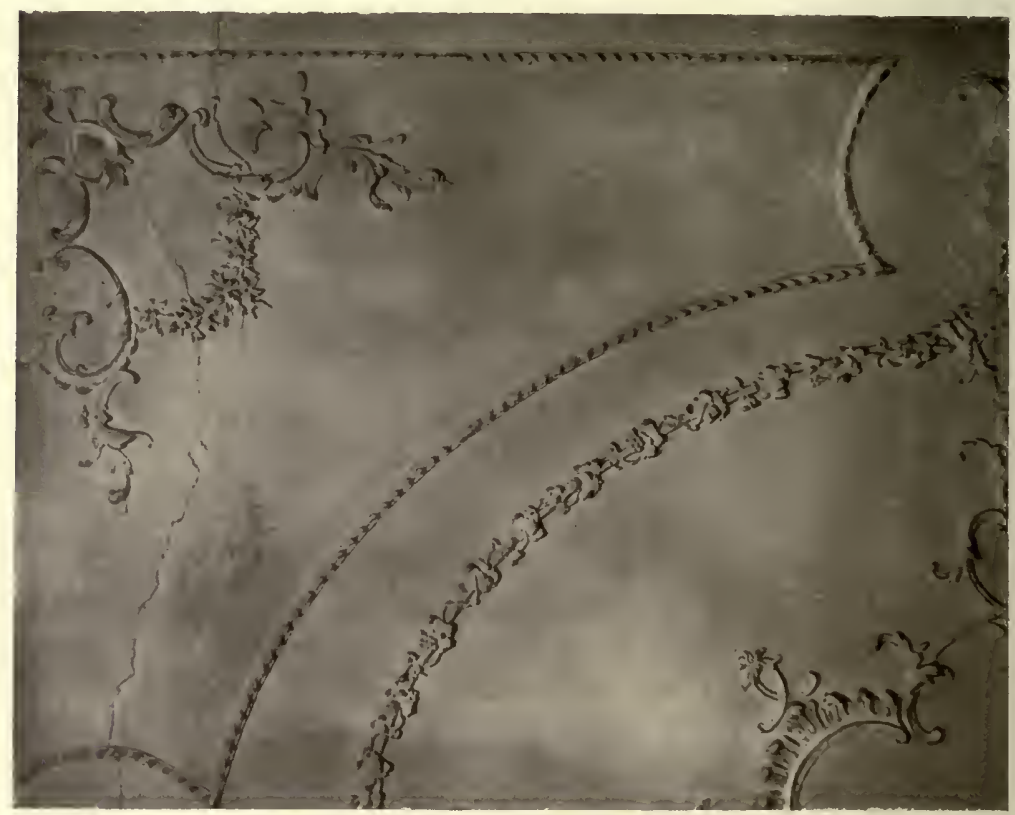

F1G. 312.-Part of Ceiling in the Spenser Room, Canons Ashby, Northamptonshire.

brooke House, in the same county, has some delicate work of much the same type (Fig. 3I3).

During the last half of the century, where ornament was applied to ceilings at all, it partook of the extreme delicacy and refinement associated with the name of the brothers Adam. The modelling was in low relief, but was done with great care and minuteness, and the flow of the thin lines of ornament was studied with close attention. This type is exemplified in the ceiling from a house in Wimpole Street (Fig. 3I4), and there are many such ceilings left in that neighbourhood, especially in Harley Street, which in its early days was inhabited by 


\section{MODELLED PLAS'TER ORNAMENT}

many distinguished people; William Pitt, Viscount Bridport, and Admiral Lord Keith did much to shape the history of their time; Allan Ramsay, portrait painter to George III., may stand for Art, and James Stuart, author of the "Antiquities of Athens," may represent architecture and archæology. At present these streets are more particularly associated with the pursuit of

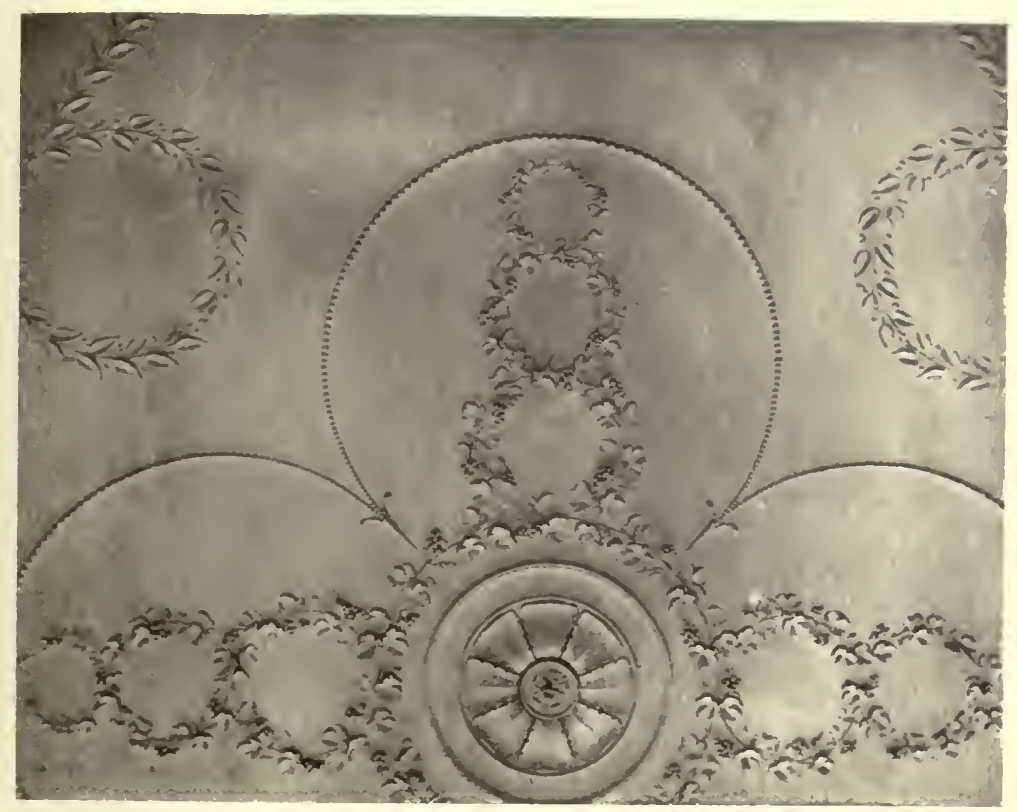

FIG. 3I3.-Part of Ceiling, Cottesbrooke Hall, Northants.

medicine; their inhabitants are no less celebrated than those of old, but their fame is of a special kind, and those who go to consult them on matters of life and death may weli be excused if they spare no thought for the decoration which corers the ceilings above their heads.

The work of the latter part of the eighteenth century was so dominated by the influence of the Adams that a few further examples of their designs may be of interest. In the staircase from a house in Mansfield Street (Fig. 315) all superfluous ornament has been eliminated, so much so that one almost longs for something less chaste and cold. In some moods and to some temperaments Venus is more attractive than Diana. 


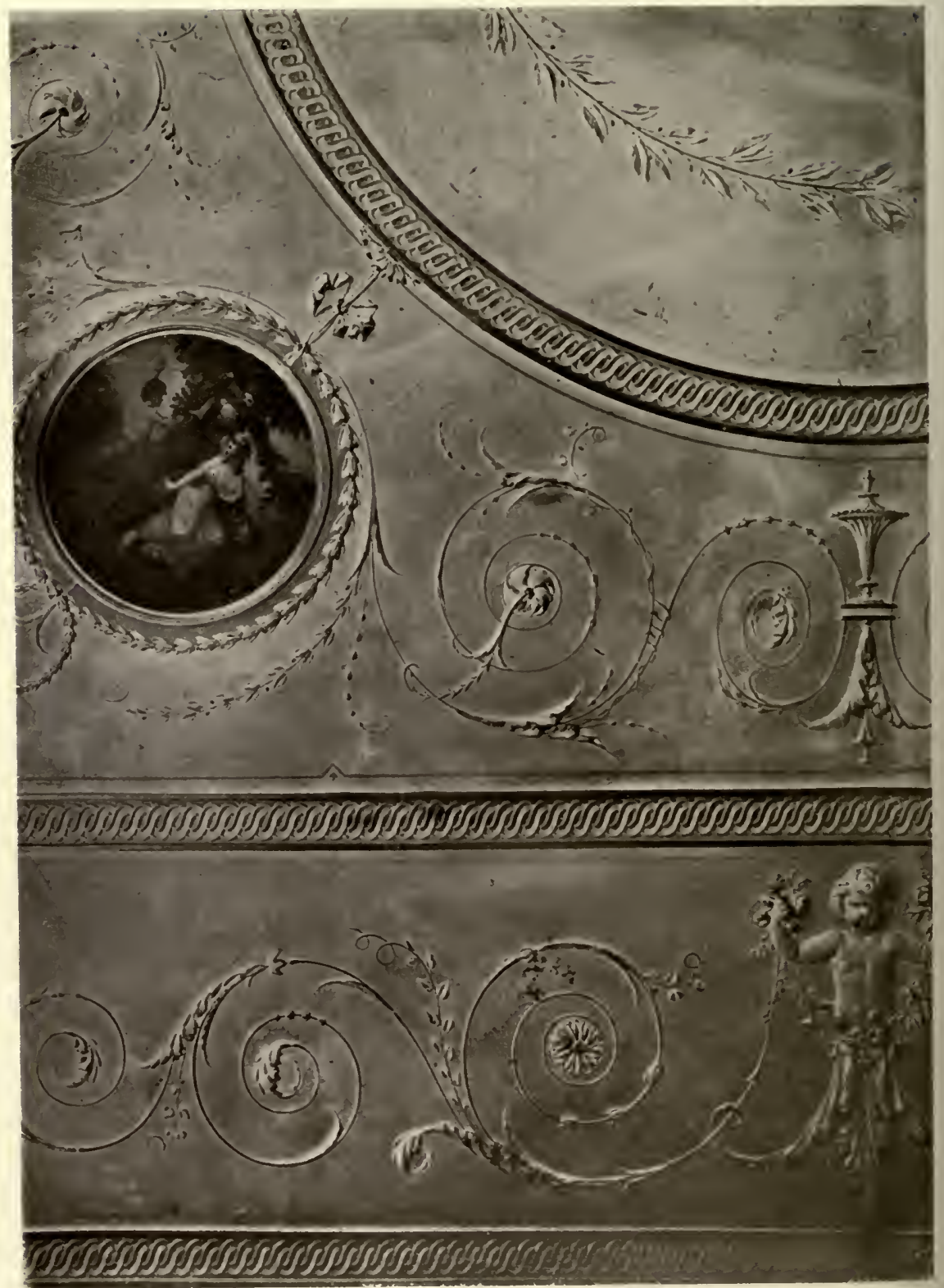

FIG. 3I4.-CEILING FROM WIMPOLE STREET, LONDON. 
But restraint is ever commendable, and restraint marks most of Adam's work. It is present in the doorway at Harewood House (Fig. 316) and in the two chimney-pieces, one from Belcombe and one from Bedford Square, figured in the illustrations 317,318 . In these it will be noticed that overmantels are replaced by designs worked on the wall itself. Their interest depends almost entirely upon grace of composition and skill in execution, and derives nothing from aptness of association with the houses or their occupants. In this respect the ornament differs from that of earlier days, when it was usually adapted from the family coat of arms; but the time had now come when houses were more often built to let to unknown tenants than as homes for particular families. In the drawingroom at Kedleston (Fig. 319) the treatment again strikes a note of simplicity and severity-a note which is seldom so well maintained in the disposition of the pictures and the choice of furniture as it is in this case. The ceiling and the great cove beneath it are filled with that flowing and delicate ornament which demands great accuracy of line and equal care in modelling its low relief.

As time went on this delicate ornament faded away and, except here and there, ceilings became merely large unbroken surfaces, save that with the introduction of gas-pendants there came the tradesman's centre-flower from which they might depend. This and an equally interesting cornice served for years as the principal decoration of most houses; the plasterer's art seemed to have died out. But for some time past matters have been improving, and, given the requisite money, ceilings can now be devised equal to anything that has been done in the past.

Indeed English craftsmen have always been able to produce good work when adequately guided. But modern conditions, among which one of the most pressing is the supply of an enormous number of cheap houses, are adverse to the display of that capacity for design and execution which requires some amount of leisure and a great amount of wealth to bring it forth.

There are indications that after the war a vast number of workmen's dwellings will have to be built, and, moreover, will have to be built cheaply. A survey of the domestic architecture of the last three hundred years is fruitful of suggestions for this undertaking, although it will be one demanding little or no ornament. Such a survey points 
towards a suitable placing of the houses on the site; avoiding dreariness and monotony on the one hand, and on the other avoiding attempts at the grandiose, and the imposing on posterity a scheme too complete in itself, to allow of those variations which time will inevitably require. It points equally to treating the houses themselves with a simplicity. corresponding to the simplicity of the requirements. It points further to the value of good, sound building. The smaller Georgian houses, which we find so charming, furnish admirable suggestions. No attempt at actual reproduction need be made; but the means which produce the effect in the old houses can be applied to the new. These means are simple enough. The general proportion, the size and shape of the windows, and the shadow of the eaves will be found on examination to be the chief causes of the pleasure which many of the old houses arouse.

The past has not only its suggestions, but also its warnings, and of these the most obvious is against the impairing of comfort and convenience for the sake of appearance. The first canon of utilitarian art is that an object should answer its purpose well. It is in availing himself of these suggestions, and in profiting by these warnings, that the architect is enabled to help his own generation and give pleasure to those that come after.

The vast increase in population during the last two hundred years has accentuated the division of the course of design into two streams; one directed by the highly trained architect, the other by the workman trained only in the use of his tools and the knowledge of his materials. Could the two streams be brought into one channel they might flow on into ideal conditions. But the very complexity of modern life has a tendency to resolve itself into the simplicity of specialisation.

Since the beginning of the eighteenth century the course of domestic architecture has been conditioned partly by the nation becoming too large and complex to admit of a single expression in national architecture; partly by the tendency, common to all the arts, for ideas to pass into excess in one direction and into tenuity in the other. A wider outlook over the civilised world, a greater knowledge of the achievements of foreign countries, led inevitably to the disappearance of a truly national style, such as that which we call Gothic. On the one hand the homes 

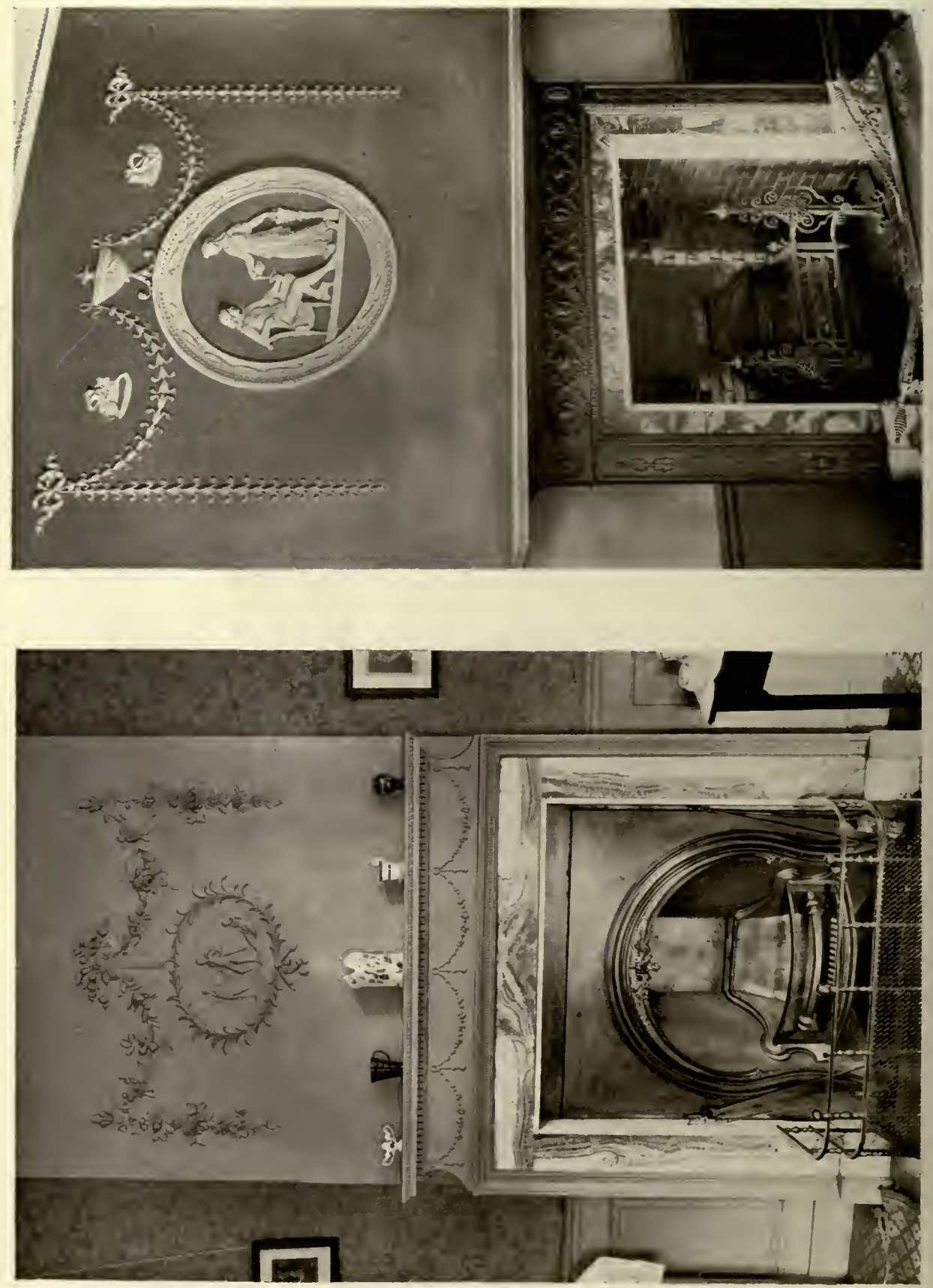


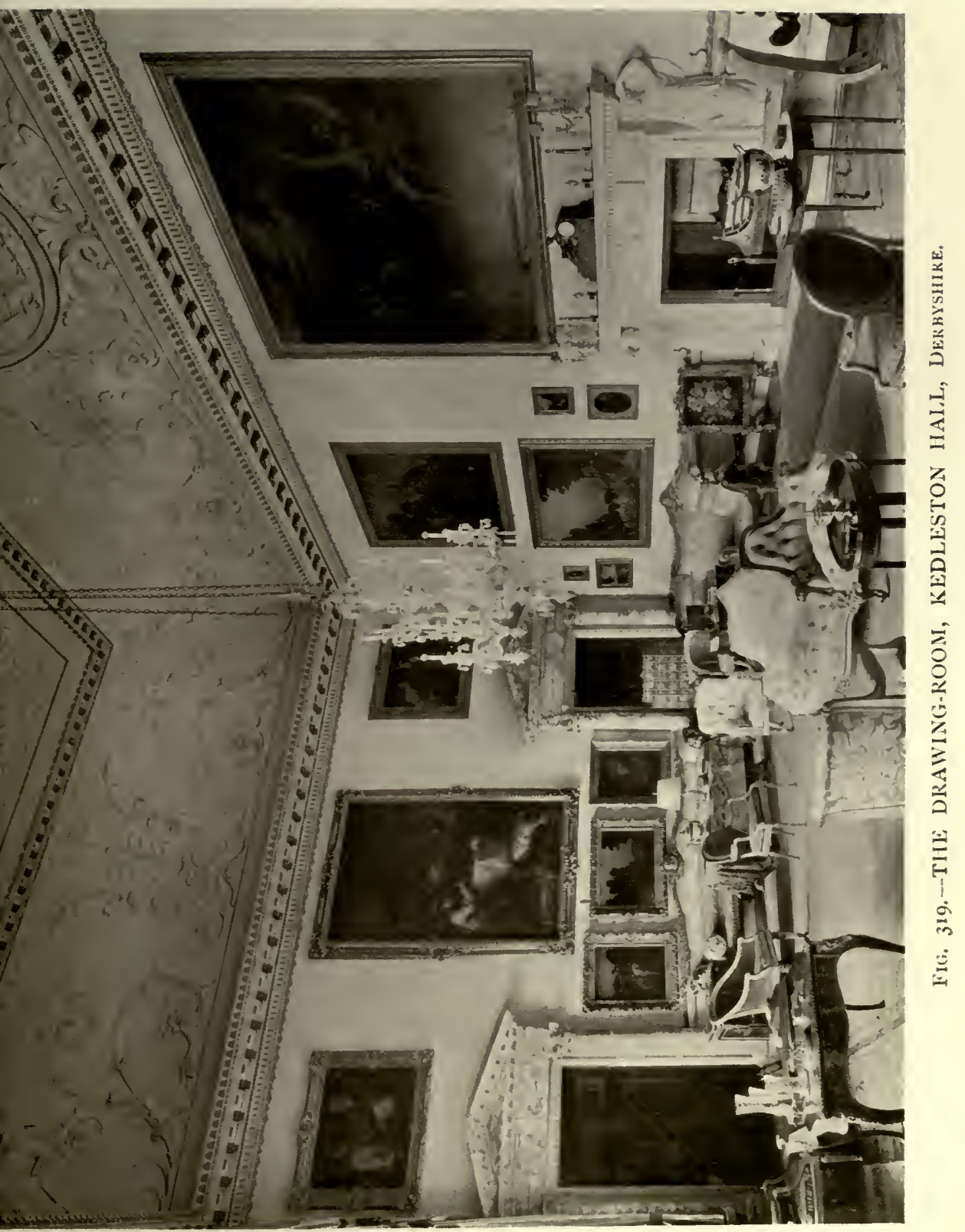




\section{PROGRESS OF DOMESTIC ARCHITECTURE}

of the wealthy grew in splendour and in fidelity to theories of architecture expounded in books, with the result that use and convenience were largely subordinated to grandiose effects. On the other hand, richness of architectural thought declined in smaller houses through the stages of dignity and comfort down either to a consistent plainness of character or one only marked by individual caprice. Such caprice, schooled by a study of bygone styles, led to the eclectic imitativeness of the nineteenth century. But the last twenty years have seen many signs of a new beginning. Based upon actual needs, and striving after beautiful expression, domestic architecture is slowly progressing on lines characteristically English. Sooner or later this movement will accelerate, and will eventually reach heights as great as those upon which we now look back with admiration and delight. Architecture, like other arts, is immortal ; the qualities of proportion, ornament, and fitness can never long be disregarded, for no building is quite complete which is not beautiful to look upon. 


\section{APPENDIX I}

\section{Sir Roger Pratt}

THE foregoing pages had already passed through the press when the contents of the note-books of Sir Roger Pratt were placed at my disposal by the courtesy of his descendant, Edward Roger M. Pratt, Esq., of Ryston Hall, Norfolk.

Roger Pratt is mentioned in the text (p. I 8o) as the architect of Clarendon House, built by the Lord Chancellor Hyde, and as one of the men whom the great fire of London led into the pursuit of architecture. But his note-books show him to have been a student and practitioner of the art before that event. He was under no necessity to earn his own living, as he appears to have been a man of means, succeeding to his father's property before he was of age, and in later years inheriting from his cousin the estate of Ryston. Still his interest in architecture was more than that of an amateur, for he clearly had a good knowledge of building, and a practical acquaintance with the many matters involved in the erection of large houses.

He was born in 1620 , and entered Magdalen College, Oxford, when he was nineteen; in the following year he became possessed of his father's property, and three years later, in I643, he went to travel abroad. He visited France, Italy, Holland, and Flanders, for the purpose, as he states, to "give himself some convenient education"; his tour lasted six years, thus keeping him away from England during the troubled times of the Civil IVar. This education was evidently in architecture, for although he became a member of the Inner Temple in 1657 , there is no record of his having followed the law as a profession. He had rooms in the Temple from the time of his entrance until 1676 , and doubtless they enabled him to enjoy congenial society and provided him with a convenient residence during his frequent visits to London. For more than half his tenancy he was a bachelor, for he did not marry until he was forty-eight, when he took to wife, in the year 1668, the eldest daughter of Sir Edward Monins of Kent, a lady of good family- "descended," as he said, "from ye second best famely in hir county"-who brought him a fortune of $£_{4}, 000$. The same year saw another 
notable event in his life, the conferring of a knighthood upon him by Charles II.

A year before his marriage he had succeeded to the Ryston estate, and thenceforward he appears to have followed the life of a country gentleman, for we hear no more of him in connection with architecture, save that he designed and built himself a new house at Ryston, which remains to this day, and is the only example of his work left, unless the attribution of Coleshill to Inigo Jones is a mistake. There is no doubt that Roger Pratt had something to do with Coleshill, which was built by a relative of his, Sir Henry Pratt; for he says, in considering the proportions of cornices for ceilings, "all wh. 4 last recited proportions have bin made use of by mee at Sr George Pratt's at Colsell." Sir George was the son and successor of Sir Henry.

Most of the gentry at this time, as John Webb tells us, had some knowledge of the theory of architecture, "but nothing of ye practicque." Roger Pratt bettered his fellows in this respect, for not only had he a wide knowledge of the art, as understood in the seventeenth century - of the architecture, that is, of modern Italy and of Palladio in particular-but he was familiar with the qualities of materials and the routine of building, not to mention tactful methods of accounting for "extras."

During his stay in Rome he met John Evelyn, who appears to have acquired and preserved a high regard for him. Twenty years later, in writing to Lord Cornbery on 20th January 1665, about his father's mansion of Clarendon House, Evelyn said that Roger Pratt, his old friend and fellow traveller (co-habitant and contemporary at Rome), had "perfectly acquitted himself." The turn of events had brought them together about this time, when both of them became commissioners for the repair of St Paul's Cathedral and for the rebuilding of London after the great fire.

Pratt's chief works were Horseheath in Cambridgeshire for Lord Allington, and Clarendon House. The former was begun in 1663, and was a magnificent mansion. There are many technical notes relating to it in the note-books, but not much of general interest beyond its dimensions. It was dismantled in 1760 , and sold for the value of the materials.

The notes concerning Clarendon House, which was begun in I664, are more voluminous. They serve to show that Pratt was a practical architect, that he was fully acquainted with the 
details of the various trades, and was alive to the chances of crooked dealing by the workmen. He deals with the levels of the site and the setting out of the house, which was to be placed central with St James's Street, truly parallel with the frontage line, and set back $160 \mathrm{ft}$., whereby a court of that depth and of a width of $2 \mathrm{I} 4 \mathrm{ft}$. would be obtained. Another lively touch is given by his instructions to the mason regarding the coat of arms in the tympanum of the "frontispiece," the central feature of the front. The description which he incidentally gives agrees with what is shown on the engraving. But more interesting and more entertaining are the reasons he adduces in a draft

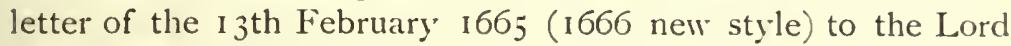
Chancellor for the cost having exceeded his estimate. The foundations were much deeper than was expected, an old pond having been found on one part of the site, and a vast hole the whole length of my lady's pavilion on another. Severe frost rendered it necessary to take down and rebuild some of the work. My Lord Cornbery caused a foot to be added to the height of the first floor, much increasing, it is true, the nobleness of the effect. The bricks cost more; the Dutch war increased the price of timber, and the carpenter threw up his contract, leaving himself to the mercy of his employer; but the plague had infected the whole town, and workmen everywhere died. It was agreed, therefore, that by fair words and promises the carpenter should be encouraged to persist in his undertaking, which he only consented to do on a fresh basis of pay, whereby his account was increased by at least one-third more than his original price.

In addition to the notes relating to these two houses in particular, there are Notes as to the building of Country Houses, dated I660, and Rules for the Guidance of Architects, dated 1662. These fill many pages, and would have made a much more useful book, had they been published, than Gerbier's "Counsel." Space forbids long extracts, which indeed might prove tedious to all but enthusiastic students of this period; but three matters are worth mentioning. First, it is recommended that a house should be placed so as to take advantage of existing trees in the approach and lay out, and to obtain a fine prospect. This must be one of the earliest expressions of a deliberate liking for natural scenery. Secondly; Pratt advises those about to build a house "to get some ingenious gentleman who hath seen much of that kind abroad and been somewhat versed in the best authors of architecture, viz., Palladio, 
Scamozzi, Serlio, etc., to doe it for you and give you a design on paper." This will be far better than trusting to a homebred architect, who would be inexperienced in such matters, as. is daily seen. The paper design having been agreed upon, a model of wood should be made, and as a final precaution, other houses of a suitable kind should be visited and studied.

The third point of interest lies in his references to Inigo Jones's work. In dealing with fine examples of architecture he says that with us in England there is nothing remarkable but the Banqueting House at Whitehall and the Portico at Paul's. Elsewhere he cites the Queen's House at Greenwich. As far as it goes, his testimony appears to confirm the view taken in the text as to Jones's work.

In addition to these notes on houses, there are others relating to St Paul's, and to the steps taken for the rebuilding of London after the fire. In relation to the latter, he was asked by the other commissioners to undertake duties which would now devolve upon the Secretary. In regard to St Paul's, he has a page or two of criticism on the model designed by "Dr Renne," I 2 th July 1673, as it offered itself upon a short and confused view of a quarter of an hour only. In 1673 Wren's farourite design was approved by the king, who issued a warrant for building in accordance with it on I 2 th November, and caused a model to be made (illustrated on p. 146). The details of Pratt's criticism do not apply very aptly to this model, and we seem to be faced with two alternatives: either that his criticisms, written from memory after a hasty examination, were rather wide of the mark; or that they refer to a design different from those which have so far come into prominence from among the numerous drawings prepared by $W$ ren in connection with St Paul's.

The later note-books are chicfly concerned with estate management, and we gather that after the building of the house at Ryston, Sir Roger Pratt settled down in the country. He died on the 20th February I684-5, and was buried at Ryston, leaving a widow and three sons. His widow subsequently married again, and survived until 1706.

The note-books, of which there are eight, are mostly bound in parchment, and by way of fastening, are tied with two sets of parchment strips. They bear a strong family resemblance to the sketch-book of Inigo Jones, preserved at Chatsworth. 


\section{APPENDIX II}

\section{The Architects of Coleshill, Berkshire}

FURTHER interesting information regarding Sir Roger Pratt's connection with Coleshill has been supplied by the kindness of Mr Pratt of Ryston, and the Hon. Mrs Pleydell Bouverie of Coleshill. It is derived in part from Sir Roger Pratt's notebooks, and in part from a diary of Sir Mark Pleydell (1692-I 768), preserved in the muniment room at Coleshill.

The estate of Coleshill was bought from the Pleydells by Sir Henry Pratt, a grandson through a junior branch of William Pratt, who was Lord of the Manor of Ryston in 1628. Sir Roger Pratt was great-grandson of the same William through the senior branch. The estate returned to the family of Pleydell in I699, by the marriage of a Pleydell with the heiress of the Pratts of Coleshill.

Sir Henry Pratt died on 6th April I647, and the old house at Coleshill which he had bought was burnt down later in the same year, shortly after the marriage of his son, Sir George. The present house was begun in 1650 , according to the tablet still preserved therein. Of this Sir Mark Pleydell says in his diary that Sir Roger Pratt of Ryston in Norfolk, knight, cousin to Sir George, was the architect in friendship to him. He also observes that "Mr Mildmay apprehended it was built by InigoJones, and Lord Barrington says it was built by one IVebb, a disciple of the said Inigo."

In the same diary it is stated that before the existing house was commenced Sir George Pratt began to build a new seat in "the present cucumber garden," which he raised to one story, when Pratt and Jones arriving, caused it to be pulled down and rebuilt where it now stands. Sir Mark adds that Pratt and Jones were frequently here, and Jones was also consulted about the ceilings. "John Buffin, who often saw them both, frequently declared this to $\mathrm{Wm}$. Pepal, who came to Coleshill in I 700, and carried him to the spot in ye cucumber garden. We found ye remains of ye walls in ye cucumber garden ye Ioth February I 746."

It is interesting to find that Jones, Webb, and Pratt were all 
concerned in the design, and it is tolerably clear that Pratt had a large hand in the matter, not only from Sir Mark Pleydell's express intimation, but also from Sir Roger Pratt's own notebooks. It will be remembered that Jones died in 1652 , but the house was not finished until some years afterwards, probably in 1664. Roger Pratt has entries in his note-books that in December $16 ; 6$ he gave Sir George Pratt's man a tip of two shillings, in April I659 he gave to six maids and two boys of Sir George two guineas, and in January 1662 he gave a dinner to Sir George and his lady at a cost of $£_{5}$. 95. Such hospitality may presumably be attributed partly to the ties of consanguinity, and partly to those of architect and client.

Sir Roger Pratt has notes relating to Coleshill under the year 1664 , which, in addition to those concerning the ceilings mentioned in Appendix I. deal with the proportion of the windows. These, he says, seemed somewhat narrow, either because not sufficiently splayed on the sides, or because the wooden frame and the iron one took so much from the glass. The windows were at that time iron casements, not sashes as they are now; and they were all alike in this respect, including the dormers in the garrets and the turret. One remark is rather puzzling in which he speaks of the heads of the windows of the dining-room being $5 \mathrm{ft}$. below the ceilings, for the vertical distance between the windows of the ground and upper floors is only about $7 \mathrm{ft}$. from glass to glass.

The testimony that the windows were casements and not sashes is interesting, so too is the detailed description of the casements and of the devices to exclude the weather. The window-bars were $\frac{1}{4}$ in. thick and $\frac{1}{2}$ in. broad; the casements $\frac{1}{4}$ in. thick and 2 in. broad. They were hanged upon three strong hooks, the opening-rod being $\frac{1}{2}$ in. thick with five rings to hold it; there was an iron plate with a pin let into the wood to hold the hook of the rod. A little piece of iron was put over the rebate of the casements to keep out the wind, and a little border of lead was nailed close to the casements on the bottom and sides, as well as a strip over the heads outside. Further there was another border inside to prevent the rain, which beat up under the casements, from flowing down upon the baseboard.

Let us hope these precautions were adequate, and that it was not necessary to lay out another $£_{5}$ on a dinner to placate Sir George and his lady, and to drown the memory of reproaches urged with cousinly freedom. 


\section{INDEX TO ILLUSTRATIONS AND TEXT}

Note.-The ordinary figures denote references to pages of text; the illustrations, which are referred to by their figure numbers, are denoted by the heavier type.

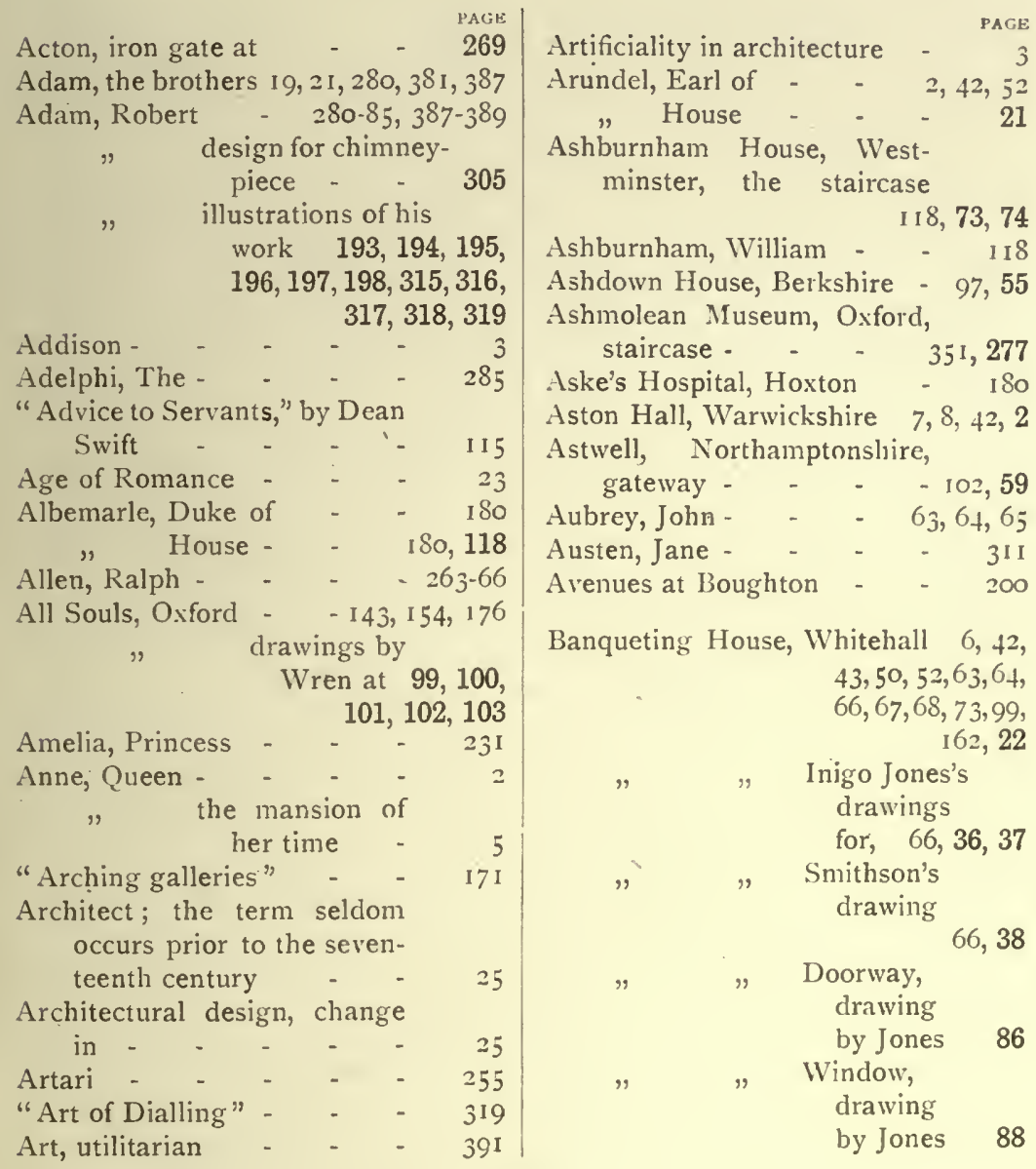


Bakewell, Robert (Smith) - 342

Barrow Gurney, Somerset, gateway - - $\quad 329,249$

Barry, Charles - - - 172

Basil, Simon - - . $\quad$ - 46

Bath, Somerset, Milsom Street 303, 211

, Pulteney Bridge

Queen's Square,

Panels in

house $\quad 363,289$

Ralph Allen's

house 302, 214

RoyalCrescent

268,185

Battle Abbey, Sussex, jamb of

fireplace -

Beaufort House, Chelsea

298

Beckford, Alderman

the younger

Beckley, Sussex, Church House

Bedford Square, London-

houses in - $\quad$ - $\quad 307,221$

chimney-piece - - $\quad$ - 318

Belcombe, chimney-piece $\quad$ - $\quad 317$

Belton House, near Grantham 157-160

$\begin{array}{lllr}" & \text { plan - - } & - & 105 \\ " & \text { chapel - } & - & 96 \\ " & \text { house - } & - & 104 \\ " & \text { iron screen } & - & 106 \\ " & \text { carving - } & - & 107\end{array}$

Bethlem Hospital, Lóndon $\quad$ I80, 116

Bignor, Sussex, chimney $\quad$ - 229

Birmingham, lead rain-water head

272

Bishopsgate Street Without,

London, ceiling - $\quad 386,307$

Blaythwayt, William - $\quad 203$

Blenheim Palace 5, 152, 223, 224, 22\%,

155

Blomfield, R. - - 216 (footnote) Bolsover Castle, Derbyshire 32, 33,

13,16

Bond, Sir Thomas - $\quad$ - $\quad$ - 180

Books on Architecture 2, 25-28, 212,

372

German, Dutch, and French
Botolph Lane, London, house

in - - - $\quad 185,119,120$

Boughton House, Northampton-

shire $178,196-203$

plan - - 132

house - 133,134

state room - 135

bird's-eye view 136

staircase $\quad 352,276$

panelling 363,286

fireplace 369,294

painted ceil-

ings $38 ;, 310,311$

Bourdon House, London, doorway

Bramham Park, Yorkshire, gardens - - 232-236, 162, 163

Brasenose College, Oxford 106, 63, 64, doorway - 127, 84

Brettingham, Matthew - - $276-278$

Brewers' Hall, London - 190, 125, 126

Bridge at Prior Park _ - 154 " at Bath - _ _ 184

Bridport, Viscount - _ - $\quad 387$

Bristol, hcuses at - $\quad$ - $30 \%, 220$

British Museum, drawings at - 64,19

Broadfield Hall, Hertfordshire 9, 3

Brownlow, Sir John - $\quad$ - 157

Buckingham (Villiers), Duke of 60, I6 I

(Sheffield), Duke of 168

House, London 168, 17 I,

$172,113,113 \mathrm{~A}$

, staircaseand

ceiling $\quad 308$

Street, Strand, doorway - $\quad$ - $\quad$ - 258

Bulwick, Northamptonshire, date-stone 235

Burford - - - - $\quad$ - 43

" Priory - - - 106, 62

Burghley House - - $\quad 385$

" Lord - - - I, 212

Burley-on-the-Hill, Rutland I76, 329,

Burlington-Devonshire draw-

ings, $52,64,65$ (footnote), $S_{3}$ (footnote), 42 , $43,44,45,76,77,86-88$, $91,92,93,94,240,241$ 
PAGE

216

Lord 2,63,64, 213-2 I6, 27 I
ances - $-~$

Butleigh, Somerset $\quad-\quad-\delta_{4}, \mathrm{I}_{42}$

Byron, Lord - - $\quad$ - 21, 32

Cambridge, Magdalene College,

Pepysian Library ıoo, 56

St John's College,

gate-piers - $\quad 325,243$

Trinity Hall, cupola

3 I 8,233

Campbell, Colin, 31, 64, 65, 66, 67, 69, $79,80,168$, I 7 I $, 172,176,207,240$

$25 I-255$

Campion, Thomas -

78

Can Court, Wiltshire, staircase I22, 78

Canons Ashby, Northampton-

shire-

Gate-piers

322, 238

Gates -

Ceiling

239

312

Canterbury, streets

296

"Capability" Brown

236

Carey Street, London, chimneypiece

303

Cariat (Coryat), Thomas

Carlisle, Earl of

44

2 I 6

27 I

Carr, of York -

Castle Combe, IViltshire, doorway -

333,252

Castle Howard, Yorkshire 216-223, $149,150,151,152$

Mausoleum 220, 153

Castor, Northamptonshire, gate-piers 329,247

Catherine Court, Tower Hill, London -

Ceilings -

Seventeenth-century I 22, 31, 34, 54, 74-77, 112, 120

Eighteenth-century $38 \mathrm{I}, 144,174$, $180,283,288,306,307,312-314$

Painted - $\quad 384,293,308.311$ Chambers, Sir William -

Changes in house design 99, I I 5 , I I 7

Chapman, George -
Charles I.

P.AGE

$"$

his influence on

tI

Charles II. - - - - IO, 84, I4I

,$\quad$ his idea of rebuild-

ing Whitehall

Palace - -

, hisinterest in build-

ing - - $\quad 1+2$

Charleton, Dr - 50 (footnote), 52

Chatham, Lord - - - $23 \mathrm{I}$

Chatsworth House, Derbyshire 204 ,

2 I 7,140

drawings at 64 , $66,36,37,40,41$

Chelmsford, street - $\quad$ - $\quad 296,210$

Cheltenhain, shop at $\quad$ - 304, 217

Cheron - - - - 198,384

Chesterfield, Lord - $\quad$ - $\quad 214$

Chimneys - - $314,229,230$

Chimney-pieces-

Seventeenth-century - $\quad$ - $\quad I_{3} S$

By Inigo Jones - _ $\quad$ I $38,91,92$

By John Webb - _ 93, 94

In the Jerusalem Chamber - $\quad 90$

At Forde Abbey - $\quad$ - $\quad$ - 95

Eighteenth-century $377,170,292$,

$294,301,302,303,304,305$

Chinese wall-papers - 36ł, 290

Chipping Campden, The Martins -

339,261

Chirurgeons' Theatre, London 50, 52

Chiswick, Lord Burlington's

Villa

2 I 4,148

"Chorea Gigantum" - jo (footnote)

Christ Church, Oxford - - 45

" Tom Tower - I 45

Christian IV. of Denmark - $\quad 45$

Church Langton, Leicester-

shire, rectory - - 294, 207

Cirencester, shop at $\quad$ - 304, 216

City churches - $\quad$ - $\quad$ - I3

Civil IVar, The - $\quad$ - $\quad$ 2, 10

Clarendon, Earl of - $\quad$ - $\quad$ - ISO

Clarke, Dr, of All Souls, Oxford - - - - - 63,64

Cliefden House, Buckingham-

shire - - I6S, I72, 114

Coke, Rev. I)'Ewes - $\quad 32$ 
Coke, Thomas, Earl of Leicester

Coke, Thomas, Earl of Leicester, killed in a duel.

276

Coleshill, Berkshire $54-58,88$

$\begin{array}{lr}\text { plan - } & 28 \\ \text { elevation } & 29 \\ \text { staircase - } & 30 \\ \text { ceiling - } & 31 \\ \text { gate-piers } & 324,242\end{array}$

College Hill, London, house

$$
\text { in }
$$

Combe Abbey

I 7 I

Comfort in houses -

Coniers, Sir John .

Cooke, "My" ladye Cooke's

$$
\text { House" - - - } \quad \text { - 36, } 18
$$

Coryat, Thomas - $\quad$ - $\quad$ - 44

Cottesbrooke, Northamptonshire $\quad$ I 78

" ceiling - 386, 313

"Counsel and Advice to all

Ijuilders," by Gerbier - I6I

Covent Garden Piazza - _ $\quad$ \%o, 24

St Paul's Church 48 ,

Cowper -

Craftsmen, English, are skilful $\quad 389$

Crane, Sir Francis - - $\quad 176,367$

Craven, William Lord - $\quad$ - 164

Croom's Hill, Greenwich,

garden house - $\quad$ - $\quad 236,161$

Cunningham, Peter, his "Life

of Inigo Jones" 45 (footnote), 50 (footnote), 60 (footnote)

Cupolas $\quad 316,5,29,51,55,104,106$, $118,231.234$

Dacres, Lord - - $\quad$ - $\quad 216$

Dance, George $\quad$ - $\quad$ - $\quad$ - 307

Daniell, Samuel - $\quad$ - $\quad 78$

Date-stones - $\quad$ - $\quad 3$ 3 $8,235,236$

D'Avenant - - - - 87

Davies, Robert (Smith) 345 (footnote)

Dawtrey Mansion, Petworth,

Sussex, staircase - 124, 79

Deanery at Wells, panelling I93, 128 chimney-piece 379 ,
Dean Street, Soho, London, house in - - - $\quad 25 \mathrm{I}, 171$

Decline of fancy in design - 3 3

Deene, Northamptonshire, the

"Seahorse" - . 291, 205

De L'Orme - - - $\quad$ - 28, 73

Denham Place, Buckinghamshire, staircase 355,280 panelling - $\quad 359,287$

Jenham, Sir John $69,70,84,87,141$, 144,212

Denmark House, chapel at - 50

Design follows two paths - 99, 39I

Designs of Inigo Jones. See

under Jones, Inigo.

Devonshire, Dukes of - $\quad-64,204$

Doorways, seventeenth-century $\quad$ I26

, exterior $13,21,35,58,59$,

84

interior $48,83,85,86,87$,

$89,124,126,129$,

130

, eighteenth-centuryexterior $333-339,196$,

197, 252-259

interior - 282.285

Dorking, shop at - $\quad$ - $\quad 305,219$

Double cube rooms - $\quad 58$

Drayton, Leicestershire, datestone

235

Drayton House, Northamptonshire, chim-

ney-piece $97,138,94$

gardens - 236, 159, 160

Dryden - - - - - 60

Du Cerceau - $\quad$ - $\quad$ - $\quad$ - 28

Dunkirk House - - $\quad$ - 180

Dunstable, street - - $\quad 296$

Durham House - $\quad$ - $\quad-97$, I I5

Dyrham, Gloucestershire 203, 204, 373

$\begin{array}{lllll}" & \text { plan - } & - & - & 138 \\ " & \text { house - } & - & - & 137 \\ " & \text { dining-room } & - & 139\end{array}$

Easton Neston, Northamp-

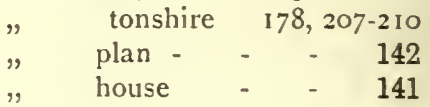


Gates and gateways $322-331,21,35$.

$$
\begin{aligned}
& \text { " }, \quad \text { still habit- } \\
& \text { able - } 3
\end{aligned}
$$

Ely, Cambridgeshire, house at 294 ,

206 ,

Emmett, William, of Bromley 64,65

Entrances to houses - $\quad 319$

Erectheus, Temple of - - 3II

Evelyn, John - $\quad$ - 2, 70, 142, 180 quoted 27, 167 (footnote)

Extinguishers near doors

Ferguson

FinsburyCircus, London, house

$$
\text { in - - - } 311,225
$$

Finsbury Square, London,

$$
\text { houses in - - 307,222 }
$$

Fire-backs - - - 370,296

" basket - - - 370, 297

" dogs - - $-370,295,296$

"grates - - - 299, 300

" places - - - 369,375

" jamb of - $\quad 298$

Fitzwilliam, Earl of $\quad-\quad 258,260$

Flaxman, design for a chimneypiece - - - - 304

Flitcroft, Henry - - 258-260

"Florimene," a pastoral - - 87

Fonthill Abbey, sale at - $\quad$ - 17 " House, Wiltshire 14, 17, 9

Ford Abbey, Dorset, chimneypiece - - - 138,95

Fournier Street, London, doorways - - - . Frogley, R. (carpenter) - - 145 Furniture of houses in 1720 - 375

Gables - $\quad$ - $\quad$ - $\quad$ - $\quad$ - 99

Gammon, Richard - - - $\quad$ 60

Ganymede - - - $\quad$ - 19

Gardens $\quad 229-236,108,136,156-162$ at Boughton - - 200
$46,50,59,110,111,238,239,241-251$

Georgian Houses - _ $\quad$ - 237

$$
\begin{aligned}
& \text { accommoda- } \\
& \text { tion in the }
\end{aligned}
$$

smaller - 287

Gerbier, Sir Balthazar 60, 161-163,168

Gibbs, James - - 31, 178, 243-251

drawings by $164-170$

Girdlers' Hall, London - $\quad$ 191, 127

Gloucester, house in Eastgate $\quad 307$

Southgate 109, 65

Godmersham Park, Kent, door-

$$
\text { way - - - - 356, } 282
$$

Goodridge, H. E., of Bath - 265

Gothic revival - $\quad$ - $\quad$ - 20,23

Grainger, of Newcastle - $\quad$ - 282

Grecian temples in English gardens - - - - 311

Greek influence - $\quad$ - $\quad$ - 21

Greenwich Hospital (formerly

$$
\text { Palace) - - - } \quad \text { I 50, } 98
$$

Greenwich Palace-

liing Charles's Block, 52, 64, 65, 83,

168,45

Ceiling - $\quad$ - $\quad$ - 77

Door - _ _ $\quad$ - 87

Queen's house at Greenwich 43 ,

50,52

Plan - - - _ $\quad$ - 25

View - - - $\quad$ - $\quad$ - 26

Elevation - $\quad$ - $\quad$ - $\quad$ - 27

Chimney-pieces by Inigo Jones - - - $\quad$ - 91, 92

Greenwich Old Palace, staircase - - - 126,82,83

Gresham College, London - $\quad 1+3$

Grinling Gibbons I60, I89, 207, 357,

Gwydyr House, Whitehall - 20, 11

Hagley, Morcestershire - - $\quad 231$

Hakewill - $\quad$ - $\quad$ - 91

Hall, the great - - - $\quad 6,7$

" of eighteenth - century

houses - - $\quad 35 \mathrm{I}$

Ham House, Surrey, staircase 126,80

Hampton Court $\quad 13,70,150,154,6$ 


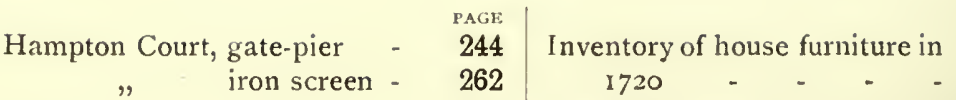

" iron balustrade -

264

, fire-dogs -

295 staircase and ceiling -

309

Hamstead Marshall, Berkshire - I63-168, 324, 108, 112 Hanbury Hall, near Droitwich

I 3,5

Harewood House, doorway - 316

Harley Street, London - $\quad 386$

Hatton

Hawes, Francis, his inventory 372,375

Hawksmoor, Nicholas - 207-212, 220

Hengrave Hall

275

Henry, Prince of Orange - $\quad$ I64

$"$ "Wales - 45, 46

Hercules

High Wycombe, Buckinghamshire, sundial -

3 I 8,234

Hinderskelf, Castle of - $\quad 216$

Hogarth - - - - $25 \mathrm{~F}$

Holdenby House - - - 167

Holkham, Norfolk - 178, 271-275

",$\quad$ plan - 188

$" \quad$ " view - 189

Holt, near Bradford-on-Avon 291, 201

Homes, English - _ -

Homes of great nobles - $\quad$ - 2

Honington Hall, Warwick-

shire, doorway and ceiling -

357,283

Hooke, Robert - - - $\quad$ I78

Horse Guards, The, White-

hall - - - 276,190

Houghton, Norfolk I78, 251-256, 35 I

$" \quad " \quad$ plan - 172

" " views - 173-178

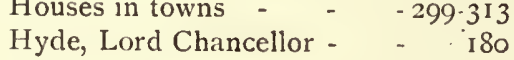

Ince Blundell, Lancashire, The

Lion Lodge - $\quad$ - 329,246

Inigo Jones. See Jones, Inigo.
Ipswich, houses at - $\quad$ - $\quad$ III, 66

Ironwork $\quad 299,339-345,212,213,262-$

266, 268-271

Isham, Sir Justinian - - 93, 95

Italian influence and inspira-

$$
\text { tion - - - } \quad 1,2,6,27,3^{6}
$$

Jackson, John - $\quad-\quad$ - 109 James I. - - - $3,45,66$

Jeffreys, Judge - $\quad$ - 13 Jerusalem Chamber, Westminster, chimney-piece $\quad$ 1 36,90 Johnson, Dr, on Kedleston Hall - - - - 278 Jones, Inigo $2,6,7, I_{3}, 20,31,33,40$, $4 \mathrm{I}-6 \mathrm{I}, 64,82,83,84,99,117,1 \mathrm{I} 8$, I $22,126,129,132,136,138,142$,

Jones, Inigo$143,146,161,162,176$

his designs for masques - 39,45 employed to purchase pictures - - - - 42 his birth - - - $\quad 44$ visits to Italy - $\quad$ - $\quad-45,46$ his sketch-book at Chatsworth - - - - 45, 46

his annotated copy of Palladio - - - 45 work attributed to him - 46-50 "the Vitruvius of his age" - 52 his death and will _ $\quad$ - 60 Kent's "Designs of Inigo Jones" $56,63,64,68,80,82$, $87,153,212,216,237-240,243$, $260,278,377$

"Designs of Inigo Jones," compared with earlier designs - $\quad-\quad 82$

designs for scenery - - 64 drawings attributed to him - 65 Jones and the designs for the Palace at Whitehall $63-80$ "Designs for Whitehall" - 68 drawings by him 77 (footnote), 79 
Jones, Inigo (continued) -

Jones as scene-painter

as surveyor

drawings by Jones--

Banqueting House -

elevations of a house

drawing for a masque

ceiling at Wilton

door at the Banqueting House

window at the same

chimney-pieces

clock-turret at Whitehall

Temple Bar

gateway -

plan of Stoke Bruerne

Jonson, Ben
PAGE

79

79

36,37

42

43

75

86

88

91,92

232

240

241

115

- 78,79

Kedleston, Derbyshire $\quad 178,271,278-$

280

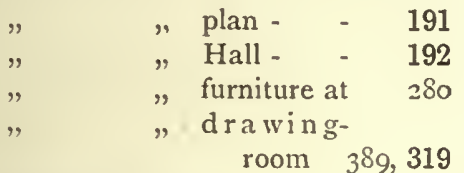

Keith, Admiral Lord - $\quad 387$

Keith, W. Grant 77 (footnote), 87

(footnote)

Kelmarsh Hall

178

liennington Common - _ . $3^{\mathrm{I}}$

Kennington Park Road, Lon-

don, houses in -

$-311,226,227$

Kent, William $63,65,66,67,68,69$, $138,229,255,256,271-278$

Kew Palace, fire-grates -

299,300

Kimbolton Castle .

224,227

King's Lynn - - $\quad$ - $\quad 296,209$

Kingston, Castle Inn, stair-

case - - - 125,81

King's Weston, Somerset $\quad I_{3}, 14,7$ $" \quad, \quad$ staircase 352 ,

275

Kip or Kyp, "Britannia Illustrata" - - - 164, 236

Kirby Hall, Northamptonshire, chimney and dormer window
Laguerre - _ _ $\quad 3 S_{4}, 38$;

Lamport Hall, Northampton-

shire - - - - 93, 52

Landor, WValter Savage - 301

Langley, B. and T. 26 (footnote)

Lanscroon - . - - 384

Laud, Archbishop - $\quad$ - $\quad 127$

Lead cisterns - $\quad$ - $\quad$ - $\quad 267,274$

Lead work - $\quad-345,349,267,274$

Lectures on Architecture in

the Seventeenth Century - $16_{3}$

Leicester, Earl of - $\quad$ - $\quad 274,273$

Leicester, Lady - $\quad$ - $\quad$ - 275

Lempster, William, Lord - 207

Le Nôtre - $\quad$ - $\quad$ - $\quad$ - 216

Lenthall, Speaker - _ _ 106

Leoni - - - - $\quad$ - 229

Leyton Great House, Essex 18 ; 122

Lewes, Sussex, house in the

High Street - - 314,228

Lincoln's Inn Fields, staircase

at No. $35 \quad$ - $\quad$ - 356,281

Lisle, Dame Alice - $\quad$ - $\quad$ - 13

London Houses - $\quad-181,307-311$

" plan - $\quad 223$

London suburbs - - $\quad$ - 313

Louvre, The - $\quad$ - $\quad$ - $\quad$ - 74

Lysicrates, Choragic Monu-

ment of -

Magdalene College, Cambridge I00, 56 Malton, Earl of - - - 258

Mansfield Street, London, stair-$$
\text { case }
$$

Market Harborough, Sign of Inn at

Mark Lane, London, doorway 333, 254

Marlborough, Duchess of - 150

" town - - 296

Masques - - 45 (footnote), 78

, drawing by Inigo Jones 77,43

Medirval houses, plan of - $\quad 115$

, traditions, decline of 20

Melbourne, Derbyshire, gardens 236

Melton Constable, Norfolk 193,131 staircase $35+, 279$

Meopham, Kent, chimney $\quad$ - 229

Middle Ages, raulted rooms of the 
PAGE

Montagu, Duke of - $\quad-178,196,369$ , House - - - 178

Montague, Lady Mary Wortley 216,364

Mortlake, factory of tapestry - $\quad 367$

Moulton, Northamptonshire, date-stone

Movable scenery, design of the first -87 (footnote)

Moyles Court, Hampshire - Io, 4

Names of rooms on plans by

Thorpe and Webb

Napoleon

Nash, Beau

Neville Holt, Leicestershire,

The Stables - - 316, 231

Newcastle House - _ $\quad$ I68, I7I

Newcastle, Earls and Dukes of

Newmarket, royal house at

Nixon, Alderman John -

, his grammar school at Oxford - - I I I, 67

Normanton Park, Rutland - I7, 10

Northampton, ceiling in Courts of Justice - $\quad$ - 381,306

Northleach - - - - 43

Northumberland House, chimney-piece -

Norwich, doorways

Oliver, Mr, City Surveyor

Oundle, doorway

Ormond, Duke of -

333,253

Osborne, Dorothy -

I 80

$\begin{array}{lr}\text { Osborne, Dorothy - } & - \\ \text { Oxford, house in the High St. } & 291,203\end{array}$

" house in St Giles 291, 200

(See also All Souls College, Ashmolean Museum,

Christ Church, Nixon's

Grammar School, Shel-

donian Theatre, St John's

College, Trinity College,

Worcester College.)
Brasenose College Chapel,

Panelling - - $\quad 136,360$

Paul's Cathedral, St, London ' 13,48 ,

63, IOI, I 42, I 45-I 49

model by Wren 97

Paul's, St, Covent Garden 48, 52, 23

Penshurst, Kent, fire-basket - 297

Pepys - - - - 2, 100, 180

Pepysian Library, Cambridge .I00, 56

"Persians" - - - - 73

Petersham, Surrey, house at 294, 208

Philibert de l'Orme

28

Physicians' College

97

Piddletown, Dorset, vicarage 29I, 199

Pitt, William - - $\quad$ - $\quad 387$

Pope - - - - 5,227, 243

Porches, open $\quad$ - $\quad$ - $\quad$ - 89

Powell, Sir Edward _ _ $\quad$ i 8

Powis Castle, Monmouth, tapestry room - _ _ 293

Powis House. See Newcastle House.

Powis, Marquis of -

Pratt, Roger

I8o, and Appendix 395-398

Price, Dr George, chimneypiece for - - - - 138,93

Prior Park, Bath, bridge. 220, 154 " $\quad$ house $260-266,182$,

$183,35 \mathrm{I}$

Proportion in architecture - 80

Puget, architect - $\quad$ - $\quad$ - 178

Pugin - - - - 20,3II

Pulteney Bridge, Bath - $\quad 267,184$

Queen Anne, wife of James I.

Queen's House at Greenwich.

See Greenwich.

Quenby Hall, Leicestershire, iron gateway - $\quad$ - 344, 266

Raleigh, Sir Walter $\quad$ - $\quad$ - $\quad$ I

Ramsay, Allan - - $\quad$ - 387

Ramsbury Manor, Wiltshire, 95, 53, 54

Chinese wall-
paper -

Raynham Park, Norfolk - $\quad 58$

Paine, James - $\quad$ - $\quad-271,278,280$ Palladio
, plan -

, view - 
Reddish Manor, Wiltshire 268,186 Reynolds, Sir Joshua - 3, 14, 229 R.I.B.A. Collection of Drawings $58-64$, $42,44,45$ Rice, R. Garraway - $\quad 34^{2}$ (footnote) Ricci Ripley - - - - - I4, $27 \mathrm{I}$

Roads in Georgian times - 299

Robinson, Thomas (Smith) - 342

Rockingham, Marquis of - $\quad 258$

Rooms named on old plans - 115

Rubens - - - - 60

Rundhurst, Sussex, gate-piers 239, 248

Rysbrach

255

Saffron Walden, Essex, houses

I I 1 ,

68,69

Salisbury, sign of an inn

213

" gateway in the Close 250

$" \quad$ staircase - 352,278

"Salmacida spolia" _ _ 87

Sandby, Thomas - - 7,60, 74,

Frontispiece, Fig. 1

Sanitary conveniences in

Georgian houses - $\quad 288$

Sappho - - - - - 21

Sash windows introduced - $\quad 134$ earliest example $\quad 136$

Scole, Norfolk, inn - - I I I, 72

Scott (Sir Walter) - $\quad$ - $\quad$ - 23

Seaton Delaval, Northumber-

land

178,224

Seckford Hall, Suffolk, doorway

285

Sedgemoor

I3

Serlio

80

Shakespeare - - - - 10,25

Shardiloes House, design for chimney-piece -

305

Shaw, Huntingdon (Smith) - 342

Sheffield, "my lord's house" " Duke of Buckingham Sheldonian Theatre, Oxford Sherborne, Gloucestershire Sherrard, Bennet, Lord

Shops - - - 304, 305, 216, 219

Short survey of twenty-six counties in $1634 \quad 43$ (foolnote)

Shrivenham, Berkshire, House 294, 204
"Siege of Rhodes"

PAGE.

Silchester, Hampshire, chimney -

Smithson, John - $\quad$ - $7,42,168$

$" \quad \Rightarrow$ his family - 31

$" \quad$ " his drawings $32 \cdot 40$,

$66,77,14,15,17$,

$18,20,21,38$

" Robert - - - 31

, Huntingdon - - 31

Snaresbrook, Elm Hall, iron gates

268

Soane Museum - - $\quad$ - $\quad 3^{\mathrm{I}}$

Somerset House - - $\quad 50$

$" \quad$ new wing $-105,61$

South Molton, fireplace in

Town Hall - - 369, 292

South Sea Company - $\quad 372$

Spalato in Dalmatia - $\quad 280$

Speculative builders, their in-

fluence on house design -

311

Spiers, Walter L. - - - 3I (footnote)

St Catherine's Court, Somer-

set - - - - - 236

St Cloud - - - - 200

St James's Palace - $\quad$ - $\quad$ - $\quad 58$

" $\quad$ chapel at - 50

" Square, No. 32 - 20, 12

St John's College, Oxford-

doorway - - - $\quad-127,85$

panelling - - - $\quad-136,89$

rain-water heads - - 345

St Lawrence Jewry, London,

carving - - $-185,123,124$

St Mary Redcliffe, Bristol, iron

gates - - - 3 342,265

St John, Oliver - $\quad$ - $\quad$ - 88

Staircases of seventeenth cen-

$$
\begin{array}{cr}
\begin{array}{c}
\text { tury } \\
\text { eighteenth }
\end{array} \begin{array}{c}
\text { cen- } \\
\text { cen- }
\end{array} \\
\text { tury } & 35 \mathrm{I}, 275-281, \\
& 308,309
\end{array}
$$

Stanton Harcourt, Oxfordshire,

farmhouse - - - 113,71

Stanway House, Gloucester-

shire, doorway - - 101, 58

Stapleford Park, Leicester-

shire - - $191,129,130$

Starkie Gardner - 345 (footnote) 
PAGE

Stationers' Hall, London - I9I , , doorway

Stoke Bruerne, Northamptonshire

Stoke Bruerne, Northamptonshire, plan

"Stone-Heng Restored" 44, 50 (foot-

Stoneleigh Abbey, Warwicknote) shireiron gateway panelling 363,288

Stone, Nicholas

Stowe House, Buckingham. shire

Stowe House, Buckinghamshire, gardens

Strafford, Earl of 258

Stratford, near London, iron gate

271

Stratton Street, London, house

Streets in towns
Stuart, James 3 Io, 224 296

Sturmer, Essex, chiınney

Sundials

Sutton Place, fire-back and dogs - - - $\quad 296$ Swakeleys, Middlesex - - I02, 60

Talman, architect 203,204

Talmash, Thomas I 26

Tapestry $367,291,293$

Temple Bar, design for, by

$$
\text { Inigo Jones - - } 323,240
$$

Temple, The, London, stair-

$$
\text { cases }
$$

Temple, Sir IVilliam

Tenche, Sir Fisher

Thornhill, Sir James

Thorpe Hall, Northampton-

$$
\text { shire }
$$

Thorpe Hall, Northampton-

\section{shire-}

$$
\text { plan }
$$

Thorpe, John -

28, $\hat{j} \mathbf{I}, 77$, I I 5

Thrale, Mrs plan of London houses - $\quad 310$

- -3 Tijou, Jean - - $\quad$ - 339,340

Town houses of the gentry - $\quad 299$

Town planning on architectural

$$
\text { lines - - } \quad 267,299,30 \mathrm{I}
$$

Towns, growth of - - _ 304

Townshend, Aurelian - $\quad$ - 78

$$
\text { George - } 275
$$

Trellis work to fronts of houses

Trinity College, Oxford - - $\quad$ I 45

Triumphal arches by Gerbier - $\quad$ I62

Tuileries, plan for the palace - 73

Uffington, nearStamford, gate-

pier -

251

Vandike, Sir Anthony - - 52

Vanbrugh, Sir John I $13,19,20,150$,

Vathek - - - - - $\quad$ I7

Vernon, Thomas - $\quad$ - $\quad$ - 13

Verrio - - - $\quad-199,384,385$

Versailles - $\quad$ - $\quad$ - $\quad$ - 196

Vignola - - - - - 163

Villiers, Duke of Buckingham 60

"Vindication of Stone Heng

Restored," by WVebb, 45(footnote), 48,50 (footnote), 52 (footnote), $\mathrm{S}_{4}$

"Vitruvius Britannicus," by

Campbell - $\quad-64,240-243$

Wade, General - $\quad$ - $\quad 2$ I4

Wall-papers - - - $\quad 364$

Walpole, Horace - 20, 3I, 32, I6I his visit to Stowe - 231 " Sir Robert - 251, 256

Wansford, Northamptonshire, chimney - - - - 229

Wanstead - - - $\quad$ - 260

Ware, Isaac - $\quad$ - $\quad$ - $\quad$ I76, 27 I

Wareham, Dorset, shop at 305,218 
Warminster, Free School $\quad \begin{array}{r}\text { PAGE } \\ \text { P } 57\end{array}$ Warwick, streets - - - 296 " Aylesford Hotel 30I, 215 $" \quad$ lead rain-water head 273 Watson, Samuel, of Heanor - 207 Webb, John 2, 7, 31, 45 (footnote), 48 $50,52,54,56,60,63$, $64,65,68$, IOI, I41, 176, commissioned to acquire works of art - -

his petition to Charles II. - 69,70 brief attached to same - $\quad 84,85$ designed the Palace at Whitehall by command of Charles I. - - 70 design for a house by him - his own work - 83-97 "Inigo Jones's man" - - 83,87 designs for masques -

drawings by him, for new wing, Somerset House ceiling at Wilton ceiling at Greenwich door at Greenwich

chimney-pieces hall or public room

Webb, William

Welbeck Wells, Deanery chimney-piece 379,302 Wentworth Castle, Yorkshire258

" Woodhouse, York-

Widcombe Manor House, near

Whitehall Palace, "Designsfor

Whitehall" 64,68 drawings for designs for
the Palace $63-80$, $1,19,39-41$

", by Wren - 103 " clockhouse by Inigo Jones 232

Wilkins, Bath

Wilkins, Dr .

William and Mary -

Williams, John, Bishop of Lincoln -

Willis, Professor

Wilton, Wiltshire - $\quad 58,97,220,34$ $" \quad, \quad$ ceilings, I1 8,122 ,

Wimpole Street, London, ceiling -

75,76

Winchester, chimney-piece - 301

" palace at - - 142

Winde, Wine, or Wynne, Capt. See Wynne.

Windows of seventeenth century $\quad 129$

Windsor Castle - - $\quad 385$ shire 256-260, 179, 181 Westminster, dormitory at

AGE 
Wren, Sir Christopher, designs for houses

99,102 " $\quad$ for palace at Whitehall - - 103

Wren, Dr Christopher - " Matthew, Bishop of Ely

Wrest, Bedfordshire, gardens

Wynne, Captain - $\quad 16,158$
$\quad$ 163, I68
Wynne, Captain, drawings by I7 I (footnote), 109, 110, 112

Yarmouth, lay-out of streets - $\quad 296$ porch at - 337,260 York, streets in - - $\quad 296$ "Assembly Rooms 214, 146, 147 " doorway - - 333, 255 York House, London - $\quad-60,161$

$\begin{array}{lll}" & \text { water-gate } 60,322 \\ \prime & \text { FRONTISPIECE, } 35\end{array}$



NA

7328

Gb

c. 3

THE LIBRARY

UNIVERSITY OF CALIFORNIA

Santa Barbara

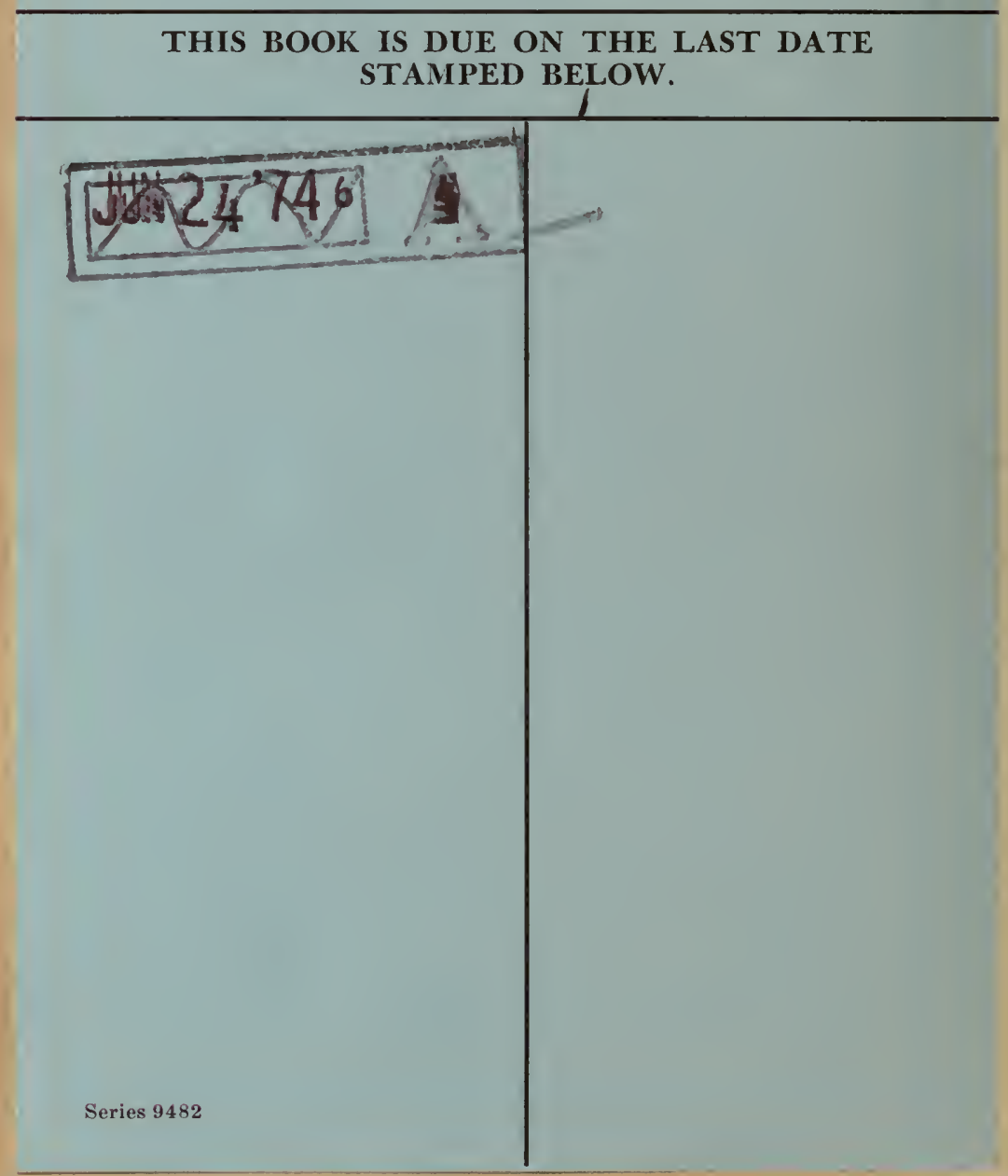




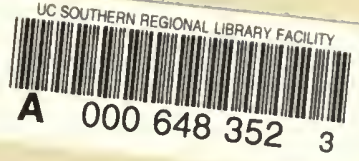

1 
7.

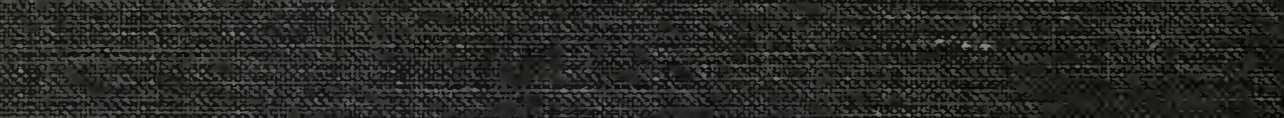

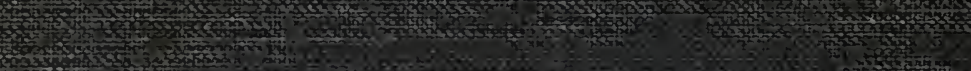

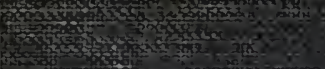

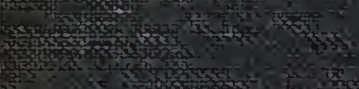

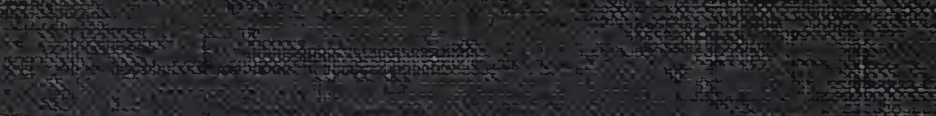

tistis

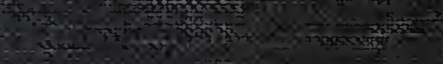

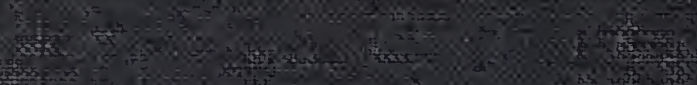

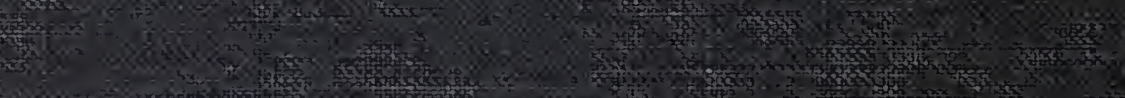

(1)

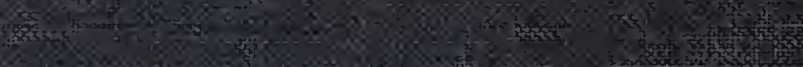

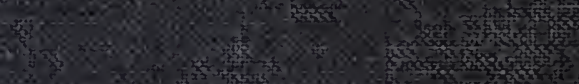

ant

(15) 